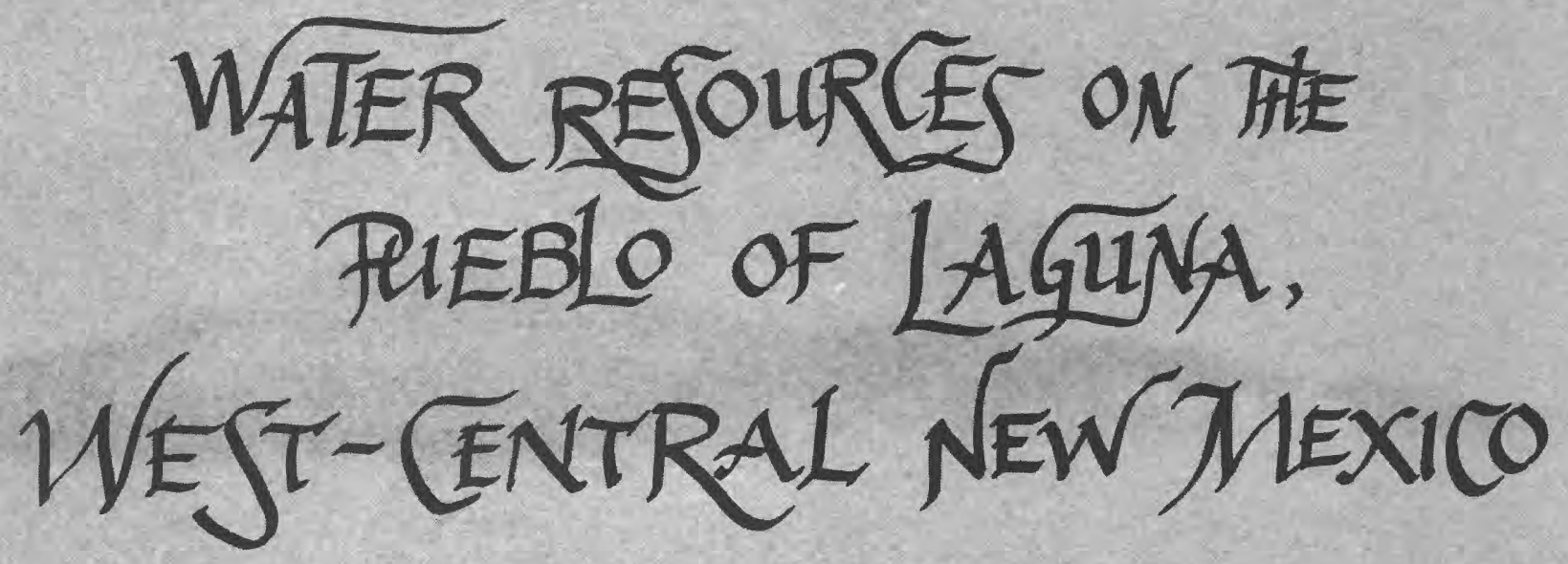

BY DENNIS W. RISSER AND FOREST P. LYFORD

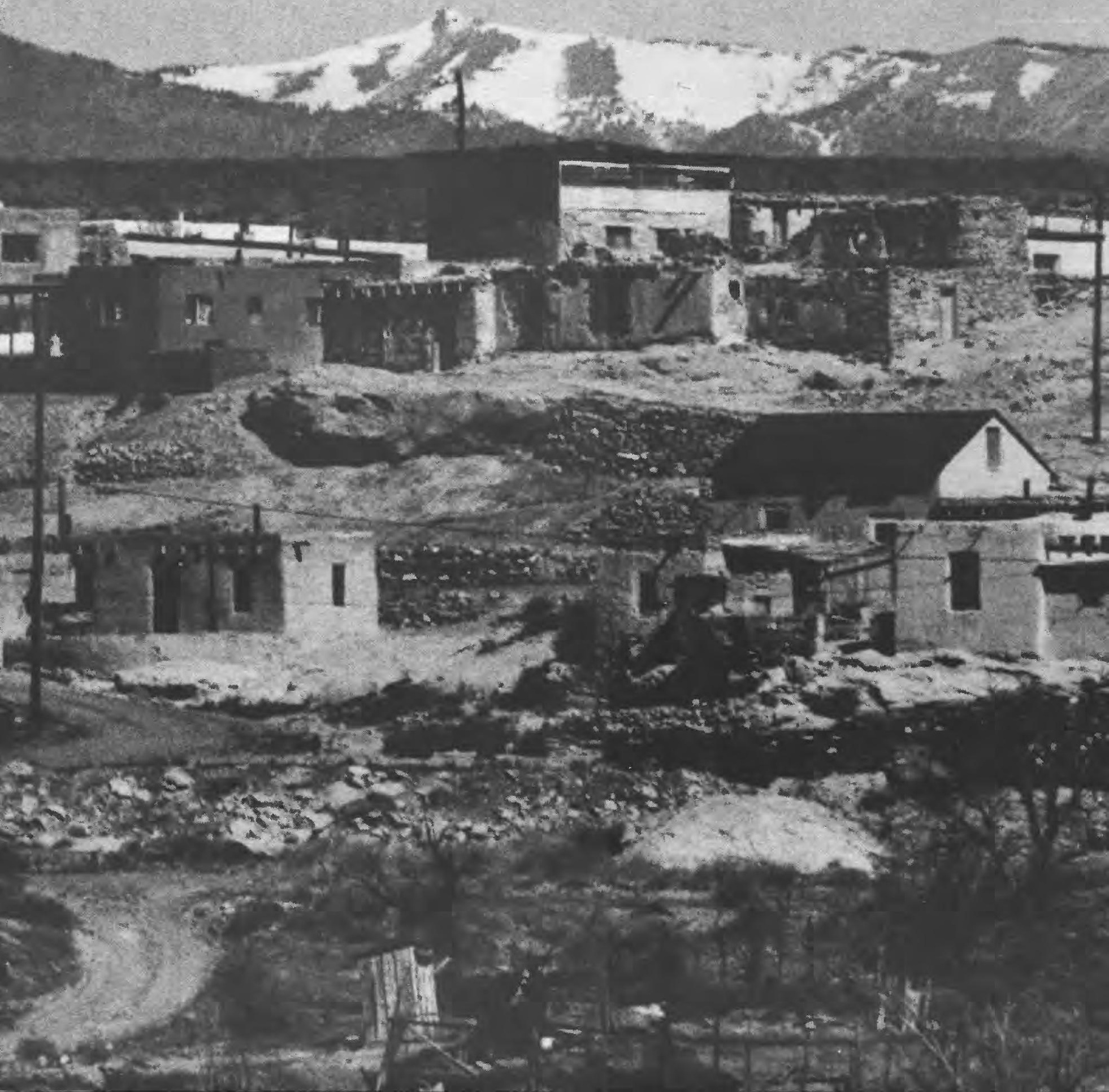




\author{
UNITED STATES DEPARTMENT OF THE INTERIOR \\ WILLIAM P. CLARK, Secretary \\ GEOLOGICAL SURVEY \\ Dallas L. Peck, Director
}

For additional information write to:

District Chief

U.S. Geological Survey

Water Resources Division

505 Marquette NW, Room 720

Albuquerque, New Mexico 87102
For sale by:

Open-File Services Section Branch of Distribution U.S. Geological Survey, MS 306 Box 25425, Denver Federal Center Denver, Colorado 80225 (303) 234-5888 
U.S. GEOLOGICAL SURVEY

WATER-RESOURCES INVESTIGATIONS REPORT $83-4038$

PREPARED IN COOPERATION WITH THE U.S. BUREAU OF INDIAN AFFAIRS

\section{ALBUQUERQUE, NEW MEXICO}

1983

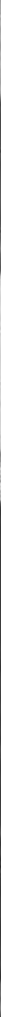


Water Resources on the Pueblo of Laguna,

\author{
West-Central New Mexico
}




\section{CONTENTS}

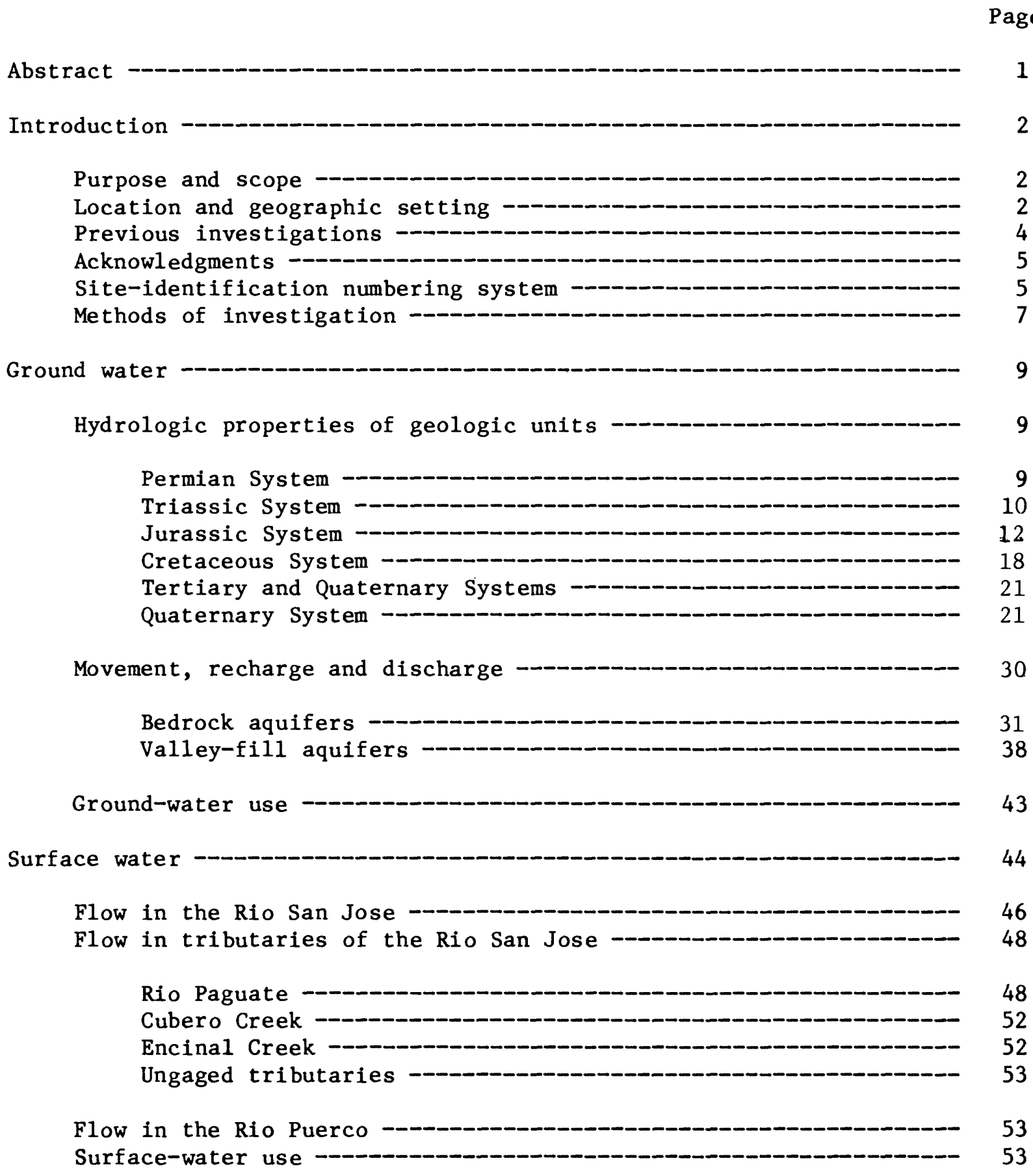




\section{CONTENTS - Concluded}

Water quality

Water-quality criteria for various uses - 54

Ground-water quality 55

Bedrock units - 55

Alluvium - 58

Surface-water quality 60

Rio San Jose - 60

Rio Puerco - 64

Tributaries of the Rio San Jose 64

Numerical model of ground-water flow in the valley-fill aquifer

along the Rio San Jose west of Laguna village

Introduction to modeling study 68

Description of the model 70

Model used - 70

Mode1 construction 70

Finite-difference grid - 70

Aquifer properties

Model boundaries and recharge 73

Model adjustments - 74

Estimates of aquifer response to future ground-water

Ground-water withdrawals for public supply - 77

Ground-water withdrawals for public supply and irrigation-- 77

Ground-water withdrawals for irrigation 78

Sensitivity analysis 79

Summary and conclusions - 81

Possible ground-water development 81

Public supply - 81

Irrigation - 83

Stock water - 84

Possible surface-water development 84

References - 86 


\section{ILLUSTRATIONS}

Figure 1. Map showing location of study area

Page

2. Diagram showing method of numbering we11s, springs, and surface-water sites

3. Map showing location of test wells and ground-water monitoring sites

4-9. Graphs showing:

4. Water-level fluctuations in well 9.4.19.124 (E1 Rito), 1973-79

5. Water-level drawdown from test of well 9.5.9.231

(Laguna 78-1)

6. Water-level drawdown from test of well 9.6.26.233

(RWP-24)

7. Water-level declines in well 10.5.5.142 (MDH-771), 1974-79

8. Water-level recovery from test of well 10.7.10.213

(Laguna 79-1)

9. Water-level recovery from test of well 10.6.9.121

(Encinal 2)

10. Map showing altitude of the base of valley fill and transmissivity values in the Rio San Jose valley west of Laguna

11-13. Graphs showing:

11. Drawdown and recovery of water level in wel1 10.7.36.424 (Laguna 76-1)

12. Drawdown and recovery of water level in well 10.7.36.322 (Laguna 76-2)

13. Drawdown in observation well 9.6.5.221 (Acoya) in response to pumping from well 9.6.5.222

(Laguna 76-6) 


\section{ILLUSTRATIONS - Continued}

Figure 14-15. Graphs showing water-level recovery:

14. From test of we11 9.6.2.123 (Laguna 76-7)

15. In observation we11 10.6.35.342 (Pueb1o Test 2)

from test of well $10.6 \cdot 35.342 a$ (Laguna Ir. 2) -.--

16-19. Maps showing potentiometric surface and specific conductance of water in the:

16. Chinle Formation - 32

17. Entrada Sandstone 33

18. Bluff Sandstone - 34

19. Morrison Formation 36

20. Map showing water-level altitude and specific conductance of water in the valley fill along the Rio San Jose west of Laguna --

21. Graph showing average winter discharge in the Rio San Jose calculated from miscellaneous measurements at selected sites between Horace Springs and Rio Puerco (1974-79) -

22. Hydrographs for wells completed in the valley fill along the Rio San Jose -

23. Map showing location of surface-water monitoring sites

24. Graphs showing average annual discharge of the Rio San Jose and the Rio Puerco

25. Graphs showing average monthly discharge of the Rio San Jose and the Rio Puerco

26. Graphs showing streamflow duration curves at gaging stations on Rio San Jose, Rio Puerco, and Rio Paguate - -

27. Graphs showing average monthly streamflow in the Rio Paguate 


\section{ILLUSTRATIONS - Concluded}

Figure 28. Water-analysis diagram for selected we11s completed in bedrock units

29. Water-analysis diagram for wells completed in valley-fill deposits along the Rio San Jose

30. Graphs showing variation of selected water-quality characteristics in the Rio San Jose from the streamflow-gaging station near Grants (08343500) to Mesita diversion, 1961-79

31. Graph showing average monthly specific conductance of the Rio San Jose on the Pueblo of Laguna upstream from Mesita, $1961-79$

32. Graphs showing relation of specific conductance to selected water-quality characteristics for the Rio San Jose between Horace Springs and Mesita diversion, $1961-79$

33. Graph showing average concentrations of major ions of winter streamflow in the Rio Paguate, 1976-79

34. Graphs showing relation of specific conductance to selected water-quality characteristics in Rio Paguate and Rio Moquino, 1976-79

35. Map showing location of modeled area

36. Map showing finite-difference grid and hydrologic boundaries used in the valley-fill model

37. Map showing hydraulic-conductivity distribution used in valley-fill model, in feet per day

38. Graph showing comparison of simulated and measured steady-state water levels -

39. Graph showing sensitivity of simulated drawdowns to changes in hydraulic conductivity, vertical hydraulic conductivity of the streambed, and specific yield after 5 years of ground-water withdrawals at nodes $9-61,8-24$, and $12-45$

The wood engravings of Laguna on pages ix, 20, and 85 are from Harper's, February 1891. 


\section{PLATES}

[Plates are in pocket]

Plate 1. Map showing water-level contours, specific conductance of water from wells and springs, and areas of possible ground-water development on the Pueblo of Laguna, New Mexico, 1973-79.

2. Generalized geologic map of the Pueblo of Laguna, New Mexico.

3. Geologic sections showing the potentiometric surfaces, the water table, and possible ground-water flow directions, Pueblo of Laguna, New Mexico.

\section{TABLES}

Table 1. Records of wells 90

2. Records of springs - 116

3. Description of formation cuttings for selected wells -

4. Summary of all aquifer tests conducted on the Pueblo of Laguna

5. Major constituents of water in selected wells and springs *

6. Nutrients and minor constituents of water in selected we11s

7. Trace elements of water in selected wells

8. Radiochemicals of water in selected wells

9. Selected major chemical constituents of surface water

10. Nutrients, bacteria, and selected minor elements in surface water -

11. Selected trace elements in surface water

12. Miscellaneous onsite measurements of streamflow and water quality 


\section{TABLES - Concluded}

Page

Table 13. Selected radiochemicals in surface water -

14. Summary of selected geologic units and their waterbearing properties

15. Estimated magnitude and frequency of 1-day flood, peakflow discharge, and total annual streamflow for tributaries of Rio San Jose

16. Chemical analyses of bed material in Rio Paguate and Rio Moquino

17. Selected water-quality standards and criteria for public water supply, freshwater aquatic life, livestock, and irrigation

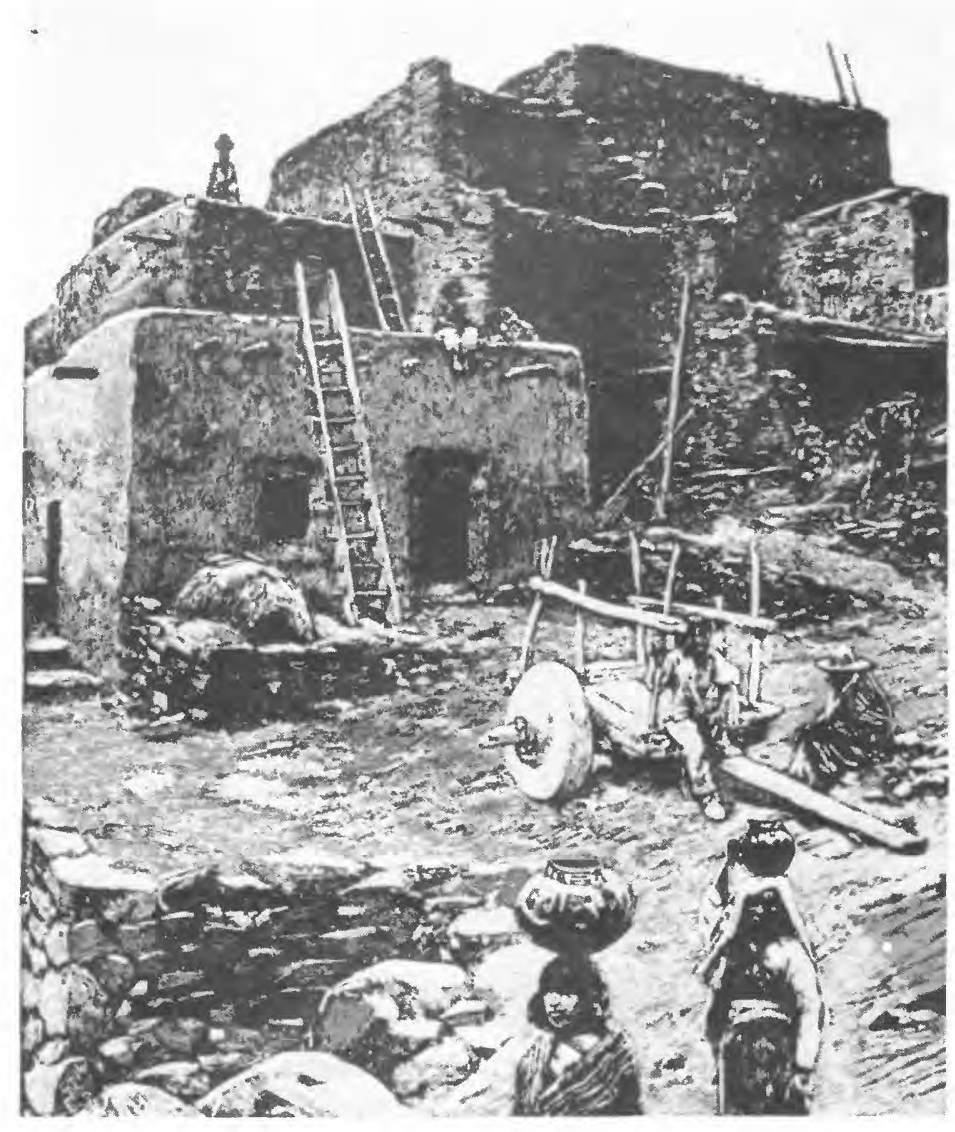


In this report, values for measurements are given in inch-pound units only. The following table contains factors for converting these units to metric units.

Multiply inch-pound units

acre

acre-foot

foot

gallon

gallon per day

gallon per minute

gallon per minute per foot

mile

square mile

inch

cubic foot per second

cubic foot per second per mile

foot per day

foot squared per day

pound per square inch

foot per mile $\underline{\text { By }}$

$$
\begin{gathered}
0.4047 \\
1,233 \\
0.3048 \\
3.785 \\
3.785 \\
0.06309 \\
0.2070 \\
1.609 \\
2.590 \\
25.40 \\
28.32 \\
17.60 \\
0.3048 \\
0.0929 \\
703.1 \\
0.1894
\end{gathered}
$$

To obtain metric units

hectare

cubic meter

meter

liter

liter per day

liter per second

liter per second per meter

kilometer

square kilometer

millimeter

liters per second

liters per second per kilometer meter per day

meter squared per day

kilograms per square meter

meter per kilometer

Chemical concentrations are given only in metric units -- milligrams per liter $(\mathrm{mg} / \mathrm{L})$ and micrograms per liter $(\mu \mathrm{g} / \mathrm{L})$. Degrees Fahrenheit are converted to degrees Celsius as follows: ${ }^{\circ} \mathrm{C}=\left[(5 / 9)^{\circ} \mathrm{F}\right]-32$

National Geodetic Vertical Datum of 1929 (NGVD of 1929): A geodetic datum derived from a general adjustment of the first-order level nets of both the United States and Canada, formerly called mean sea level. NGVD of 1929 is referred to as sea level in this report. 


\title{
WATER RESOURCES ON THE PUEBLO OF LAGUNA, WEST-CENTRAL NEW MEXICO
}

\author{
by Dennis W. Risser and Forest P. Lyford
}

\section{ABSTRACT}

The Pueblo of Laguna, located on semiarid lands in west-central New Mexico, needs additional quantities of water chemically suitable for public supply and irrigation. This study evaluates the quantity and quality of water available on the Pueblo of Laguna.

Ground water for public supply can be found in the valley fill along the Rio San Jose, in the Paguate and Encinal areas, and possibly in the northern part of the Sedillo Grant. The valley fill along the Rio San Jose at the mouths of Cubero and Encinal Creeks will supply 50 to 450 galions per minute of water containing 500 to 1,200 milligrams per 1iter of dissolved solids to properly constructed wells. In the alluvium along Rio Paguate, as much as 250 gallons per minute of ground water containing 300 to 500 milligrams per liter of dissolved solids can be developed. Sandstone units in the Morrison Formation will yield 5 to 50 gallons per minute of water containing 500 to 1,500 milligrams per liter of dissulved solids to properly constructed wells. About 15 to 30 gallons per minute of water from Encinal Springs are present1y (1982) used for public supply for the village of Encinal. An additional 70 to 85 gallons per minute of springflow containing less than 200 milligrams per liter of dissolved solids is suitable for public supply. The Dakota Sandstone near Encinal also may supply water suitable for public supply. About 20 to 50 gallons per minute of water containing 800 to 1,200 milligrams per liter of dissolved solids may be obtained in this area. Tertiary sediments that fill a graben structure near Canon de los Apaches on Sedillo Grant may yield 20 to 100 gallons per minute of water containing 300 to 1,500 milligrams per liter of dissolved solids to properly constructed wells.

Ground water for irrigation is restricted by available well yields and quality to the valley fill along the Rio San Jose and possibly the western part of the Major's Ranch area. In the Rio San Jose valley west of New Laguna, well yields of 50 to 450 gallons per minute of water containing 1,200 to 3,000 milligrams per liter of dissolved solids can be obtained. At the mouths of Cubero and Encinal Creeks, dissolved-solids concentrations are less, about 500 to 1,200 milligrams per 1iter. Digital-model simulations of the valley-fill aquifer west of the village of Laguna show a potential evapotranspiration salvage of as much as 900 acre-feet per year if water levels are lowered. On the western part of the Major's Ranch area, the Morrison Formation may yield several hundred gallons per minute of water containing 1,000 to 2,000 milligrams per liter of dissolved solids to properly constructed wells. 
As much as 300 acre-feet of additional surface water could be used for irrigation from the Rio Paguate if water flow into the pueblo during winter months were stored in a reservoir. Digital-model studies indicate that the winter flow of the Rio San Jose could be used to recharge the ground-water reservoir in the valley.

\title{
INTRODUCTION
}

\author{
Purpose and Scope
}

The economic growth of the Pueblo of Laguna and the lifestyle of the Laguna people are dependent, to a great extent, upon the availability of water for irrigation and public supply. Because ground- and surface-water resources on the pueblo are limited, detailed knowledge of these resources is needed to insure their protection and efficient use.

In response to the need for hydrologic information expressed by the Laguna Indians, the U.S. Bureau of Indian Affairs in 1970 requested a comprehensive study of the hydrology on the Pueblo of Laguna. The resulting plan of study consisted of a qualitative investigation followed by an intensive hydrologic investigation. The findings of both phases of the study are presented in this report.

The purpose of this study was to assess the quality and quantity of ground and surface water on the Pueblo of Laguna. The work focused on aspects of the hydrologic system that were recognized in the early phase of the investigation as needing further study. Specific objectives of this study were to: (1) Define areas of potential ground-water development for irrigation and public supply; (2) estimate the availability and suitability of surface water for irrigation; (3) predict possible long-term effects of ground-water withdrawals in the Rio San Jose valley on water levels and streamflow; and (4) report the results of test drilling.

The scope of this study was limited to ground- and surface-water resources on the pueblo that could be used for irrigation and public supply. However, brackish-water resources, which may be important in the future as the demand for water increases, also are discussed briefly in this report.

\section{Location and geographic setting}

The Pueblo of Laguna is located in west-central New Mexico (fig. 1). Pueblo lands consist of about 690 square miles, which include the original Spanish grant and lands acquired later by purchase and executive order. The 


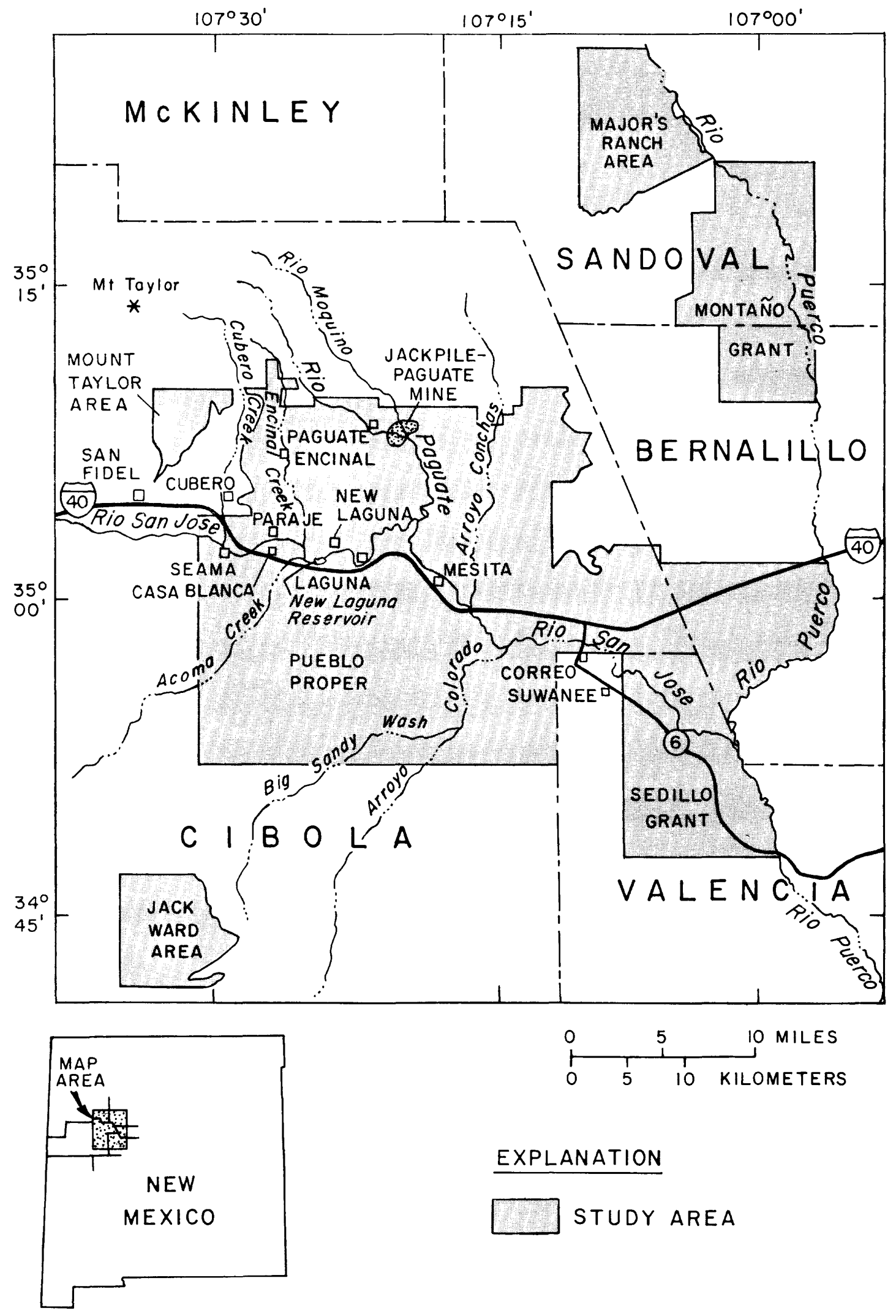

Figure 1.--Location of study area. 
major divisions of the pueblo referred to in this report are: Pueblo Proper, Sedillo Grant, Montaño Grant, Mount Taylor Area, Major's Ranch Area, and Jack Ward Area.

Most of the pueblo lands are situated in the Datil section of the Colorado Plateaus physiographic province (Fenneman, 1931). The province is characterized by high mesas, canyons, and abundant evidence of volcanic activity. The Puerco fault zone passes through the Montaño and Sedillo Grants and is the boundary separating the Colorado Plateaus province from the Rio Grande trough to the east. The most prominent feature in the area is Mount Taylor, northwest of the Pueblo of Laguna, which rises to an altitude of 11,301 feet.

The major stream on the pueblo is the Rio San Jose, which flows eastward through the center of the Laguna lands. The stream empties into the Rio Puerco at the southeast corner of the pueblo. Major tributaries of the San Jose include: Cubero Creek, Encinal Creek, Acoma Creek, Rio Paguate, Arroyo Conchas, and Arroyo Colorado.

The climate of the area is semiarid with mean annual precipitation of 7.8 inches and mean annual temperature of $53.3^{\circ}$ Fahrenheit at Laguna (New Mexico State Engineer Office, 1956a, and U.S. Department of Commerce, 1955-79).

The resident population on the Pueblo of Laguna in 1980 was 6,233 (Daniel Carr, U.S. Bureau of Indian Affairs, written commun., 1980). The population distribution by village was as follows: Casa Blanca (303), Encinal (347), Laguna (1,585), Mesita (791), Paguate (1,483), Paraje (791), and Seama (933).

\section{Previous investigations}

A number of hydrologic studies have been conducted on or near the Pueblo of Laguna. A report on ground water in eastern Valencia County by Titus (1963) contains data for wells on Sedillo Grant and Major's Ranch area. Dinwiddie (1963) briefly described the ground-water resources in the vicinity of Paguate. The availability of ground water on parts of the Pueblos of Acoma and Laguna was studied by Dinwiddie and Motts (1964). Their report includes the results of exploratory drilling and aquifer testing in the alluvium along the Rio San Jose and its tributaries. Cooper and West (1967) wrote a general report describing the major aquifers between the Pueblo of Laguna and city of Gallup, New Mexico. 


\section{Acknowledgments}

Several individuals and companies provided data and assistance during the course of this project. John Martinez of the Pueblo of Laguna acted as interpreter during onsite investigations, collected historical data pertaining to wells and springs from tribal members, and made monthly water-level measurements. Ray Johnson of the Pueblo of Laguna also made monthly measurements of ground-water levels and surface-water quality on the pueblo. Daniel Carr of the U.S. Bureau of Indian Affairs provided information on many occasions on wells and irrigation systems on the Pueblo of Laguna. Norm Fairbanks, Field Engineer for the Indian Health Service, provided information on public-supply wells and the water-distribution system of the pueblo. Many water samples were analyzed by the U.S. Bureau of Indian Affairs' Soils, Water, and Materials Testing Laboratory in Gallup, New Mexico. The Anaconda Company, El Paso Natural Gas Company, and Transwestern Pipeline Company provided useful information pertaining to their water-related activities. The Continental Oil Company provided data for exploratory test holes on Montaño Grant, and Standard Oil of Ohio (Sohio) provided information for their deep wells north of the pueblo.

\section{Site-identification numbering system}

The location of wells, springs, and surface-water sampling sites in this report is identified by a number based on the common subdivision of lands into townships, ranges, and sections. Section lines are extended from sectionized lands across previously unsectionized areas for the purpose of accurately locating wells, springs, and other features.

The location number based on the township-range system is divided by periods into four segments. The first indicates the township north of the New Mexico Base Line, and the second denotes the range west of the New Mexico Principal Meridian. The third segment is the number of the section within the township, and the fourth segment indicates the tract within which the well or spring is situated. To determine the fourth segment of the location number, the section is divided into four quarters numbered 1, 2, 3, and 4 for the $\mathrm{NW}^{\frac{1}{4}}, \mathrm{NE}^{\frac{1}{4}}, \mathrm{SW}^{\frac{1}{4}}$, and $\mathrm{SE} \frac{1}{4}$, respectively. Where map accuracy permits, these quarters are further subdivided down to the nearest 10-acre tract. The numbers are based on a 1-mile-square section that is determined from the southeast corner of the section. The use of zeros in the fourth segment of the location numbers indicates that the well or spring could not be accurately located. For example, well number 9.7.28.400 would indicate that the well could not be located any closer than the southeast quarter of section 28. Letters a, b, c, d, and e are added to the last segment to designate the second through sixth wells in the same 10-acre tract. An example of the numbering system is shown in figure 2 . 


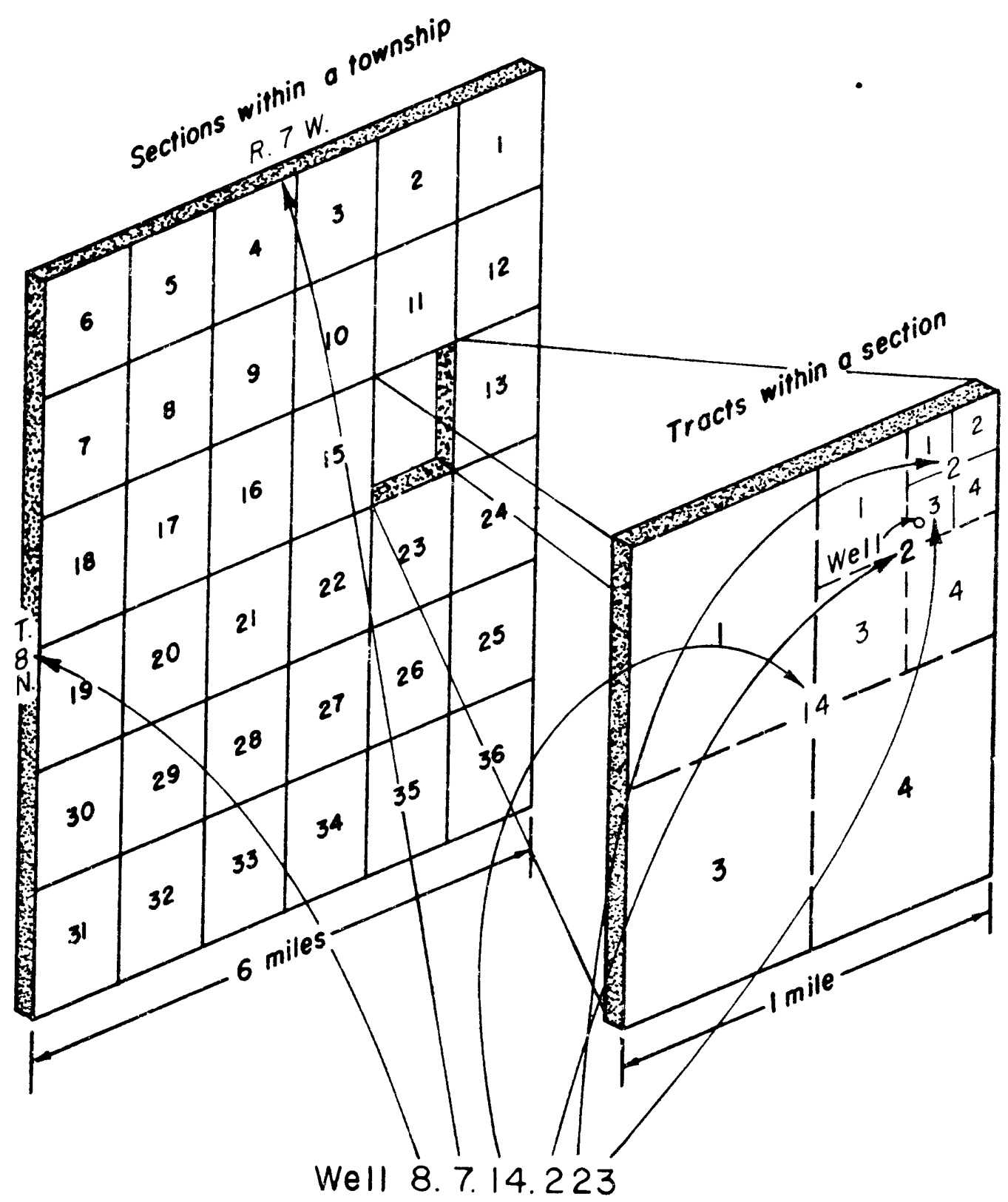

Figure 2.--Method of numbering wells, springs, and surface-water sites. 
Methods of investigation

The hydrologic investigation began with an inventory of a11 we1ls and springs located on or near the Pueblo of Laguna except for those on the Major's Ranch area, which was purchased by the pueblo after the inventory was complete. The wells and springs are listed in tables 1 and 2 (all tables are at the back of the report); their locations are shown on plate 1.

The potential yields of aquifers on the Pueblo of Laguna were evaluated by a program of well drilling and aquifer testing. The locations of new test wells and wells selected for pumping are shown on figure 3. Eight shallow test holes were drilled in the alluvium along the Rio San Jose, Encinal Creek, Seco Canyon, and Castillo Canyon. Three deeper wells were drilled on the Pueblo Proper and Mount Taylor area to test bedrock aquifers. Descriptions of formation cuttings for all new test wells are listed by location number in table 3. Samples of the formation cuttings and geophysical logs of the test wells are on file at the U.S. Geological Survey, Al buquerque, New Mexico.

Nine of the 11 new wells and 6 existing stock, public-supply, or irrigation wells were pumped to evaluate aquifer properties. Results of these tests and other previously reported tests are summarized in table 4.

To evaluate surface- and ground-water relations, water levels in 10 shallow wells completed in the alluvium along the Rio San Jose valley were monitored monthly (fig. 3). Continuous recorders were placed on wells 10.7.36.322 (Laguna 76-2) and 10.6.35.342 (Pueblo Test 2). Water levels were also measured monthly in three deep wells that are completed in bedrock aquifers.

Samples of ground and surface water were collected and analyzed for major ions, nutrients and minor elements, trace elements, and radiochemicals. Results of the water analyses collected from selected wells and springs are listed in tables 5-8. Water-quality samples of surface waters were collected from the Rio Puerco, Rio San Jose, and some tributaries of the Rio San Jose. These analyses are 1isted in tables 9-13.

A 2-dimensional digital-computer model was used to help evaluate some alternative plans of ground-water development in the alluvium along the Rio San Jose. The model simulates ground-water flow in the valley between the western boundary of the pueblo and the village of Laguna. 


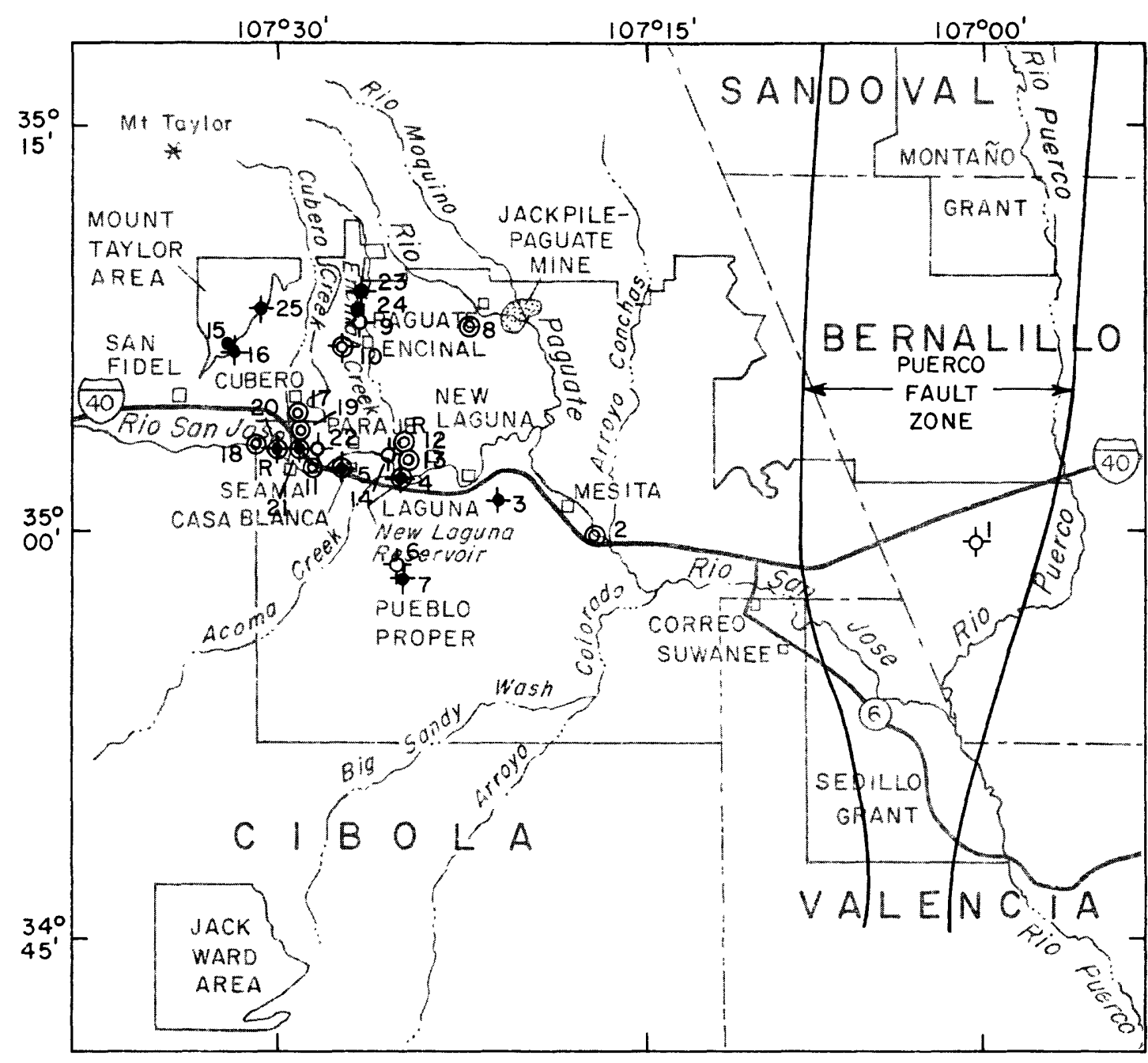

\begin{tabular}{|c|c|c|}
\hline $\begin{array}{l}\text { NUMBER } \\
\text { ON } \\
\text { FIGURE }\end{array}$ & $\begin{array}{l}\text { WELL } \\
\text { NAME }\end{array}$ & $\begin{array}{l}\text { LOCATION } \\
\text { NUMBER }\end{array}$ \\
\hline $\begin{array}{l}1 \\
2 \\
3 \\
4 \\
5 \\
6 \\
7 \\
8 \\
9 \\
10 \\
11 \\
12 \\
13 \\
14 \\
15 \\
16 \\
17 \\
18 \\
19 \\
20 \\
21 \\
22 \\
23 \\
24 \\
25\end{array}$ & $\begin{array}{l}\text { BIA Sedillo } \\
\text { El Rito } \\
\text { Laguna } 78-1 \\
\text { Laguna } 76-7 \\
\text { Laguna } 76-6 \\
\text { RWP } 24 \\
\text { Timia Well } \\
\text { MDH } 771 \\
\text { Encinal } 1 \\
\text { Encinal } 2 \\
\text { Seama P.S. } \\
\text { Pueblo Test } 1 \\
\text { Pueblo Test } 2 \\
\text { Laguna Irrigation } 2 \\
\text { Seco Canyon } 1 \\
\text { Laguna } 79-1 \\
\text { Abandoned New York } \\
\text { Irrigation Test } 6 \\
\text { New York } 1 \\
\text { Laguna } 76-2 \\
\text { Laguna } 76-1 \\
\text { Laguria Irrigation } 1 \\
\text { Encinal Canyon } 1 \\
\text { Encinal Canyon } 2 \\
\text { Castillo Canyon } 1\end{array}$ & 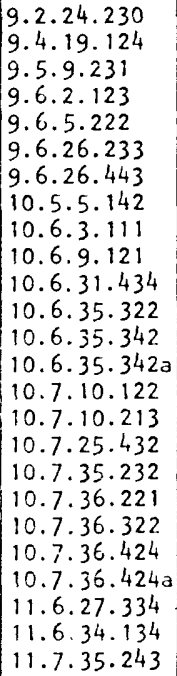 \\
\hline
\end{tabular}

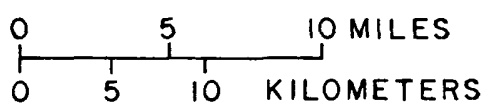

\section{EXPLANATION}

- WELL

-\$ WELL WITH AQUIFER TEST (See table 4)

$\bigcirc_{R}$ OBSERVATION WELL--" $R$ " indicates continuous water-level recorder.

NOTE: Solid circle (•) indicates well that was drilled for this study.

Figure 3.--Location of test wells and ground-water monitoring sites. 


\title{
GROUND WATER
}

\author{
Hydrologic properties of geologic units
}

Geologic units that crop out on and around the Pueblo of Laguna range in age from Permian to Holocene. The location and distribution of these units are shown on the geologic map of the pueblo (plate 2) and on geologic sections (plate 3 ). The geologic characteristics, general water quality, and well yields that may be expected from the different geologic units are summarized in table 14.

The areas on the Pueblo of Laguna that have geologic units capable of providing water of suitable quality for public supply, irrigation, and stock are shown on plate 1. The contoured water levels (plate 1) indicate only the elevation of water beneath the pueblo in various geologic formations; the reader should not assume that formations are hydraulically connected or that ground water flows perpendicular to the contours. The geologic units on the Pueblo of Laguna and their hydrologic properties are discussed in detail in the following sections.

\section{Permian System}

Permian rocks in the study area include limestone, sandstone, siltstone, and gypsum of the Yeso Formation, Glorieta Sandstone, and San Andres Limestone. These units crop out on Mesa Lucero in the southern part of the Sedillo Grant. Permian units probably are not major aquifers and would supply water with excessive dissolved-solids concentrations to wells in the study area. The water-bearing characteristics of the Glorieta Sandstone and San Andres Limestone warrant special discussion because: (1) Some data exist for the study area; (2) these units are important aquifers in some parts of New Mexico, particularly the Grants-Bluewater area (Gordon, 1961); and (3) many individuals and companies have expressed an interest in the water-bearing properties of these units in the study area.

Glorieta Sandstone and San Andres Limestone--The Mesita test hole $(9.5 .12 .442)$ was drilled by the U.S. Bureau of Indian Affairs during 1963 and 1964 to test the San Andres Limestone and Glorieta Sandstone for water yield and quality. G. A. Dinwiddie and S. W. West (U.S. Geological Survey, written commun., 1965) believed that the well did not fully penetrate the Chinle Formation at a total depth of 1,729 feet. However, re-examination of cuttings from the well during this study led to the conclusion that the limestone, starting at a depth of about 1,615 feet, is the San Andres and that sandstone beds near the total depth are part of the San Andres Limestone. 
The Mesita test hole had a shut-in pressure of 170 pounds per square inch and yielded 15 gallons per minute when allowed to flow. Specific capacity of the well computed from these data is 0.04 gallon per minute per foot of drawdown.

Other deep wells on or near the pueblo that may have penetrated the San Andres include one 8 miles south of Mesita (8.5.17.213) and one about 1 mile south of Suwanee $(8.3 .15 .413$ ) (table 1$)$. Both wells were drilled by the Atchison, Topeka, and Santa Fe Railway early in this century. In 1974, well 8.5.17.213 flowed less than 0.5 gallon per minute, and the specific conductance of the water was 82,800 micromhos (micromhos per centimeter at $25^{\circ}$ Celsius) (table 5); we11 8.3.15.413 flowed less than 24 gallons per minute and had a specific conductance of 15,800 micromhos. Gas from this well is predominantly carbon dioxide with a little helium, hydrogen, argon, and nitrogen (J. L. Kunkler, U.S. Geological Survey, written commun., 1974).

Shell oil Company drilled a deep oil test hole (9.1.8.142) at the east edge of the pueblo on Sedillo Grant. Tests of the well showed that water in the Glorieta Sandstone had a dissolved-solids concentration of about 15,500 milligrams per liter and that the San Andres Limestone was not a permeable reservoir rock for oil production (N. J. Isto, Shell Oil Company, written commun., 1973).

A well north of Paguate in the Bibo area (11.5.14.241) drilled in 1974 by Standard Oil of Ohio (Sohio) to a depth of 3,390 feet penetrated the San Andres Limestone and Glorieta Sandstone. Water rose in the well to within 10 feet of the land surface. The well was pumped at 5 gallons per minute, which lowered the water level 390 feet, giving a specific capacity of 0.01 gallon per minute per foot (Dr. Lynn Jacobson, Sohio, oral commun., 1975).

Evidently, the conditions that create significant permeabilities in carbonate rocks in the Grants-Bluewater area do not exist in the study area. A long period of erosion prior to deposition of the overlying Triassic Chinle Formation either did not create solution permeability or the permeability was later destroyed. The likelihood of obtaining large yields of water chemically suitable for public supply and irrigation in rocks of Permian age under the Pueblo of Laguna probably is small.

\section{Triassic System}

The Triassic System on the Pueblo of Laguna consists of siltstones and mudstones of the Chinle Formation. Occasional sandstone beds in the formation are minor aquifers of local importance.

Chinle Formation of Late Triassic age lies beneath all Laguna lands with the exception of several small areas on Sedillo Grant, where it was displaced by faults and subsequently eroded (plate 2). The formation crops out or is covered by a veneer of alluvium in the southeast section of the Pueblo Proper 
and dips gently to the north and west. The Petrified Forest Member of the Chinle Formation is composed of as much as 1,500 feet of grayish-red siltstones and mudstones; the Petrified Forest Member contains the Correo Sandstone Bed, which is composed of as much as 100 feet of grayish-red, arkosic sandstone in the upper part of the Petrified Forest Member (Moench and Schlee, 1967).

Wells completed in only the Petrified Forest Member of the Chinle Formation probably have ylelds of less than 5 gallons per minute. Wells 8.6.21.224 (RWP 30) and 8.6.24.412 (RWP 22) completed in the Petrified Forest Member were reported as "dry holes" at depths greater than 400 feet.

The Correo Sandstone Bed of the Petrified Forest Member is the most productive water-bearing unit in the Chinle Formation although its areal extent is restricted to a narrow zone between Mesita and Correo. Water from the Correo Sandstone Bed is pumped from wells 9.5.24.413 (EPNG 3 ) and 9.5.24.414 (EPNG 2) by the E1 Paso Natural Gas Company. About 1 mile to the northeast, yearly water-level fluctuations of 6 to 14 feet were recorded at well 9.4.19.124 (E1 Rito) in response to withdrawals from the E1 Paso wells at rates that averaged from 25 gallons per minute during summer months to less than 1 gallon per minute during winter months (Pat Adkins, El Paso Natural Gas Company, oral commun., 1979) (fig. 4). The large water-level fluctuations in the El Rito well and the small areal extent of the aquifer Indicate that the sandstone could not support large withdrawals of ground water. Although the El Paso Natural Gas Company wells were tested at rates as great as 40 gallons per minute (D.C. Kelly, El Paso Natural Gas Company, written commun., 1973), the Correo Sandstone Bed probably is able to sustain yields of only 5 to 20 gallons per minute for long periods.

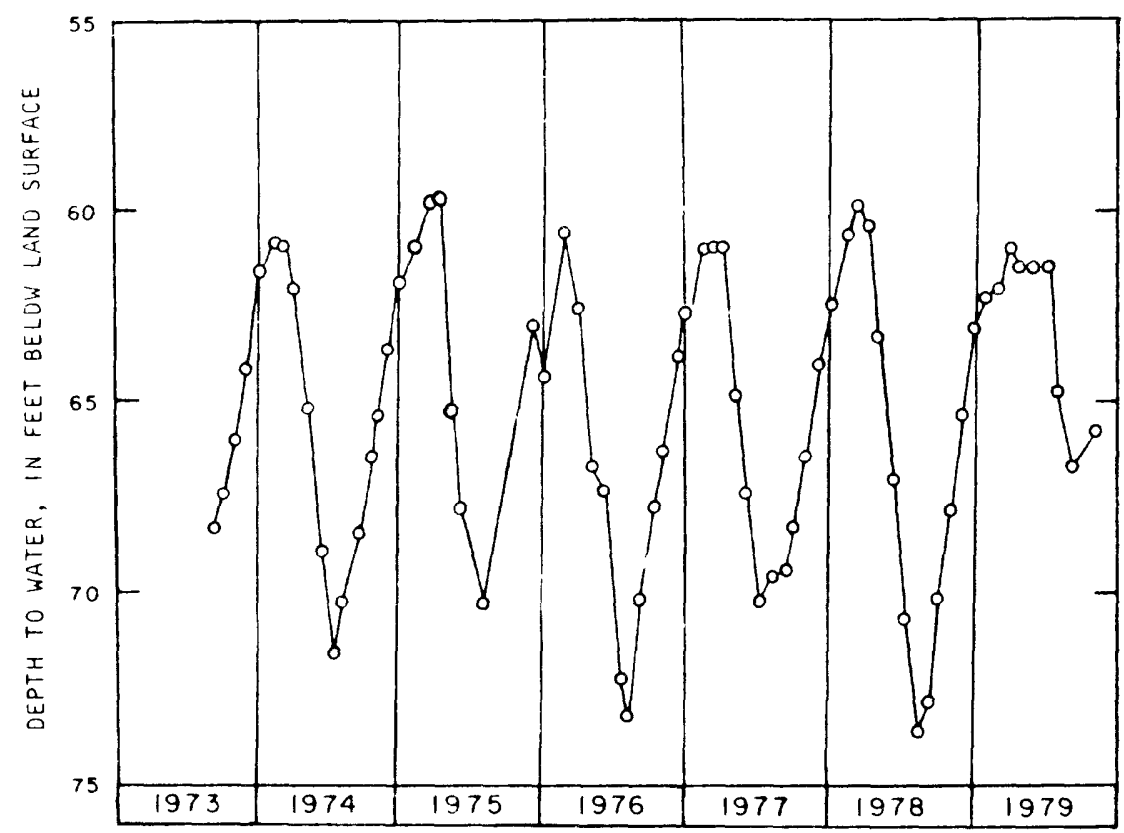

Figure 4.--Water-level fluctuations in well 9.4.19.124 (El Rito), 1973-79. 


\section{Jurassic System}

Jurassic rocks on the Pueblo of Laguna include the Entrada Sandstone, Todilto Formation, Summerville Formation, Bluff Sandstone, and Morrison Formation. Many stock wells and a few public-supply and industrial wells on the pueblo obtain water from the Jurassic sandstone units.

Entrada Sandstone--The Entrada Sandstone of Middle Jurassic age lies beneath all Laguna lands with the exception of the southeast corner of the Pueblo Proper and small parts of the Jack Ward area and Sedillo Grant (plate 2). The sandstone crops out from the northeast to southwest across the Pueblo Proper and dips about 50 feet per mile to the north and west. Three units are recognized in the Entrada Sandstone: (1) A basal, fine- to coarse-grained, crossbedded sandstone; (2) a medial silty member; and (3) an upper unit composed of a fine to medium-grained, crossbedded sandstone (Moench and Schlee, 1967). The three geologic units are considered together in this report as a single hydrologic unit.

Wells deriving water from the Entrada primarily are used to water stock because yields are small and the quality is marginal for other uses. Well 9.5.13.233 (Mesita P.S.), however, provides part of the public supply for the village of Mesita. This well is completed in both the Correo Sandstone Bed of the Petrified Forest Member of the Chinle Formation and Entrada Sandstone.

The hydrologic properties of the Entrada were tested in two wells (9.6.26.443, Timia We11; and 9.5.9.231, Laguna 78-1), both drilled to the top of the Chinle Formation (fig. 3 and tables 1 and 3 ). The Timia well produced less than 1 gallon per minute from a 495-foot, open-hole section that included the Bluff Sandstone, Summerville Formation, Todilto Formation, and Entrada Sandstone. Laguna 78-1, drilled in the sand-dune area south of Laguna, produced water mainly from the Todilto Formation. Little additional water was yielded from the Entrada Sandstone. Transmissivity values for the Entrada at both locations probably are minimal.

Reported yields from the Entrada Sandstone on other areas of the pueblo also are small. The Standard well (9.6.4.433) flowed at a rate of 3 gallons per minute with a shut-in pressure of $51 / 2$ pounds per square inch, giving a specific capacity of 0.24 gallon per minute per foot of drawdown. The Paraje deep test hole (10.6.33.122) was bailed dry following completion. It is probable that sustained yields from the Entrada Sandstone will be less than 10 gallons per minute on Laguna lands.

Todilto Formation--North of the Rio San Jose valley, the Todilto Formation of Middle Jurassic age, mainly consists of 100 feet or less of gypsum overlying 40 feet or less of limestone. Anhydrite occurs in place of gypsum at depths greater than 1,000 feet (Moench and Schlee, 1967, p. 12). Gypsum occurs in isolated areas on mesas south of the Rio San Jose valley, and the limestone pinches out south of the Pueblo Proper (plate 2). 
We11 9.5.9.231 (Laguna 78-1) was drilled in 1978 to a depth of 510 feet to test water quality and yields in Jurassic units. The well penetrated sandstones and siltstones of the Bluff Sandstone and Summerville Formation to a depth of 280 feet. A 70-foot thickness of Todilto Formation, composed primarily of gypsum, was penetrated from 310 to 380 feet, directly beneath about 30 feet of diabase. The diabase probably was part of one of the numerous dikes or sills that crop out in the vicinity of the well (Moench, 1963a). At the bottom of the hole, between depths of 380-503 feet, the Entrada Sandstone was present (table 3). The we11 was completed only with 30 feet of surface casing. Therefore, water could be contributed to the well from the Bluff Sandstone and Summerville Formation, Todilto Formation, and Entrada Sandstone. Because the dominant ions in the water are calcium and sulfate, possibly a large percent of the water produced by the well is contributed from gypsum in the Todilto Formation.

The well was pumped for 24 hours beginning on December 20, 1978 . Discharge averaged 74 gallons per minute for the first 820 minutes of the test but was decreased to 64 gallons per minute for the remainder of the test. The water level could not be measured from 660 to 840 minutes and 1,155 to 1,410 minutes into the test because the water level was below the access tubing in the wel1. Specific capacity calculated at the end of 660 minutes of pumping at 74 gallons per minute is 0.39 gallon per minute per foot of drawdown. Transmissivity of the aquifer is about 55 feet squared per day based on the first 100 minutes of drawdown data using the modified nonequilibrium formula (Ferris, and others, 1962, p. 98) (fig. 5). Drawdowns after 100 minutes of pumping appear to be affected by a barrier of less permeable material. This barrier could be caused by a change in the number of interconnected fractures in the Todilto Formation away from the well or by intersecting of the aquifer by one of the igneous intrusives near the well.

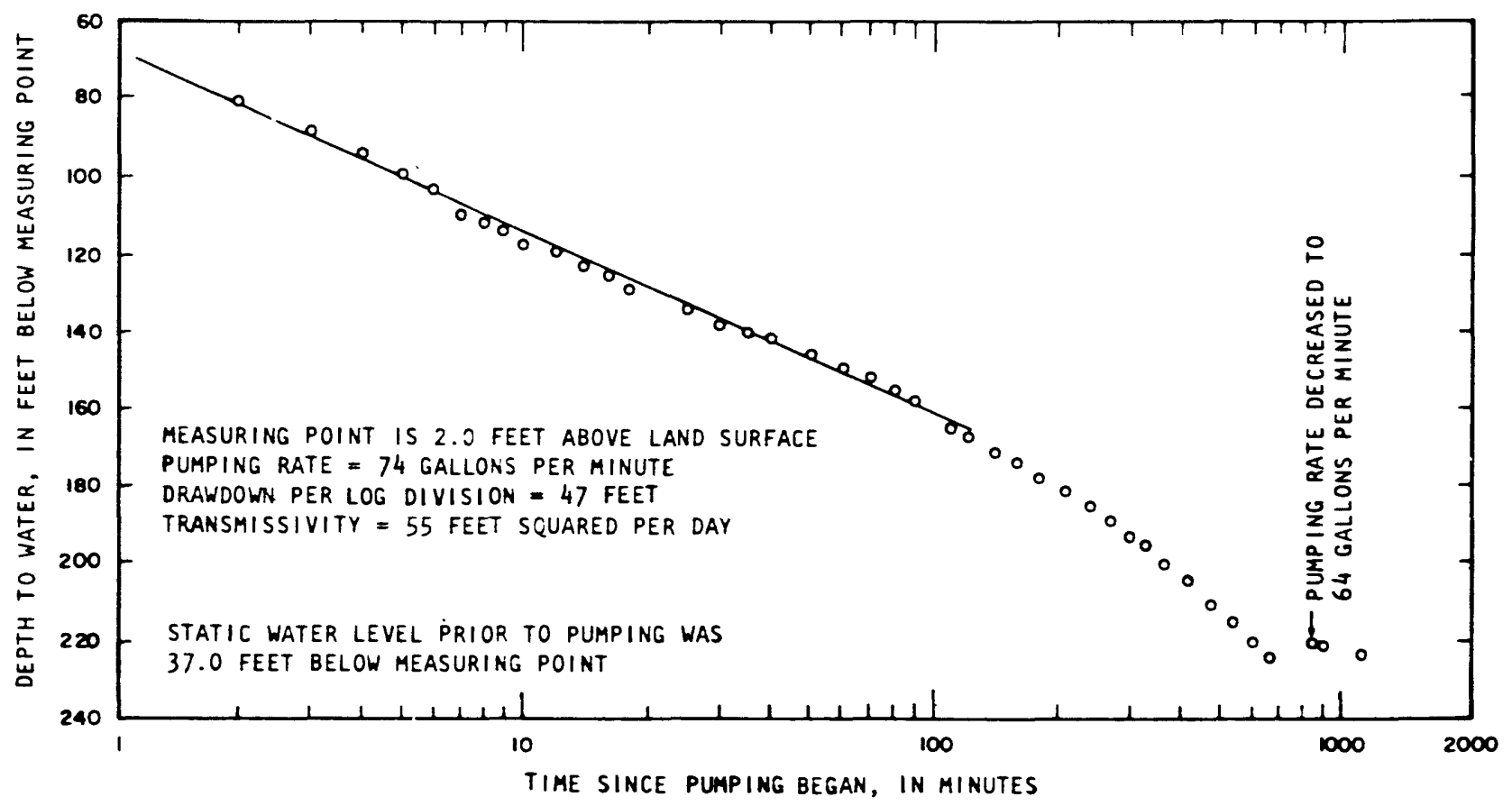

Figure 5.--Water-level drawdown from test of well 9.5.9.231 (Laguna 78-1). 
Two sinkholes and other evidence of solution and collapse near the Rio San Jose valley between Laguna and Mesita indicate that solution porosity and permeability may be present in this area. A sinkhole south of the Jackpile-Paguate mine $(10.5 .14 .234)$ probably is about 500 feet above the soluble Todilto gypsum, indicating the former occurrence of a large solution cavity. This sinkhole contains water at a depth of 50 feet.

Another sinkhole about 300 feet from Dipping Vat Spring (8.3.12.413) probably is the result of the solution of Todilto gypsum and collapse of the overlying Summerville Formation and Bluff Sandstone. The large flow from this spring, averaging more than 500 gallons per minute, may be partly due to solution permeability.

Summerville Formation--The Summerville Formation of Middle Jurassic age consists of alternating beds of mudstone and sandstone, which crop out from the southwest corner to the east-central part of the Pueblo Proper (plate 2). The Summerville Formation does not readily yield water to wells. Test wells 9.5.9.231 (Laguna 78-1) and 9.6.26.443 (Timia well), located south of the Rio San Jose, showed that no water flowed from the Summerville Formation during drilling. The $\log$ of well 10.6.33.213 (ECW 12) indicates that a sma11 quantity of water flowed from the Summerville Formation during drilling. No other wells on the pueblo are known to obtain water from this unit.

Bluff Sandstone--The Bluff Sandstone of Middle Jurassic age is present beneath all Laguna lands except the southeast part of the Pueblo Proper, along Acoma Creek, and small sections of the Sedillo Grant (plate 2). The sandstone crops out in a wide band across the center of the pueblo and dips to the north and northwest. The Bluff Sandstone consists of 200 to 400 feet of very fine to medium-grained, moderate to well-sorted sandstone. An upper eolian sandstone and a lower fluviatile sandstone can be recognized in some areas. The upper eolian sandstone is named the Zuni Sandstone and the lower fluviatile sandstone is named the Bluff Sandstone (C. H. Maxwell, U.S. Geological Survey, written commun., 1973). Both units are termed Bluff Sandstone in this report.

Most wells deriving water from the Bluff Sandstone are used to water stock because of the generally small well yields and water quality unacceptable for other uses. However, water suitable for public supply may be obtained from the Bluff Sandstone in outcrop areas south of the Rio San Jose valley. Yields are variable, however, ranging from less than $1 / 2$ gallon per minute in Transwestern Company wells and test holes (9.5.17.141 through 9.5.19.421 on table 1) to perhaps 30 gallons per minute or more in well 9.6.26.233 (RWP 24). 
The hydraulic properties of the Bluff Sandstone were tested on outcrop areas south of Laguna in stock well 9.6.26.233 (RWP 24) and test we1ls 9.6.26.443 (Timia) and 9.5.9.231 (Laguna 78-1) (fig. 3 and tables 1 and 3 ). Stock well 9.6.26.233 (RWP 24) was pumped for 8 hours at a rate of 5.1 gallons per minute, which resulted in lowering the water level in the well 1.1 feet (table 4). Transmissivity calculated from the test by the modified nonequilibrium method (Ferris and others, 1962, p. 98) is about 450 feet squared per day (fig. 6), a large value for the Bluff Sandstone. Drawdown data collected during the first 8 minutes of the test were not used due to fluctuations in the pumping rate.

A new test wel1, 9.6.26.443 (Timia), was drilled about $1 / 2$ mile south of stock well 9.6.26.233 (RWP 24) to verify the large yields and chemical quality of the water in this area. However, the well produced less than 1 gallon per minute from an interval that included not only the Bluff Sandstone but also the Summerville Formation, Todilto Formation, and Entrada Sandstone (table 3). This test indicates that the transmissivity of the Bluff calculated for stock well RWP 24 may be the result of local fracture permeability caused by igneous intrusives and faulting in the area (Moench, 1964b).

Test we11 9.5.9.231 (Laguna 78-1) seems to confirm the results of the Timia well test. Laguna $78-1$ was drilled by cable-tool method in the sand-dune area south of Laguna, where less than 1 gallon per minute of water was produced from the Bluff Sandstone. Apparently, when fractures are not encountered, yields are minimal from this formation. Sustained yields from wells, in general, may be expected to be less than 10 gallons per minute from the Bluff Sandstone.

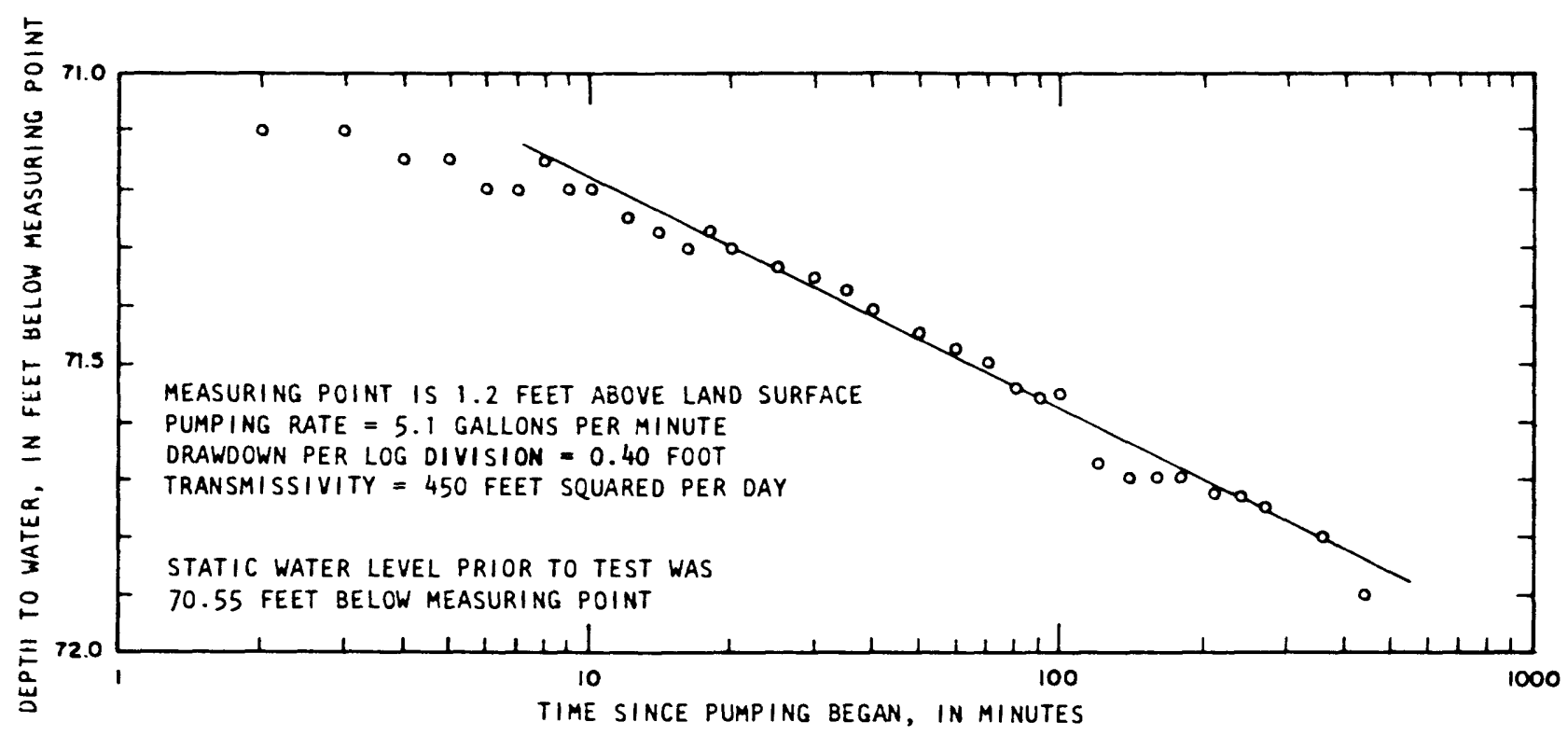

Figure 6.--Water-level drawdown from test of well 9.6.26.233 (RWP-24). 
Morrison Formation--The Morrison Formation of Late Jurassic age is present beneath the northern one-half of the Pueblo Proper and all outlying lands except the Jack Ward area. The Morrison crops out in areas shown on plate 2 and dips to the north and northwest into the San Juan Basin. The Morrison Formation is divided into three members and one informal unit. In ascending order the units are: (1) Recapture Member, composed of as much as 50 feet of interbedded mudstone, siltstone, sandstone, and limestone; (2) Westwater Canyon Member, composed of as much as 300 feet of fine- to coarse-grained sandstone; (3) Brushy Basin Member, composed of as much as 300 feet of interbedded mudstone, siltstone, sandstone, and limestone; and the Jackpile sandstone (economic usage), as much as 200 feet of kaolinitic sandstone within the Brushy Basin Member, which is restricted in location to a zone about 13 miles wide extending from Seama to the Major's Ranch area (Moench and Schlee, 1967 ).

The principal water-bearing units in the Morrison Formation are the Westwater Canyon Member and sandstones in the Brushy Basin Member, which include the Jackpile sandstone. Near Paguate, wells completed in the Westwater Canyon and Brushy Basin Members presently produce water for domestic, industrial, and stock uses. Most wells $\therefore$ in this area produce from 5 to 50 gallons per minute although well 11.5.27.322 (Anaconda 4) reportedly was pumped at 100 gallons per minute. In the Major's Ranch and Montaño areas, yields of several hundred gallons per minute may be possible from the Westwater Canyon Member. The rate of ground-water pumpage from Kerr McGee's Rio Puerco and Bokum's Marquez underground uranium mines averaged 1,400 and 1,030 gallons per minute during 1979 (New Mexico Environmental Improvement Division, 1980). Wel1 12.2.36.442 (Conoco WW-101) completed in the Westwater Canyon was pumped in 1976 at an average rate of 1,212 gallons per minute (D. K. Green and L. C. Halpenny, Water Development Corporation, written commun., 1976).

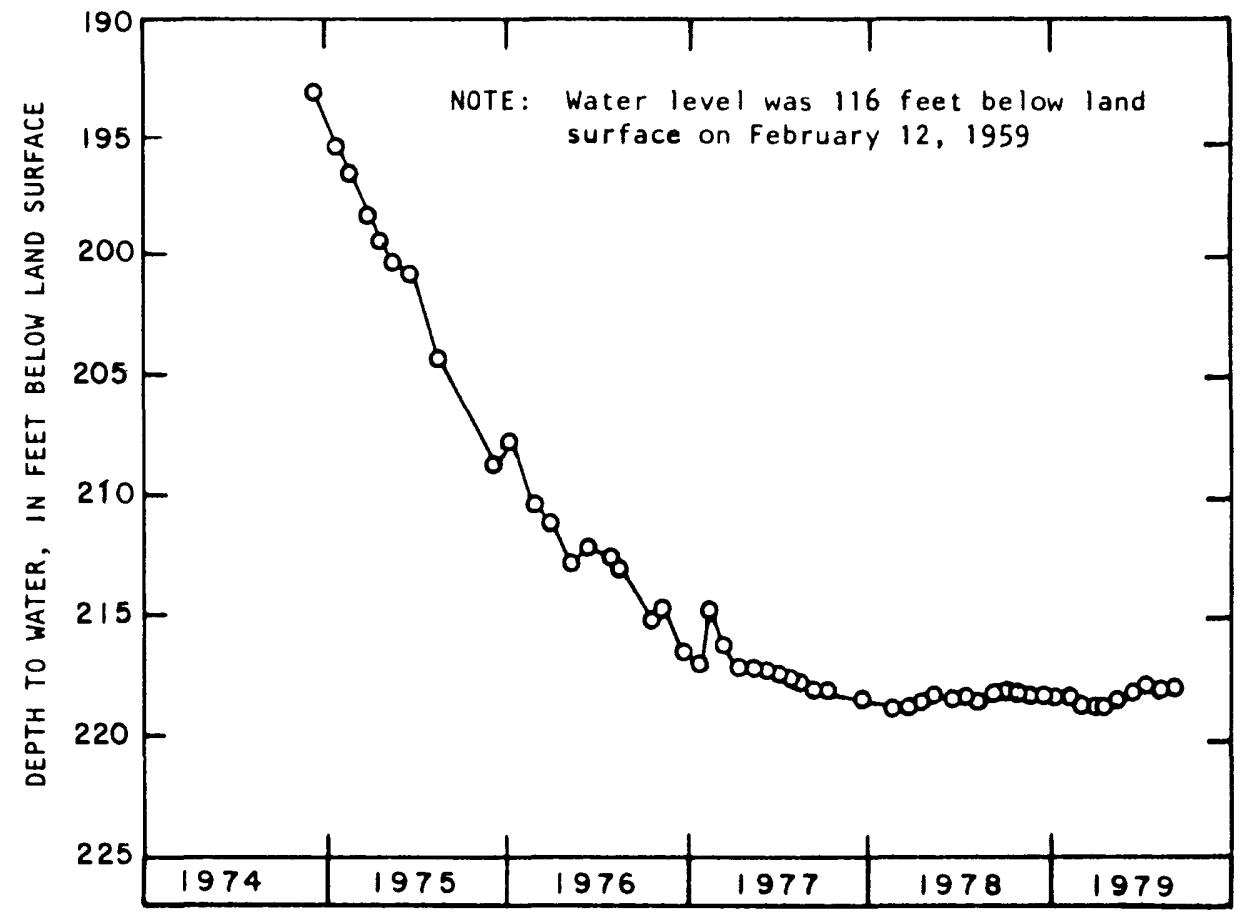

Figure 7.--Water-level declines in well 10.5.5.142 (MDH-771), 1974-79. 
The water level in well 10.5.5.142 (MDH-771), which is completed in the Jackpile sandstone, declined 25 feet from December 1974 to December 1977, at least partly in response to mine dewatering from Anaconda's underground workings ( $\mathrm{fig}, \mathrm{7}$ ). Dewatering for Anaconda's P-10 underground mine began in the fall of 1974 at a rate of 86,000 gallons per day and averaged 200,000 gallons per day during 1978 (U.S. Geological Survey, 1978). The water-level decline in well MDH-771 from 1959 to 1979 was about 102 feet. Apparently even before the start of underground mining in 1974, water levels had declined, possibly as a result of ground-water discharging into the pits excavated for the surface 'nining that began in the early 1950's.

Wel1 10.7.10.213 (Laguna 79-1) was drilled in 1979 in Seco Canyon on the Mount Taylor area to test yields and water quality of the Morrison Formation (fig. 3, tables 1 and 3). The aquifer of greatest interest was the Westwater Canyon Member of the Morrison Formation because of the large quantity of water yielded in the uranium mining areas west of the Pueblo of Laguna. A second reason for drilling a deep test well at this location was to monitor possible hydraulic-head declines in the Westwater Canyon Member due to extensive pumping from this unit by the uranium mines. The well was drilled to a depth of 1,330 feet and was open to the Dakota Sandstone and Westwater Canyon Member.

To determine hydraulic properties, the well was pumped for 24 hours at an average rate of 10 gallons per minute, which resulted in lowering the water level in the well 128 feet (table 4). Transmissivity of the open-hole section is 19 feet squared per day, calculated from the recovery data shown in figure 8 using the Theis recovery formula (Ferris and others, 1962, p. 100). The nonlinearity of the curve for recovery times of $t / t^{\prime}$ greater than 10 was probably caused by the effect of we11-bore storage. Therefore, late-time data were used to calculate transmissivity. The late-time drawdown data should have projected back to a residual drawdown of zero at $t / t^{\prime}=1$. The apparent incomplete recovery shown in figure 8 indicates that the hydrologic units supplying water may be of small size and therefore have experienced a permanent lowering of the water level, at least until leakage is received from adjacent units.

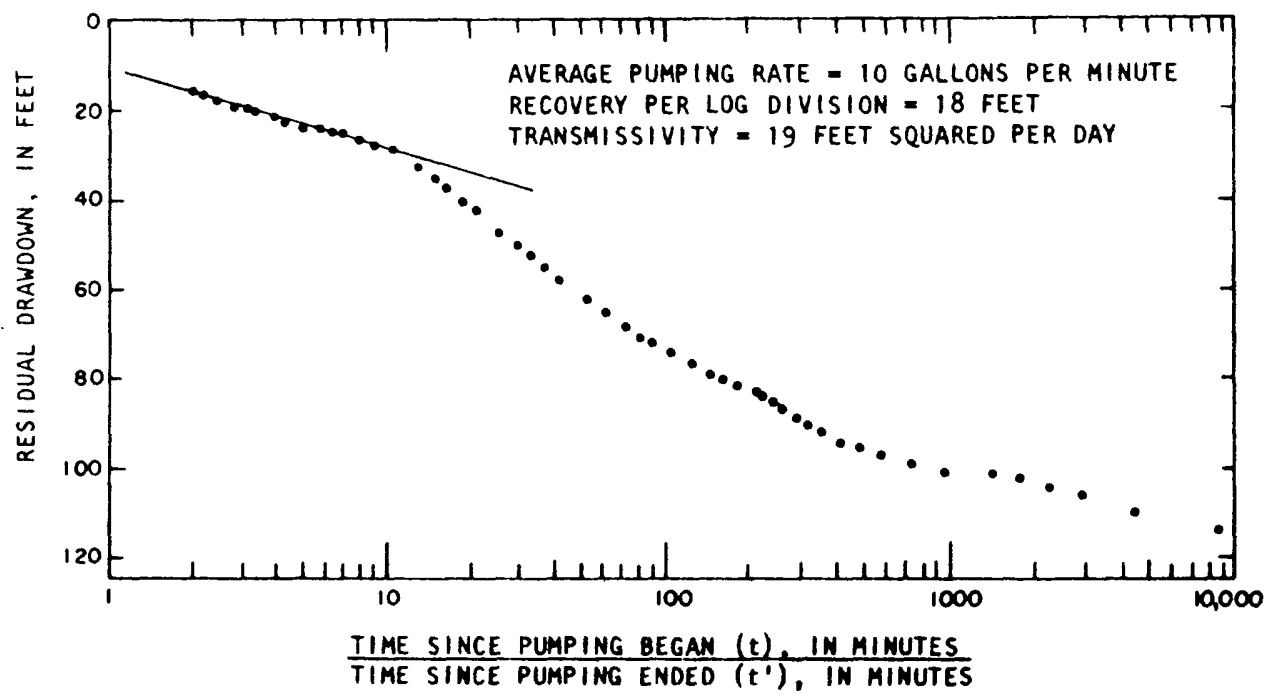

Figure 8.--Water-level recovery from test of well 10.7.10.213.(Laguna 79-1). 
The calculated transmissivity of 19 feet squared per day and well yield of 10 gallons per minute were unexpectedly small, especially because the formation samples of the Westwater Canyon Member showed it to be a well-sorted sandstone and neutron logs indicated significant apparent porosity. Possibly drilling mud had plugged the formation and was not properly removed during development of the well.

An aquifer test was conducted on well 12.2.36.442 (Conoco WW-101) by Continental Oil Company on the Montaño Grant. The well penetrated the entire thickness of the Westwater Canyon between depths of 1,381 and 1,685 feet. The well was pumped for 14 days at an average rate of 1,212 gallons per minute, which lowered the water level 470 feet in the well (D. K. Green and L. C. Halpenny, Water Development Corp., written commun., 1976). Transmissivity of the Westwater Canyon determined from the aquifer test was reported to be 240 feet squared per day; however, numerous faults in the area act as hydrologic boundaries that make the test results difficult to interpret.

\section{Cretaceous System}

On the Pueblo of Laguna, the Cretaceous System consists of the Dakota Sandstone, the Mancos Shale, and the Mesaverde Group. The geologic units with the greatest water-bearing capabilities are the Dakota Sandstone and sandstone units of the Mesaverde Group.

Dakota Sandstone--The Dakota Sandstone of Late Cretaceous age is present beneath the northern section of the Pueblo Proper and parts of all outlying Laguna lands (plate 2). The Dakota Sandstone is composed of four, fine- to coarse-grained, well-consolidated sandstone beds separated by intertonguing beds of Mancos Shale. Collectively, the sandstone beds range in thickness from 0 to 200 feet (Moench and Schlee, 1967). The sandstones and interbedded shales crop out in areas shown on plate 2 and dip to the north and northwest.

Most wells that penetrate the Dakota Sandstone yield less than 15 gallons per minute of water, which generally is used for stock purposes. However, near Encinal the Dakota yields 10 to 50 gallons per minute of potable water. Well 10.6.3.111 (Encinal 1), for example, is connected to the Encinal public-supply system to augment the better quality spring source when needed. Two aquifer tests were conducted by pumping wells 10.6.3.111 (Encinal 1) and 10.6.9.121 (Encinal 2) to better define the water resource in the Encinal area.

Well 10.6.3.111 (Encinal 1) was drilled in 1964 in the valley of Encinal Creek about 1 mile north of the village of Encinal. Bailing tests conducted by the driller in the open hole indicated a yield of at least 25 gallons per minute from a combined thickness of about 235 feet of Dakota Sandstone and Mancos Shale. After casing off all but the lower 25 feet of Dakota Sandstone, a pumping test was conducted on Encinal 1 by the driller. The 
we11 was pumped for an unknown duration at 14 gallons per minute with 63 feet of drawdown. The decrease in yield between the bailer test and pumping test possibly was caused by casing off the upper beds of Dakota Sandstone. The aquifer was tested again by pumping the well on November 17, 1978. The well was pumped for 24 hours at a rate that decreased irregularly from 44 to 8 gallons per minute. The pumping resulted in lowering the water level in the well 190 feet at the end of the test (table 4). Transmissivity of the aquifer could not be determined from the data collected during the test due to the irregular pumping rate.

Wel1 10.6.9.121 (Encinal 2) was drilled in 1964 about 1 mile west of Encinal. The well yield reportedly was tested in 1964 by pumping "all day" at 30 gallons per minute, which lowered the water level in the pumped well only 1 foot. To estimate transmissivity of the Dakota Sandstone, the well was pumped for 24 hours on November 8, 1978. The pumping rate decreased irregularly during the test from 100 to 47 gallons per minute and averaged 54 gallons per minute (table 4). To analyze the test, pumping was separated into 4 successive steps with average discharge rates of $100,69,60$, and 50 gallons per minute. Transmissivity estimated from the recovery data using the method of Harrill (1970, p. C212) is 2,000 feet squared per day (fig. 9).

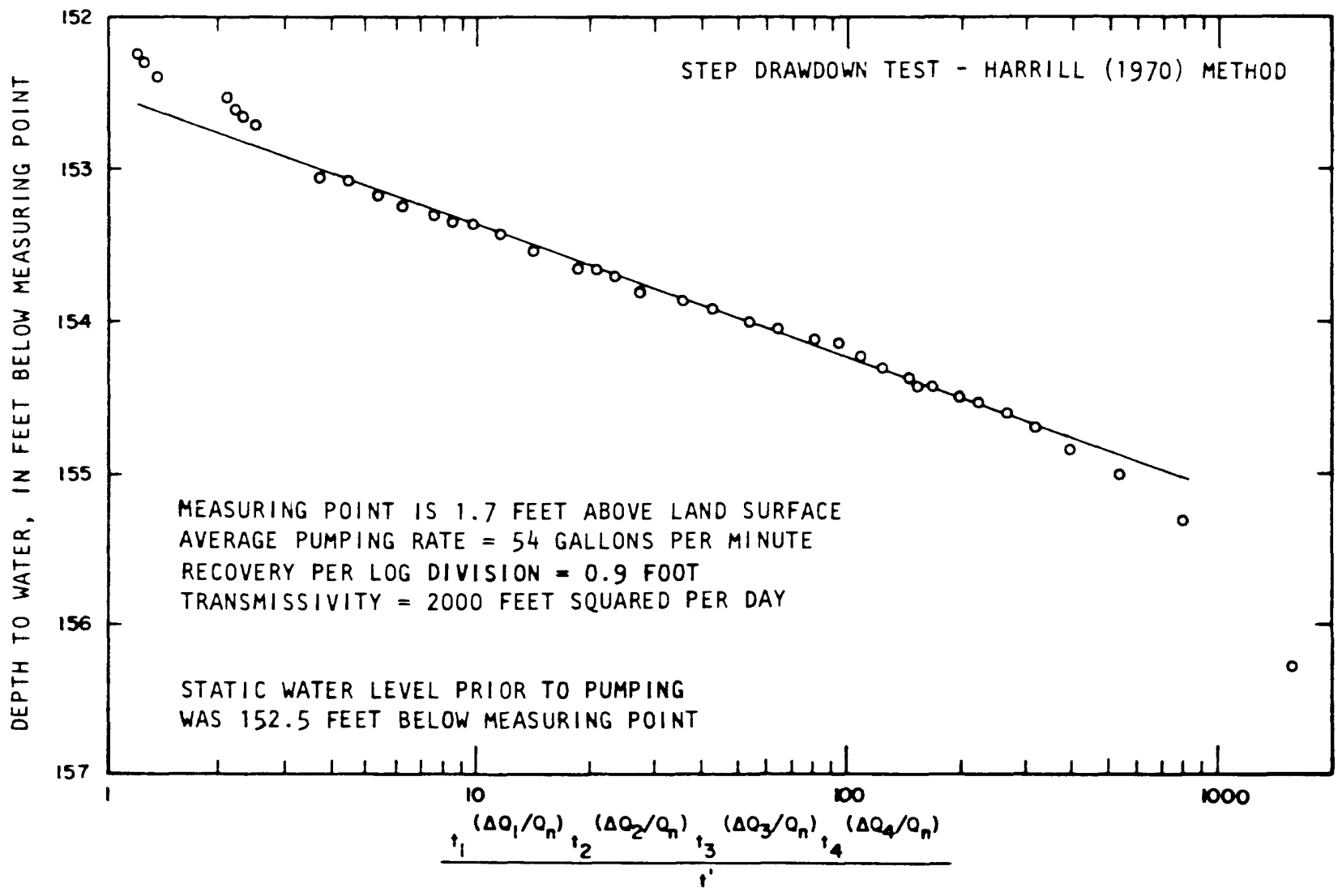

Figure 9.--Water-level recovery from test of well 10.6.9.121 (Encinal 2). 
A transmissivity of 2,000 feet squared per day is a large value for 20 feet of Dakota Sandstone; possibly, fracturing in the unit has increased the hydraulic conductivity in the vicinity of the well. The late-time recovery data ( $t / t^{\prime}$ less than 3 ) were not used to calculate this transmissivity value. The steeper slope of the late-time data indicates the possible effect of a hydrologic boundary of lesser permeability. The igneous intrusives mapped by Moench (1963b) about 1 mile west of the well could represent the hydrologic boundary indicated by the recovery curve. The fact that water levels recovered 0.3 foot above the initial static level may be due to a change in barometric pressure during the recovery period.

Mesaverde Group--Sandstone units of the Mesaverde Group of Late Cretaceous age, including the basal Gallup Sandstone, yield water to stock wells in the southern part of Montaño Grant and the northern part of Sedillo Grant. Reported yields for wells completed in the Mesaverde Group range from 8 to 30 gallons per minute in these areas. Well 11.7.35.243 (Castillo Canyon 1) yielded about 5 gallons per minute of water containing 670 milligrams per liter of dissolved solids from a 20-foot thickness of Gallup Sandstone on the Mount Taylor area. Some of the flow in Paguate Creek also may come from the Mesaverde Group.

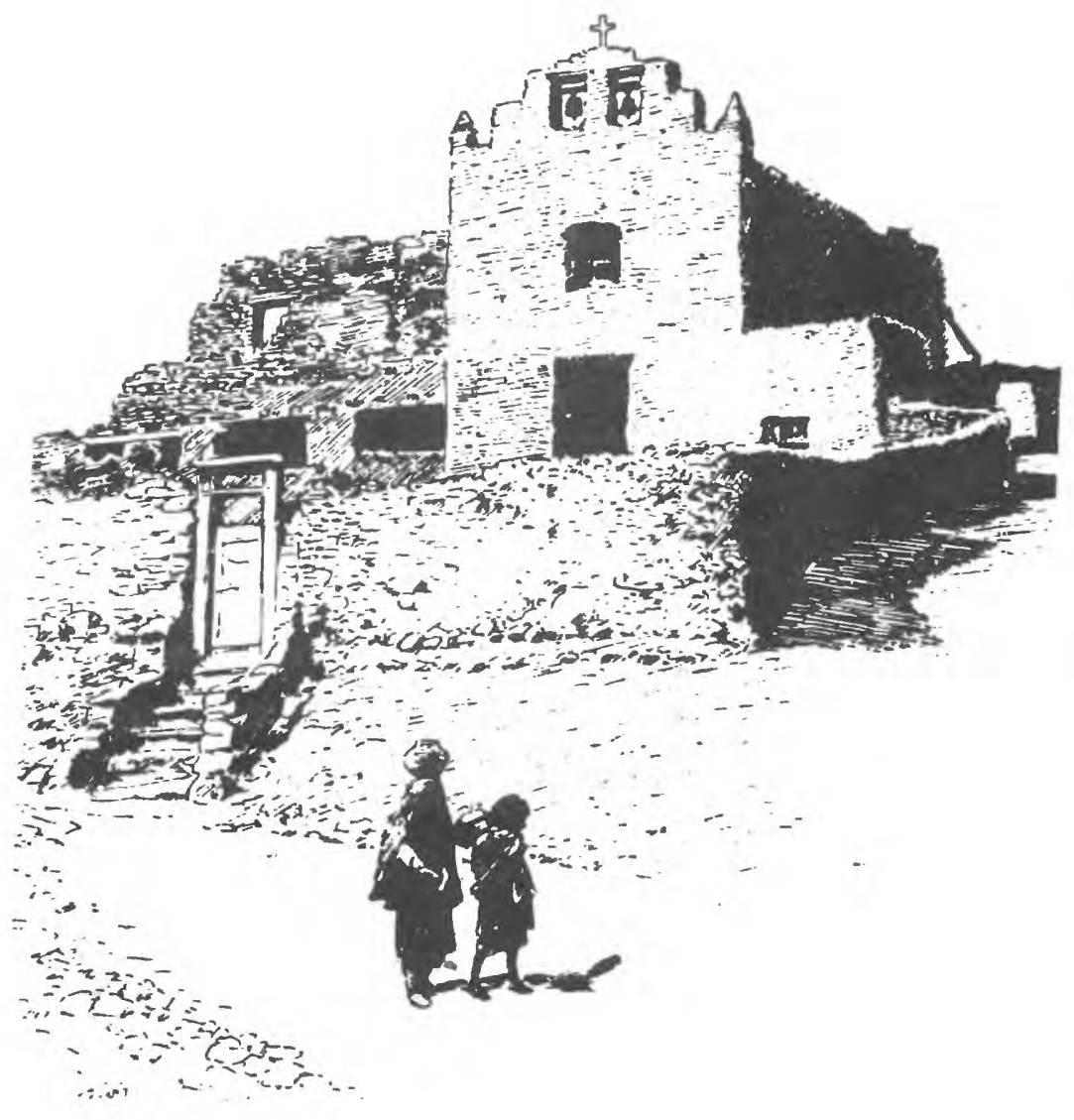




\section{Tertiary and Quaternary Systems}

The major water-bearing units in the Tertiary and Quaternary Systems are the Mount Taylor basalt flows and unconsolidated valley-fill deposits of the Santa Fe Group.

Basalt--The combined flow from six springs that issue from basalt around Mount Taylor is about 200 gallons per minute. These springs contribute water with a specific conductance generally less than 300 micromhos to streamflow in Encinal Canyon and Paguate Creek. The springs discharge about 100 gallons per minute to Encinal Creek upstream from the village of Encinal.

Santa Fe Group--The Santa Fe Group of Miocene, Pliocene, and Pleistocene age is composed of unconsolidated sand, gravel, and clay. These sediments were deposited in the Puerco fault zone on Sedillo Grant (plate 2). We1ls completed in the Santa Fe Group near Interstate Highway 40 just east of the pueblo yield water with specific conductances ranging from 4,000 to 6,000 micromhos, which is suitable for stock use but not for domestic use or irrigation. Wells penetrating a north-trending graben, which probably is present under the Pueblo of Laguna in the vicinity of Cañada de los Apaches, produce water with specific conductances ranging from 460 to 2,180 micromhos (p1. 1). Well 9.2.24.230 (BIA Sedillo), drilled in 1980 by the U.S. Bureau of Indian Affairs in this graben, produced about 12 gallons per minute of water with a specific conductance of 1,600 micromhos. This well is located away from stream valleys, which could provide a source of local recharge. Wells completed in the graben may yield 20 to 100 gallons per minute of water containing dissolved-solids concentrations of between 300 and 1,500 milligrams per liter. This water probably is the best quality water in the sedillo Grant area.

\section{Quaternary System}

The major water-bearing units of the Quaternary System consist of valley-fill deposits of basalt and alluvium.

Basalt--Two basalt flows near the Laguna and Suwanee are present in the study area (plate 2). The Laguna basalt flow originated from volcanic centers west of pueblo lands and flowed eastward down the valley. The basalt is as much as 60 feet thick and overlies 20 to 80 feet of alluvium. The Laguna flow crops out from New Laguna to Mesita but is buried on Laguna lands west of New Laguna by as much as 40 feet of more recent alluvium. The Suwanee basalt flow, which originated about 7 miles south of the pueblo, is present between Correo and Suwanee although locally it may be buried by a thin layer of alluvium. 
Two springs (9.5.8.113 and 9.5.8.121) near Laguna discharge from the base of the Laguna flow at a rate of 2 gallons per minute or less. These and other seeps and springs from the Laguna basalt contribute to the perennial flow in the Rio San Jose in this area. Several wells in the Rio San Jose valley west of New Laguna may produce part of their water from the Laguna basalt flow.

Several springs issue from the Suwanee basalt flow near Correo where the Rio San Jose has eroded into and through this unit. One of these, Suwanee Spring, flowed approximately 100 gallons per minute in 1973. The specific conductance of water from springs in this area averages about 4,000 micromhos with only minor differences between springs.

Alluvium and basalt along the Rio San Jose--The valley of the Rio San Jose ranges from $1 / 2$ mile to more than 2 miles wide through the center of the Pueblo Proper and Sedillo Grant (plate 2). The valley was cut mainly in shales and sandstones of the Morrison Formation, San Rafael Group, and Chinle Formation to depths as much as 160 feet below the present valley floor and then filled in Quaternary time with deposits of alluvium and basalt. The altitude of the base of the valley-fill deposits west of the village of Laguna (fig. 10) was mapped based on data from 16 well logs.

The composition of the alluvial deposits is quite variable in both vertical and lateral extent. The alluvium consists of unconsolidated deposits ranging in grain size from very fine sand to gravel. Clay layers, which probably exist as discontinuous lenses, commonly are penetrated in test drilling. Correlation of individual alluvial deposits between wells was not attempted because of the wide spacing between wells and discontinuous nature of the alluvial deposits.

The valley-fill deposits along the Rio San Jose comprise a significant aquifer on the pueblo. The unconsolidated alluvial deposits and the basalt flows that comprise the valley fill probably are the only known source of ground water on the pueblo capable of supplying yields sufficient for irrigation. In general, yields from alluvium increase with increasing saturated thickness and grain size. Relatively large saturated thicknesses combined with large grain size at the mouths of Encinal Canyon and Cubero Creek result in yields from 50 to 450 gallons per minute to public-supply we1ls and test holes in these areas.

Transmissivity of the valley fill west of New Laguna ranges from 290 to 17,000 feet squared per day based on aquifer tests at wells penetrating 40 to 138 feet of saturated aquifer thickness (table 4 and fig. 10). Hydraulic conductivity of the valley fill based on these tests ranges from 2.4 to 300 feet per day (fig. 10), and specific capacity of the test wells ranges from 0.04 to 33.9 gallons per minute per foot of drawdown. A detailed account of the results from six aquifer tests conducted in the Rio San Jose valley during this study is presented in the following paragraphs. 


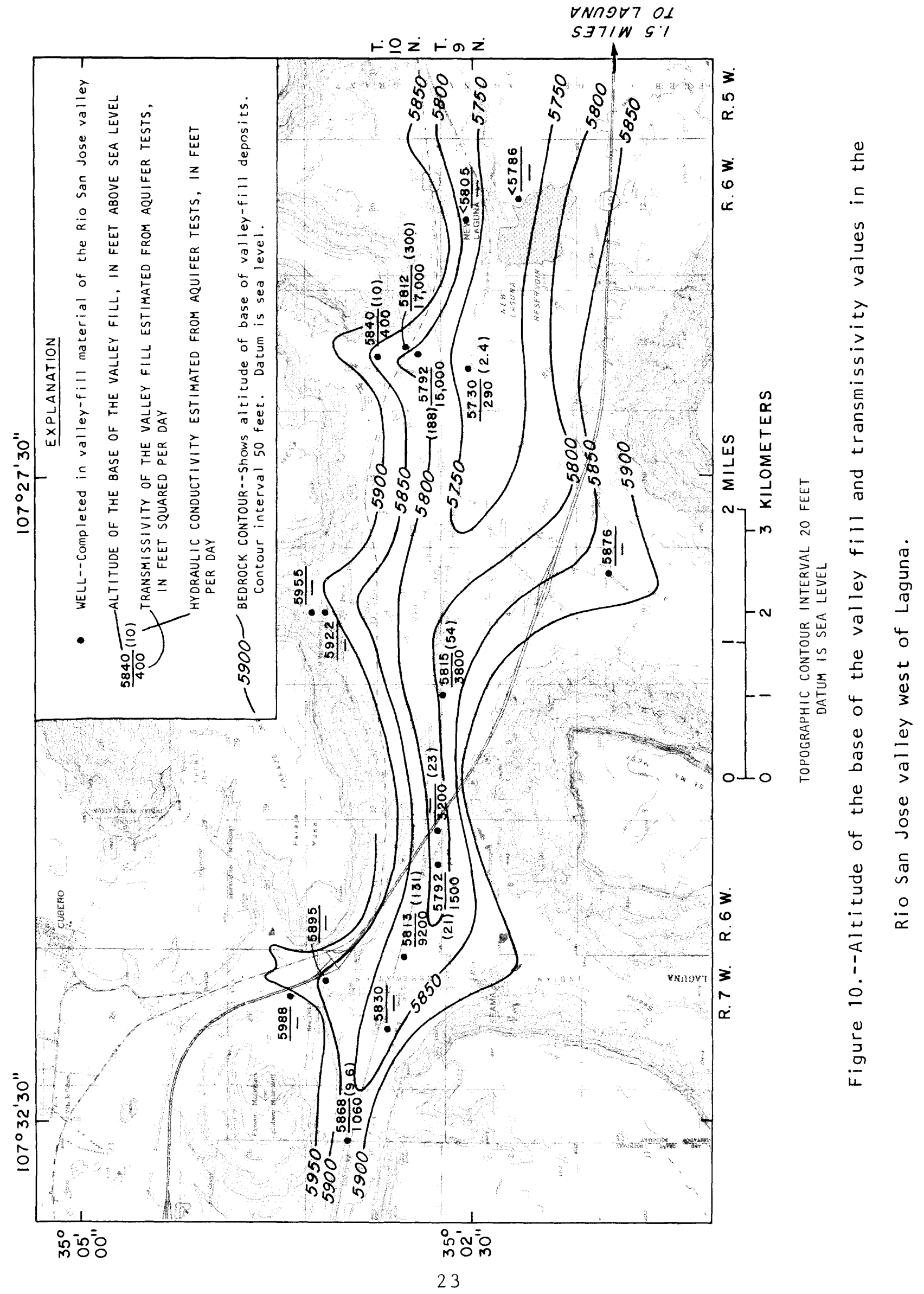


Wel1 10.7.36.424 (Laguna 76-1) was drilled about $3 / 4$ mile north of Seama (fig. 3). To test the aquifer properties of the valley fill, the well was pumped at 140 gallons per minute. After pumping for 3 hours, the pump stopped and the water level in the well recovered for 4.5 hours. The test was started again and the well pumped for 20 hours at 140 gallons per minute, resulting in a total drawdown of 8.5 feet from both pumping periods. Transmissivity calculated from the drawdown data using the modified non-equilibrium formula (Ferris and others, 1962, p. 98) is about 8,200 feet squared per day (fig. 11). However, recovery data indicate a slightly greater transmissivity of 9,200 feet squared per day calculated by the Theis recovery method (Ferris and others, 1962). The late-time recovery data may indicate the presence of a boundary of lesser permeability but the change in slope is slight so the data were included in the analysis. The recovery data probably give a more accurate estimate of transmissivity because of the difficulty in measuring drawdown in the pumped well.

Irrigation wel1 10.7.36.424a (Laguna Ir. 1) was pumped at rates that ranged from 240 to 490 gallons per minute primarily to determine the capacity of the well. The test was conducted for 24 hours, resulting in a final drawdown of 86 feet while pumping at 490 gallons per minute. Specific capacity of the well at the end of the test was 5.7 gallons per minute per foot.

Well 10.7.36.322 (Laguna 76-2) was drilled in the Rio San Jose valley about 1 mile northwest of Seama (fig. 3). The well was pumped for 24 hours at an average rate of 80 gallons per minute to test the hydrologic properties of the valley-fill material at this location. A maximum drawdown of 53 feet was reached after pumping about 200 minutes, then the water level rose about 8 feet for the remainder of the test (fig. 12). The rise in water level may have been caused by a slight decrease in the pumping rate or increase in well efficiency when the well began to produce sand. Because of the possible change in well efficiency during the test and effects of nearby boundaries and water-table conditions, a transmissivity value for the aquifer was not determined for this test.

Well 9.6.5.222 (Laguna 76-6) was drilled in the Rio San Jose valley about 1 mile southwest of Casa Blanca (fig. 3). The we11 was pumped for 24 hours at an average rate of 125 gallons per minute to test the aquifer properties at this location. Drawdown and recovery of the water level was observed in the pumped well and in stock well 9.6.5.221 (Acoya), located 413 feet away. Transmissivity and storage coefficient were estimated by the Theis non-equilibrium method (Ferris and others, 1962, p. 92) using drawdown data in the stock well. The estimated value of transmissivity is about 3,800 feet squared per day (fig. 13). The calculated value of storage coefficient of $1.9 \times 10^{-4}$ indicates that confined conditions existed for the duration of the test. For longer periods of pumping, however, the aquifer will become dewatered and a specific yield value of between .05 and .20 should be used in any estimates of long-term pumping effects. 

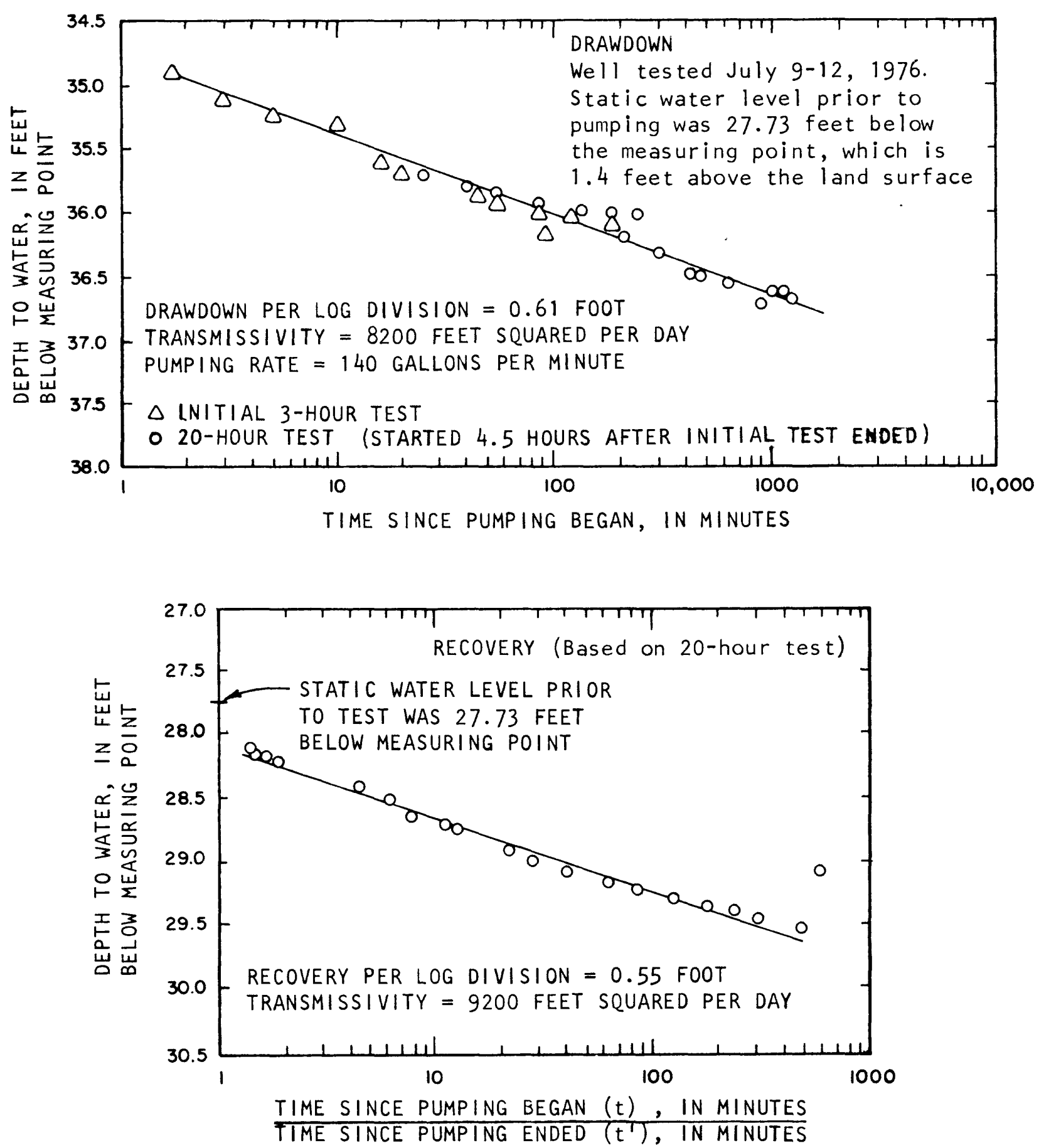

Figure 11.--Drawdown and recovery in well 10.7.36.424 (Laguna 76-1). 

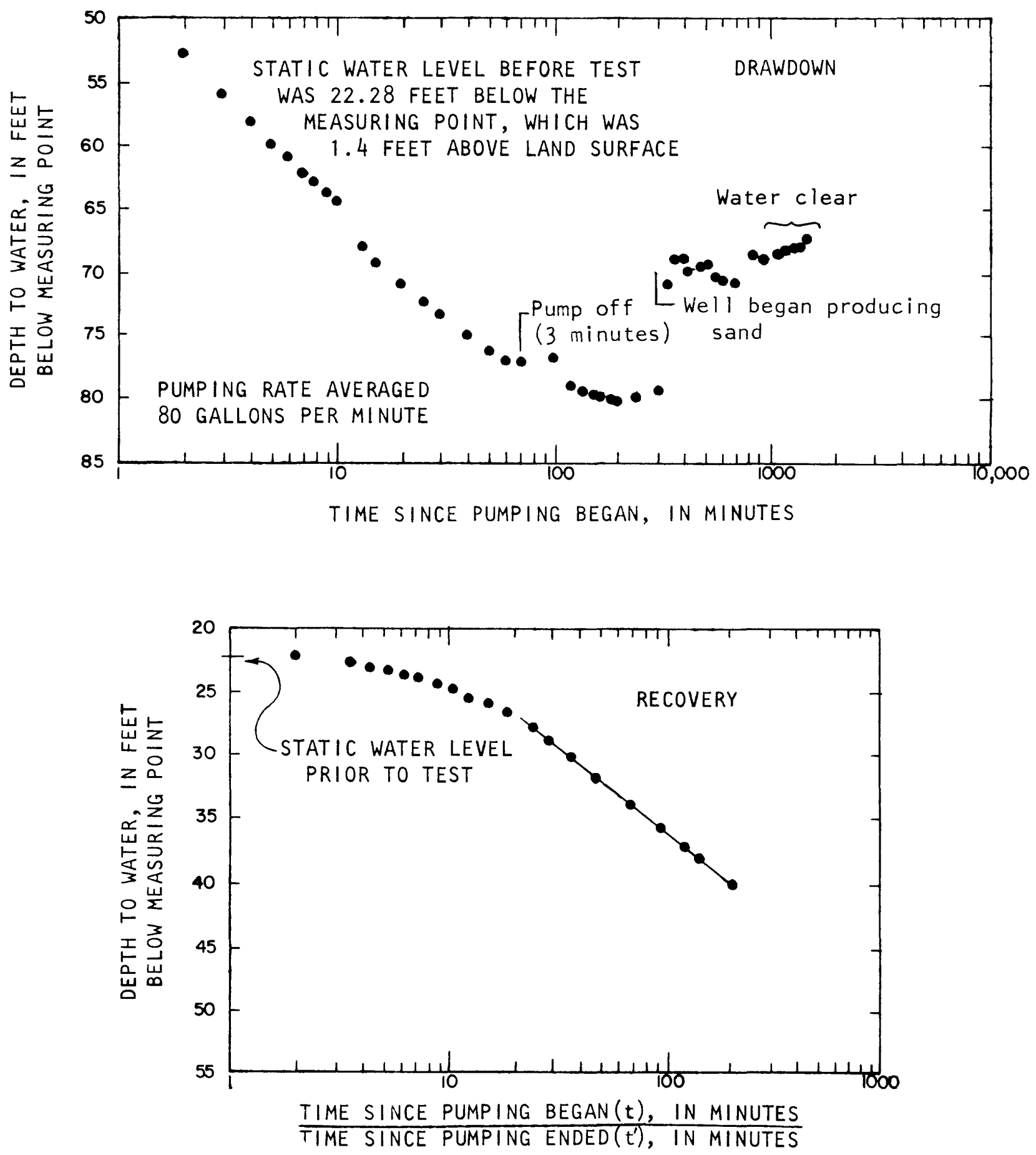

Figure 12.--Drawdown and recovery of water level in well 10.7.36.322 (Laguna 76-2). 


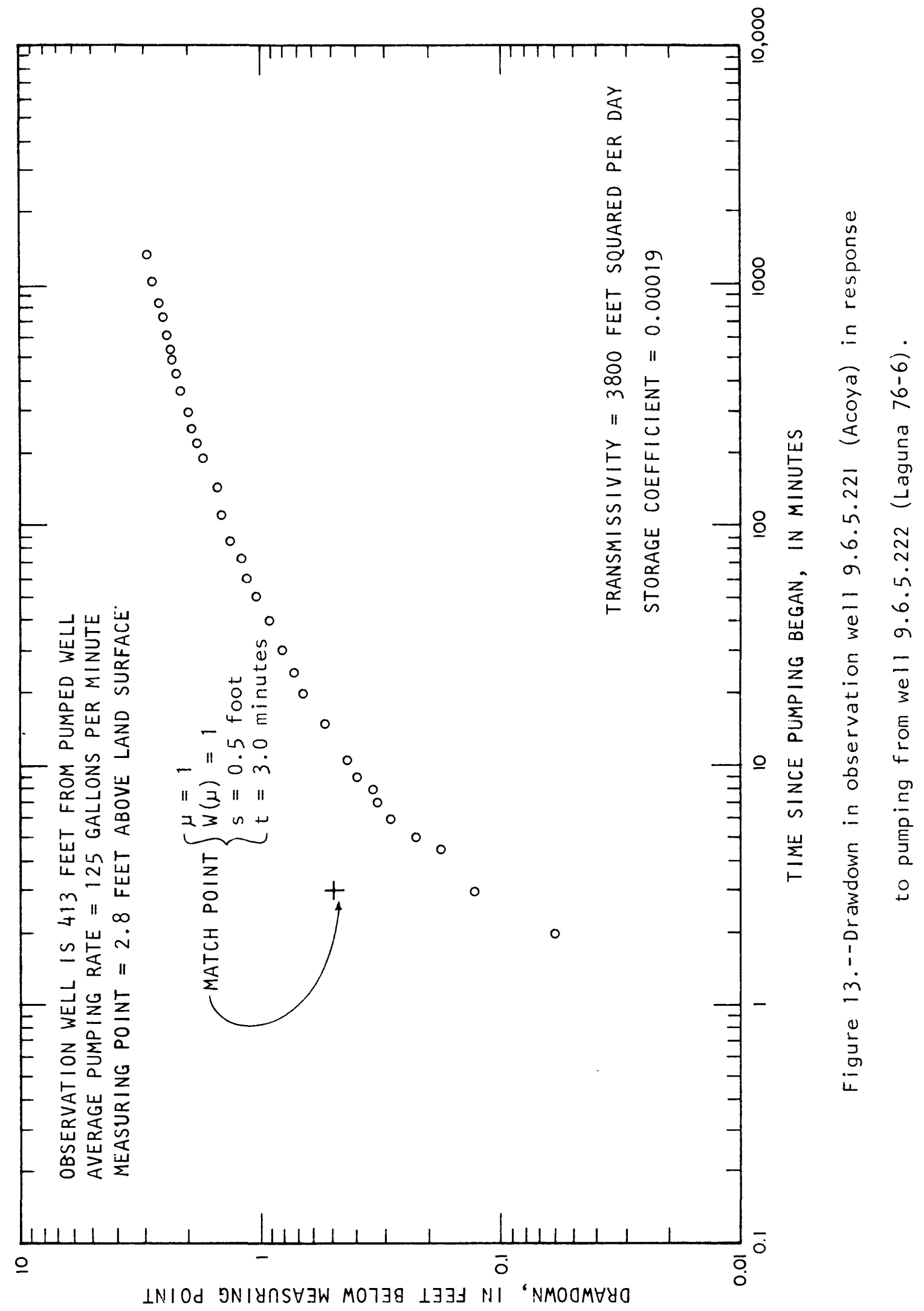


We11 9.6.2.123 (Laguna 76-7) was drilled in the Rio San Jose valley where Encinal Creek joins the Rio San Jose (fig. 3). The well was pumped for 24 hours at an average rate of 4.5 gallons per minute, which caused 105 feet of drawdown in the pumped wel1. Transmissivity estimated from the Theis recovery method (Ferris and others, 1962, p. 100) using data from the pumped we11 is about 290 feet squared per day (fig. 14). About a year after conducting the aquifer test, the well was cleaned and bailed at a rate of about 20 gallons per minute with less than 5 feet of drawdown. This indicates that the well was not properly developed when the initial aquifer test was conducted. Therefore, the specific capacity value estimated from that initial test probably is less than the actual value.

Well 10.6.35.342a (Laguna Ir. 2) was drilled by the U.S. Bureau of Indian Affairs in 1977 in the Rio San Jose valley at the mouth of Encinal Creek (fig. 3). To test aquifer properties at this location, the well was pumped for 24 hours at a rate that ranged from 80 to 212 gallons per minute, which resulted in lowering the water level in the well 31 feet. Transmissivity of the aquifer was estimated to be about 15,000 feet squared per day from early-time water-level recovery data measured in wel1 10.6.35.342 (Pueblo Test 2) located about 130 feet from the pumped well (fig. 15). The pumping rates during each of 4 steps (80, 120, 165, and 200 gallons per minute) were used in the calculation of transmissivity by a method described by Harrill (1970, p. C212). The late-time recovery data appear to be affected by a hydrologic boundary of lesser permeability, possibly the valley wall, which is less than $1 / 2$ mile from the pumped well.

Alluvium along the Rio Puerco--The alluvium near the Rio Puerco on Montaño Grant is reported to be as much as 250 feet thick (Gene Saucier, Continental Oil Company, oral commun., 1973). Although yields of as much as 100 gallons per minute may be possible along the Rio Puerco valley, the specific conductance value of the water probably exceeds 6,000 micromhos at most places, which indicates the water quality would be unacceptable for irrigation or public supply.

Alluvium along the Rio Paguate--The alluvium is about 60 feet thick near the two Paguate public-supply wells, $11.5 .32 .234 \mathrm{a}$ (Paguate P.S. 1) and 11.5.32.232 (Paguate P.S. 2). The wells have been pumped at rates of 90 and 75 gallons per minute, respectively. During this study, however, only the Paguate P.S. 2 well was in use. It pumped 53,000 gallons of water per day during August 1-8, 1979, and was estimated to produce about one-half that quantity during winter months when demand was less (Norm Fairbanks, Indian Health Service, written commun., 1979).

Additional development of ground water in the alluvium along the Rio Paguate is possible. Presently, as much as 250 gallons per minute of water is lost to evapotranspiration in the swamp area in the vicinity of the public-supply wells. 


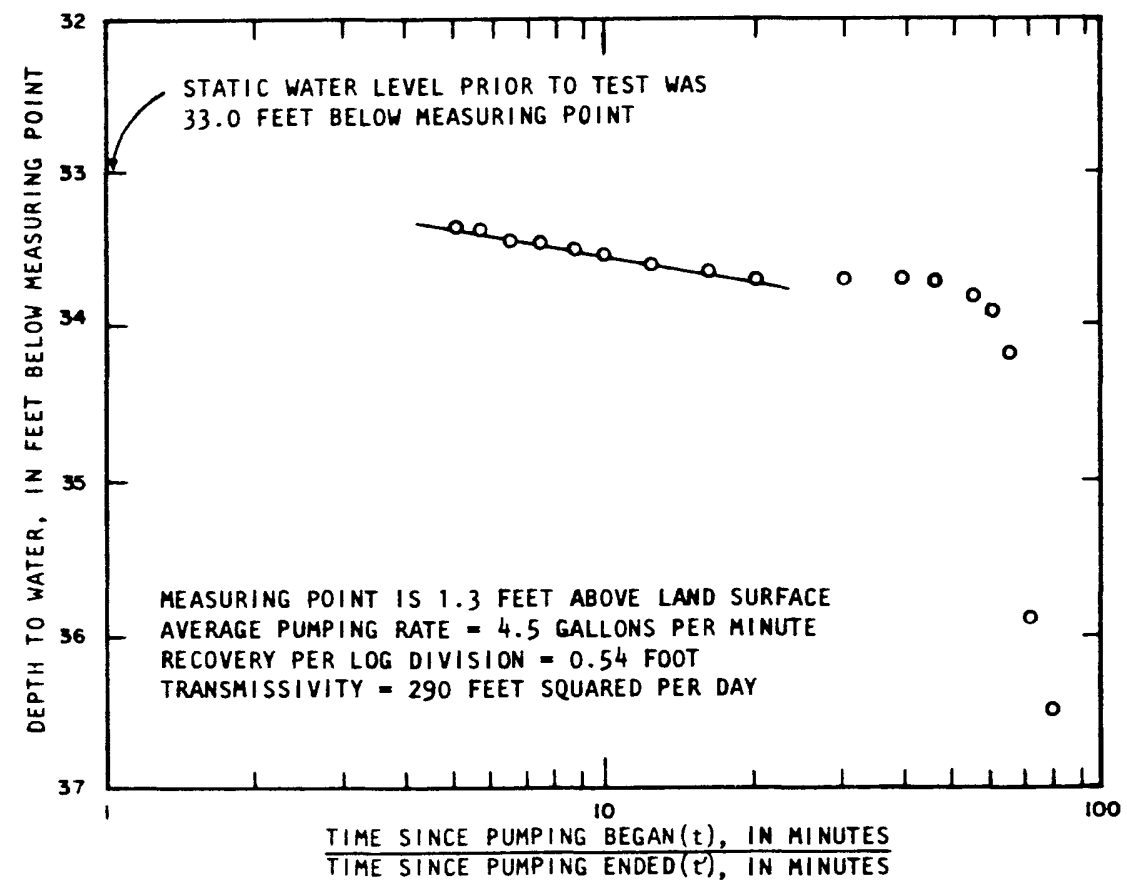

Figure 14.--Water-level recovery from test of well 9.6.2.123 (Laguna 76-7).

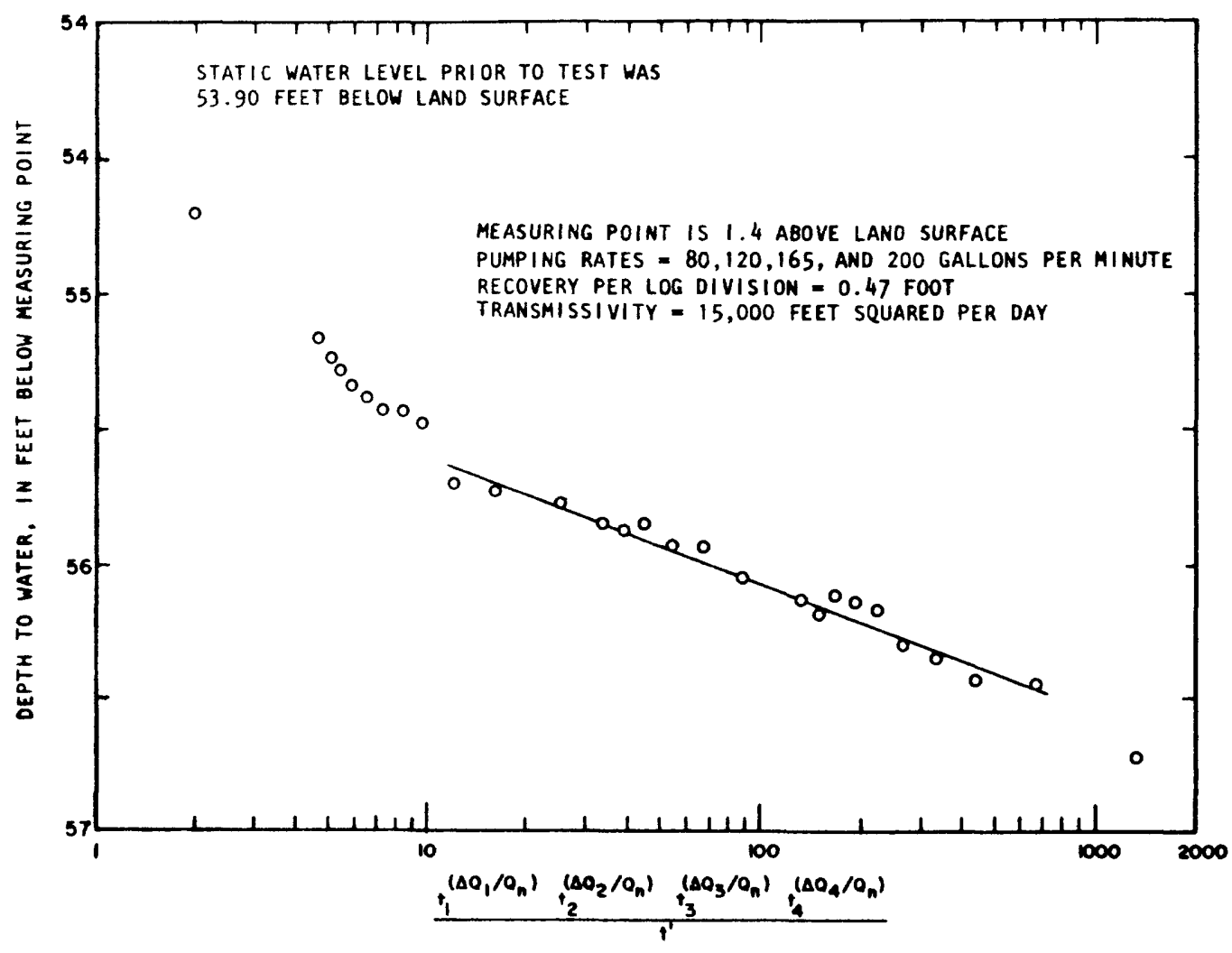

Figure 15.--Water-level recovery in observation well 10.6.35.342 (Pueblo Test 2) from test of well 10.6.35.342a (Laguna Ir. 2). 
Alluvium in Encinal Canyon--Two wells were drilled in alluvium in Encinal Canyon about 2 miles up the canyon from the village of Encinal (fig. 3 and table 3). The drilling was performed to determine if the springflow at the head of Encinal Canyon that seeps into the alluvium could be salvaged by pumpage.

Well 11.6.27.334 (Encinal Canyon 1) penetrated 35 feet of alluvium and 75 feet of Mancos Shale. The well produced water containing 1,570 milligrams per liter of dissolved solids from a 3- to 5-foot zone at the base of the alluvium. The well was dry after 100 minutes of bailing at an average rate of 5.3 gallons per minute. Of the 530 gallons of water bailed from the hole, about 300 gallons were provided from water stored in the borehole. The water level in the well rose 4.3 feet from July 1978 to June 1979, probably as a result of recharge from stormflow and snowmelt runoff in Encinal Creek.

We11 11.6.34.134 (Encinal Canyon 2) penetrated 31 feet of alluvium and 4 feet of Mancos Shale. Less than 1 foot of alluvium appeared to be saturated at the contact with the Mancos Shale. The well was bailed dry after removing only 10 to 15 gallons of water, most of which probably came from borehole storage. Specific conductance of the water was 950 micromhos.

Alluvium in Seco and Castillo Canyons--We1ls were drilled in Seco and Castillo Canyons on the Mount Taylor area of Laguna lands to test the quality and yields of the unconsolidated valley fill (fig. 3). These valleys were investigated because springflow and storm runoff could provide recharge to the alluvium.

Well 10.7.10.122 (Seco Canyon 1) penetrated 35 feet of alluvium near the mouth of Seco Canyon. The well produced only 10 gallons of water in about 12 hours. The specific conductance of water from the we11 was 3,000 micromhos.

We11 11.7.35.243 (Castillo Canyon 1) penetrated alluvium to a depth of 40 feet, Gallup Sandstone from 40 to 60 feet, and Mancos Shale from 60 to 75 feet. The alluvium did not produce water at this site.

\section{Movement, recharge and discharge}

Aquifers on the Pueblo of Laguna are recharged by precipitation, streamflow and leakage from adjacent geologic units. Water moves through the aquifers to discharge as springflow, evapotranspiration, leakage to adjacent units, and ground-water withdrawals. An understanding of the ground-water flow system is necessary to determine areas on the pueblo where adequate supplies of potable water may be found. 


\section{Bedrock aquifers}

The general horizontal direction of ground-water movement can be determined from potentiometric-surface maps of the Chinle Formation, Entrada Sandstone, Bluff Sandstone, and Morrison Formation shown in figures 16 through 19. It can be assumed that water flows at right angles to the potentiometric contours. Flow directions illustrated by arrows on the potentiometric maps show that the shallow water moves toward the Rio San Jose in most areas. Flow directions in the Puerco fault zone generally are eastward into the Rio Grande trough.

The flow directions shown in figures 16 through 19 illustrate only the horizontal component of ground-water movement. In the study area, the vertical component (upward or downward movement) also is important, especially as it affects water quality. Possible directions of ground-water movement in two geologic sections are shown on plate 3.

Bedrock aquifers of Permian age beneath the pueblo probably are recharged by streamflow and precipitation on outcrop areas in the Grants area, about 20 miles west of the Pueblo of Laguna. Based on water levels in that area and in wells 11.5.14.241 (L-Bar 2) and 9.5.12.442 (Mesita Test), ground water moves southeast across the pueblo with an average gradient of about 20 feet per mile. Discharge to overlying units takes place mainly in the Puerco fault zone where fractures allow upward movement of water from the Permian units. The excessively mineralized springflow in the Montaño and Sedillo Grants is due to this discharge. Ground water also is probably discharged to the Santa Fe Group, which fills the Rio Grande trough.

The Chinle Formation, of Triassic age, is recharged mainly by precipitation on outcrop areas along Arroyo Colorado. Inflow of water to the formation also occurs by upward leakage from Permian rocks. Water movement probably is mostly in the vertical direction in the Petrified Forest Member. The Correo Sandstone Bed in the Petrified Forest Member probably is recharged by precipitation on outcrops and discharges to the alluvium along the Rio San Jose.

Jurassic aquifers south of the Rio San Jose probably are recharged for the most part on and to the southwest of the pueblo where the units crop out. Ground-water flows northeast and discharges into the alluvium along the Rio San Jose. Jurassic aquifers north of the Rio San Jose probably are recharged west of Mount Taylor by precipitation on outcrops and by leakage from the overlying Cretaceous sandstones. Some discharge is to the Rio Paguate and Rio Moquino where they join in the Jackpile-Paguate Mine and to the Rio San Jose valley west of Mesita. Discharge from the Jurassic units also occurs where ground water is withdrawn by the Anaconda Company to operate the Jackpile-Paguate Mine. These withdrawals averaged about 250,000 gallons per day during 1978. 


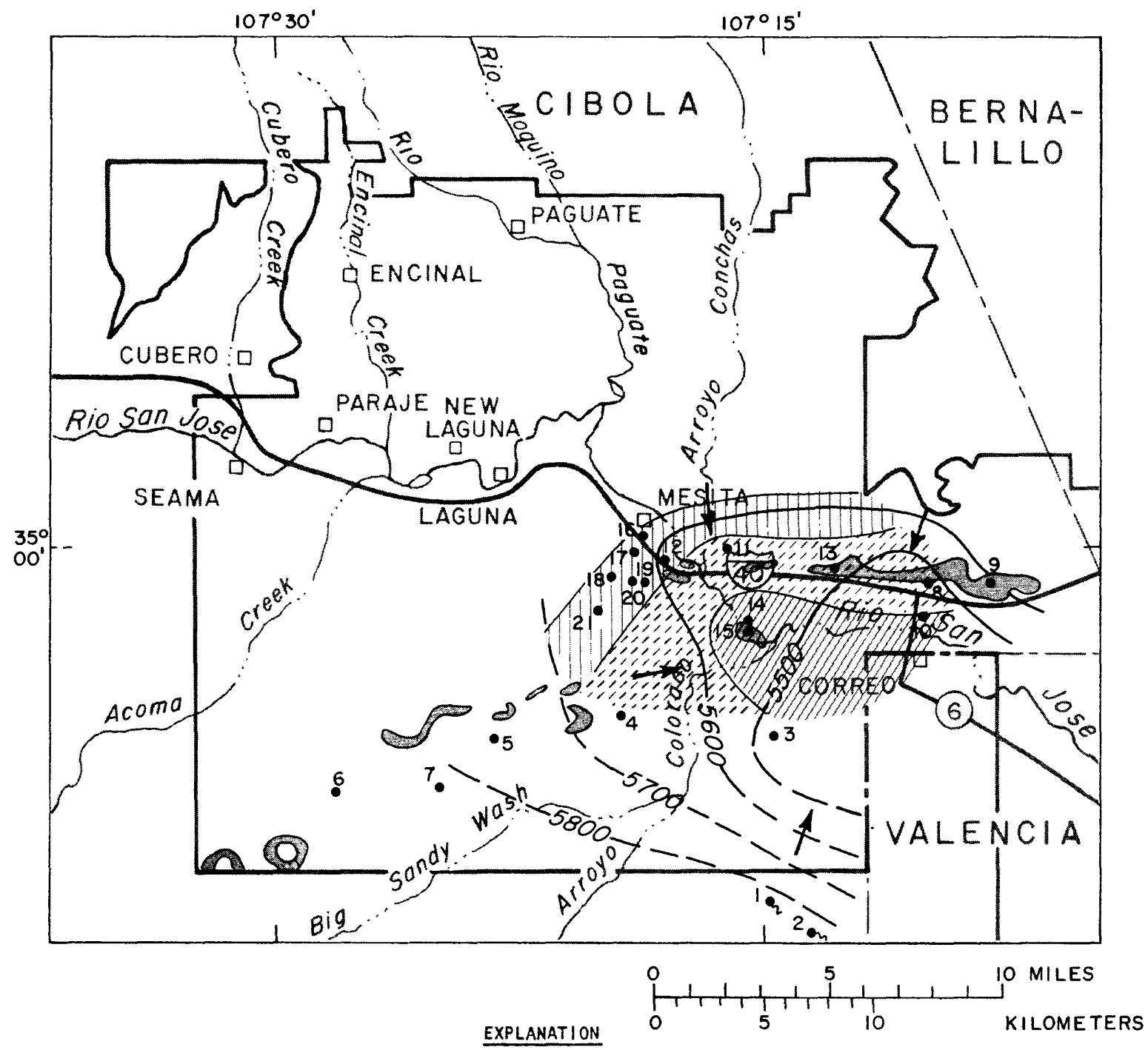

\begin{tabular}{|c|l|l|}
\hline IDENTIFIER & $\begin{array}{c}\text { NAME OF } \\
\text { WELL OR SPRING }\end{array}$ & $\begin{array}{l}\text { LOCATION } \\
\text { NUMBER }\end{array}$ \\
\hline 1 & Salt Spring 195 & 7.4 .3 .344 \\
2 & LuCero SPring & 7.4 .11 .431 \\
3 & ECW-10 & 8.4 .15 .123 \\
4 & RWP-21 & 8.5 .12 .311 \\
5 & -5.17 .213 \\
6 & RWP-30 & 8.6 .21 .224 \\
7 & RWP-22 & 8.6 .24 .412 \\
8 & RWP-15 & 9.3 .20 .441 \\
9 & COYOte SPrIng & 9.3 .22 .443 \\
10 & ECW-3 & 9.3 .29 .414 \\
11 & RWP-16 & 9.4 .16 .341 \\
12 & EI Rito & 9.4 .19 .124 \\
13 & RWP-19 & 9.4 .24 .322 \\
14 & Pino 1 & 9.4 .33 .223 \\
15 & Pino 2 & 9.4 .33 .2230 \\
16 & Mesita P. S. & 9.5 .13 .233 \\
17 & Burnel1 2 & 9.5 .13 .411 \\
18 & RWP-20 & 9.5 .23 .424 \\
19 & EPNG-2 & 9.5 .24 .414 \\
20 & EPNG-3 & 9.5 .24 .413 \\
21 & RWP-29 & 9.5 .26 .411 \\
\hline
\end{tabular}

WELL--Derives water mainly from the Chinle Formation

m SPRING--Derives water mainly from the Chinle Formation OUTCROP AREA OF CHINLE FORMATION, APPROXIMATELY LOCATED POTENTIOMETRIC CONTOUR--Shows altitude at which water level would have stood in tightly cased wells, 1973-79. Dashed where approximately located. Contour interval 100 feet. Datum is sea level.

APPROXIMATE DIRECTION OF GROUND-WATER FLOW

SPECIFIC CONDUCTANCE OF WATER, IN MICROMHOS PER CENTIMETER AT $25^{\circ}$ CELSIUS

$$
\begin{aligned}
& 1000-2000 \\
& 2000-4000
\end{aligned}
$$

Greater than 4000

Figure 16.--Potentiometric surface and specific conductance of water in the Chinle Formation. 
$107^{\circ} 30^{\prime}$ $107^{\circ} 15^{1}$

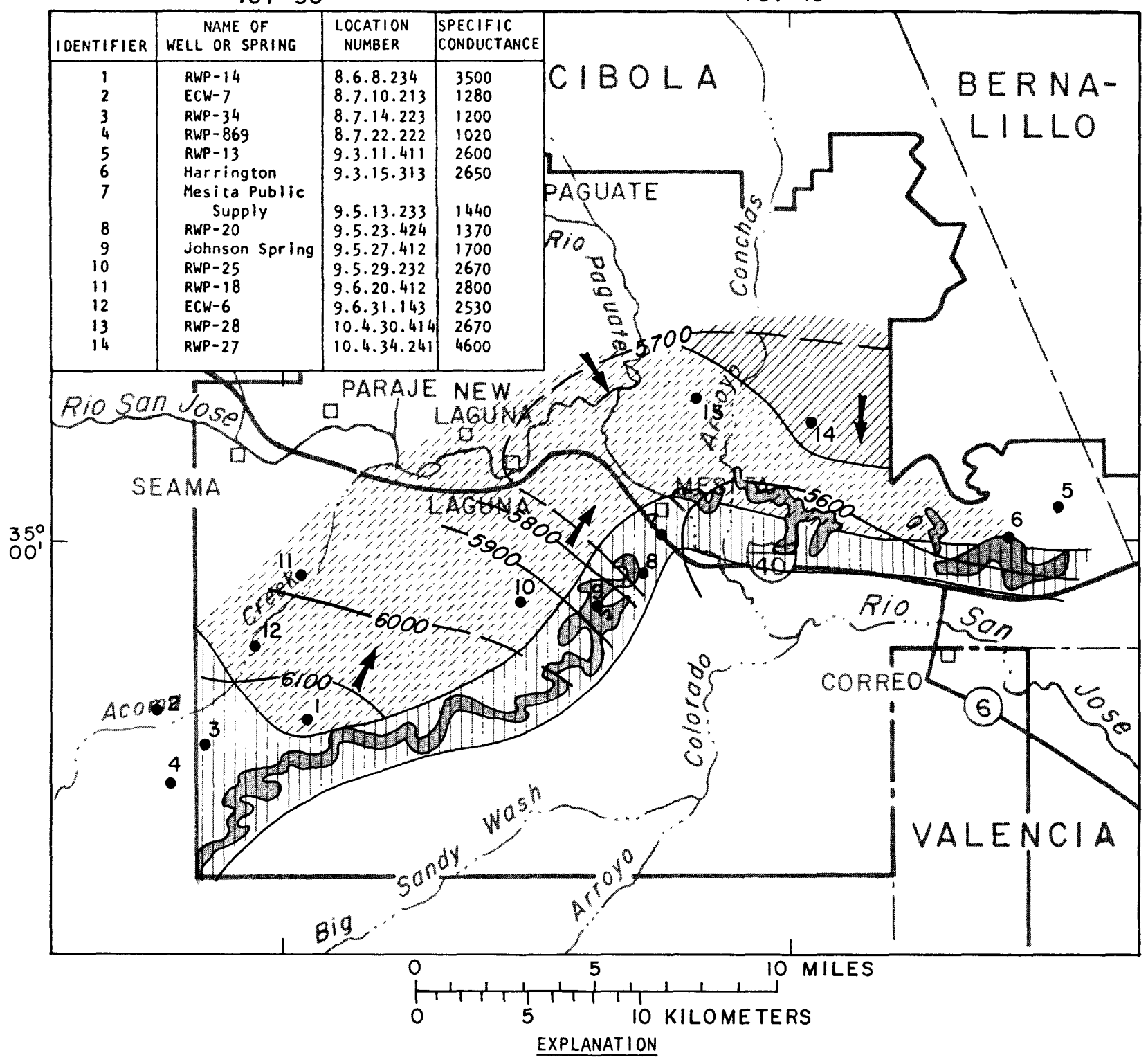

- WELL--Derives water mainly from the Entrada Sandstone

an SPRING--Derives water mainly from the Entrada Sandstone

-6000 POTENTIOMETRIC CONTOUR--Shows altitude at which water level would have stood in tightly cased wells, 1973-79. Dashed where approximately located. Contour interval 100 feet. Datum is sea level.

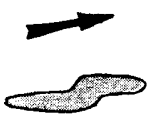

APPROXIMATE DIRECTION OF GROUND-WATER FLOW

OUTCROP AREA OF ENTRADA SANDSTONE, APPROXIMATELY LOCATED

SPECIFIC CONDUCTANCE OF WATER, IN MICROMHOS PER CENTIMETER AT $25^{\circ}$ CELSIUS

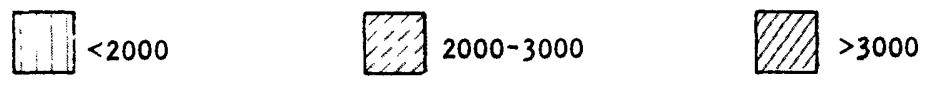

Figure 17.--Potentiometric surface and specific conductance of water in the Entrada Sandstone. 


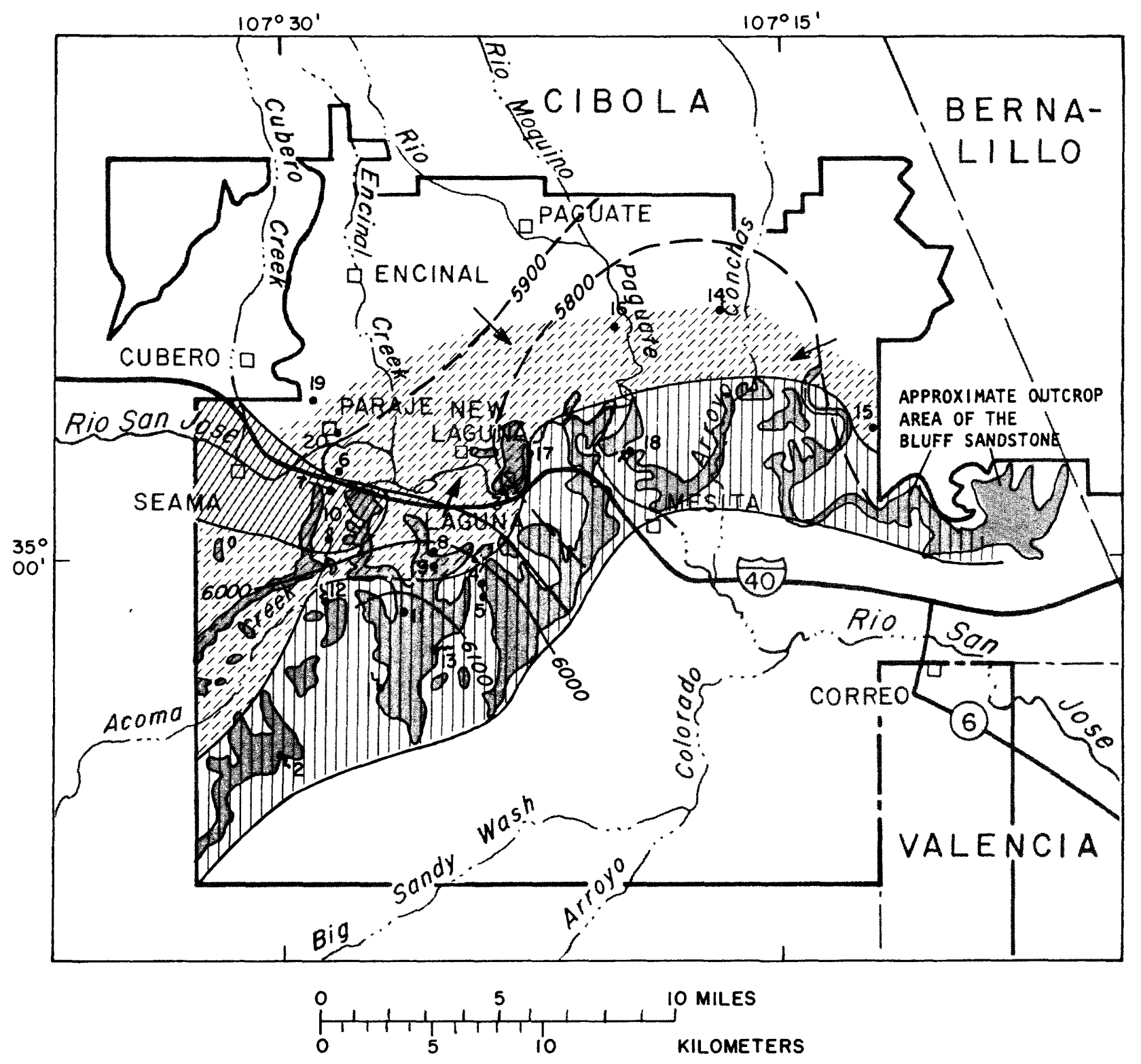

Figure 18.--Potentiometric surface and specific conductance of water in the Bluff Sandstone. 


\section{EXPLANATION FOR FIGURE 18}

- WELL--Derives water mainly from the Bluff Sandstone

on SPRING--Derives water mainly from the Bluff Sandstone

- POTENTIOMETRIC CONTOUR--Shows altitude at which water level would have stood in tightly cased wells, 1973-79. Dashed visere approximately located. Contour interval 100 feet. Datum is sea level.

APPROXIMATE DIRECTION OF GROUND-WATER FLOW

SPECIFIC CONDUCTANCE OF WATER, IN MICROMHOS PER CENTIMETER AT $25^{\circ}$ CELSIUS

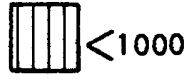

\begin{tabular}{|c|l|c|c|}
\hline IDENTIFIER & $\begin{array}{c}\text { NAME OF WELL } \\
\text { OR SPRING }\end{array}$ & $\begin{array}{l}\text { LOCATION } \\
\text { NUMBER }\end{array}$ & $\begin{array}{c}\text { SPECIFIC } \\
\text { CONDUCTANCE } \\
\text { IN MICROMHOS }\end{array}$ \\
\hline 1 & KEMP SANTIAGO & 8.6 .3 .243 & 460 \\
2 & SPRING & $\begin{array}{l}\text { DRIPPING SPRING } \\
\text { D.6.18.232 }\end{array}$ & 340 \\
3 & - & 9.5 .8 .121 & 2800 \\
4 & TEST HOLE 2 & 9.5 .19 .234 & 510 \\
5 & TEST HOLE 3 & 9.5 .19 .421 & 370 \\
6 & MOONEY & 9.6 .4 .243 & 2590 \\
7 & STANDARD & 9.6 .4 .433 & 4200 \\
8 & TRANSWESTERN 2 & 9.6 .13 .322 & 1110 \\
9 & TRANSWESTERN 1 & 9.6 .13 .343 & 1150 \\
10 & & 9.6 .16 .122 & 4000 \\
11 & RWP-24 & 9.6 .26 .233 & 460 \\
12 & TURQUOISE SPRING & 9.6 .28 .122 & 440 \\
13 & COYOTE SPRING & 9.6 .36 .144 & 900 \\
14 & ECW-3 & 9.3 .29 .414 & 4000 \\
15 & RWP-32 & 10.4 .36 .224 & 2810 \\
16 & SINKHOLE & 10.5 .14 .234 & 2310 \\
17 & RWP-1 & 10.5 .33 .333 & 650 \\
18 & GOYEA SPRING & 10.5 .36 .331 & 180 \\
19 & RWP-17 & 10.6 .29 .244 & - \\
20 & ECW-12 & 10.6 .33 .213 & 2810 \\
& & & \\
\hline
\end{tabular}




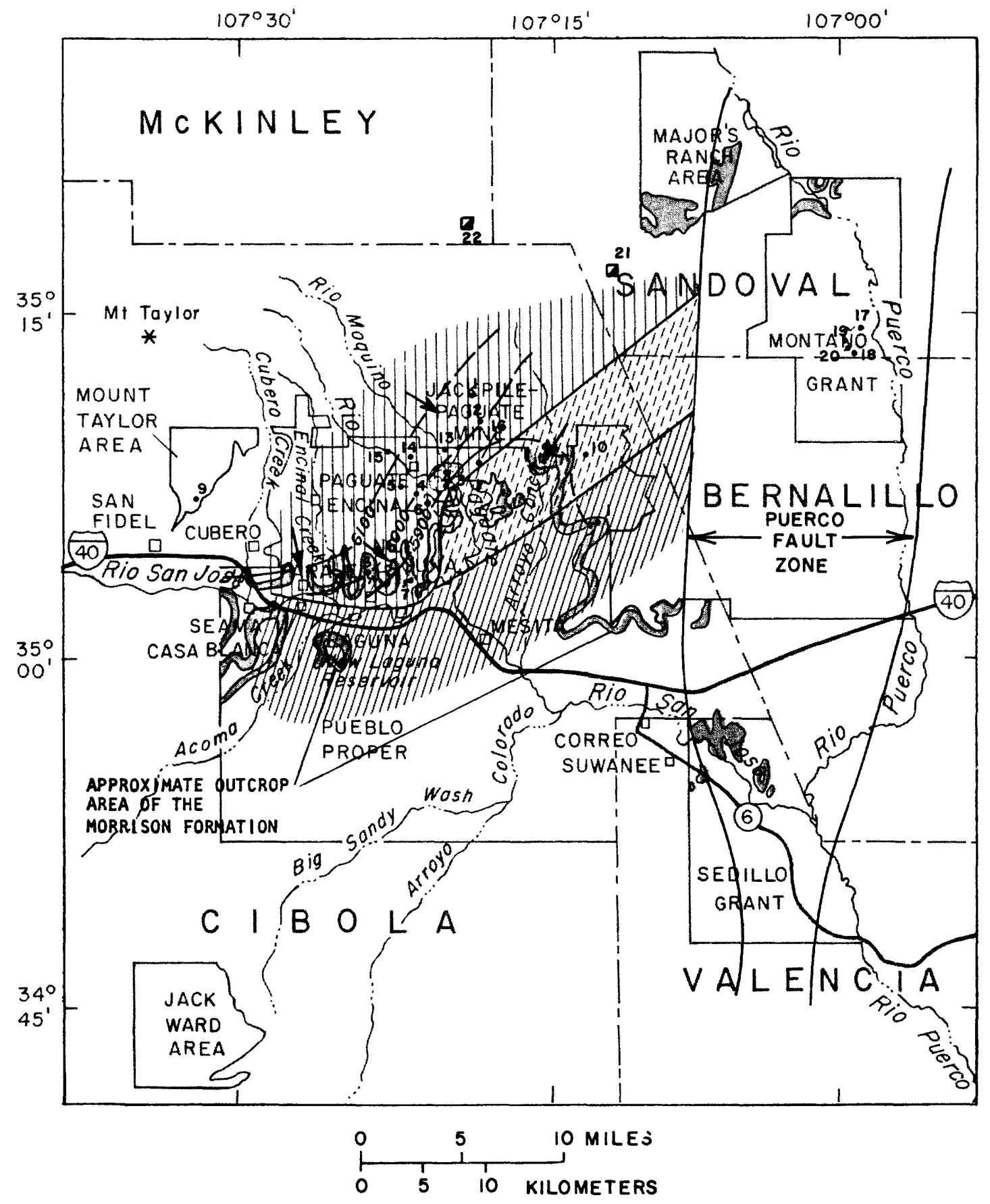

Figure 19.--Potentiometric surface and specific conductance of water in the Morrison Formation. 


\section{EXPLANATION FOR FIGURE 19}

- WELL--Derives water mainly from the Morrison Formation

on SPRING--Derives water mainly from the Morrison Formation

-6000- POTENTIOMETRIC CONTOUR--Shows altitude at which water level would have stood in tightly cased wells, 1973-79. Dashed where approximately located. Contour interval 100 feet.

Datum is sea level.

$\longrightarrow$ APPROXIMATE DIRECTION OF GROUND-WATER FLOW

SPECIFIC CONDUCTANCE OF WATER, IN MICROMHOS PER CENTIMETER AT $25^{\circ}$ CELSIUS

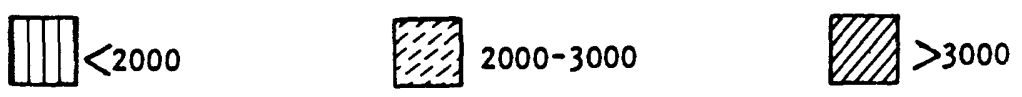

\begin{tabular}{|c|l|l|l|}
\hline IDENTIFIER & NAME OF WELL, SPRING & $\begin{array}{l}\text { LOCATION } \\
\text { OR MINE }\end{array}$ & $\begin{array}{l}\text { SPECIFIC } \\
\text { CONDUCTANCE } \\
\text { IN MICROMHOS }\end{array}$ \\
\hline 1 & CHEROMIAH SPRING & 10.4 .12 .342 & 4,000 \\
2 & HOUSING-1 & 10.5 .2 .134 & 2,200 \\
3 & HOUSING-2 & 10.5 .2 .143 & 2,250 \\
4 & P-10 & 10.5 .4 .323 & 1,650 \\
5 & MDH-771 & 10.5 .5 .142 & 1,350 \\
6 & PAGUATE SHOP & 10.5 .9 .223 & 1,900 \\
7 & SPRING 15 & 10.5 .28 .332 & 1,500 \\
8 & FROG POND SPRING & 10.6 .25 .242 & 1,670 \\
9 & LAGUNA 79-1 & 10.7 .10 .213 & 2,000 \\
10 & ECW-4 & 11.4 .26 .444 & 2,500 \\
11 & LJ-205 & 11.5 .13 .112 & $590 *$ \\
12 & ANACONDA-1 & 11.5 .24 .213 & 1,750 \\
13 & ANACONDA-4 & 11.5 .27 .322 & 1,200 \\
14 & - & 11.5 .29 .444 & 1,900 \\
15 & PUEBLO TEST 3 & 11.5 .30 .422 & 670 \\
16 & JACKPILE SHOP & 11.5 .35 .442 & 1,950 \\
17 & CONOCO 65-A & 12.1 .30 .324 & 12,900 \\
18 & CONOCO WQ-7 & 12.1 .31 .331 & 11,800 \\
19 & CONOCO OW-192 & 12.2 .36 .421 & 12,800 \\
20 & CONOCO WW-101 & 12.2 .36 .442 & 11,000 \\
21 & RIO PUERCO MINE & 12.3 .18 .000 & 1,770 \\
22 & MARQUEZ MINE & 13.5 .36 .000 & 1,650 \\
\hline
\end{tabular}

* Milligrams per liter of dissolved solids 
Cretaceous units cap high mesas on the pueblo. Recharge to these units mainly is from precipitation and streamflow on outcrops and from leakage through overlying basalts. These units discharge to the Rio Moquino upstream from the Jackpile-Paguate Mine, to the Rio Paguate upstream from Paguate, as springflow around mesas, and to underlying geologic units.

\section{Valley-fill aquifers}

Rio San Jose Valley-Movement of water in the valley-fill deposits of alluvium and basalt is predominantly down the valley. In the Rio San Jose valley, between the western boundary of the pueblo and New Laguna, ground water flows down valley at a gradient of about 18 feet per mile (fig. 20). Cross-valley components also exist where ground water is recharged from or discharged to the Rio San Jose. Flow is toward the Rio San Jose at the western end of the valley where ground water discharges to the stream. East of Casa Blanca, where the stream recharges the aquifer, ground water moves cross-valley away from the stream.

Water in the valley fill is recharged by infiltration through the streambed of the Rio San Jose, seepage from tributary streams, and to a smaller extent from irrigation return flows, upward discharge of water from bedrock units, and downward percolation of precipitation.

Recharge to the valley fill aquifer takes place along several reaches of the Rio San Jose (fig. 21). The major recharge areas are from Casa Blanca diversion to New Laguna (average loss in streamflow of 0.26 cubic foot per second per mile), Mesita diversion to Correo (average 1oss 0.23 cubic foot per second per mile), and from Dipping Vat Spring to the Rio Puerco (average loss 0.35 cubic foot per second per mile).

Seepage from tributary streams also is an important source of recharge to the valley fill along the Rio San Jose because of the potability of the tributary flow. Cubero Creek, for example, loses an average of 0.30 cubic foot per second of water containing 450 to 520 milligrams per liter of dissolved solids to the valley fill near New York. An unknown volume of stormflow runoff in Cubero Creek also recharges the alluvium. Average yearly runoff in Cubero Creek is estimated to be 1.0 cubic foot per second based on physical characteristics of the drainage basin as described by Borland (1970). Stormflows in Encinal Creek also recharge the valley fill at the mouth of the creek with potable water. Mean annual flow in Encinal Creek estimated from basin characteristics is about 0.89 cubic foot per second. The volume of recharge to the valley fill is not known but is expected to vary considerably from year to year. 


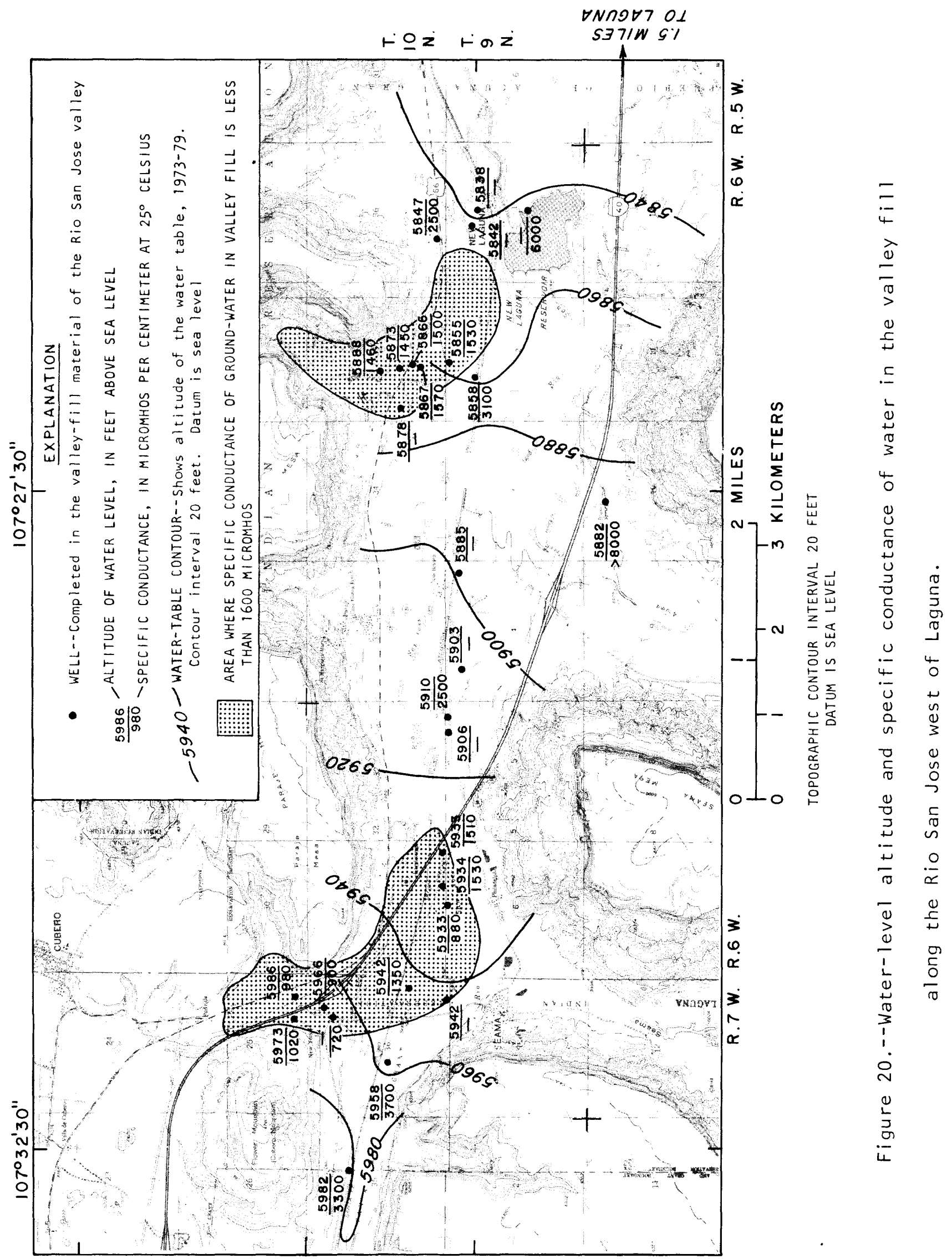




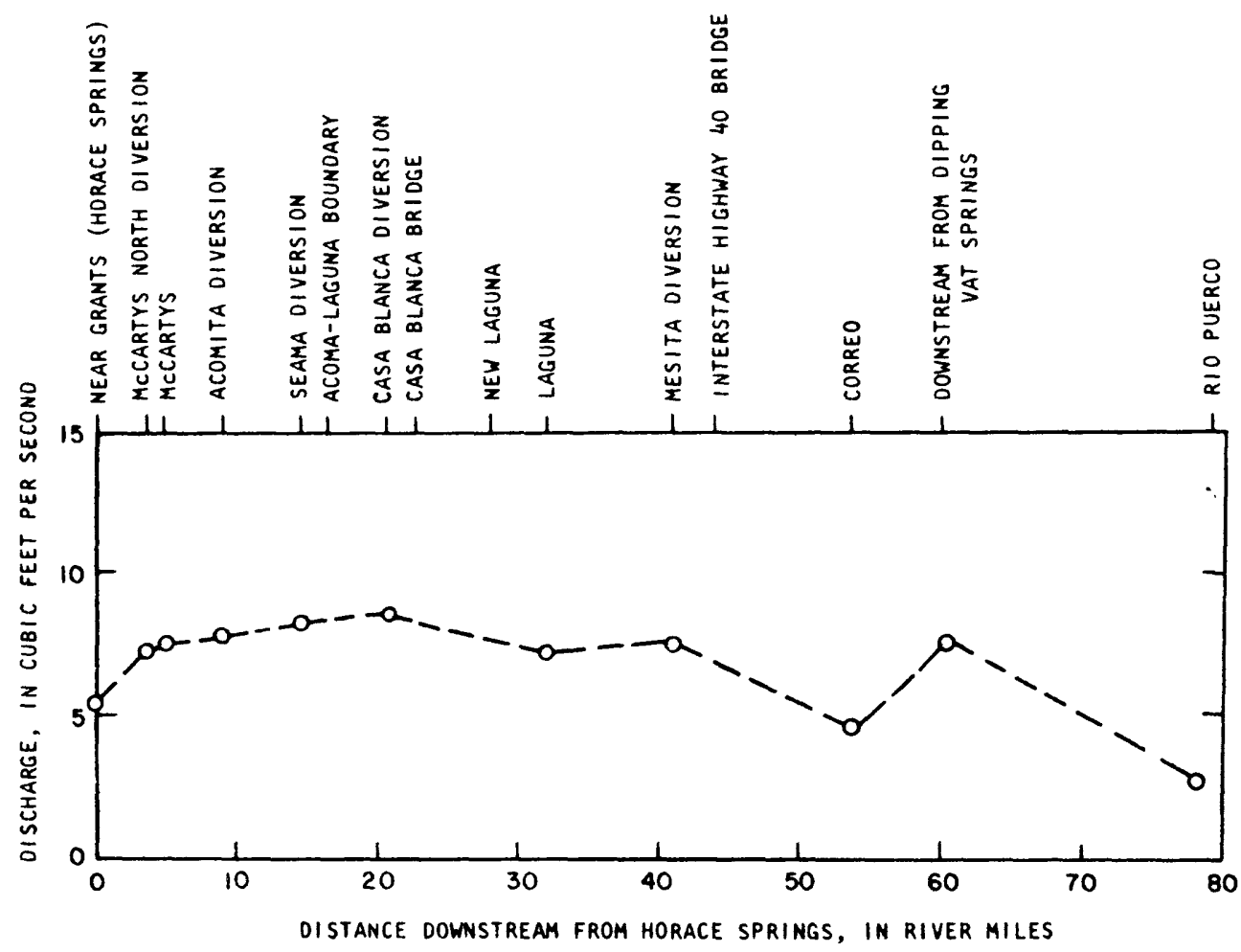

Figure 21.--Average winter discharge in the Rio San Jose calculated from miscellaneous measurements at selected sites between Horace Springs and Rio Puerco (1974-79).

Water in the valley fill discharges to the Rio San Jose and directly to the atmosphere through evapotranspiration. The gaining reaches of the Rio San Jose, between the western pueblo boundary and Casa Blanca diversion (0.02 cubic foot per second per mile) and between Correo and Dipping Vat Spring (0.52 cubic foot per second per mile), are discharge areas for the valley fill (fig. 21). Large volumes of ground water also are lost to evapotranspiraton although exact quantities are difficult to estimate. The volume of water transpired by plants probably is greatest along the channel of the Rio San Jose where phreatophytes are abundant. The annual consumptive use calculated for salt cedar for an area with climatic conditions similar to Laguna is 51.4 inches (Blaney and Hanson, 1965, p. 47). Using this rate and assuming that salt cedars cover an area about 200 feet on each side of the stream, ground-water losses to transpiration in the valley west of the village of Laguna would be about 3.4 cubic feet per second.

Large volumes of surface water also are evapotranspired from New Laguna Reservoir and the surrounding swampy area. Evapotranspiration from this 400-acre area may be as much as 2.4 cubic feet per second.

Ground-water withdrawals also account for a small volume of discharge from the valley fill. During summer months, wells near New York and Seama withdraw about 370 gallons of water por minute for public supply. During the irrigation season, two wells near New Laguna withdraw a combined total of as much as 575 gallons per minute. 
Water levels in wells completed in the valley fill fluctuate in response to recharge and discharge. Water levels in wells 10.6.35.322 (Pueblo Test 1) and 10.6.35.342 (Pueblo Test 2) rose from 1966 to 1968, probably in response to recharge from stormflows in Encinal Creek (fig. 22). The larger increase measured in Pueblo Test 1 was probably because the well is nearer the creek. The discontinuation of pumpage from well 10.6.35.324 (New Laguna P. S.) in 1974 may have stopped the water-level declines in Pueblo Test 1 . Water levels in well 10.7.35.232 (Ir.Test 6), located near the western pueblo boundary, showed no apparent trend from 1960 to 1979.

Water-level fluctuations for wells in the New York-Seama area are shown in figure 22. Steady declines have been recorded in wells 10.7.36.322 (Laguna 76-2), 10.7.36.424 (Laguna 76-1), 10.7.25.432 (Abandoned New York), and 10.7.36.221 (New York 1) since 1976. The declines are probably in response to ground-water withdrawals for the Laguna public supply from wells 10.7.36.221 (New York 1), 10.7.36.212 (New York 2) and 10.6.31.434 (Seama P.S.). Water levels in well 9.6.6.211 (Seama-Mesita) show no apparent downward trend despite its location less than $1 / 4$ mile southwest of the Seama P.S. well. Possibly, pumpage from Seama P.S. well is derived to a large extent from induced infiltration from the Rio San Jose.

Water levels in well 9.6.5.222 (Laguna 76-6), 9.6.2.123 (Laguna 76-7) and 10.7.36.322 (Laguna 76-2) illustrate the seasonal fluctuations that exist to some extent everywhere in the valley (fig. 22). The fluctuations probably are due to changes in pumping and evapotranspiraton rates, changes in the stream stages in the Rio San Jose, and changes in the amount of recharge from Encinal Creek.

Rio Paguate valley--Ground water in the alluvium along the Rio Paguate is hydraulically connected to streamflow in the Rio Paguate and the bedrock aquifers that bound the valley fill. Upstream from the village of Paguate, the stream recharges the alluvium with potable water containing between 190 and 590 milligrams per liter of dissolved solids. Measurements of winter streamflow, when irrigation withdrawals were not taking place, indicate an average streamflow loss of about 300 gallons per minute from a point about $2 \frac{1}{2}$ miles northwest of the village of Paguate to the State Highway 279 bridge. About 30 gallons per minute of the recharge is pumped from the alluvium near Paguate for public supply of the village.

The remainder of the recharge from the stream probably is lost to transpiration in the marshy area near the public-supply wells. Assuming a consumptive use by grasses of about 30 inches per year (Blaney and Hanson, 1965, p. 62) and a marshy area of about 160 acres, water loss to evapotranspiration is about 250 gallons per minute. In addition, ground water is withdrawn for public supply in this area at an average rate of about 30 gallons per minute. More wells withdrawing water at a combined rate of as much as 250 gallons per minute might lower the water table and decrease the water lost to transpiration. This action, however, would dry up the marshy area, which may be an important wetland habitat for wildlife. Downstream from Paguate, water quality in the alluvium becomes more mineralized as water from Jurassic sandstones discharge to the alluvium. 

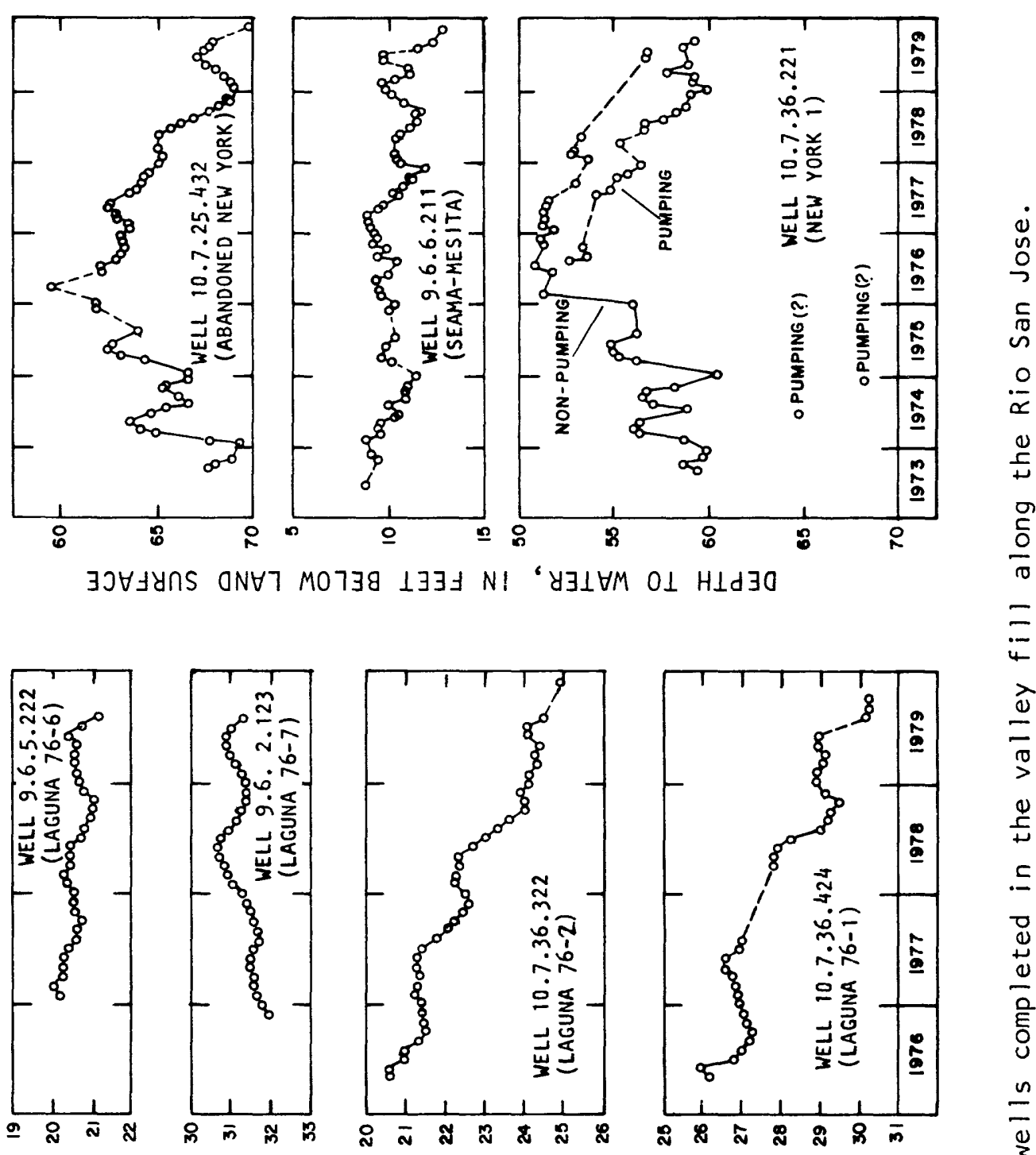

$\Xi$

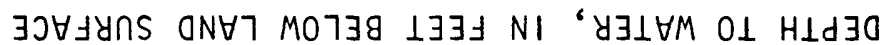
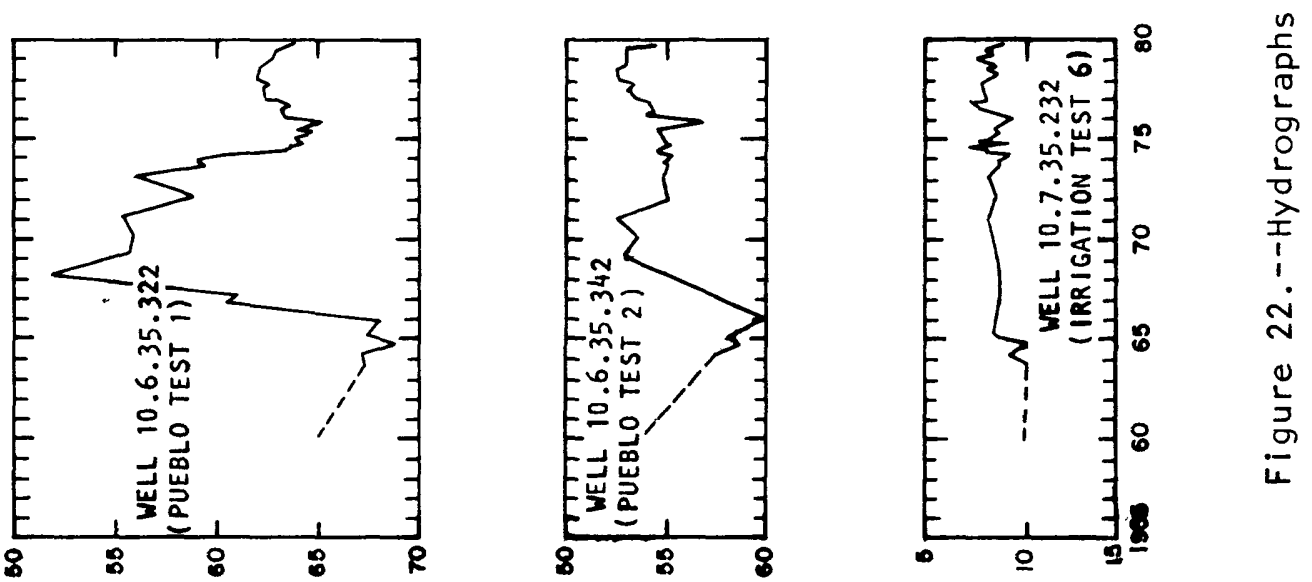

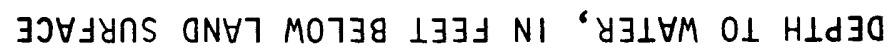




\section{Ground-water use}

The main water system on the Pueblo of Laguna supplies the residents along the Rio San Jose from wells that derive water from the alluvium in the New York-Seama area. Production from wells 10.7.36.221 (New York 1), 10.7.36.212 (New York 2), and 10.6.31.434 (Seama P.S.) totaled about 370 gallons per minute during August 1-8, 1979 (Norm Fairbanks, Indian Health Service Field Engineer, written commun., 1979). Water consumption by the valley residents was approximately 100 gallons per day per person during this period. The water use by valley residents was estimated to be about one-half this quantity during winter months when gardens and lawns are not being watered.

The village of Encinal obtains about 100 gallons per minute of water for public supply from Encinal Spring, which issues from basalt flows near Mount Taylor. Water use at Encinal has not been measured, but based upon per capita consumption by valley residents, the residents of Encinal probably only use 15 to 30 gallons per minute of the springflow for domestic purposes. The remaining 70 to 85 gallons per minute is either used for other purposes, such as irrigation, or allowed to seep into the alluvium along Encinal Creek.

The village of Paguate obtains water from public-supply wells 11.5.32.234a (Paguate P.S. 1) and 11.5.32.232 (Paguate P.S. 2), which are completed in the alluvium along the Rio Paguate. In August 1979, the Paguate P.S. 2 well was pumped 12 hours per day at an average rate of 73 gallons per minute. Water use during August for the Paguate residents averaged 54 gallons per day per person. The Paguate P.S. 1 well was pumped only occasionally during this study.

The old village of Mesita obtains water from well 9.5.13.233 (Mesita P.S.), which produces from the Entrada Sandstone and Correo Sandstone Bed of the Petrified Forest Member of the Chinle Formation. On the average, the wel1 is pumped for 2 days every 2 weeks at a rate of 10 gallons per minute to fill a 30,000-gallon storage tank. Per capita consumption measured during August 1-8, 1979, averaged 20 gallons per day.

The E1 Paso Natural Gas Company uses water for domestic and industrial purposes from wells 9.5.24.414 (E1 Paso Natural Gas 2) and 9.5.24.413 (E1 Paso Natural Gas 3), which produce from the Correo. Sandstone Bed of the Chinle Formation. Pumpage from the two wells ranges from less than 1 gallon per minute during winter to as much as 25 gallons per minute during summer (Pat Adkins, E1 Paso Natural Gas Co., oral commun., 1979). 
Water is pumped from sandstone units of the Brushy Basin Member of the Morrison Formation for industrial and domestic uses by the Anaconda Copper Company near Paquate. Water also is pumped to dewater the P-10 underground uranium mine. Approximate total pumpage for 1978 by Anaconda is summarized below (U.S. Geological Survey, 1978; Meade Stirland, The Anaconda Company, written commun., 1978):

\section{Source of pumpage}

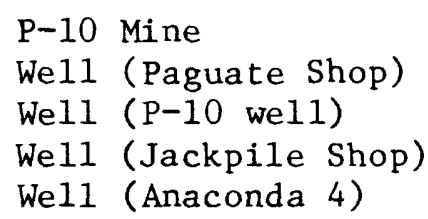

Total

\section{Discharge rate (gallons per day)}

$$
\begin{array}{r}
200,000 \\
12,400 \\
17,800 \\
400 \\
15,500
\end{array}
$$

246,100

Water for irrigation is pumped during summer months from the alluvium along the Rio San Jose at wells 10.7.36.424a (Laguna Ir. 1) and 10.6.35.342a (Laguna Ir. 2). During the irrigation season, Laguna Ir. 1 pumps about 25 hours per week at 400 gallons per minute, and Laguna Ir. 2 pumps about 25 hours per week at 175 gallons per minute (Denny Fic, Pueblo of Laguna, oral commun., 1981).

\section{SURFACE WATER}

Nearly all Laguna lands are drained by the Rio San Jose, which flows eastward through the center of the pueblo and joins the Rio Puerco about 24 miles east of Correo. Major tributaries of the Rio San Jose on the Pueblo of Laguna are Cubero Creek, Seama Creek, Encinal Creek, Acoma Creek, Rio Paguate, Arroyo Conchas, and Arroyo Colorado. Cubero Creek, Encinal Creek, and Rio Paguate, which drain the southeastern flank of Mount Taylor are sustained by spring flow and are perennial in their upper reaches. Other tributary streams flow only in response to storms or snowmelt.

Locations of water-quality and streamflow-gaging sites are shown in figure 23. Streamflow measurements and water-quality data for these sites are listed in tables 9 through 13. 


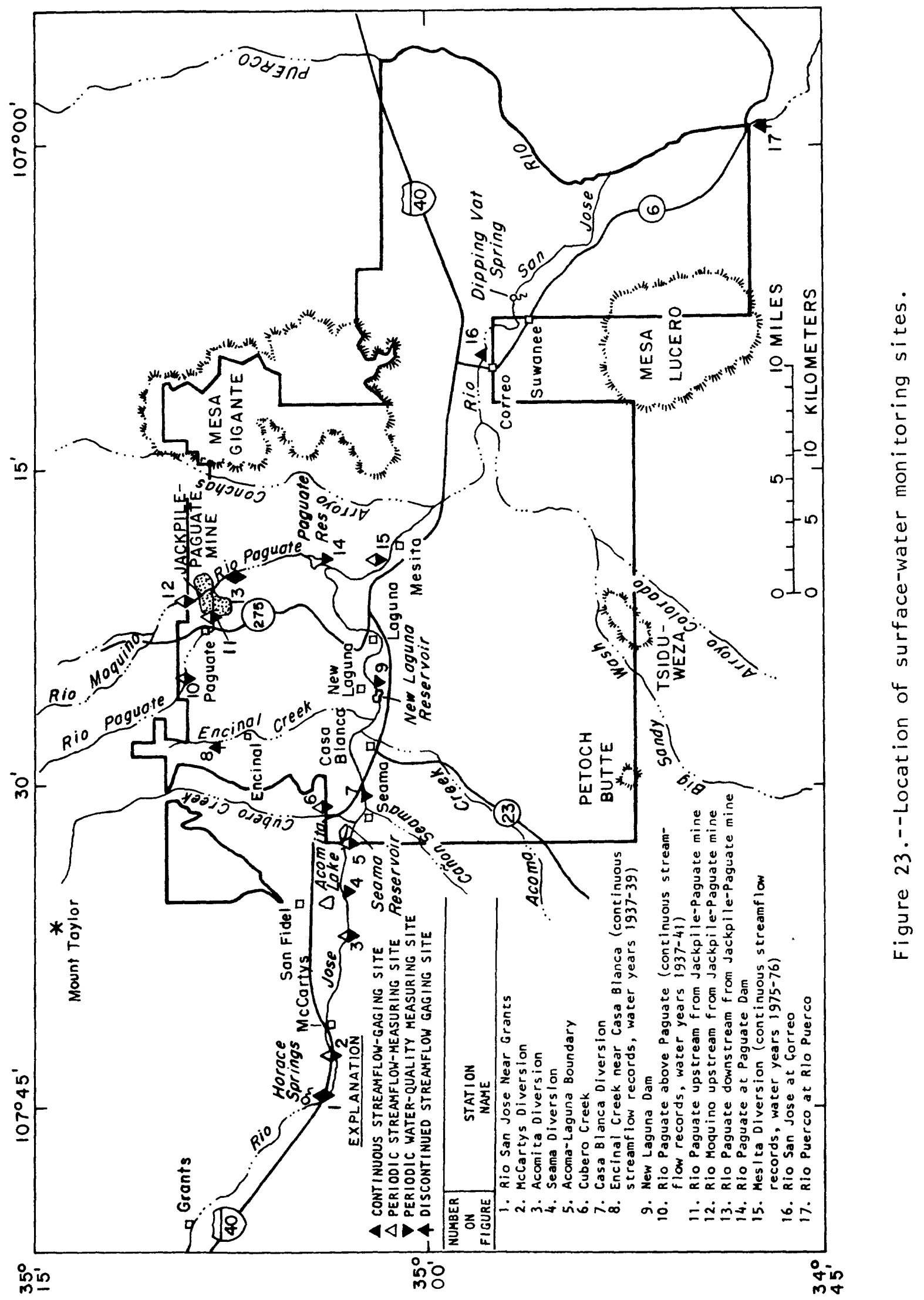


The majority of flow in the Rio San Jose is sustained by Horace Springs, which have an average discharge of about 5 cubic feet per second from the valley fill about 16 miles west of Seama. The ephemeral runoff upstream from Horace Springs contributed about 80 acre-feet per year (or less than 2 percent of the total streamflow) from 1969 through 1978 at the gaging station near Grants (08343500). Runoff, however, may have been greater prior to surface- and ground-water use in the Grants-Bluewater area, which began in the 1870's (Risser, 1982).

An additional component of the total flow is the wastewater effluent discharged by the city of Grants into the channel of the Rio San Jose. The effluent travels about 8 miles between Grants and Horace Springs. About 1 to 2 cubic feet per second of wastewater reaches Horace Springs. The streamflow downstream from Horace Springs consists of a mixture that is about 60 to 90 percent springflow and 10 to 40 percent wastewater.

The annual streamflow of the Rio San Jose downstream from Horace Springs averaged 4,710 acre-feet during water years 1937 through 1978 (fig. 24). The constancy of the flow throughout the 52 years is due to the large springflow contribution. Downstream, the flow in the Rio San Jose becomes quite variable due to extensive use of the stream for irrigation during summer months, tributary inflow, and natural gains and losses to and from the alluvium. Gaining and losing reaches of the stream are shown for non-irrigation and non-storm periods on figure 21. Major gains in streamflow from ground-water discharge take place at Horace Springs ( 5.0 cubic feet per second) between Horace Springs and McCartys (2.7 cubic feet per second), between Acomita and Seama diversions ( 0.8 cubic foot per second), and between Correo and Dipping Vat Springs (3.4 cubic feet per second). Losing reaches occur from Casa Blanca diversion to New Laguna Dam ( 1.0 cubic foot per second) and from Mesita diversion to Correo ( 3.2 cubic feet per second).

Non-storm winter streamflow entering the pueblo in the Rio San Jose averages about 8.5 cubic feet per second. This amounts to about 3,600 acre-feet during the non-irrigation season (October through April). The volume of non-storm runoff entering the pueblo during summer months is difficult to estimate because of extensive use of the water for irrigation on the Pueblo of Acoma. However, miscellaneous streamflow measurements made where the Rio San Jose enters the Pueblo of Laguna average 2.3 cubic feet per second from May through September (table 12). These measurements include water in irrigation ditches entering the pueblo, which probably contains some water released from Acomita Lake in addition to flow diverted from the Rio San Jose. The average non-storm flow in the Rio San Jose available during the growing season from May through September is about 700 acre-feet. 


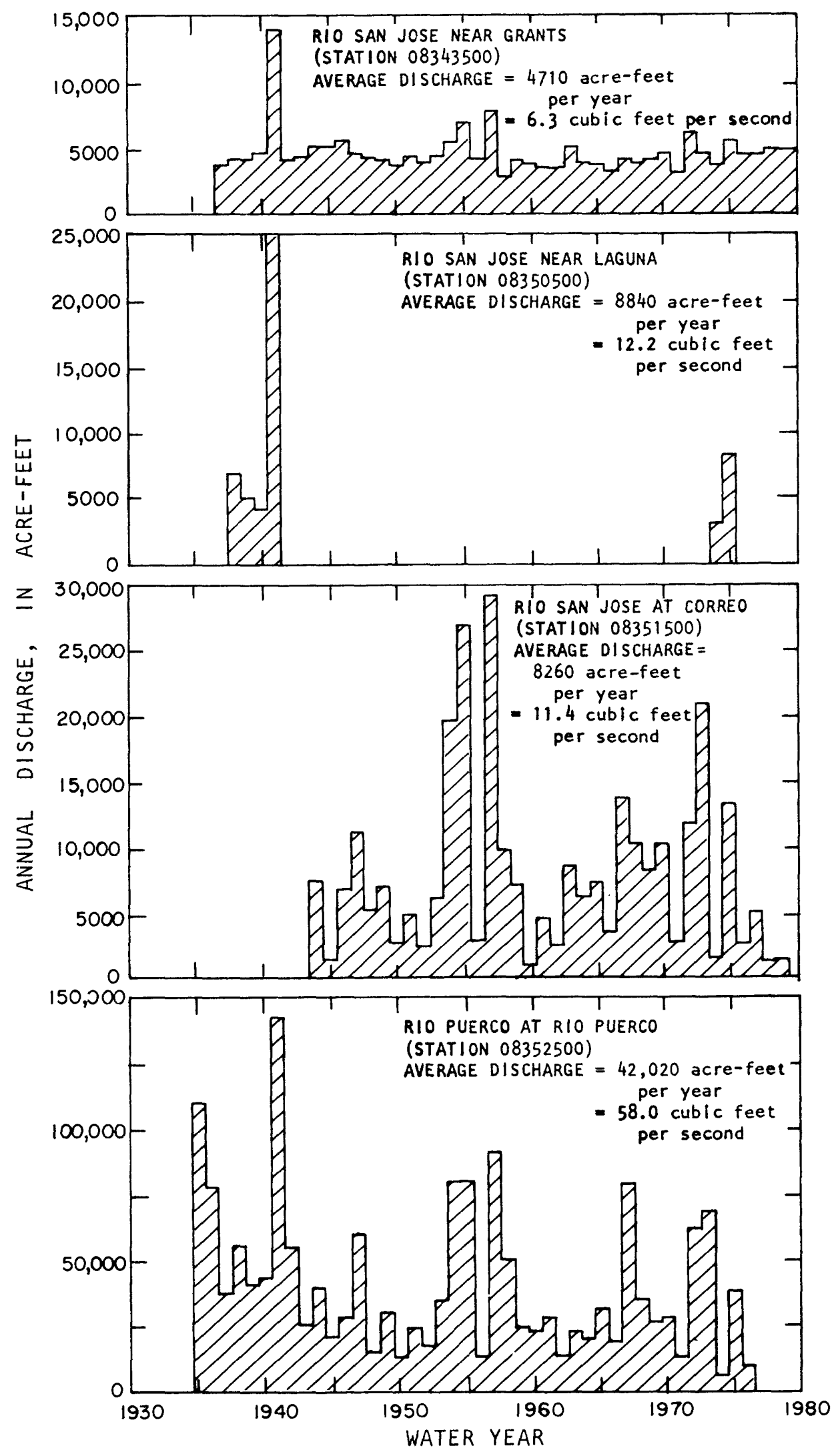

Figure 24.--Average annual discharge of the Rio San Jose and the Rio Puerco. 
Storm runoff is a large part of the total flow of the Rio San Jose on Laguna lands. The volume of storm runoff entering the pueblo is unknown but is at least as much as the 80 acre-feet per year measured at the gaging station near Grants (08343500). Records for the Rio San Jose near Casa Blanca upstream from New Laguna Dam for water years 1937 through 1941 show that storms contributed an average of about 2,000 acre-feet per year (U.S. Geological Survey, 1960, p. 472). Farther downstream, stormflows are an even greater part of the total flow. For example, about 48 percent, or 5,400 acre-feet, of the annual streamflow measured at the discountinued gaging station near Laguna (08350500) was contributed by summer stormflows (fig. 25). At Correo, about 6,400 acre-feet per year, or nearly 80 percent of the annual flow of the Rio San Jose, is contributed by storms from July tinrough October.

Duration curves illustrate the distribution of recorded streamflow of the Rio San Jose (fig. 26). There was no flow near Laguna and at Correo as much as 28 and 60 percent of the time. The steepness of the curves for all stations except the one near Grants indicates the extreme variability of streamflow.

\section{Flow in tributaries of the Rio San Jose}

All tributaries are ephemeral at their confluence with the Rio San Jose. However, Rio Paguate, Cubero Creek, and Encinal Creek are perennial in their upstream reaches, losing flow by seepage to streambed sands and gravels and by evapotranspiration before reaching the Rio San Jose.

\section{Rio Paguate}

Streamflow in the upstream reaches of the Rio Paguate mainly is sustained by spring discharge from basalt and colluvium. Mean-daily streamflow gaged at the Pueblo of Laguna boundary during the 1937-41 water years ranged from 0.2 to 174 cubic feet per second and averaged 1.6 cubic feet per second (fig. 27). An average discharge of 1.0 cubic foot per second calculated by excluding the abnormally wet year of 1941 probably is a more representative value of normal streamflow. The 12 miscellaneous discharge measurements recorded from 1975 through 1979 also average 1.0 cubic foot per second (tables 9 and 12).

The flow of 1.0 cubic foot per second represents about 400 acre-feet of streamflow that could be stored during the winter (October through April). Presently two small reservoirs store about 100 acre-feet of the winter streamflow. Additional reservoir capacity could store about 300 acre-feet of winter streamflows that are not presently used. 

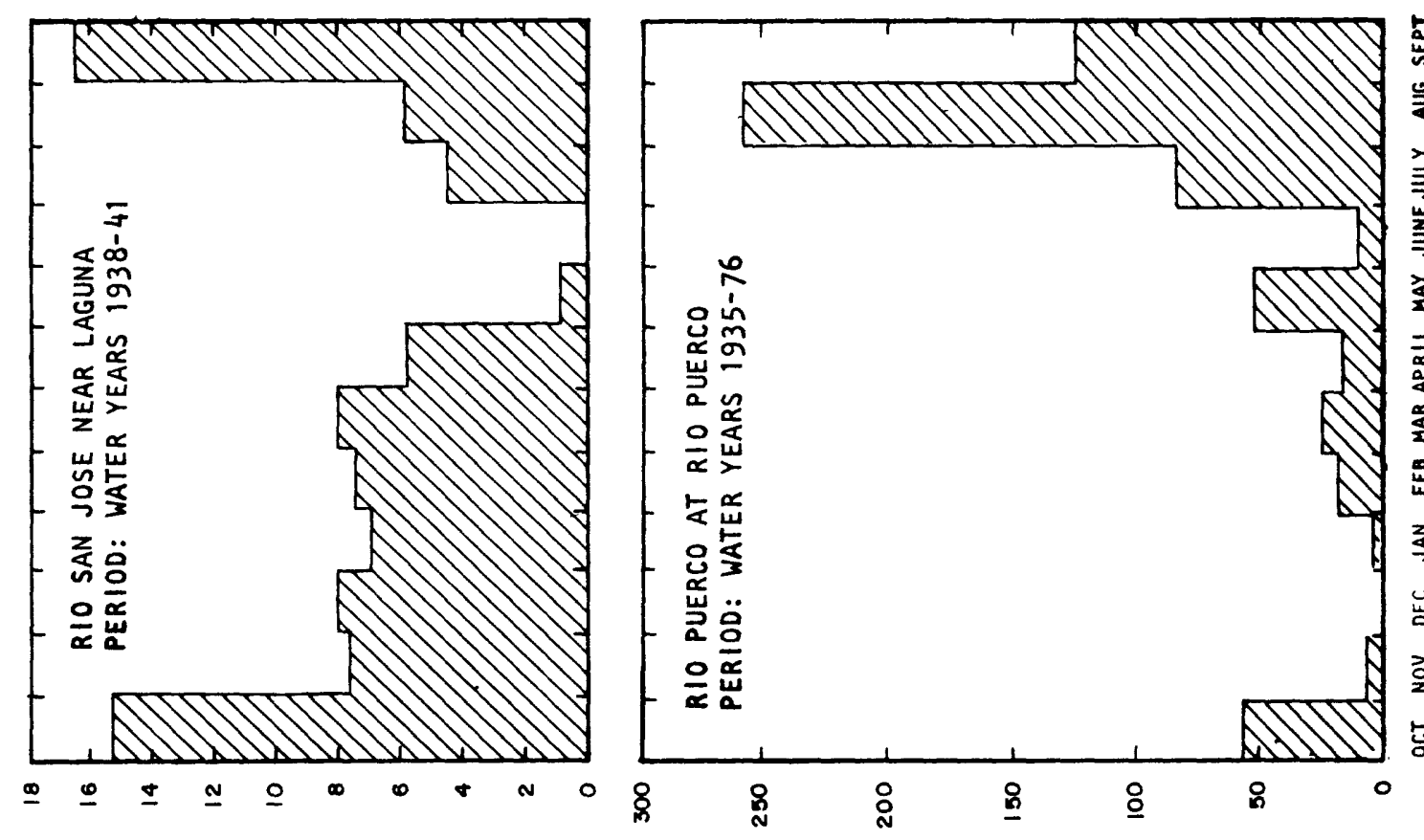

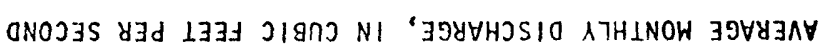
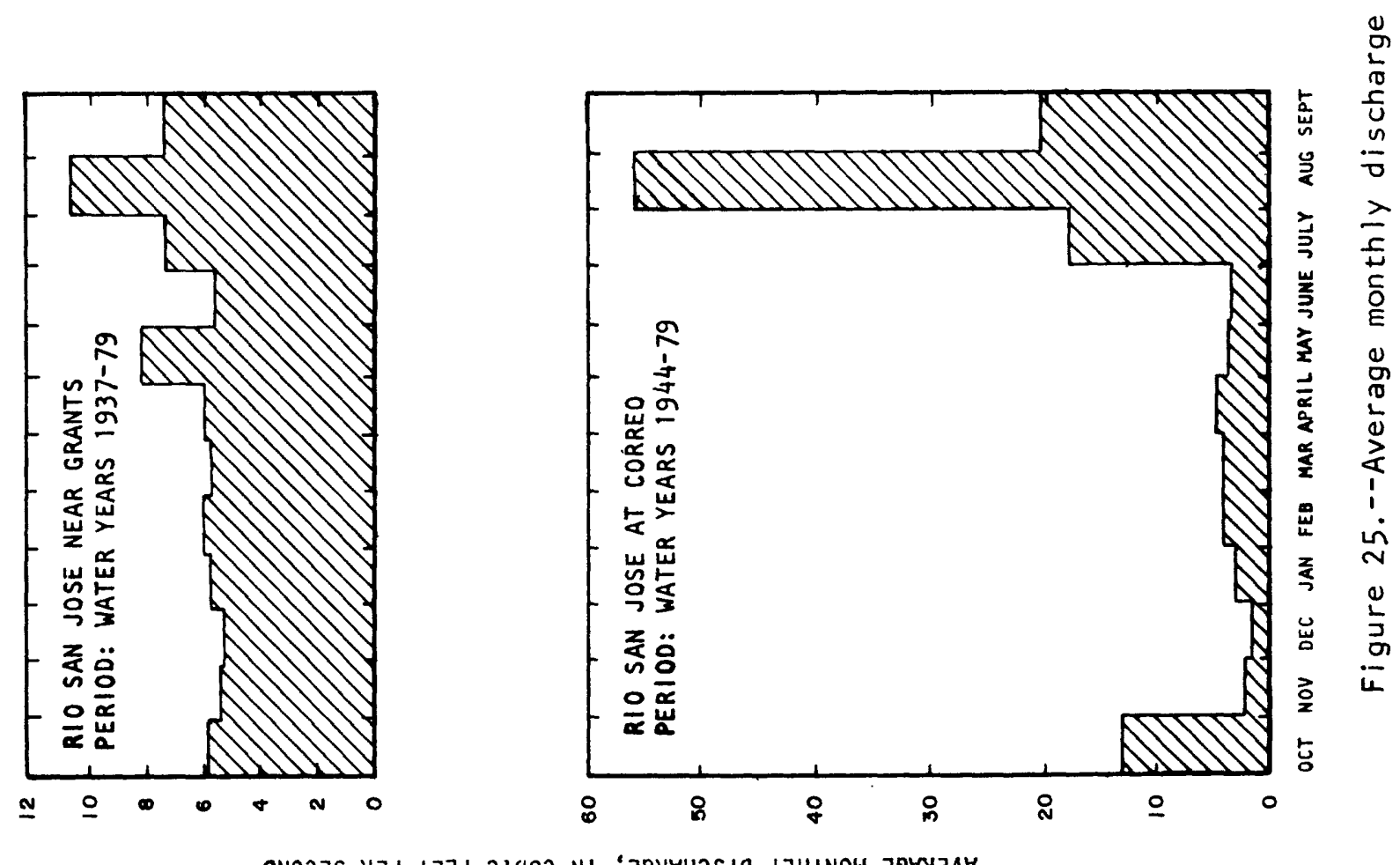

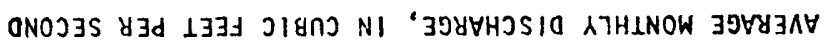




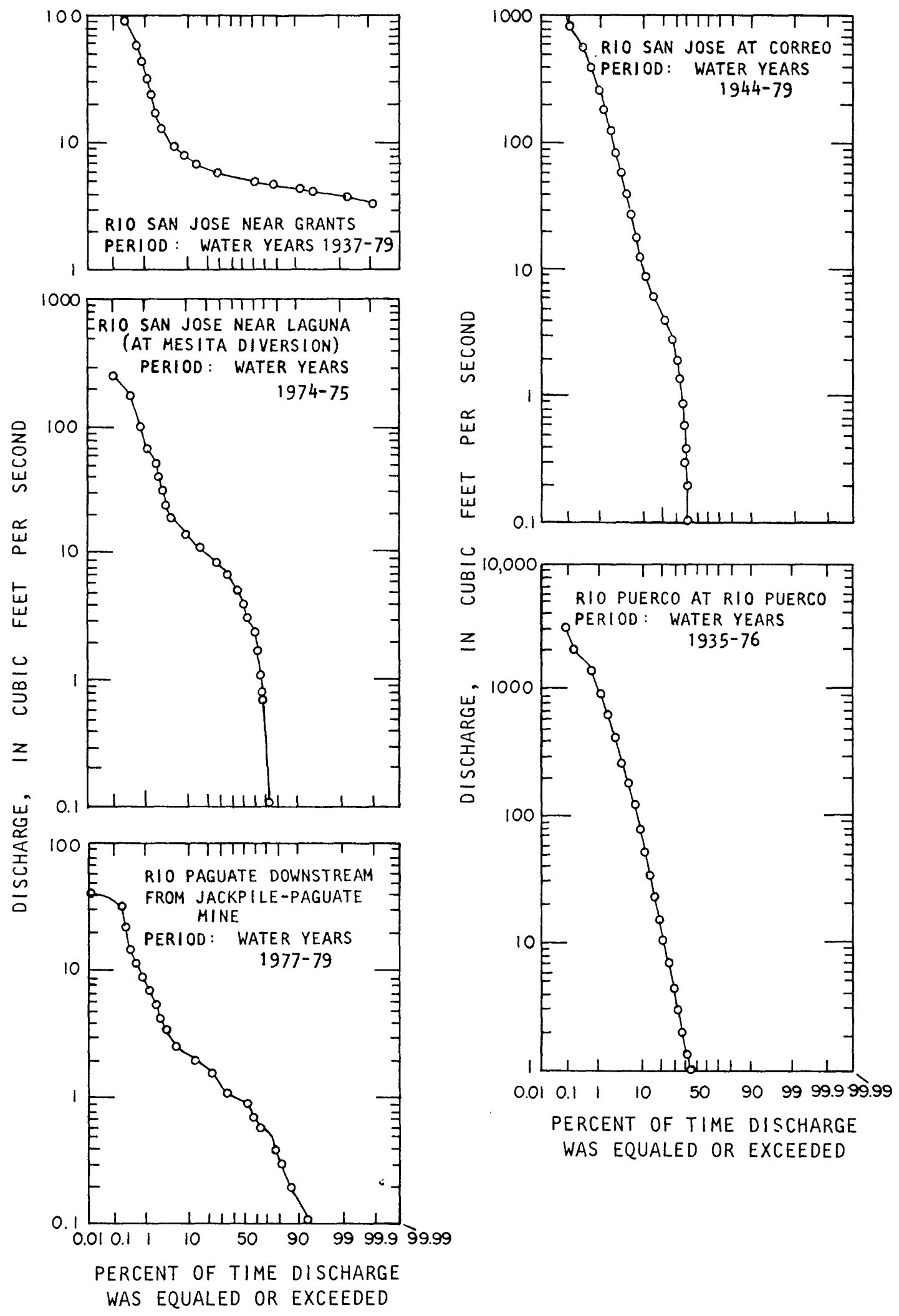

Figure 26.--Streamflow duration curves at gaging stations on Rio San Jose, Rio Puerco, and Rio Paguate. 


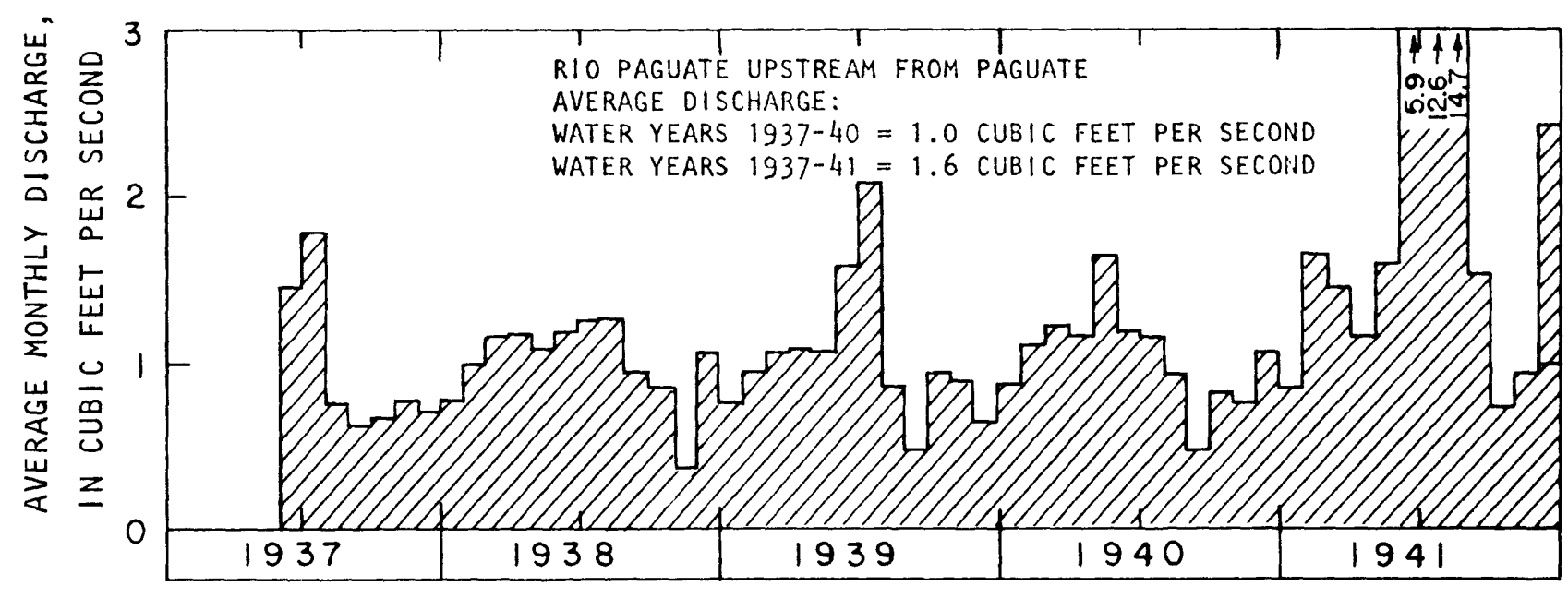

WATER YEAR

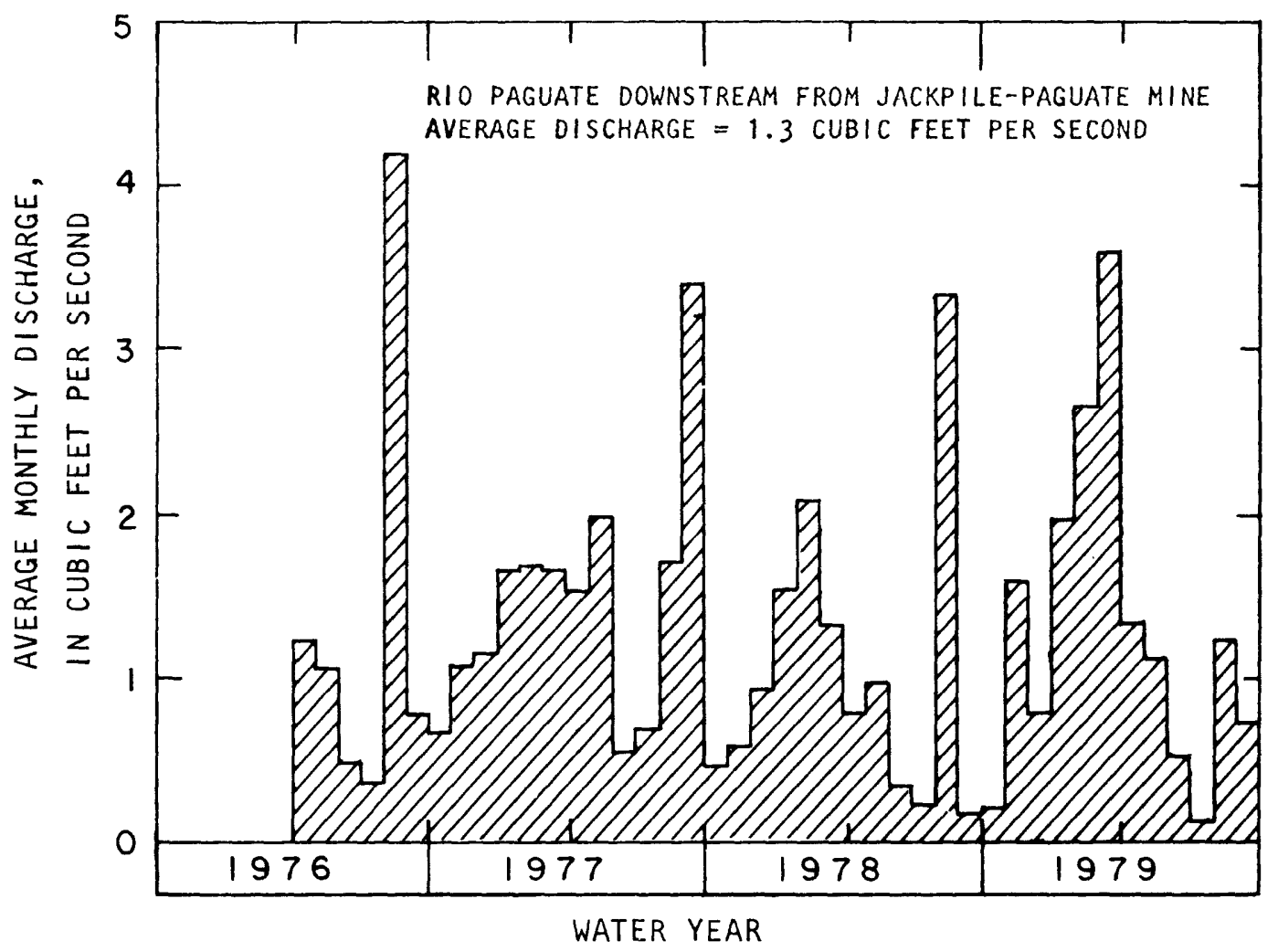

Figure 27.--Average monthly streamflow in the Rio Paguate. 
Sixteen miscellaneous streamflow measurements made downstream from the village of Paguate from 1975 through 1979 ranged from 0.1 to 1.4 cubic feet per second. Some of the apparent stream losses occurring between the reservation boundary and Paguate are caused by irrigation diversions during summer months. Comparison of non-irrigation periods at the two sites indicates net seepage losses of about 0.7 cubic foot per second.

Downstream from Paguate, the stream gains water from ground-water discharge and from the Rio Moquino. Streamflow in the Rio Moquino measured at the pueblo boundary about $1 / 2$ mile upstream from the Jackpile-Paguate Mine ranged from 0.09 to 4.6 cubic feet per second and averaged 1.1 cubic feet per second based on 14 miscellaneous measurements made from 1975 through 1977.

Monthly flow of the Rio Paguate downstream from the Jackpile-Paguate Mine from April 1976 through September 1979 is shown in figure 27. Flow averaged 1.3 cubic feet per second and ranged from 0.04 to 2,900 cubic feet per second. In the reach downstream from the Jackpile-Paguate Mine, large quantities of water are lost through seepage and evapotranspiration in the stream channel and in Paguate Reservoir.

Stormflows in the Rio Paguate probably contribute the majority of the annual flow reaching the Rio San Jose. Annual streamflow of 4,550 acre-feet was estimated based on watershed characteristics as described in Borland (1970) and Scott (1971). The magnitude and frequency of floods estimated by the same techniques are shown in table 15.

\section{Cubero Creek}

The perennial flow of Cubero Creek at the Pueblo of Laguna boundary is sustained mainly by a spring (10.7.24.411) that issues from the alluvium along the channel. Streamflow entering the reservation ranged from 0.22 to 0.42 cubic foot per second and averaged 0.30 cubic foot per second based on 14 miscellaneous measurements made during 1975-79. Most of this flow seeped into the alluvium in the New York-Seama area.

Stormflows of unknown quantity also added to the total flow of Cubero Creek. Total streamflow was estimated to be about 720 acre-feet per year based on the physical characteristics of the drainage basin as described in Borland (1970). The magnitude and frequency of flood discharges estimated according to techniques in Borland (1970) and Scott (1971) are shown in table 15 .

\section{Encinal Creek}

Streamflow in Encinal Creek was not measured during this study; however, during the 1937-39 water years, streamflow averaged 0.19 cubic foot per second at a gaging station (08348500) located about 1.5 miles north of Encinal. The streamflow at this point was sustained by numerous springs that issued from basalt at the head of Encinal Creek. Discharge varied seasonally 
due to winter snowmelt, stormflows, and upstream irrigation withdrawals during summer months. Discharge averaged 0.28 cubic foot per second during winter months when no withdrawals for irrigation were made. Streamflow today may have decreased since 1939 due to development of Encinal Spring as a source of public-supply water.

Stormflows contribute most of the flow in the downstream reaches of Encinal Creek. Total flow at the mouth of the stream was estimated to be 640 acre-feet per year from the physical characteristics of the watershed as described by Borland (1970). The magnitude and frequency of flood flows (table 15) were estimated according to Borland (1970) and Scott (1971).

\section{Ungaged tributaries}

Major tributary streams of the Rio San Jose that have never been gaged include Cañon Seama, Acoma Creek, Arroyo Conchas, and Arroyo Colorado. Total annual discharge and the magnitude of certain floods were calculated based upon the physical characteristics of drainage areas (table 15) as described in Scott (1971) and Borland (1970).

\section{Flow in the Rio Puerco}

Streamflow of the Rio Puerco at the southeast corner of the Sedillo Grant (station 08352500) averaged 58 cubic feet per second during the 1935-76 water years (fig. 24). The duration curves in figure 26 show that the Rio Puerco is dry about 50 percent of the time at this location. Summer stormflows occurring from July to October contribute 77 percent of the total flow at this station ( $f i g .25$ ). Most of the flow during non-storm periods is contributed by the Rio San Jose, which flows into the Rio Puerco about 6 miles upstream from the gaging station.

\section{Surface-water use}

Most of the non-storm flow in the Rio San Jose upstream from Mesita is used to irrigate crops on the Pueblos of Laguna and Acoma. About 700 acre-feet of water from the Rio San Jose enters Pueblo of Laguna during the growing season, which includes part of the 650 acre-feet stored in Acomita Reservoir during winter months. During 1979, the water was used to irrigate about 70 acres in the Rio San Jose valley (Daniel Carr, U.S. Bureau of Indian Affairs, written commun. 1980). Seama Reservoir, recently constructed in the valley where the Rio San Jose enters the pueblo, will store as much as 480 acre-feet of the water that presently flows through the pueblo during winter months.

Surface water from the Rio Paguate is stored in two small reservoirs that together have a capacity of about 100 acre-feet. This water and the summer flow was used to irrigate about 52 acres near Paguate. Surface water from Encinal Creek was used to irrigate about 19 acres near Encinal. 


\section{WATER QUALITY}

Development of water resources on the Pueblo of Laguna is largely restricted by water quality. This section discusses water-quality criteria for various uses, ground-water quality, and surface-water quality. Though ground water and surface water are discussed separately, the two are closely related; most surface water, except stormflows and snowmelt runoff, is contributed from ground-water sources.

\section{Water-quality criteria for various uses}

The suitability of water for various uses depends on the concentration of dissolved solids and the concentration of particular constituents. The U.S. Environmental Protection Agency (1976a, 1976b) and Federal Water Pollution Control Administration (1968) list water-quality standards and recommended criteria for public supply, freshwater aquatic life, livestock, and irrigation (table 17).

Waters which meet the quality standards and criteria set for public supply are limited on the Pueblo of Laguna. Surface and ground waters in the Encinal and Paguate areas meet all the standards and criteria. Ground water in the alluvium along the Rio San Jose in the New York-Seama and New Laguna areas meet most of the standards and criteria except for specific conductance, hardness, and sulfate.

The water-quality criteria for Ereshwater aquatic life listed on table 17 were not exceeded in samples analyzed from the Rio San Jose, Rio Paguate, Cubero Creek, Rio Moquino and Rio Puerco except for certain values of iron and cadmi um.

Water suitable for consumption by livestock may be obtained almost anywhere on the pueblo except on the Sedillo Grant. Salt springs in that area commonly discharge water with specific-conductance values in excess of 17,000 micromhos.

Water-quality criteria for irrigation are difficult to evaluate because other factors such as soil characteristics, quantity of water available, and types of crops also are important. The three chemical characteristics commonly used to evaluate the suitability of water for irrigation are boron concentration, sodium concentration, and specific conductance. Most surface water and ground water on the pueblo that may be available in sufficient quantities for irrigation have boron concentrations well within the allowable range (500-1,000 micrograms per 1iter) for sensitive crops. For this reason, boron concentrations should not restrict development of irrigation water. However, waters with large specific-conductance values and sodium concentrations are very common on the pueblo. Large values for these characteristics are good indicators of an excessive dissolved-solids concentration and sodium hazard that may restrict use of the water for irrigation. 


\section{Ground-water quality}

Bedrock units

The quality of water in bedrock units is affected by many factors including the types of minerals present in the rock, the length of time the water has been in contact with the rock, ion exchange, various chemical reactions, and ground-water movement, which may cause mixing of different water types. Water in bedrock units in the study area is chemically suitable for all uses near areas of recharge but is chemically unsuitable for most uses in salt springs near the Puerco fault zone and in deep wells throughout the study area (tables 5 through 8 ).

Water in bedrock units can be placed in four general categories determined by the relative abundance of major ionic constituents. These categories are illustrated on the water-analysis diagram of figure 28. The water-analysis diagram may illustrate, in a general way, the chemical evolution of ground water on the pueblo. The major ions in water in or near areas of recharge are calcium, magnesium, and bicarbonate. As the water moves from recharge areas downward through the rock units gypsum is dissolved, which is disseminated in the Mancos Shale, Jurassic sandstones, and found as an identifiable unit in the Todilto Formation. Thus, water becomes enriched in calcium and sulfate. Ion-exchange processes then replace one calcium or magnesium ion in the water with two sodium ions. Ion exchange is most readily accomplished in shale units, such as those in the Mancos Shale, Chinle Formation, and Brushy Basin and Recapture Members of the Morrison Formation. The water resulting from the ion-exchange process contains sodium and sulfate as the major constituents. This is the most common type of water found on the pueblo.

Water discharging from deep units, such as the Permian and Triassic rocks, plots in the right corner of the anion triangle (fig. 28). This water has been deep in the ground-water system a very long time. Because little mixing of water occurs at depth, the water becomes enriched in sodium and chloride ions probably by coming in contact with soluble salt beds in the Permian rocks.

The quality of water is determined by the total ionic concentration as well as the type of ions in solution. Dissolved-solids concentrations for bedrock units are discussed in the following sections.

Permian System--Water in rocks of the Permian System contains excessive concentrations of dissolved solids. Well 8.5.17.213 produced water with a specific conductance of 82,800 micromhos (the specific-conductance value multiplied by 0.7 is approximately equal to the dissolved-solids concentration in milligrams per 1iter). Water from wells 9.5.12.442 (Mesita Test) and 9.1.8.142 (Shel1 0il Test) contained 18,000 and 15,500 milligrams per liter of dissolved solids respectively. The salt springs on the Sedillo 
ARROWS SHOW CHEMICAL

EVOLUTION OF GROUND WATER

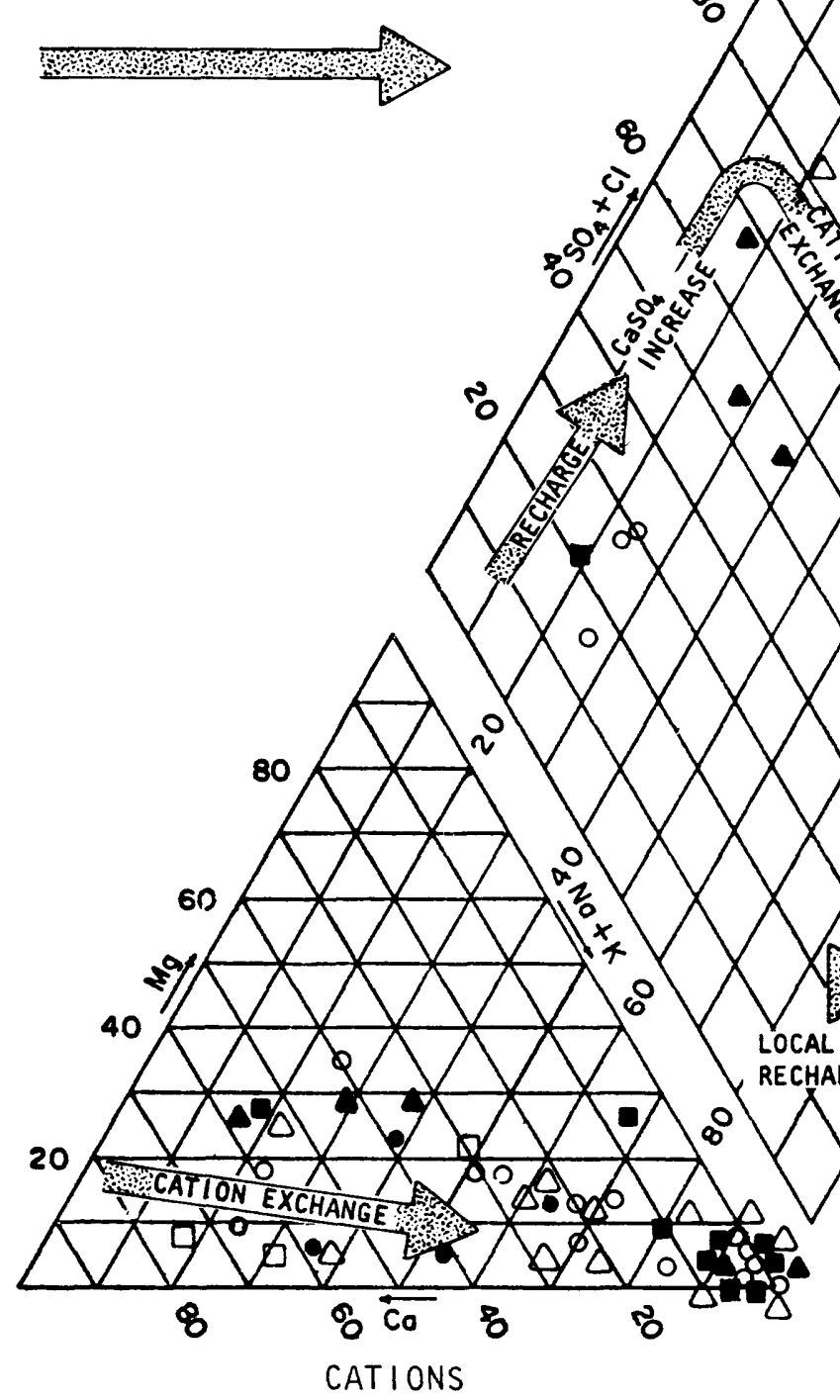

\section{EXPLANATION}

WATER FROM:

- DAKOTA SANDSTONE

- MORRISON FORMATION

O BLUFF SANDSTONE

口TODILTO FORMATION

- ENTRADA SANDSTONE

$\triangle$ CHINLE FORMATION

NOTE: symbol locations are approximate where densely spaced.

Figure 28.--Water-analysis diagram for selected wells completed in bedrock units. 
Grant are caused, in part, by upward seepage of water from Permian rocks. Specific-conductance values of the springflow mainly are in the 30,000 to 40,000 micromhos range. It is unlikely that water with dissolved-solids concentrations acceptable for stock, irrigation, or public-supply use will be found beneath the Pueblo of Laguna in Permian rocks.

Triassic System--Water quality in the Chinle Formation is least mineralized (dissolved-solids concentrations between 700 and 1,500 milligrams per liter) near Mesita along outcrops of the Correo Sandstone Bed of the Petrified Forest Member of the Chinle Formation. Dissolved-solids concentrations increase to the east in the direction of ground-water flow as shown on figure 16. Several springs in the southern part of the Sedillo Grant discharge small quantities of excessively mineralized water. These springs probably represent upward movement of water from deeper units throughout the Puerco fault zone.

Jurassic System--Water quality in the Entrada Sandstone is least mineralized in recharge areas near outcrops. A map delineating water-quality zones based upon specific-conductance measurements is shown in figure 17. Dissolved-solids concentrations are less than 1,500 milligrams per liter on outcrop areas and range from 1,500 to 4,000 milligrams per liter on the remainder of the Pueblo Proper. No water-quality data are available for the Jack Ward, Montaño, Mount Taylor, Sedillo, and Major's Ranch areas; water in the Puerco fault zone is expected to be quite mineralized due to upward movement of water from deeper units.

Specific-conductance values illustrate the distribution of dissolved-solids concentration for water in the Bluff Sandstone (fig. 18). Dissolved-solids concentrations are less than 700 milligrams per liter in outcrop areas and range from 1,000 to 3,000 milligrams per liter in other parts of the Pueblo Proper. Water is quite mineralized in eastern pueblo lands within the Puerco fault zone.

The quality of water in the Morrison Formation based on specific-conductance measurements is shown in figure 19. Dissolved-solids concentrations on the Pueblo Proper range from about 500 to 1,500 milligrams per liter and increase toward the Puerco fault zone (tables 5-8). Near Paguate, the ground water contains between 500 and 1,500 milligrams per liter of dissolved solids. Water in the Morrison Formation on Sedillo and Montaño Grants contains between 7,000 and 24,000 milligrams per 1iter of dissolved solids due to upward leakage of water throughout the Puerco fault zone. Radium-226 concentrations ranging from 0.95 to 38.7 picocuries per 1iter were present in water sampled from the Jackpile sandstone unit and Westwater Canyon Member on the Montaño Grant (U.S. Geological Survey, Conservation Division, written commun., 1978). Water quality on the Major's Ranch area is untested; but west of the Puerco fault zone, the Westwater Canyon Member and Jackpile sandstone may yield water with dissolved-solids concentrations ranging from 1,000 to 2,000 milligrams per liter. 
Cretaceous System--Dissolved-solids concentrations in the Dakota Sandstone on the Pueblo Proper and Mount Taylor areas range between about 200 and 1,100 milligrams per liter. Most wells in the Encinal area produce water containing 800 to 1,100 milligrams per liter of dissolved solids. The dissolved-solids concentration of 27,600 milligrams per liter at a spring (7.2.6.434, Spring 190 ) on the Sedillo Grant is due to mixing with ground water from deeper units. Water quality on most of the Jack Ward, Montaño, and Major's Ranch areas is untested but dissolved-solids concentrations probably range from 2,000 to 4,000 milligrams per liter.

The specific conductance of water in the Mesaverde Group on the Sedillo and Montaño Grants ranges from 2,700 to 2,900 micromhos, which is suitable for stock use but not human consumption. Well 11.7.35.243 (Castillo Canyon 1) on the Mount Taylor area contained water with 670 milligrams per liter of dissolved solids. Rainfall and snowmelt on Mount Taylor probably provide recharge water with little dissolved-solids concentration to Mesaverde units near Paguate, Encinal, and on the Mount Taylor area.

\section{Alluvium}

Rio San Jose valley--The quality of water in alluvium along the Rio San Jose valley is quite variable. Specific conductance ranges from 720 to more than 8,000 micromhos. This great variation probably is due to several factors including variations in lithology of the valley fill and recharge of varying quality from different sources.

The general water-quality zones in the valley fill east of the village of Laguna are delineated on the basis of specific conductance in figure 20. Valley fill at the mouth of tributary valleys on the north (Cubero and Encinal Creeks) receives recharge from springs and runoff from Mount Taylor. Specific-conductance values of water in the valley fill range from 720 to 1,570, which represent dissolved-solids concentrations of between about 500 and 1,200 milligrams per liter. Ground water containing about 2,500 milligrams per liter of dissolved solids moving down the Rio San Jose valley from the west mixes with the less mineralized water recharged from Cubero Creek.

The geochemistry of waters in the Rio San Jose valley shows the mixing of different water types ( $\mathrm{fig}, 29$ ). Sodium and sulfate are the predominant ions in the water entering the pueblo in the valley from the west. This water mixes with recharge from Cubero Creek, which is predominantly a calcium bicarbonate water. Therefore, water in the alluvium appears to be a mixture, containing large concentrations of sodium, sulfate, calcium, and bicarbonate.

Water in the alluvium downstream from New Laguna Reservoir and in the Rio Puerco valley has a very high salinity hazard (specific conductances exceed 2,250 micromhos). The sodium hazard also may be high though sufficient chemical-quality data are not available. 


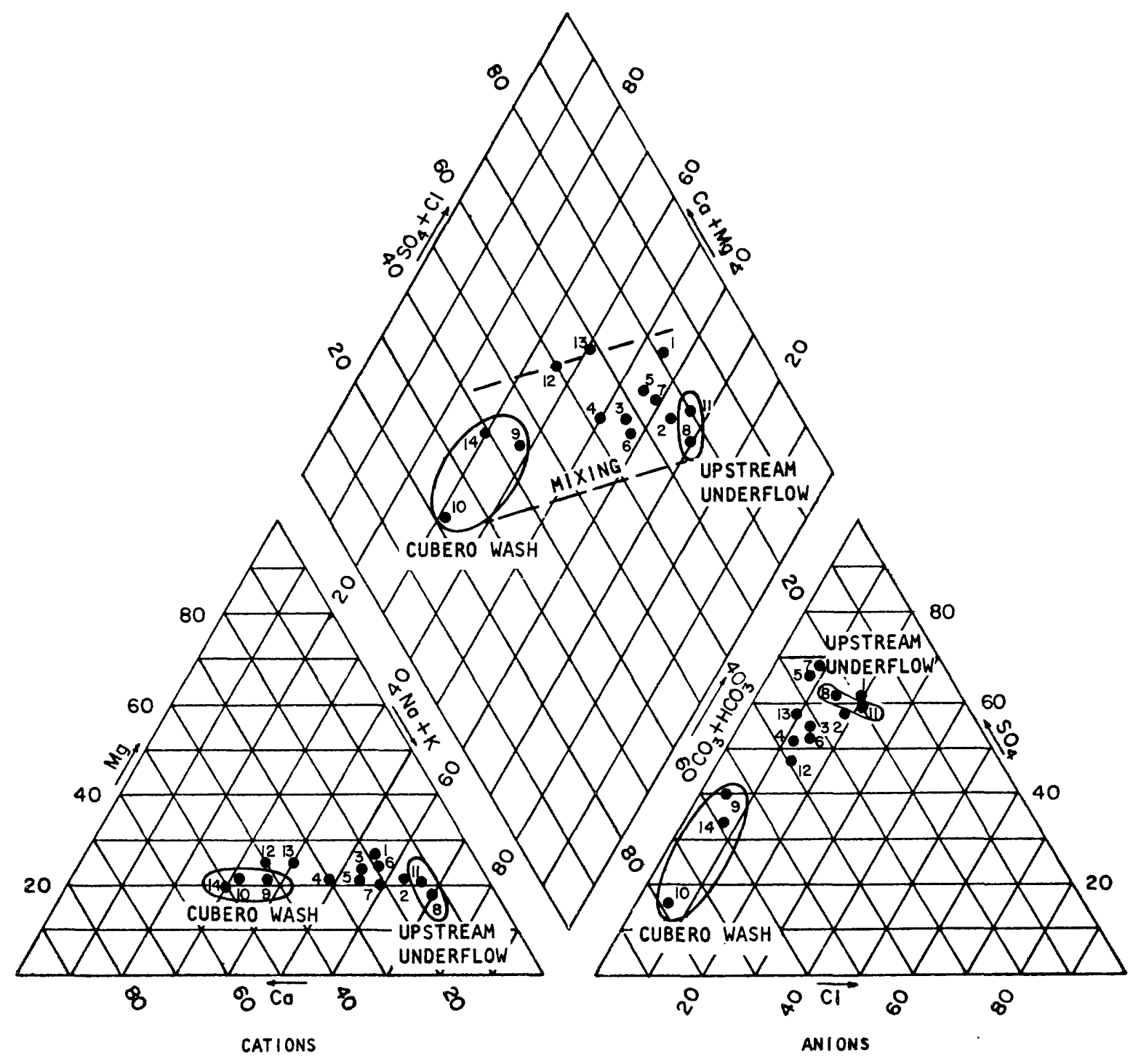

\begin{tabular}{|c|l|l|c|l|l|}
\hline IDENTIFIER & $\begin{array}{c}\text { LOCATION } \\
\text { NUMBER }\end{array}$ & $\begin{array}{c}\text { NAME OF WELL } \\
\text { OR SPRING }\end{array}$ & IDENTIFIER & $\begin{array}{c}\text { LOCATION } \\
\text { NUMBER }\end{array}$ & $\begin{array}{c}\text { NAME OF WELL } \\
\text { OR SPRING }\end{array}$ \\
\hline 1 & 9.6 .2 .123 & Laguna 76-7 & 8 & 10.7 .35 .232 & Irrigation Test 6 \\
\hline 2 & 9.6 .5 .222 & Laguna 76-6 & 9 & 10.7 .36 .212 & New York 2 \\
\hline 3 & 10.6 .31 .434 & Seama Publlc Supply & 10 & 10.7 .36 .221 & New York 1 \\
\hline 4 & 10.6 .31 .443 & Irrlgation Test 7 & 11 & 10.7 .36 .322 & Laguna 76-2 \\
\hline 5 & 10.6 .35 .322 & Pueblo Test 1 & 12 & 10.7 .36 .424 & Laguna 76-1 \\
\hline 6 & 10.6 .35 .324 & New Laguna Public Supply & 13 & $10.7 .36 .424 a$ & Laguna Irrigation 1 \\
\hline 7 & 10.6 .35 .342 & Pueblo Test 2 & & & \\
\hline
\end{tabular}

Figure 29. - Water-analys is diagram for wells completed in valley-fill deposits along the Rio San Jose. 
Rio Paguate valley--Water in the alluvium along the Rio Paguate upstream from the village of Paguate is recharged by streamflow generally containing between 190 and 600 milligrams per liter of dissolved solids. The dissolved-solids concentration of ground water in this area is about 300 to 500 milligrams per liter.

Downstream from Paguate, water in the alluvium becomes more mineralized as water from Jurassic sandstones discharge to the alluvium and streamflow from the Rio Moquino containing 1,040 to 3,060 milligrams per liter of dissolved solids joins the Rio Paguate. Water from well 10.5.26.223 (Ir. Test 8), drilled downstream from Paguate Reservoir, has a specific-conductance value of 10,000 micromhos, which corresponds to a dissolved-solids concentration of about 7,000 milligrams per 1iter.

\section{Surface-water quality}

Rio San Jose

The quality of water in the Rio San Jose varies with distance downstream from Horace Springs and from season to season as the volume of irrigation withdrawals, contributions from stormflow and snowmelt, and discharge of wastewater effluent change. Changes in selected water-quality characteristics are shown in figure 30. In general, the average winter concentrations of most constituents increase downstream from McCartys diversion due to ground-water contributions. Average dissolved-solids concentration of water upstream from McCartys is about 890 milligrams per liter. On the Pueblo of Laguna, the average dissolved-solids concentration of water in the Rio San Jose is 1,660 milligrams per liter at the western pueblo boundary, 1,300 milligrams per liter at the mouth of Cubero Creek, due to less mineralized ground-water contributions, and 1,800 milligrams per liter at Mesita diversion. Water with a dissolved-solids concentration between 890 and 1,800 milligrams per liter has a moderate to high salinity hazard for irrigation.

Water quality in the Rio San Jose changes from season to season in part due to changes in streamflow and upstream irrigation withdrawals. Average monthly specific-conductance values from the western pueblo boundary to Mesita were least from January through April, prior to the start of irrigation withdrawals, and peaked in the early summer months (fig. 31). Lesser values in the late summer months were caused by streamflows containing smaller concentrations of dissolved solids.

Specific conductance can be used as a tool to estimate values of other water-quality constituents (Hem, 1970, p. 96). Empirical relations between specific conductance and dissolved-solids concentration, sodium-adsorption ratio, chloride concentration, total hardness, and sulfate concentration in the Rio San Jose from Horace Springs to Mesita diversion are shown in figure 32 . 

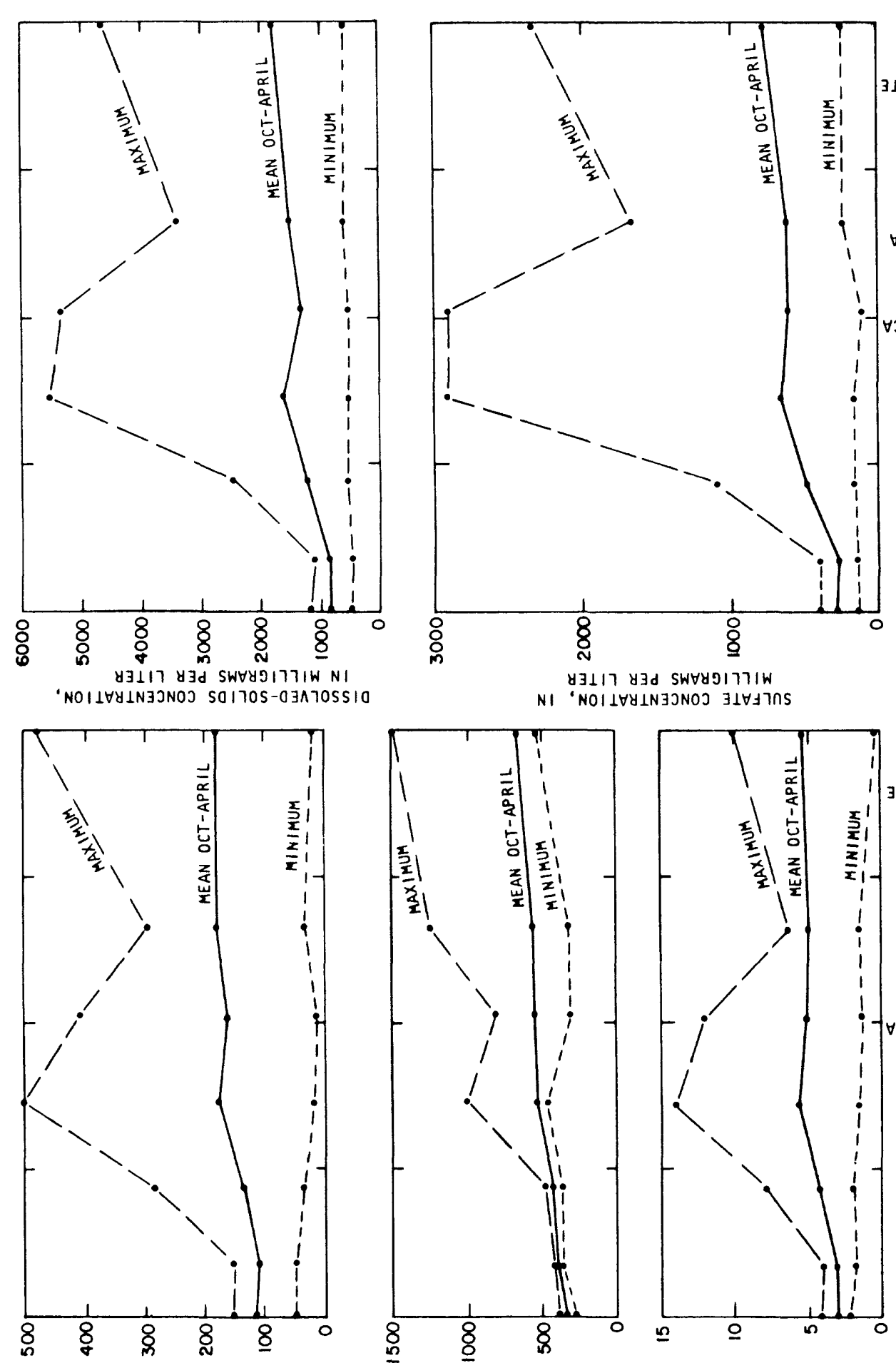

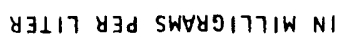

'NOII $Y$ INJJNOJ JOIYOTHO

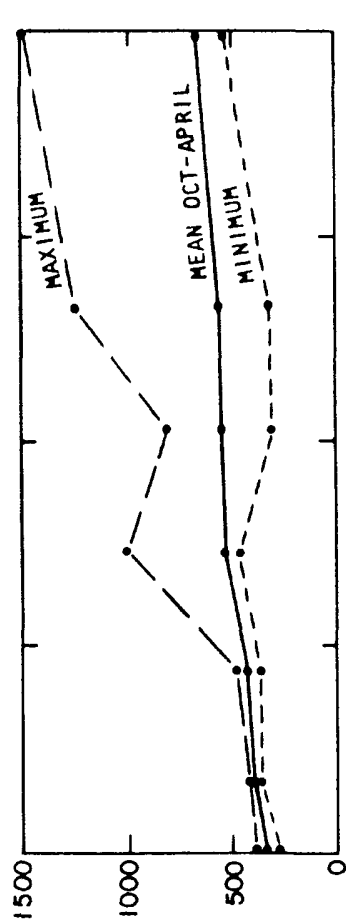

Y3117 У3d SW甘Y9177IW NI 'SSJNOY 7 V 101

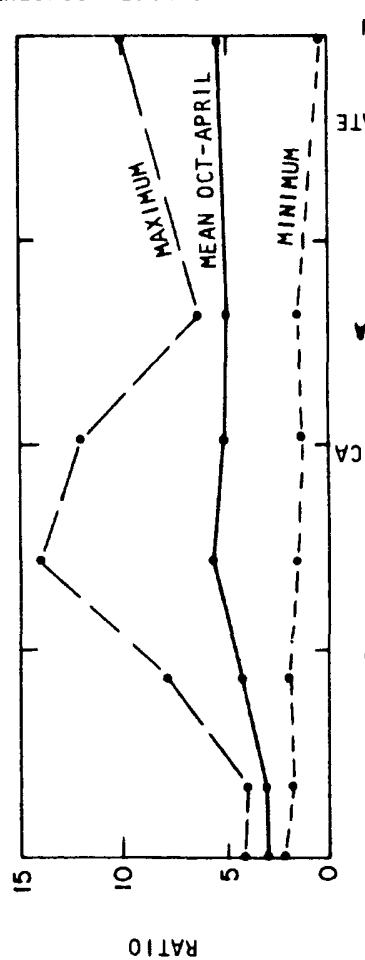

NOI IdYOSOY WNIOOS

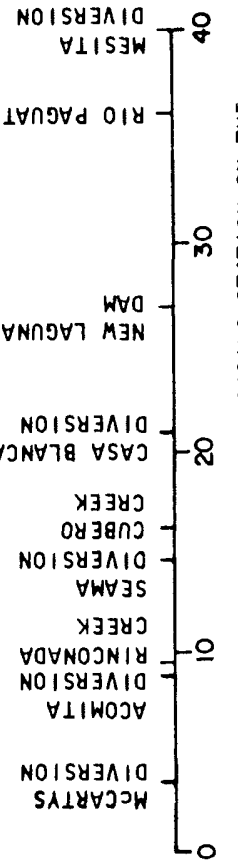

岁

zo

z岁政

$\because \dot{0}$

ำ

i

똪응

完

$\frac{1}{6}$

产参

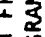

$x$

○

व

言出

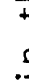

崖交

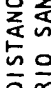

NOISY 3910

$\forall 1153 T^{\circ}$

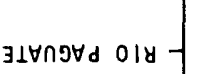

논

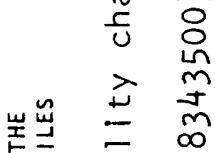

$\bar{x}=\stackrel{m}{0}$

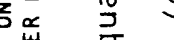

$-\infty$

zo

i

$\frac{1}{2}$

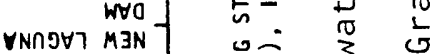

N015Y3N10 过倠 D

วN甘7 \& $\forall S \forall J$ -

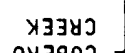
oष 38 กกว

NOISY3AIO

$\forall W \forall J S$

$\times 33 \mathrm{Z3}$

ZOANOJNIY -0

NOISY $3 \wedge 10$

$\forall \perp$ IWOJ

NOISY $3 \wedge 10$

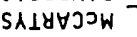




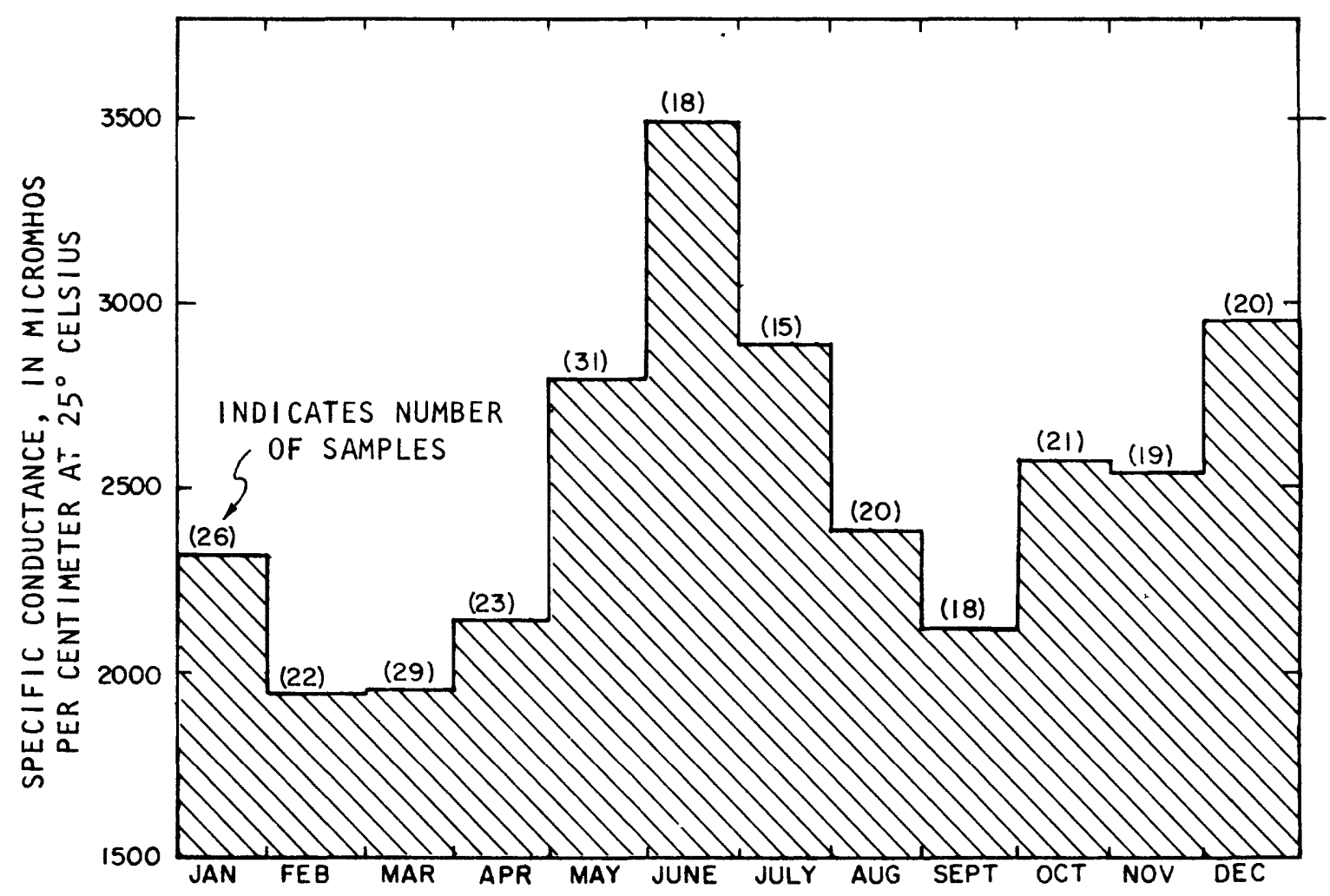

Figure 31.--Average monthly specific conductance of the Rio San Jose on the Pueblo of Laguna upstream from Mesita, 1961-79. 


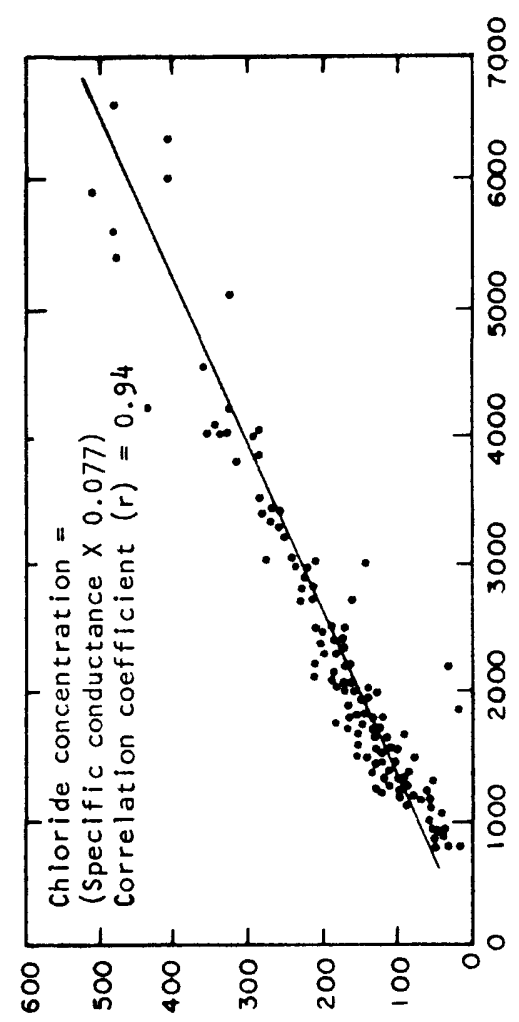

Y3117 YJd SWHYII77/W NI NOII 1 Y INJJNOJ JOIYOTHJ

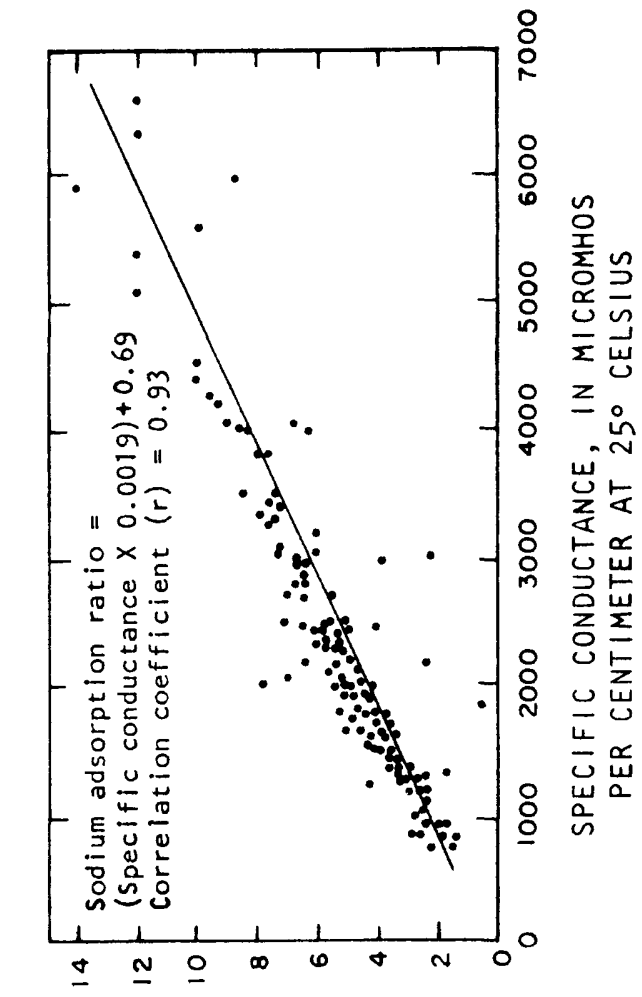

OI IVY NOI IdYOSOH WNIOOS

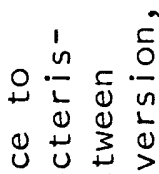

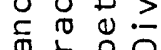

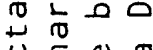

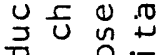

ट

U. $=\frac{\pi}{\pi}$

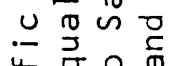

४

u ! $\bar{\alpha}$ u

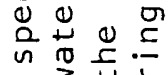

$43 \pm \frac{1}{0}$

ᄃ

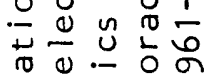

$\frac{0}{0} \stackrel{0}{\sim} \div \frac{1}{1} \stackrel{0}{-}$

$\frac{1}{1}$

ì

$\frac{1}{3}$

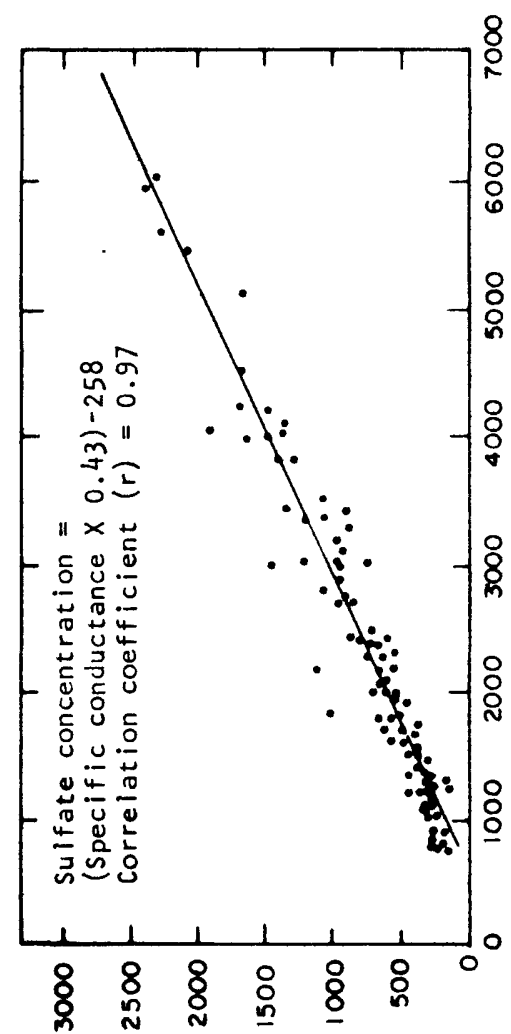

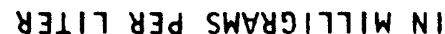

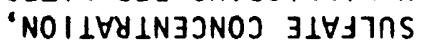

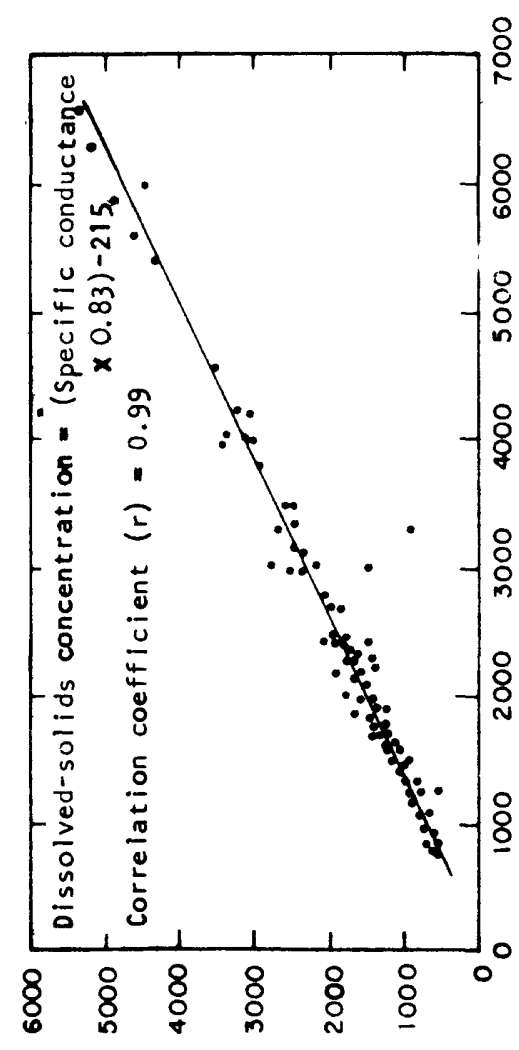

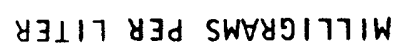

NI "NOI I $N$ INJJNOJ

SOITOS-03ATOSS10

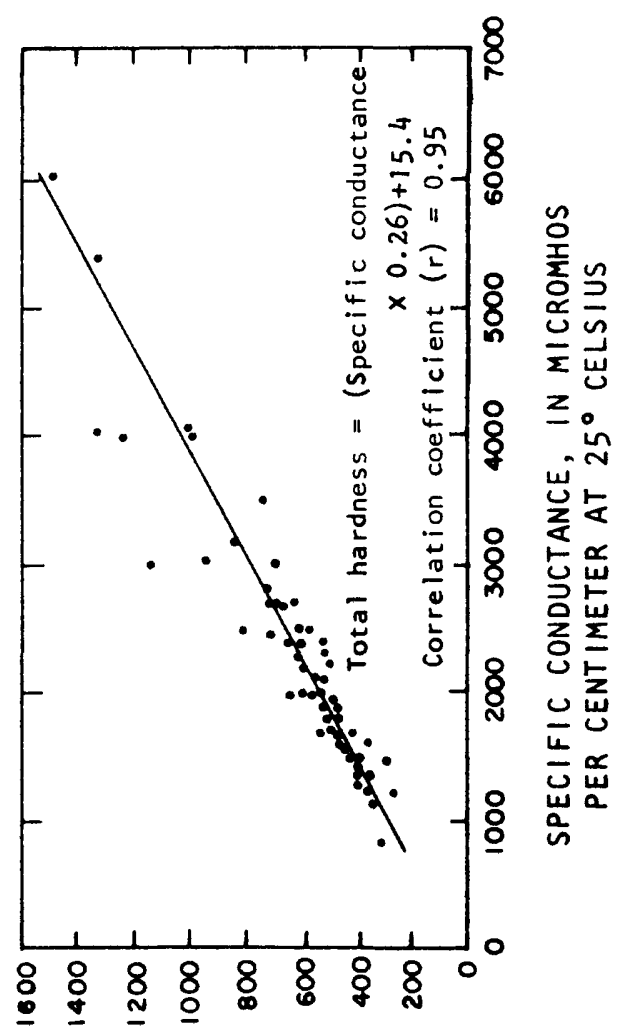

Y3117 y3d SWYY9177IW

NI 'SSJNOYZH $7 \forall 101$ 
Sodium, calcium, magnesium, sulfate, and bicarbonate are the predominant ions in water in the Rio San Jose. The chemistry changes downstream from Horace Springs by the enrichment of sodium and sulfate and relative decrease of calcium and bicarbonate. The chemical change probably is due to water discharge from Jurassic bedrock units, which typically contains greater concentrations of sodium and sulfate.

\section{Rio Puerco}

Water quality of the Rio Puerco was sampled on August 24, 1978, during runoff from a summer storm (table 9). The dissolved-solids concentration was 1,550 milligrams per liter. Suspended-sediment concentrations exceeding 200,000 milligrams per liter have been measured in the Rio Puerco at the gaging station near Bernardo about 25 miles south of the Sedillo Grant (U.S. Geological Survey, 1947-78). The large suspended-sediment concentrations limit the use of this water.

\section{Tributaries of the Rio San Jose}

Rio Paguate--Upstream from the Jackpile-Paguate Mine, dissolved-solids concentrations in the Rio Paguate range from 190 to 590 milligrams per liter and the water is suitable for irrigation and public supply (tables 9-13). Downstream from the mine, the dissolved-solids concentration in the river ranges from 990 to 6,420 milligrams per liter and the water is only marginally suited for irrigation. The degradation in quality partly is caused by the addition of water containing 1,040 to 3,060 milligrams per liter of dissolved solids from the Rio Moquino. Changes in quality also may occur where surface runoff comes in contact with the disturbed overburden at the Jackpile-Paguate Mine. Additional quality changes downstream from the mine probably are due to ground-water discharge to the stream and to concentration of dissolved solids by evaporation at Paguate Reservoir. Chemically, the water-quality change is represented by increased concentrations of all dissolved cations and a large increase in sulfate concentration ( $\mathrm{fig} \cdot 33$ ).

Water from storm runoff and snowmelt at the gaging station downstream from the Jackpile-Paguate Mine usually contains lesser dissolved-solids concentrations than does base streamflow (tables 9 and 12). In general, specific conductance decreases with increasing discharge. Suspended-sediment concentrations in six high streamflows ranged from 105,000 to 811,000 milligrams per liter.

Specific conductance can be used to estimate specific water-quality characteristics of the Rio Paguate. Empirical relations between specific conductance and dissolved-solids concentration, calcium magnesium hardness, sulfate concentration, sodium-adsorption ratio, and chloride concentration for the Rio Paguate and Rio Moquino are shown in figure 34. 


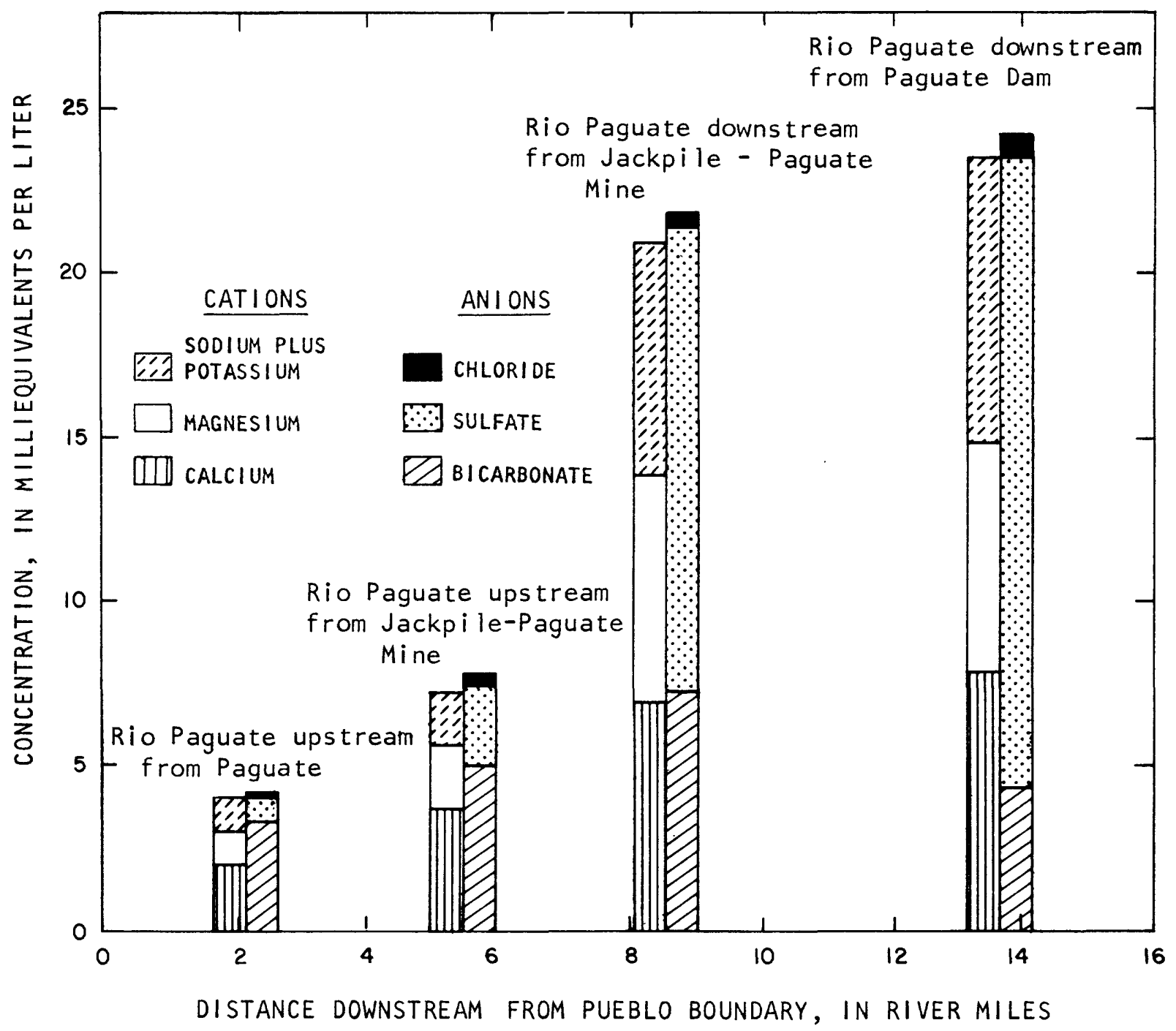

Figure 33.--Average concentrations of major ions of winter streamflow in the Rio Paguate, 1976-79. 


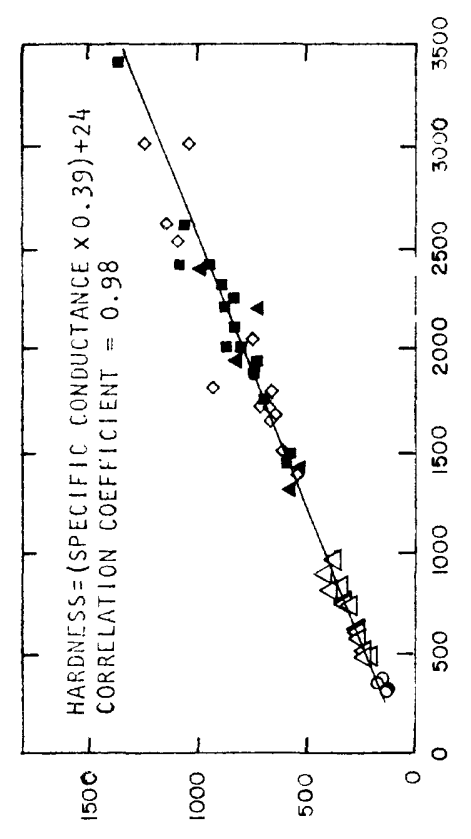

13117 yad SiNGJ91771W NI

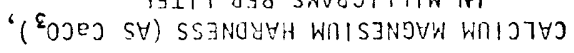

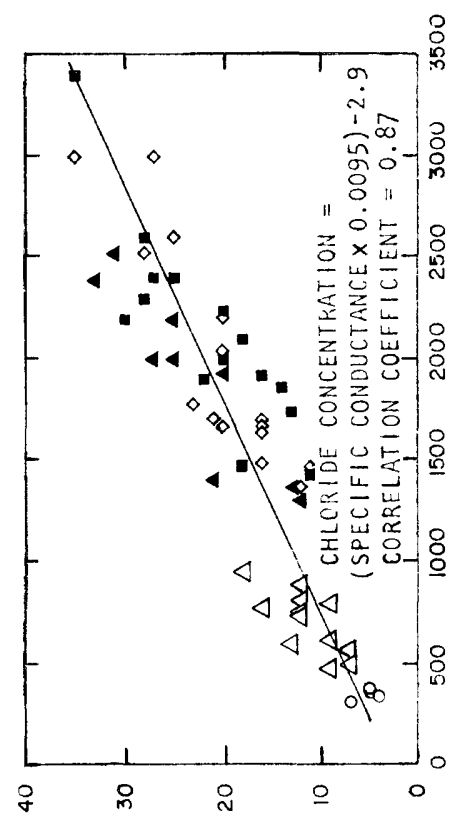

83117 83d SWVy $1771 W \mathrm{NI}$ "Noldralnganos JOLOTHO

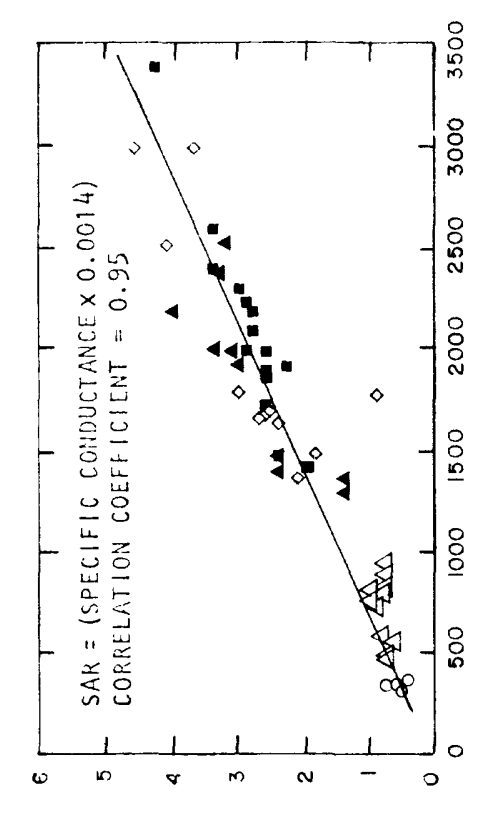

Olive hulldyesaV Whloos

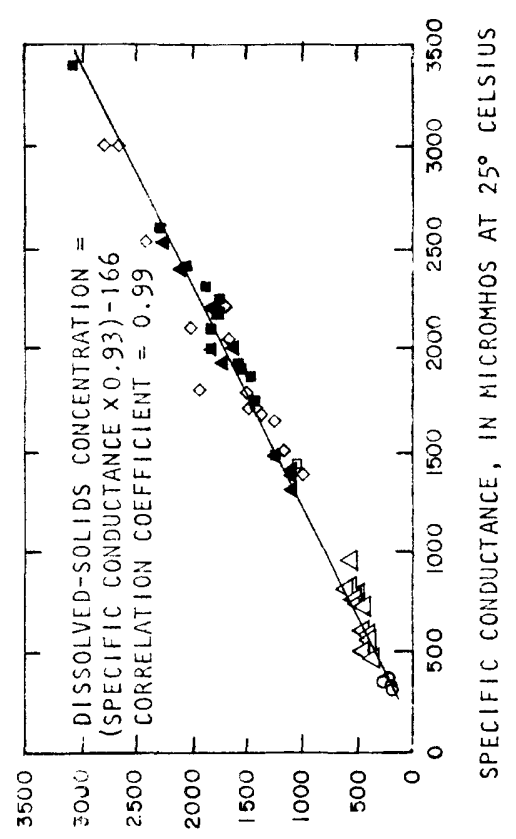

Y3117 घJd SW甘Y $1771 \mathrm{WN}$ "NOILUDINJJNOJ SOITOS-0JATOSSIO
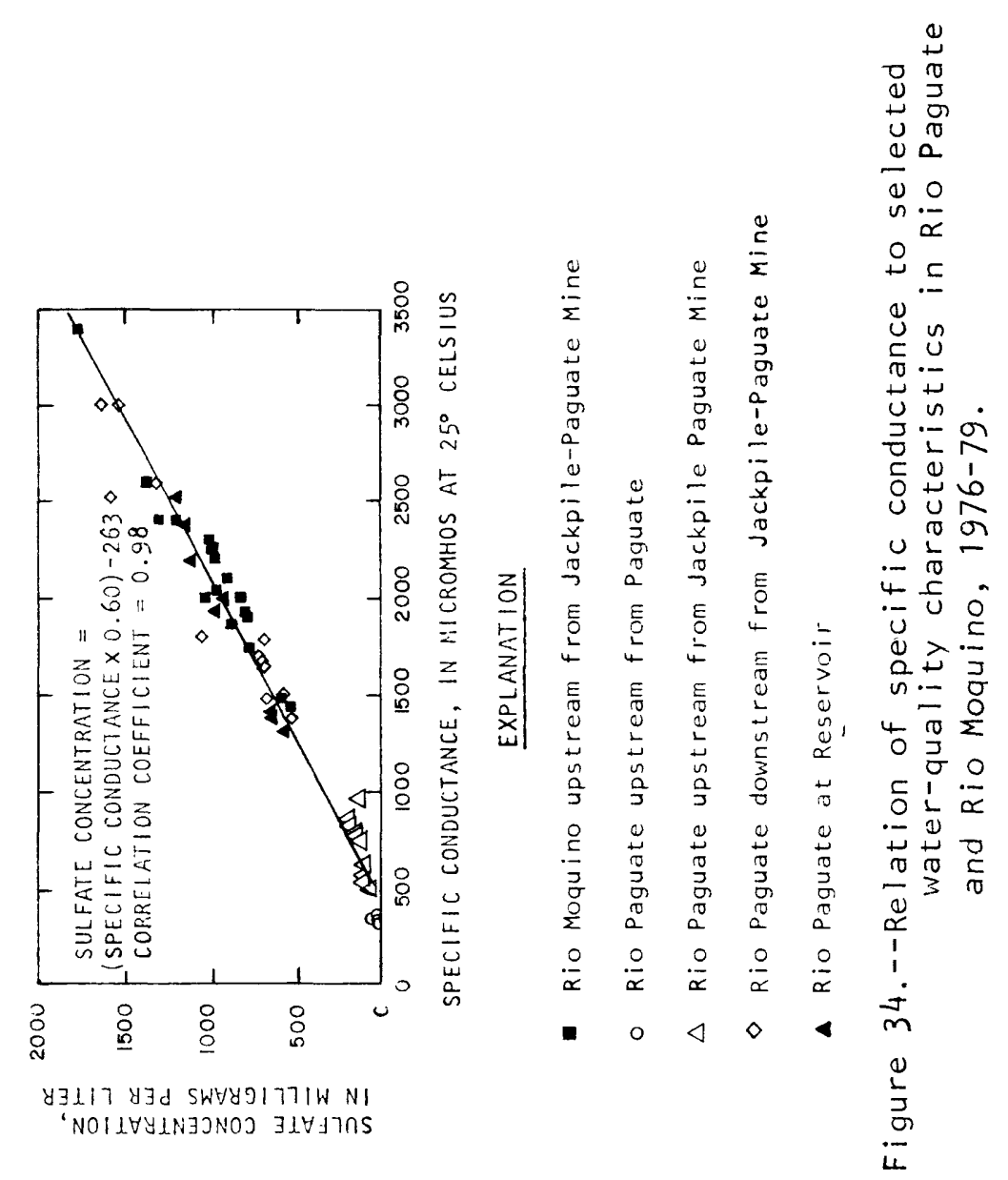
Water samples had increases in radiochemical concentrations downstream from the Jackpile-Paguate Mine. Concentrations of radium-226 and uranium collected at the streamflow-gaging station downstream from the mine ranged from 1.7 to 8.3 picocuries per liter and 73 to 330 micrograms per liter, respectively (table 13). Concentrations of radium-226 collected upstream from the mine ranged from 0.04 to 0.09 picocurie per liter for Rio Paguate and 0.08 to 0.12 picocurie per liter for Rio Moquino. Concentrations of uranium upstream from the mine ranged from 0.7 to 2.2 micrograms per liter for Rio Paguate and 4.7 to 8.3 micrograms per liter for Rio Moquino. The lesser concentrations of radium-226 and uranium in Rio Moquino and Rio Paguate upstream from the mine indicate that the increase of radiochemicals primarily takes place where the Rio Paguate and Rio Moquino flow through the Jackpile-Paguate Mine.

Sediments from the streambed of the Rio Paguate were sampled for trace elements and radiochemicals at several points upstream and downstream from the Jackpile-Paguate Mine (table 16). Sediments collected at the gaging station downstream from the mine had concentrations of trace elements and radiochemicals comparable to sites sampled on the Rio Moquino and Rio Paguate upstream from the mine. However, much greater concentrations of radiochemicals were found in sediments from 1.5 miles downstream from the mine to Paguate Reservoir. Radium-226 concentrations ranged from 121 to 153 picocuries per liter, and uranium concentrations ranged from 194 to 308 milligrams per liter in these samples. Evidently, at least a part of the sediment load in the Rio Paguate is being deposited in Paguate Reservoir and in the aggrading channel upstream from the reservoir.

Cubero Creek--The quality of water in Cubero Creek was fairly constant when sampled during the study (tables 9-13) because the streamflow was sustained by spring discharge. The dissolved-solids concentration ranged from 450 to 520 milligrams per liter, which is considerably less than the concentration in the Rio San Jose. The quality of this streamflow probably is acceptable for irrigation and for public supply if proper methods are used to filter suspended solids and remove bacterial contamination. Water quality in the alluvium around the New York-Seama area is improved considerably due to seepage from Cubero Creek.

The dissolved-solids concentration of stormflows is at least that of springflow contributions based upon three miscellaneous measurements (table 12). Measured suspended-sediment concentrations of greater than 40,000 milligrams per liter in these stormflows may render the water unsuitable for certain uses.

Encinal Creek--Analyses of water from Encinal Springs, which provide most of the base streamflow in the upstream reaches of Encinal Creek, indicate the water is acceptable for irrigation and public-supply use (table 5). Dissolved-solids concentration in two samples from the springs were 114 and 158 milligrams per liter. The quality of storm runoff is not well documented but specific conductances of 403 and 856 micromhos were measured for two 
stormflows. The large suspended-sediment concentrations of 45,000 and 151,000 milligrams per liter accompaning these flows may render the water unsuitable for certain uses.

\section{NUMERICAL MODEL OF GROUND-WATER FLOW}

\section{IN THE VALLEY-FILL AQUIFER ALONG \\ THE RIO SAN JOSE WEST OF LAGUNA VILLAGE}

\section{Introduction to modeling study}

The availability of water for irrigation, industry, and public supply is a major constraint on the economic growth and prosperity of the Pueblo of Laguna. Because significant new sources of water are unlikely to be discovered, the known water resources on the pueblo must be utilized as carefully as possible. A ground-water flow model of the valley-fill aquifer along the Rio San Jose was constructed to illustrate how ground water can be effectively used for the increased benefit of the tribe.

The valley of the Rio San Jose is $1 / 2$ to 2 miles wide through the center of the Pueblo Proper. The part of the valley selected for modeling is about 11 miles in length, encompasses an area of about 25 square miles, and extends from valley wall to valley wall along the stream from about 2 miles west of the Acoma-Laguna boundary to the village of Laguna (fig. 35). The western part of the valley was chosen for modeling because the area has the greatest potential for additional ground-water development for irrigation and public supply. Because the quality of ground water in the valley fill deteriorates down the valley, it is unlikely that ground-water development in the Quaternary alluvium and basalt of the Rio San Jose valley will take place east of the village of Laguna.

The model allows predictions to be made of aquifer response to various potential stresses placed upon the hydrologic system. Some specific objectives of the study were to predict water-level declines and effects on streamflow of the Rio San Jose caused by different hypothetical amounts of ground-water withdrawals. The study also illustrates the potential use of ground-water storage to salvage unused winter streamflows for use later during the irrigation season. 


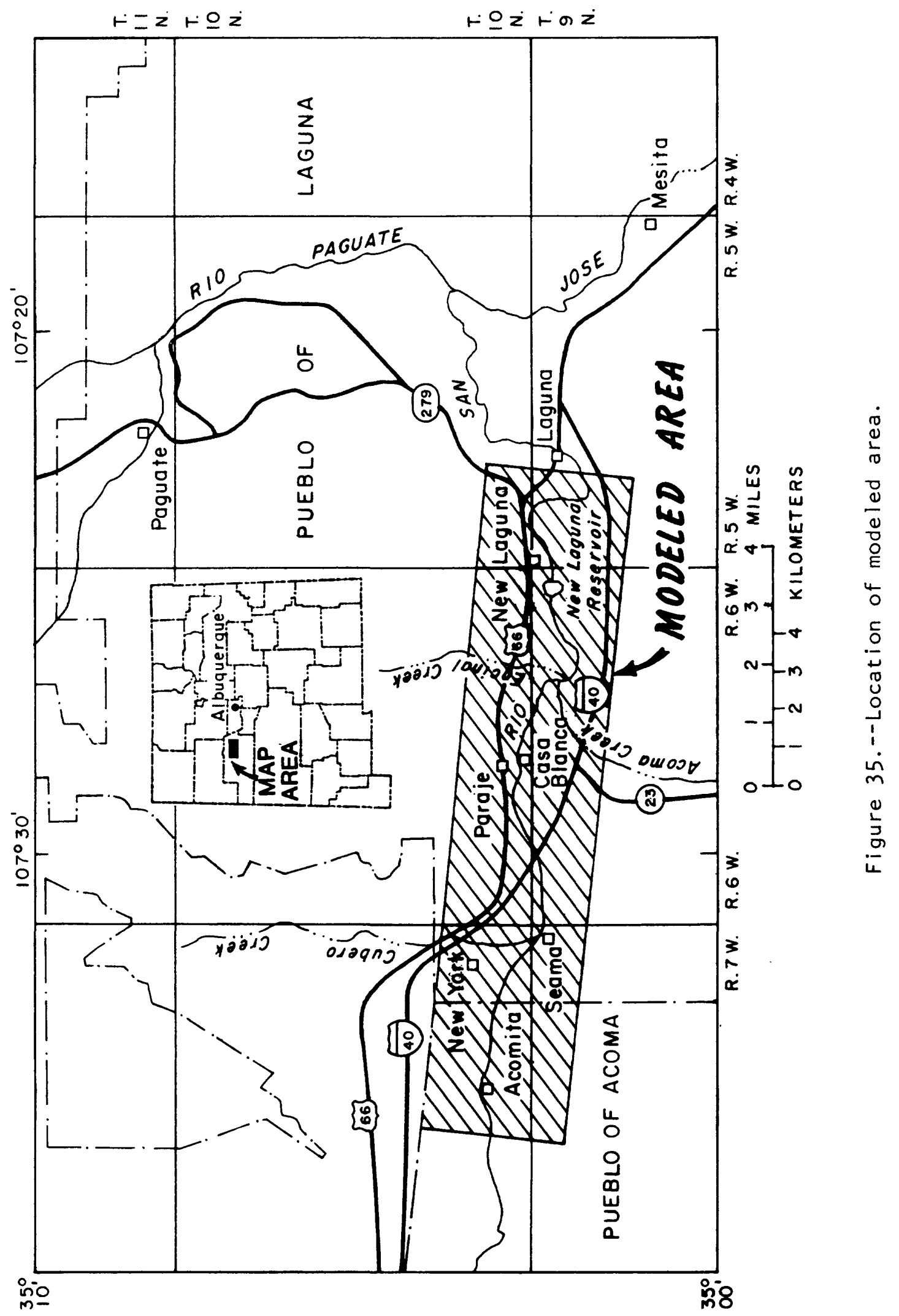


Description of the Model

Model used

To solve the equation of ground-water flow, a 2-dimensional, finite-difference numerical model written and documented by Trescott, Pinder, and Larson (1976) was used. The differential, ground-water flow equation is approximated in the model by a series of algebraic, finite-difference equations. The study area was divided into a rectangular-grid system that defined a nodal point at the center of each cell. The finite-difference equations were then solved at each node on a digital computer using the strongly implicit procedure.

A 2-dimensional model was used because vertical components of ground-water flow were believed to be insignificant in the valley. Buried basalt flows do confine ground water locally, but the extent of this condition is not we11 known.

\section{Model construction}

The initial setup of the model involved making a finite-difference grid, deciding on boundary conditions, and entering initial estimates of hydrologic characteristics. The initial estimates of hydrologic characteristics such as hydraulic conductivity of the aquifer, hydraulic conductivity of the leaky streambed, recharge from tributary streams, and evapotranspiration rate then were varied in a trial-and-error method until the model satisfactorily met the adjustment criteria. Model construction then was complete.

\section{Finite-difference grid}

A rectangular, finite-difference grid consisting of 24 rows and 79 columns was superimposed on the study area (fig. 36). The grid divides the area into 1,896 separate cells for which data is entered and water levels simulated for the node at the center of the cell. The nodal locations are referenced by the row and column numbers of the grid. The data specified at a given node are the average values of these characteristics for the entire cel1. The grid is aligned with one axis parallel to the principal down-valley component of ground-water flow. The grid spacing is varied throughout the valley to provide higher resolution for simulated drawdowns in areas near existing pumping centers. The grid spacing near pumping centers is 500 feet in both downstream and cross-valley directions. In other areas the grid spacing is 1,000 feet in the downstream direction and 500 feet in the cross-valley direction. 


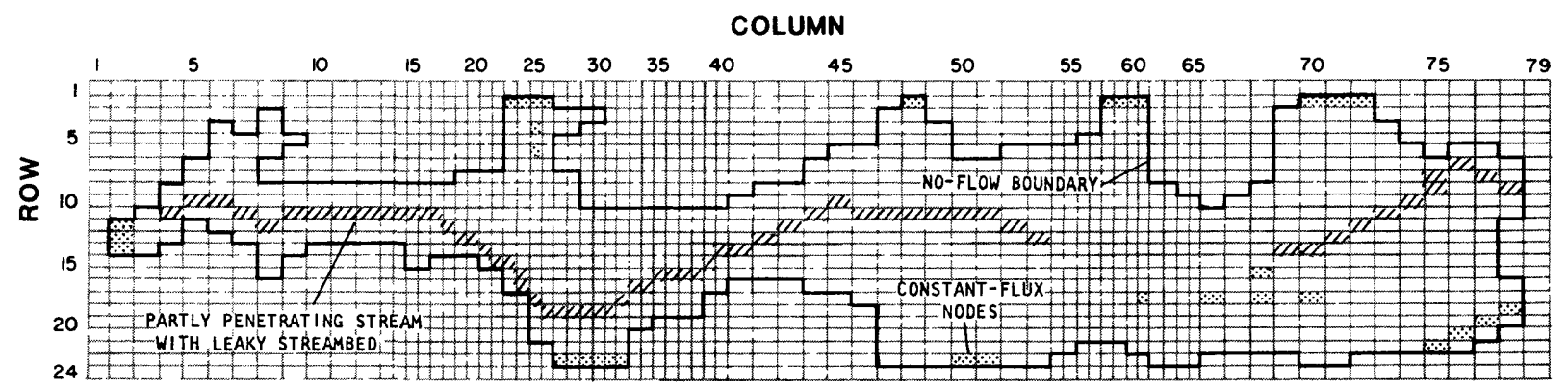

Figure 36.--Finite-difference grid and hydrologic boundaries used in the valley-fill model.

\section{Aquifer properties}

The valley-fill aquifer along the Rio San Jose consists of alluvium and a basalt flow that is buried throughout most of the area and crops out near New Laguna. For modeling purposes, all of the valley-fill material is grouped together as a vertically homogeneous unit. Water levels measured during drilling indicate that in most areas a good hydraulic connection exists between alluvium above and below the basalt flow.

The hydraulic conductivity of an aquifer is the volume of water at the existing kinematic viscosity that will move in a unit time under a unit hydraulic gradient through a unit area measured at right angles to the direction of flow (Lohman and others, 1972, p. 4). Initial estimates of hydraulic conductivity used in the model were determined by aquifer tests (table 4). A map of the distribution of hydraulic conductivity values decided on after model adjustment is shown in figure 37.

The hydraulic conductivity values used in the model vary considerably. At the eastern end of the modeled area near New Laguna, hydraulic conductivity was assigned a value of 10 feet per day. This small value reflects the large amount of fine-grained silt and clay deposited by lakes that occupied this part of the valley at various times during the Quaternary. The abrupt change in hydraulic conductivity assigned at the mouth of Encinal 


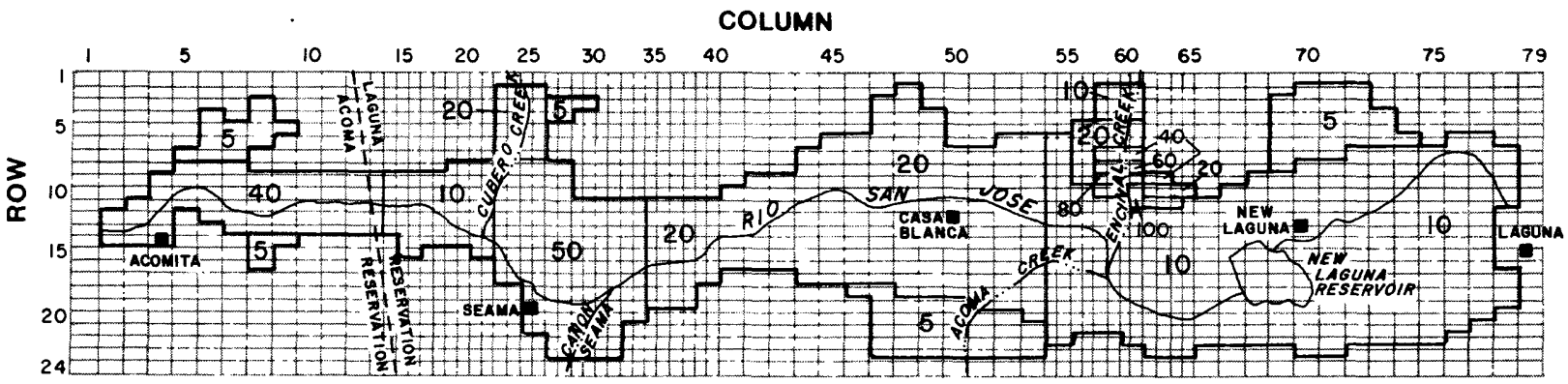

Figure 37.--Hydraulic-conductivity distribution used in the valley-fill model, in feet per day.

Creek may represent the deposition of course-grained valley-fill deposits by Encinal Creek. The variation in hydraulic conductivity from Acomita to Seama in the western part of the modeled area was needed to minimize the error between measured and simulated water levels and streamflow. The physical characteristics of the valley fill observable at this location do not clearly show why this abrupt zonation of hydraulic conductivity should be necessary. However, several single-well aquifer tests conducted in this area ( $\mathrm{fig} \cdot 10$ ) indicate that the zonation used in the model is reasonable.

The specific yield of the valley-fill aquifer was estimated from examination of well cuttings and geophysical logs. Because the fill is composed of clay, sand, gravel, and basalt, an average specific yield of 0.15 was used for the entire valley. Specific yield was estimated using average values for various geologic materials given in Johnson (1967). Locally, the specific yield will vary greatly with clay and basalt layers as low as 0.01 and sand lenses as great as 0.32 (Johnson, 1967 p. 70), but 0.15 is probably reasonable for an average value. Aquifer-test data were not used to estimate specific yield because of the short duration of most tests. 


\section{ILLUSTRATIONS - Concluded}

Figure 28. Water-analysis diagram for selected wells completed

in bedrock units

29. Water-analysis diagram for wells completed in valley-fill deposits along the Rio San Jose

30. Graphs showing variation of selected water-quality characteristics in the Rio San Jose from the streamflow-gaging station near Grants (08343500) to Mesita diversion, 1961-79

31. Graph showing average monthly specific conductance of the Rio San Jose on the Pueblo of Laguna upstream from Mesita, $1961-79$

32. Graphs showing relation of specific conductance to selected water-quality characteristics for the Rio San Jose between Horace Springs and Mesita diversion; 1961-79

33. Graph showing average concentrations of major ions of winter streamflow in the Rio Paguate, 1976-79

34. Graphs showing relation of specific conductance to selected water-quality characteristics in Rio Paguate and Rio Moquino, 1976-79.

35. Map showing location of modeled area

36. Map showing finite-difference grid and hydrologic boundaries used in the valley-fill model

37. Map showing hydraulic-conductivity distribution used in valley-fill model, in feet per day

38. Graph showing comparison of simulated and measured steady-state water levels

39. Graph showing sensitivity of simulated drawdowns to changes in hydraulic conductivity, vertical hydraulic conductivity of the streambed, and specific yield after 5 years of ground-water withdrawals at nodes $9-61,8-24$, and $12-45$

The wood engravings of Laguna on pages ix, 20, and 85 are from Harper's, February 1891. 


\section{PLATES}

[P1ates are in pocket]

Plate 1. Map showing water-level contours, specific conductance of water from wells and springs, and areas of possible ground-water development on the Pueblo of Laguna, New Mexico, 1973-79.

2. Generalized geologic map of the Pueblo of Laguna, New Mexico.

3. Geologic sections showing the potentiometric surfaces, the water table, and possible ground-water flow directions, Pueblo of Laguna, New Mexico.

\section{TABLES}

Table 1. Records of wells

2. Records of springs

3. Description of formation cuttings for selected wells

4. Summary of all aquifer tests conducted on the Pueblo of Laguna

5. Major constituents of water in selected we11s and springs

6. Nutrients and minor constituents of water in selected we11s

7. Trace elements of water in selected wells

8. Radiochemicals of water in selected wells

9. Selected major chemical constituents of surface water

10. Nutrients, bacteria, and selected minor elements in surface water

11. Selected trace elements in surface water

12. Miscellaneous onsite measurements of streamflow and water quality 
Model boundaries and recharge

The boundary conditions of the model define the physical geometry and hydraulic flux of the ground-water flow system. Boundary conditions used in the model are shown in figure 36 and are described in the following paragraphs.

The Rio San Jose valley in the modeled area is incised into shales and sandstones of Jurassic age, which form a relatively impermeable barrier to ground-water flow. Therefore, the altitude of the base of the valley fill was used as the lower boundary of the model across which no flow is assummed to take place (fig. 10). The lateral model boundaries are located where the alluvium butts against the bedrock valley walls. This boundary, across which no flow is assummed to take place is shown in figure 36. In reality, ground water does flow from Jurassic bedrock units into the alluvium, but most of this recharge probably takes place west of the modeled area and is included in the ground-water flow in the alluvium entering the modeled area from the west.

Constant-flux nodes were used in simulating steady-state conditions at points of major ground-water flow entering or leaving the model. Estimates of flow initially were made by flow-net analyses and were varied within plausible limits during model adjustment. Initial estimates of recharge from tributaries were made using streamflow measurements (tables 9 and 12) and indirect estimates of annual average stormflow calculated from the physical characteristics of each watershed (table 15).

The Rio San Jose gains and loses water throughout the reach being modeled and is simulated as a partially penetrating, leaky stream except in a 2-mile stretch upstream from New Laguna Reservoir. An initial estimate of the vertical hydraulic conductivity of 0.086 foot per day for the confining bed beneath the stream was determined by analyzing seepage losses outside of the modeled area between gaging stations on the Rio San Jose near Laguna and at Correo. If this value of vertical hydraulic conductivity were present on the 13-mile reach of the Rio San Jose west of New Laguna Reservoir, the valley-fill aquifer could be recharged by 3,000 acre-feet during the non-growing season. In the model, the vertical hydraulic conductivity of the confining bed was adjusted to represent the ratio of streambed area in a cell to total area of the cell. Leakage from the stream as simulated in the model will increase until the hydraulic head in the aquifer falls 10 feet below the altitude of the streambed. The leakage is then limited to a maximum value of 0.56 cubic foot per second per mile.

In the 2-mile reach upstream from and including New Laguna Reservoir, the Rio San Jose was simulated by a constant flux from the stream to ground water in the valley fill. In this area, ground-water levels in wells about $1 / 2$ mile from the stream are 20 to 40 feet below the altitude of the streambed. Ground-water levels adjacent to the stream and reservoir probably are also below the streambed throughout much of the year. Certainly this is 
true during summer months when upstream irrigation withdrawals cause this reach of the stream and the reservoir to be dry.

Water is lost through evaporation and transpiration where the water table is at or near the land surface. Evapotranspiration takes place from the water surface in the stream and through phreatophytes, which are abundant near the channel of the Rio San Jose. A variable-head flux boundary was used to estimate evapotranspiration. The maximum evapotranspiration rate for water at the land surface was set equal to 55 inches per year, which is the mean evaporation rate for shallow reservoirs in the area (Hale and others, 1965). Annual consumptive use of water by salt cedar calculated for Las Vegas, New Mexico, which has climatic conditions similar to Laguna, is 51.6 inches (Blaney and Hanson, 1965, p. 47). The evapotranspiration rate is extrapolated linearly from land surface to a depth of 10 feet below land surface where evapotranspiration was assumed to be negligible.

\section{Model adjustments}

For the model to be used with confidence in predicting aquifer response to future stresses, a set of measured aquifer properties must be compared to model simulations of the same conditions. In the part of the valley chosen for modeling, significant water-level declines caused by pumping did not take place prior to 1976 ( $\mathrm{fig}$. 22) even though a small amount of pumping was taking place in the valley. Estimated total ground-water withdrawals for public supply in the New York-Seama area was about 75 gallons per minute in 1975. Prior to 1976, water levels in the valley probably represent a nearly steady-state condition. Because the flow system prior to 1976 was assumed to be in a steady-state condition, the simulated aquifer characteristics were adjusted by comparing the measured pre-1976 potentiometric surface in the aquifer with simulated steady-state water levels.

Adjustment of the model involved varying the values specified for certain hydrologic characteristics to achieve a "best fit" between measured and simulated steady-state water levels. The best fit was achieved by minimizing the square of the deviations between observed and simulated water levels. The adjustment process was subjective because values of most aquifer characteristics were known only within large bounds. Steady-state simulations are independent of the specific yield of the aquifer, thus for transient simulations the initial estimate of specific yield was used without any adjustment. Adjustments of both vertical and horizontal hydraulic conductivity and recharge rates were made within estimated plausible limits to match the measured water levels. The degree to which each characteristic was adjusted depended upon the uncertainty in the data base. The steady-state solution determined after numerous adjustments of the hydrologic characteristic is not a unique solution but simply a solution that matches, within acceptable error, the water-level criteria chosen for adjustment of the model. 
For the initial simulation, the average error calculated as the square root of the minimum sum of deviations squared divided by the number of nodes with measured water levels was about 8 feet. However, the absolute error at individual nodes exceeded 20 feet. To achieve a better fit, horizontal hydraulic conductivity at the mouths of Cubero and Encinal Creeks was increased by about 30 percent. Estimated recharge from Cubero and Encinal Creeks was increased by about 30 percent, and inflow from upstream throughflow was raised from 0.3 to 0.9 cubic foot per second to account for inflow from bedrock aquifers west of the modeled area.

After adjusting the horizontal hydraulic conductivity of the aquifer and recharge rates, a reasonably good fit between measured and simulated steady-state water levels was achieved (figure 38). Because the land-surface altitudes at wells were determined from topographic maps having contour intervals of 20 feet, differences between measured and simulated water-levels of 10 feet were considered satisfactory. The average least squares error between measured and simulated water levels at 26 wells was 5.6 feet.

The simulated steady-state recharge and discharge for the valley-fill aquifer is shown in the following table.

Ground-water recharge

Rate, in

cubic feet

Recharge from per second
Groind-water discharge

Rate in cubic feet

Discharge to per second

\begin{tabular}{llll}
\hline \hline Cubero Creek & 0.42 & Rio San Jose & 0.25 \\
Encinal Creek & 0.08 & Flow from area & \\
Cañon Seama & 0.04 & to east & 0.07 \\
Acoma Creek & 0.15 & Evapotranspiration & 3.10 \\
Rio San Jose & 1.78 & & \\
Misc. small trib. & 0.05 & & \\
Flow into aquifer & 0.90 & & \\
\hline Total & 3.42 & Total & 3.42 \\
\hline
\end{tabular}




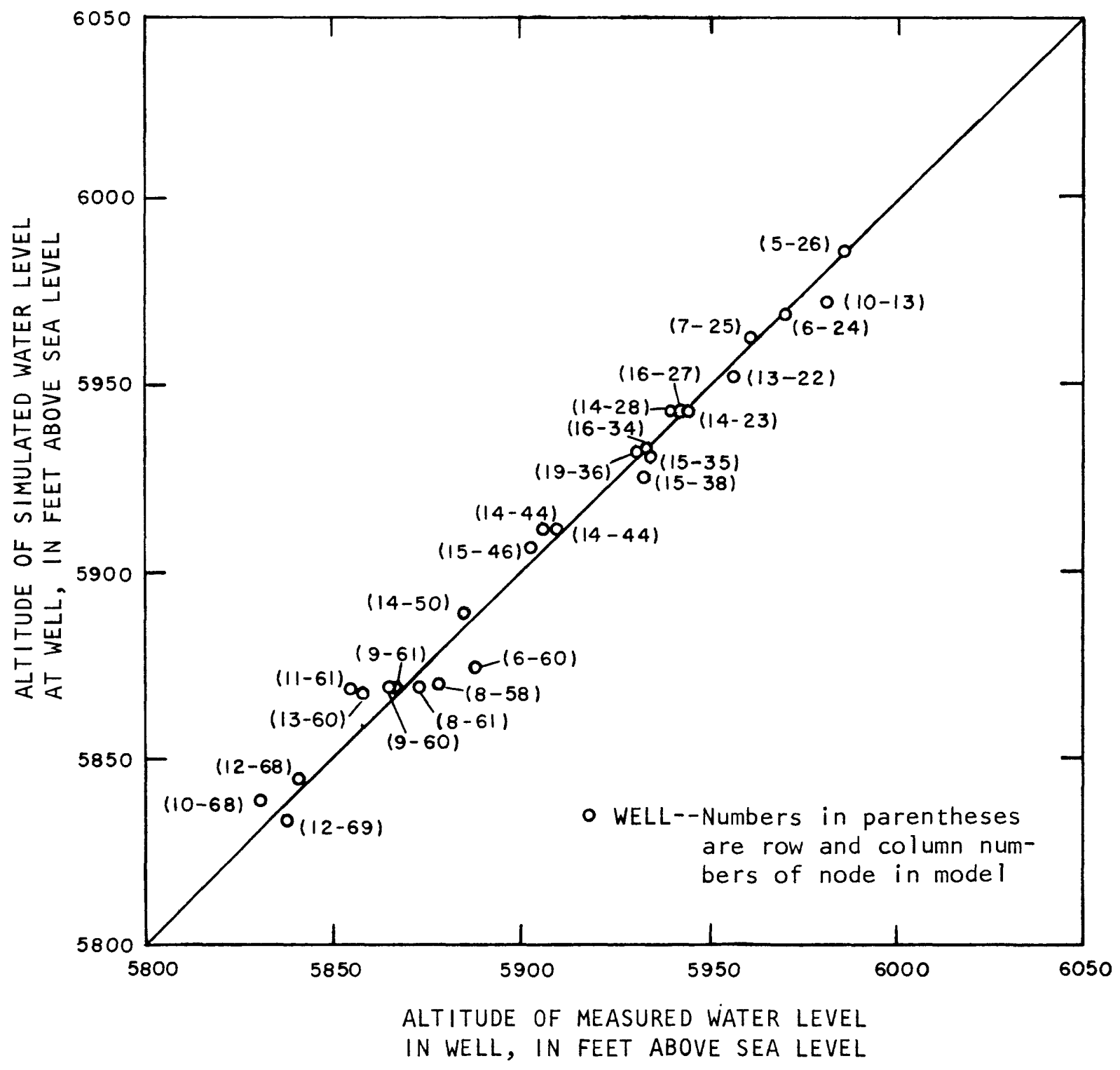

Figure 38.--Comparison of simulated and measured steady-state water levels. 
Estimates of aquifer response to future ground-water withdrawals

The objective of the modeling study was to a simulate aquifer response to alternative methods of ground-water development in the valley-fill aquifer. The simulations represent withdrawals that, in many cases, would require pumping from several production wells at a node. Predicted drawdowns represent the average drawdown at a node rather than drawdown in a specific pumping well. The predictions must be viewed as estimates of aquifer response because the predictive capabilities of the model have not been evaluated by comparing modeled and measured aquifer response to stress over time. An idea of the possible error inherent in the predictions may be obtained from the sensitivity analysis; however, a detailed error analysis has not been made for each simulation. If an accurate record of ground-water withdrawals in the valley is kept in the future, the model could be further adjusted to become a better predictive tool.

\section{Ground-water withdrawals for public supply}

The existing public-supply well field in the New York-Seama area has three wells: 10.7.36.221 (New York 1), 10.7.36.212 (New York 2), and 10.6.31.434 (Seama P.S.). Pumpage from the three wells varies during the year; however, the 1980 average rate of withdrawal was about 280 gallons per minute. Aquifer response to 10 years of pumping at 280 and 560 gallons per minute at nodes 7-25 ( row 7, column 25), 8-24, and 15-35 was simulated. The simulation represents year-round withdrawals of ground-water averaged over the cell area. The drawdowns predicted also are average values for the node, calculated as if the water were pumped at 100-percent efficiency over the entire cell area. Ground-water declines in the pumping nodes after 10 years of pumping at 280 and 560 gallons per minute were as much as 12 and 32 feet, respectively.

After 10 years of withdrawals, the hydrologic system nearly establishes a new equilibrium and iittle of the pumpage is derived from storage. Most of the withdrawals are derived from a reduction in the streamflow of the Rio San Jose and a decrease in loss of water to evapotranspiration. After 10 years of pumping at 280 and 560 gallons per minute, 50 and 48 percent of the pumpage are derived from a reduction in flow in the Rio San Jose. The remainder of the water withdrawn is derived from a reduction in the amount of water evapotranspired near the Rio San Jose due to the lowered water table.

Ground-water withdrawals for public supply and irrigation

Seasonal ground-water withdrawal for irrigation at nodes 13-28 and 9-61 was simulated in addition to the continuous pumping in the New York-Seama area for public supply at nodes 7-25, 8-24, and 15-35. Nodes 13-28 and 9-61 are located in the area of existing Laguna irrigation wells $10.7 .36 .424 \mathrm{a}$ and 10.6.35.342a. The pumping for irrigation was assummed to take place only from May through September. At nodes 13-28 and 9-61, ground water was withdrawn at a rate of 200 gallons per minute for a 153-day pumping period 
followed by a 212-day recovery period each year. The simulated public-supply pumpage was set at the approximate present-day rate of 280 gallons per minute from nodes 7-25, 8-24, and 15-35. The predicted water-level declines were about 7 feet at node 13-28 and 14 feet at node 9-61 after the 10 th pumping period. To predict aquifer response to more intensive ground-water development in the area, the simulated pumping rate at each node was dou'sled, resulting in a pumping rate of 400 gallons per minute for irrigation at nodes 13-28 and 9-61 and 560 gallons per minute for public supply at nodes 7-25, 8-24 and 15-35. At these pumping rates, the predicted water-level declines were about 18 feet at node $13-28$ and 37 feet at node 9-61 after the 10th pumping period.

The seasonal irrigation pumping increased the simulated drawdown at the nodes representing public-supply wells. Irrigation pumping at 200 gallons per minute at nodes 13-28 and 9-61 caused an additional drawdown of as much as 3 feet at nodes 7-25,8-24, and 15-35 when their combined pumping rate was 280 gallons per minute. For irrigation withdrawals of 400 gallons per minute at nodes 13-28 and 9-61, drawdowns were increased in the New York-Seama area by as much as 14 feet after 10 years of pumping.

During each nonirrigation period, water levels recovered. For simulations at 200 gallons per minute, water levels nearly recovered to the levels that would have existed had irrigation pumpage not taken place. The recovery of water levels during the winter nonirrigation months was due in part to recharge of the aquifer from surface water in the Rio San Jose. In the simulation, winter flows of the Rio San Jose (which are not presently being used) were stored in the aquifer for use during the following irrigation season. During the 10th nonirrigation season, for example, recharge to ground-water storage was 269 and 370 acre-feet for simulations of irrigation pumping of 270 and 540 acre-feet (withdrawals from two nodes at 200 and 400 gallons per minute for 153 days). Much of this recharge was derived from the Rio San Jose.

\section{Ground-water withdrawals for irrigation}

A simulation based solely on intensive ground-water withdrawals for irrigation was examined because: (1) Intensive ground-water withdrawals for irrigation may cause unacceptable water-level declines in public-supply wells completed in the valley-fill aquifer; and (2) surface- and ground-water supplies of suitable quality for public supply exist in several areas of the pueblo away from the modeled area. The response of the valley-fill aquifer to 10 years of seasonal withdrawals of ground water for irrigation was simulated based on total pumping rates of 1,400 and 2,600 gallons per minute. Pumping rates at specific nodes are shown in the following table.

Total simulated pumping rate, in gallons per minute

Pumping rate 1,400

Pumping rate 2,600
Pumping rate, in gallons per minute at specific node

\begin{tabular}{llllll}
$9-69$ & $14-63$ & $15-49$ & $10-57$ & $13-36$ & $13-53$ \\
\hline
\end{tabular}

$200 \quad 200 \quad 200 \quad 200 \quad 300 \quad 300$

$\begin{array}{lllll}200 & 400 & 400 & 400 & 600\end{array}$


Withdrawals of 1,400 gallons per minute resulted in predicted drawdowns of as much as 20 feet near pumping centers at the end of 10 years. However, after the 10 th recovery period, water levels rose to within about 5 feet of initial pre-pumping levels. During the recovery period, ground-water storage was recharged by 700 acre-feet, about 73 percent of the amount of water withdrawn in the previous pumping period.

Increasing withdrawals to 2,600 gallons per minute resulted in predicted drawdowns of more than 30 feet near pumping centers after 10 years. Water levels rose to within about 10 feet of prepumping levels after the 10th recovery period. Ground-water storage was replenished by 1,000 acre-feet during the 10 th recovery period, which was 58 percent of the amount of water withdrawn during the previous pumping period.

Pumping at high rates lowers the water table and may reduce the amount of water lost to evapotranspiration. The model simulation at 1,400 gallons per minute indicated that about 540 acre-feet of water per year was salvaged in this manner. For the 2,600 gallons-per-minute simulation, an even greater salvage, about 900 acre-feet, was predicted. Estimates of water salvaged by lowering the effective loss to evapotranspiration are, at best, only educated guesses. In practice, most attempts to actually salvage the predicted quantities of water have been unsuccessful.

\section{Sensitivity analysis}

Model predictions will be in error if the hydrologic properties that were entered to the model were estimated incorrectly. To test the sensitivity of the steady-state model to variations in horizontal hydraulic conductivity, specific yield, and stream leakage, several simulations were performed, changing only one property in each simulation.

The sensitivity of the model to changes in hydraulic conductivity, specific yield, and stream leakage was evaluated based on 5 years of ground-water withdrawals at nodes 9-61, 8-24, and 12-45 (fig. 39). The three pumping centers were chosen to evaluate model sensitivity in areas of probable ground-water development and at various distances from hydrologic boundaries. Node $9-61$ is located at the mouth of Encinal Canyon, where ground water is presently being withdrawn for irrigation; node 8-24 is located in the New York well field; and node $12-45$ is located near the Rio San Jose south of Casa Blanca.

The sensitivity analyses were conducted over the range of plausible values for hydraulic conductivity $(+100$ to -50 percent of the best-fit values), vertical hydraulic conductivity of the streambed $(+100$ to -50 percent), and specific yield ( +33 to -33 percent). The modeled aquifer response is most sensitive to changes in hydraulic conductivity. A 50-percent decrease in the estimate of hydraulic conductivity caused a 96-percent increase in simulated drawdown at node 9-61 after 5 years. A comparable 50-percent decrease in streambed leakage resulted in an increase of 45 percent at node 12-45; a 33-percent decrease in specific yield resulted in an increase of 13 percent at node 9-61. 


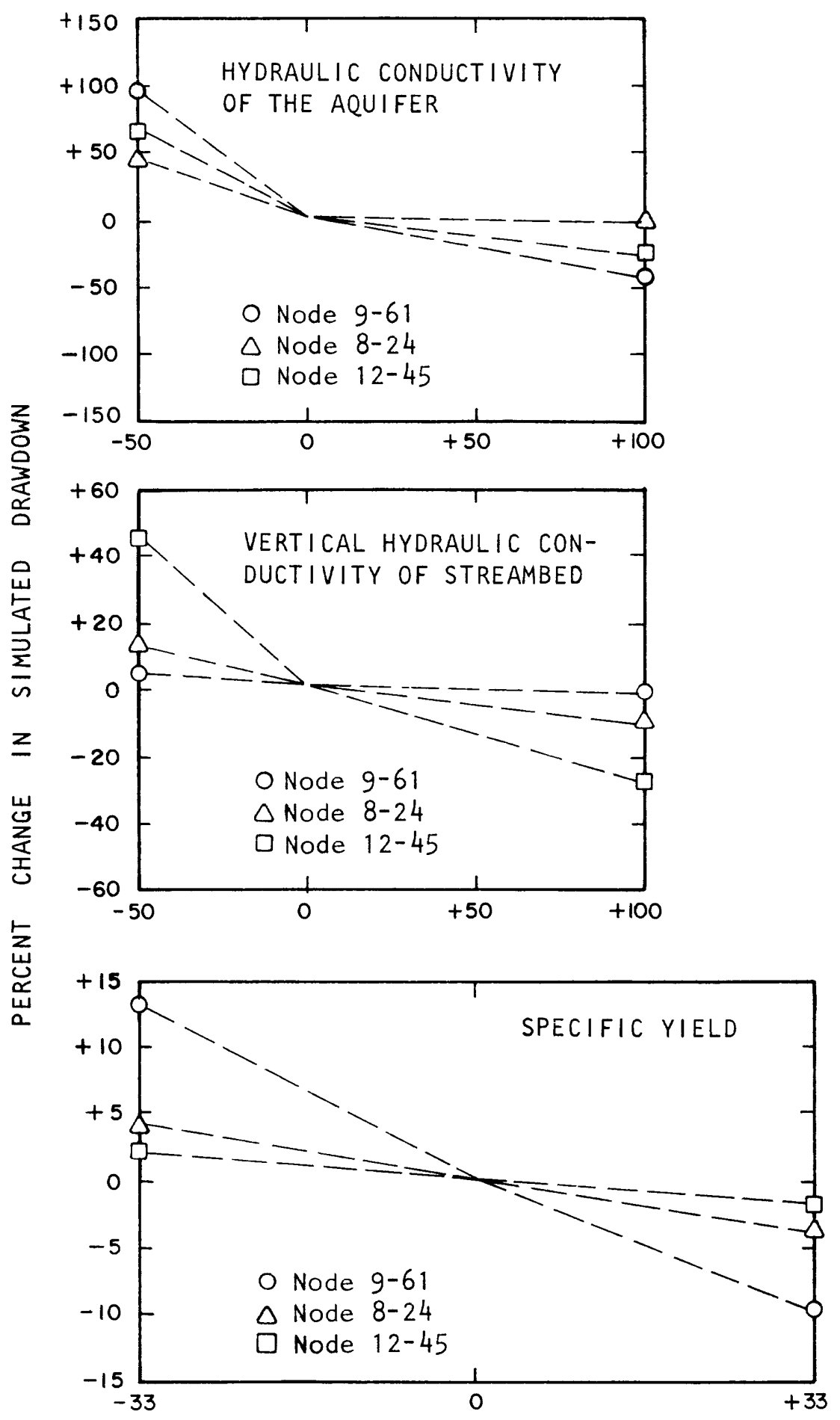

Figure 39.--Sensitivity of simulated drawdowns to changes in hydraulic conductivity, vertical hydraulic conductivity of the streambed, and specific yield after 5 years of groundwater withdrawals at nodes 9-61, 8-24, and 12-45. 
For a node, the degree of sensitivity of simulated drawdown to changes in hydrologic properties is dependent on the location of that node in the modeled area. Changes in hydraulic conductivity of the aquifer affected predicted drawdowns at node 9-61 the greatest amount. Of the three nodes, this node is farthest away from the stream. Node $12-45$, closest to the Rio San Jose, was most affected by changes in the vertical hydraulic conductivity of the streambed, whereas node 9-61 was relatively insensitive. The opposite effect was observed when the specific yield was varied; the most sensitive node (9-61) was farthest away from the stream, and the least sensitive node (12-45) was closest.

Estimates of the amount of water salvaged when the water table is lowered (and evapotranspiration rates decreased) also are sensitive to changes in hydrologic parameters. The estimated salvage resulting from pumping for 5 years at nodes 9-61, 8-24, and 12-45 was about 200 acre-feet per year using the best fit hydrologic parameters. Lowering the specific-yield value used in the simulation by 33 percent resulted in a 38-percent increase in the estimated quantity of water salvaged. A 50-percent decrease in the value for the hydraulic conductivity of the streambed resulted in a 73-percent increase in the amount of water salvaged, and doubling the value of the hydraulic conductivity of the aquifer caused a 63-percent decrease in the estimated salvage.

\section{SUMMARY AND CONCLUSIONS}

The purpose of this study was to better define ihe hydrology of the Pueblo of Laguna; major emphasis was placed on quantifying potential water resources available for irrigation and public supply. Areas of potential ground- and surface-water development are shown on plate 1 and summarized in the following sections.

\section{Possible ground-water development}

\section{Public supply}

New York-Seama area.--The alluvium and basalt that fill the valley along the Rio San Jose yield 50 to 450 gallons per minute of water to wells. Aquifer tests indicate that the transmissivity of the valley fill ranges from 290 to 17,000 feet squared per day (table 4). Although the alluvium yields adequate quantities of water throughout the valley, water quality is acceptable for public supply only where Cubero and Encinal Creeks recharge the alluvium.

Ground water in the alluvium in the New York-Seama area presently is the major source of public-supply water for valley residents (plate 1). The alluvium in this area yields ground water containing 500 to 1,200 milligrams per liter of dissolved solids. Perennial, spring-fed streamflow of Cubero 
Creek, which averages 0.30 cubic foot per second, recharges the alluvium with water of excellent quality. Modeling indicates that total recharge from Cubero Creek, which includes seepage from ungaged stormflows, is about 0.42 cubic foot per second. Modeling also indicates that present withdrawals in this area could be increased to about 560 gallons per minute if several wells were used. At this rate, drawdowns of more than 32 and 12 feet are predicted in the New York and Seama areas, respectively. However, pumping will draw water from outside of the zone of good-quality water created by recharge from Cubero Creek. The result will be a degradation of the water quality.

New Laguna area--Ground water for public supply can be obtained from the alluvium at the mouth of Encinal Canyon (plate 1). The alluvium at this location is recharged at a rate of about 0.08 cubic foot per second by stormflows of good-quality water in Encinal Creek. The alluvium yields water containing 500 to 1,200 milligrams per liter dissolved solids. However, the water quality may be expected to deteriorate if ground water is pumped from the area.

Encinal area.--Ground water for public supply can be obtained from the Dakota Sandstone near Encinal (plate 1). Wells yield about 20 to 50 gallons per minute of water containing 800 to 1,200 milligrams per liter of dissolved solids. This water could be mixed with better quality water such as that from Encinal Springs. An additional 70 to 85 gallons per minute of water containing less than 200 milligrams per liter of dissolved solids is available from springs.

Paguate area.--Ground water of excellent quality is presently obtained for public supply from the alluvium along Paguate Creek near the village of Paguate (plate 1). Additional development is possible in this area. The alluvium will sustain individual well yields of as much as 50 gallons per minute of water containing 300 to 500 milligrams per liter of dissolved solids. The alluvium is recharged by seepage of about 300 gallons per minute of water from the Rio Paguate on pueblo lands upstream from State Highway 279. Presently, the majority of this water probably is lost to evapotranspiration. Additional ground-water withdrawals of as much as 250 gallons per minute might salvage some of this water loss.

Another possible source of ground water in the Paguate area is from sandstones of the Morrison Formation. Although yields of these individual sandstones are not high, wells completed in several of the units will produce 5 to 50 gallons per minute of water containing 500 to 1,500 milligrams per liter of dissolved solids.

Caprock-Sand dune area.--An 18-square mile area south of the village of Laguna was previously believed to be an area of possible ground-water development for public supply. Two test wells drilled in Jurassic sandstones in this area produce potable water but yield, in general, less than 5 gallons per minute. 
Tributary valleys on flanks of Mount Taylor.--Test drilling for ground water in the alluvium in Seco, Castillo, and Encinal Canyons indicated that the saturated thickness of the alluvium was insufficient to yield water for public supply.

Santa Fe Group on Sedillo Grant.--The unconsolidated deposits of the Santa Fe Group probably yield 20 to 100 gallons per minute of water to wells penetrating a graben structure near Cañon de los Apaches (plate 1). The water contains 300 to 1,500 milligrams per liter dissolved solids. This area probably contains the best quality ground water available on the Sedillo Grant.

Major's Ranch area.--Obtaining ground water for public supply may be possible from sandstone units in the Brushy Basin Member and Westwater Canyon Member of the Morrison Formation on the western part of the Major's Ranch area (plate 1). Although no we1ls were drilled or inventoried in this area, yields and water quality from nearby uranium mines indicate that these sandstones may yield several hundred gallons of water per minute containing 1,000 to 2,000 milligrams per liter of dissolved solids.

\section{Irrigation}

Ground-water development for irrigation is severely limited by the low yields or inadequate quality of water in the geologic units beneath the pueblo.

Valley fill along the Rio San Jose--Probably the only shallow aquifer on the pueblo capable of supplying large amounts of water to irrigation wells is the valley-fill aquifer along the Rio San Jose. Water-quality deterioration east of the village of Laguna restricts ground-water development to a section of the valley from the western pueblo boundary to New Laguna Reservoir (plate 1). Most ground water in the valley fill presents salinity and sodium hazards to various degrees. Irrigation water could be used with careful management practices to avoid salt buildup or hardpan conditions caused by sodium dispersal of clays.

Yields from the valley fill are extremely variable due to the heterogeneous composition of the fill. Aquifer tests indicate that transmissivities range from 290 to 17,000 feet squared per day and specific capacities from 0.04 to 33.9 gallons per minute per foot of drawdown. Most wells properly completed throughout the entire thickness of the aquifer probably will produce 50 to 450 gallons per minute.

Ground water withdrawals for irrigation water were simulated by a digital model of the valley-fill aquifer. Water-level declines of more than 30 feet were estimated for ground-water withdrawals of 2,600 gallons per minute in the valley west of Laguna. The model included the influences of recharge from the Rio San Jose and boundary conditions of the valley walls on drawdowns. The modei illustrated that ground water in storage may be used 
during irrigation seasons and replenished during nonirrigation periods. If the water table is lowered, the aquifer becomes a reservoir for storage of previously unused winter flows of the Rio San Jose. After withdrawals during the previous irrigation period, the potential for recharge to storage during the nonirrigation season was estimated by model simulation to be as much as about 1,000 acre-feet. The model also indicated that ground water previously lost through evapotranspiration may be salvaged in amounts as much as 900 acre-feet per year.

Major's Ranch area.--Ground water from the Westwater Canyon Member of the Morrison Formation might be available in sufficient quantity on the Major's Ranch area to supply irrigation wells. Although no wells were drilled or tested in the area for this study, dewatering of nearby uranium mines indicates that the Westwater Canyon Member might yield several hundred gallons per minute of water containing 1,000 to 2,000 milligrams per liter of dissolved solids. This water probably will contain moderate to high sodium and salt hazards, but with careful management practices it may be acceptable for use.

\section{Stock water}

Water suitable for livestock may be obtained from various aquifers beneath all parts of the pueblo. Water-quality criteria for livestock are listed in table 17 and may be compared to water-quality analyses for selected wells in this report (tables 5-8).

\section{Possible surface-water development}

Rio San Jose.--Possible additional development of surface water for irrigation may be obtained by storing winter flows of the Rio San Jose for later use. Summer flow in the stream presently is fully utilized. After filling Acomita Lake, winter flows in the Rio San Jose totaling about 2,400 acre-feet flow unused through the pueblo. A part of this flow will be stored in Seama Reservoir, which presently is under construction on the Pueblo of Laguna. The maximum storage capacity of Seama Reservoir will be about 480 acre-feet.

Another method of salvaging unused winter streamflow that has been proposed previously (Dinwiddie and Motts, 1964) is to use ground-water storage. Lowering ground-water levels by pumping during the irrigation season will cause the Rio San Jose to recharge the valley-fill aquifer during the nonirrigation season. The maximum leakage rate of the Rio. San Jose was estimated based upon gaging-station records near Laguna and at Correo. The maximum stream loss for an average flow of 7 cubic feet per second is 0.56 cubic foot per second per mile. Digital-model simulations of irrigation pumping based on this leakage rate predict possible recharge volumes of as much as 1,000 acre-feet after water levels in the aquifer were lowered by pumping. Irrigation with water from the Rio San Jose needs to be used with careful management practices due to the high dissolved-solids concentrations and moderate sodium hazards. 
Encinal Creek.--The perennial flow in the headwaters of Encinal Creek is sustained by springs that have a combined flow of about 100 gallons per minute. About 15 to 30 gallons per minute is used for the public supply of the village of Encinal and the remainder is used for irrigation or lost to seepage in the alluvium along the stream. An additional supply of 70 to 85 gallons per minute of excellent-quality water containing less than 200 milligrams per liter of dissolved solids (suitable for public supply) is available from springs in Encinal Canyon.

Rio Paguate.--The average streamflow entering the Pueblo of Laguna in the Rio Paguate is about 1 cubic foot per second. The streamflow presently is used for irrigation during summer months, although the quality is acceptable for public supply. Winter flows of as much as 100 acre-feet are stored in two small reservoirs northwest of Paguate. Additional reservoir capacity could store as much as 300 acre-feet of winter streamflows that are presently unused.

The streamflow also could be used indirectly by increasing ground-water withdrawals in the alluvium along the stream. Presently, about 250 gillons per minute of streamflow that seeps into the alluvium is lost through evapotranspiration. Increased pumpage would lower ground-water levels and salvage some of this loss while drying up the marshy surface.

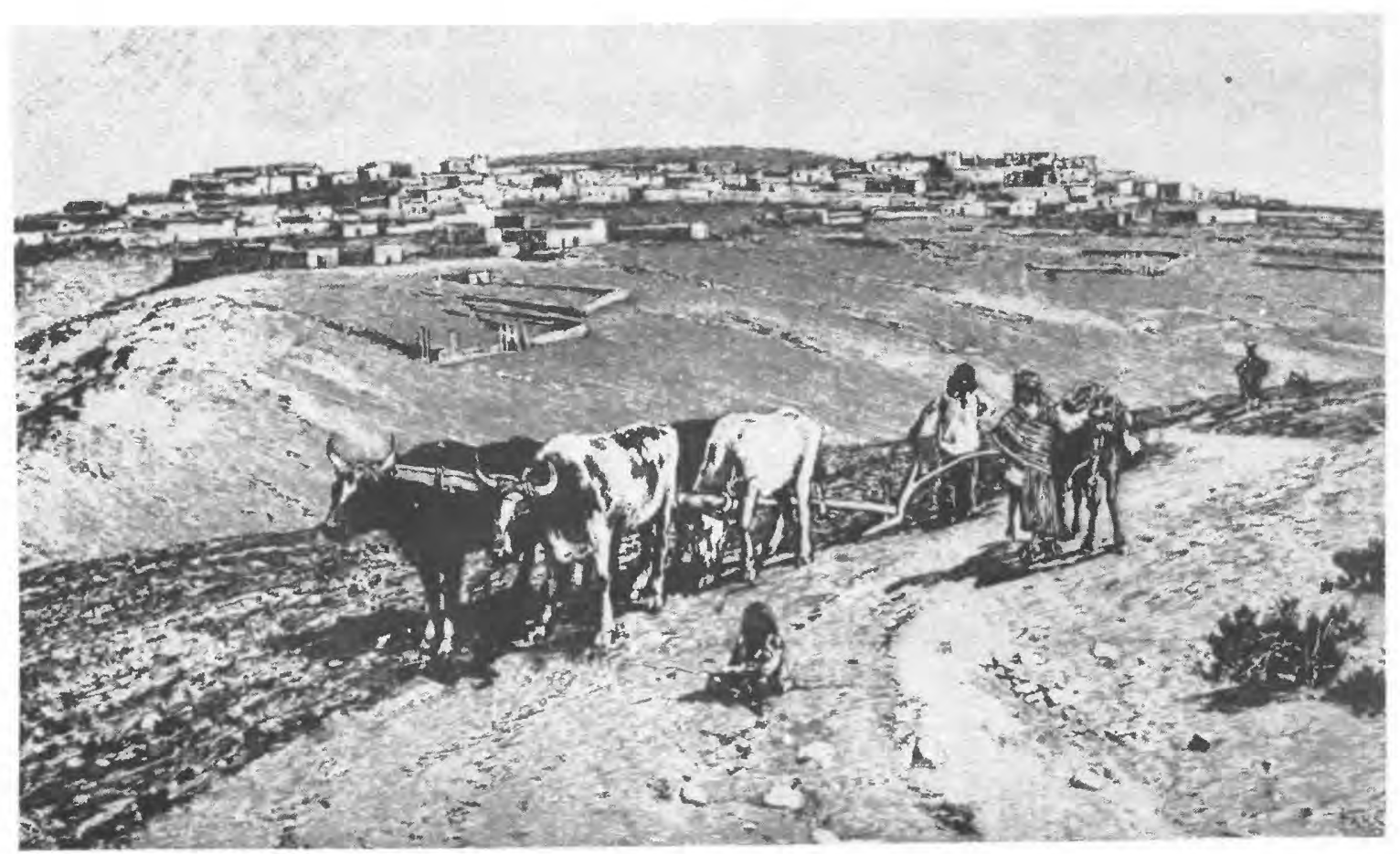




\section{REFERENCES}

Blaney, H. F. and Hanson, E. G., 1965, Consumptive use and water requirements in New Mexico: New Mexico State Engineer Technical Report. 32, 82 p.

Borland, J. P., 1970, A proposed streamflow-data program for New Mexico: U.S. Geological Survey open-file report, $71 \mathrm{p}$.

Campbe11, Jock, 1967, Geology and structure of a portion of the Rio Puerco fault belt, western Bernalillo County, New Mexico: Albuquerque, University of New Mexico, unpublished M. S. Thesis, 89 p.

Cooper, J. B. and West, S. W., 1967, Principal aquifers and uses of water between Laguna Pueblo and Gallup, New Mexico, in Guidebook of the Defiance-Zuni-Mount Taylor Region: New Mexico Geological Society, 18th Field Conference, p. 145-149.

Dane, C. H., and Bachman, G. O., 1965, Geologic map of New Mexico: U.S. Geological Survey Map, scale 1:500,000, 2 sheets.

Dinwiddie, G. A., 1963, Ground water in the vicinity of the Jackpile and Paquate mines, in Kelley, V. C., ed., Geology and technology of the Grants uranium region: New Mexico Bureau of Mines and Mineral Resources Memoir 15, p. 217-218.

Dinwiddie, G. A. and Motts, W. S., 1964, Availability of ground water in parts of the Acoma and Laguna Indian Reservations, New Mexico: U.S. Geological Survery Water-Supply Paper 1576-E., 62 p.

Federa1 Water Pollution Control Administration, 1968, Water-quality criteria [Report of the National Technical Advisory Committee to the Secretary of the Interior.]: Washington, D.C., 234 p.

Fenneman, N. M., 1931, Physiography of the Western United States: New York, McGraw-Hill, 534 p.

Ferris, J. G., Knowles, D. B., Brown, R. H., and Stallman, R. W., 1962, Theory of aquifer tests: U.S. Geological Survey Water-Supply Paper 1536-E, p. 69-174.

Goddard, E. N., 1948, Rock-color chart: Washington, D.C., National Research Council.

Gordon, E. D., 1961, Geology and ground-water resources of the Grants-Bluewater area, Valencia County, New Mexico: New Mexico State Engineer Technical Report 20, 109 p. 
Hackman, R. J., 1967, Photogeologic map of the NE, NW, and SE quarters of Laguna 1 Quadrang1e, Sandova1 County, New Mexico: U.S. Geologica1 Survey open-file map, scale 1:62,500.

Hale, W. E., Reiland, L. J., and Beverage, J. P., 1965, Characteristics of the water supply in New Mexico: New Mexico State Engineer Technical Report 31, 131 p.

Harril1, J. R., 1970, Determining transmissivity from water-1evel recovery of a step-drawdown test: U.S. Geological Survey Prof. Paper 700-C, p. C212-C213.

Hem, J. H., 1970, Study and interpretation of the chemical characteristics of natural water: U.S. Geological Survey Water-Supply Paper 1473, 358 p.

Hemphil1, W. R., 1967, Photogeologic map of the east half of the Laguna 4 Quadrangle, Bernalillo, Sandoval, and Valencia Counties, New Mexico: U.S. Geological Survey open-file map, scale 1:62,500.

Hunt, C. B., 1938, Igneous geology and structure of the Mount Taylor volcanic field, New Mexico: U.S. Geological Survey Professional Paper 189-B, p. 51-80.

Hunt, C. B., and Dane, C. H., 1954, Map showing geologic structure of the southern part of the San Juan Basin, including parts of San Juan, McKinley, Sandoval, Valencia, and Bernalillo Counties, New Mexico: U.S. Geologica1 Survey 0i1 and Gas Investigations Map 158, scale 1:26,720.

Johnson, A. I., 1967, Specific yield-compilation of specific yields for various materials: U.S. Geological Survey Water-Supply Paper 1662-D, $74 \mathrm{p}$.

Kelley, V. C., and Wood, G. H., 1946, Geology of the Lucero uplift, Valencia, Socorro, and Bernalillo Counties, New Mexico: U.S. Geological Survey 0i1 and Gas Investigations Map 47, scale 1:64,000.

Knox, A. S , 1967, Photogeologic map of the Grants 4 Quadrangle, Valencia County, New Mexico: U.S. Geological Survey open-file map, scale $1: 62,500$.

Lohman, S. W., and others, 1972, Definitions of selected ground-water terms-Revisions and conceptual refinements: U.S. Geological Survey Water-Supply Paper 1988, 21 p.

Moench, R. H, 1963a, Geologic map of the Laguna Quadrangle, New Mexico: U.S. Geological Survey Quadrangle Map GQ-208, scale 1:24,000. 
Moench R. H., 1963b, Geologic map of the Seboyeta Quadrangle, New Mexico: U.S. Geological Survey Geologic Quadrangle Map GQ-207, scale 1:24,000.

1964a, Geology of the Dough Mountain Quadrangle, New Mexico: U.S. Geological Survey Geologic Quadrangle Map GQ-354, scale 1:24,000.

1964b, Geology of the South Butte Quadrangle, Valencia County, New Mexico: U.S. Geological Survey Geologic Quadrangle Map GQ-355, scale $1: 24,000$.

Moench, R. H., and Puffett, W. P., 1963a, Geologic map of the Arch Mesa Quadrangle, New Mexico: U.S. Geological Survey Geologic Quadrangle Map GQ-211, scale 1:24,000.

1963b, Geologic map of the Mesa Gigante Quadrangle, New Mexico: U.S. Geological Survey Geologic Quadrangle Map GQ-212, scale 1:24,000.

Moench, R. H. and Schlee, J. S., 1967, Geology and uranium deposits of the Laguna district, New Mexico: U.S. Geological Survey Professional Paper $519,117 \mathrm{p}$.

Moench, R. H., Schlee, J.S., and Bryan, W. B., 1965, Geologic map of the La Gotera Quadrangle, Sandoval and Valencia Counties, New Mexico: U.S. Geological Survey Geologic Quadrangle Map GQ-371, scale 1:24,000.

New Mexico Environmental Improvement Division, 1980, Water-quality data for discharges from uranium mines and mills in New Mexico: Water Pollution Control Bureau report, $87 \mathrm{p}$.

New Mexico State Engineer Office, 1956a, Climatological summary, New Mexico, temperature 1850-1954, frost 1850-1954, evaporation 1912-1954: New Mexico State Engineer Technical Report 5, 277 p.

1956b, Climatological summary, New Mexico, precipitation 1849-1954:

New Mexico State Engineer Technical Report 6, 407 p.

Risser, D. W., 1982, Estimated natural streamflow in the Rio San Jose upstream from the Pueblos of Acoma and Laguna, New Mexico: U.S. Geological Survey Water Resources Investigation 82-4096, 51 p.

Scott, A. G., 1971, Preliminary flood-frequency relations and summary of maximum discharges in New Mexico--A progress report: U.S. Geological Survey open-file report, 76 p.

Titus, F. B., Jr., 1963, Geology and ground-water conditions in eastern Valencia County, New Mexico: New Mexico Bureau of Mines and Mineral Resources Ground Water Report 7, 113 p. 
Trescott, P. C., Pinder, G. F., and Larson, S. P., 1976, Finite-difference model for aquifer simulation in two-dimensions with results of numerical experiments: U.S. Geological Survey Techniques of Water-Resources Investigations, Book 7, Chapter $\mathrm{Cl}, 116 \mathrm{p}$.

U.S. Department of Commerce, 1955-79, Climatological data, New Mexico: v. 59-83.

U.S. Environmental Protection Agency, 1976a, National interim primary drinking water regulations: U.S. Environmental Protection Agency Publication, EPA-57019-76-003, 159 p.

,1976b, Quality criterion for water: U.S. Environmental Protection Agency Publication, 256119.

U.S. Geological Survey, 1947-78, Water-resources data for New Mexico--Water years 1947-78. Albuquerque, published annually.

1960, Compilation of records of surface waters of the United States through September 1950: U.S. Geological Survey Water-Supp1y Paper 1312, $633 \mathrm{p}$.

1978, Mining and reclamation plan, Jackpile-Paguate mining operations, The Anaconda Company, Pueblo of Laguna uranium mining leases numbers 1, 4, and 6, Laguna Indian Reservation, Valencia County, New Mexico Environmental Analysis: Albuquerque, U.S. Minerals Management Service, $193 \mathrm{p}$.

Wright, H. E., Jr., 1946, Tertiary and Quaternary geology of the Lower Rio Puerco area, New Mexico: Geological Society of America Bulletin, v. 57, no. 5, p. 383-456. 


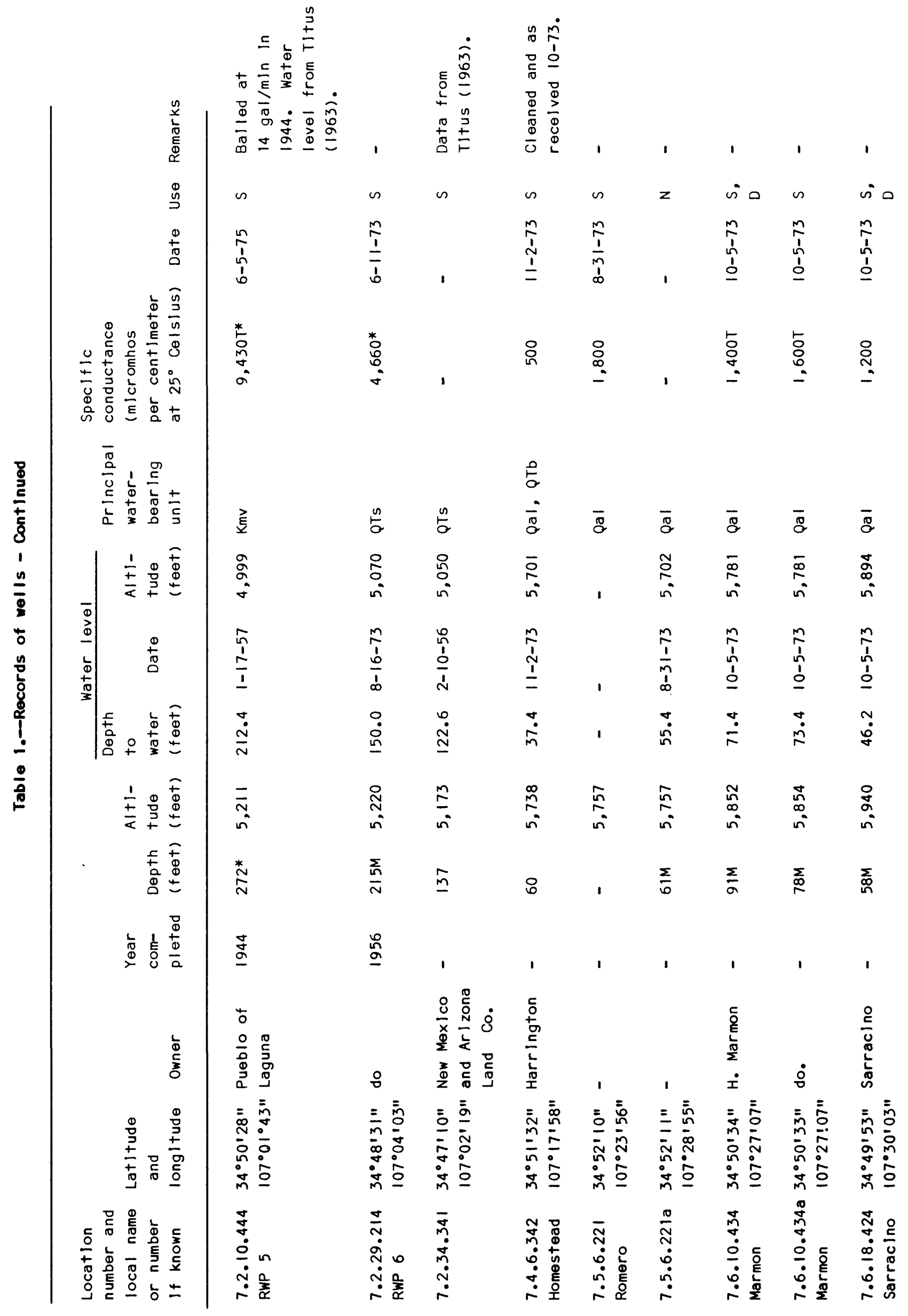




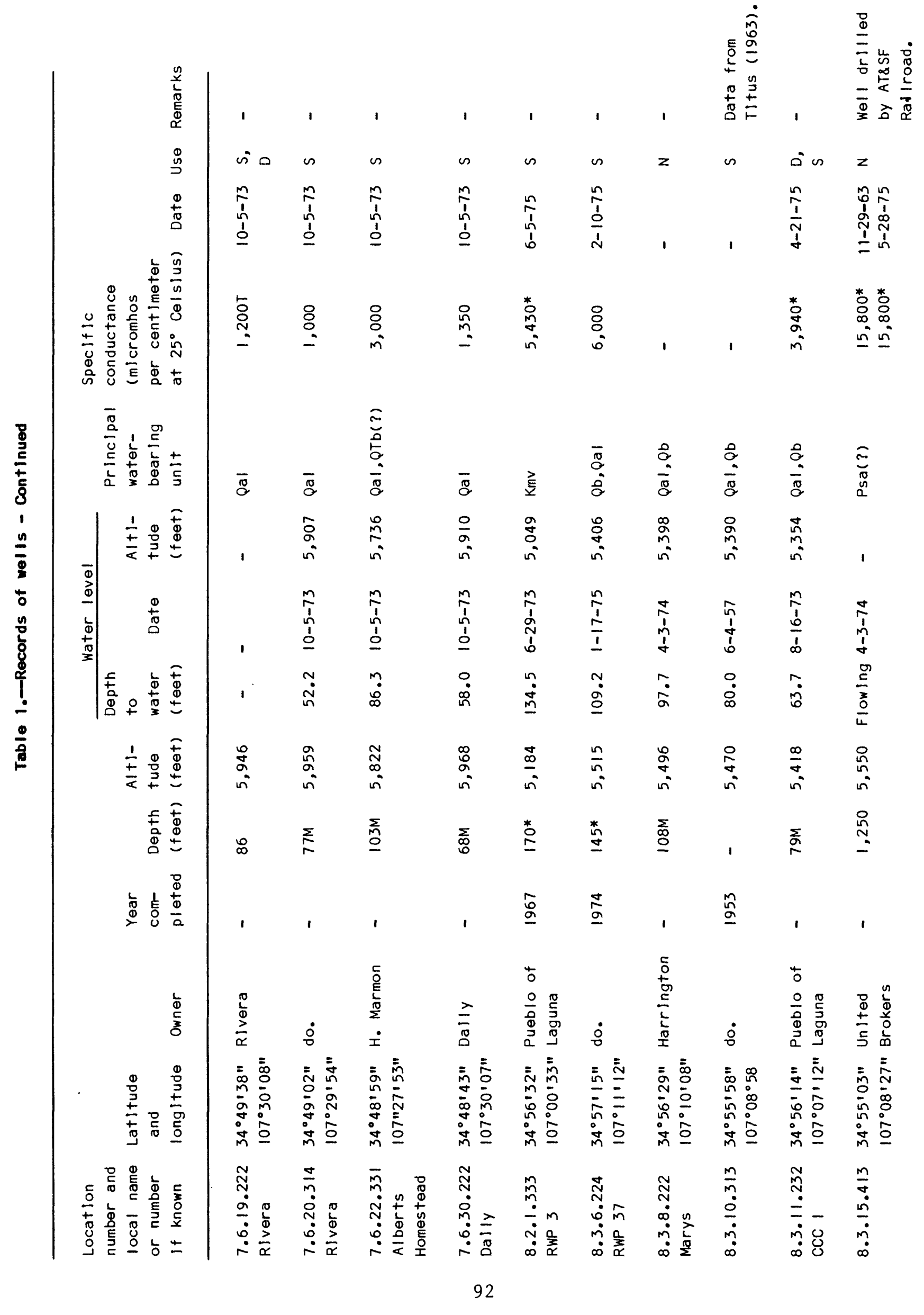




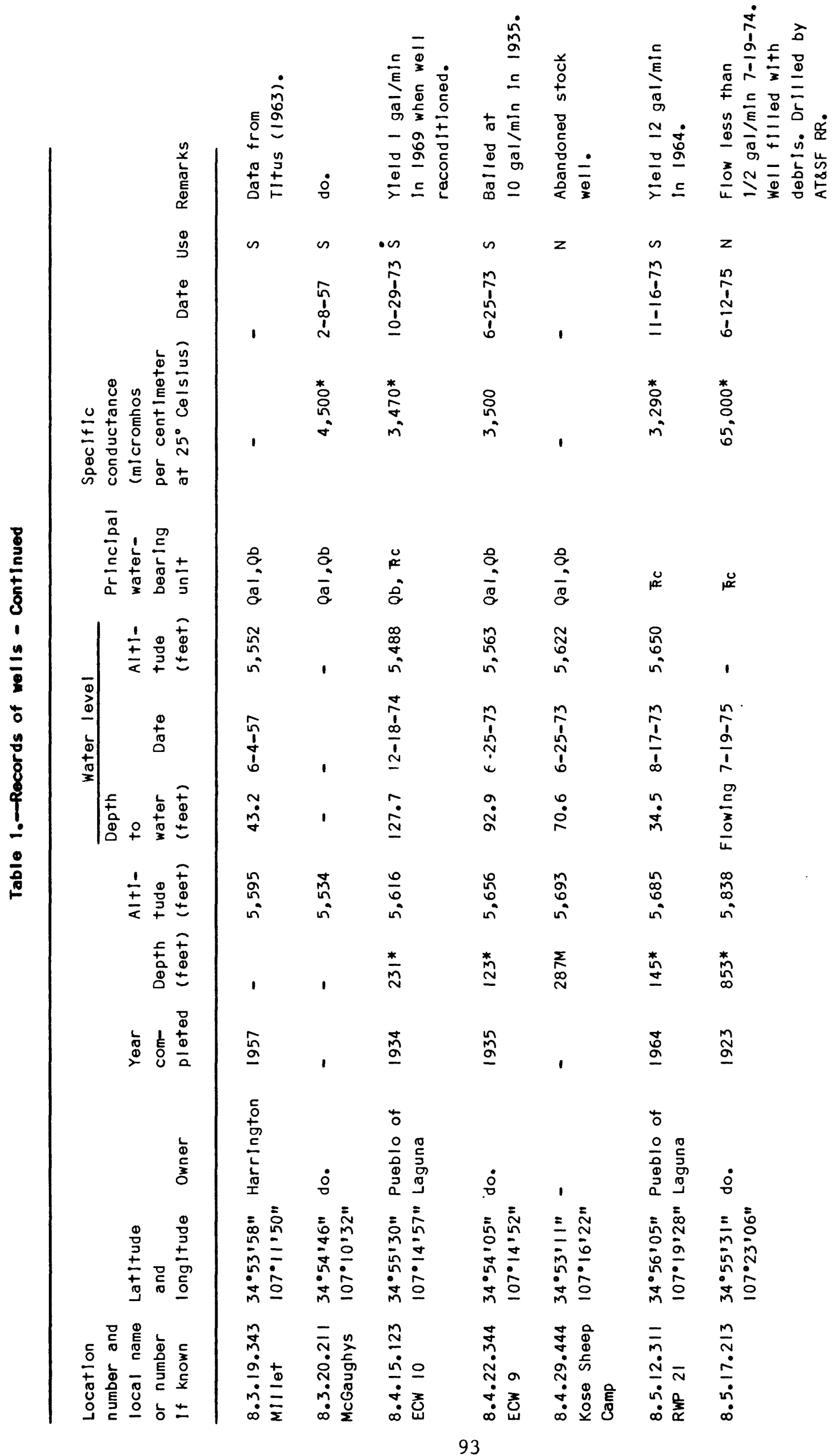




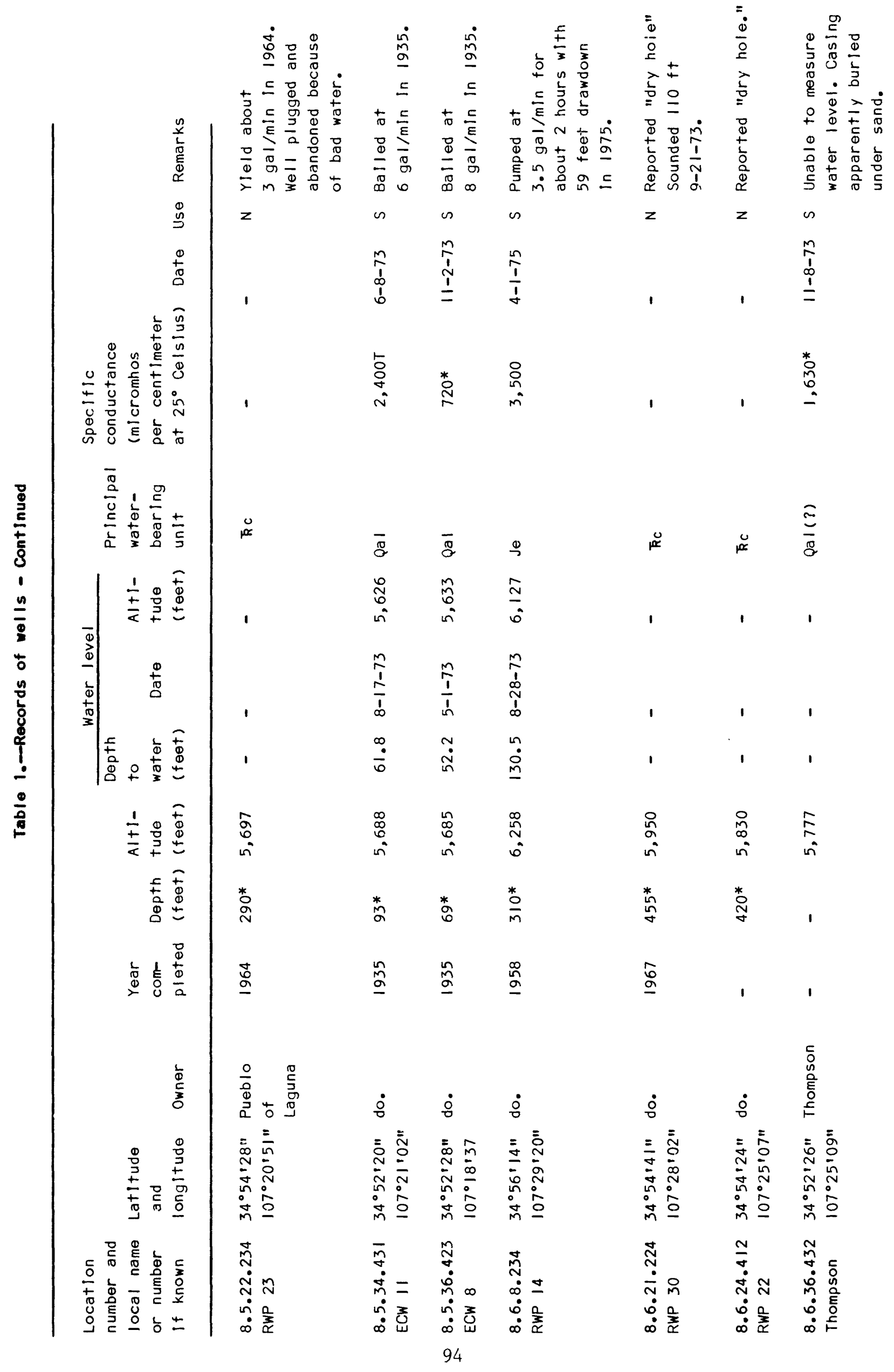




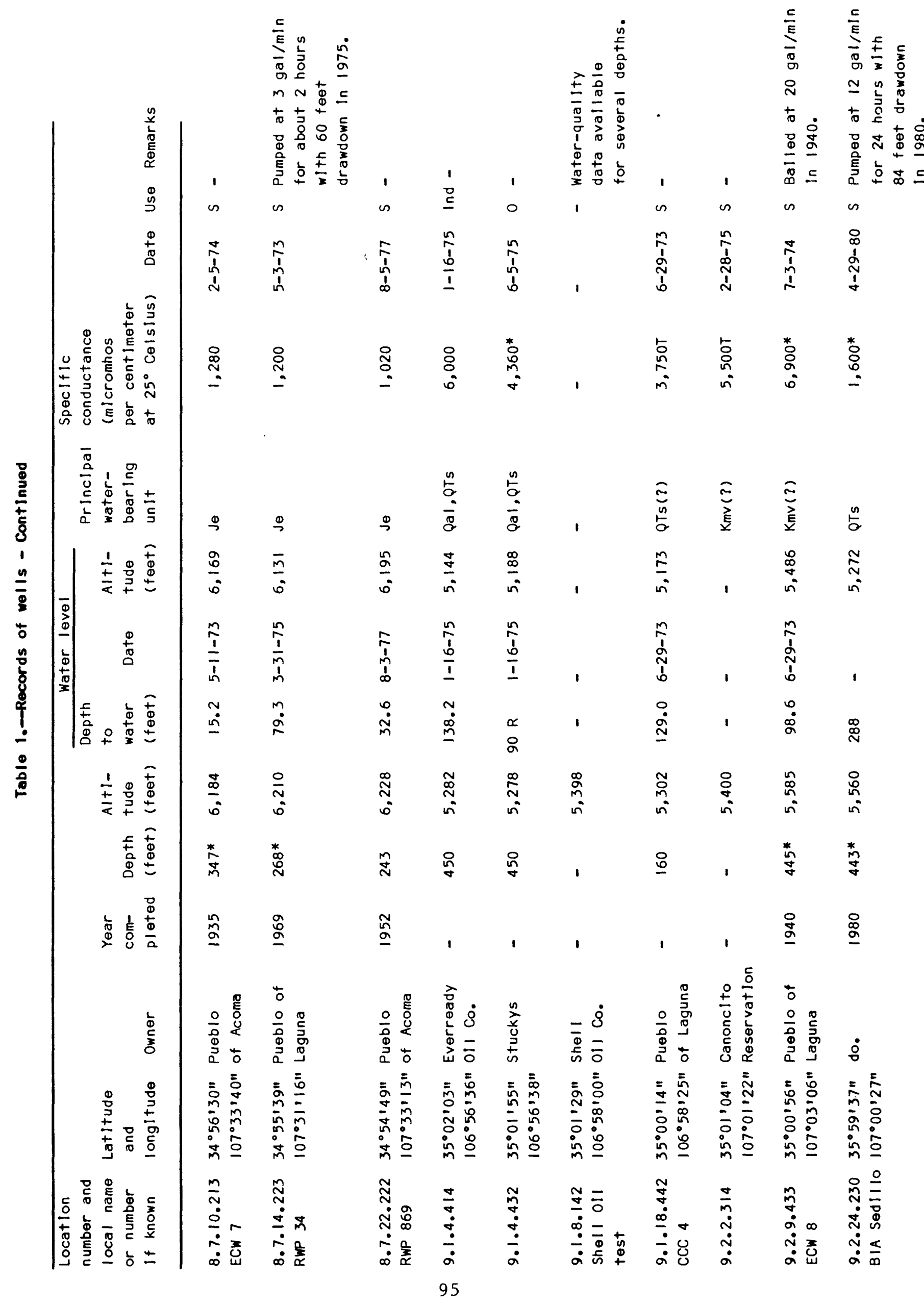




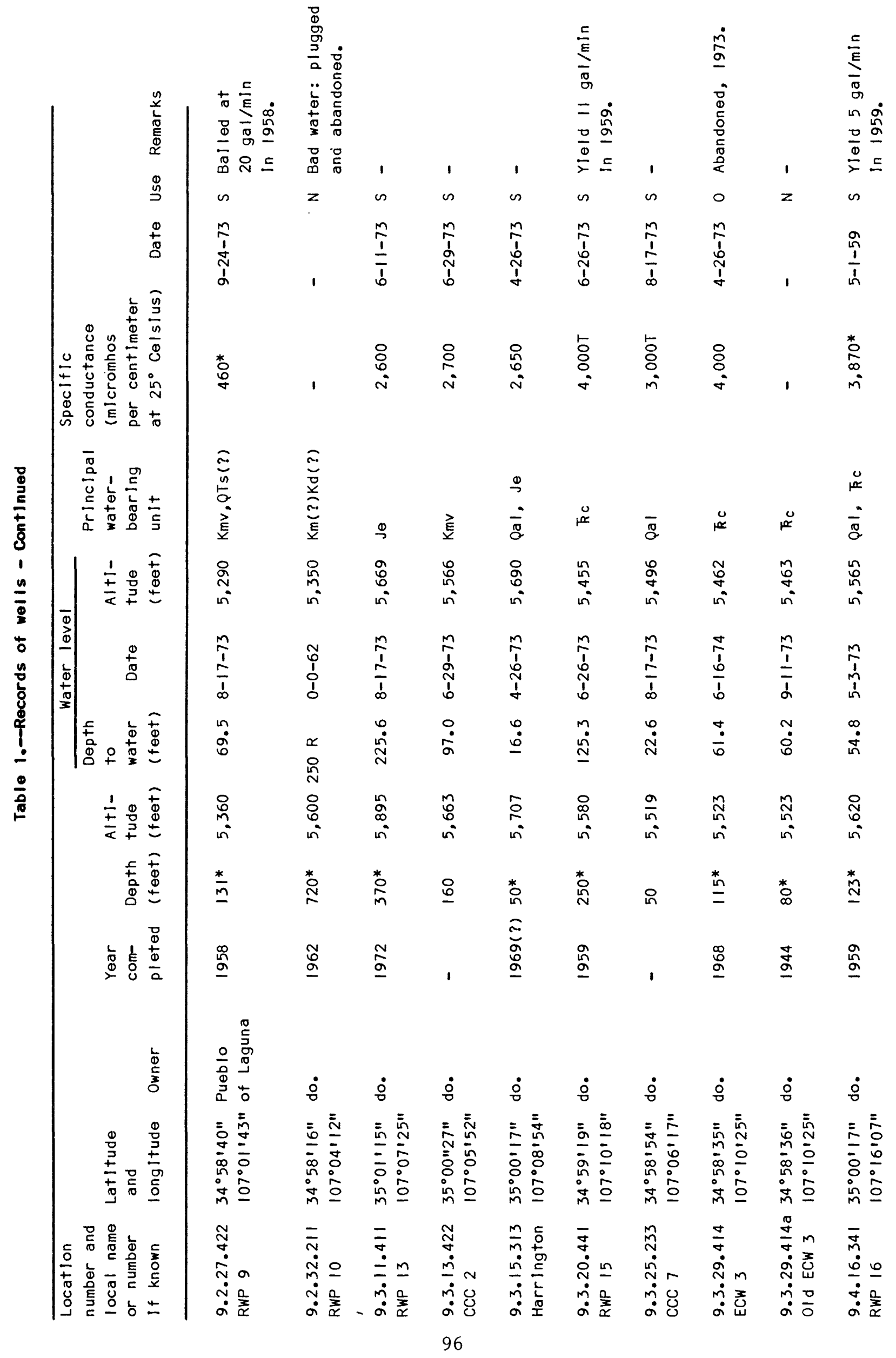




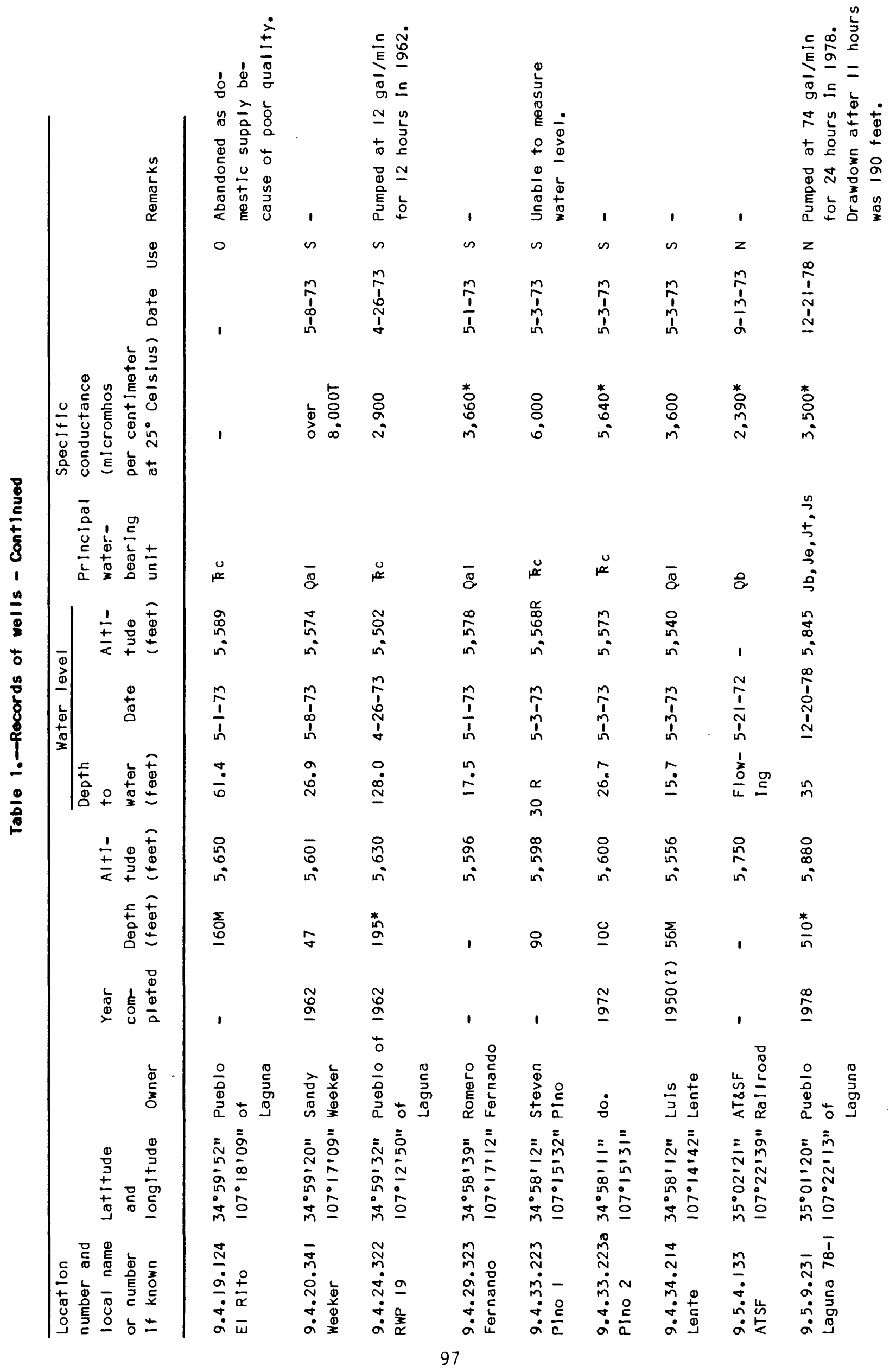




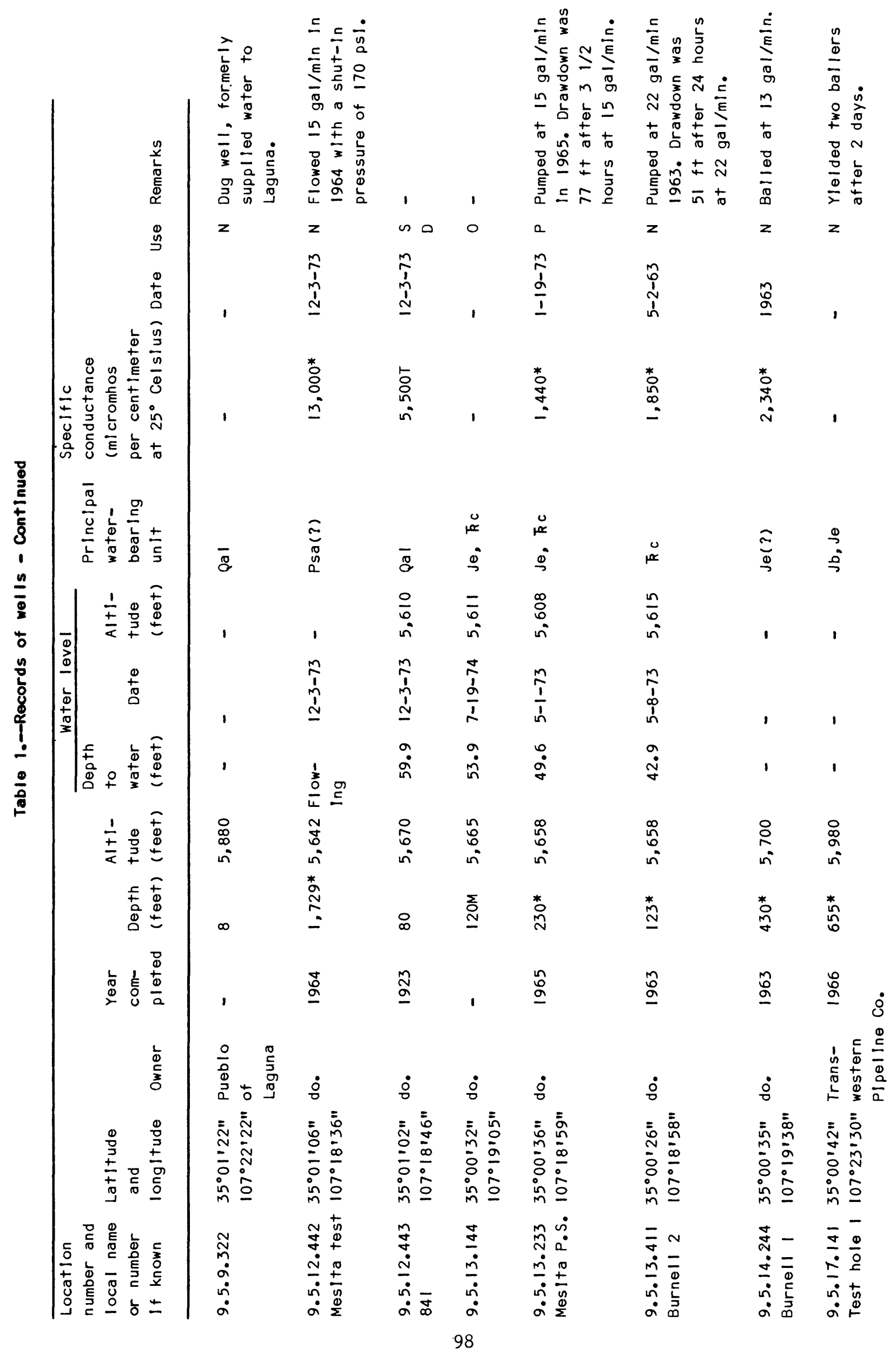




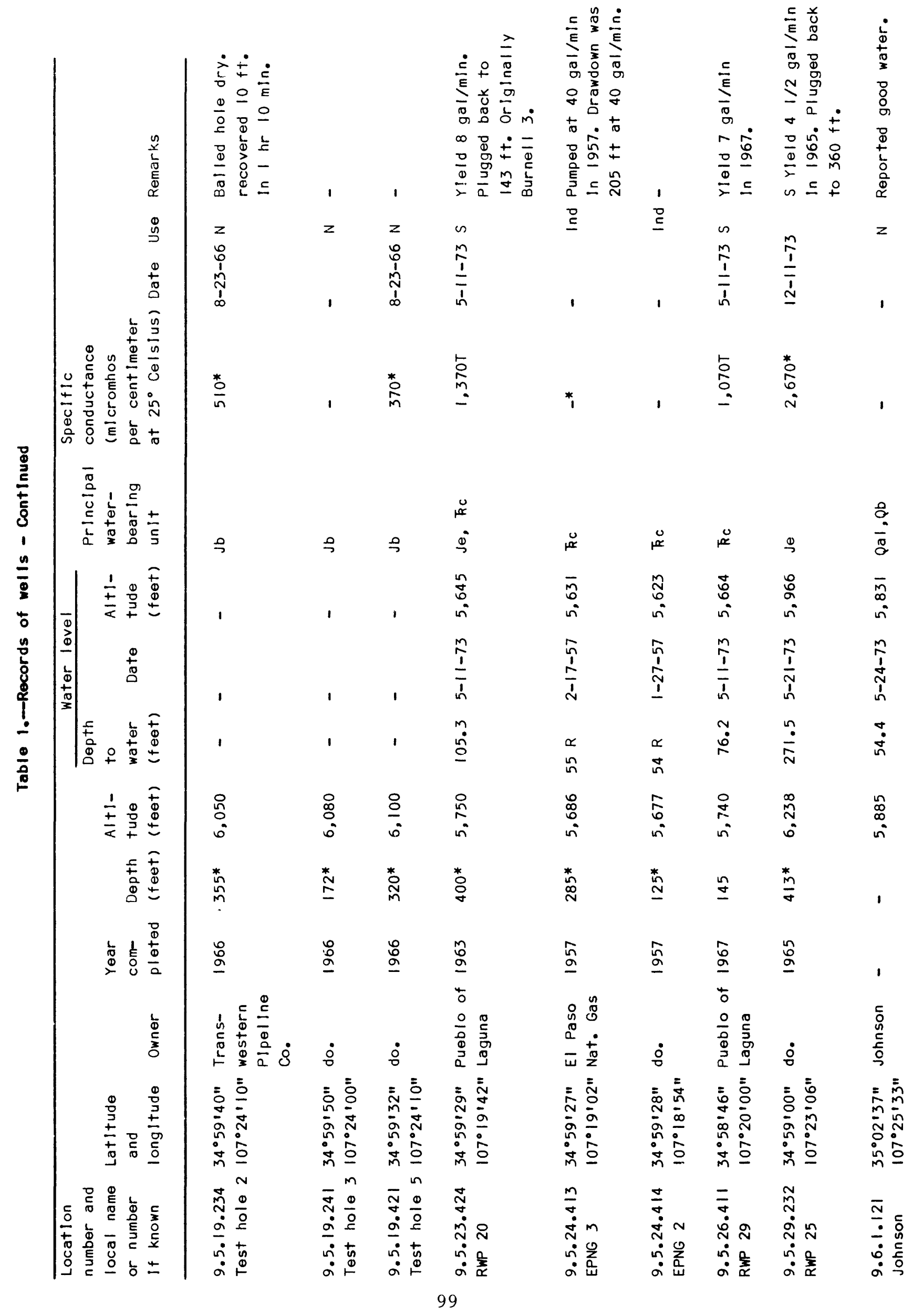




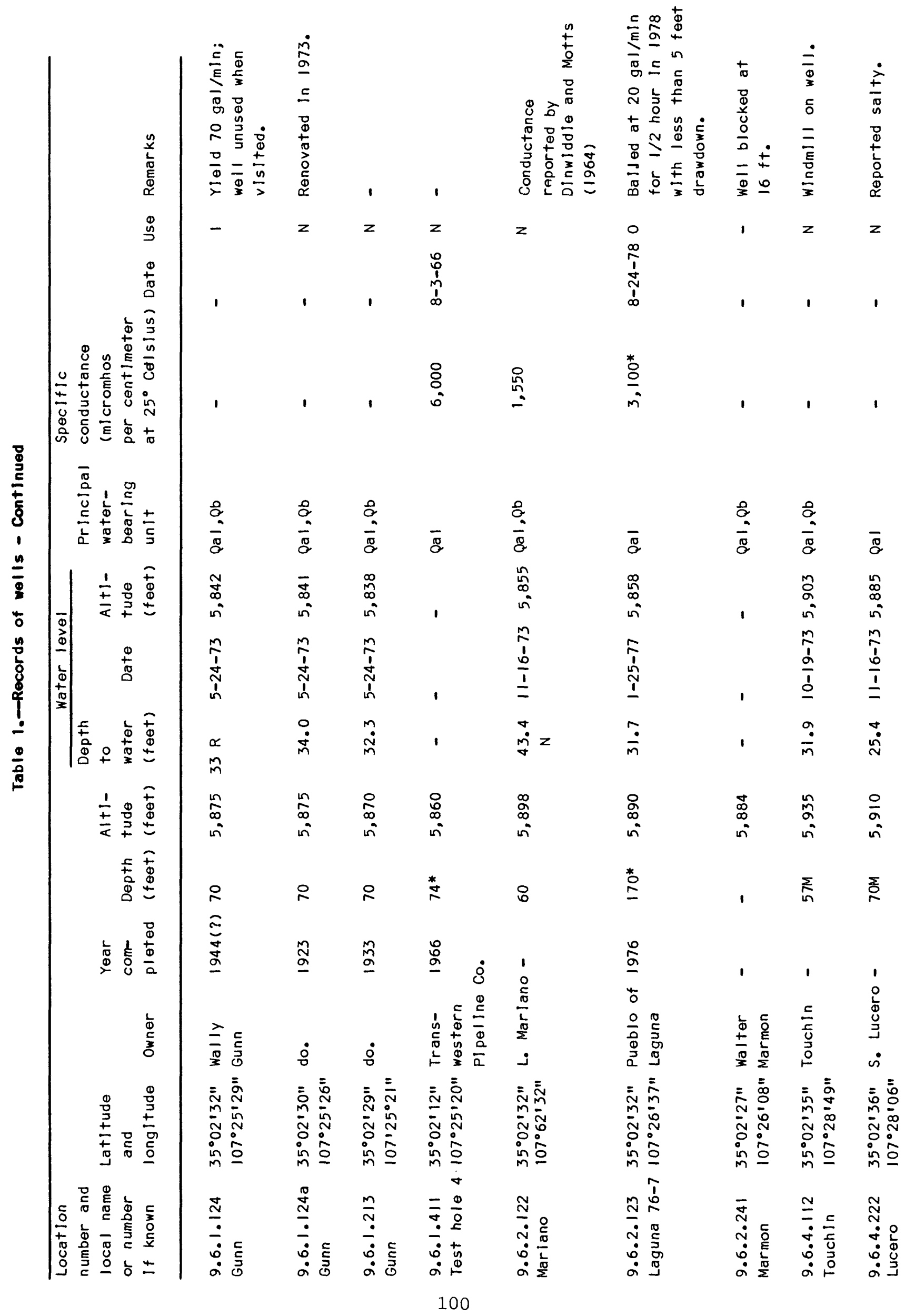




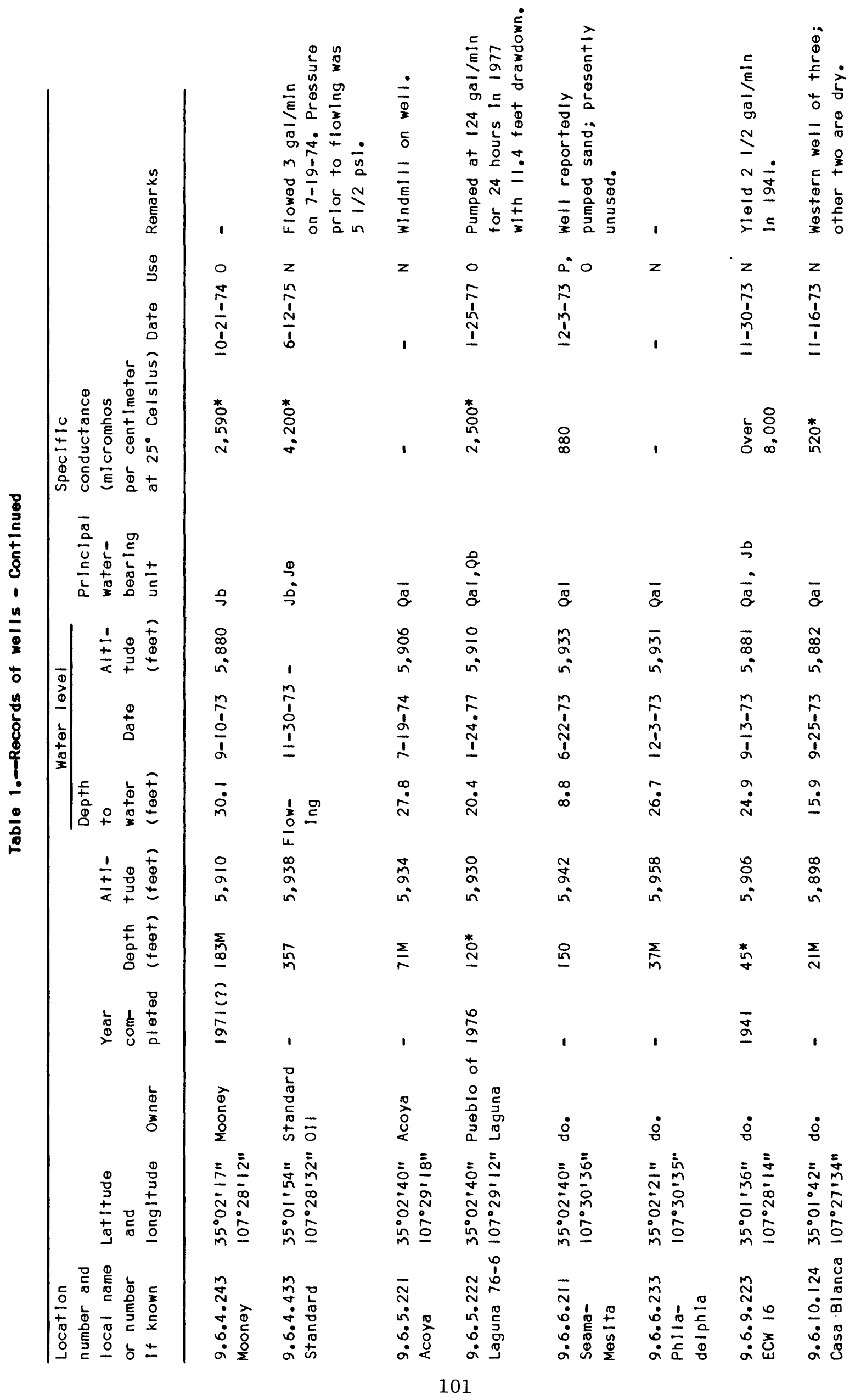




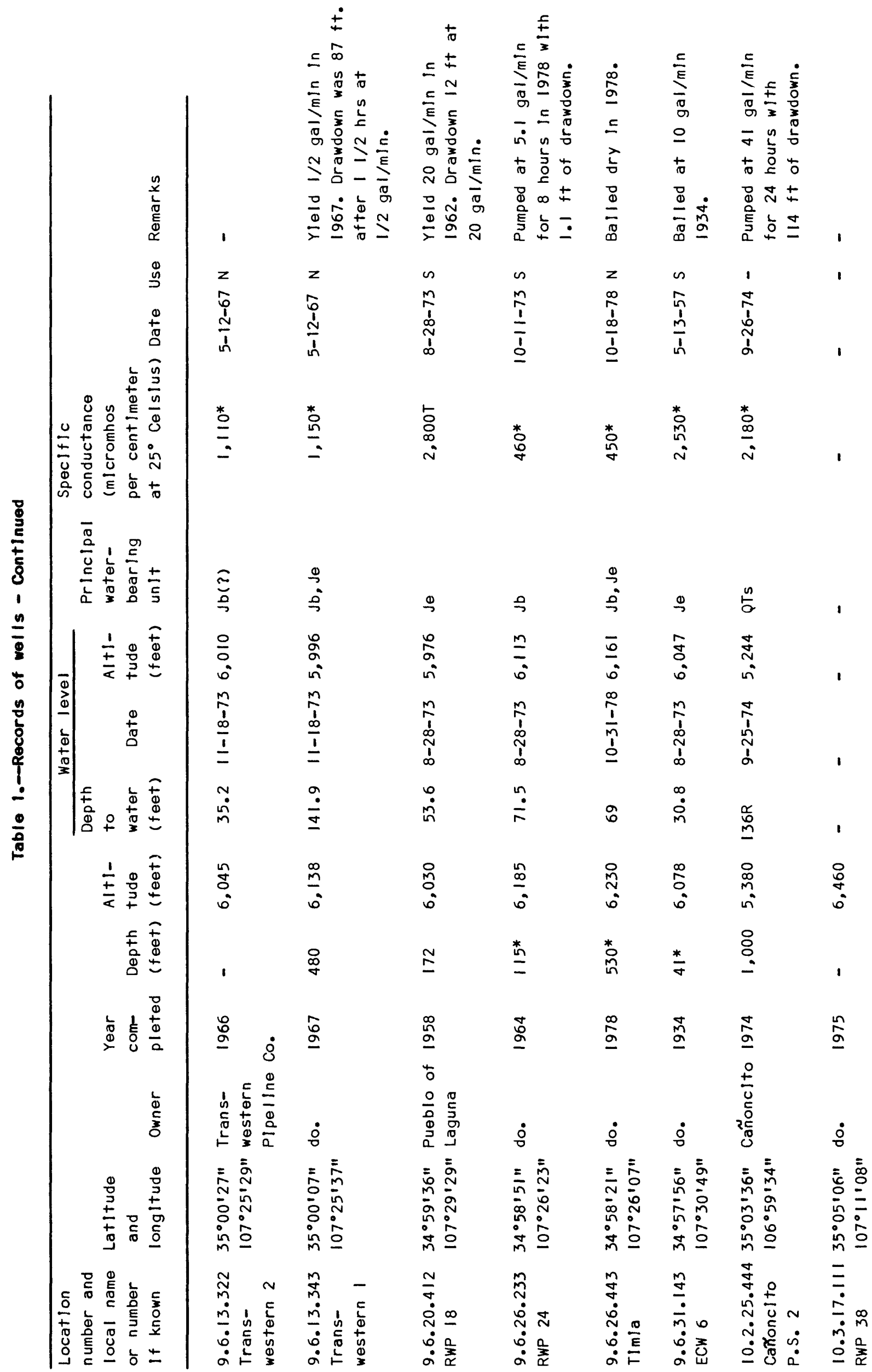




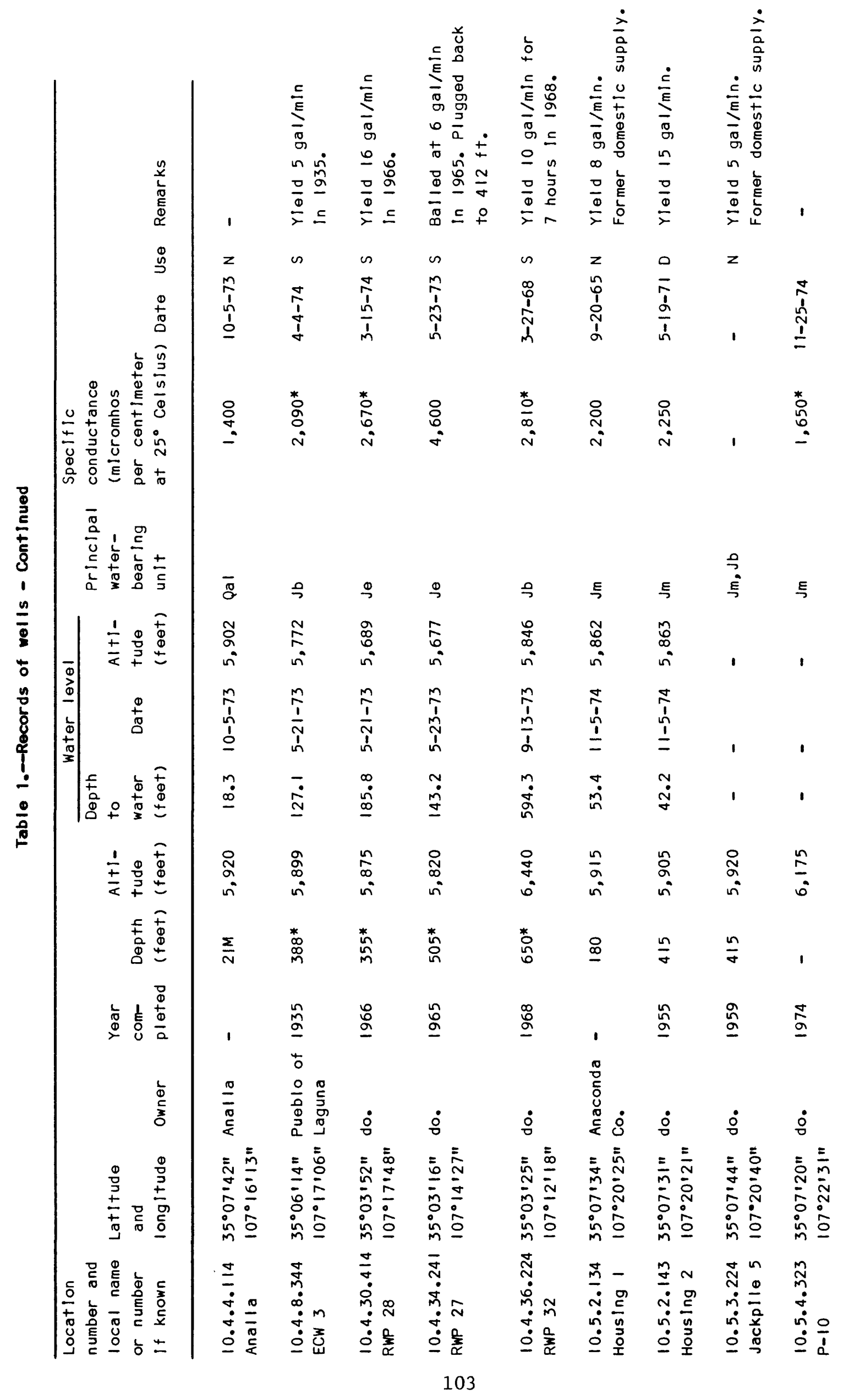




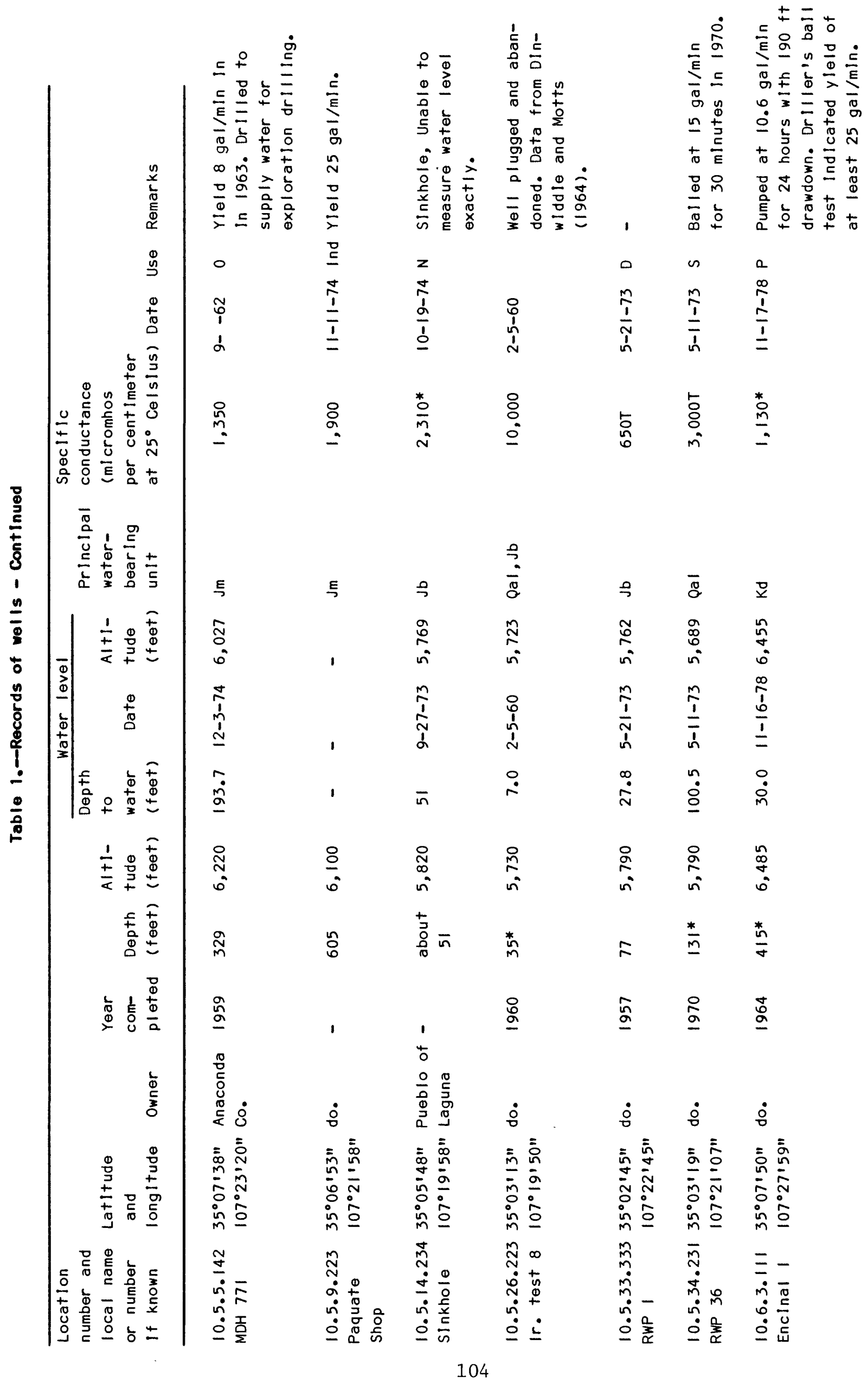




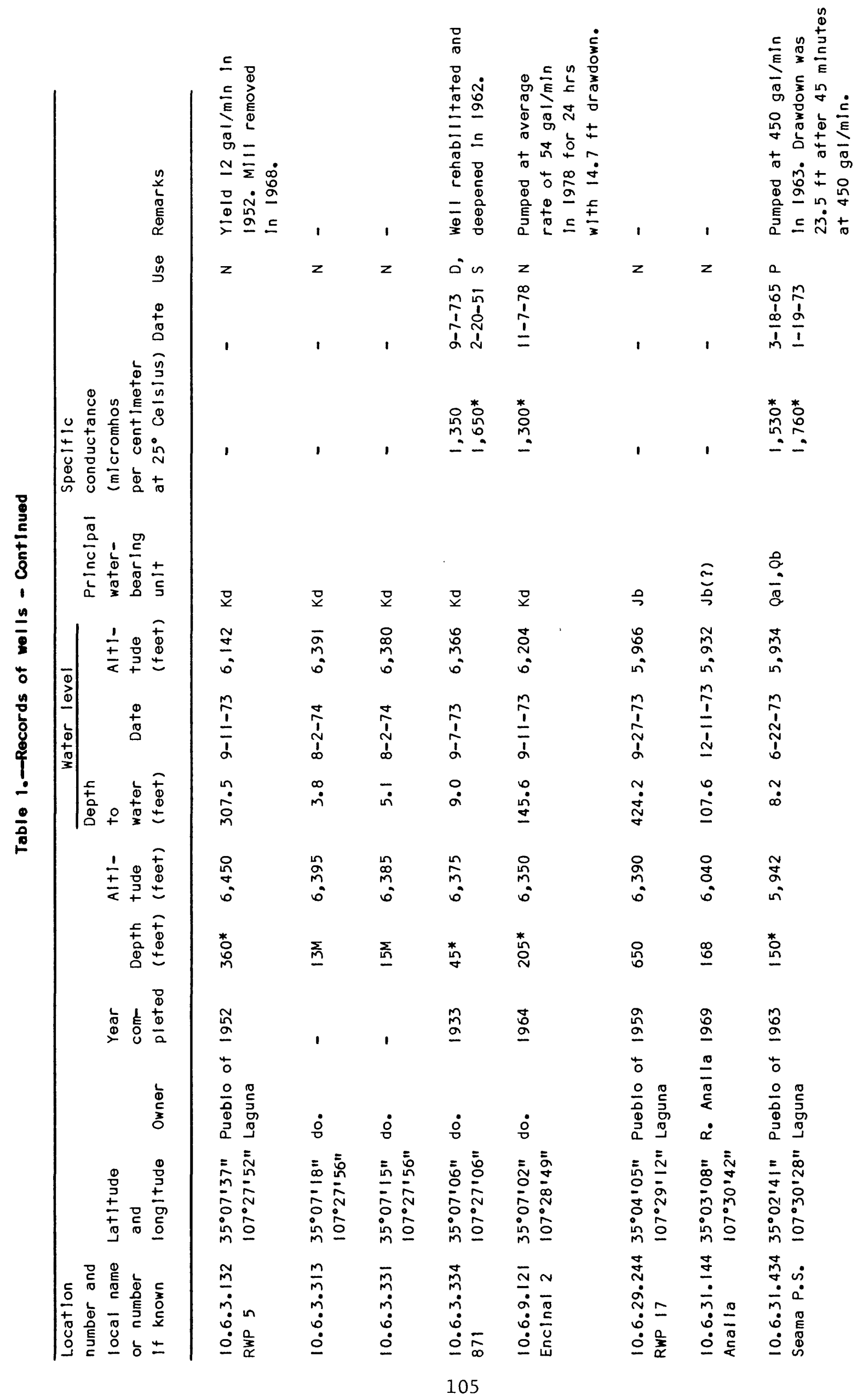




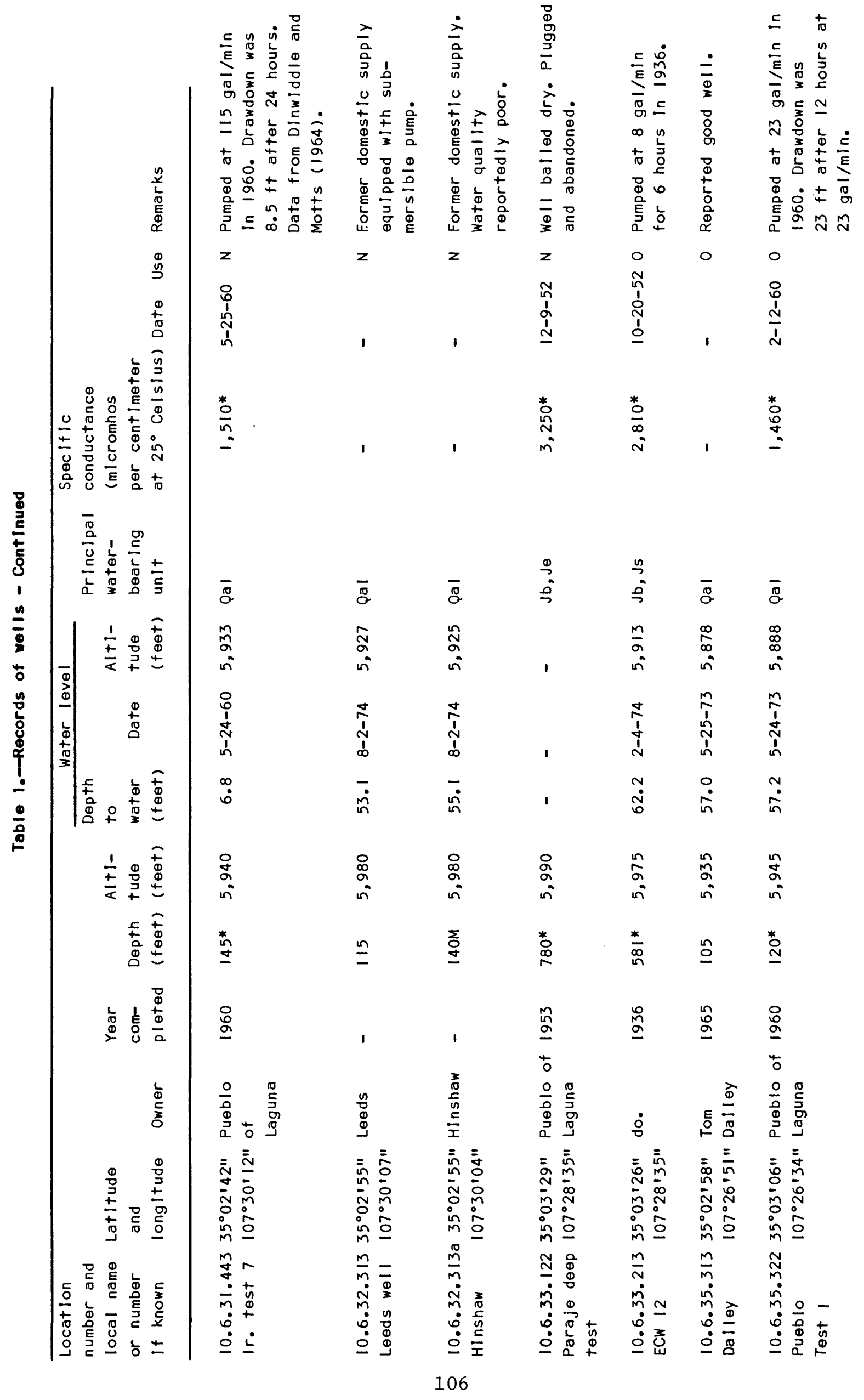




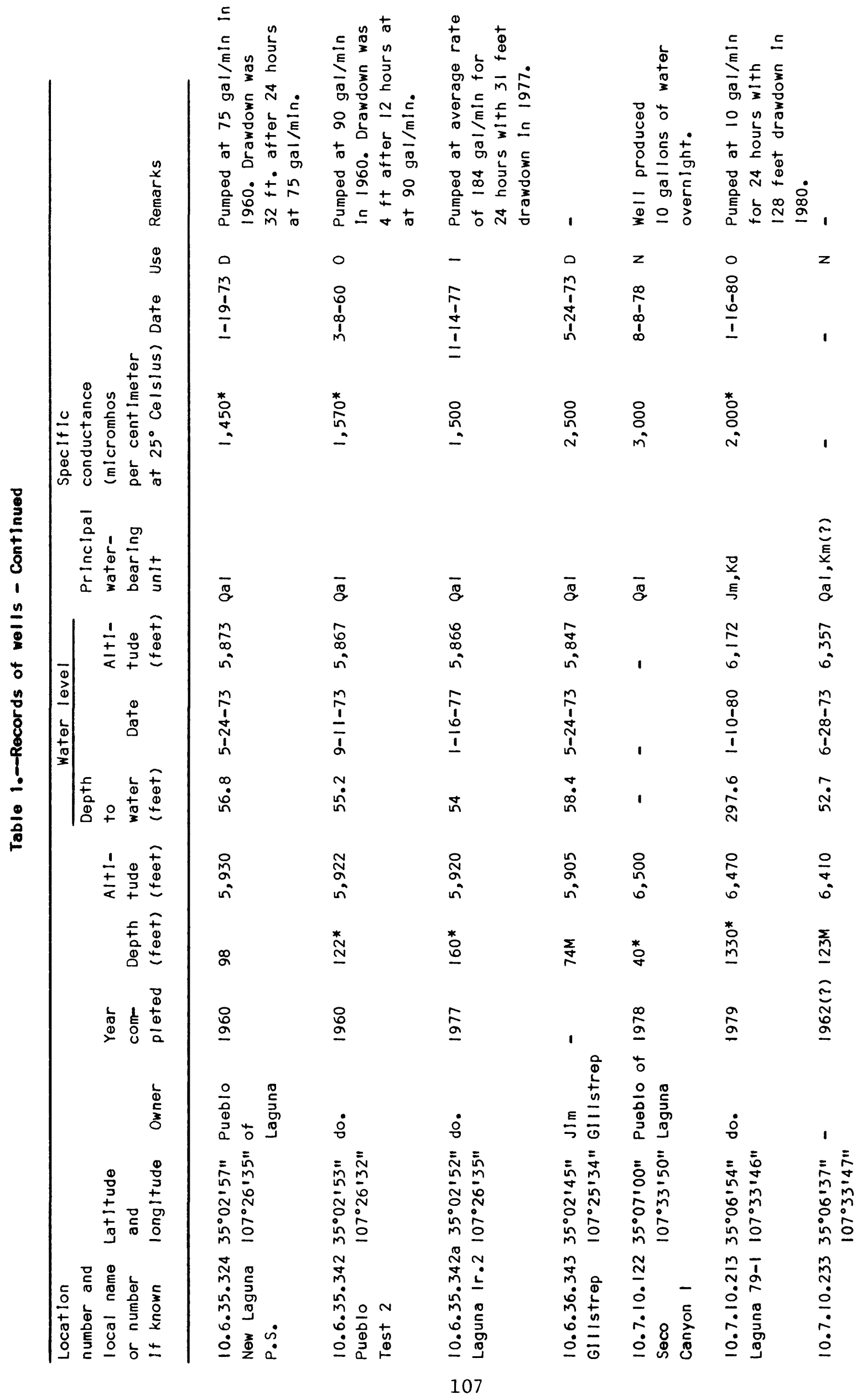




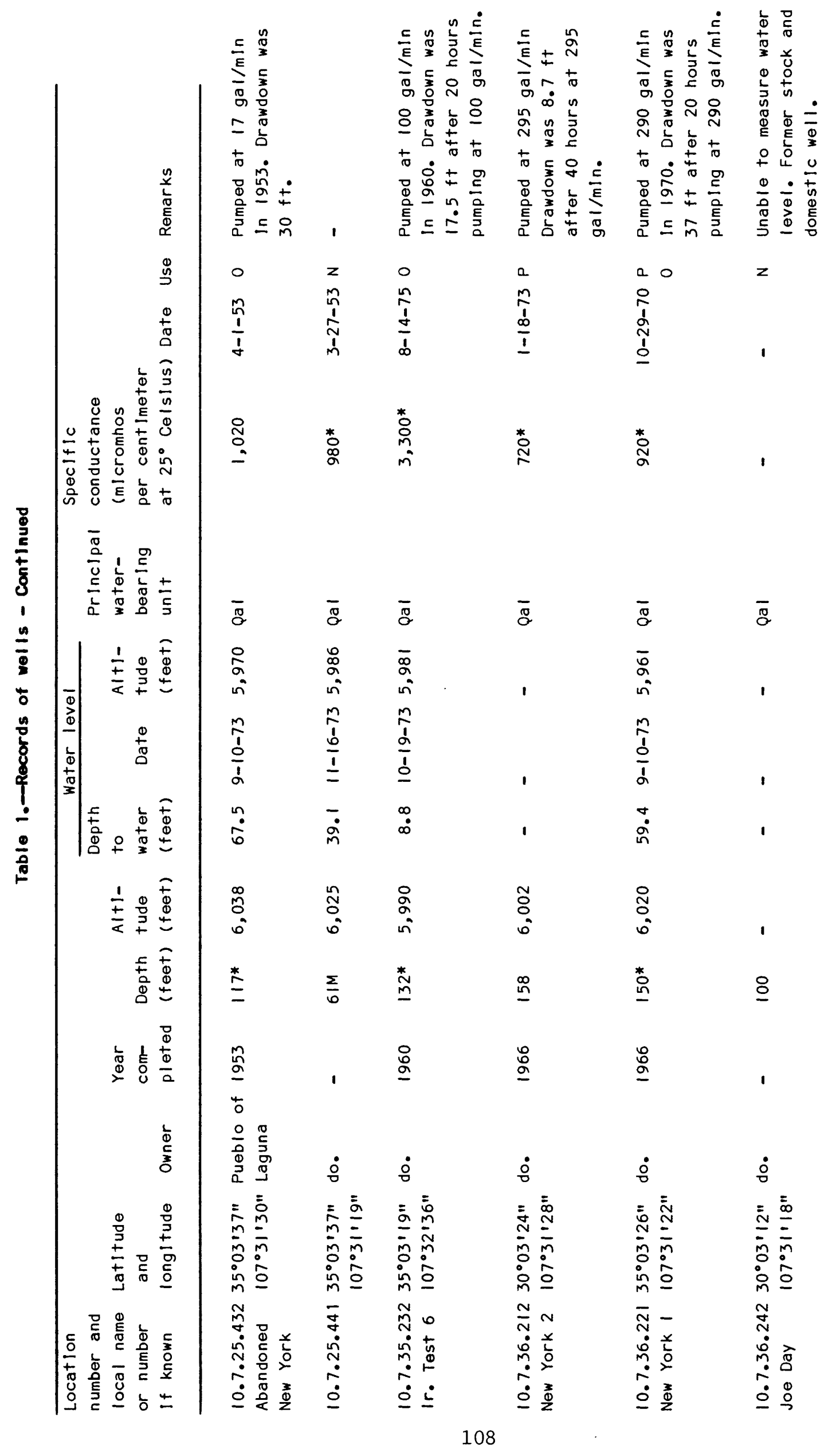




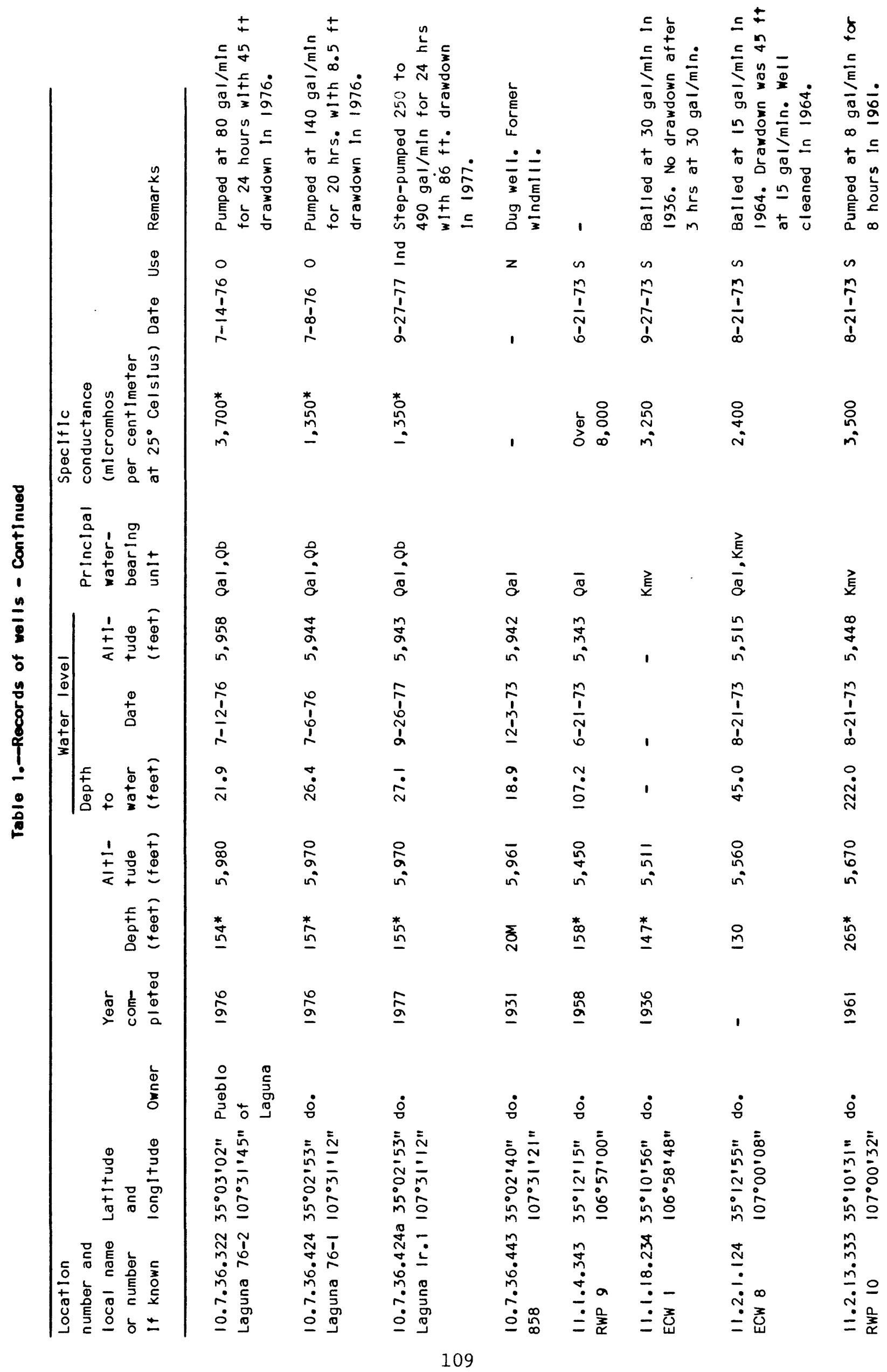




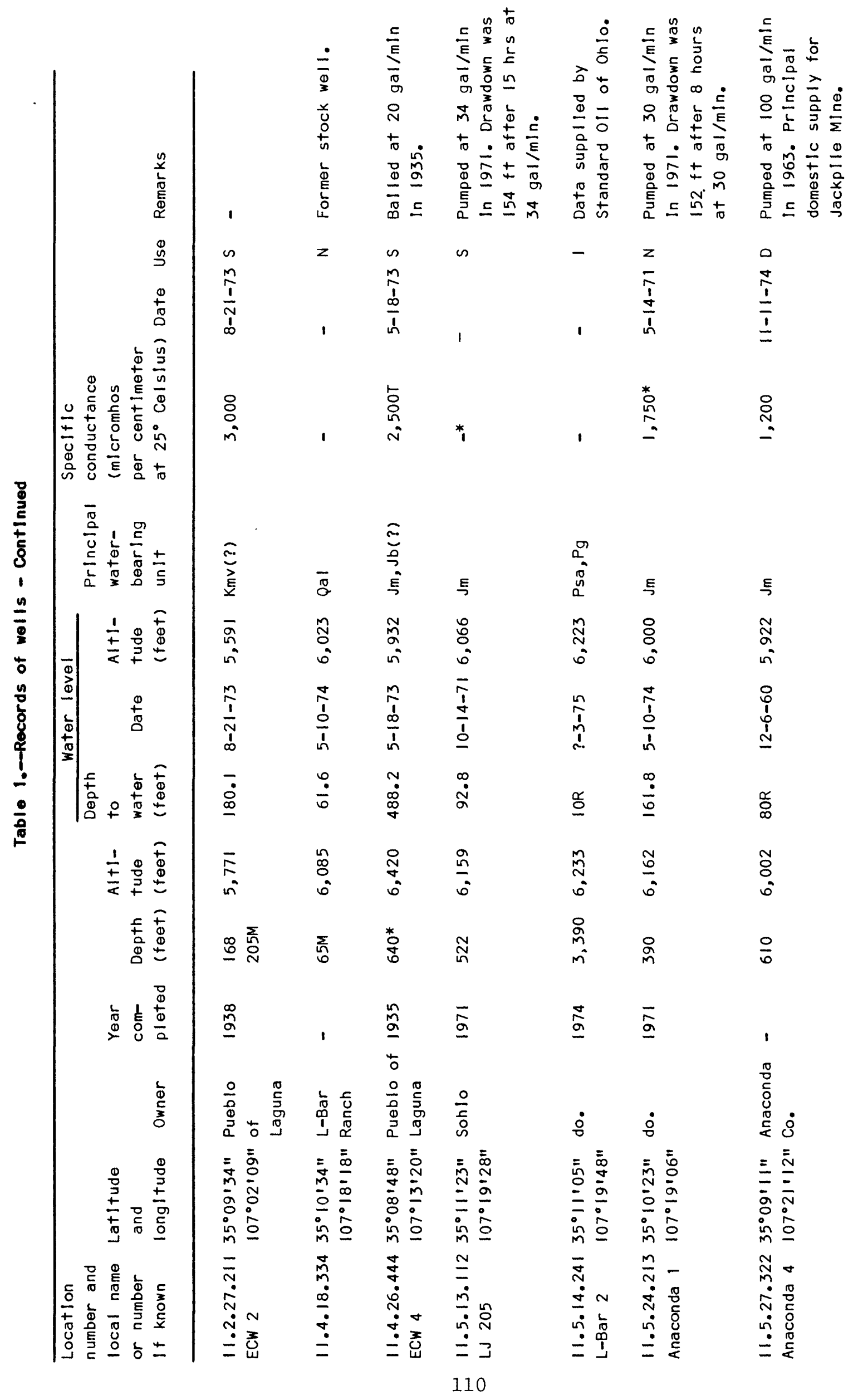




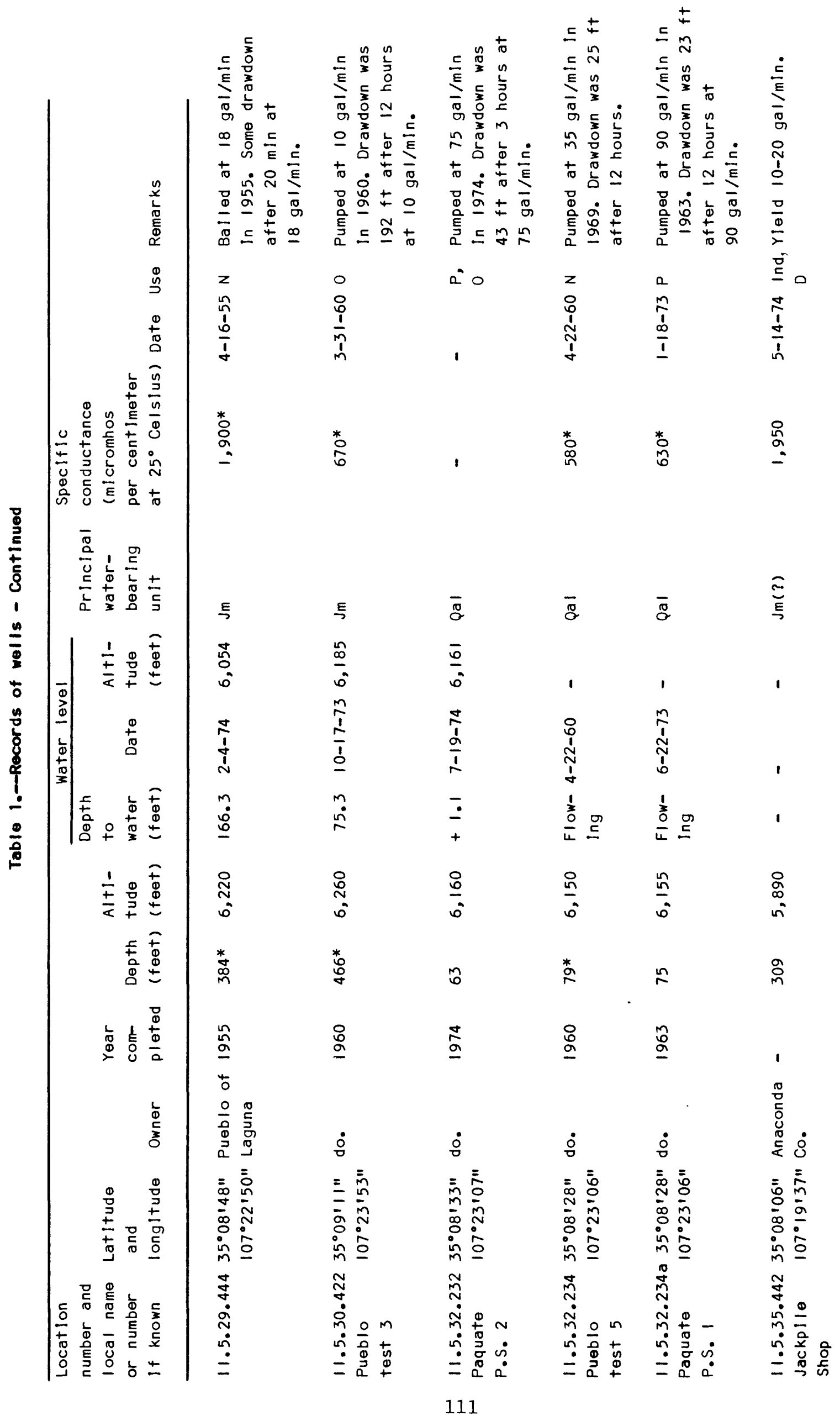




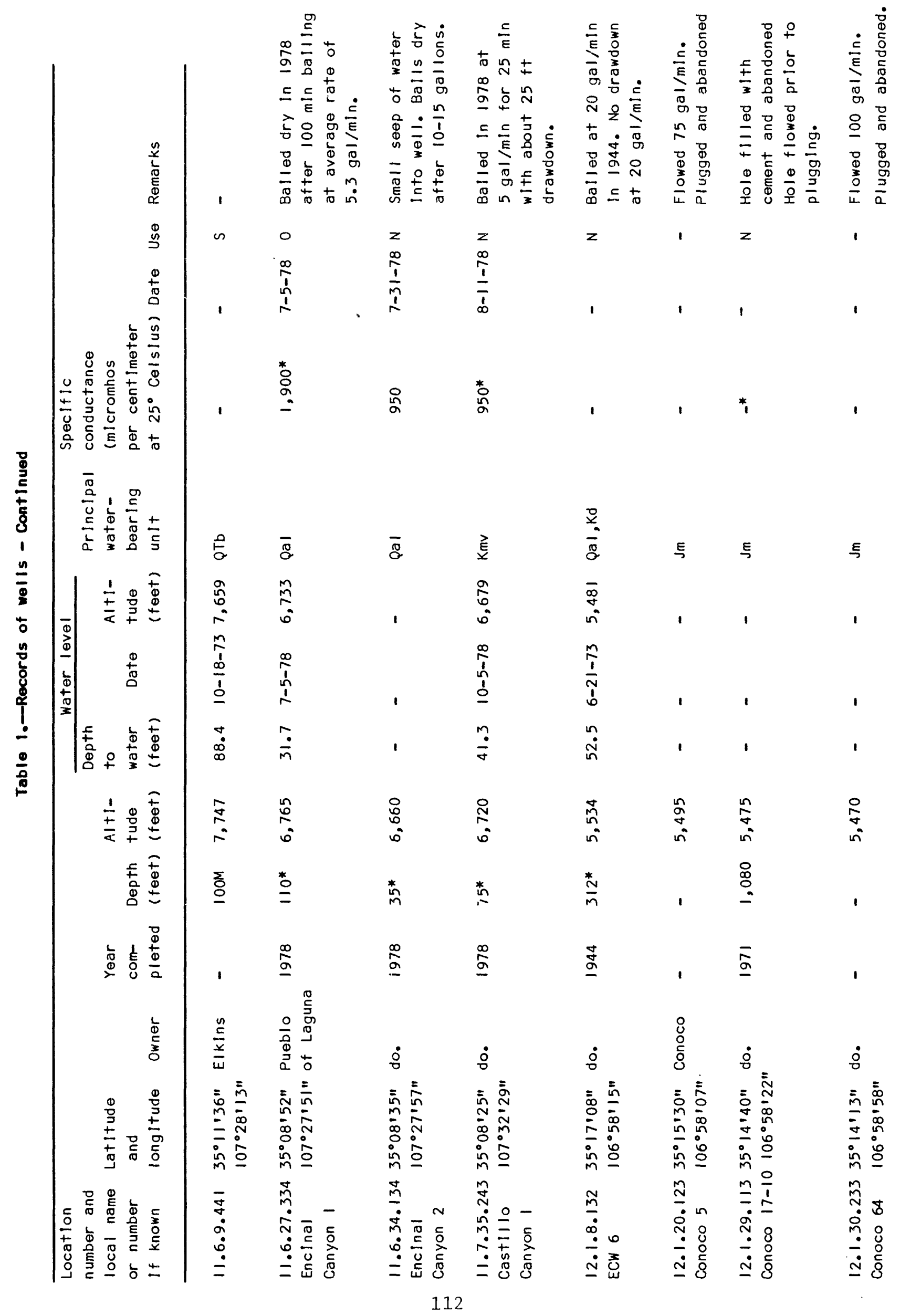




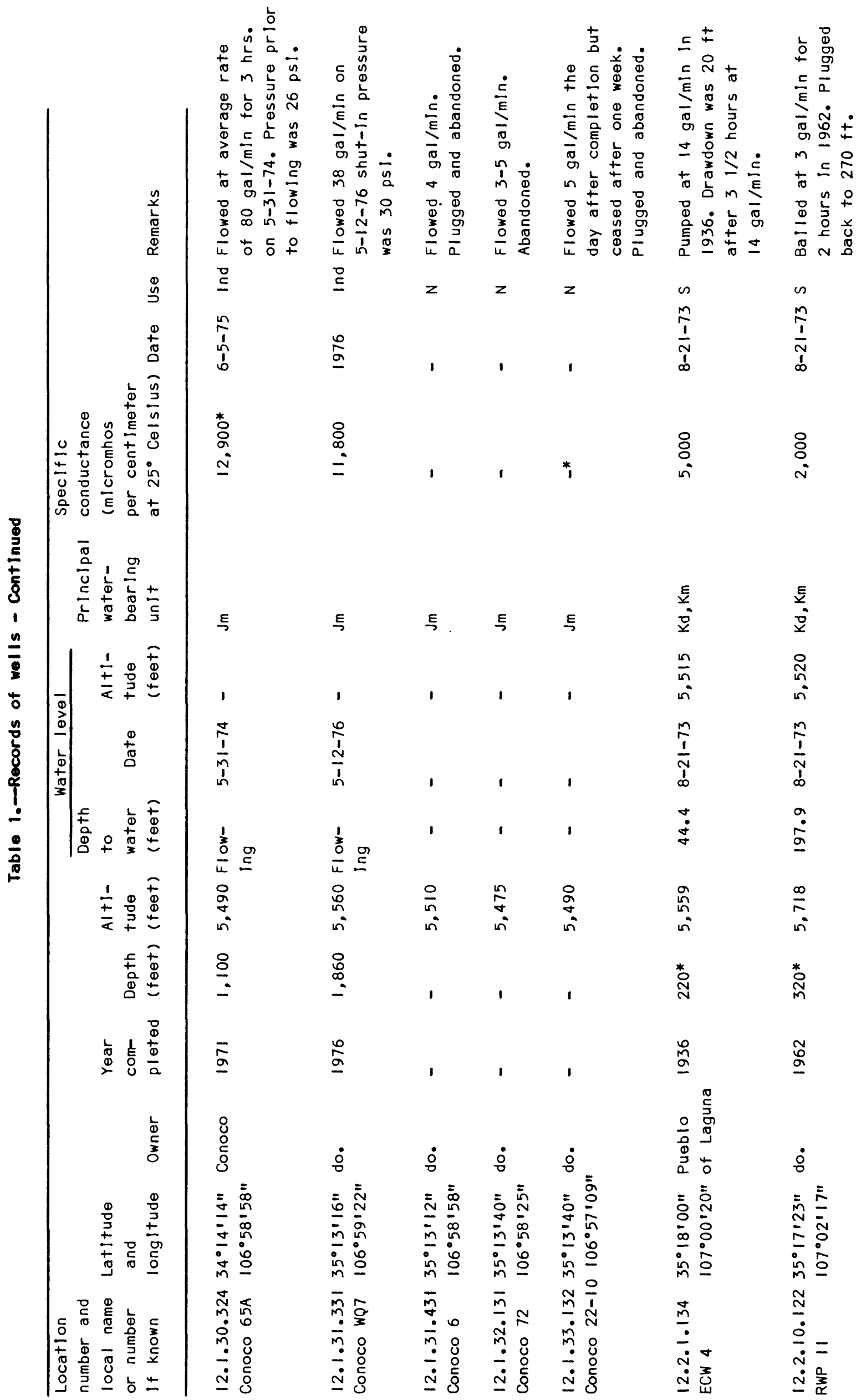




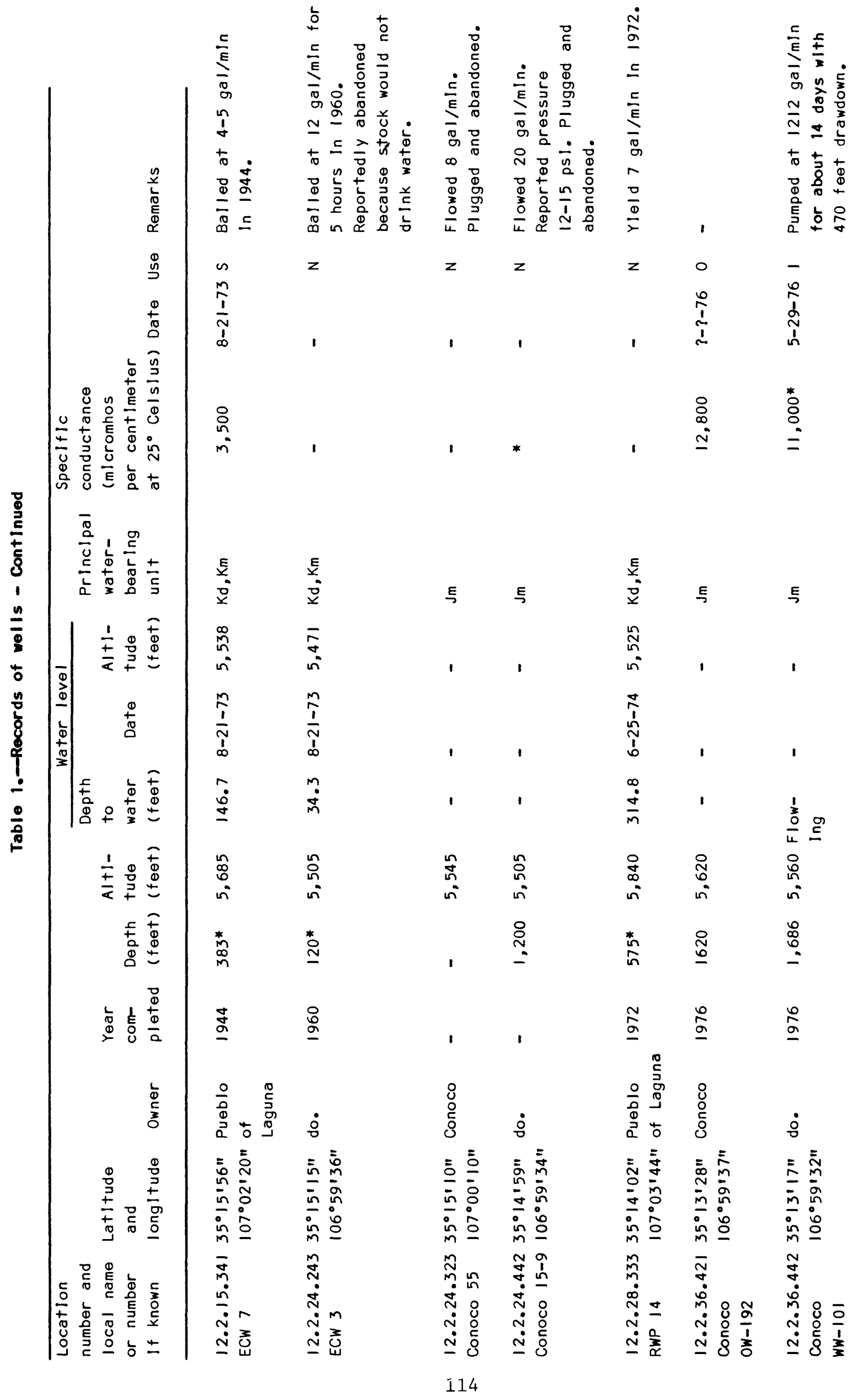




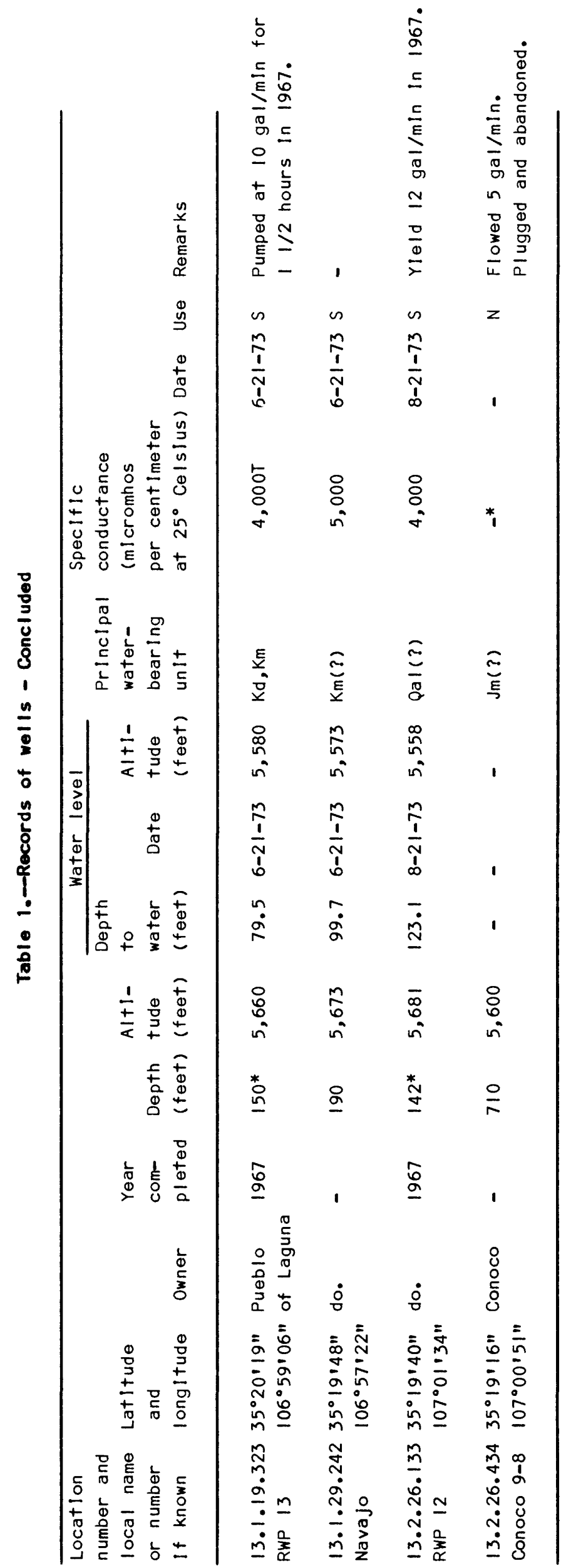




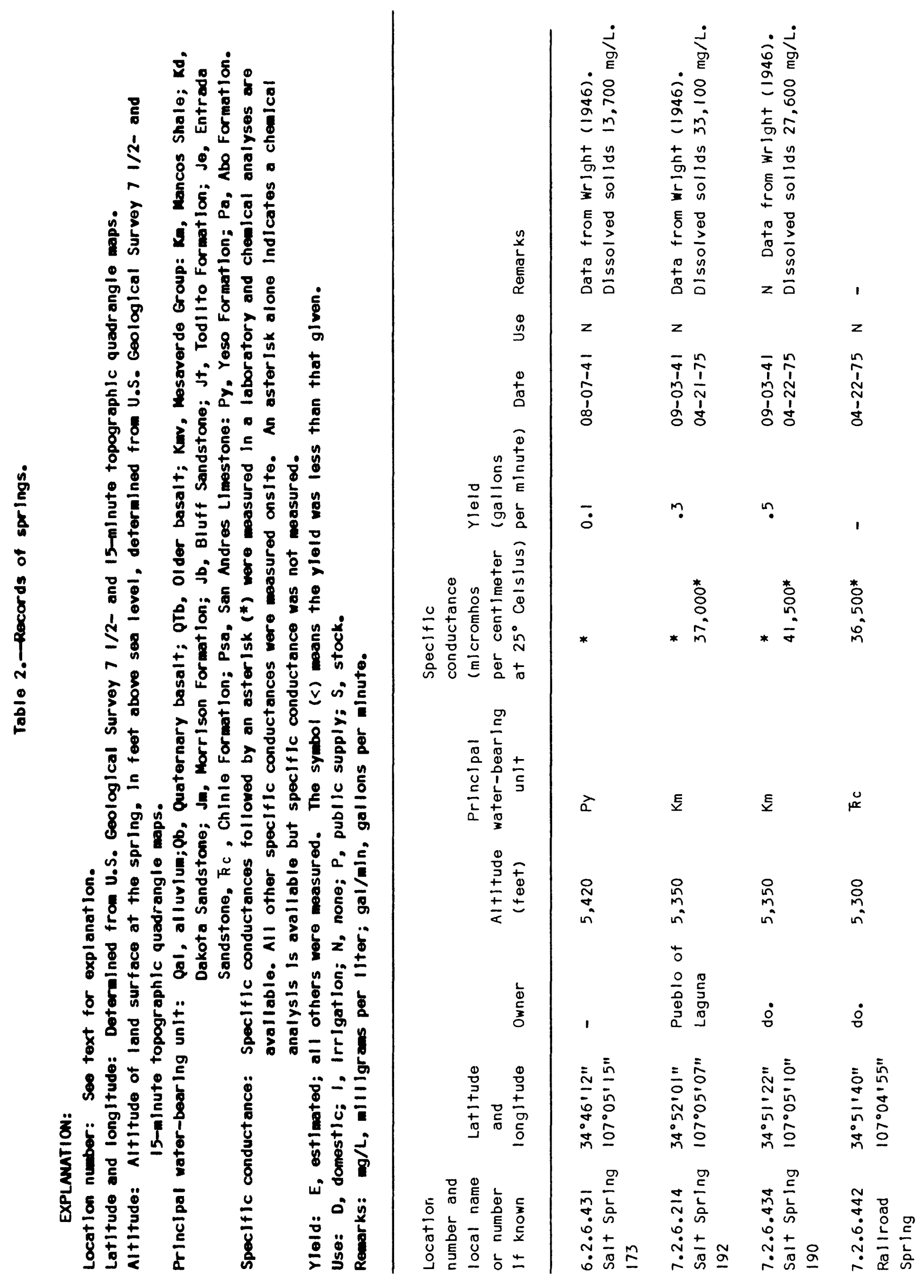




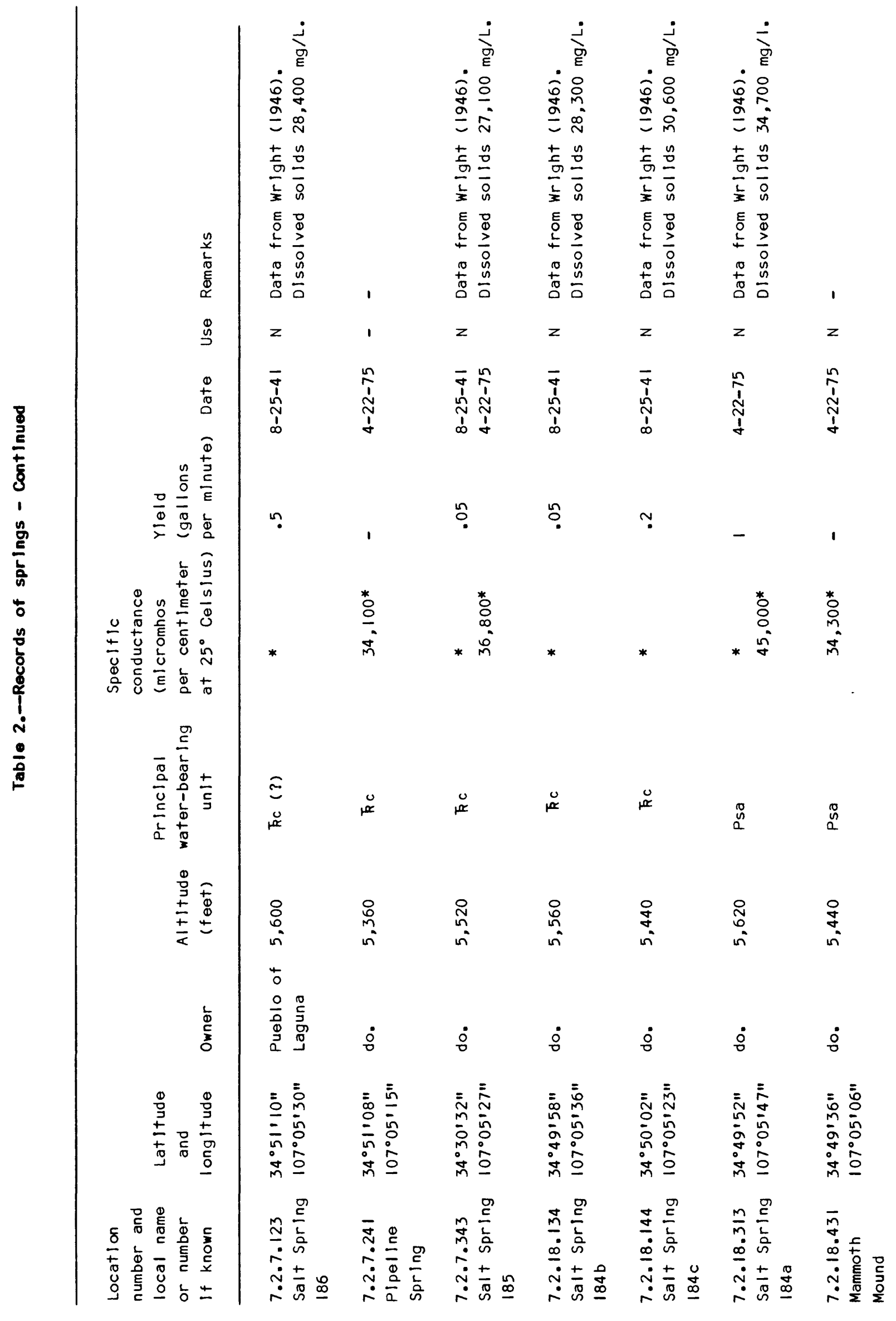




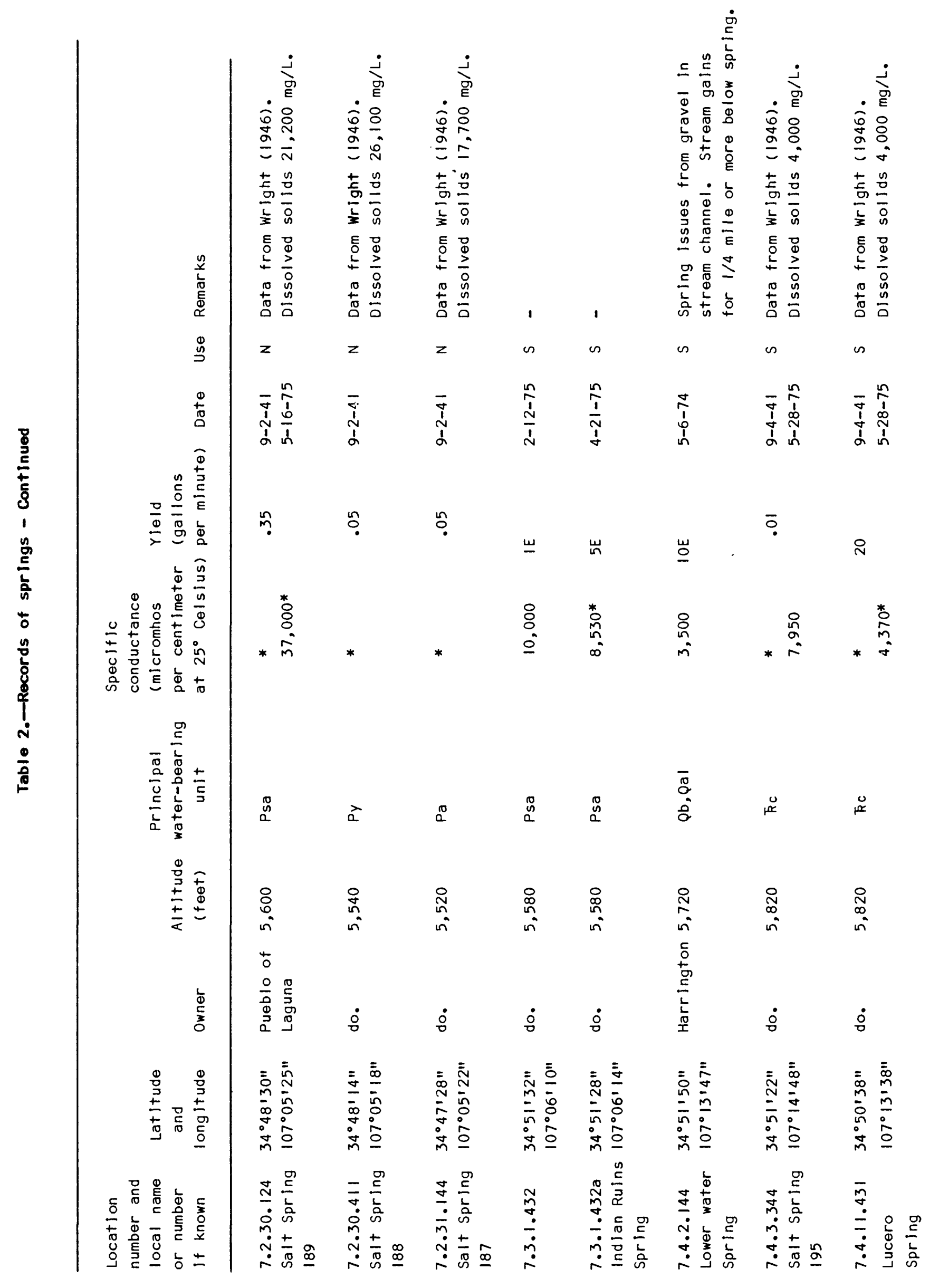




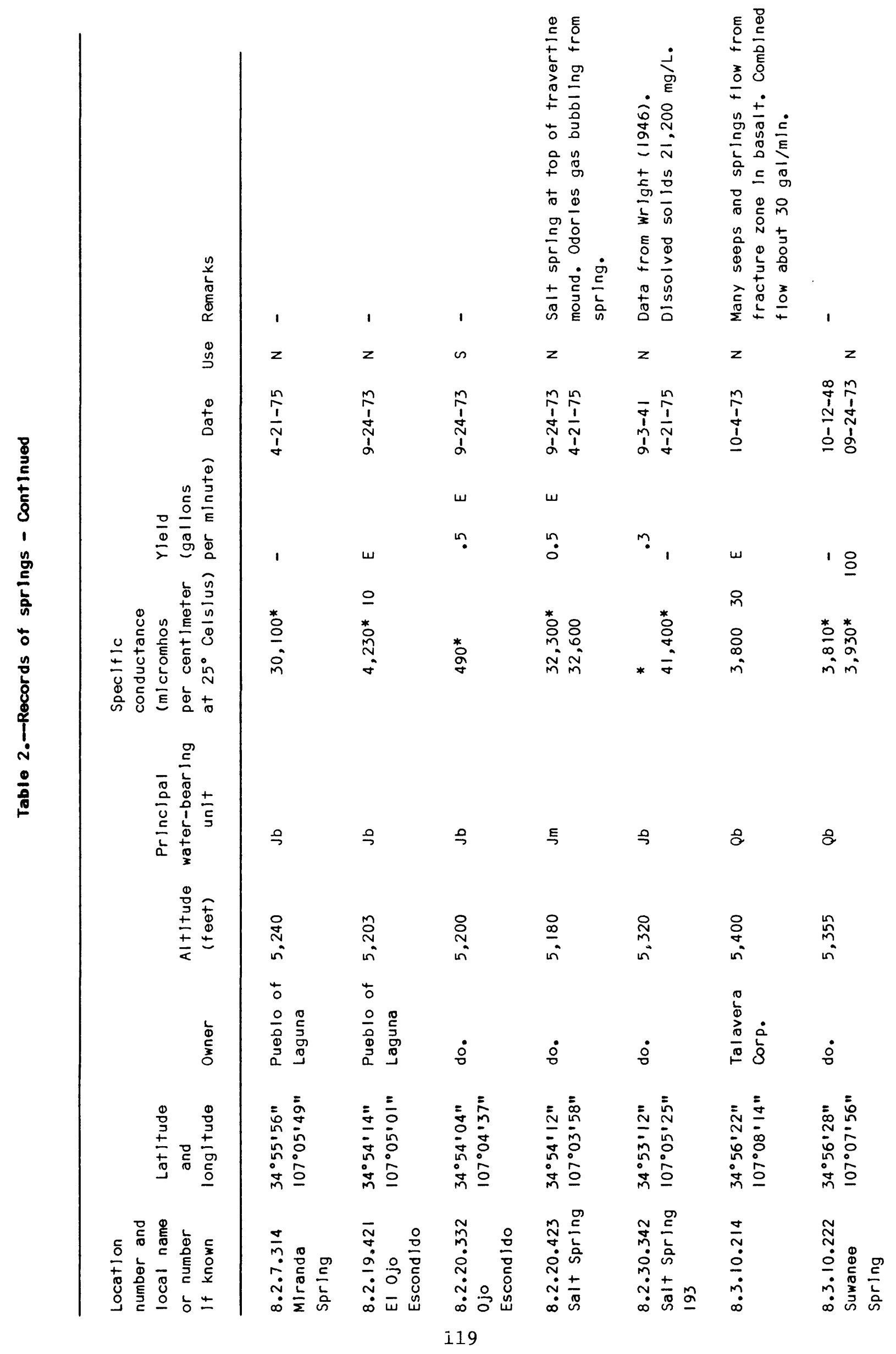




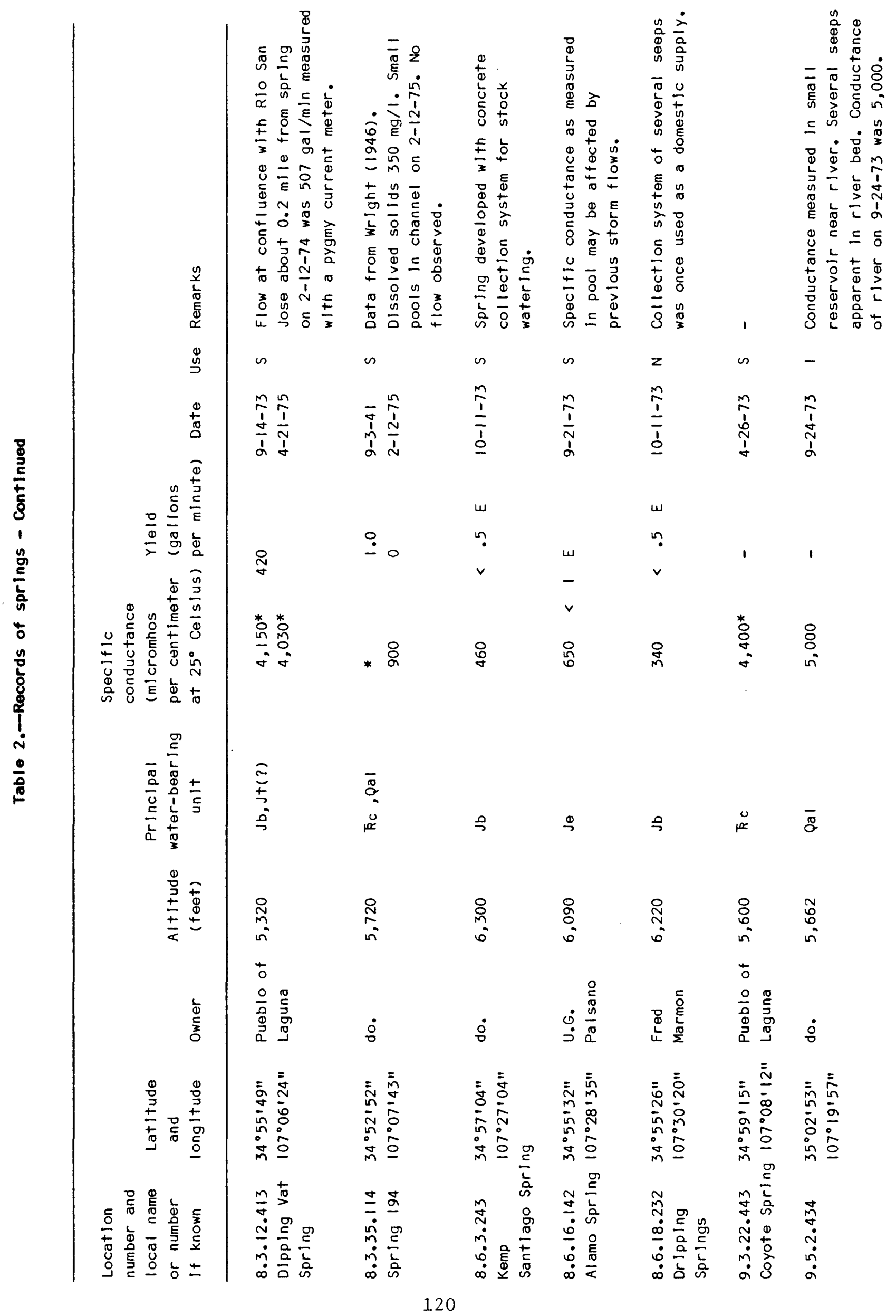




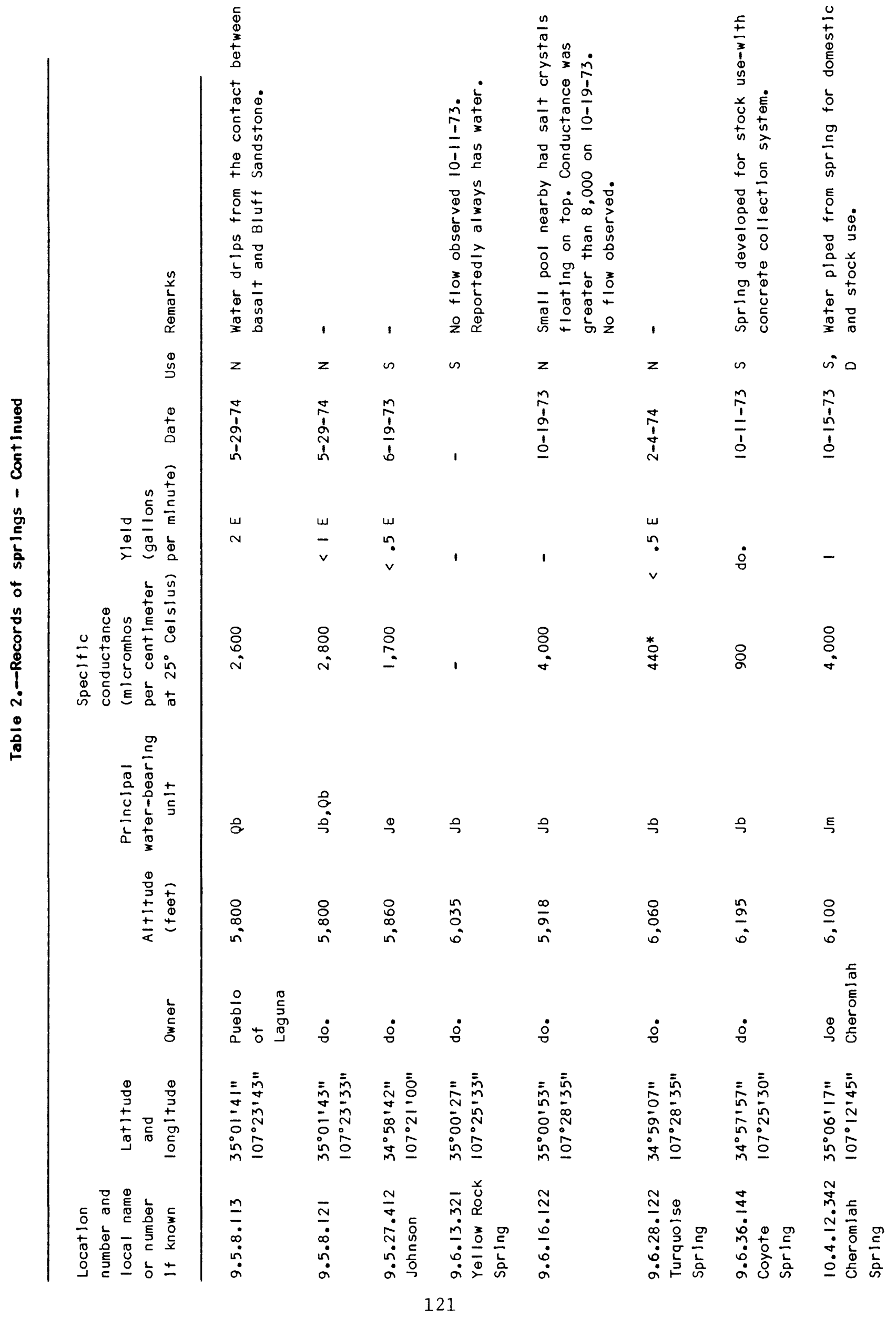




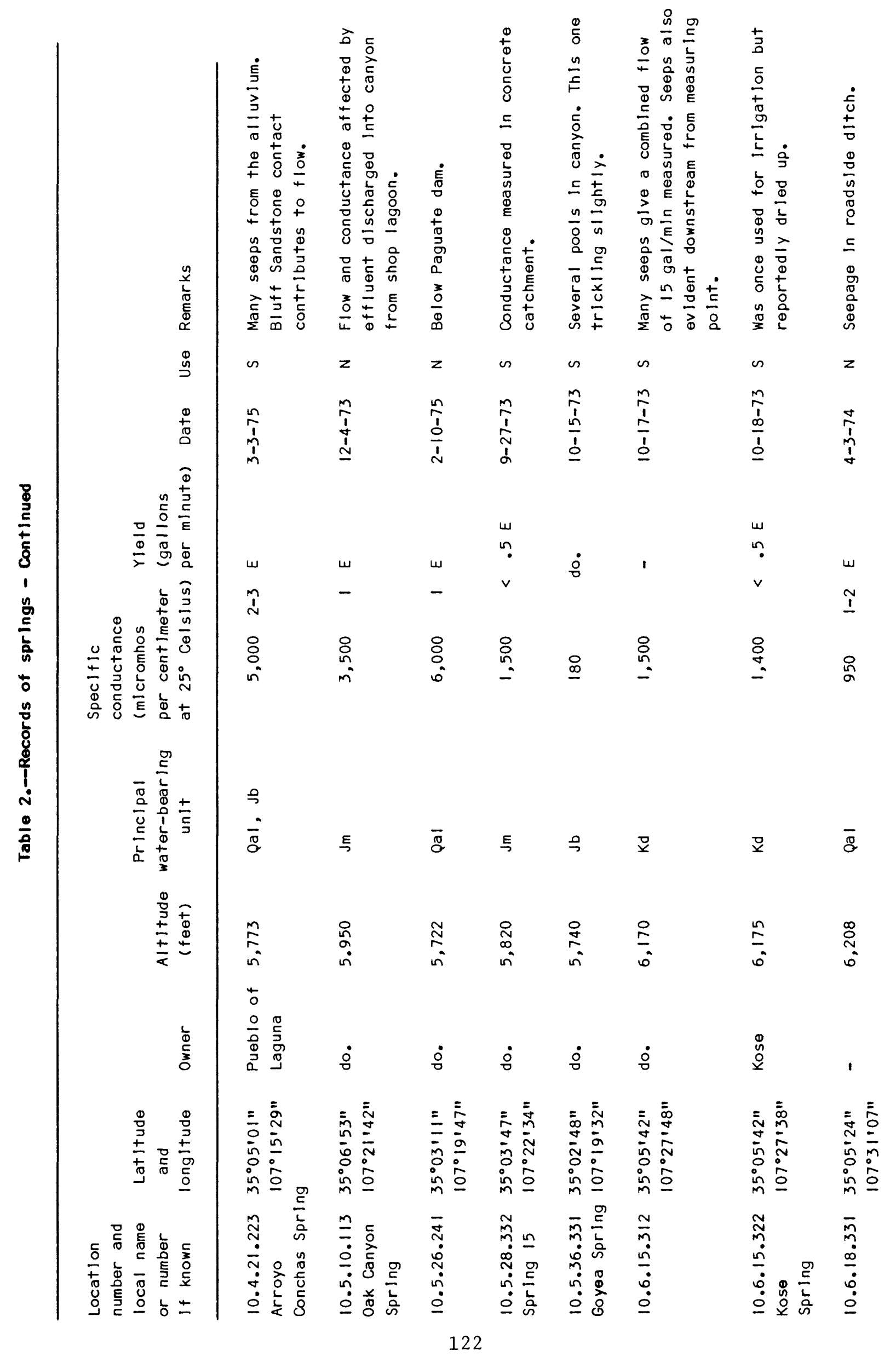




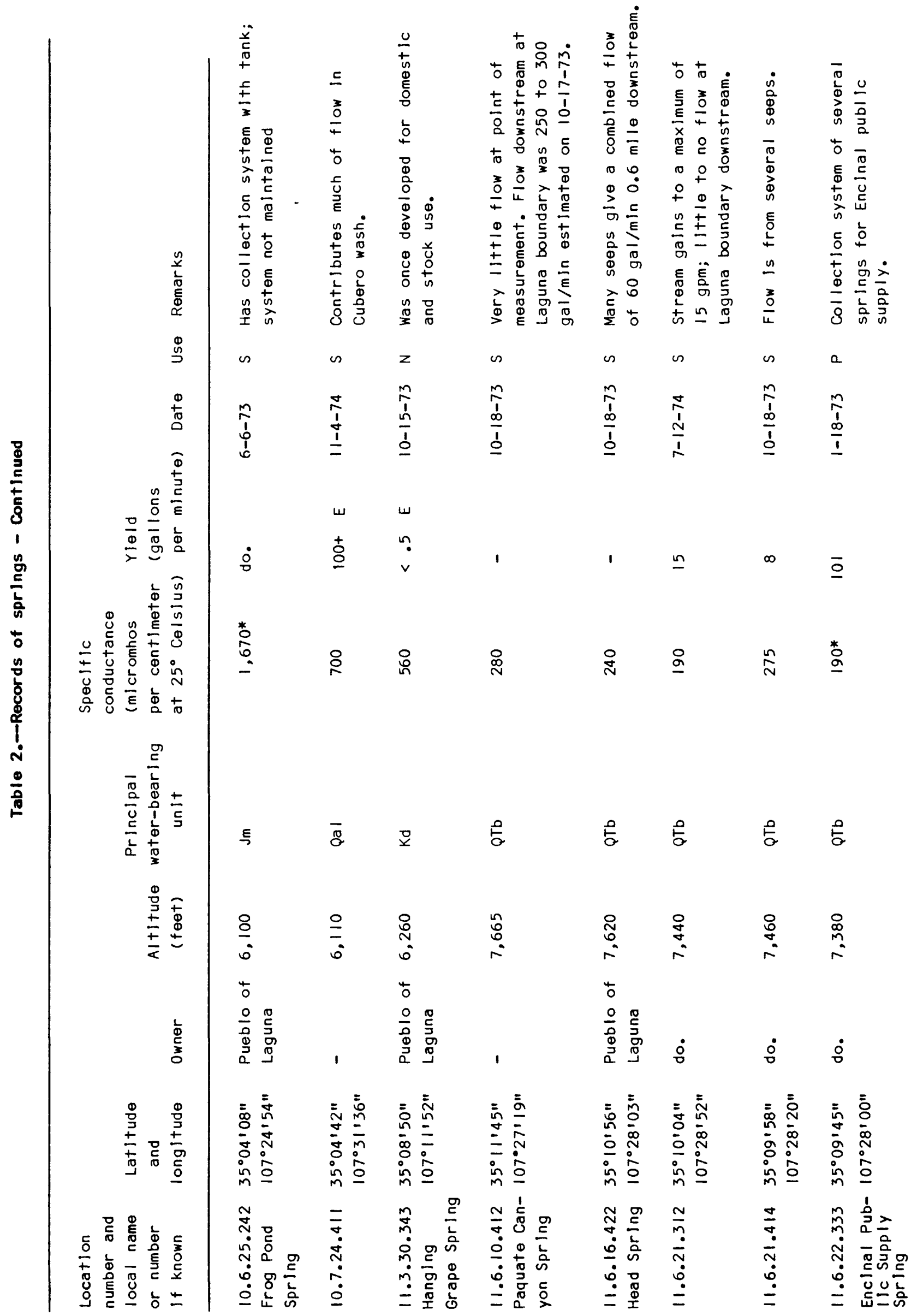




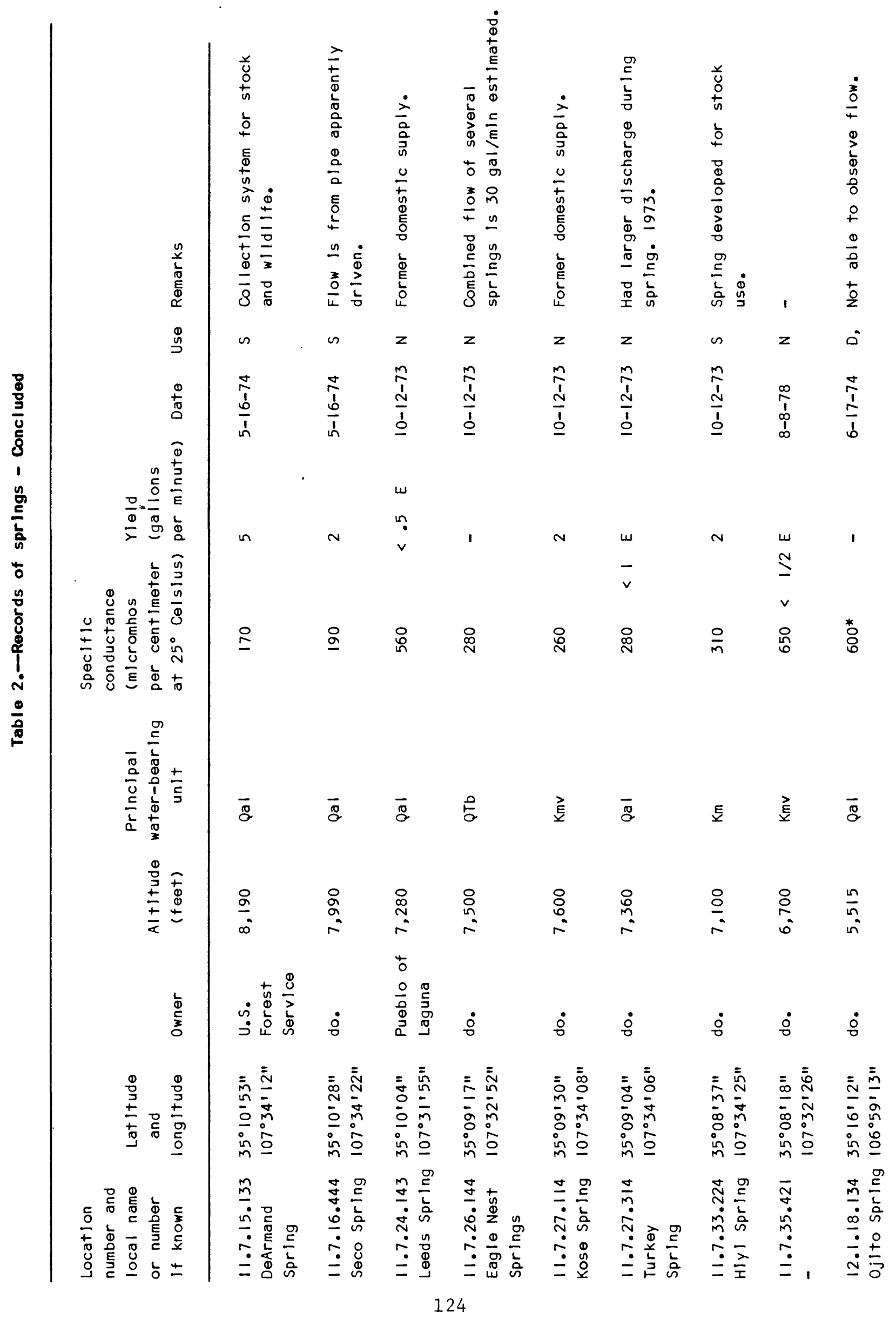


Table 3. Description of formation cuttlings for selected wells

\author{
Location number: 9.5.9.231 (see text for explanation) \\ Local well name: Laguna 78-1 test well \\ Samples described by E. T. Padgett \\ Formation determinations by D. W. Risser
}

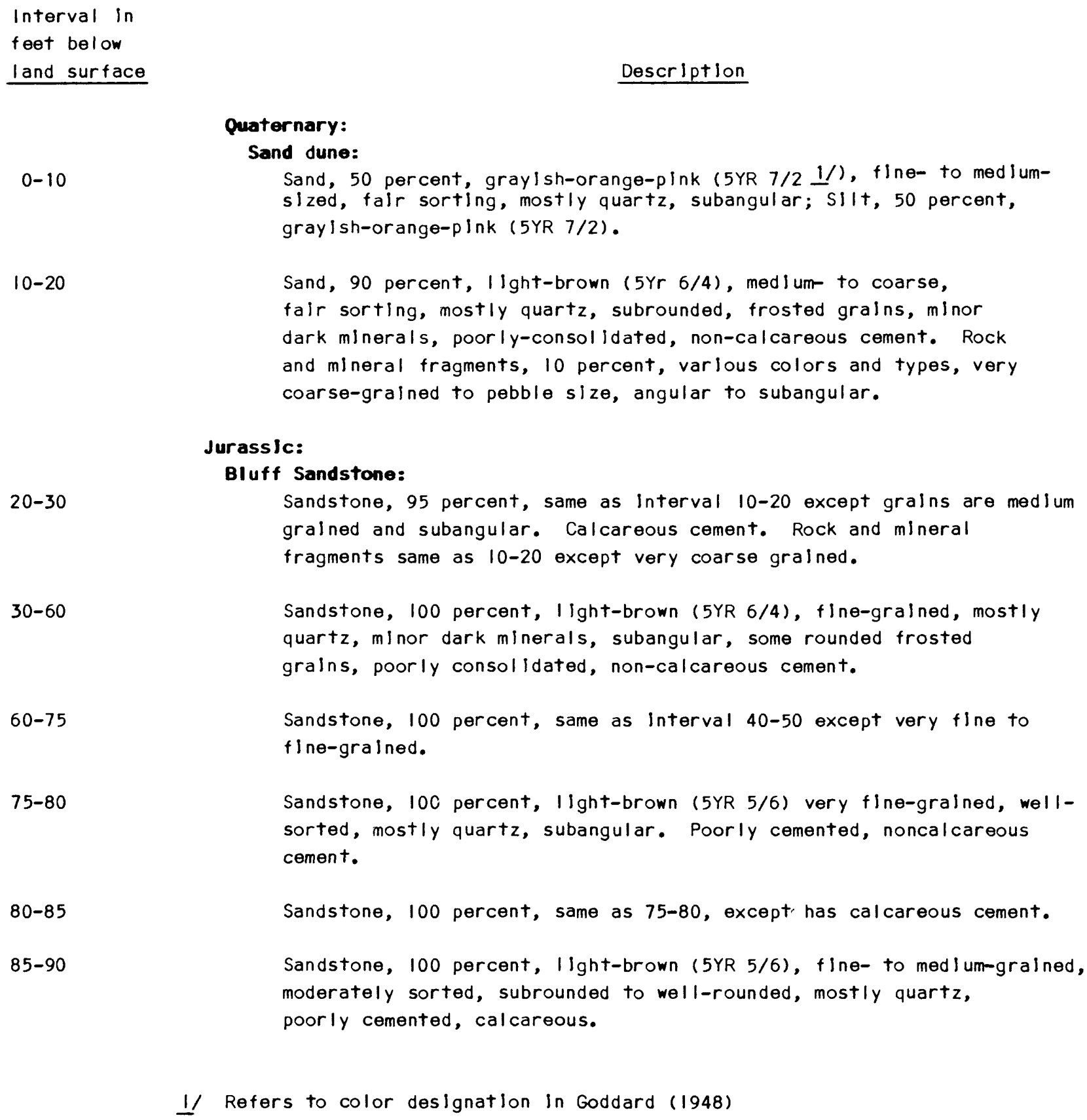

1/ Refers to color designation in Goddard (1948) 
Table 3. Description of formation cuttings for selected wells - Continued

Interval in
feet below
land surface

90-95

$95-100$

$100-110$

$110-115$

$115-120$

$120-125$

$125-130$

$130-135$

$135-140$

Description

\section{Jurasslc:}

Bluff Sandstone - continued:

Sandstone, 100 percent, 1 ight-brown (5YR 5/6), fine-grained, mostly quartz, well-sorted, subangular to subrounded, very poorly cemented, calcareous cement.

Sandstone, 100 percent, Iight-brown (5YR 6/4) fine-grained, wellsorted, angular grains, mostly quartz, poorly cemented, noncalcareous cement.

Sandstone, 45 percent, moderate-brown (5YR 4/4), fine-grained, some medlum grains, fair sorting, mostly quartz, subrounded grains, well-cemented, noncalcareous cement. Sand, 50 percent, I ight-brown (5YR 6/4), medium- to fine-grained, fair sorting, mostly quartz, angular to subangular, poor consolidation. Black minerals, 5 percent.

Sandstone, 100 percent, 1 ight-brown (5YR 6/4), fine-to medium-grained, some coarse grains, falr sorting, mostly quartz, some dark minerals, subangular to angular, poorly consolldated, slightly effervescent.

Sandstone, 50 percent, light-brown (5YR 6/4), fine-grained, well-sorted, mostly quartz, very minor black minerals, angular to subangular, poorly consolidated, calcareous. Sandstone, 50 percent, moderatebrown, (5YR 4/4), very fine-grained to fine-grained, fair sorting, thin streaks of white sandstone, good consolidation, noncalcareous cement.

Sandstone, 100 percent, IIght-brown (5YR 5/6) fine- to coarse-grained, poorly sorted, mostly quartz; coarse grains are rounded; medlum to fine grains are subangular, poorly consolidated.

Sandstone, 95 percent, same as 120-125. Sandstone, 5 percent, moderatebrown ( $5 Y R$ 4/4), fine to medium-grained, fair sorting, mostly quartz, subrounded, good consolidation, calcareous cement.

Sandstone, 95 percent, same as 120-125. Sandstone, 5 percent, same as 125-130.

Sandstone, Iight-brown (5YR 6/4), fine- to medium-grained, fair sorting, mostly quartz, subangular, some frosted graine, poorly consolidated, calcareous cement. 
Table 3. Description of formation cuttings for selected wells - Continued

Interval in

feet below

land surface

$140-145$

$145-150$

$150-155$

$155-160$

$160-165$

$165-170$

$170-180$

$180-190$

$190-200$

$200-210$

$210-220$

Description

\section{Jurass Ic: \\ Bluff Sandstone - concluded:}

Sandstone, 90 percent, same as 135-140. Sandstone, 10 percent, moderate-brown, (5YR 4/4), very fine-grained, well-sorted, mostly quartz, sub-angular, falrly well consolidated, calcareous cement.

\section{Sumervilite formation:}

Siltstone, 100 percent, moderate brown (5YR 4/4), sandy. Fairly well consolldated, calcareous cement.

Siltstone, 100 percent, I ight-brown (5YR 6/4), very sandy, very flne-grained very well-consolidated, calcareous cement.

Sandstone, 100 percent, I Ight-brown (5YR 6/4), very fine to slity, well-sorted, friable poorly consolldated, calcareous cement.

Siltstone, 100 percent, same as 145-150.

Sandstone, 100 percent, same as 155-160.

Siltstone, 100 percent, IIght-brown (5YR 6/4). Very sandy; very fine-gralned sand. Very well consolidated, calcareous cement. Sandstone, 100 percent, I ight-brown (5YR 6/4). Very silty; very fine-grained. Well sorted. Fairly well consolldated, frlable, calcareous cement.

Sandstone, 85 percent, light-brown (5YR 6/4), very fine to finegrained. Fair sorting, mostly quartz, subangular, poorly consolidated, calcareous cement. Sandstone, 10 percent, very paleorange (IOYR 8/2), appears white in sample, fine-gralned, wellsorted, mostly quartz, subrounded, only slightly effervescent, Sandstone, 5 percent, same as 140-145 (second constituent).

Sandstone, 90 percent, I ight brown (5YR 6/4), very fine-grained, fairly well-sorted, mostly quartz, minor black minerals, subangular, some frosted grains, poorly consolidated. Sand, 5 percent, same as 190-200 (second constituent). Sand, 5 percent, same as 140-145, (second constituent).

Sandstone, 100 percent, I ight brown (5YR 6/4), very fine-gralned to sllt, well-sorted, mostly quartz, minor black minerals, subangular, well-consolidated, calcareous cement. 
Table 3. Description of formation cuttings for selected wells - Continued

Interval in

feet below

land surface

$220-230$

$230-240$

$240-250$

$250-260$

$260-270$

$270-280$

$280-290$

$290-300$

\section{Description}

\section{Jurass Ic:}

Sumerville Formation - Concluded:

Sandstone, 80 percent, moderate-brown ( $5 Y R$ 4/4), very fine-grained and slity, falr sorting, mostly quartz, subangular, subrounded, well-consolidated, calcareous cement. Streaks of white sandstone (20 percent) same as 190-200 (second constituent) except effervescent.

Sandstone, 80 percent, IIght-brown (5YR 6/4), same as 210-220. Sandstone streaks, 20 percent, same as 190-200, (second constituent), except effervescent.

No sample.

Sandstone, 90 percent, same as 210-220, Sandstone streaks, 5 percent, same as 190-200 (second constituent) except pinkishgray $(5 Y R \quad 8 / 1)$ and effervescent. Sandstone, 5 percent, same as 140-145 (second constituent), minor white streaks.

Sandstone, 90 percent, grayish-orange-pink (5YR 7/2) very fine-grained, well-sorted, mostly quartz, minor dark minerals, subangular to subrounded, very poorly consolldated. Sandstone, 5 percent, same as 140-145. Sandstone, 5 percent, same as 190-200 except very I ight-gray (N8).

Sandstone, 90 percent, very-light-gray (N8), very fine-grained, well-sorted, mostly quartz, minor black minerals, subangular, well-consolidated, calcareous cement. Sandstone, 10 percent, grayish-orange-pink ( $5 Y R$ 7/2) fine-grained, well-sorted, mostly quartz, some minor black minerals, fair consolidation, calcareous cement. Appears to have sharp contact with above sandstone.

\section{Tertlary:}

Diabase:

Porphyritlc plagioclase sandstone, 45 percent, porphyritic plagloclase same as 270-280 (first constituent). Dlabase, 55 percent, greenlsh-black ( 56 2/1), finely crystalline, porphyritic plagloclase.

Dlabase, 90 percent, same as 280-290, Sand, 10 percent, color undefinable due to the basalt, very-fine to fine-grained, sorting undefinable, mostly quartz, subangular to subrounded, poorly consolldated. Very few fragments of sandstone, same as 270-280, ( $f$ irst constituent). 


\section{Table 3. Description of formation cuttings for selected wells - Continued}

Interval in

feet below

land surface

$300-310$

$310-320$

$320-330$

$330-340$

$340-350$

$350-355$

$355-360$

$360-370$

$370-380$

Description

Jurasslc:

\section{Sumerville formation :}

Sandstone, 30 percent, graylsh-orange-pink (5YR 7/2), very-finegralned to silty, falr to good sortine, mostly quartz, minor black minerals, subangular, fair consolidation, calcareous cement. Sandstone, 60 percent, I ight-gray (N7), very-fine-gralned to slity, falr to good sorting, mostly quartz, minor black minerals, subangular, good consolidation, calcareous cement.

Note: Both of these sandstones have incorporated medlum to coarse grained pleces of a black materlal, posslbly dlabase. The materlal may or may not be a true part of the sample.

Diabase, 10 percent same as 280-290.

\section{Todil to Limestone:}

Gypsum, 70 percent, I ight-gray to white (N7, N8, N9), microcrystalline. Limestone, 10 percent, medlum-dark gray (N4), microcrystalline. Silt, 10 percent, white to very IIght-gray (N9, N8), possible gypsum. Sand, 10 percent, grains of varlous colors, fine to very-fine, mostly quartz, unconsolidated.

Sample same in all respect to 320-330, except gypsum, 60 percent; limestone, 20 percent.

Sample same in all respect to 320-330, except gypsum, 50 percent; Iimestone, 30 percent.

Gypsum, 50 percent, white. Limestone, 30 percent, medlum gray (5, N4). Sand, 10 percent, varlous colors, very-fine and finegrained to silty, cannot determine sorting, mostly quartz, subangular, poor consolidation.

Same as above in all respects.

Sandstone, 50 percent, pinkish gray (5YR 8/1), fine and very finegrained to silty, falr to poor sorting, mostly quartz, fine grains subangular, poor consolidation. Gypsum, 25 percent, white. Limestone, 25 percent, medlum-gray to dark-medlum-gray (N5, N4).

Same as above.

Limestone, 75 percent; medium-gray to medium-dark-gray to darkgray (N5, N4, N3). Gypsum, white, 10 percent. Sand, 15 percent, very-light-gray (N8), very fine-grained to silty, good sorting, mostly quartz, subangular, poor consolldation. 


\section{Table 3. Description of formation cuttings for selected wells - Continued}

Interval in
feet below
land surface

$380-390$

$390-400$

$400-410$

$410-420$

$420-430$

$430-440$

$440-450$

$450-460$

$460-470$

$470-480$

$480-490$

\section{Description}

\section{Jurassic:}

\section{Entrada Formation:}

Sandstone, 90 percent, pinkish-gray ( $5 Y R$ 8/1) very fine-grained, well sorted, mostly quartz, subangular. Limestone, 10 percent, same as above. Included in sample are two pleces of a black unidentified mineral.

Sandstone, 98 percent, yellowish-gray (5Y 8/1) fine-grained, wellsorted, mostly quartz, angular to subangular, poor consolidation, $\mathrm{CaCO}_{3}$ cement, minor dark minerals. Limestone, 2 percent, same as above.

Sandstone, 100 percent, grayish-orange-pink (5YR 7/2), very finegrained, well-sorted, mostly quartz, minor dark minerals, subangular, poorly consolidated, calcareous cement.

Sandstone, 100 percent, light-brown, (5YR 6/4), fine-grained, some medium grains, well sorted, mostly quartz, minor dark minerals, subangular, poor consolidation, calcareous cement.

Sandstone, 70 percent, I ight-brown ( 5 YR 6/4), fine to very fine-grained, fair sorting, mostly quartz, minor dark minerals, subangular, poor consolidation, calcareous cement. Sandy silt, 30 percent, palebrown, (5YR 5/2), very fine-grained, good sorting, subangular grains, well-consolidated, noncalcareous cement.

Sandstone, 100 percent, I ight-brown (5YR 6/4), very fine to mediumgrained, poor sorting, mostly quartz, minor dark minerals, smaller grains subangular, larger sub-rounded to rounded, some frosted, poor consolidation, calcareous cement.

Siltstone, sandy, 100 percent, IIght-brown (5YR 6/4). Silt, 50 percent. Sand, 50 percent, same as 430-440.

Sandstone, 100 percent, same as $430-440$.

Sandstone, 100 percent, same as 430-440, except fine-grained, minor medlum grains, good sorting.

Sandstone, 100 percent, same as $430-440$.

Sandstone, silty, 100 percent, Iight-brown (5YR 6/4), very fine to fine grained, fair sorting, mostly quartz, smaller grains subangular, some medium grains rounded poor consolidation calcareous cement. 
Table 3. Description of formation cuttings for selected vells - Continued

Interval in

feet below

land surface

$490-500$

$500-510$

\section{Description}

\section{Jurass Ic:}

Entrada Formation - concluded:

Sandstone, 100 percent, same as 480-490.

Siltstone, 50 percent, moderate-brown (5YR 4/4), very fine-grained to slit, streaks of white sand. Sand, 40 percent, very Iight-gray, fine grained, mostly quartz, minor dark minerals, well-consolidated, carbonate cement. Sand, 10 percent, same as 480-490. 
Table 3. Description of formation cuttings for selected vells - Continued

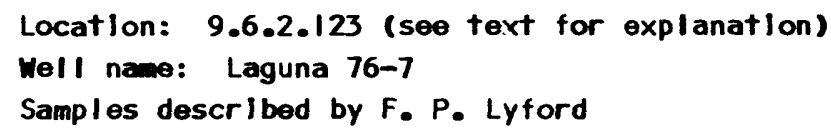

Gravel, 100 percent, granuie and pebble, many rock types as above. Minor slit as above.

Sand, 80 percent, grayish-orange-pink ( $5 Y R$ 7/2), medium-gralned, quartz. Gravel, 20 percent, as above. (Very clean samples).

As above but less gravel. 
Table 3. Description of formation cuttings for selected wells - Continued

Location: 9.6.5.222 (see text for explanation).

Nell name: Laguna 76-6

Samples described by F. P. Lyford

Interval in
feet below
land surface

\section{Description}

\section{Quaternary:}

$0-5$

Alluvium and basalt:

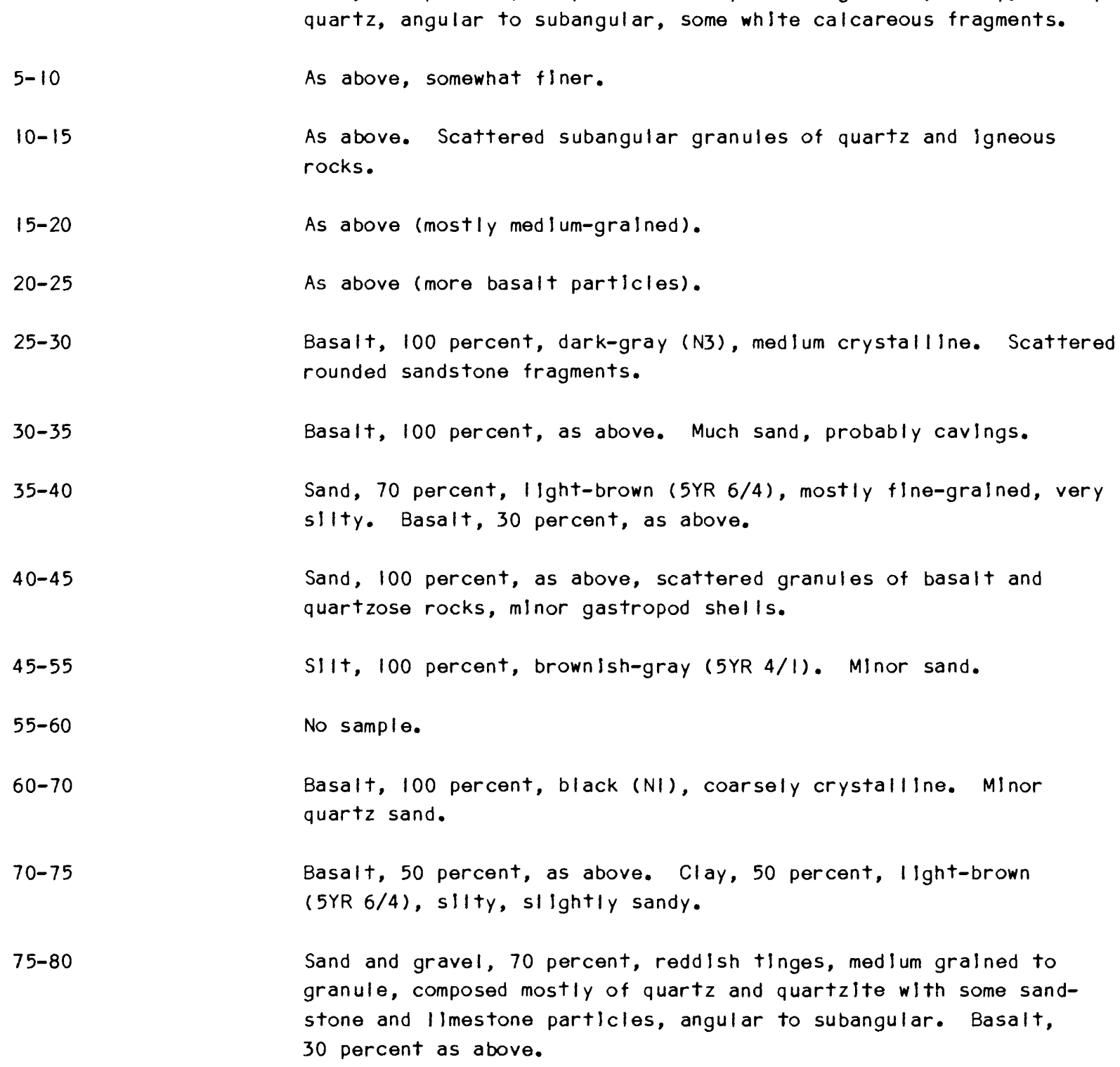


Table 3. Description of formation cuttings for selected wells - Continued

Interval in

feet below

land surface

$80-105$

$105-110$

$110-115$

$115-120$

\section{Description}

\section{Quaternary:}

Al luvlua and basalt - concluded:

Sand and gravel, 100 percent as above except grains are rounded.

Gravel, 60 percent, as above. Clay 40 percent, graylsh-orange (IOYR 7/4).

- Gravel, 100 percent, granule and pebble, colorful, Includes limestone, sandstone, quartzite, varlous crystalline rocks, quartz, rounded to subrounded.

Sandstone, 100 percent, pale-red (10R 6/2), fine to medium-grained, poorly cemented, quartz, angular to rounded, some frosted. 
Table 3. Description of formation cuttings for selected wells - Continued

Location: 9.6.26.443 (see text for explanation)

Well name: Timia

Described by John J. Rote

Formation plcks by D. W. Risser

Interval in

feet below

land surface

Description

Quaternary:
Alluvium:

$0-25$

Silt, pale-yellowish-brown (lOYR 6/2); with some medlum-grained sand (25 percent).

$25-30$

Silt, moderate-yel lowish-brown $(10$ YR 5/4), with very-fine to finesand (25 percent) highly cemented and calcareous.

Jurassic:

Bluff Sandstone:

$30-45$

Sandstone, grayish-orange (IOYR 7/4), very-fine to fine-grained, highly cemented and calcareous.

$45-50$

Same as 30-35; at 49 feet sandstone, very pale-orange (lOYR $8 / 2)$ to pale-yellowlsh-orange (lOYR 8/6), fine to medium-gralned, moderately cemented and slightly calcareous; water seep here ylelds approximately $1 / 4$ gallon per minute with a specific conductance of 450 . 


\section{Table 3. Description of forwation cuttings for selected vells - Continued}

Interval in

teet below

land surface

Jurassic

Bluff Sandstone - Continued

$50-90$

$90-105$

$105-110$

$110-115$

$115-120$

$120-125$

$125-130$

$130-135$

$135-140$ calcareous. calcareous.

Same as $125-130$
Same as 49-50; at 54 feet sandstone, very pale-orange (lOYR $8 / 2)$, very-fine to fine-grained hightly cemented and calcareous.

Same as 54-55; slightly higher percentage of fine sand and not

Same as 54-55; at 106 feet siltstone, I ight-brown (5YR 6/4),

Siltstone, grayish-orange-pink ( $5 Y r$ 7/2), calcareous. Sandstone at $112-113$ feet, pinkish-gray ( $5 Y R 8 / 1$ ), silt to very fine-grained, moderate to highly cemented and calcareous.

Sandstone, very light-gray (N8), silt to very fine-grained, calcareous, spotted ( 1 percent) with brown and black minerals.

Sandstone, very light-gray (N8), very fine to fine-grained, calcareous, spotted ( 1 percent) with brown and black minerals.

Sandstone, light-brown ( $5 Y R 6 / 4$ ), silt to very fine-grained, calcareous, with 10 percent unknown brown mineral.

Sandstone, light-brown ( $5 Y R$ 6/4) and white (N9), silt to very fine-grained, very calcareous, with 10 percent unknown brown mineral. 


\section{Table 3. Description of formation cuttings for selected vells - Continued}

Interval In
teet below
land surface

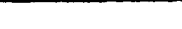

$140-145$

$145-160$

$160-170$

$170-175$

$175-200$

$200-215$

$215-250$

250-255

$255-290$

Description

\section{Jurasslc \\ Bluff Sandstone - Concluded}

Sandstone, pinkish-gray $(5 Y R 8 / 1)$, silt to very fine-grained, very calcareous, with 5 percent unknown brown mineral.

Sandstone, grayish-orange-pink (5YR 7/2), silt to very finegrained, calcareous, with 5 percent brown and pale blue green (5BG 7/2) minerals.

Sandstone, light brown (5YR 6/4) and white streaks (N9), silt to very fine-grained, calcareous, unknown minerals above are absent.

\section{Sumerville Formation:}

Siltstone, Iight-brown (5YR 6/4), with very fine-grained sand, calcareous with 5 percent brown, pale-blue-green minerais and bits of mica.

Siltstone, light-brown (5YR 6/4) and white streaks (N9), calcareous, with very fine-grained sand.

Siltstone, I ight-brown (5YR 6/4), calcareous.

Same as 200-205; with bits of mica.

Siltstone, grayish-orange-pink (5YR 7/2), calcareous, with veryfine sand and bits of mica and of unknown brown mineral.

Sandstone, grayish-orange-pink ( $5 Y R 7 / 2)$, silt to very finegrained, calcareous, with bits of mica and of an unknown brown mineral. 
Table 3. Description of formation cuttlings for selected wells - Continued

Interval in feet below Iand surface

290-295

$295-300$

$300-305$

$305-310$

$310-315$

$315-320$

$320-325$

$325-340$

$340-345$

$345-430$

$430-440$

$440-445$

$445-465$

465-475

Description

Jurassic:

Sumerville Formation - concluded:

Sandstone, pinkish-gray (5YR $8 / 1)$, silt to very fine-gralned, calcareous, with bits of unknown brown mineral.

Same as 290-295.

Todilto Formation:

Sandstone, pinkish-gray $(5 Y R 8 / 1)$, slit to very fine-grained; and IImestone (25 percent), medium gray (N5).

Same as 300-305; except increase in IImestone (40 percent).

Same as 300-305 except increase in 1 imestone (50 percent).

Same as $310-315$

\section{Entrada Sandstone:}

Sandstone, very pale-orange $(10 Y R 8 / 2)$, sllt to very finegralned, calcareous, with bits of 1 imestone and ( 5 percent) fine to medium-gralned sand.

Sandstone, very-pale-orange (lOYR 8/2), sllt to fine-grained, calcareous, with bits of mica and unknown brown mineral.

Sandstone, grayish-orange-plnk (5YR 7/2), slit to fine-grained, calcareous, with bits of $\mathrm{mlca}$ and unknown brown mineral.

Sandstone, IIght-brown (5YR 6/4), slit to fine-grained; calcareous with bits of $\mathrm{mlca}$ and unknown brown mineral.

Sandstone, IIght-brown (5YR 5/6) with touches of white (N9), silt to very fine-grained, calcareous, with slitstone (10 percent), moderate brown (5YR 4/4) and bits of mica.

Same as 430-435, except increase in siltstone (40 percent).

Siltstone, moderate-brown ( $5 Y R$ 4/4), and Iight-brown (5YR 5/6), calcareous, with very fine-gralned, touches of white (N9) sand and bits of mica.

Slltstone, IIght-brown (5YR 5/6), calcareous, with blts of mica. 
Table 3. Description of formation cuttings for selected vells - Continued

Interval in

feet below

land surface

$475-480$

480-505

$505-510$

$510-530$

\section{Description}

\section{Jurassic:}

Entrada Sandstone - concluded:

Siltstone, IIght-brown ( $5 Y R$ 5/6) to moderate-brown (5YR 4/4), calcareous, with touches of white (N9) siltstone.

Same as 475-480, except white absent.

Siltstone, light-brown (5YR 5/6), calcareous.

\section{Triassic:}

Chinle Formation:

Shale, moderate-reddlsh-brown (IOR 4/6) to dark-reddish-brown (lOR 3/4), calcareous. 
Table 3. Description of formation cuttings for selected wells - Continued

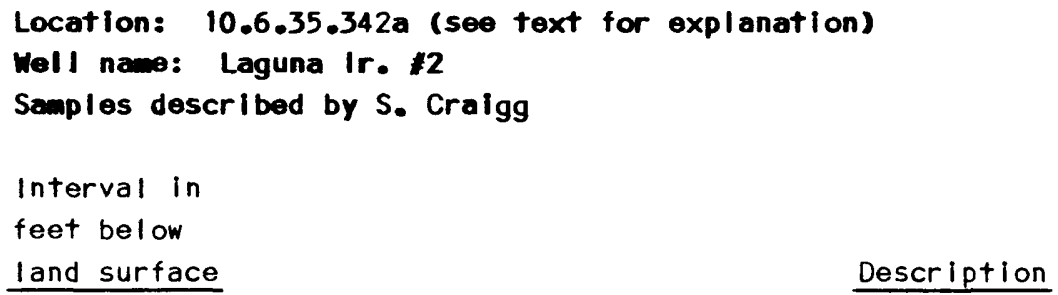

Gravel, as above, grain size from coarse sand to medium pebbles. No limestone fragments. Basalt fragments account for about 70 percent of sample. The smaller grain sizes are subangular to round. 
Table 3. Description of formation cuttings for selected wils - Coatinum

Interval in

feet below

land surface

$94-100$

$100-110$

$110-120$

$120-130$

$130-140$

$140-146$

$146-150$

$150-156$

$156-160$

\section{Description}

\section{Quaternary:}

Al luvlum and basalt - concluded:

Gravel, as above.

Gravel, as above. Basalt chips account for about 50 percent of sample. Cream-colored dendritic IImestone chips present in small quantities.

Gravel, as above, 50 percent. Medium-grained, well-rounded, frosted, clean quartz sand accounts for other 50 percent of sample.

Gravel, as above, 80 percent. Quartz sand, as above, 20 percent.

Gravel as above, 20 percent. Sandstone, Iight brown (5YR 6/4), 80 percent, medium to coarse-grained, mostly quartz, subround, polished grains, friable, clay matrix, slightly calcareous.

Gravel, as above, 15 percent. Sandstone, as above 85 percent, grain size is fine to coarse.

Gravel, as above, 15 percent. Sandstone, as above, 70 percent. Clay, 15 percent, grayish pink ( $5 R$ 8/2).

Gravel, as above, 10 percent. Sandstone, as above, 60 percent. $\mathrm{Clay}$, as above, 5 percent. Highly calcareous "gralny" gypsum, white, 25 percent.

Same as above. 
Table 3. Description of formation cuttings for selected wells - Continued

Location: 10.7.10.122 (see text for explanation)

vell name: Seco Canyon 1

Samples described by John J. Rote

Interval in

feet below

land surface

$5-10$

$10-15$

$15-20$

$20-25$

$25-30$

$30-35$

$35-40$

\section{Description}

\section{Quaternary:}

Al luviun:

Basalt boulders, medium-dark-gray $(\mathrm{NH})$; with silt, moderateyellowish-brown (lOYR 5/4); slightly calcareous.

Same as 0-5.

Same as $0-5$

Silt, yellowish-gray (5Y 7/2) and sandstone gravel, darkyell owish-orange (IOYR 6/6).

Same as 15-20.

Same as 15-20.

Silt, Iight-ollve-gray (5Y $6 / 1)$.

Shale, medium-light-gray (N6). 
Table 3. Description of formation cuttings for selected wells - Contlnued

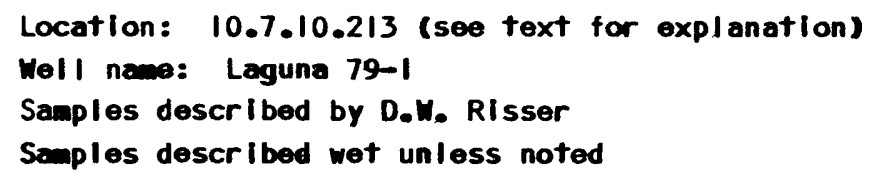

\section{Cretaceous:}

$60-70$

\section{Mancos Shale:}

Shale, 90 percent, medium-dark-gray, (N4), slity, poorlyindurated, calcareous, sandstone and basalt 10 percent, probably cavings.

Shale, 90 percent, medium-dark-gray, (N4), silty, poorly-indurated, calcareous, sandstone and basalt 10 percent, probably cavings.

$80-90$

Shale, 85 percent, as above, sandstone and basalt 15 percent, probably cavings.

$90-100$

Shale, 100 percent, as above, minor sandstone and basalt fragments present.

$100-110$

Shale, 100 percent, as above, very sticky, poorly indurated, minor sandstone and basalt.

$110-120$

Shale, 100 percent, as above with minor sandstone and basalt. 
Table 3. Description of formation cuttings for selected wells - Continued

Interval in

feet below

land surface

$120-130$

$130-140$

$140-150$

$150-160$

$160-170$

$170-180$

$180-190$

$190-200$

$200-210$

$210-220$

$200-230$

$230-240$

$240-250$

$250-260$

$260-270$

$270-280$

\section{Description}

\section{Cretaceous:}

Mancos Shale - continued:

Shale, 100 percent, medlum-dark-gray, (N4), very slity, calcareous, poorly indurated.

Shale, 100 percent, as above with minor sandstone.

Shale, 100 percent, medlum-dark-gray, (N4), silty, carbonaceous calcareous, less sticky and better indurated than above, fissility more apparent.

Shale, 100 percent, as previous interval.

Shale, 97 percent, as previous interval with 3 percent basalt fragments.

Shale, 95 percent, as above with basalt and sandstone 5 percent.

Shale, 100 percent, medlum-dark-gray, (N4), sllty, carbonaceous sticky, not as well indurated as previous 40 feet, highly cal careous.

Shale, 100 percent, as above poorly indurated and slightly calcareous.

Shale, 100 percent, as above.

Shale, 100 percent, as above.

Shale, 100 percent, medlum-dark-gray, (N4), sllty, contains abundant well-rounded, sand-slze quartz grains, carbonaceous, calcareous fissile, better indurated than previous 40 feet.

Shale, 100 percent, as above.

Shale, 100 percent, as above.

Shale, 100 percent, as above, with minor sandstone.

Shale, 100 percent, as above, with minor sandstone.

Siltstone, 80 percent, medium-dark-gray, (N4), clayey, carbonaceous, sand-size quartz grains present, highly calcareous shale 20 percent, medlum-dark-gray, (N4), silty, calcareous. 
Table 3. Description of formation cuttings for selected wells - Continued

Interval in
feet below
land surface

\section{Description}

$280-290$

$290-300$

$300-310$

$310-320$

$320-330$

$330-340$

$340-350$

$350-360$

$360-370$

$370-380$

$380-390$

$390-400$

$400-410$

\section{Cretaceous:}

\section{Mancos Shale - concluded:}

Siltstone, 70 percent, as above, shale 20 percent as above, sandstone 10 percent, I ight-brown ( 5 YR 5/6), composed mainly of quartz and feldspar, minor sand-size quartz grains present, minor marcasite.

Shale, 50 percent, medium-dark-gray, (N4), very sandy, sand predominantly well-rounded quartz grains, sllty, calcareous; siltstone 50 percent, medium-dark-gray, (N4), clayey, calcareous.

\section{Dakota Sandstone:}

Sandstone, 80 percent, medium-dark-gray, (N4), very fine-grained, composed mainly of well-rounded quartz, slity, friable, carbonaceous calcareous; siltstone 20 percent, as above.

Sandstone, 100 percent, as above.

Sandstone, 100 percent, as above with minor moderate-reddlshbrown (10R 4/6) sandstone.

Sandstone, 100 percent, as above, with slightly more clay content.

Sandstone, 100 percent, as above.

Sandstone, 100 percent, as above.

Sandstone, 100 percent, as above.

Siltstone, 90 percent, medlum-dark-gray, (N4), very sandy with well-rounded quartz, carbonaceous, calcareous; shale 10 percent medium-dark-gray, silty, poorly indurated, calcareous.

Siltstone, 50 percent, as above; sandstone, 50 percent, mediumgray, (N5), composed of well-rounded quartz, sllty, frlable, carbonaceous, calcareous.

Siltstone, 60 percent, medlum-dark-gray, (N4), sandy, carbonaceous, calcareous; sandstone, 20 percent, as above; shale 20 percent, poorly indurated, calcareous.

Siltstone, 50 percent; shale, 50 percent, as above. 


\section{Table 3. Description of formation cuttings for selected wells - Continued}

Interval in

feet below

land surface

$410-420$

$420-430$

$430-440$

$440-450$

$450-460$

$460-470$

$470-480$

$480-490$

490-500

$500-510$

$510-520$

$520-530$

$530-540$

$540-550$

$550-560$

\section{Description}

\section{Cretaceous:}

Mancos Shale:

Shale, 100 percent, dark-gray, (N3), silty and sandy sticky, poorly indurated, less calcareous than prevlous intervals.

Shale, 100 percent, as above.

Shale, 100 percent, as above but sandier and less sticky.

Siltstone, 100 percent, medium-dark-gray, (N4), very silty, abundant sand size quartz grains, very clayey, sticky and friable, highly calcareous.

Siltstone, 100 percent, as above.

Siltstone, 100 percent, dark-gray, (N3), hard, brittle, silty with sand-size quartz present, slightly calcareous, carbonanceous.

Siltstone, 100 percent, as above.

Siltstone, 100 percent, as above.

Siltstone, 100 percent, grayish-black, (N2), poorly indurated, silty, calcareous.

Siltstone, 95 percent, as above but much sandier; sandstone, 5 percent, white (N9), composed of very fine-grained quartz, calcareous.

\section{Dakota Sandstone:}

Sandstone, 90 percent, medium to light-gray, (N5-N7), composed of very-clean, fine-grained, well-rounded quartz, silty, calcareous, friable; shale, 10 percent, grayish-black, (N2), silty, calcareous.

Sandstone, 50 percent, as above but somewhat coarser; shale, 50 percent, as above.

Sandstone, 60 percent; shale, 40 percent, as above.

Shale, 70 percent, medium-dark-gray, (N4), very silty and sandy, poorly indurated, calcareous; sandstone, 30 percent, as above.

Shale, 50 percent; sandstone, 50 percent, as above. 
Table 3. Description of formation cuttings for selected wells - Continued

Interval in

feet below

land surface

$560-570$

$570-580$

$580-590$

$590-600$

$600-610$

$610-620$

$620-630$

$630-640$

$640-650$

$650-660$

$660-670$

\section{Description}

\section{Cretaceous:}

Dakota Sandstone - concluded:

Sandstone, 90 percent, light-gray, (N3), composed of very finegrained, well-rounded quartz, and minor dark minerals, friable, highly calcareous; siltstone, 10 percent, dark-gray, (N3), sandy, calcareous, minor chert present.

Sandstone, 90 percent, as above; shale, 10 percent, dark-gray, (N3), silty, calcareous, minor chert present.

\section{Mancos Shale:}

Shale, 100 percent, medium-dark-gray, (N4), silty, carbonaceous, calcareous, poorly indurated.

Shale, 100 percent, as above but much sandier.

\section{Dakota Sandstone:}

Sandstone, 90 percent, light to medium-dark-gray, (N4-N7), medium to very fine-gralned quartz, well-rounded, minor dark minerals, friable, slightly calcareous, carbonaceous; siltstone, 10 percent, medium-dark gray, (N4), very clayey, carbonaceous, calcareous.

Sandstone, 90 percent; siltstone, 10 percent, as above.

Sandstone, 90 percent; siltstone, 10 percent, as above.

Sandstone, 90 percent; siltstone, 10 percent, as above.

\section{Jurassic:}

Morrison Formation, Brushy Basin Member:

Sandstone, 70 percent, very-light to medium-gray, (N8-N5), composed of rounded to subangular quartz, medium to very-finegrained, darker colored sandstone contains silt and carbonaceous material, minor pyrite also present, friable, non-calcareous; siltstone, 30 percent, dark-gray, (N3), clayey with some sandsize quartz grains, calcareous, carbonaceous.

Sandstone, 80 percent; siltstone, 20 percent, as above.

Sandstone, 80 percent; siltstone, 20 percent, as above. 
Table 3. Description of foration cuttings for selected vells - Continued

Interval in

feet below

land surface

$670-680$

$680-690$

$690-700$

$700-710$

$710-720$

$720-730$

$730-740$

$740-750$

$750-760$

\section{Description}

Jurassic:

Morrison Forwation, Brushy Basin nuber - continued:

Shale, 60 percent, greenish-gray, (5 G 6/1), slightiy silty, non-calcareous; sandstone, 40 percent, very light-gray to mediumgray (N8-N5), composed mainly of very-fine to fine-grained, rounded to subangular quartz. Sandstone varies from very wellmashed or thoquartzite to a very silty, carbonaceous sandstone. silty sandstone is calcareous, or thoquartzite is non-calcareous.

Siltstone, 40 percent, medium-dark-gray, (N4), very clayey, calcareous, carbonaceous; claystone, 40 percent, very-light-gray to greenish-gray (N8-5 G 6/I), slightly sllty, noncalcareous; sandstone, 20 percent, very light-gray to light-gray (N8-N7), very-fine to fine-grained, rounded to subangular quartz, calcareous.

Siltstone, 40 percent; claystone, 40 percent; sandstone, 20 percent, as above.

Siltstone, 40 percent; sandstone, 40 percent; claystone, 20 percent, as above.

Claystone, 40 percent; siltstone, 30 percent; sandstone, 30 percent, as above.

Sandstone, 50 percent; claystone, 25 percent; siltstone, 25 percent, as above.

Sandstone, $40^{\circ}$ percent, very light-gray to medium light-gray, (N8-N6), composed mainly of subangular quartz grains, some grains iron-stained, fine-grained, minor carbonaceous materlal, calcareous. Claystone, 40 percent, yellowish-gray to greenishgray with minor brownish-gray, ( 5 Y $8 / 1$ - 5GY 6/1), slightly silty, non-calcareous. Siltstone, 20 percent, light to mediumgray (N7-N5), clayey and sandy, carbonaceous, calcareous.

Claystone, 70 percent, mainly ol ive-gray ( $5 \mathrm{Y} 4 / 1)$; siltstone, 20 percent; sandstone, 10 percent, as above.

Claystone, 70 percent; sandstone, 20 percent; siltstone, 10 percent as previous interval. 
Table 3. Description of formation cuttings for selected vells - Continued

Interval in

feet below

I and surface

$760-770$

$770-780$

$780-790$

$790-800$

$800-810$

$810-820$

$820-830$

$830-840$

$840-850$

$850-860$

\section{Description}

\section{Jurassic:}

Morrison Formation, Brushy Bas in Memer - concluded:

Claystone, 50 percent, I ight-olive-gray ( 5 Y $6 / 1)$, to greenishgray $(5 G 6 / 1)$, much sandier than above. Sandstone, 40 percent, very I Ight-gray (N8), to I Ight-greenish-gray, (5 G 8/I). Siltstone, 10 percent, sandier and more carbonaceous than previous intervals.

Claystone, 50 percent; siltstone, 30 percent; sandstone, 20 percent, as previous interval.

Claystone, 50 percent; siltstone, 30 percent; darker colored medi um-dark-gray, (N4); sandstone, 20 percent, as above.

Siltstone, 60 percent, medium-dark-gray, (N4), carbonaceous, as above; claystone, 30 percent; sandstone, 10 percent, as above.

Siltstone, 70 percent; claystone, 20 percent; sandstone, 10 percent, as above.

Siltstone, 60 percent; sandstone, 30 percent; claystone, 10 percent, as above.

\section{Morrison Formation, Westwater Canyon Mumber:}

Sandstone, 80 percent, light-gray, (N7), composed mainiy of fine to medium-grained, well-rounded to subangular quartz grains, contains carbonaceous materlal, but few accessory minerals, minor pyrite, very friable and poorly cemented, grains appear frosted. Siltstone, 15 percent, medium-dark-gray, (N4), greenish-gray, ( $5 G 6 / 1$ ) and moderatered (5R 5/4), contains sand-size quartz and abundant clay, carbonaceous, calcareous. Claystone, 5 percent, Iight-brownish-gray, (5 YR 6/I) to dark-greenish-gray (5 G 4/I), slity, non-cal careous.

Sandstone, 80 percent; siltstone, 10 percent; claystone, 10 percent, as above.

Sandstone, 80 percent; slltstone, 15 percent; claystone, 5 percent as above.

Sandstone, 70 percent; siltstnne, 25 percent; claystone, 5 percent, as above. 
Table 3. Description of formation cuttings for selected velis - Continued

\begin{tabular}{l}
$\begin{array}{l}\text { Interval in } \\
\text { feet below } \\
\text { land surface }\end{array}$ \\
\hline
\end{tabular}

$860-870$

$870-880$

$880-890$

$890-900$

$900-910$

$910-920$

$920-930$

$930-940$

$940-950$

$950-960$

$960-970$

$970-980$

$980-990$

$990-1000$

\section{Description}

\section{Jurassic:}

Morrison Formation, Westwater Canyon Member - continued:

Sandstone, 80 percent; siltstone, 15 percent; claystone, 5 percent, as above.

Sandstone, 80 percent; siltstone, 15 percent; claystone, 5 percent, as above.

Sandstone, 90 percent; siltstone, 5 percent; claystone, 5 percent, as above.

Sandstone, 90 percent; siltstone, 5 percent; claystone, 5 percent, as above.

Sandstone, 90 percent; siltstone, 5 percent; claystone, 5 percent, as above.

Sandstone, 80 percent; siltstone, 15 percent; claystone, 5 percent, as above.

Sandstone, 75 percent; siltstone, 20 percent; claystone, 5 percent, as above.

Sandstone, 80 percent; slitstone, 15 percent; claystone, 5 percent, as above.

Sandstone, 80 percent; siltstone, 15 percent; claystone, 5 percent, as above.

Sandstone, 80 percent; siltstone, 15 percent; claystone, 5 percent, as above.

Sandstone, 80 percent; siltstone, 15 percent; claystone, 5 percent, as above.

Sandstone, 80 percent; slitstone, 15 percent; claystone, 5 percent, as above.

Sandstone, 80 percent; siltstone, 15 percent; claystone, 5 percent, as above.

Sandstone, 80 percent, siltstone, 15 percent; claystone, 5 percent, as above. 
Table 3. Description of formation cuttings for selected wells - Continued

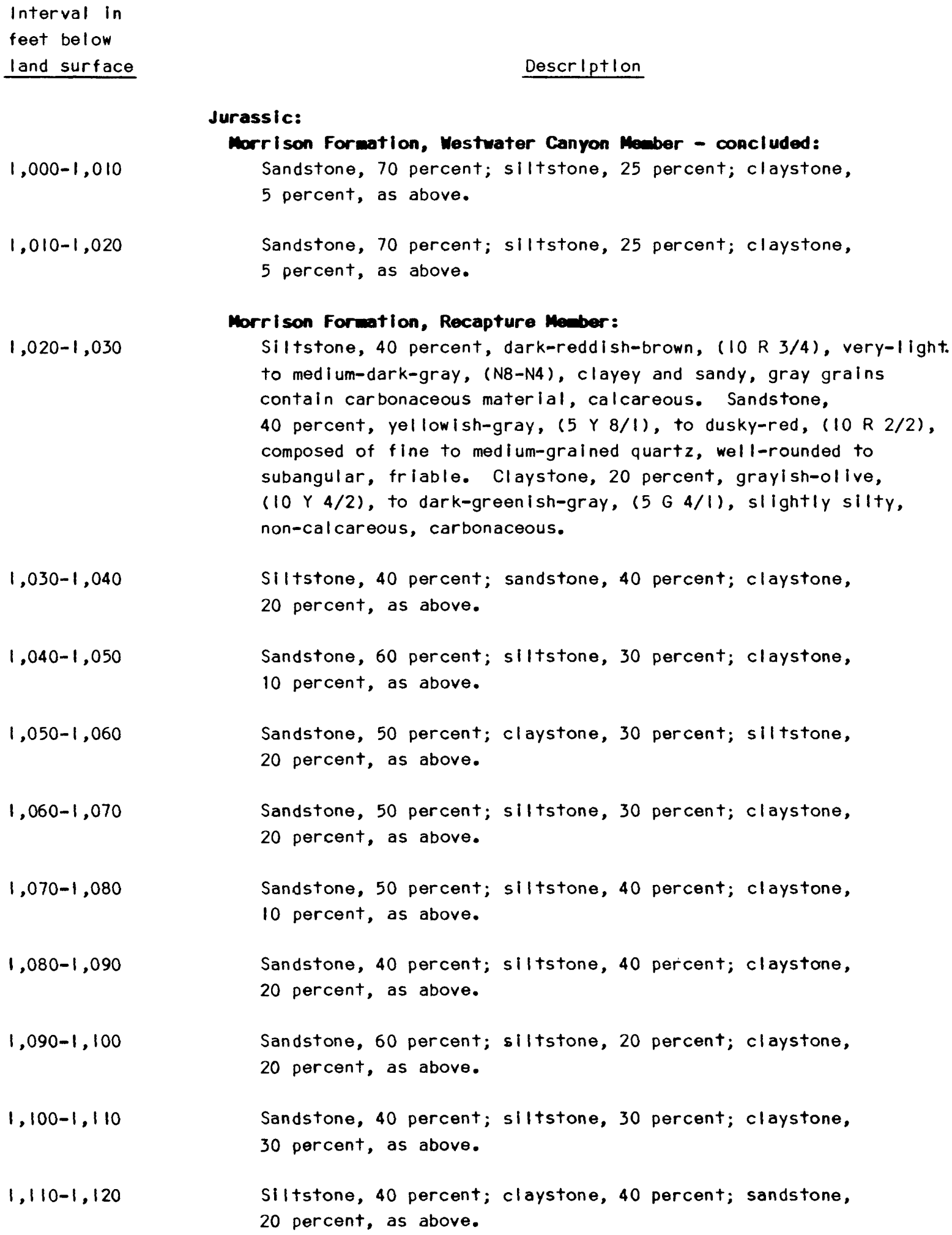


Table 3. Description of formation cuttings for selected welis - Continued

Interval in

feet below

I and surface

\section{Description}

\section{Jurassic:}

Morrison Forwation, Recapture Member - continued:

$1,120-1,130$

$1,130-1,140$

$1,140-1,150$

$1,150-1,160$

$1,160-1,170$

$1,170-1,180$

$1,180-1,190$

$1,190-1,200$

$1,200-1,210$

$1,210-1,220$

$1,220-1,230$

$1,230-1,240$
Siltstone, 40 percent, harder and better indurated than above; sandstone, 30 percent; claystone, 30 percent, as above.

Siltstone, 40 percent; claystone, 40 percent; sandstone, 20 percent, as above.

Siltstone, 50 percent; claystone, 30 percent; sandstone, 20 percent, as above.

Siltstone, 60 percent; claystone, 20 percent; sandstone, 20 percent, as above.

Missing sample.

Sandstoni, 50 percent; yellowish-gray ( 5 Y $8 / 1$ ) to dusky-red ( $10 \mathrm{R} 2 / 2$ ), composed mainly of very-fine to medium-grained quartz, well-rounded to subangular grains, friable, calcareous. Siltstone, 40 percent, mainly light to medium-dark-gray (N3-N6), some grains dark-reddish-brown (10 R 3/4), clayey and sandy, gray grains contain abundant carbonaceous material, calcareous. Claystone, 10 percent, greenish-gray ( 5 GY 6/1), to darkyellowish-brown (10 YR 4/2), non-calcareous.

Sandstone, 60 percent; siltstone, 30 percent; claystone, 10 percent, as above.

Sandstone, 50 percent; siltstone, 40 percent; claystone, 10 percent, as above.

Sandstone, 50 percent; siltstone, 40 percent; claystone, 10 percent, as above except more carbonaceous.

Sandstone, 60 percent; slltstone, 30 percent; claystone, 10 percent; sandstone and siltstone very carbonaceous, pyrite common.

Sandstone, 60 percent; slitstone, 30 percent; claystone, 10 percent; very carbonaceous with abundant pyrite, minor IImestone also present.

Sandstone, 60 percent; siltstone, 30 percent; claystone, 10 percent; pyritic sandstone abundant and very carbonaceous. 
Table 3. Description of formation cuttings for selected wellis - Continued

Interval in

feet below

land surface

$1,240-1,250$

$1,250-1,260$

$1,260-1,270$

$1,270-1,280$

$1,280-1,290$

$1,290-1,300$

$1,300-1,310$

$1,310-1,320$

$1,320-1,330$

\section{Description}

\section{Jurassic:}

Morrison Formation, Recapture Member - concluded:

Sandstone, 65 percent; siltstone, 30 percent; claystone, 5 percent; as above, carbonaceous with pyrite abundant.

Sandstone, 60 percent; siltstone, 35 percent; claystone, 5 percent; as above with abundant pyrite.

Sandstone, 65 percent; siltstone, 35 percent; claystone, 5 percent; reddish-sandstone becoming more abundant, pyrite abundant.

Sandstone, 50 percent, as above; siltstone, 40 percent, with dark-reddish-brown color $(10 \mathrm{R} 3 / 4)$, more abundant than gray siltstone; claystone, 10 percent, as above.

Sandstone, 50 percent; siltstone, 40 percent; claystone, 10 percent, as previous interval.

Siltstone, 60 percent, dark-reddish-brown (10 R 3/4) and mediumdark-gray (N4); sandstone, 35 percent; claystone, 5 percent; as above, minor 1 imestone presents.

Siltstone, 60 percent; sandstone, 35 percent; claystone, 5 percent, as above.

Siltstone, 70 percent, mostly medium-dark-gray (N4); sandstone, 25 percent; claystone, 5 percent, as above.

Siltstone, 70 percent, dark-reddish-brown and dark-gray; sandstone, 25 percent; claystone, 5 percent, as above, minor pyrite present. 
Table 3. Description of formation cuttings for selected wells - Continued

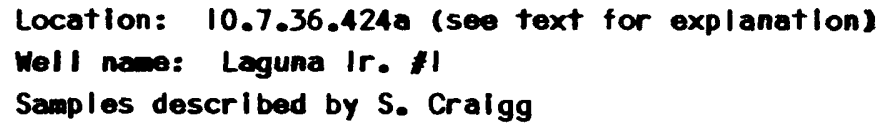

\section{Quaternary:}

\section{Alluviu and basalt:}

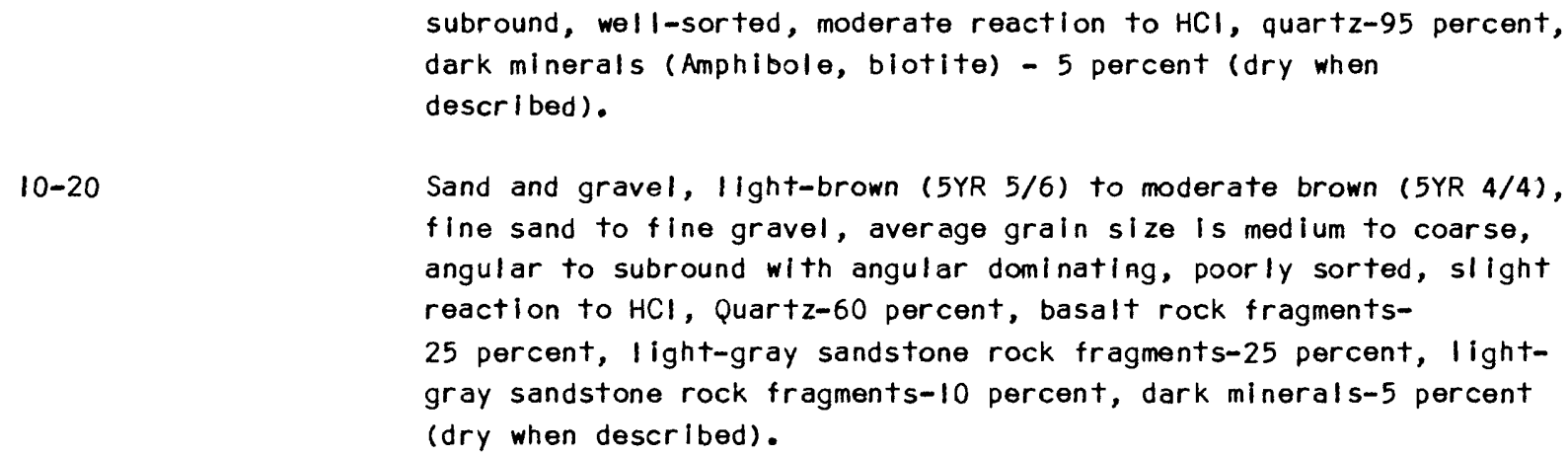

Sand and gravel, light-brown (5YR 5/6) to moderate brown ( $5 Y R$ 4/4), fine sand to fine gravel, average grain size is medium to coarse, angular to subround with angular dominating, poorly sorted, slight reaction to $\mathrm{HCl}$, Quartz-60 percent, basalt rock fragments25 percent, light-gray sandstone rock fragments-25 percent, lightgray sandstone rock fragments -10 percent, dark minerals-5 percent (dry when described).

Gravel, ol ive-black ( $5 Y 2 / 1$ ) to greenish black ( 5 GY $2 / 1$ ), coarse sand to medium gravel, angular to subround with angular predominating, poorly sorted, basalt rock fragments -75 percent, Quartz-15 percent, gray sandstone and Quartzite fragments10 percent (dry when described). coarse sand to coarse gravel, poorly sorted, angular to subangular, basalt rock fragments-85 percent; quartz, sandstone fragments, and Quartzite fragments-15 percent (wet when described).

Gravel, medlum-gray (N5) to greenish black (5 GY 2/1), coarse sand to coarse gravel, poorly sorted, angular to subround, basalt rock fragments-75 percent, gray and pink Quartzite rock fragments and sand-25 percent (dry when described).

Gravel, brownish-black ( 5 YR 2/1), medium sand to coarse gravel, poorly sorted, angular to round, larger fragments are angular, smaller grains are more rounded. Basalt rock fragments-75 percent, coarse Quartz sand-5 percent, gray Quartz-25 percent (wet when described). 
Table 3. Description of formation cuttings for selected wells - Continued

Interval in

feet below

land surface

$34-49$

49-55

55-65

$65-75$

$75-85$

85-90

$90-95$

$95-100$

$100-105$

$105-115$

$115-125$

\section{Description}

\section{Quaternary:}

Al Iuvium and basalt - continued:

Gravel, medium-gray (N5) to ol ive-gray ( $5 Y$ 2/1), medium sand to coarse gravel, poorly sorted, angular to round, basalt rock fragments-80 percent, coarse Quartz sand 10 percent, gray Quartzite fragments-10 percent (dry when described).

Basalt, medium-dark-gray (N4), flnely veslcular,--60 percent; a very light-gray, probably monesilicic rock with aphanltic testure (resembles a dacite/syenite rock)- -25 percent; alluvlal gravels and sands as described above-15 percent (dry when descrlbed).

Same as above, except basalt-85 percent; "dacite/syen ite" rock10 percent; gravels-5 percent, (dry when described).

Basalt, 100 percent, amydaloidal, medium dark gray (N4), vesicles are filled with silica, (dry when described).

Same as above; (wet when described).

Same as above; except occurs both as amygdaloldal and vesicular fragments (wet when described).

Basalt fragments-25 percent; alluvial sand-75 percent, Iight brown (5YR 5/6), fine to very-coarse sand, poorly sorted, angular to round, Quartz-80 percent, I ight-gray to Iron-stained sandstone rock fragments-14 percent, dark minerals-3 percent, opaque minerals (magnetite)-3 percent (dry when described; driller reports to have broken through basalt layer In this interval).

Gravel, 70 percent, coarse sand to fine pebbles, angular to subround, poorly sorted, rock fragments and grains include the following: iron-stalned sandstone chips, green (chloritic) schistose rock chips, I ight and dark-gray Quartzlte chips, dark and opague minerals grains, "granitic" rock chips, pinkish whlte massive quartz chips. Basalt cuttings from above intervals30 percent (dry when descrlbed).

Same as above, except cuttings are 80 percent gravel, fine sand to fine pebbles; 20 percent basalt fragments (dry when described).

Same as above, except gravel is 70 percent, basalt is 30 percent (dry when described).

Gravel, as above, except grain slze from fine sand to coarse gravel. Only a minor amount of basalt cuttings (dry when described). 
Table 3. Description of formation cuttings for selected wells - Continued

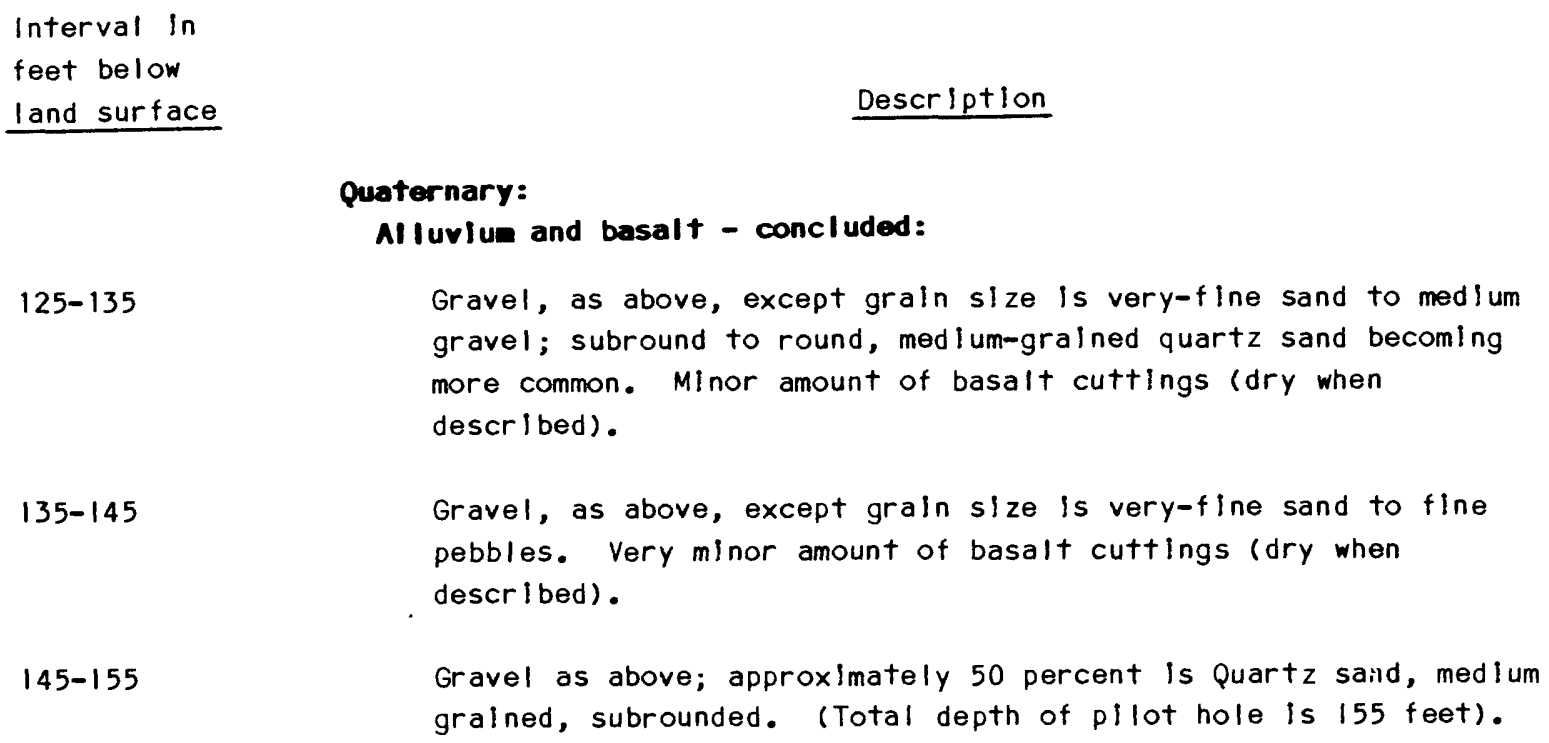

* Note: Samples were washed to remove drllling mud, therefore a small amount of finer grained material in the cuttings was probably also washed out.

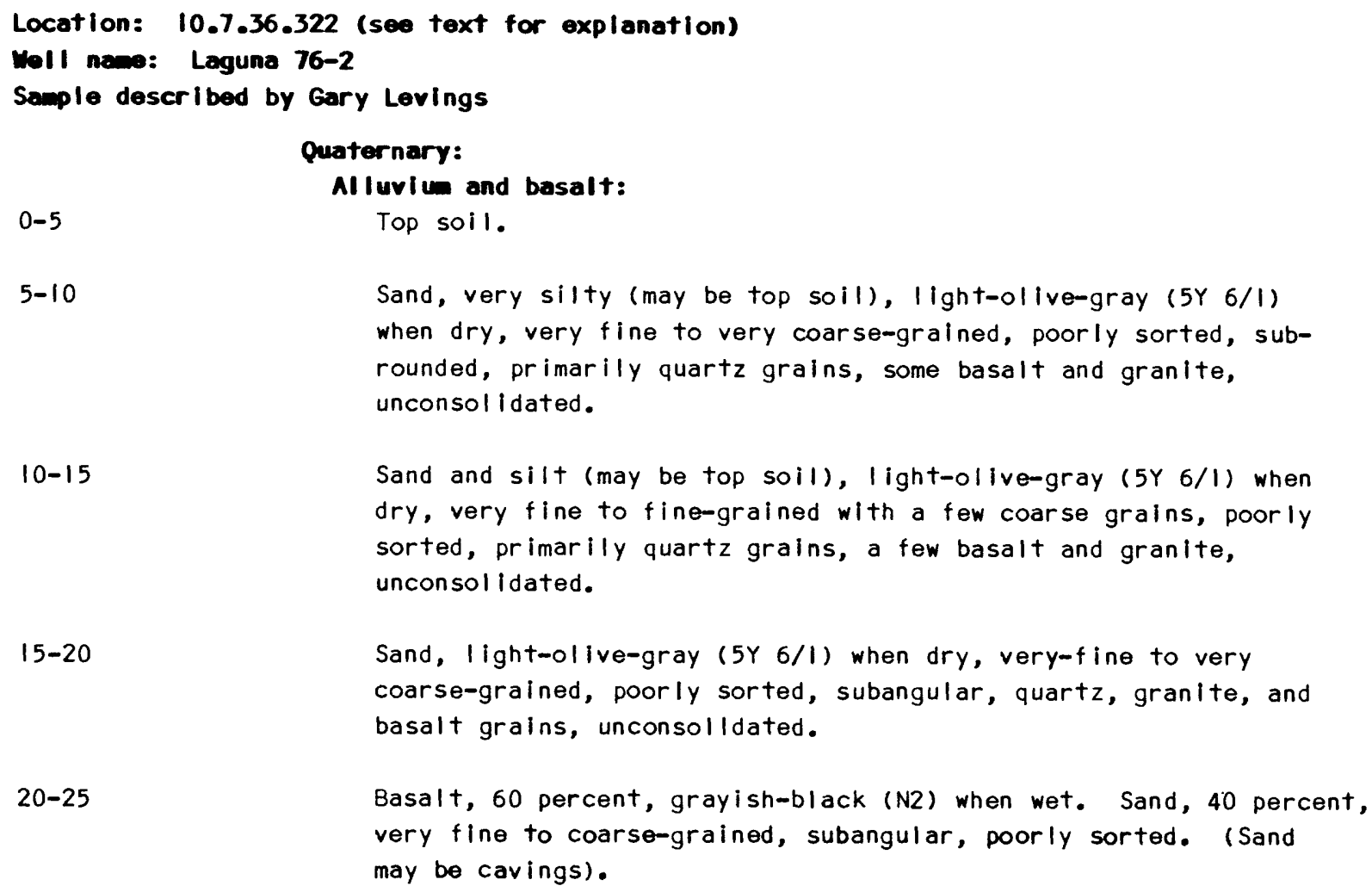


Table 3. Description of formation cuttings for selected wells - Contianud

Interval in
feet below
land surface

\section{Description}

\section{Quaternary:}

\section{Al luvium and besalt - concluded:}

$25-30$

$30-35$

$35-55$

$55-75$

$75-80$

80-85

90-95

$95-100$

$100-110$

$110-115$

$115-125$

$125-130$

$130-135$

$135-150$

$150-154$
Same as above except 80 percent basalt and 20 percent sand.

Same as above except 50 percent basalt and 50 percent sand.

Same as above except 80 percent basalt and 20 percent sand.

Same as above except less than 3 percent sand.

Basalt, 95 percent, grayish-black (N2) when wet. Sand, 5 percent, I Ight-ol ive-gray ( $5 Y$ 6/1) when dry, very fine to medium-grained, poorly sorted.

$\mathrm{Clay}, 90$ percent, sand 5 percent, basalt 5 percent, mixture is I ight-olive-brown (5Y 5/6) when dry.

Same as above except mixture is light-gray (N7) - Clay, lightol ive-gray ( $5 Y 5,1$ ) when wet. Minor sand, very fine-grained.

Clay, Iight-olive-gray $(5 Y 6 / 1)$ when wet, sandy, sand grains composed of basalt and sandstone with a few quartz grains.

Clay, I ight-gray (N7) when wet. Minor sand grains composed of basalt and quartz.

Clay, I ight-gray (N7) when wet. Minor sand grains composed mainly of sandstone, some chips $1 / 4$ inch in diameter.

Sand, 80 percent, fine-gralned to $1 / 4$ inch in diameter, composed of sandstone, basalt, and siltstone, poorly sorted, very angular chips.

Same as above except grain size is very fine to coarse, less siltstone chips.

Sand, very fine to coarse-grained, a few large chlps of greenishgray (5GY 6/1) sandstone, mostly grains from quartz sandstone, mostly angular, poorly sorted. Less than 10 percent clay.

Sand, very fine to medlum-grained, poorly sorted, subangular to subrounded mostly quartz. Less than 3 percent siltstone and sandstone grains.

Same as above except some large chlps of sandstone. 
Table 3. Description of formation cuttings for selected vells - Continued

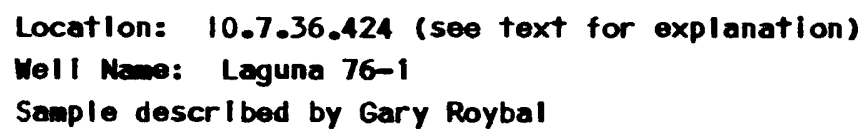

Description

\section{Quaternary:}

\section{Alluvium and basalt:}

$0-10$

$10-15$

$15-20$

$20-35$

$35-40$

40-45

$45-50$

$50-55$

$55-65$

$65-70$

$70-85$

$85-90$
Clay, moderate brown (5YR 4/4). Silt, less than 5 percent. strong reaction to hydrochloric acld.

Clay and silt, 80 to 90 percent, as above. Gravel, 10 to 20 percent, various colors, mostly dark-gray particles up to $1 / 2$ inch in diameter, subrounded to angular.

Clay, 50 percent, as above. Gravel, 50 percent, as above.

Clay, 90 percent, as abcre. Gravel, 10 percent as above, but smaller-sized particles.

Clay, 70 percent, as above. Gravel, 30 percent as above but very large range of particles sizes.

As above, some fine-grained sand as quartz.

Clay, 80 percent, pale-red (1OR 6/2) to grayish-orange (1OYR 7/4) slightly sllty, only slightly reactive hydrochloric acid. Sand and gravel, 20 percent, angular.

No sample.

Clay, 80 percent, pale-yellowish-brown (lOYR 6/2), nonreactive to hydrochloric acid. Gravel 20 percent, as above.

Clay, 50 percent, as above. Basalt, 50 percent, very dark, scattered olivine crystals.

Basalt, 100 percent, as above.

Basalt, 40 percent, as above. Sand, 40 percent, very fine-grained, quartz. Silt, 20 percent, nonreactive hydrochloric acid. 
Table 3. Description of formation cuttings for selected wells - Continued

\begin{tabular}{l}
$\begin{array}{l}\text { Interval in } \\
\text { feet below } \\
\text { land surface }\end{array}$ \\
\hline
\end{tabular}

land surface

$95-100$

$100-115$

$115-120$

$120-125$

$125-130$

$130-140$

$140-145$

$145-150$

$150-157$

\author{
Description
}

\title{
Quaternary:
}

Alluviun and basalt - concluded:

Gravel, 80 percent, size range 1/8 to 1/2 inch, angular. Clay 20 percent, pale yellowish-brown $($ lOYR $6 / 2)$, nonreactive to hydrochloric acid.

Gravel, 40 percent, as above except somewhat smaller particle size. Sand, 30 percent, very fine to medium-grained, mostly quartz. Clay, 30 percent, as above.

Sand, 60 percent, as above. Clay, 30 percent as above. Gravel, 10 percent, as above.

As above except somewhat less sand and gravel and highly reactive to hydrochloric acid.

As above except high sand percentage.

As above except no reaction to hydrochloric acid.

Sand, 50 percent, as above. Gravel, 30 percent, as above. Clay, 20 percent, as above.

Sand, 50 percent, very fine to medium-grained, mostly quartz. Gravel, 30 percent, 1/4 inch dlameter or less. Clay, 20 percent, pale yellowish-brown (IOYR 6/2), no reaction to hydrochloric acld.

As above except somewhat less sand.

Silt and clay, 55 percent, I ight-brown, (5YR 6/4) to pale-brown (5YR 5/2), highly calcareous. Sand, 40 percent, as above. Gravel 5 percent. 
Table 3. Description of formation cuttings for selected wells - Continued

Location: II.6.27.334 (see text for explanation)

Well nama: Enclinal Canyon II

well cuttings described by John J. Rote.

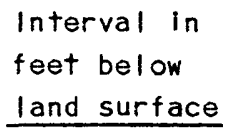

\section{Descrlption}

\section{Quaternary:}

\section{Al luvium:}

$0-5$

Silt, pale-yellowish-brown (lOYR 6/2), with scattered basalt granules. Minor caliche.

$5-10$

Same as $0-5$.

$10-15$

Same as 0-5 except color is light-brown (5YR 6/4). No caliche.

$15-20$

Same as $10-15$.

$20-25$

Same as $10-15$

$25-30$

Same as $10-15$

$30-35$

Same as 10-15; basalt granules absent.

$35-40$

Shale, Iight gray (N7); with limestone fragments (numerous).

$40-45$

Same as $35-40$.

$45-50$

Shale, calcareous, Iight gray (N7).

50-55

Same as $45-50$.

$55-60$

Same as $45-50$.

$60-65$

Same as $45-50$.

$65-70$

Same as $45-50$

70-75

Same as $45-50$.

$75-80$

Same as $45-50$.

80-85

Same as $45-50$.

85-90

Same as 45-50.

90-95

Same as 45-50. 
Table 3. Description of formation cuttings for seiected wells - Continued

Interval in

feet below

land surface

Description

\section{Quaternary:}

$95-100$

Alluvium - concluded:

$100-105$

Same as 95-100.

$105-110$

Same as 95-100. 
Table 3. Description of formation cuttings for selected wells - Continued

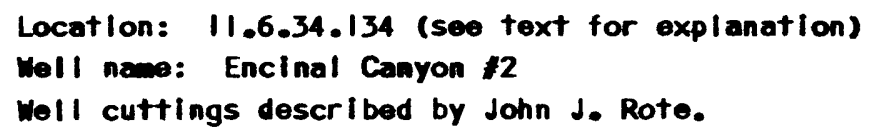

$0-30$

Silt, grayish-orange (IOYR 7/4); slightly calcareous scattered basalt and gravel (50 percent).

$30-35$

Shale, pale yellowish brown (lOYR 6/2), calcareous, scattered basalt and gravel.

Note: Percentage of basalt and gravel probably decrease as depth increases, because of drill hole caving near top. 
Table 3. Description of formation cuttings for selected wells - Concluded

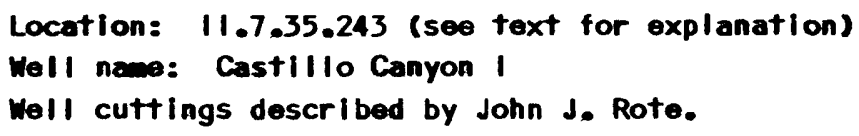

\section{Quaternary:}

\section{Al Iuviun:}

$0-5$

Silt, pale-yellowish-brown (lOYR 6/2), slightly calcareous.

$5-10$

Same as $0-5$.

$10-15$

Same as $0-5$.

$15-20$

Shale, I Ight-gray (N7).

$20-25$

Same as 15-20.

$25-30$

Same as 15-20.

$30-35$

Same as 15-20.

$35-40$

Silt, Iight-gray (N7).

$40-45$

Sandstone, very light-gray (N8) fine grained, poorly cemented.

45-50

Same as 40-45.

$50-55$

Same as 40-45.

$55-60$

Sandstone, as above, to silt, very light-gray (N8).

$60-65$

Shale, very light gray (N8), to light-gray (N7).

$65-70$

Same as 60-65.

$70-75$

Same as 60-65. 


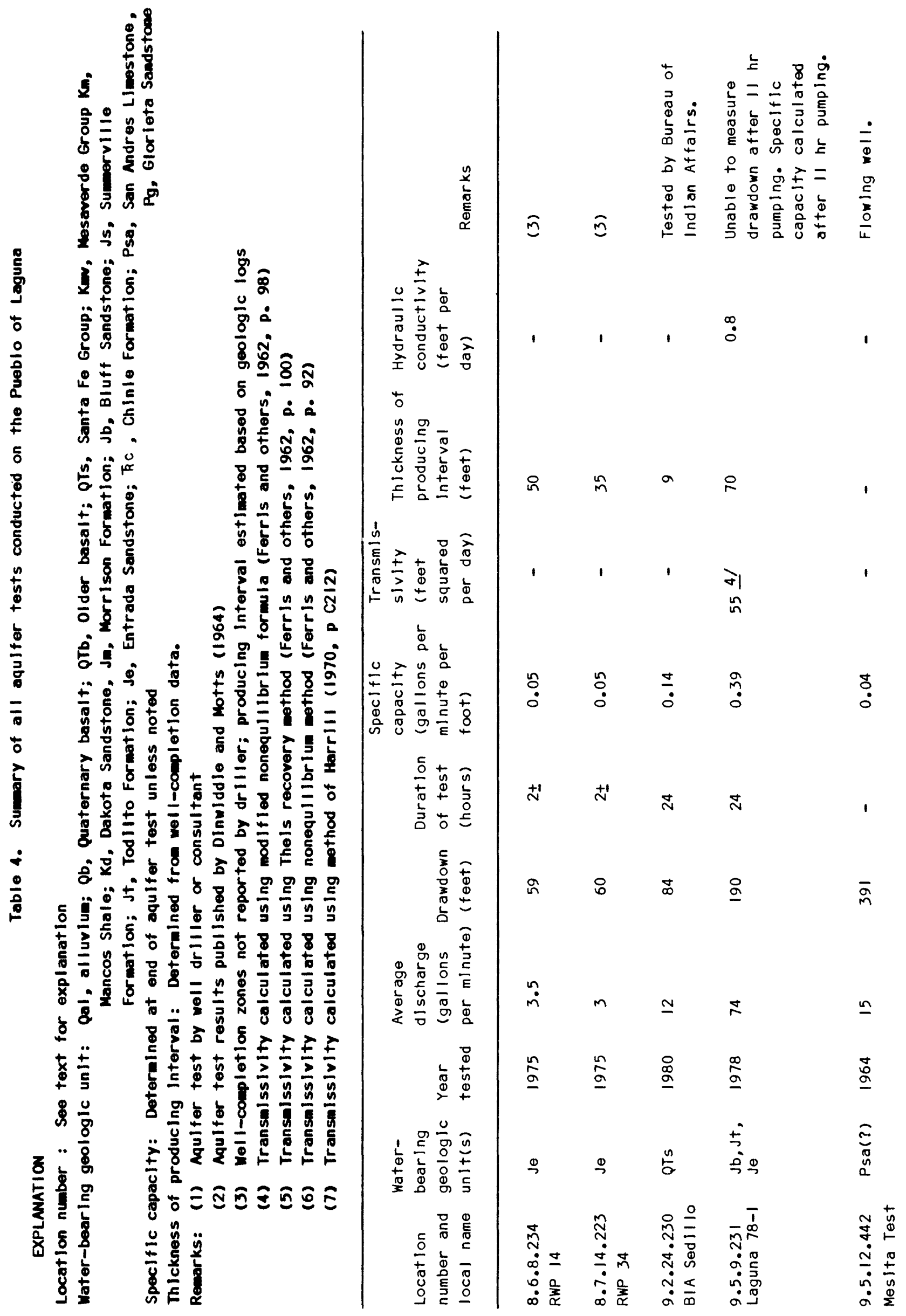




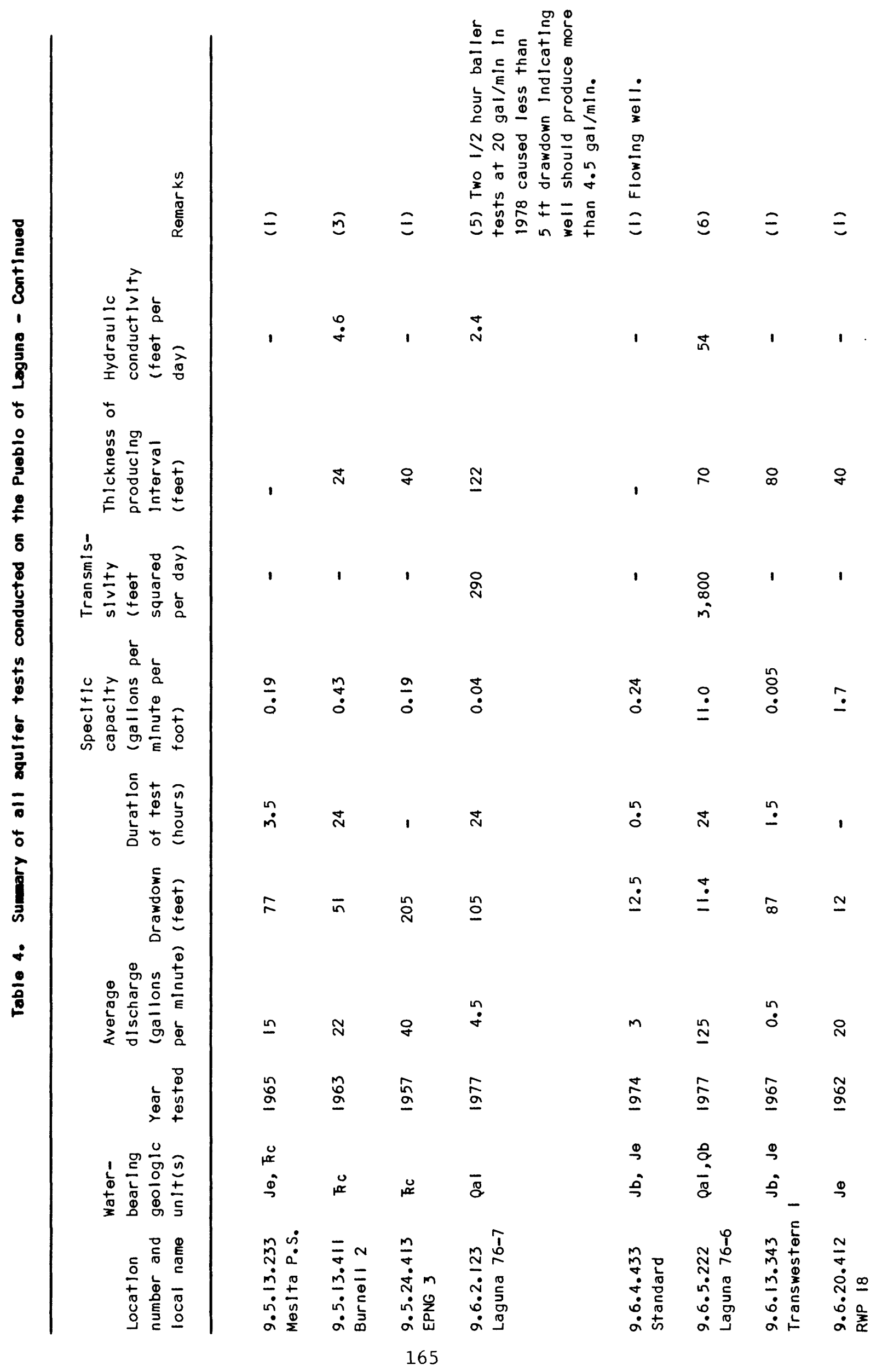




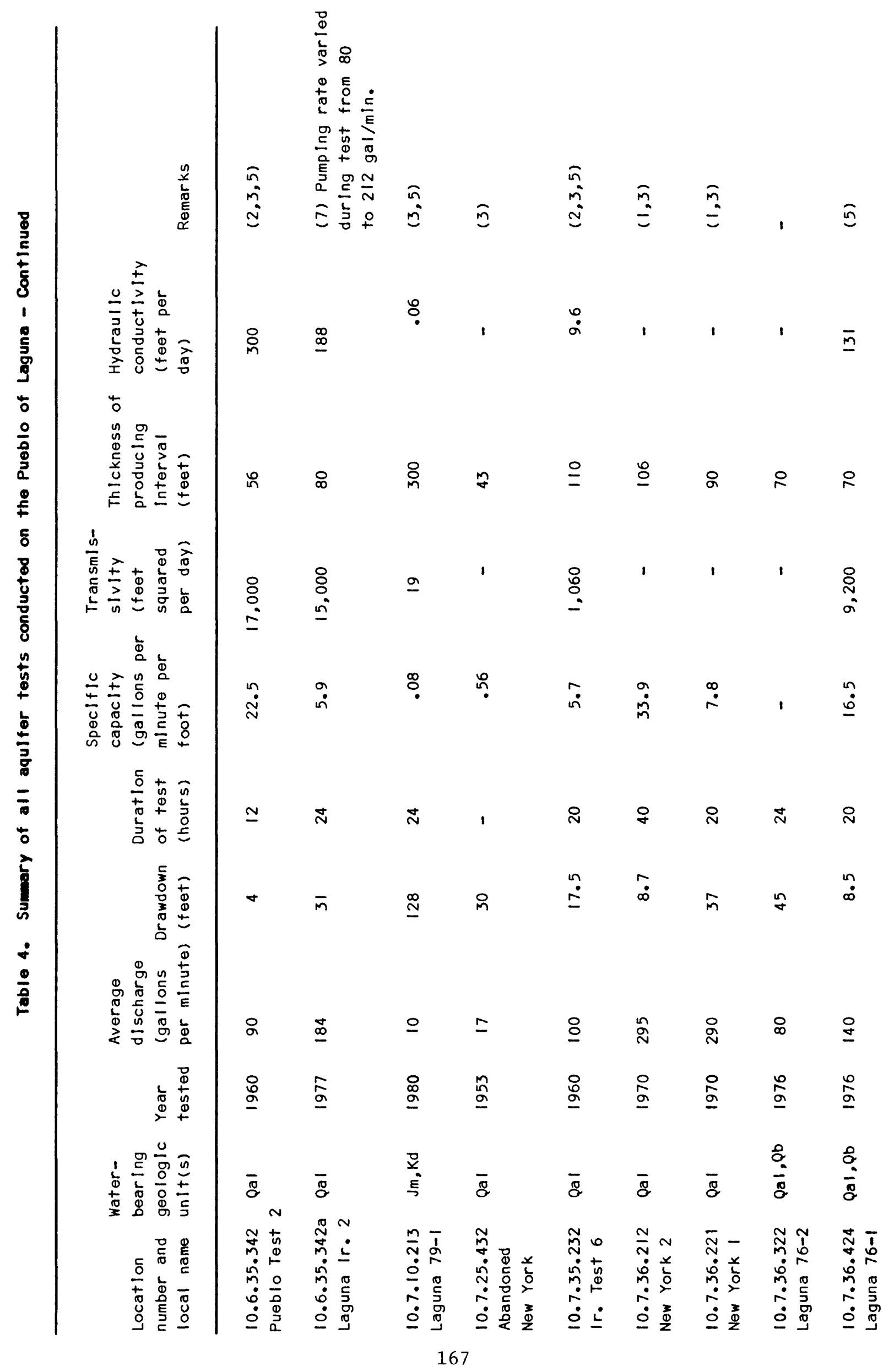




\begin{tabular}{|c|c|c|c|c|c|c|c|c|c|c|}
\hline 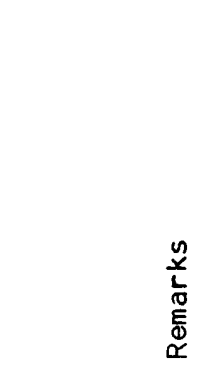 & 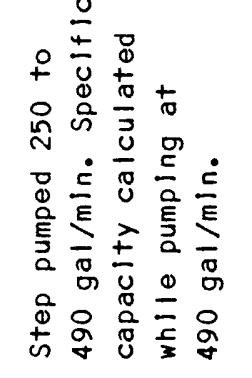 & $\Xi$ & $\equiv$ & $\equiv$ & $\equiv$ & 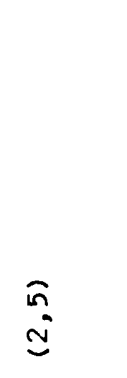 & 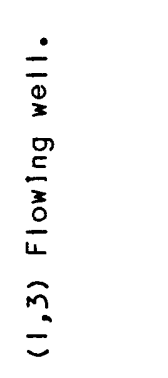 & 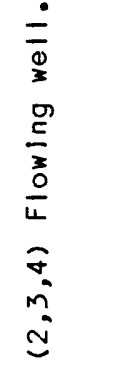 & 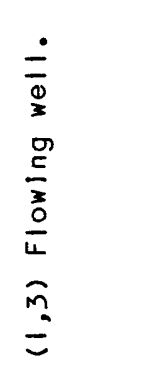 & 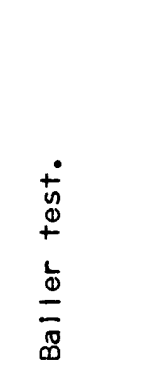 \\
\hline 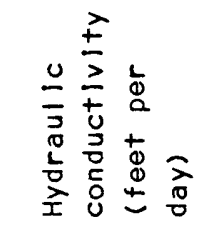 & ' & . & 1 & . & 1 & 1 & 1 & $\stackrel{n}{-}$ & , & 1 \\
\hline 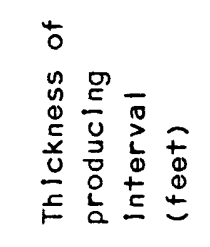 & $\mathscr{8}$ & 1 & 1 & 1 & ' & 1 & in & 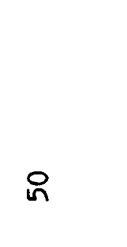 & in & n \\
\hline 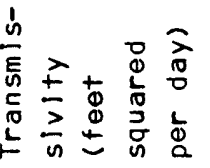 & , & , & . & ' & $\underline{\infty}$ & $\stackrel{m}{m}$ & . & $\stackrel{n}{\kappa}$ & ' & . \\
\hline 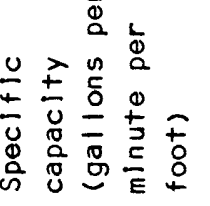 & $\dot{n}$ & $\dddot{m}$ & ำ & $\bar{o}$ & $\because$ & $\stackrel{n}{\leftrightarrow}$ & 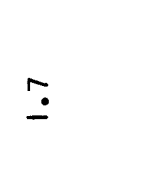 & $\stackrel{\square}{\square}$ & $\stackrel{a}{m}$ & . \\
\hline 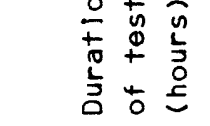 & 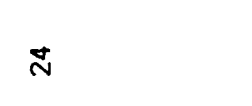 & 1 & $\underline{n}$ & ' & $\infty$ & $\simeq$ & m & $\simeq$ & $\simeq$ & 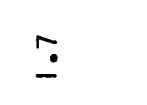 \\
\hline 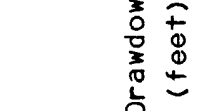 & $\stackrel{\infty}{\infty}$ & $\xi$ & II & 品 & $\underline{\tilde{n}}$ & $\cong$ & 7 & $\stackrel{n}{n}$ & $\ddot{\nu}$ & ' \\
\hline 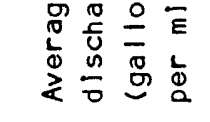 & m & $\underline{n}$ & in & in & in & 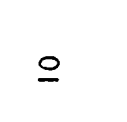 & $\stackrel{n}{n}$ & $n$ & 8 & $\stackrel{m}{n}$ \\
\hline 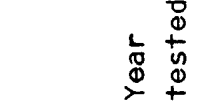 & $\underline{\underline{a}}$ & $\stackrel{\square}{\stackrel{\Delta}{0}}$ & $\bar{\alpha}$ & $\stackrel{n}{a}$ & $\bar{\sigma}$ & $\stackrel{\circ}{\circ}$ & $\underset{\Xi}{\tilde{a}}$ & $\stackrel{8}{\circ}$ & $\stackrel{\tilde{o}}{\stackrel{0}{2}}$ & $\stackrel{\infty}{\stackrel{\infty}{\sigma}}$ \\
\hline 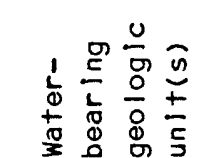 & $\begin{array}{l}\frac{8}{a} \\
\frac{1}{0}\end{array}$ & $\frac{\overrightarrow{\mathrm{E}}}{\frac{\overline{\bar{a}}}{\mathrm{a}}}$ & $\xi$ & 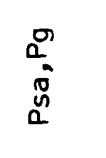 & 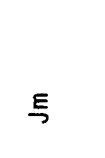 & $\xi$ & $\overline{\mathrm{o}}$ & $\bar{\alpha}$ & $\bar{\sigma}$ & $\overline{8}$ \\
\hline 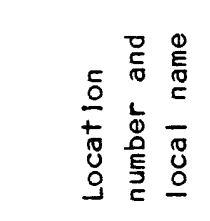 & 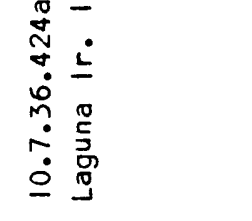 & 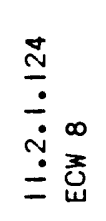 & 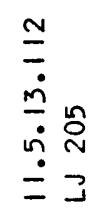 & 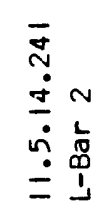 & 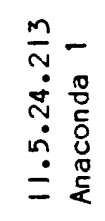 & 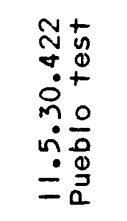 & 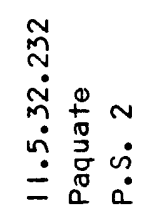 & 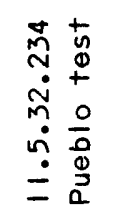 & 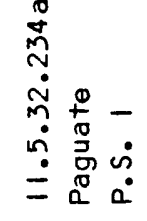 & 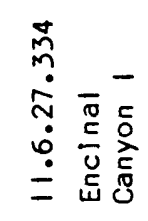 \\
\hline
\end{tabular}




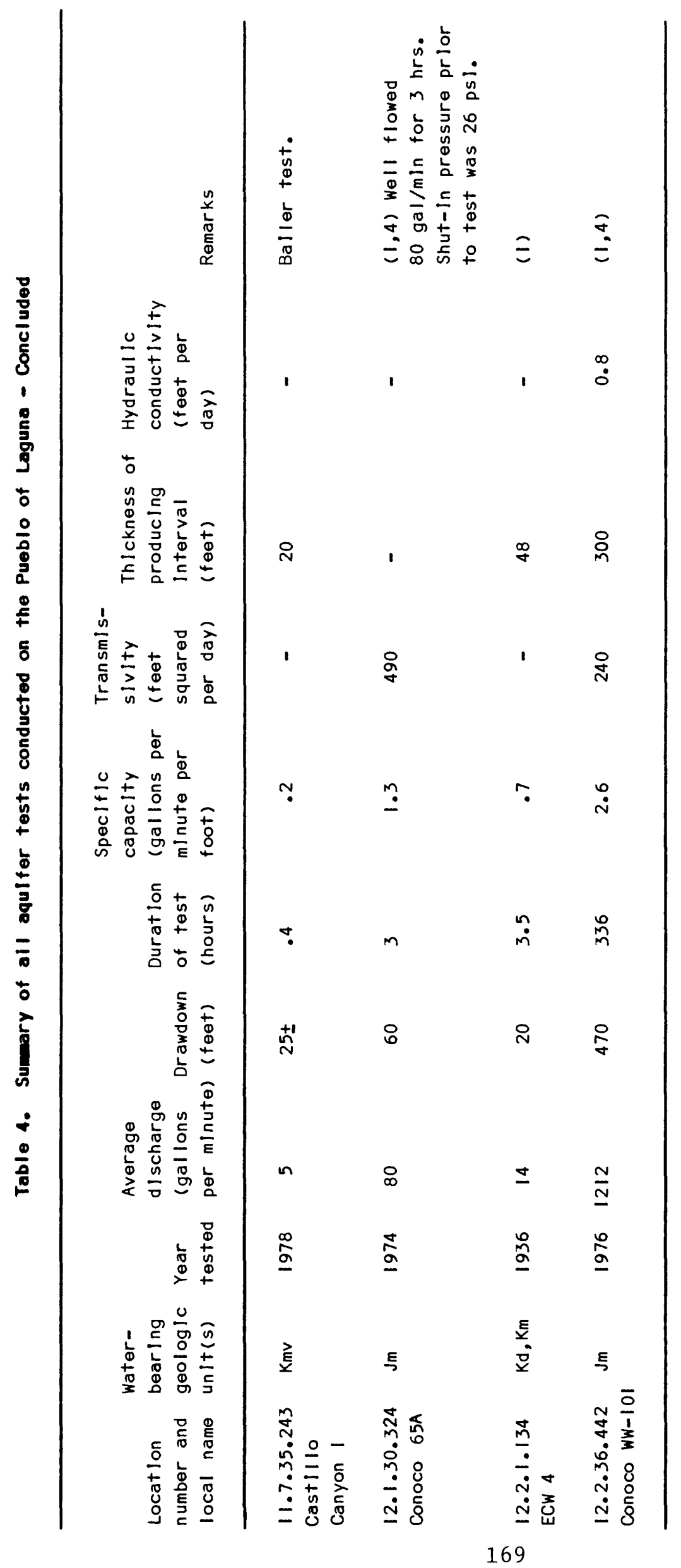


Table 5. Major constituents of water In selected wells and springs

\section{EXPLANATION}

Location number: See text for explanation

Laboratory: BIA, U.S. Bureau of Indlan Affalrs; USGS, U.S. Ceologlcal Survey; P, Private laboratory; PHS, U.S. Public Health Servlce;

Note: All constituents are dissolved and reported in milligrans per Ilter. Values for bicarbonate, carbonate, temperature, $\mathrm{pH}$, and speclfic conductance were measured onslte after August 1, 1975 unless marked with asterlsk. "T" Indlcates trace amount.

\begin{tabular}{|c|c|c|c|c|c|c|c|c|c|}
\hline $\begin{array}{l}\text { Location } \\
\text { number }\end{array}$ & $\begin{array}{l}\text { Local well } \\
\text { or } \\
\text { spring name }\end{array}$ & $\begin{array}{l}\text { Date } \\
\text { of } \\
\text { coll ec- } \\
\text { tion }\end{array}$ & $\begin{array}{l}\text { Labor- } \\
\text { atory }\end{array}$ & $\begin{array}{l}\text { Pumpling } \\
\text { rate } \\
\text { (gallon } \\
\text { per } \\
\text { minute) }\end{array}$ & $\begin{array}{l}\text { Cal- } \\
\text { clum }\end{array}$ & $\begin{array}{l}\text { Mag- } \\
\text { nesium }\end{array}$ & Sod i um & $\begin{array}{l}\text { Potas- } \\
\text { slum }\end{array}$ & $\begin{array}{l}\text { Bicar- } \\
\text { bonate } \\
\text { (as } \\
\mathrm{HCO}_{3} \text { ) }\end{array}$ \\
\hline \multirow[t]{2}{*}{6.2 .6 .431} & Salt Spg. & $08-07-41$ & USGS & - & 540 & 450 & 3,700 & 38 & 1,390 \\
\hline & 173 & $06-05-75$ & USGS & - & - & - & 3,100 & 36 & 960 \\
\hline 6.7 .18 .113 & WiIson & $07-09-63$ & USGS & - & 550 & 520 & 210 & 15 & 460 \\
\hline 6.7 .34 .341 & $\begin{array}{l}\text { Blue } \\
\text { Water }\end{array}$ & $11-02-73$ & $B \mid A$ & - & 66 & 29 & 22 & 2.0 & 230 \\
\hline 7.1 .31 .124 & - & $04-26-56$ & USGS & - & 110 & 55 & 1,940 & - & 910 \\
\hline \multirow{2}{*}{7.2 .6 .214} & Salt Spg. & $09-03-41$ & USGS & - & 230 & 190 & - & - & 2,100 \\
\hline & 192 & $04-21-75$ & USGS & - & 210 & 110 & 10,000 & 280 & - \\
\hline \multirow[t]{2}{*}{7.2 .6 .434} & $\mathrm{Salt} \mathrm{Spg}$ & $09-03-41$ & USGS & - & 320 & 130 & - & - & 2,140 \\
\hline & 190 & $04-22-75$ & USGS & - & 110 & 160 & 11,000 & 320 & 1,910 \\
\hline 7.2 .6 .442 & $\begin{array}{c}\text { Rallroad } \\
\text { Spg. }\end{array}$ & $04-22-75$ & USGS & - & 350 & 350 & 9,300 & 260 & 2,460 \\
\hline $7 \cdot 2 \cdot 7 \cdot 123$ & $\begin{array}{c}\text { Salt Spg } \\
186\end{array}$ & $08-25-41$ & USGS & - & 110 & 140 & 9,900 & 290 & 1,750 \\
\hline 7.2 .7 .241 & $\begin{array}{c}\text { Pipeline } \\
\text { Spg. }\end{array}$ & $04-22-75$ & USGS & - & 490 & 140 & 9,100 & 260 & 2,950 \\
\hline
\end{tabular}




\begin{tabular}{|c|c|c|c|c|c|c|c|c|c|c|c|}
\hline $\begin{array}{l}\text { Car- } \\
\text { bonate } \\
\text { (as } \\
\mathrm{CO}_{3} \text { ) }\end{array}$ & $\begin{array}{l}\text { Sul- } \\
\text { fate }\end{array}$ & $\begin{array}{l}\text { Chlo } \\
\text { ride }\end{array}$ & $\begin{array}{l}\text { SII- } \\
\text { lca }\end{array}$ & $\begin{array}{l}\text { Calclum- } \\
\text { magneslum } \\
\text { hardness } \\
\text { (as } \mathrm{CaCO}_{3} \text { ) }\end{array}$ & $\begin{array}{l}\text { Hard- } \\
\text { ness, } \\
\text { noncar- } \\
\text { bonate }\end{array}$ & $\begin{array}{l}\text { Dis- } \\
\text { solved } \\
\text { sollds } \\
\text { residue } \\
\text { at } 105^{\circ} \\
\text { Celslus }\end{array}$ & $\begin{array}{l}\text { Tem- } \\
\text { pera- } \\
\text { ture } \\
\text { (de- } \\
\text { grees } \\
\text { Cel- } \\
\text { sl- } \\
\text { us) }\end{array}$ & (units) & $\begin{array}{l}\text { Spe- } \\
\text { clflc } \\
\text { conduct- } \\
\text { ance } \\
\text { (mlcro- } \\
\text { mhos per } \\
\text { centl- } \\
\text { meter at } \\
25^{\circ} \text { Cel- } \\
\text { slus) }\end{array}$ & $\begin{array}{l}\text { Sodlum } \\
\text { absorp- } \\
\text { tlon } \\
\text { ratio }\end{array}$ & $\begin{array}{l}\text { Irri- } \\
\text { gation } \\
\text { class }\end{array}$ \\
\hline- & 2,700 & 5,200 & 21 & 3,200 & - & 13,700 & 25.5 & - & - & - & - \\
\hline - & - & 4,400 & - & - & - & - & 15.0 & 8.7 & - & - & - \\
\hline 0 & 3,200 & 71 & 8.8 & 3,500 & 3,100 & 4,970 & - & 6.9 & 5,070 & 1.5 & $\mathrm{C}_{4} \mathrm{~S}_{1}$ \\
\hline 9 & 94 & 17 & - & 290 & 99 & 380 & 14 & 7.9 & 630 & .6 & $c_{2} s_{1}$ \\
\hline 0 & 2,440 & 1,010 & 27 & 500 & 0 & 6,170 & 18 & 7.7 & 8,540 & 89 & $\mathrm{C}_{4} \mathrm{~S}_{4}$ \\
\hline - & 8,000 & 12,000 & - & - & - & 33,100 & - & - & - & - & - \\
\hline - & 6,700 & 11,000 & 20 & 980 & - & - & - & 8.6 & 37,000 & 139 & $\mathrm{C}_{4} \mathrm{~S}_{4}$ \\
\hline- & 6,500 & 9,800 & - & - & - & 27,600 & - & - & - & - & - \\
\hline 180 & 7,400 & 12,000 & 30 & 930 & 0 & 32,200 & - & 9.1 & 41,500 & 157 & $\mathrm{C}_{4} \mathrm{~S}_{4}$ \\
\hline 0 & 6,200 & 10,000 & 22 & 2,300 & 300 & 27,700 & 13.5 & 6.9 & 36,500 & 84 & $\mathrm{C}_{4} \mathrm{~S}_{4}$ \\
\hline- & 6,800 & 10,000 & 38 & 850 & - & 28,400 & - & - & - & - & - \\
\hline 0 & 5,600 & 9,000 & 23 & 1,800 & 0 & 26,100 & 14.0 & 7.7 & 34,100 & 93 & $\mathrm{C}_{4} \mathrm{~S}_{4}$ \\
\hline
\end{tabular}




\begin{tabular}{|c|c|c|c|c|c|c|c|c|c|}
\hline $\begin{array}{l}\text { Location } \\
\text { number }\end{array}$ & $\begin{array}{l}\text { Local well } \\
\text { or } \\
\text { spring name }\end{array}$ & $\begin{array}{l}\text { Date } \\
\text { of } \\
\text { collec- } \\
\text { tion }\end{array}$ & $\begin{array}{l}\text { Labor- } \\
\text { atory }\end{array}$ & $\begin{array}{l}\text { Pumplng } \\
\text { rate } \\
\text { (gallon } \\
\text { per } \\
\text { minute) }\end{array}$ & $\begin{array}{l}\text { Cal- } \\
\text { clum }\end{array}$ & $\begin{array}{l}\text { Mag- } \\
\text { nes! um }\end{array}$ & Sod i um & $\begin{array}{l}\text { Potas- } \\
\text { sium }\end{array}$ & $\begin{array}{l}\text { Blcar- } \\
\text { bonate } \\
\text { (as } \\
\mathrm{HCO}_{3} \text { ) }\end{array}$ \\
\hline \multirow[t]{2}{*}{$7 \cdot 2 \cdot 7 \cdot 343$} & Salt Spg. & $08-25-41$ & USGS & - & 330 & 150 & - & - & 2,250 \\
\hline & 185 & $04-22-75$ & USGS & - & 140 & 160 & 9,400 & 320 & 1,920 \\
\hline 7.2 .10 .444 & RWP 5 & $06-05-75$ & USGS & - & 92 & 30 & 2,200 & 33 & 460 \\
\hline 7.2 .18 .134 & $\begin{array}{l}\text { Salt Spg. } \\
184 b\end{array}$ & $08-25-41$ & USGS & - & 580 & 190 & - & - & 2,070 \\
\hline 7.2 .18 .144 & $\begin{array}{c}\text { Salt Spg. } \\
184 \mathrm{C}\end{array}$ & $08-25-41$ & USGS & - & 430 & 190 & - & - & 1,640 \\
\hline \multirow[t]{2}{*}{7.2 .18 .313} & Salt Spg. & $08-25-41$ & USGS & - & 940 & 230 & 11,000 & 290 & 2,910 \\
\hline & $184 a$ & $04-22-75$ & USGS & - & 380 & 230 & 12,000 & 310 & 1,960 \\
\hline 7.2 .18 .431 & $\begin{array}{l}\text { Mammoth } \\
\text { Mound }\end{array}$ & $04-22-75$ & USGS & - & 390 & 170 & 8,600 & 230 & 2,720 \\
\hline 7.2 .29 .214 & RWP 6 & $05-16-75$ & USGS & - & 410 & 110 & 520 & 34 & 120 \\
\hline \multirow[t]{2}{*}{7.2 .30 .124} & Salt Spg. & $09-02-41$ & USGS & - & 710 & 220 & 6,600 & 170 & 2,210 \\
\hline & 189 & $05-16-75$ & USGS & - & 340 & 230 & 9,500 & 280 & 1,490 \\
\hline 7.2 .30 .411 & $\begin{array}{l}\text { Salt Spg. } \\
188\end{array}$ & $09-02-41$ & USGS & - & 300 & 230 & - & - & 1,390 \\
\hline 7.2 .31 .144 & $\begin{array}{c}\text { Salt Spg. } \\
187\end{array}$ & $09-02-41$ & USGS & - & 610 & 270 & 5,300 & 120 & 1,630 \\
\hline $7.3 \cdot 1.432 a$ & $\begin{array}{l}\text { Indlan } \\
\text { Ruins Spg. }\end{array}$ & $04-21-75$ & USGS & - & 540 & 200 & 1,300 & 31 & 640 \\
\hline $7 \cdot 4 \cdot 3 \cdot 344$ & $\begin{array}{l}\text { Salt Spg. } \\
195\end{array}$ & - & USGS & - & 610 & 150 & - & - & 410 \\
\hline
\end{tabular}




\begin{tabular}{|c|c|c|c|c|c|c|c|c|c|c|c|}
\hline $\begin{array}{l}\text { Car- } \\
\text { bonate } \\
(\text { as } \\
\left.\mathrm{CO}_{3}\right)\end{array}$ & $\begin{array}{l}\text { Sul- } \\
\text { fate }\end{array}$ & $\begin{array}{l}\text { Chlo- } \\
\text { rlde }\end{array}$ & $\begin{array}{l}\text { SII- } \\
\text { ica }\end{array}$ & $\begin{array}{l}\text { Calclum- } \\
\text { magnes lum } \\
\text { hardness } \\
\text { (as } \mathrm{CaCO}_{3} \text { ) }\end{array}$ & $\begin{array}{l}\text { Hard- } \\
\text { ness, } \\
\text { noncar- } \\
\text { bonate }\end{array}$ & $\begin{array}{l}\text { Dis- } \\
\text { solved } \\
\text { solids } \\
\text { resldue } \\
\text { at } 105^{\circ} \\
\text { Celslus }\end{array}$ & $\begin{array}{l}\text { Tem- } \\
\text { pera- } \\
\text { ture } \\
\text { (de- } \\
\text { grees } \\
\text { Cel- } \\
\text { sl- } \\
\text { us) }\end{array}$ & $\begin{array}{c} \\
\mathrm{pH} \\
(\text { units) }\end{array}$ & $\begin{array}{l}\text { Spe- } \\
\text { clflc } \\
\text { conduct- } \\
\text { ance } \\
\text { (mlcro- } \\
\text { mhos per } \\
\text { centl- } \\
\text { meter at } \\
25^{\circ} \text { Cel- } \\
\text { slus) }\end{array}$ & $\begin{array}{l}\text { Sodlum } \\
\text { absorp- } \\
\text { tlon } \\
\text { ratlo }\end{array}$ & $\begin{array}{l}\text { Irrl- } \\
\text { gatlon } \\
\text { class }\end{array}$ \\
\hline - & 6,800 & 9,200 & - & - & - & 27,100 & - & 8.3 & - & - & - \\
\hline 0 & 6,200 & 10,000 & 32 & 1,000 & 0 & 27,200 & 13.5 & 8.3 & 36,800 & 129 & $\mathrm{C}_{4} \mathrm{~S}_{4}$ \\
\hline 0 & 2,600 & 1,500 & 15 & 350 & 0 & 6,730 & - & 8.3 & 9,430 & 51 & $\mathrm{C}_{4} \mathrm{~S}_{4}$ \\
\hline- & 7,500 & 9,400 & - & - & - & 28,300 & - & - & - & - & - \\
\hline- & 8,200 & 10,300 & - & - & - & 30,600 & - & - & - & - & - \\
\hline - & 9,100 & 11,400 & 35 & 3,300 & - & 34,700 & 28 & - & - & - & - \\
\hline 54 & 9,100 & 12,000 & 26 & 1,900 & 200 & 35,100 & - & 8.7 & 45,000 & 120 & $\mathrm{C}_{4} \mathrm{~S}_{4}$ \\
\hline 0 & 5,900 & 9,900 & 27 & 1,700 & 0 & 22,600 & 11.5 & 7.8 & 34,300 & 49 & $\mathrm{C}_{4} \mathrm{~S}_{4}$ \\
\hline 0 & 1,900 & 480 & 13 & 1,500 & 1,400 & 3,550 & 19.0 & 7.7 & 4,660 & 5.9 & $\mathrm{C}_{4} \mathrm{~S}_{2}$ \\
\hline - & 5,700 & 6,700 & 32 & 2,700 & - & 21,200 & 24 & - & - & - & - \\
\hline 0 & 7,400 & 10,000 & 23 & 1,800 & 570 & 28,600 & 21.5 & 8.3 & 37,000 & 98 & $\mathrm{C}_{4} \mathrm{~S}_{4}$ \\
\hline- & 6,800 & 9,000 & - & - & - & 26,100 & 30 & - & - & - & - \\
\hline- & 5,400 & 5,200 & 20 & 2,700 & - & 17,700 & 26.5 & - & - & - & - \\
\hline 0 & 2,800 & 1,100 & 21 & 2,200 & 1,600 & 6,320 & - & 7.6 & 8,530 & 12 & $\mathrm{C}_{4} \mathrm{~S}_{4}$ \\
\hline - & 2,000 & 150 & - & - & - & 6,400 & 18.5 & - & - & - & - \\
\hline
\end{tabular}




\begin{tabular}{|c|c|c|c|c|c|c|c|c|c|}
\hline $\begin{array}{l}\text { Location } \\
\text { number }\end{array}$ & $\begin{array}{l}\text { Local well } \\
\text { or } \\
\text { spring name }\end{array}$ & $\begin{array}{l}\text { Date } \\
\text { of } \\
\text { collec- } \\
\text { tion }\end{array}$ & $\begin{array}{l}\text { Labor- } \\
\text { atory }\end{array}$ & $\begin{array}{l}\text { Pumping } \\
\text { rate } \\
\text { (gallon } \\
\text { per } \\
\text { minute) }\end{array}$ & $\begin{array}{l}\mathrm{CaI-} \\
\text { clum }\end{array}$ & $\begin{array}{l}\text { Mag- } \\
\text { nes I um }\end{array}$ & Sod i um & $\begin{array}{l}\text { Potas- } \\
\text { slum }\end{array}$ & $\begin{array}{l}\text { Blcar- } \\
\text { bonate } \\
\text { (as } \\
\mathrm{HCO}_{3} \text { ) }\end{array}$ \\
\hline \multirow[t]{2}{*}{7.4 .11 .431} & Lucero & $09-04-41$ & USGS & - & 640 & 180 & 300 & 26 & 630 \\
\hline & Spg. & $05-28-75$ & USGS & - & - & - & 300 & 15 & - \\
\hline 8.2 .1 .333 & RWP 3 & $06-05-75$ & USGS & - & 140 & 53 & 1,100 & 28 & 565 \\
\hline 8.2 .7 .314 & $\begin{array}{c}\text { Miranda } \\
\text { Spg. }\end{array}$ & $04-21-75$ & USGS & - & 260 & 130 & 7,400 & 440 & 1,780 \\
\hline 8.2 .19 .421 & $\begin{array}{l}\text { El ojo } \\
\text { Escond I do }\end{array}$ & $09-24-73$ & $B \mid A$ & - & 270 & 110 & 580 & 11 & 190 \\
\hline 8.2 .20 .332 & $\begin{array}{l}\text { Ojo Es- } \\
\text { cond Ido }\end{array}$ & $\begin{array}{l}09-08-41 \\
09-24-73\end{array}$ & $\begin{array}{l}\text { USGS } \\
\text { BIA }\end{array}$ & - & $\begin{array}{l}33 \\
42\end{array}$ & $\begin{array}{l}20 \\
22\end{array}$ & $\begin{array}{l}23 \\
25\end{array}$ & $\begin{array}{l}5.6 \\
5.5\end{array}$ & $\begin{array}{l}220 \\
230\end{array}$ \\
\hline $8.2 \cdot 20.423$ & $\begin{array}{l}\text { Salt } \\
\text { Spq. }\end{array}$ & $\begin{array}{l}09-24-73 \\
04-21-75\end{array}$ & $\begin{array}{l}\text { BIA } \\
\text { USGS }\end{array}$ & - & $\begin{array}{l}630 \\
570\end{array}$ & $\begin{array}{l}120 \\
150\end{array}$ & 8,100 & 6.3 & 2,810 \\
\hline \multirow[t]{2}{*}{$8 \cdot 2 \cdot 30 \cdot 342$} & Salt & $09-03-41$ & USGS & - & 520 & 170 & 6,700 & 200 & 1,360 \\
\hline & Spg. 193 & $04-21-75$ & USGS & - & 560 & 350 & 11,000 & 320 & 1,530 \\
\hline \multirow[t]{2}{*}{$8 \cdot 3 \cdot 10 \cdot 222$} & Suwanee & $10-12-48$ & USGS & - & 260 & 120 & 500 & - & 230 \\
\hline & Spg. & $09-24-73$ & $B \mid A$ & - & 280 & 100 & 510 & 7.8 & 180 \\
\hline 8.3 .11 .232 & $\operatorname{ccc} 1$ & $04-21-75$ & USGS & - & 250 & 100 & 530 & 12 & 219 \\
\hline \multirow[t]{3}{*}{8.3 .12 .413} & Dipping & $12-07-57$ & USGS & - & 270 & 110 & 600 & 11 & 220 \\
\hline & Vat Spg. & $09-14-73$ & $B \mid A$ & - & 270 & 110 & 540 & 12 & 190 \\
\hline & & $04-21-75$ & USGS & - & 270 & 100 & 560 & 12 & 230 \\
\hline \multirow[t]{2}{*}{8.3 .15 .413} & United & $11-29-63$ & USGS & - & 680 & 180 & 3,500 & 120 & 2,390 \\
\hline & Brokers & $05-28-75$ & USGS & - & - & - & 3,300 & 110 & - \\
\hline 8.3 .20 .211 & McGaughys & $02-08-57$ & USGS & - & 450 & 250 & - & 380 & 160 \\
\hline
\end{tabular}




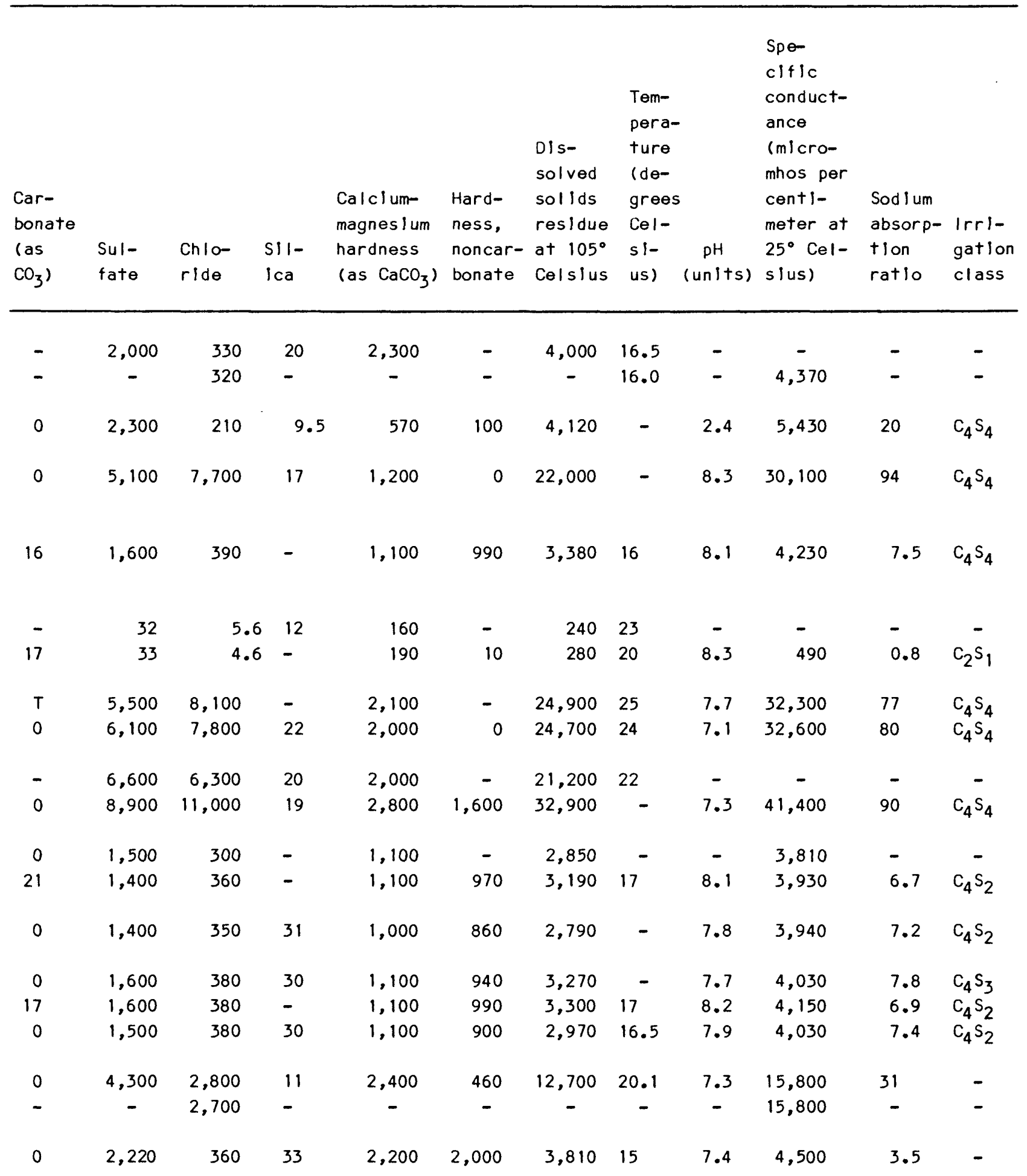




\begin{tabular}{|c|c|c|c|c|c|c|c|c|c|}
\hline $\begin{array}{l}\text { Location } \\
\text { number }\end{array}$ & $\begin{array}{l}\text { Local well } \\
\text { or } \\
\text { spring name }\end{array}$ & $\begin{array}{l}\text { Date } \\
\text { of } \\
\text { collec- } \\
\text { tion }\end{array}$ & $\begin{array}{l}\text { Labor- } \\
\text { atory }\end{array}$ & $\begin{array}{l}\text { Pumpling } \\
\text { rate } \\
\text { (gallon } \\
\text { per } \\
\text { minute) }\end{array}$ & $\begin{array}{l}\text { Cal- } \\
\text { clum }\end{array}$ & $\begin{array}{l}\text { Mag- } \\
\text { nesium }\end{array}$ & Sod I um & $\begin{array}{l}\text { Potas- } \\
\text { sium }\end{array}$ & $\begin{array}{l}\text { Bicar- } \\
\text { bonate } \\
\text { (as } \\
\mathrm{HCO}_{3} \text { ) }\end{array}$ \\
\hline 8.3 .35 .114 & $\begin{array}{c}\text { Spring } \\
194\end{array}$ & $09-03-41$ & USGS & - & 65 & 18 & 43 & 3.9 & 380 \\
\hline $8 \cdot 4 \cdot 15 \cdot 123$ & ECW 10 & $10-29-73$ & $B \mid A$ & - & 66 & 45 & 730 & 1.2 & 460 \\
\hline 8.5 .12 .311 & RWP 21 & $11-16-73$ & $B \mid A$ & - & 460 & 24 & 360 & 5.5 & 48 \\
\hline 8.5 .17 .213 & - & $\begin{array}{l}04-04-74 \\
06-12-75\end{array}$ & $\begin{array}{l}\text { BIA } \\
\text { USGS }\end{array}$ & - & $\begin{array}{c}4,700 \\
-\end{array}$ & $\begin{array}{c}370 \\
-\end{array}$ & $\begin{array}{l}12,000 \\
12,000\end{array}$ & $\begin{array}{l}T \\
7.8\end{array}$ & $\begin{array}{l}10 \\
-\end{array}$ \\
\hline 8.5 .36 .423 & ECW 8 & $11-02-73$ & $B \backslash A$ & - & 36 & 19 & 85 & 1.2 & 230 \\
\hline 8.6 .36 .432 & Thompson & $11-08-73$ & $B \mid A$ & - & 4.0 & $T$ & 420 & $\mathrm{~T}$ & 710 \\
\hline 9.1 .4 .432 & Stuckys & $06-05-75$ & USGS & - & 45 & 13 & 1,000 & 7.1 & 900 \\
\hline 9.2 .9 .433 & ECW 8 & $\begin{array}{c}1940 \\
07-03-74\end{array}$ & $\begin{array}{l}\text { USGS } \\
B \backslash A\end{array}$ & - & $\begin{array}{l}28 \\
26\end{array}$ & $\begin{array}{l}10 \\
11\end{array}$ & $\begin{array}{l}1,600 \\
1,300\end{array}$ & -.78 & $\begin{array}{l}510 \\
550\end{array}$ \\
\hline 9.2 .24 .230 & $\begin{array}{l}\text { BIA } \\
\text { Sed } 1110\end{array}$ & $04-29-80$ & $B \mid A$ & 12 & 8.0 & $\mathrm{~T}$ & 380 & 10 & $440^{*}$ \\
\hline 9.2 .27 .422 & RWP 9 & $09-24-73$ & $B \mid A$ & - & 34 & 7.3 & 52 & 3.9 & 180 \\
\hline 9.3 .22 .443 & $\begin{array}{c}\text { Coyote } \\
\text { Spg. }\end{array}$ & $04-26-73$ & $B \mid A$ & - & 220 & 24 & 890 & $T$ & 150 \\
\hline $9.4 \cdot 16.341$ & RWP 16 & $05-01-59$ & USGS & - & - & - & - & - & - \\
\hline 9.4 .29 .323 & Fernando & $05-01-73$ & $B \mid A$ & - & 420 & 55 & 470 & $T$ & 140 \\
\hline
\end{tabular}




\begin{tabular}{|c|c|c|c|c|c|c|c|c|c|c|c|}
\hline $\begin{array}{l}\text { Car- } \\
\text { bonate } \\
(\text { as } \\
\mathrm{CO}_{3} \text { ) }\end{array}$ & $\begin{array}{l}\text { Sul- } \\
\text { fate }\end{array}$ & $\begin{array}{l}\text { Chlo- } \\
\text { ride }\end{array}$ & $\begin{array}{l}\text { SII- } \\
\text { lca }\end{array}$ & $\begin{array}{l}\text { Calclum- } \\
\text { magnes lum } \\
\text { hardness } \\
\text { (as } \mathrm{CaCO}_{3} \text { ). }\end{array}$ & $\begin{array}{l}\text { Hard- } \\
\text { ness, } \\
\text { noncar- } \\
\text { bonate }\end{array}$ & $\begin{array}{l}\text { Dis- } \\
\text { solved } \\
\text { sollids } \\
\text { residue } \\
\text { at } 105^{\circ} \\
\text { Celslus }\end{array}$ & $\begin{array}{l}\text { Tem- } \\
\text { pera- } \\
\text { ture } \\
\text { (de- } \\
\text { grees } \\
\text { Cel- } \\
\text { si- } \\
\text { us) }\end{array}$ & (unlts) & $\begin{array}{l}\text { Spe- } \\
\text { clflc } \\
\text { conduct- } \\
\text { ance } \\
\text { (mlcro- } \\
\text { mhos per } \\
\text { centl- } \\
\text { meter at } \\
25^{\circ} \text { Cel- } \\
\text { slus) }\end{array}$ & $\begin{array}{l}\text { Sodlum } \\
\text { absorp- } \\
\text { tlon } \\
\text { ratio }\end{array}$ & $\begin{array}{l}\text { Irri- } \\
\text { gation } \\
\text { class }\end{array}$ \\
\hline- & 13 & 31 & 28 & 240 & - & 360 & 18.5 & - & - & - & - \\
\hline 16 & 1,100 & 320 & - & 350 & - & 2,570 & - & 8.0 & 3,470 & 17 & - \\
\hline$T$ & 1,700 & 99 & - & 1,300 & 1,200 & 2,750 & - & 7.7 & 3,290 & 4.4 & - \\
\hline$T$ & 940 & 28,000 & - & 13,000 & 13,000 & 52,200 & - & 7.1 & 82,800 & 44 & - \\
\hline - & - & 27,000 & - & - & - & - & 18.5 & - & 65,000 & - & - \\
\hline 9 & 130 & 19 & - & 170 & - & 437 & 17 & 8.0 & 720 & 2.8 & - \\
\hline 40 & 120 & 110 & - & 10 & - & 1,200 & 16.5 & 8.3 & 1,630 & 57 & - \\
\hline 0 & 1,300 & 200 & 13 & 170 & 0 & 3,030 & - & 8.1 & 4,360 & 34 & - \\
\hline 50 & 2,800 & 84 & - & - & - & 4,990 & - & - & - & - & - \\
\hline 41 & 2,300 & 83 & - & 110 & - & 4,170 & - & 8.4 & 6,900 & 53 & - \\
\hline $31 *$ & 320 & 60 & - & 20 & 0 & 1,070 & - & 8.8 & $1,600^{*}$ & 37 & $\mathrm{C}_{3} \mathrm{~S}_{4}$ \\
\hline 19 & 44 & 4.6 & - & 110 & - & 290 & 20 & 8.1 & 460 & 2.1 & - \\
\hline 12 & 2,100 & 63 & - & 660 & 540 & 3,570 & - & 8.3 & 4,400 & 15 & - \\
\hline- & - & 330 & - & - & - & - & - & - & 3,870 & - & - \\
\hline 12 & 1,800 & 140 & - & 1,300 & 1,200 & 3,230 & 13 & 8.2 & 3,660 & 5.8 & - \\
\hline
\end{tabular}




\begin{tabular}{|c|c|c|c|c|c|c|c|c|c|}
\hline $\begin{array}{l}\text { Location } \\
\text { number }\end{array}$ & $\begin{array}{l}\text { Local well } \\
\text { or } \\
\text { spring name }\end{array}$ & $\begin{array}{l}\text { Date } \\
\text { of } \\
\text { collec- } \\
\text { tion }\end{array}$ & $\begin{array}{l}\text { Labor- } \\
\text { atory }\end{array}$ & $\begin{array}{l}\text { Pumpling } \\
\text { rate } \\
\text { (gallon } \\
\text { per } \\
\text { minute) }\end{array}$ & $\begin{array}{l}\mathrm{Cal}- \\
\text { clum }\end{array}$ & $\begin{array}{l}\text { Mag- } \\
\text { nesium }\end{array}$ & Sod i um & $\begin{array}{l}\text { Potas- } \\
\text { sium }\end{array}$ & $\begin{array}{l}\text { Blcar- } \\
\text { bonate } \\
\text { (as } \\
\mathrm{HCO}_{3} \text { ) }\end{array}$ \\
\hline $9.4 .33 .223 a$ & Pino 2 & $05-03-73$ & $\mathrm{BI} A$ & - & 340 & 100 & 910 & 18 & 270 \\
\hline \multirow[t]{2}{*}{9.5 .4 .133} & ATSF & $03-19-65$ & USGS & - & 300 & 76 & - & 160 & 210 \\
\hline & & $09-13-73$ & $B \mid A$ & - & 310 & 63 & 170 & 5.1 & 190 \\
\hline \multirow[t]{3}{*}{9.5 .9 .231} & Laguna & $11-13-78$ & $B \mid A$ & 50 & 630 & 43 & 170 & 10 & $107^{*}$ \\
\hline & $78-1$ & $11-29-78$ & $B \mid A$ & 40 & 580 & 30 & 230 & 5.9 & $120^{*}$ \\
\hline & & $12-21-78$ & $B \mid A$ & 70 & 550 & 24 & 310 & 5.9 & $130^{*}$ \\
\hline \multirow[t]{4}{*}{9.5 .12 .442} & Mesita & $09-19-63$ & USGS & - & 510 & 300 & 5,500 & 32 & 1,320 \\
\hline & test & $11-10-64$ & USGS & - & 320 & 330 & 4,100 & 59 & 1,770 \\
\hline & & $12-03-73$ & $B \mid A$ & - & 180 & 150 & 3,200 & 28 & 1,500 \\
\hline & & $06-12-75$ & USGS & - & - & - & 2,900 & 31 & - \\
\hline \multirow[t]{2}{*}{9.5 .13 .233} & Mesita & $03-19-65$ & USGS & - & 95 & 38 & - & 230 & 220 \\
\hline & P.S. & $01-19-73$ & PHS & - & 72 & 28 & 220 & 13 & 200 \\
\hline 9.5 .13 .411 & Burnell 2 & $05-02-63$ & USGS & - & 74 & 28 & - & 320 & 270 \\
\hline 9.5 .14 .244 & Burnel I I & 1963 & USGS & - & - & - & - & - & \\
\hline 9.5 .19 .234 & $\begin{array}{l}\text { Test } \\
\text { hole } 2\end{array}$ & $08-23-66$ & USGS & - & - & - & - & - & 264 \\
\hline 9.5 .19 .421 & $\begin{array}{l}\text { Test } \\
\text { hole } 5\end{array}$ & $08-23-66$ & USGS & - & - & - & - & - & 208 \\
\hline 9.5 .24 .413 & EPNG 3 & $02-25-57$ & $P$ & - & - & - & - & - & - \\
\hline 9.5 .29 .232 & RWP 25 & $12-11-73$ & $B \mid A$ & - & 240 & 27 & 350 & 4.3 & 210 \\
\hline
\end{tabular}




\begin{tabular}{|c|c|c|c|c|c|c|c|c|c|c|c|}
\hline $\begin{array}{l}\text { Car- } \\
\text { bonate } \\
\text { (as } \\
\mathrm{CO}_{3} \text { ) }\end{array}$ & $\begin{array}{l}\text { Sul- } \\
\text { fate }\end{array}$ & $\begin{array}{l}\text { Chlo- } \\
\text { ride }\end{array}$ & $\begin{array}{l}\text { SII- } \\
\text { ica }\end{array}$ & $\begin{array}{l}\text { Calclum- } \\
\text { magneslum } \\
\text { hardness } \\
\text { (as } \mathrm{CaCO}_{3} \text { ) }\end{array}$ & $\begin{array}{l}\text { Hard- } \\
\text { ness, } \\
\text { noncar- } \\
\text { bonate }\end{array}$ & $\begin{array}{l}\text { Dis- } \\
\text { solved } \\
\text { sollds } \\
\text { residue } \\
\text { at } 105^{\circ} \\
\text { Celsius }\end{array}$ & $\begin{array}{l}\text { Tem- } \\
\text { pera- } \\
\text { ture } \\
\text { (de- } \\
\text { grees } \\
\text { Cel- } \\
\text { sl- } \\
\text { us) }\end{array}$ & $\begin{array}{c}\mathrm{pH} \\
(\text { unlts) }\end{array}$ & $\begin{array}{l}\text { Spe- } \\
\text { ciflc } \\
\text { conduct- } \\
\text { ance } \\
\text { (micro- } \\
\text { mhos per } \\
\text { centl- } \\
\text { meter at } \\
25^{\circ} \text { Cel- } \\
\text { slus) }\end{array}$ & $\begin{array}{l}\text { Sod lum } \\
\text { absorp- } \\
\text { tlon } \\
\text { ratio }\end{array}$ & $\begin{array}{l}\text { Irr|- } \\
\text { gation } \\
\text { class }\end{array}$ \\
\hline 19 & 2,000 & 630 & - & 1,300 & 1,100 & 4,620 & 15.5 & 8.2 & 5,640 & 11 & - \\
\hline 0 & 1,000 & 110 & 27 & 1,100 & 890 & 1,810 & - & 7.6 & 2,280 & 2.1 & - \\
\hline 13 & 1,000 & 220 & - & 1,000 & 880 & 1,980 & 15.5 & 8.1 & 2,390 & 2.4 & - \\
\hline$T^{*}$ & 1,880 & 77 & - & 1,750 & 1,660 & 3,050 & 15.0 & 7.6 & 3,100 & 1.8 & $\mathrm{C}_{4} \mathrm{~S}_{1}$ \\
\hline$T^{*}$ & 1,980 & 35 & - & 1,580 & 1,480 & 3,110 & - & 8.2 & 3,200 & 3.0 & $\mathrm{C}_{4} \mathrm{~S}_{1}$ \\
\hline$T^{*}$ & 1,950 & 37 & - & 1,480 & 1,370 & 3,150 & 17.0 & 7.4 & 3,500 & 3.5 & $\mathrm{C}_{4} \mathrm{~S}_{2}$ \\
\hline 0 & 4,800 & 5,800 & 14 & 2,500 & 1,400 & 17,700 & - & 7.3 & 23,200 & 48 & - \\
\hline 0 & 4,300 & 3,700 & 14 & 2,200 & 710 & 13,700 & 31.7 & 6.7 & 18,000 & 38 & - \\
\hline 62 & 3,300 & 2,000 & - & 1,100 & - & 9,770 & 26.5 & 8.3 & 13,000 & 42 & - \\
\hline - & - & 2,000 & - & - & - & - & 26.0 & - & - & - & - \\
\hline 0 & 550 & 86 & 25 & 390 & 210 & 1,140 & - & 7.8 & 1,660 & 5.0 & - \\
\hline$T$ & 450 & 79 & - & - & - & - & - & - & 1,440 & 5.6 & - \\
\hline 0 & 550 & 110 & 20 & 300 & 76 & 1,270 & - & 7.5 & 1,850 & 8.0 & $\mathrm{C}_{3} \mathrm{~S}_{2}$ \\
\hline- & 470 & 290 & - & - & - & - & - & - & 2,340 & - & - \\
\hline 0 & 38 & 11 & 10 & - & - & - & - & - & 510 & - & - \\
\hline 0 & 22 & 4.3 & 9.9 & - & - & - & - & - & 370 & - & - \\
\hline- & 360 & 4 & - & 60 & - & 920 & - & 8.5 & - & - & - \\
\hline$T$ & 1,200 & 34 & - & 720 & 550 & 2,090 & - & 8.1 & 2,670 & 5.7 & $\mathrm{C}_{4} \mathrm{~S}_{2}$ \\
\hline
\end{tabular}




\begin{tabular}{|c|c|c|c|c|c|c|c|c|c|}
\hline $\begin{array}{l}\text { Location } \\
\text { number }\end{array}$ & $\begin{array}{l}\text { Local well } \\
\text { or } \\
\text { spring name }\end{array}$ & $\begin{array}{l}\text { Date } \\
\text { of } \\
\text { collec- } \\
\text { tion }\end{array}$ & $\begin{array}{l}\text { Labor- } \\
\text { atory }\end{array}$ & $\begin{array}{l}\text { Pumplng } \\
\text { rate } \\
\text { (gallon } \\
\text { per } \\
\text { minute) }\end{array}$ & $\begin{array}{l}\text { Cal- } \\
\text { clum }\end{array}$ & $\begin{array}{l}\text { Mag- } \\
\text { neslum }\end{array}$ & Sod I um & $\begin{array}{l}\text { Potas- } \\
\text { slum }\end{array}$ & $\begin{array}{l}\text { Bicar- } \\
\text { bonate } \\
\text { (as } \\
\mathrm{HCO}_{3} \text { ) }\end{array}$ \\
\hline \multirow[t]{2}{*}{9.6 .2 .123} & Laguna & $01-27-77$ & USGS & 4.5 & 130 & 90 & 410 & 6.6 & 420 \\
\hline & $76-7$ & $08-24-78$ & $B \mid A$ & 20 & 160 & 110 & 450 & 6.3 & $400 *$ \\
\hline 9.6 .4 .243 & Mooney & $10-21-74$ & $B \mid A$ & - & 78 & 95 & 420 & 1.6 & 92 \\
\hline \multirow[t]{2}{*}{9.6 .4 .433} & Standard & $10-19-74$ & $B \mid A$ & - & 4.0 & 2.4 & 940 & 2.0 & 190 \\
\hline & & $06-12-75$ & USGS & - & - & - & 870 & 6.8 & - \\
\hline $9 \cdot 6 \cdot 5 \cdot 222$ & $\begin{array}{c}\text { Laguna } \\
76-6\end{array}$ & $01-25-77$ & USGS & 125 & 80 & 75 & 400 & 8.6 & 430 \\
\hline $9.6 \cdot 10.124$ & $\begin{array}{l}\text { Casa } \\
\text { Blanca }\end{array}$ & $11-16-73$ & $B \mid A$ & - & 76 & 12 & 19 & 3.5 & 290 \\
\hline $9 \cdot 6 \cdot 13.322$ & $\begin{array}{l}\text { Trans- } \\
\text { western } 2\end{array}$ & $05-12-67$ & PHS & - & 5.0 & 3.5 & 230 & 2.3 & 450 \\
\hline 9.6 .13 .343 & $\begin{array}{l}\text { Trans- } \\
\text { western } 1\end{array}$ & $05-12-67$ & PHS & - & 11 & 1.3 & 210 & 2.7 & 250 \\
\hline 9.6 .26 .233 & RWP 24 & $10-11-73$ & $B I A$ & - & 54 & 9.7 & 22 & 2.0 & 170 \\
\hline & & $12-11-78$ & $B \mid A$ & 5 & 50 & 11 & 28 & 2.4 & 210 \\
\hline 9.6 .26 .443 & TImia & $10-18-78$ & $B \mid A$ & $<1$ & 60 & 6 & 23 & 2.0 & $190^{*}$ \\
\hline $9 \cdot 6 \cdot 28 \cdot 122$ & $\begin{array}{c}\text { Turquolse } \\
\text { Spg. }\end{array}$ & $02-04-74$ & $B \mid A$ & - & 64 & .12 & 13 & 1.2 & 210 \\
\hline 9.6 .31 .143 & ECW 6 & $05-13-57$ & USGS & - & 240 & 89 & - & 270 & 270 \\
\hline 10.2 .25 .444 & $\begin{array}{c}\text { Canoñclto } \\
\text { P.S. } 2\end{array}$ & $09-26-74$ & $B \mid A$ & - & 92 & 1.2 & 380 & 5.9 & 89 \\
\hline
\end{tabular}




\begin{tabular}{|c|c|c|c|c|c|c|c|c|c|c|c|}
\hline $\begin{array}{l}\text { Car- } \\
\text { bonate } \\
\text { (as } \\
\mathrm{CO}_{3} \text { ) }\end{array}$ & $\begin{array}{l}\text { Sul- } \\
\text { fate }\end{array}$ & $\begin{array}{l}\text { Chlo- } \\
\text { ride }\end{array}$ & $\begin{array}{l}\text { Sil- } \\
\text { ica }\end{array}$ & $\begin{array}{l}\text { Calclum- } \\
\text { magnesium } \\
\text { hardness } \\
\text { (as } \mathrm{CaCO}_{3} \text { ) }\end{array}$ & $\begin{array}{l}\text { Hard- } \\
\text { ness, } \\
\text { noncar- } \\
\text { bonate }\end{array}$ & $\begin{array}{l}\text { Dis- } \\
\text { solved } \\
\text { solids } \\
\text { residue } \\
\text { at } 105^{\circ} \\
\text { Celsius }\end{array}$ & $\begin{array}{l}\text { Tem- } \\
\text { pera- } \\
\text { ture } \\
\text { (de- } \\
\text { grees } \\
\text { Cel- } \\
\text { si- } \\
\text { us) }\end{array}$ & $\begin{array}{c}\mathrm{pH} \\
\text { (units) }\end{array}$ & $\begin{array}{l}\text { Spe- } \\
\text { ciflc } \\
\text { conduct- } \\
\text { ance } \\
\text { (m) cro-- } \\
\text { mhos per } \\
\text { centl- } \\
\text { meter at } \\
25^{\circ} \text { Cel- } \\
\text { sius) }\end{array}$ & $\begin{array}{l}\text { Sodium } \\
\text { absorp- } \\
\text { tion } \\
\text { ratio }\end{array}$ & $\begin{array}{l}\text { Irri- } \\
\text { gation } \\
\text { class }\end{array}$ \\
\hline 0 & 970 & 220 & 25 & 700 & 360 & 2,060 & - & 7.6 & 2,900 & 6.7 & $\mathrm{C}_{4} \mathrm{~S}_{2}$ \\
\hline$T^{*}$ & 1,110 & 230 & - & 850 & 510 & 2,460 & - & 8.0 & $3,100 *$ & 6.8 & $\mathrm{C}_{4} \mathrm{~s}_{2}$ \\
\hline 12 & 210 & 260 & 12 & 390 & 310 & 1,800 & - & 7.2 & 2,590 & 9.3 & $\mathrm{C}_{4} \mathrm{~S}_{3}$ \\
\hline 97 & 1,600 & 83 & 16.5 & 20 & - & 2,910 & - & 9.8 & 4,120 & 92 & $\mathrm{C}_{4} \mathrm{~S}_{4}$ \\
\hline - & - & 80 & - & - & - & - & 15.0 & - & 4,200 & - & - \\
\hline 0 & 790 & 170 & 32 & 510 & 160 & 1,770 & - & 7.8 & 2,500 & 7.7 & $\mathrm{C}_{4} \mathrm{~S}_{2}$ \\
\hline$T$ & 24 & 3.6 & 15 & 240 & 3 & 350 & - & 8.2 & 520 & .5 & $c_{2} s_{1}$ \\
\hline 23 & 110 & 13 & - & 27 & - & 910 & - & 8.7 & 1,110 & - & - \\
\hline 8 & 270 & 15 & - & 61 & - & 770 & - & 8.5 & 1,150 & - & - \\
\hline 11 & 43 & 17 & - & 170 & 33 & 270 & 16 & 8.3 & 460 & .7 & $\mathrm{C}_{2} \mathrm{~s}_{1}$ \\
\hline 0 & 38 & 18 & - & 180 & 15 & 260 & 14.5 & 7.8 & 480 & 0.9 & $\mathrm{c}_{2} \mathrm{~s}_{1}$ \\
\hline - & 39 & 16 & - & 180 & 21 & 280 & - & 8.2 & $450^{*}$ & 0.8 & $\mathrm{c}_{2} \mathrm{~s}_{1}$ \\
\hline 6 & 28 & 20 & - & 210 & 35 & 255 & - & 8.2 & 440 & .4 & $c_{2} s_{1}$ \\
\hline 0 & 1,200 & 60 & 21 & 970 & 740 & 2,000 & 14.4 & 7.4 & 2,530 & 3.7 & $\mathrm{C}_{4} \mathrm{~S}_{1}$ \\
\hline$T$ & 870 & 53 & - & 280 & 180 & 1,570 & - & - & 2,180 & 9.8 & $\mathrm{C}_{3} \mathrm{~S}_{3}$ \\
\hline
\end{tabular}




\begin{tabular}{|c|c|c|c|c|c|c|c|c|c|}
\hline $\begin{array}{l}\text { Location } \\
\text { number }\end{array}$ & $\begin{array}{l}\text { Local well } \\
\text { or } \\
\text { spring name }\end{array}$ & $\begin{array}{l}\text { Date } \\
\text { of } \\
\text { collec- } \\
\text { tion }\end{array}$ & $\begin{array}{l}\text { Labor- } \\
\text { atory }\end{array}$ & $\begin{array}{l}\text { Pumping } \\
\text { rate } \\
\text { (gallon } \\
\text { per } \\
\text { minute) }\end{array}$ & $\begin{array}{l}\text { Cal- } \\
\text { clum }\end{array}$ & $\begin{array}{l}\text { Mag- } \\
\text { nes l um }\end{array}$ & Sodl um & $\begin{array}{l}\text { Potas- } \\
\text { slum }\end{array}$ & $\begin{array}{l}\text { Bicar- } \\
\text { bonate } \\
\text { (as } \\
\mathrm{HCO}_{3} \text { ) }\end{array}$ \\
\hline 10.4 .8 .344 & ECW 3 & $04-04-74$ & $\mathrm{~B} \mid \mathrm{A}$ & - & 58 & 6.1 & 390 & 2.7 & 280 \\
\hline 10.4 .30 .414 & RWP 28 & $03-15-74$ & $\mathrm{BI} A$ & - & 370 & 18 & 260 & 3.3 & 180 \\
\hline 10.4 .36 .224 & RWP 32 & $03-27-68$ & PHS & - & 36 & 12 & 650 & 5.9 & 480 \\
\hline 10.5 .4 .323 & $P-10$ & $11-25-74$ & $P$ & - & 11 & 2 & 450 & - & 370 \\
\hline \multirow[t]{2}{*}{10.5 .14 .234} & Sinkhole & $08-03-72$ & $\mathrm{~B} \mid \mathrm{A}$ & - & 98 & 39 & 350 & 6.7 & 200 \\
\hline & & $10-19-74$ & $B \mid A$ & - & 108 & 39 & 370 & 2.3 & 180 \\
\hline \multirow[t]{3}{*}{10.6 .3 .111} & Encinal & $09-11-52$ & USGS & - & 20 & 9.8 & - & 300 & 400 \\
\hline & 1 & $03-25-65$ & USGS & - & 22 & 8.5 & - & 350 & 400 \\
\hline & & $11-17-78$ & $B \mid A$ & 12 & 160 & 45 & 46 & 4.7 & 280 \\
\hline $10 \cdot 6.3 .334$ & 871 & $02-20-51$ & USGS & - & 130 & 67 & - & 160 & 300 \\
\hline \multirow[t]{2}{*}{10.6 .9 .121} & Enclnal & $12-13-66$ & PHS & - & 120 & 68 & 110 & 4.7 & 380 \\
\hline & 2 & $11-07-78$ & USGS & 69 & 140 & 59 & 110 & 4.3 & 480 \\
\hline \multirow[t]{2}{*}{10.6 .25 .242} & Frog & $11-26-73$ & $B \backslash A$ & - & 26 & 51 & 270 & 7.4 & 190 \\
\hline & Pond Spg. & & & & & & & & \\
\hline \multirow[t]{2}{*}{10.6 .31 .434} & Seama P.S. & $03-18-65$ & USGS & - & 97 & 53 & - & 180 & 380 \\
\hline & & $01-19-73$ & PHS & - & 96 & 55 & 250 & 9.4 & 390 \\
\hline 10.6 .31 .443 & $\begin{array}{l}\text { Ir. } \\
\text { Test } 7\end{array}$ & $05-25-60$ & USGS & - & 100 & 47 & - & 180 & 360 \\
\hline 10.6 .33 .122 & $\begin{array}{l}\text { Paraje } \\
\text { deep test }\end{array}$ & $12-09-52$ & USGS & - & - & - & - & - & 520 \\
\hline 10.6 .33 .213 & ECW 12 & $10-20-52$ & USGS & - & 130 & 31 & - & 530 & 420 \\
\hline
\end{tabular}




\begin{tabular}{|c|c|c|c|c|c|c|c|c|c|c|c|}
\hline $\begin{array}{l}\text { Car- } \\
\text { bonate } \\
(\text { as } \\
\mathrm{CO}_{3} \text { ) }\end{array}$ & $\begin{array}{l}\text { Sul- } \\
\text { fate }\end{array}$ & $\begin{array}{l}\text { Chlo- } \\
\text { ride }\end{array}$ & $\begin{array}{l}\text { S!l- } \\
\text { lca }\end{array}$ & $\begin{array}{l}\text { Calclum- } \\
\text { magneslum } \\
\text { hardness } \\
\text { (as } \mathrm{CaCO}_{3} \text { ) }\end{array}$ & $\begin{array}{l}\text { Hard- } \\
\text { ness, } \\
\text { noncar- } \\
\text { bonate }\end{array}$ & $\begin{array}{l}\text { Dis- } \\
\text { solved } \\
\text { sollds } \\
\text { residue } \\
\text { at } 105^{\circ} \\
\text { Celslus }\end{array}$ & $\begin{array}{l}\text { Tem- } \\
\text { pera- } \\
\text { ture } \\
\text { (de- } \\
\text { grees } \\
\text { Cel- } \\
\text { s!- } \\
\text { us) }\end{array}$ & $\begin{array}{c} \\
\mathrm{pH} \\
\text { (units) }\end{array}$ & $\begin{array}{l}\text { Spe- } \\
\text { clflc } \\
\text { conduct- } \\
\text { ance } \\
\text { (mlcro- } \\
\text { mhos per } \\
\text { centl- } \\
\text { meter at } \\
25^{\circ} \text { Cel- } \\
\text { slus) }\end{array}$ & $\begin{array}{l}\text { Sodlum } \\
\text { absorp- } \\
\text { tlon } \\
\text { ratlo }\end{array}$ & $\begin{array}{l}\text { Irri- } \\
\text { gation } \\
\text { class }\end{array}$ \\
\hline 19 & 660 & 37 & - & 170 & - & 1,390 & - & 8.5 & 2,090 & 13 & $\mathrm{C}_{3} \mathrm{~S}_{4}$ \\
\hline 9 & 1,400 & 39 & - & 990 & 840 & 2,220 & 11 & 8.0 & 2,670 & 3.6 & $\mathrm{C}_{4} \mathrm{~S}_{1}$ \\
\hline 0 & 1,100 & 37 & - & 140 & - & - & - & 8.2 & 2,810 & - & - \\
\hline- & 580 & 26 & - & - & - & 1,240 & - & 8.2 & 1,650 & - & - \\
\hline 11 & 830 & 95 & - & 410 & 240 & 1,610 & - & 8.3 & 2,240 & 7.6 & $\mathrm{C}_{3} \mathrm{~S}_{2}$ \\
\hline 24 & 800 & 100 & - & 430 & 280 & 1,700 & 14 & 8.0 & 2,310 & 7.8 & $\mathrm{C}_{4} \mathrm{~S}_{2}$ \\
\hline 0 & 370 & 20 & 12 & 90 & 0 & 940 & - & - & 1,410 & - & - \\
\hline 0 & 450 & 23 & 12 & 90 & 0 & 1,070 & - & 8.1 & 1,620 & - & - \\
\hline 0 & 420 & 9 & - & 580 & 360 & 910 & 18.0 & 7.3 & 1,130 & 0.8 & $\mathrm{C}_{3} \mathrm{~S}_{1}$ \\
\hline 0 & 560 & 80 & 50 & 610 & 360 & 1,190 & - & - & 1,650 & 2.8 & $\mathrm{C}_{3} \mathrm{~S}_{1}$ \\
\hline 0 & 400 & 25 & - & 580 & - & - & - & 7.5 & 1,370 & - & - \\
\hline 0 & 410 & 19 & 18 & 600 & 200 & 1,000 & 16.0 & 7.0 & 1,300 & 2.0 & $c_{3} s_{1}$ \\
\hline 38 & 560 & 21 & - & 270 & 120 & 1,080 & 15 & 8.9 & 1,670 & 7.2 & $\mathrm{C}_{3} \mathrm{~S}_{2}$ \\
\hline 0 & 430 & 68 & 28 & 460 & 150 & 1,050 & - & 8.0 & 1,530 & 3.7 & $c_{3} S_{1}$ \\
\hline$T$ & 520 & 92 & - & 610 & - & 1,270 & - & 7.8 & 1,760 & 5.0 & $\mathrm{C}_{3} \mathrm{~S}_{2}$ \\
\hline 0 & 420 & 70 & 36 & 440 & 150 & 1,040 & 14.4 & 7.7 & 1,510 & 3.8 & - \\
\hline 12 & - & 47 & - & 370 & 0 & - & - & - & 3,250 & - & - \\
\hline 0 & 1,200 & 37 & 13 & 450 & 110 & 2,110 & - & - & 2,810 & - & - \\
\hline
\end{tabular}




\begin{tabular}{|c|c|c|c|c|c|c|c|c|c|}
\hline $\begin{array}{l}\text { Location } \\
\text { number }\end{array}$ & $\begin{array}{l}\text { Local well } \\
\text { or } \\
\text { spring name }\end{array}$ & $\begin{array}{l}\text { Date } \\
\text { of } \\
\text { collec- } \\
\text { tion }\end{array}$ & $\begin{array}{l}\text { Labor- } \\
\text { atory }\end{array}$ & $\begin{array}{l}\text { Pumpling } \\
\text { rate } \\
\text { (gallon } \\
\text { per } \\
\text { minute) }\end{array}$ & $\begin{array}{l}\mathrm{Cal-} \\
\text { clum }\end{array}$ & $\begin{array}{l}\text { Mag- } \\
\text { neslum }\end{array}$ & Sod I um & $\begin{array}{l}\text { Potas- } \\
\text { slum }\end{array}$ & $\begin{array}{l}\mathrm{Blcar}- \\
\text { bonate } \\
\text { (as } \\
\mathrm{HCO}_{3} \text { ) }\end{array}$ \\
\hline $10 \cdot 6 \cdot 35.322$ & $\begin{array}{l}\text { Pueblo } \\
\text { test } 1\end{array}$ & $02-12-60$ & USGS & - & 62 & 50 & - & 210 & 260 \\
\hline 10.6 .35 .324 & $\begin{array}{l}\text { New } \\
\text { Laguna } \\
\text { P.S. }\end{array}$ & $\begin{array}{l}09-09-60 \\
03-25-65 \\
01-19-73\end{array}$ & $\begin{array}{l}\text { USGS } \\
\text { USGS } \\
\text { PHS }\end{array}$ & $\begin{array}{l}- \\
- \\
-\end{array}$ & $\begin{array}{l}85 \\
84 \\
78\end{array}$ & $\begin{array}{l}47 \\
56 \\
55\end{array}$ & $\begin{array}{l}- \\
- \\
240\end{array}$ & $\begin{array}{r}230 \\
250 \\
3.1\end{array}$ & $\begin{array}{l}280 \\
280 \\
320\end{array}$ \\
\hline 10.6 .35 .342 & $\begin{array}{l}\text { Pueblo } \\
\text { test } 2\end{array}$ & $03-08-60$ & USGS & - & 73 & 44 & - & 230 & 280 \\
\hline $10.7 \cdot 10.213$ & $\begin{array}{l}\text { Laguna } \\
79-1\end{array}$ & $01-16-80$ & $B \mid A$ & 10 & 52 & 25 & 400 & 24 & $530^{*}$ \\
\hline 10.7 .25 .441 & - & $03-27-53$ & USGS & - & - & - & - & - & 350 \\
\hline 10.7 .35 .232 & $\begin{array}{l}\text { Ir. } \\
\text { test } 6\end{array}$ & $\begin{array}{l}05-01-60 \\
08-14-75\end{array}$ & $\begin{array}{l}\text { USGS } \\
B \mid A\end{array}$ & - & $\begin{array}{r}99 \\
110\end{array}$ & $\begin{array}{l}81 \\
89\end{array}$ & $\begin{array}{l}570 \\
570\end{array}$ & - & $\begin{array}{l}490 \\
420^{*}\end{array}$ \\
\hline 10.7 .36 .212 & $\begin{array}{l}\text { New } \\
\text { York } 2\end{array}$ & $\begin{array}{l}08-29-70 \\
01-18-73\end{array}$ & $\begin{array}{l}\text { PHS } \\
\text { PHS }\end{array}$ & - & $\begin{array}{l}80 \\
78\end{array}$ & $\begin{array}{l}24 \\
24\end{array}$ & $\begin{array}{l}60 \\
70\end{array}$ & $\begin{array}{l}7.4 \\
8.2\end{array}$ & $\begin{array}{l}310 \\
300\end{array}$ \\
\hline 10.7 .36 .221 & $\begin{array}{l}\text { New } \\
\text { York } 1\end{array}$ & $08-29-70$ & PHS & - & 80 & 24 & 60 & 7.4 & 300 \\
\hline $10 \cdot 7 \cdot 36 \cdot 322$ & $\begin{array}{c}\text { Laguna } \\
76-2\end{array}$ & $07-14-76$ & $B \mid A$ & 80 & 100 & .100 & 600 & 11 & $520^{*}$ \\
\hline 10.7 .36 .424 & $\begin{array}{c}\text { Laguna } \\
76-1\end{array}$ & $\begin{array}{l}07-08-76 \\
07-10-76\end{array}$ & $\begin{array}{l}\text { BIA } \\
\text { USGS }\end{array}$ & - & $\begin{array}{l}120 \\
-\end{array}$ & $\begin{array}{l}47 \\
-\end{array}$ & $\begin{array}{l}120 \\
-\end{array}$ & $\begin{array}{l}10 \\
-\end{array}$ & $\begin{array}{l}320^{*} \\
-\end{array}$ \\
\hline $10 \cdot 7 \cdot 36.424 a$ & $\begin{array}{l}\text { Laguna } \\
\text { Ir. } 1\end{array}$ & $09-27-77$ & $B \mid A$ & 340 & 130 & 56 & 160 & 11 & $320^{*}$ \\
\hline 11.5 .13 .112 & LJ 205 & $09--71$ & $P$ & - & 1 & 1 & 310 & - & 260 \\
\hline
\end{tabular}




\begin{tabular}{|c|c|c|c|c|c|c|c|c|c|c|c|}
\hline $\begin{array}{l}\text { Car- } \\
\text { bonate } \\
\text { (as } \\
\left.\mathrm{CO}_{3}\right)\end{array}$ & $\begin{array}{l}\text { Sul- } \\
\text { fate }\end{array}$ & $\begin{array}{l}\text { Chlo } \\
\text { ride }\end{array}$ & $\begin{array}{l}\text { Sil- } \\
\text { ica }\end{array}$ & $\begin{array}{l}\text { Calclum- } \\
\text { magneslum } \\
\text { hardness } \\
\text { (as } \mathrm{CaCO}_{3} \text { ) }\end{array}$ & $\begin{array}{l}\text { Hard- } \\
\text { ness, } \\
\text { noncar- } \\
\text { bonate }\end{array}$ & $\begin{array}{l}\text { Dis- } \\
\text { solved } \\
\text { sollds } \\
\text { residue } \\
\text { at } 105^{\circ} \\
\text { Celslus }\end{array}$ & $\begin{array}{l}\text { Tem- } \\
\text { pera- } \\
\text { ture } \\
\text { (de- } \\
\text { grees } \\
\text { Cel- } \\
\text { sl- } \\
\text { us) }\end{array}$ & $\begin{array}{c}\mathrm{pH} \\
(u n l+s)\end{array}$ & $\begin{array}{l}\text { Spe- } \\
\text { clflic } \\
\text { conduct- } \\
\text { ance } \\
\text { (micro- } \\
\text { mhos per } \\
\text { centl- } \\
\text { meter at } \\
25^{\circ} \text { Cel- } \\
\text { sius) }\end{array}$ & $\begin{array}{l}\text { Sod lum } \\
\text { absorp- } \\
\text { tion } \\
\text { ratio }\end{array}$ & $\begin{array}{l}\text { Irri- } \\
\text { gation } \\
\text { class }\end{array}$ \\
\hline 0 & 520 & 38 & 29 & 360 & 150 & 1,040 & 15 & 8.1 & 1,460 & 4.8 & $\mathrm{C}_{3} \mathrm{~S}_{1}$ \\
\hline 0 & 590 & 42 & 27 & 400 & 180 & 1,170 & - & 7.6 & 1,650 & 5.0 & $\mathrm{C}_{3} \mathrm{~S}_{2}$ \\
\hline 0 & 650 & 48 & 28 & 440 & 210 & 1,240 & - & 7.8 & 1,760 & 5.1 & $\mathrm{C}_{3} \mathrm{~S}_{2}$ \\
\hline 19 & 500 & 61 & - & 570 & - & 1,170 & - & 8.0 & 1,450 & 5.2 & $\mathrm{C}_{3} \mathrm{~S}_{2}$ \\
\hline 0 & 560 & 43 & 24 & 360 & 140 & 1,110 & 16.1 & 7.8 & 1,570 & 5.3 & $\mathrm{C}_{3} \mathrm{~S}_{2}$ \\
\hline $12^{*}$ & 560 & 69 & 12 & 240 & 0 & 1,400 & 28.0 & 7.4 & 2,000 & 11 & $\mathrm{C}_{3} \mathrm{~S}_{3}$ \\
\hline 0 & - & 22 & - & 210 & - & - & - & 7.8 & 980 & - & - \\
\hline 0 & 1,100 & 200 & 27 & 580 & 180 & 2,310 & 15.6 & 7.6 & 3,250 & 10 & $\mathrm{C}_{4} \mathrm{~S}_{3}$ \\
\hline $40^{*}$ & 1,060 & 230 & - & 640 & 230 & 2,500 & - & 8.1 & 3,300 & 9.9 & $\mathrm{C}_{4} \mathrm{~S}_{3}$ \\
\hline 0 & 150 & 13 & - & 300 & - & 590 & - & 7.9 & 880 & - & - \\
\hline$T$ & 160 & 18 & - & - & - & - & - & 8.0 & 720 & 1.8 & $\mathrm{C}_{3} \mathrm{~S}_{1}$ \\
\hline 0 & 150 & 14 & - & 300 & - & 600 & - & 8.2 & 920 & - & - \\
\hline$T^{*}$ & 1,180 & 280 & - & 770 & 350 & 2,680 & 15.5 & 7.8 & 3,700 & 10 & $\mathrm{C}_{4} \mathrm{~S}_{3}$ \\
\hline $14^{*}$ & 340 & 66 & - & 500 & 220 & 910 & - & 8.3 & 1,350 & 2.2 & $C_{3} S_{1}$ \\
\hline- & - & - & - & - & - & - & - & 8.1 & 1,500 & - & - \\
\hline $17^{*}$ & 470 & 74 & - & 550 & 250 & 1,140 & 15.0 & 8.3 & 1,350 & 3.0 & $\mathrm{C}_{3} \mathrm{~s}_{1}$ \\
\hline 37 & 140 & 38 & - & - & - & 590 & - & - & - & - & - \\
\hline
\end{tabular}




\begin{tabular}{|c|c|c|c|c|c|c|c|c|c|}
\hline $\begin{array}{l}\text { Location } \\
\text { number }\end{array}$ & $\begin{array}{l}\text { Local well } \\
\text { or } \\
\text { spring name }\end{array}$ & $\begin{array}{l}\text { Date } \\
\text { of } \\
\text { collec- } \\
\text { tion }\end{array}$ & $\begin{array}{l}\text { Labor- } \\
\text { atory }\end{array}$ & $\begin{array}{l}\text { Pumping } \\
\text { rate } \\
\text { (gallon } \\
\text { per } \\
\text { minute) }\end{array}$ & $\begin{array}{l}\mathrm{Cal}- \\
\text { clum }\end{array}$ & $\begin{array}{l}\text { Mag- } \\
\text { nes! um }\end{array}$ & Sod i um & $\begin{array}{l}\text { Potas- } \\
\text { slum }\end{array}$ & $\begin{array}{l}\text { Bicar- } \\
\text { bonate } \\
\text { (as } \\
\mathrm{HCO}_{3} \text { ) }\end{array}$ \\
\hline 11.5 .24 .213 & Anaconda 1 & $05-14-71$ & USGS & - & 21 & 12 & 370 & 3.0 & 480 \\
\hline 11.5 .29 .444 & - & $04-16-55$ & USGS & - & 11 & 6.5 & - & 440 & 400 \\
\hline 11.5 .30 .422 & $\begin{array}{l}\text { Pueblo } \\
\text { test } 3\end{array}$ & $03-31-60$ & USGS & - & 5.5 & 1.1 & - & 150 & 230 \\
\hline 11.5 .32 .234 & $\begin{array}{l}\text { Pueblo } \\
\text { test } 5\end{array}$ & $04-22-60$ & USGS & - & 69 & 20 & - & 30 & 310 \\
\hline $11.5 .32 .234 a$ & $\begin{array}{l}\text { Paquate } \\
\text { P.S. } 1\end{array}$ & $\begin{array}{l}03-18-65 \\
01-18-73\end{array}$ & $\begin{array}{l}\text { USGS } \\
\text { PHS }\end{array}$ & $\begin{array}{l}- \\
-\end{array}$ & $\begin{array}{l}60 \\
70\end{array}$ & $\begin{array}{l}18 \\
21\end{array}$ & - & $\begin{array}{r}31 \\
300\end{array}$ & $\begin{array}{l}270 \\
250\end{array}$ \\
\hline 11.6 .22 .333 & $\begin{array}{l}\text { Encinal } \\
\text { Public } \\
\text { Supply } \\
\text { Spring }\end{array}$ & $\begin{array}{l}08-08-69 \\
01-18-73\end{array}$ & $\begin{array}{l}\text { BIA } \\
\text { PHS }\end{array}$ & - & $\begin{array}{l}19 \\
20\end{array}$ & $\begin{array}{l}4.3 \\
3.6\end{array}$ & $\begin{array}{l}11.5 \\
11.5\end{array}$ & $\begin{array}{l}3.1 \\
3.5\end{array}$ & $\begin{array}{l}93 \\
97\end{array}$ \\
\hline 11.6 .27 .334 & $\begin{array}{l}\text { Encinal } \\
\text { Canyon } 1\end{array}$ & $07-05-78$ & $B \mid A$ & 5 & 180 & 70 & 170 & 8.2 & $310^{*}$ \\
\hline 11.7 .35 .243 & $\begin{array}{l}\text { Castillo } \\
\text { Canyon } 1\end{array}$ & $08-14-78$ & $B \mid A$ & 4 & 10 & 1 & 250 & 3.5 & $620^{*}$ \\
\hline $12 \cdot 1 \cdot 18 \cdot 134$ & $\begin{array}{l}\text { Ojito } \\
\text { Spg. }\end{array}$ & $06-17-74$ & $B \mid A$ & - & 68 & 13 & 40 & $T$ & 180 \\
\hline 12.1 .29 .113 & $\begin{array}{r}\text { Conoco } \\
17-10\end{array}$ & - & $P$ & - & - & - & - & - & - \\
\hline $12 \cdot 1.30 \cdot 324$ & Conoco & $08-05-71$ & PHS & - & - & - & - & - & 420 \\
\hline & $65 A$ & $\begin{array}{r}05-13-74 \\
06-05-75 \\
-\quad-76\end{array}$ & $\begin{array}{l}\text { BIA } \\
\text { USGS } \\
P\end{array}$ & $\begin{array}{l}- \\
- \\
0\end{array}$ & $\begin{array}{l}94 \\
- \\
74\end{array}$ & $\begin{array}{l}14 \\
- \\
12\end{array}$ & $\begin{array}{l}3,100 \\
3,200 \\
3,300\end{array}$ & $\begin{array}{l}4.7 \\
10 \\
9.4\end{array}$ & $\begin{array}{l}430 \\
500 \\
380^{*}\end{array}$ \\
\hline
\end{tabular}




\begin{tabular}{|c|c|c|c|c|c|c|c|c|c|c|c|}
\hline $\begin{array}{l}\text { Car- } \\
\text { bonate } \\
\text { (as } \\
\left.\mathrm{CO}_{3}\right)\end{array}$ & $\begin{array}{l}\text { Sul- } \\
\text { fate }\end{array}$ & $\begin{array}{l}\text { Chlo- } \\
\text { ride }\end{array}$ & $\begin{array}{l}\text { Sil- } \\
\text { ica }\end{array}$ & $\begin{array}{l}\text { Calclum- } \\
\text { magnesium } \\
\text { hardness } \\
\text { (as } \mathrm{CaCO}_{3} \text { ) }\end{array}$ & $\begin{array}{l}\text { Hard- } \\
\text { ness, } \\
\text { noncar- } \\
\text { bonate }\end{array}$ & $\begin{array}{l}\text { Dis- } \\
\text { solved } \\
\text { solids } \\
\text { residue } \\
\text { at } 105^{\circ} \\
\text { Celsius }\end{array}$ & $\begin{array}{l}\text { Tem- } \\
\text { pera- } \\
\text { ture } \\
\text { (de- } \\
\text { grees } \\
\text { Cel- } \\
\text { si- } \\
\text { us) }\end{array}$ & (units) & $\begin{array}{l}\text { Spe- } \\
\text { cific } \\
\text { conduct- } \\
\text { ance } \\
\text { (micro- } \\
\text { mhos per } \\
\text { centi- } \\
\text { meter at } \\
25^{\circ} \text { Cel- } \\
\text { slus) }\end{array}$ & $\begin{array}{l}\text { Sodium } \\
\text { absorp- } \\
\text { tion } \\
\text { ratio }\end{array}$ & $\begin{array}{l}\text { Irri- } \\
\text { gation } \\
\text { class }\end{array}$ \\
\hline 0 & 470 & 16 & 13 & 100 & 0 & 1,140 & 18.0 & 7.5 & 1,750 & 16 & $\mathrm{C}_{3} \mathrm{~S}_{4}$ \\
\hline 7 & 610 & 25 & 15 & 54 & 0 & 1,310 & - & 8.4 & 1,900 & 26 & $\mathrm{C}_{3} \mathrm{~S}_{4}$ \\
\hline 5 & 120 & 7.3 & 15 & 18 & 0 & 420 & 18.9 & 8.4 & 670 & 15 & $\mathrm{C}_{2} \mathrm{~S}_{3}$ \\
\hline 0 & 53 & 7.6 & 42 & 254 & 1 & 380 & 13.3 & 7.3 & 580 & .8 & $c_{2} S_{1}$ \\
\hline 0 & 45 & 14 & 42 & 220 & 0 & 350 & - & 7.4 & 510 & .9 & $c_{2} s_{1}$ \\
\hline$T$ & 95 & 11 & - & 320 & - & 410 & - & 7.6 & 630 & .8 & $\mathrm{C}_{2} \mathrm{~S}_{1}$ \\
\hline$T$ & 6.2 & 6.0 & - & 65 & - & 110 & 15 & 7.7 & 190 & .6 & $\mathrm{C}_{1} \mathrm{~s}_{1}$ \\
\hline$T$ & 2.9 & 3.5 & - & 65 & - & 160 & - & 8.0 & 190 & .6 & $c_{1} s_{1}$ \\
\hline $10^{*}$ & 800 & 16 & - & 750 & 480 & 1,570 & 15.0 & 7.6 & 1,900 & 2.8 & $C_{3} S_{1}$ \\
\hline $14^{*}$ & 17 & 12 & - & 30 & 0 & 670 & 17.0 & 8.4 & 950 & 20 & $\mathrm{C}_{3} \mathrm{~S}_{4}$ \\
\hline 15 & 108 & 11 & - & 230 & 24 & 400 & - & 8.1 & 600 & 1.2 & $\mathrm{C}_{2} \mathrm{~S}_{1}$ \\
\hline- & - & - & - & 350 & - & 9,690 & - & 7.6 & - & - & - \\
\hline 0 & 4,000 & 2,100 & - & 290 & - & 9,630 & - & 7.6 & 14,000 & - & - \\
\hline 32 & 3,700 & 2,100 & - & 290 & - & 9,650 & - & 8.2 & 16,000 & 79 & $\mathrm{C}_{4} \mathrm{~S}_{4}$ \\
\hline- & - & 2,100 & - & - & - & - & 26.0 & 8.2 & 12,900 & - & - \\
\hline $0^{*}$ & 3,840 & 2,130 & 15 & 230 & 0 & 9,520 & - & $8.0^{*}$ & - & 510 & $\mathrm{C}_{4} \mathrm{~S}_{4}$ \\
\hline
\end{tabular}




\begin{tabular}{|c|c|c|c|c|c|c|c|c|c|}
\hline $\begin{array}{c}\text { Location } \\
\text { number }\end{array}$ & $\begin{array}{l}\text { Local well } \\
\text { or } \\
\text { spring name }\end{array}$ & $\begin{array}{l}\text { Date } \\
\text { of } \\
\text { collec- } \\
\text { tion }\end{array}$ & $\begin{array}{l}\text { Labor- } \\
\text { atory }\end{array}$ & $\begin{array}{l}\text { Pumpling } \\
\text { rate } \\
\text { (gallon } \\
\text { per } \\
\text { minute) }\end{array}$ & $\begin{array}{l}\text { Cal- } \\
\text { clum }\end{array}$ & $\begin{array}{l}\text { Mag- } \\
\text { neslum }\end{array}$ & Sod ium & $\begin{array}{l}\text { Potas- } \\
\text { slum }\end{array}$ & $\begin{array}{l}\text { Blcar- } \\
\text { bonate } \\
\text { (as } \\
\mathrm{HCO}_{3} \text { ) }\end{array}$ \\
\hline 12.1 .33 .132 & $\begin{array}{r}\text { Conoco } \\
22-10\end{array}$ & - & $P$ & - & - & - & - & - & - \\
\hline 12.2 .24 .442 & $\begin{array}{c}\text { Conoco } \\
15-9\end{array}$ & - & $\mathrm{P}$ & - & - & - & - & - & - \\
\hline 12.2 .36 .442 & $\begin{array}{l}\text { Conoco } \\
W W-101\end{array}$ & $05-29-76$ & $P$ & 1,212 & 70 & 13 & 3,300 & 10 & $250^{*}$ \\
\hline 13.2 .26 .434 & $\begin{array}{c}\text { Conoco } \\
9-8\end{array}$ & - & $\mathrm{P}$ & - & - & - & - & - & - \\
\hline
\end{tabular}




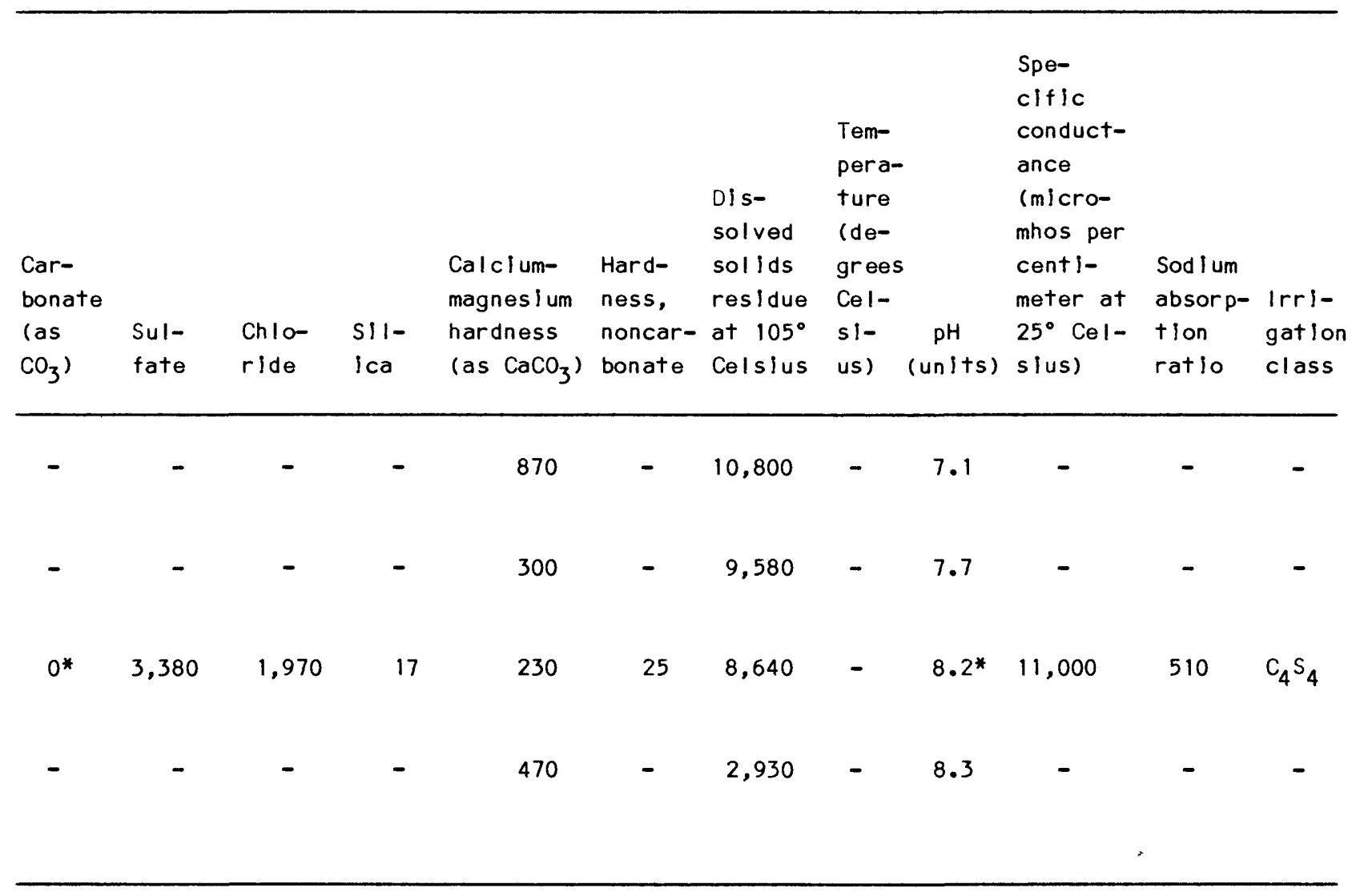


Table 6. Nutrlents and minor constltuents of water in selected wells

\section{EXPLNATION}

Location number: See text for explanation.

Note: All constituents reported in milligrans per liter. Concentrations of dissolved nitrate (as N), boron, and phosphorus (as P) were determined by U.S. Bureau of Indlan Affalrs unless marked with asterisks. Those marked with asterisks and all other concentrations were determined by U.S. Geological Survey. "Tn indicates trace concentration detected.

\begin{tabular}{|c|c|c|c|c|c|c|}
\hline Location number & $\begin{array}{l}\text { Local } \\
\text { well name }\end{array}$ & $\begin{array}{l}\text { Date of } \\
\text { collection }\end{array}$ & $\begin{array}{c}\text { Nitrate } \\
\text { (dissolved } \\
\text { as N) }\end{array}$ & $\begin{array}{c}\text { Nitrite } \\
\text { plus } \\
\text { nitrate } \\
\text { (dissolved } \\
\text { as } N \text { ) }\end{array}$ & $\begin{array}{l}\text { Nitrogen } \\
\text { (total } \\
\text { Kjeldahl } \\
\text { as } N \text { ) }\end{array}$ & $\begin{array}{c}\text { Phosphorus } \\
\text { (dlssolved } \\
\text { as P) }\end{array}$ \\
\hline \multirow[t]{3}{*}{9.5 .9 .231} & Laguna 78-1 & $11-13-78$ & 0.28 & - & - & $T$ \\
\hline & & $11-29-78$ & .01 & - & - & $T$ \\
\hline & & $12-21-78$ & .04 & 0.00 & - & $T$ \\
\hline \multirow[t]{2}{*}{9.6 .2 .123} & Laguna 76-7 & $01-27-77$ & - & .57 & 0.10 & $0.04^{*}$ \\
\hline & & $08-24-78$ & .28 & - & - & $T$ \\
\hline $9 \cdot 6 \cdot 5 \cdot 222$ & Laguna $76-6$ & $01-25-77$ & .06 & .43 & .02 & $.07^{*}$ \\
\hline 9.6 .26 .233 & RWP 24 & $12-11-78$ & .56 & 1.5 & - & $T$ \\
\hline 9.6 .26 .443 & Timia & $10-18-78$ & .28 & - & - & $T$ \\
\hline $10 \cdot 6 \cdot 3.111$ & Encinal 1 & $11-17-78$ & .07 & - & - & .05 \\
\hline $10 \cdot 6 \cdot 9 \cdot 121$ & Encinal 2 & $11-07-78$ & .04 & .05 & - & .01 \\
\hline 10.7 .10 .213 & Laguna 79-1 & $01-16-80$ & .98 & - & - & .03 \\
\hline $10 \cdot 7 \cdot 35 \cdot 232$ & Ir. Test 6 & $08-14-75$ & .14 & - & - & .11 \\
\hline $10 \cdot 7 \cdot 36.322$ & Laguna 76-2 & $07-13-76$ & .28 & - & - & $\mathrm{T}$ \\
\hline 10.7 .36 .424 & Laguna 76-1 & $07-08-76$ & 2.5 & - & - & .05 \\
\hline $10.7 .36 .424 a$ & Laguna Ir. 1 & $09-27-77$ & .14 & - & - & .90 \\
\hline 11.6 .27 .334 & Encinal Canyon 1 & $07-05-78$ & .07 & - & - & .10 \\
\hline 11.7 .35 .243 & Castillo Canyon 1 & $08-14-78$ & .14 & - & - & .01 \\
\hline
\end{tabular}




\begin{tabular}{|c|c|c|c|c|c|c|}
\hline $\begin{array}{l}\text { Phosphate } \\
\text { (total ortho } \\
\text { as } P \text { ) }\end{array}$ & $\begin{array}{l}\text { Phosphate } \\
\text { (dissolved } \\
\text { ortho as } \\
\text { as P) }\end{array}$ & $\begin{array}{l}\text { Carbon } \\
\text { (organlc, } \\
\text { total } \\
\text { as C) }\end{array}$ & $\begin{array}{l}\text { Carbon } \\
\text { (organlc, } \\
\text { dissolved } \\
\text { as C) }\end{array}$ & $\begin{array}{c}\text { Chemlcal } \\
\text { oxygen } \\
\text { demand }\end{array}$ & $\begin{array}{l}\text { Sulfide } \\
\text { (d) ssolved) }\end{array}$ & $\begin{array}{l}\text { Boron } \\
\text { (dissolved) }\end{array}$ \\
\hline- & - & - & - & - & - & 1.2 \\
\hline- & - & - & - & - & - & 0.58 \\
\hline- & 0.00 & 0.7 & - & 6.0 & - & $T$ \\
\hline 0.04 & .04 & 1.1 & - & - & - & $0.47^{*}$ \\
\hline- & - & - & - & - & - & .65 \\
\hline .07 & .06 & 0.9 & - & - & - & $.47^{*}$ \\
\hline- & .01 & - & - & 9.0 & 0.0 & .13 \\
\hline- & - & - & - & - & - & .15 \\
\hline- & .01 & - & 1.7 & 1.0 & 0.1 & .20 \\
\hline- & .01 & - & 2.0 & 4.0 & - & $.20^{*}$ \\
\hline- & - & - & - & - & - & .30 \\
\hline- & - & - & - & - & - & .40 \\
\hline- & - & - & - & - & - & 2.0 \\
\hline- & - & - & - & - & - & 0.13 \\
\hline - & - & - & - & - & - & .18 \\
\hline- & - & - & - & - & - & .29 \\
\hline- & - & - & - & - & - & .65 \\
\hline
\end{tabular}


Table 7. Trace elements of water in selected wells

\section{EXPLANATION}

Location number: See text for explanation.

Note: All constituents are reportod in micrograms per liter unless noted otherwise; concentratlons less than the detection Ilalt of the analytical method used are Indicated by "<n; "fw indicates trace concentration detected.

\section{Part I}

\begin{tabular}{|c|c|c|c|c|c|c|c|}
\hline \multirow[b]{2}{*}{ Location number } & \multirow{2}{*}{$\begin{array}{l}\text { Local } \\
\text { well name }\end{array}$} & \multirow{2}{*}{$\begin{array}{l}\text { Date of } \\
\text { collection }\end{array}$} & \multirow{2}{*}{$\begin{array}{l}\text { Al I um I num } \\
\text { (d) ssolved) }\end{array}$} & \multirow{2}{*}{$\begin{array}{l}\text { Arsenlc } \\
\text { (total) }\end{array}$} & \multicolumn{2}{|c|}{ Bar lum } & \multirow{2}{*}{$\begin{array}{l}\text { Cadmlum } \\
\text { (total) }\end{array}$} \\
\hline & & & & & (d) ssolved) & (total) & \\
\hline \multirow[t]{3}{*}{9.5 .9 .231} & Laguna $78-1$ & $11-13-78$ & - & 2 & - & 480 & $<1$ \\
\hline & & $11-29-78$ & - & 2 & - & 80 & $T$ \\
\hline & & $12-21-78$ & 0 & 4 & 0 & 140 & 8 \\
\hline \multirow[t]{2}{*}{9.6 .2 .123} & Laguna $76-7$ & $01-27-77$ & - & 2 & - & 0 & 10 \\
\hline & & $08-24-78$ & - & 1 & - & 110 & $\mathrm{~T}$ \\
\hline $9.6 \cdot 5.222$ & Laguna $76-6$ & $01-25-77$ & - & 3 & - & 0 & 10 \\
\hline $9 \cdot 6.26 .233$ & RWP 24 & $12-11-78$ & 0 & 2 & 0 & 180 & $i$ \\
\hline 9.6 .26 .443 & Timla Well & $10-18-78$ & - & $<1$ & - & 340 & 2 \\
\hline 10.6 .3 .111 & Encinal 1 & $11-17-78$ & 0 & 2 & 0 & 110 & $T$ \\
\hline 10.6 .9 .121 & Enclnal 2 & $11-07-78$ & 0 & 2 & 0 & - & 2 \\
\hline $10.7 \cdot 10.213$ & Laguna 79-1 & $01-16-78$ & - & - & 90 & - & - \\
\hline $10 \cdot 7 \cdot 36 \cdot 322$ & Laguna $76-2$ & $07-14-76$ & - & 6 & - & - & - \\
\hline \multirow[t]{2}{*}{10.7 .36 .424} & Laguna $76-1$ & $07-08-76$ & - & - & - & - & - \\
\hline & & $07-10-76$ & - & 3 & - & - & - \\
\hline 11.6 .27 .334 & Encinal Canyon & $107-05-78$ & - & $T$ & - & 220 & $\mathrm{~T}$ \\
\hline $12 \cdot 1 \cdot 30 \cdot 324$ & Conoco $65 A$ & $-\quad-76$ & $<100$ & $<10$ & $<100$ & - & $<1$ \\
\hline 12.2 .36 .442 & Conoco WW- 101 & $05-29-76$ & 6 & 10 & $<100$ & - & $<1$ \\
\hline
\end{tabular}




\begin{tabular}{|c|c|c|c|c|c|c|c|c|c|}
\hline \multirow{2}{*}{$\begin{array}{l}\text { Chromium } \\
\text { (total) }\end{array}$} & \multicolumn{2}{|c|}{ Cobalt } & & per & \multirow{2}{*}{$\begin{array}{l}\text { Flourlde } \\
\text { (dissolved, in } \\
\text { milligrams } \\
\text { per liter) }\end{array}$} & \multicolumn{2}{|c|}{$\begin{array}{c}\text { Iron } \\
\text { (m)l|| igrams } \\
\text { per ||ter) }\end{array}$} & \multicolumn{2}{|c|}{ Lead } \\
\hline & (disso & Ived)(total) & (d)ssol & $(\operatorname{total)}$ & & (d)ssol & $\overline{(t o t a l)}$ & (d)ssolv & 1) (total) \\
\hline 24 & - & - & - & - & 1.0 & .02 & 16.8 & - & $\bullet$ \\
\hline$T$ & - & - & - & - & - & $T$ & 13.5 & - & $T$ \\
\hline 8 & - & - & - & - & - & 0.01 & 1.4 & - & 90 \\
\hline 0 & - & 70 & - & $<50$ & 1.1 & 0.01 & 6.3 & - & $<100$ \\
\hline$T$ & - & - & - & - & 1.5 & 0.02 & 1.7 & - & $T$ \\
\hline 0 & - & $<50$ & - & $<50$ & 1.5 & 0.01 & 1.9 & - & $<100$ \\
\hline$T$ & - & - & - & - & 0.4 & $T$ & 0.3 & - & $T$ \\
\hline$<10$ & - & - & - & - & 0.2 & $\mathrm{~T}$ & 1.4 & - & $T$ \\
\hline$T$ & - & - & - & - & 1.2 & $T$ & 1.2 & - & $T$ \\
\hline$<10$ & 0 & - & 0 & - & 0.9 & 0.5 & 0.7 & 2 & $T$ \\
\hline- & $<3$ & - & $<10$ & - & 3.4 & 0.12 & - & $<10$ & - \\
\hline- & - & - & - & - & 1.6 & $T$ & - & - & - \\
\hline- & - & - & - & - & 1.0 & $T$ & - & - & - \\
\hline- & - & - & - & - & - & - & - & - & - \\
\hline$T$ & - & - & - & - & 0.5 & 0.01 & 11.5 & - & 62 \\
\hline$<1$ & $<1$ & - & $<1$ & - & 0.7 & 3.4 & - & $<1$ & - \\
\hline 7 & 2 & - & $<1$ & - & 0.9 & 0.2 & - & 5 & - \\
\hline
\end{tabular}


Table 7. Trace elements of water in selected wells - Concluded

\section{EXPLANATION}

Location number: See text for explanation.

Note: All analyses are reported in micrograns per IIter unless noted otherwise; concentrations less than the detection IImit of the analytical mothod used are indicated by "<"; "T" indicates trace concentration detected.

\section{Part II}

Lithium

(dlssolved) (total)

$\frac{\text { Manganese }}{\text { (dissolved) (total) }}$

Mercury total

\begin{tabular}{|c|c|c|c|c|c|c|}
\hline \multirow[t]{3}{*}{9.5 .9 .231} & Laguna 78-1 & - & - & - & - & $<2$ \\
\hline & & - & - & - & - & $<2$ \\
\hline & & - & - & - & 120 & $<2$ \\
\hline \multirow[t]{2}{*}{9.6 .2 .123} & Laguna $76-7$ & 250 & 260 & - & 350 & .1 \\
\hline & & - & - & - & - & $T$ \\
\hline 9.6 .5 .222 & Laguna 76-6 & 370 & 390 & - & 110 & .1 \\
\hline 9.6 .26 .233 & RWP 24 & - & - & - & - & $<2$ \\
\hline 9.6 .26 .443 & Timla & - & - & - & - & - \\
\hline 10.6 .3 .111 & Encinal 1 & - & - & - & - & $<2$ \\
\hline $10 \cdot 6.9 \cdot 121$ & Enclnal 2 & - & - & 90 & - & $<2$ \\
\hline 10.7 .10 .213 & Laguna 79-1 & 140 & - & 60 & - & - \\
\hline $10.7 \cdot 36.322$ & Laguna 76-2 & - & - & - & - & .2 \\
\hline 10.7 .36 .424 & Laguna 76-1 & - & - & - & - & - \\
\hline & & - & - & - & - & .3 \\
\hline 11.6 .27 .334 & Encinal Canyon 1 & - & - & - & - & $\mathrm{T}$ \\
\hline 12.1 .30 .324 & Conoco 65A & - & - & 110 & - & - \\
\hline 12.2 .36 .442 & Conoco WW-101 & - & - & 80 & - & - \\
\hline
\end{tabular}




\begin{tabular}{|c|c|c|c|c|c|c|c|c|c|}
\hline- & - & - & $T$ & - & $<10$ & - & - & - & - \\
\hline- & - & - & $T$ & - & $T$ & - & - & - & - \\
\hline 6 & $T$ & - & $T$ & - & $T$ & 10.0 & - & 0.0 & - \\
\hline- & 4 & - & 3 & - & $<10$ & - & 2.8 & 2.9 & - \\
\hline- & - & - & $T$ & - & $T$ & - & - & - & - \\
\hline- & 7 & - & 2 & - & $<10$ & - & 1.8 & 3.6 & - \\
\hline 2 & 0 & - & $T$ & - & $T$ & .44 & - & 0.0 & - \\
\hline- & - & - & $T$ & - & $<10$ & - & - & - & - \\
\hline 3 & - & - & $T$ & - & $<10$ & 1.6 & - & 0.0 & - \\
\hline 8 & - & 0 & $T$ & - & $<10$ & 2.7 & - & 0.0 & 10 \\
\hline 38 & - & 0 & - & - & - & 2.7 & - & $<6$ & 36 \\
\hline- & 7 & - & 1 & - & - & - & - & 1.1 & - \\
\hline - & - & - & - & - & - & - & - & - & - \\
\hline- & 3 & - & 3 & - & - & - & - & 1.1 & - \\
\hline - & - & - & $T$ & - & $T$ & - & - & - & - \\
\hline$<1$ & - & $<10$ & - & $<1$ & - & - & - & $<10$ & 10 \\
\hline$<1$ & - & $<10$ & - & 33 & - & - & - & $<10$ & 20 \\
\hline
\end{tabular}


Table 8. Radiochealcals of water in selected wells

\section{EXPLANATION}

Location number: See text for explanation.

Note: All constituents are reported In plcocurles per IIter unless noted otherwlse. All analyses by U.S. Geological Survey. Concentrations less than the detection IInit of the analytical method used are indicated by "<n. U, uranlum; Cs, ceslum; St, strontium; Yt, yttriun.

\begin{tabular}{|c|c|c|c|c|c|}
\hline Location number & $\begin{array}{l}\text { Local } \\
\text { wel I name }\end{array}$ & $\begin{array}{c}\text { Date of } \\
\text { collection }\end{array}$ & $\begin{array}{l}\text { Gross } \\
\text { alpha } \\
\text { (d) } \\
\text { assolved } \\
\text { (mlcrograms } \\
\text { per llter) }\end{array}$ & $\begin{array}{l}\text { Gross } \\
\text { alpha } \\
\text { (suspended } \\
\text { as U) } \\
\text { (micrograms } \\
\text { per (Iter) }\end{array}$ & $\begin{array}{c}\text { Gross } \\
\text { beta } \\
\text { (dissolved } \\
\text { as Cs-137) }\end{array}$ \\
\hline $9 \cdot 5 \cdot 9 \cdot 231$ & Laguna $78-1$ & $12-21-78$ & 100 & - & 23 \\
\hline $9 \cdot 6.2 .123$ & Laguna $76-7$ & $01-27-77$ & $<32$ & 2.4 & 10 \\
\hline 9.6 .5 .222 & Laguna $76-6$ & $01-25-77$ & $<30$ & 12 & 8.1 \\
\hline 9.6 .26 .233 & RWP 24 & $12-11-78$ & 9.6 & - & 4.0 \\
\hline 10.6 .3 .111 & Enclnal 1 & $11-17-78$ & $<17$ & - & 9.5 \\
\hline 10.6 .9 .121 & Enclnal 2 & $11 \div 07-78$ & 29 & - & 7.4 \\
\hline $10.7 \cdot 10.213$ & Laguna 79-1 & $01-16-80$ & $<19$ & $<28$ & 26 \\
\hline
\end{tabular}




\begin{tabular}{|c|c|c|c|c|c|}
\hline $\begin{array}{c}\text { Gross } \\
\text { beta } \\
\text { (dissolved } \\
\text { as } \mathrm{Sr} / \mathrm{Yt}-90 \text { ) }\end{array}$ & $\begin{array}{l}\text { Gross } \\
\text { beta } \\
\text { (suspended } \\
\text { as Cs-137) }\end{array}$ & $\begin{array}{c}\text { Gross } \\
\text { beta } \\
\text { (suspended } \\
\text { as } \mathrm{Sr} / \mathrm{Yt}-90 \text { ) }\end{array}$ & $\begin{array}{l}\text { Rad i um- } 226 \\
\text { (d issolved, } \\
\text { radon method) }\end{array}$ & $\begin{array}{l}\text { Uranium } \\
\text { (dissolved } \\
\text { as U) } \\
\text { (micrograms } \\
\text { per Iiter) }\end{array}$ & $\begin{array}{c}\text { Potassium- } \\
40 \\
\text { (dissolved) }\end{array}$ \\
\hline 21 & - & - & 3.5 & 3.5 & 4.9 \\
\hline 8.2 & 2.6 & 2.1 & .19 & 7.2 & 4.8 \\
\hline 6.5 & 12 & 10 & .09 & 7.9 & 6.2 \\
\hline 3.7 & - & - & .13 & 3.5 & 1.4 \\
\hline 8.5 & - & - & .05 & 4.5 & 3.9 \\
\hline 6.8 & - & - & 1.0 & 9.2 & 3.2 \\
\hline 24 & - & - & 1.0 & 1.0 & - \\
\hline
\end{tabular}


Table 9.--Selected major chemical constituents of surface water

\section{EXPLANATION}

Laboratory: BIA, U.S. Bureau of Indlan Affalrs; USGS, U.S. Geological Survey Notes:

All constituents are dissolved. All values of water temperature were measured onslte. Speclflc conductance, pH, blcarbonate, and carbonate values marked by w*in were measured onsite. All other values were determined In the laboratory. Trace concentrations indicated by $m$ Tw. g/ indicates discharge measurement is dally mean value from streanflow-gaging station. All other discharge measurements were of Instantaneous flow.

\begin{tabular}{|c|c|c|c|c|c|c|c|c|c|}
\hline & & Discharge & & & & & & & \\
\hline & & $\begin{array}{l}\text { (cublc } \\
\text { feet }\end{array}$ & & & & & $\begin{array}{l}\text { Bicar- } \\
\text { bonate }\end{array}$ & $\begin{array}{l}\text { Car- } \\
\text { bonate }\end{array}$ & \\
\hline $\begin{array}{l}\text { Date of } \\
\text { collection }\end{array}$ & Laboratory & $\begin{array}{c}\text { per } \\
\text { second) }\end{array}$ & $\begin{array}{l}\text { Cal- } \\
\text { clum }\end{array}$ & $\begin{array}{c}\text { Mag- } \\
\text { nesium }\end{array}$ & Sod I um & $\begin{array}{l}\text { Potas- } \\
\text { sium }\end{array}$ & $\begin{array}{l}\text { (as } \\
\mathrm{HCO}_{3} \text { ) }\end{array}$ & $\begin{array}{l}(\mathrm{as} \\
\left.\mathrm{CO}_{3}\right)\end{array}$ & Sulfate \\
\hline
\end{tabular}

Rlo San Jose near Grants (below Horace Sprlngs) (10.9.23.444)

\begin{tabular}{|c|c|c|c|c|c|c|c|c|c|c|}
\hline 04- & -61 & $B \mid A$ & - & 81 & 41 & 130 & 4.7 & 240 & 6 & 280 \\
\hline 05- & -61 & $B \mid A$ & - & 80 & 36 & 97 & 2.3 & 220 & 13 & 250 \\
\hline 06- & -61 & $B \mid A$ & - & 80 & 35 & 110 & 5.5 & 210 & 13 & 280 \\
\hline $07-$ & -61 & $B \mid A$ & - & 79 & 35 & 110 & 3.9 & 220 & 4 & 280 \\
\hline $08-$ & -61 & $B \backslash A$ & - & 84 & 36 & 120 & .4 & 240 & 8 & 280 \\
\hline $09-$ & -61 & $B \mid A$ & - & 82 & 35 & 110 & 4.7 & 210 & 21 & 260 \\
\hline $10-$ & -61 & $B \mid A$ & - & 94 & 33 & 140 & 7.8 & 230 & 24 & 290 \\
\hline $02-$ & -62 & $B ! A$ & - & - & - & - & - & - & - & - \\
\hline $11-$ & -62 & $B \mid A$ & - & - & - & - & - & - & - & - \\
\hline \multicolumn{2}{|c|}{$06-26-67$} & $\mathrm{BI} A$ & $2.99 /$ & 130 & 10 & 100 & 4.2 & 230 & $T$ & 260 \\
\hline \multicolumn{2}{|c|}{$07-15-68$} & $B ! A$ & $4.69 /$ & 81 & 36 & 110 & 4.3 & 240 & $T$ & 260 \\
\hline \multicolumn{2}{|c|}{$10-14-68$} & $B \mid A$ & $3.9 \mathrm{~g} /$ & 81 & 38 & 110 & 3.9 & 250 & 6 & 250 \\
\hline
\end{tabular}




\begin{tabular}{|c|c|c|c|c|c|c|c|c|c|}
\hline \multirow[b]{2}{*}{$\begin{array}{l}\text { Chlo- } \\
\text { rlde }\end{array}$} & \multirow[b]{2}{*}{ Sllica } & \multirow[b]{2}{*}{$\begin{array}{l}\text { Calclum } \\
\text { magneslum } \\
\text { hardness } \\
\text { (as } \\
\mathrm{CaCO}_{3} \text { ) }\end{array}$} & \multirow[b]{2}{*}{$\begin{array}{l}\text { Hardness, } \\
\text { noncar- } \\
\text { bonate }\end{array}$} & \multirow[b]{2}{*}{$\begin{array}{l}\text { Dissolved } \\
\text { sollds }\end{array}$} & \multirow[b]{2}{*}{$\begin{array}{l}\text { Temper- } \\
\text { ature } \\
\text { (degrees } \\
\text { celslus) }\end{array}$} & \multirow[b]{2}{*}{$\mathrm{pH}$} & \multirow{2}{*}{$\begin{array}{l}\text { Spe- } \\
\text { clflc } \\
\text { conduct- } \\
\text { ance } \\
\text { (micro- }\end{array}$} & \multirow[b]{2}{*}{ Sod I um } & \multirow[b]{2}{*}{$\begin{array}{l}\text { Irri- } \\
\text { gation } \\
\text { class }\end{array}$} \\
\hline & & & & & & & & & \\
\hline 99 & - & 370 & 170 & - & - & 7.9 & 1,280 & 2.9 & $\mathrm{C}_{3} \mathrm{~S}_{1}$ \\
\hline 84 & - & 350 & 170 & - & - & 8.4 & 1,170 & 2.2 & $\mathrm{C}_{3} \mathrm{~S}_{1}$ \\
\hline 80 & - & 350 & 180 & - & - & 8.4 & 1,200 & 2.6 & $c_{3} s_{1}$ \\
\hline 60 & - & 350 & 170 & - & - & 8.1 & 1,130 & 2.5 & $c_{2} s_{1}$ \\
\hline 91 & - & 360 & 160 & - & - & 8.2 & 1,250 & 2.8 & $\mathrm{C}_{3} \mathrm{~S}_{1}$ \\
\hline 84 & - & 350 & 180 & - & - & 8.5 & 1,180 & 2.6 & $\mathrm{C}_{3} \mathrm{~S}_{1}$ \\
\hline 100 & - & 370 & 180 & - & - & 8.4 & 1,300 & 3.1 & $\mathrm{C}_{3} \mathrm{~S}_{1}$ \\
\hline- & - & - & - & - & - & - & 1,580 & 3.3 & $c_{3} s_{1}$ \\
\hline- & - & - & - & - & - & - & 1,180 & 2.5 & $\mathrm{C}_{3} \mathrm{~S}_{1}$ \\
\hline 87 & - & 360 & 170 & 784 & - & 8.3 & 1,090 & 2.3 & $\mathrm{C}_{3} \mathrm{~S}_{1}$ \\
\hline 68 & - & 350 & 150 & 752 & - & 8.2 & 1,130 & 2.5 & $\mathrm{C}_{3} \mathrm{~S}_{1}$ \\
\hline 94 & - & 360 & 140 & 808 & - & 8.2 & 1,190 & 2.5 & $C_{3} S_{1}$ \\
\hline
\end{tabular}




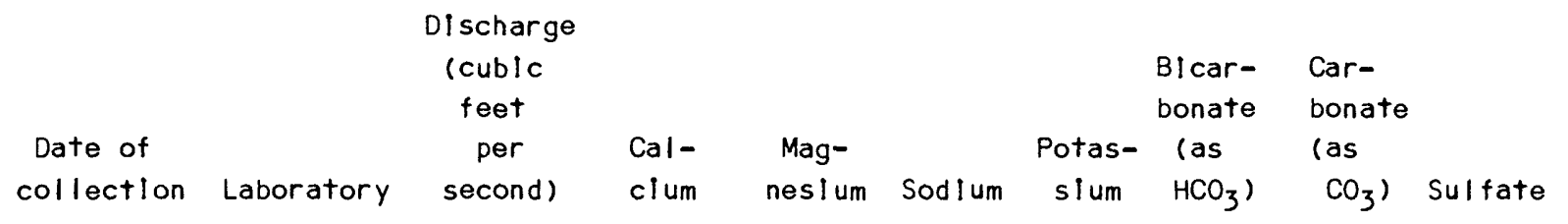

RIo San Jose near Grants (below Horace Springs) (10.9.23.444) - contInued

\begin{tabular}{|c|c|c|c|c|c|c|c|c|c|}
\hline $05-06-69$ & $B \mid A$ & $6.69 /$ & 95 & 51 & 200 & 7.0 & 270 & 6 & 390 \\
\hline $06-19-69$ & $B \mid A$ & $4.69 /$ & 88 & 39 & 130 & 3.9 & 260 & 7 & 250 \\
\hline $07-\quad-69$ & $B \mid A$ & - & 83 & 40 & 120 & 3.9 & 240 & 6 & 280 \\
\hline $08-08-69$ & $B \mid A$ & 5.79 & 90 & 41 & 150 & 6.3 & 280 & 4 & 310 \\
\hline $09-69$ & $B \mid A$ & - & 73 & 26 & 100 & 8.2 & 190 & 3 & 230 \\
\hline $10-\quad-69$ & $B \mid A$ & - & 91 & 46 & 150 & 3.9 & 270 & 4 & 290 \\
\hline $05-07-70$ & $B \mid A$ & $4.0 \mathrm{~g}$ & 89 & 44 & 150 & 5.9 & 250 & 10 & 360 \\
\hline $06-22-70$ & $B \mid A$ & $4.69 /$ & 97 & 50 & 190 & 8.6 & 270 & $T$ & 410 \\
\hline $08-05-70$ & $B \mid A$ & 6.39 & 89 & 44 & 170 & 9.8 & 260 & 9 & 370 \\
\hline $09-\quad-70$ & $B \mid A$ & - & 86 & 39 & 110 & 3.1 & 240 & 13 & 350 \\
\hline $07-26-71$ & $B \mid A$ & $5.2 \mathrm{~g}$ & 92 & 40 & 150 & 4.8 & 240 & 5 & 350 \\
\hline $08-\quad-71$ & $B \mid A$ & - & 86 & 38 & 110 & 1.6 & 240 & 10 & 260 \\
\hline $10-27-71$ & $B \mid A$ & $7.5 \mathrm{~g} /$ & 96 & 47 & 190 & 11 & 220 & 18 & 400 \\
\hline $07-10-72$ & $B \mid A$ & 4.39 & 92 & 40 & 150 & 7.4 & 270 & 5 & 320 \\
\hline $08-31-72$ & $B \mid A$ & 119 & 58 & 17 & 76 & 4.3 & 210 & $T$ & 140 \\
\hline $11-01-73$ & $B \mid A$ & $4.99 /$ & 86 & 40 & 120 & 5.5 & 260 & 6 & 250 \\
\hline
\end{tabular}




\begin{tabular}{llll}
\hline per liter & & Spe- & cific \\
conduct- \\
ance \\
(micro- \\
\end{tabular}

\begin{tabular}{|c|c|c|c|c|c|c|c|c|}
\hline 180 & - & 450 & 220 & 1,180 & - & 8.1 & 1,740 & 4.2 \\
\hline 120 & - & 380 & 170 & 854 & - & 8.3 & 1,310 & 2.8 \\
\hline 98 & - & 370 & 170 & 820 & - & 8.0 & 1,240 & 2.8 \\
\hline 130 & - & 390 & 160 & 940 & - & 8.0 & 1,440 & 3.3 \\
\hline 74 & - & 290 & 140 & 664 & - & 8.1 & 1,010 & 2.6 \\
\hline 140 & - & 420 & 190 & 1,010 & - & 8.8 & 1,470 & 3.4 \\
\hline 130 & - & 410 & 200 & 943 & - & 8.3 & 1,410 & 3.3 \\
\hline 150 & - & 450 & 230 & 1,100 & - & 7.8 & 1,620 & 3.8 \\
\hline 150 & - & 400 & 190 & 1,020 & - & 7.9 & 1,580 & 3.7 \\
\hline 99 & - & 380 & 180 & 841 & - & 8.3 & 1,220 & 2.6 \\
\hline 120 & - & 400 & 190 & 935 & - & 7.9 & 1,380 & 3.2 \\
\hline 98 & - & 370 & 180 & 809 & - & 8.1 & 1,220 & 2.6 \\
\hline 150 & - & 440 & 250 & 1,200 & - & 8.1 & 1,650 & 4.0 \\
\hline 120 & - & 400 & 180 & 920 & - & 8.1 & 1,350 & 3.4 \\
\hline 48 & - & 220 & 39 & 493 & - & 8.0 & 760 & 2.2 \\
\hline 110 & - & 380 & 170 & 836 & - & 7.9 & 1,260 & 2.7 \\
\hline
\end{tabular}


Table 9.--Selected major chemical constituents of surface water-Continued

Constituents in milligrams

\begin{tabular}{|c|c|c|c|c|c|c|c|c|c|}
\hline \multicolumn{10}{|c|}{ Discharge } \\
\hline & & (cub) ic & & & & & Blcar- & Car- & \\
\hline & & feet & & & & & bonate & bonate & \\
\hline Date of & & per & Cal- & Mag- & & Potas- & (as & (as & \\
\hline collection & Laboratory & second) & clum & neslum & Sod lum & slum & $\mathrm{HCO}_{3} \mathrm{~s}$ & $\mathrm{CO}_{3}$ ) & Sulfate \\
\hline
\end{tabular}

Rlo San Jose near Grants (below Horace Springs) (10.9.23.444) - continued

\begin{tabular}{|c|c|c|c|c|c|c|c|c|c|}
\hline $01-25-74$ & $B \mid A$ & $5.19 /$ & 92 & 41 & 140 & 5.5 & 250 & 14 & 280 \\
\hline $04-03-74$ & $B \mid A$ & $5.9 \mathrm{~g} /$ & 88 & 39 & 110 & 5.5 & 250 & 12 & 260 \\
\hline $07-08-74$ & $B \mid A$ & $6.39 /$ & 84 & 38 & 110 & 1.6 & 230 & 18 & 250 \\
\hline $03-28-75$ & $B \mid A$ & 5.0 & 86 & 36 & 130 & 5.9 & 230 & 17 & 300 \\
\hline $04-20-76$ & $B \mid A$ & 5.1 & 80 & 41 & 130 & 5.9 & 330 & 22 & 230 \\
\hline $09-12-76$ & $B \mid A$ & 4.2 & 42 & 41 & 150 & 8.2 & 110 & 10 & 340 \\
\hline $01-21-77$ & USGS & 6.5 & 85 & 38 & 130 & 7.4 & 260 & 0 & 290 \\
\hline $04-06-77$ & $B \mid A$ & 5.5 & 96 & 38 & 170 & 7.8 & 240 & 19 & 310 \\
\hline $04-19-78$ & USGS & 6.5 & 85 & 40 & 150 & 7.6 & $280^{*}$ & $0^{*}$ & 270 \\
\hline $07-24-78$ & $B \mid A$ & 5.3 & 84 & 33 & 120 & 6.3 & $270^{*}$ & $0^{*}$ & 250 \\
\hline $10-25-78$ & $B \mid A$ & 5.7 & 90 & 35 & 140 & 8.6 & $300^{*}$ & $0^{*}$ & 300 \\
\hline $01-23-79$ & $B \mid A$ & 5.7 & 130 & 17 & 140 & 9.4 & $340^{*}$ & $0^{*}$ & 280 \\
\hline $03-08-79$ & $B \mid A$ & 4.9 & - & - & - & - & - & - & - \\
\hline $06-20-79$ & $B \mid A$ & 5.6 & 94 & 38 & 182 & 8.6 & $312^{*}$ & $0^{*}$ & 380 \\
\hline $11-13-79$ & $B \mid A$ & $6.0 \mathrm{~g} /$ & 96 & 40 & 150 & 8.6 & 270 & $T$ & 310 \\
\hline
\end{tabular}




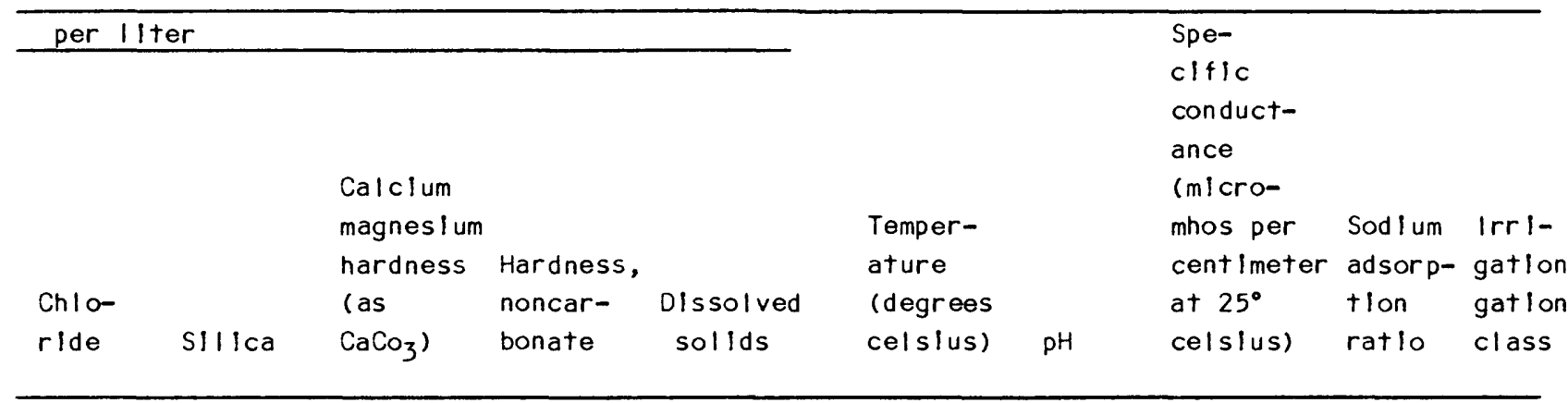

\begin{tabular}{|c|c|c|c|c|c|c|c|c|}
\hline 110 & - & 400 & 200 & 897 & - & 8.2 & 1,300 & 3.1 \\
\hline 110 & - & 380 & 180 & 822 & - & 8.2 & 1,270 & 2.5 \\
\hline 99 & - & 370 & 190 & 819 & - & 8.4 & 1,190 & 2.5 \\
\hline 110 & - & 370 & 180 & 850 & - & 8.4 & 1,240 & 2.9 \\
\hline 100 & - & 370 & 67 & 870 & - & 8.6 & 1,250 & 2.9 \\
\hline 130 & - & 280 & 170 & 820 & - & 9.0 & 1,230 & 4.2 \\
\hline 110 & 28 & 370 & 160 & 830 & 10.0 & $7.8^{*}$ & $1,350^{*}$ & 2.9 \\
\hline 120 & - & 400 & 170 & 920 & - & 8.0 & 1,370 & 3.6 \\
\hline 130 & 29 & 380 & 140 & 870 & 10.0 & $8.1^{*}$ & $1,350^{*}$ & 3.4 \\
\hline 100 & - & 350 & 130 & 820 & 16.0 & $7.9^{*}$ & $1,180^{*}$ & 2.8 \\
\hline 130 & - & 370 & 150 & 860 & 12.0 & $7.6^{*}$ & $1,350^{*}$ & 3.2 \\
\hline 120 & - & 390 & 170 & 900 & 9.5 & $7.9^{*}$ & $1,300^{*}$ & 3.2 \\
\hline 160 & - & - & - & - & 13.5 & - & $1,480^{*}$ & - \\
\hline 160 & - & 390 & 170 & 970 & 20.5 & 8.2 & $1,500^{*}$ & 4.0 \\
\hline 130 & - & 410 & 180 & 880 & - & $7.8^{*}$ & $1,400^{*}$ & 3.2 \\
\hline
\end{tabular}




\begin{tabular}{|c|c|c|c|c|c|c|c|c|c|}
\hline \multicolumn{10}{|c|}{ Discharge } \\
\hline & & $\begin{array}{c}\text { (cublc } \\
\text { feet }\end{array}$ & & & & & $\begin{array}{l}\text { Blcar- } \\
\text { bonate }\end{array}$ & $\begin{array}{l}\text { Car- } \\
\text { bonate }\end{array}$ & \\
\hline $\begin{array}{l}\text { Date of } \\
\text { collection }\end{array}$ & Laboratory & $\begin{array}{c}\text { per } \\
\text { second) }\end{array}$ & $\begin{array}{l}\text { Cal- } \\
\text { clum }\end{array}$ & $\begin{array}{c}\text { Mag- } \\
\text { nes I um }\end{array}$ & Sodlum & $\begin{array}{l}\text { Potas- } \\
\text { slum }\end{array}$ & $\begin{array}{l}(\mathrm{as} \\
\left.\mathrm{HCO}_{3}\right)\end{array}$ & $\begin{array}{l}(\mathrm{as} \\
\left.\mathrm{CO}_{3}\right)\end{array}$ & Sulfate \\
\hline
\end{tabular}

Rlo San Jose at McCartys North Diversion (10.8.29.423)

\begin{tabular}{|c|c|c|c|c|c|c|c|c|c|c|}
\hline 04- & -61 & $B \mid A$ & - & 81 & 41 & 140 & 3.9 & 240 & 11 & 280 \\
\hline 05- & -61 & $B \mid A$ & - & 79 & 38 & 120 & 3.1 & 210 & 21 & 300 \\
\hline $06-$ & -61 & $B \mid A$ & - & 76 & 36 & 110 & 3.1 & 220 & 8 & 270 \\
\hline 07- & -61 & $B \mid A$ & - & 77 & 34 & 120 & 4.7 & 220 & 6 & 250 \\
\hline 08 - & -61 & $B \mid A$ & - & 85 & 36 & 140 & .8 & 240 & 6 & 310 \\
\hline 09- & -61 & $B \mid A$ & - & 86 & 38 & 130 & 8.6 & 230 & 18 & 310 \\
\hline $10-$ & -61 & $B \mid A$ & - & 94 & 35 & 78 & 6.3 & 250 & 18 & 160 \\
\hline $02-$ & -62 & $B \mid A$ & - & - & - & - & - & - & - & - \\
\hline $11-$ & -62 & $B \mid A$ & - & - & - & - & - & - & - & - \\
\hline $06-2$ & $6-67$ & $B \mid A$ & - & 120 & 12 & 110 & 3.7 & 230 & $\mathrm{~T}$ & 280 \\
\hline $05-0$ & $6-69$ & $B \mid A$ & - & 90 & 47 & 180 & 5.9 & 270 & 10 & 350 \\
\hline $06-$ & -69 & $B \mid A$ & - & 86 & 39 & 140 & 5.1 & 240 & 16 & 300 \\
\hline 07- & -69 & $B \mid A$ & - & 81 & 38 & 110 & 3.5 & 240 & 11 & 240 \\
\hline $08-0$ & $8-69$ & $B \mid A$ & - & 83 & 38 & 120 & 4.7 & 270 & 6 & 270 \\
\hline 09- & -69 & $B \mid A$ & - & 68 & 22 & 97 & 10 & 160 & $T$ & 240 \\
\hline $10-$ & -69 & $B \mid A$ & - & 86 & 43 & 150 & 3.1 & 260 & 11 & 290 \\
\hline
\end{tabular}




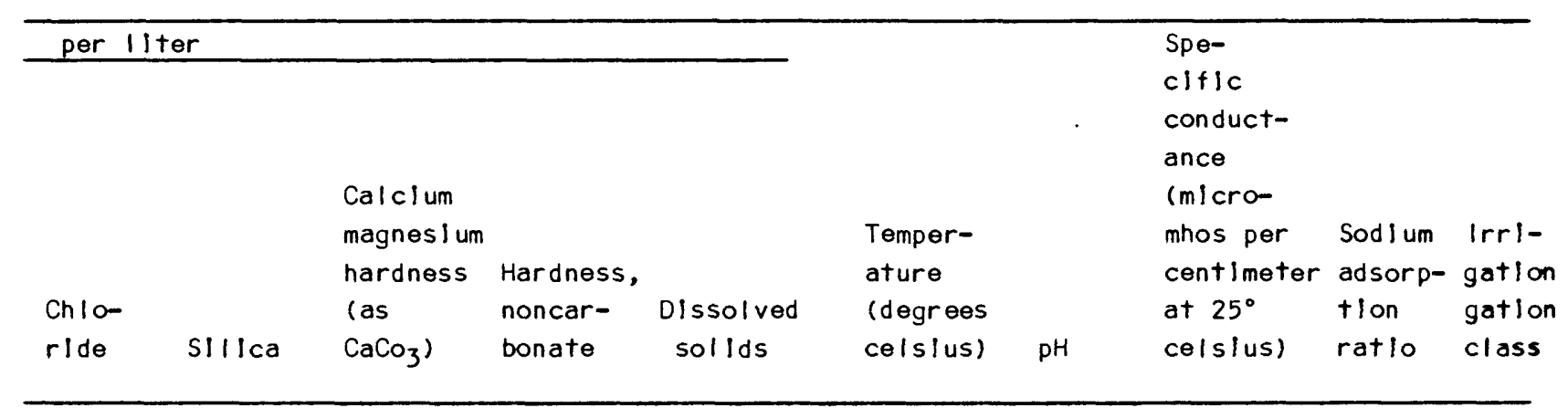

\begin{tabular}{|c|c|c|c|c|c|c|c|c|c|}
\hline 100 & - & 370 & 170 & - & - & 8.1 & 1,300 & 3.2 & $\mathrm{C}_{3} \mathrm{~S}_{1}$ \\
\hline 89 & - & 350 & 180 & - & - & 8.6 & 1,290 & 2.6 & $C_{3} S_{1}$ \\
\hline 80 & - & 340 & 160 & - & - & 8.1 & 1,180 & 2.6 & $\mathrm{C}_{3} \mathrm{~S}_{1}$ \\
\hline 98 & - & 330 & 150 & - & - & 7.9 & 1,150 & 2.8 & $\mathrm{C}_{2} \mathrm{~S}_{1}$ \\
\hline 93 & - & 360 & 160 & - & - & 8.1 & 1,320 & 3.2 & $C_{3} s_{1}$ \\
\hline 93 & - & 370 & 180 & - & - & 8.3 & 1,320 & 3.0 & $\mathrm{C}_{3} \mathrm{~S}_{1}$ \\
\hline 100 & - & 380 & 170 & - & - & 8.2 & 1,320 & 1.7 & $\mathrm{C}_{3} \mathrm{~S}$ \\
\hline - & - & - & - & - & - & - & 1,420 & 3.2 & $\mathrm{C}_{3} \mathrm{~S}_{1}$ \\
\hline - & - & - & - & - & - & - & 1,150 & 2.4 & $\mathrm{C}_{3} \mathrm{~S}_{1}$ \\
\hline 89 & - & 350 & $\begin{array}{l}160 \\
,\end{array}$ & 740 & - & 8.4 & 1,110 & 2.4 & \\
\hline 150 & - & 420 & 200 & 1,040 & - & 8.2 & 1,560 & 3.8 & \\
\hline 110 & - & 380 & 180 & 870 & - & 8.5 & 1,340 & 3.1 & $\mathrm{C}_{3} \mathrm{~S}_{1}$ \\
\hline 92 & - & 360 & 160 & 804 & - & 8.2 & 1,200 & 2.6 & $\mathrm{C}_{3} \mathrm{~S}_{1}$ \\
\hline 99 & - & 370 & 150 & 802 & - & 8.1 & 1,260 & 2.8 & \\
\hline 65 & - & 260 & 130 & 654 & - & 8.0 & 940 & 2.6 & $\mathrm{C}_{3} \mathrm{~S}$ \\
\hline 120 & - & 390 & 180 & 956 & - & 8.3 & 1,390 & 3.0 & \\
\hline
\end{tabular}




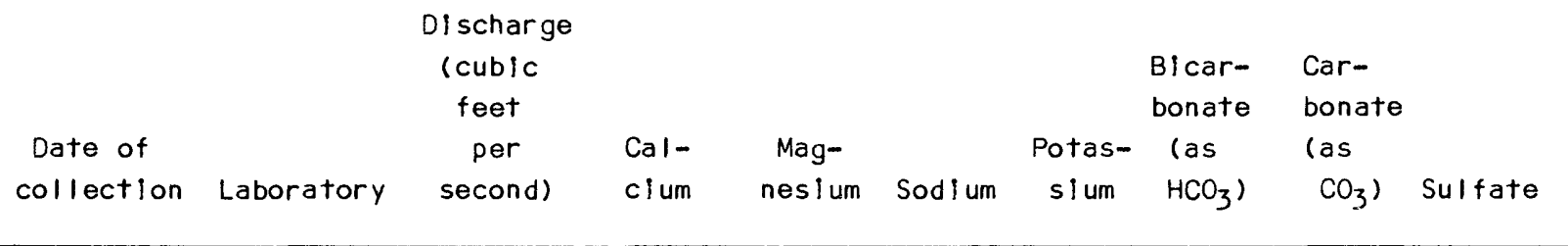

RIo San Jose at McCartys North Diversion (10.8.29.423) - continued

\begin{tabular}{|c|c|c|c|c|c|c|c|c|c|}
\hline $05-08-70$ & $B \mid A$ & - & 86 & 43 & 140 & 8.6 & 260 & 11 & 300 \\
\hline $06-\quad-70$ & $B \mid A$ & - & 90 & 47 & 170 & 9.0 & 260 & 7 & 350 \\
\hline $08-05-70$ & $B \mid A$ & - & 80 & 40 & 130 & 5.1 & 260 & 10 & 280 \\
\hline $09-\quad-70$ & $B \mid A$ & - & 86 & 39 & 120 & 3.5 & 260 & 10 & 260 \\
\hline $07-26-71$ & $B \mid A$ & - & 100 & 45 & 180 & 5.7 & 250 & 10 & 400 \\
\hline $08-\quad-71$ & $B \mid A$ & - & 86 & 43 & 140 & $T$ & 250 & 19 & 280 \\
\hline $10-27-71$ & $B \mid A$ & - & 86 & 39 & 160 & 9.8 & 220 & 17 & 310 \\
\hline $07-10-72$ & $B \mid A$ & - & 92 & 43 & 160 & .4 & 280 & 17 & 280 \\
\hline $08-31-72$ & $B \mid A$ & - & 56 & 18 & 77 & 5.5 & 200 & $T$ & 160 \\
\hline $11-01-73$ & $B \mid A$ & - & 86 & 39 & 130 & 4.7 & 370 & 12 & 260 \\
\hline $01-25-74$ & $B \mid A$ & - & 86 & 39 & 130 & 4.7 & 250 & 12 & 260 \\
\hline $04-03-74$ & $B \mid A$ & - & 88 & 39 & 130 & 4.3 & 250 & 19 & 270 \\
\hline $07-08-74$ & $B \mid A$ & - & 76 & 40 & 110 & 2.0 & 220 & 22 & 230 \\
\hline $10-21-74$ & $B \mid A$ & - & 86 & 43 & 130 & 3.1 & 230 & 24 & 300 \\
\hline $03-28-75$ & $B \mid A$ & - & 88 & 39 & 140 & 5.9 & 230 & 24 & 270 \\
\hline $04-20-76$ & $B \mid A$ & - & 88 & 46 & 160 & 6.7 & 270 & 12 & 290 \\
\hline
\end{tabular}




\begin{tabular}{llll}
\hline per liter & & Spe- \\
clfic \\
conduct- \\
ance \\
(micro- \\
\end{tabular}

$\begin{array}{llllllllll}120 & - & 390 & 180 & 906 & - & 8.3 & 1,380 & 3.2 & C_{3} S_{1} \\ 130 & - & 420 & 210 & 977 & - & 8.0 & 1,470 & 3.7 & C_{3} S_{1} \\ 100 & - & 370 & 150 & 892 & - & 8.0 & 1,290 & 3.0 & C_{3} S_{1} \\ 110 & - & 380 & 160 & 776 & - & 8.3 & 1,260 & 2.7 & C_{3} S_{1} \\ 150 & - & 390 & 160 & 1,120 & - & 8.1 & 1,610 & 3.7 & C_{3} S_{1} \\ 100 & - & 390 & 180 & 899 & - & 8.2 & 1,290 & 3.0 & C_{3} S_{2} \\ 120 & - & 380 & 190 & 951 & - & 8.2 & 1,430 & 3.6 & C_{3} S_{1} \\ 120 & - & 410 & 170 & 970 & - & 8.3 & 1,390 & 3.5 & C_{3} S_{1} \\ 48 & - & 220 & 47 & 504 & - & 8.0 & 1,280 & 2.3 & C_{3} S_{1} \\ 98 & - & 380 & 170 & 786 & - & 8.1 & 1,160 & 2.9 & C_{3} S_{1} \\ 120 & - & 380 & 170 & 872 & - & 8.4 & 1,190 & 2.8 & C_{3} S_{1} \\ 110 & - & 380 & 180 & 838 & - & 8.3 & 1,270 & 2.8 & C_{3} S_{1} \\ 88 & - & 360 & 170 & 839 & - & 8.3 & 1,190 & 2.5 & C_{3} S_{1} \\ 99 & - & 390 & 200 & 892 & - & 8.1 & 1,250 & 2.9 & C_{3} S_{1} \\ 110 & - & 380 & 190 & 890 & - & 8.3 & 1,340 & 3.1 & C_{3} S_{1} \\ 120 & - & 160 & 1,010 & 10.0 & 8.5 & 1,450 * & 3.4 & C_{3} S_{1}\end{array}$


Table 9.--Selected major cheelcal constltuents of surface water-Continued

Constituents in milligrams

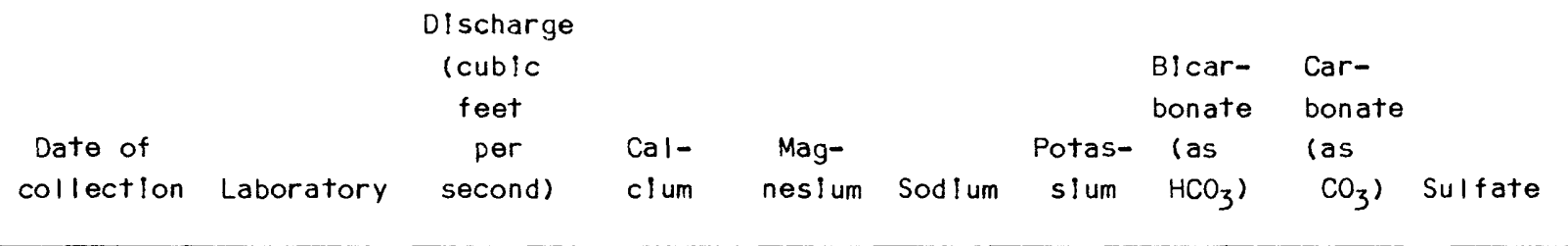

Rlo San Jose at McCartys North Diversion (10.8.29.423) - contInued

$\begin{array}{llllllllll}09-12-76 & \text { B।A } & - & 78 & 40 & 130 & 6.3 & 160 & 24 & 330 \\ 04-06-77 & \text { B।A } & - & 88 & 38 & 140 & 7.4 & 220 & 22 & 300 \\ 05-31-78 & \text { B।A } & - & 88 & 38 & 150 & 7.0 & 280^{*} & 0^{*} & 320 \\ 07-20-78 & \text { B।A } & 1.9 & 84 & 36 & 130 & 6.3 & 300^{*} & 0^{*} & 280 \\ 11-01-78 & \text { B।A } & 8.0 & 86 & 35 & 140 & 7.4 & 270^{*} & 0^{*} & 250 \\ 01-31-79 & \text { B।A } & 7.0 & 88 & 36 & 140 & 8.2 & 290^{*} & 0^{*} & 270\end{array}$

Rlo San Jose at Aconita Diversion $(10.8 .36 .223)$

\begin{tabular}{|c|c|c|c|c|c|c|c|c|c|c|}
\hline $04-$ & -61 & $B \mid A$ & - & 140 & 97 & 420 & 9.0 & 240 & 13 & 950 \\
\hline 05- & -61 & $B \mid A$ & - & 100 & 78 & 360 & 3.1 & 250 & 19 & 730 \\
\hline $06-$ & -61 & $B \mid A$ & - & 90 & 55 & 210 & 4.9 & 230 & 17 & 470 \\
\hline 07- & -61 & $B \mid A$ & - & 88 & 15 & 74 & 9.4 & 150 & - & 260 \\
\hline $08-$ & -61 & $B \mid A$ & - & 97 & 45 & 170 & .4 & 250 & 10 & 410 \\
\hline 09- & -61 & $B \mid A$ & - & 150 & 44 & 190 & 6.2 & 230 & 27 & 550 \\
\hline $10-$ & -61 & $B \mid A$ & - & 94 & 42 & 170 & 7.0 & 220 & 30 & 380 \\
\hline 02- & -62 & $B \mid A$ & - & - & - & - & - & - & - & - \\
\hline $11-$ & -62 & $B \mid A$ & - & - & - & - & - & - & - & - \\
\hline
\end{tabular}




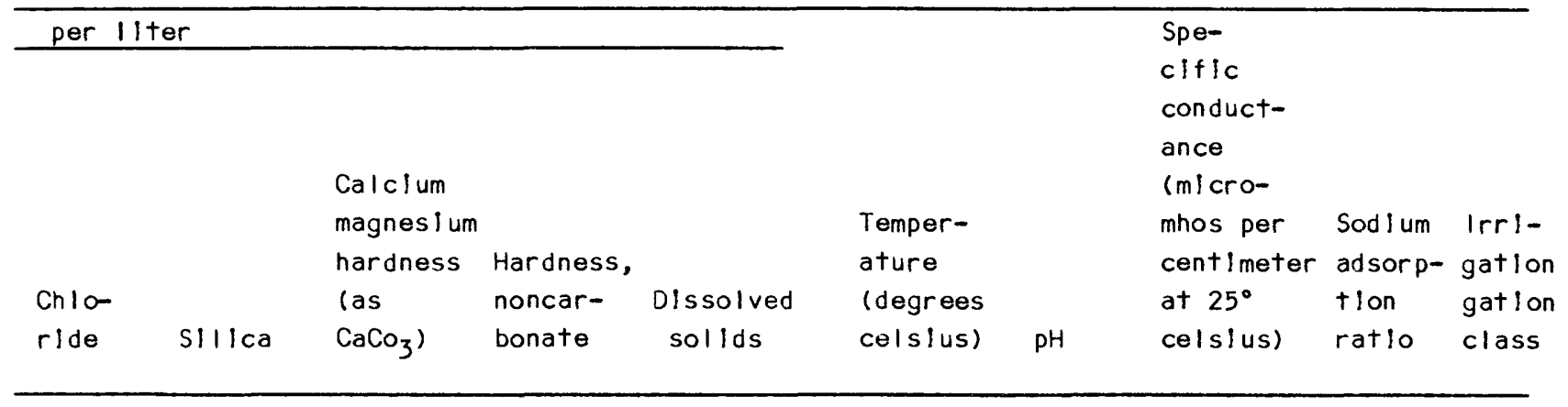

\begin{tabular}{|c|c|c|c|c|c|c|c|c|c|}
\hline 120 & - & & 360 & 190 & 890 & 16.0 & 9.2 & $1,350^{*}$ & 3.0 \\
\hline 110 & - & & 380 & 160 & 870 & 15.0 & 8.0 & $1,250^{*}$ & 3.1 \\
\hline 120 & 23 & & 380 & 150 & 900 & 14.5 & $7.7^{*}$ & $1,300^{*}$ & 3.3 \\
\hline 110 & - & $a$ & 360 & 130 & 820 & 18.0 & $7.7^{*}$ & $1,290^{*}$ & 3.1 \\
\hline 110 & - & & 360 & 140 & 810 & 13.0 & $8.1^{*}$ & $1,280^{*}$ & 3.1 \\
\hline 120 & - & & 370 & 150 & 880 & 4.0 & $7.8^{*}$ & $1,330^{*}$ & 3.1 \\
\hline 210 & - & & 750 & 550 & - & - & 8.1 & 3,090 & 6.7 \\
\hline 170 & - & & 570 & 360 & - & - & 8.3 & 2,470 & 6.5 \\
\hline 120 & - & & 450 & 260 & - & - & 8.4 & 1,730 & 4.2 \\
\hline 35 & - & & 280 & 160 & - & - & 8.0 & 900 & 1.9 \\
\hline 110 & - & & 430 & 220 & - & - & 8.3 & 1,560 & 3.6 \\
\hline 120 & - & & 560 & 370 & - & - & 8.6 & 1,720 & 3.6 \\
\hline 110 & - & . & 410 & 230 & - & - & 8.5 & 1,430 & 3.6 \\
\hline- & - & & - & - & - & - & - & 1,550 & 3.6 \\
\hline - & - & & - & - & - & - & - & 2,800 & 6.6 \\
\hline
\end{tabular}




\begin{tabular}{|c|c|c|c|c|c|c|c|c|c|}
\hline & & Discharge & & & & & & & \\
\hline & & (cub) & & & & & Bicar- & Car- & \\
\hline & & feet & & & & & bonate & bonate & \\
\hline $\begin{array}{l}\text { Date of } \\
\text { collection }\end{array}$ & Laboratory & $\begin{array}{c}\text { per } \\
\text { second) }\end{array}$ & $\begin{array}{l}\text { Cal- } \\
\text { clum }\end{array}$ & $\begin{array}{c}\text { Mag- } \\
\text { neslum }\end{array}$ & Sod I um & $\begin{array}{c}\text { Potas- } \\
\text { slum }\end{array}$ & $\begin{array}{l}(\mathrm{as} \\
\left.\mathrm{HCO}_{3}\right)\end{array}$ & $\begin{array}{l}(\mathrm{as} \\
\left.\mathrm{CO}_{3}\right)\end{array}$ & Sulfate \\
\hline
\end{tabular}

Rlo San Jose at Acomita Diversion (10.8.36.223) - continued

\begin{tabular}{|c|c|c|c|c|c|c|c|c|c|}
\hline $06-26-67$ & $B \mid A$ & - & 170 & 5.5 & 190 & 5.4 & 250 & $T$ & 480 \\
\hline $05-06-69$ & $B \mid A$ & - & 110 & 62 & 250 & 6.6 & 280 & 17 & 590 \\
\hline $06-\quad-69$ & $B \mid A$ & - & 93 & 49 & 180 & 2.7 & 250 & 18 & 410 \\
\hline $07-\quad-69$ & $B \mid A$ & - & 92 & 51 & 160 & 3.9 & 250 & 20 & 390 \\
\hline $08-08-69$ & $B \mid A$ & - & 110 & 48 & 200 & 7.4 & 280 & $T$ & 490 \\
\hline $09-\quad-69$ & $B \mid A$ & - & 82 & 33 & 140 & 9.8 & 180 & 4 & 340 \\
\hline $10-\quad-69$ & $B \mid A$ & - & 100 & 56 & 190 & 3.1 & 290 & 14 & 450 \\
\hline $05-07-70$ & $B \mid A$ & - & 110 & 71 & 300 & 7.8 & 310 & 20 & 670 \\
\hline $06-\quad-70$ & $B \mid A$ & - & 98 & 52 & 190 & 7.0 & 280 & 12 & 410 \\
\hline $08-05-70$ & $B \mid A$ & - & 130 & 64 & 240 & 10 & 360 & 8 & 550 \\
\hline $09-\quad-70$ & $B \mid A$ & - & 100 & 52 & 170 & 3.5 & 280 & 18 & 380 \\
\hline $07-26-71$ & $B \mid A$ & - & 120 & 57 & 250 & 8.6 & 270 & 17 & 560 \\
\hline $08-\quad-71$ & $B \mid A$ & - & 140 & 94 & 500 & $T$ & 330 & 19 & 1,100 \\
\hline $10-27-71$ & $B \mid A$ & - & 92 & 58 & 240 & 11 & 250 & 18 & 530 \\
\hline $07-10-72$ & $B \mid A$ & - & 94 & 47 & 160 & 4.3 & 250 & 19 & 360 \\
\hline $08-31-72$ & $B \mid A$ & - & 56 & 21 & 85 & 3.1 & 200 & $T$ & 170 \\
\hline
\end{tabular}




\begin{tabular}{|c|c|c|c|c|c|c|c|c|c|}
\hline \multicolumn{5}{|c|}{ per IIter } & \multicolumn{5}{|c|}{ Spe- } \\
\hline & & & & & & & $\begin{array}{l}\text { clflc } \\
\text { conduct- } \\
\text { ance }\end{array}$ & & \\
\hline & & Calclum & & & & & (m) cro- & & \\
\hline & & magnes : um & & & Temper- & & mhos per & Sod I um & $|r r|-$ \\
\hline & & hardness & Hardness, & & ature & & centimeter & adsorp- & gation \\
\hline Chlo- & & (as & noncar- & Dissolved & (degrees & & at $25^{\circ}$ & tion & gation \\
\hline ride & Sllica & $\left.\mathrm{CaCO}_{3}\right)$ & bonate & sollids & celsius) & $\mathrm{pH}$ & celsius) & ratlo & class \\
\hline
\end{tabular}

\begin{tabular}{|c|c|c|c|c|c|c|c|c|}
\hline 120 & - & 460 & 250 & 1,200 & - & 8.3 & 1,600 & 3.9 \\
\hline 160 & - & 520 & 300 & 1,420 & - & 8.3 & 2,020 & 4.8 \\
\hline 130 & - & 440 & 230 & 1,090 & - & 8.5 & 1,620 & 3.8 \\
\hline 110 & - & 440 & 230 & 1,060 & - & 8.3 & 1,530 & 3.4 \\
\hline 140 & - & 480 & 250 & 1,250 & - & 8.1 & 1,800 & 4.0 \\
\hline 94 & - & 340 & 190 & 868 & - & 8.1 & 1,250 & 3.2 \\
\hline 130 & - & 490 & 250 & 1,240 & - & 8.4 & 1,700 & 3.8 \\
\hline 170 & - & 580 & 320 & 1,560 & - & 8.5 & 2,180 & 5.4 \\
\hline 130 & - & 460 & 230 & 1,120 & - & 8.2 & 1,640 & 3.9 \\
\hline 160 & - & 590 & 300 & 1,440 & - & 8.1 & 1,980 & 4.2 \\
\hline 120 & - & 470 & 240 & 1,130 & - & 8.4 & 1,600 & 3.4 \\
\hline 210 & - & 540 & 290 & 1,540 & - & 8.2 & 2,150 & 4.8 \\
\hline 280 & - & 750 & 480 & 2,460 & - & 8.4 & 3,360 & 7.9 \\
\hline 150 & - & 470 & 270 & 1,330 & - & 8.3 & 1,940 & 4.8 \\
\hline 120 & - & 430 & 220 & 1,010 & - & 8.4 & 1,470 & 3.4 \\
\hline 48 & - & 230 & 65 & 576 & - & 8.1 & 820 & 2.5 \\
\hline
\end{tabular}




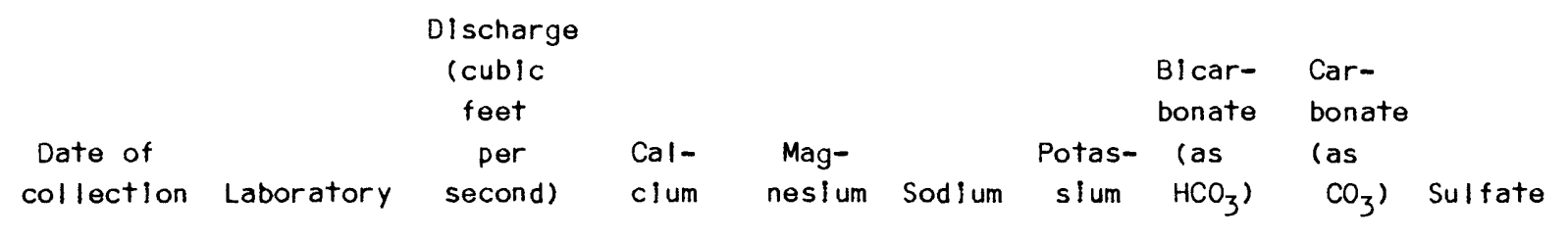

Rio San Jose at Aconlta Diversion (10.8.36.223) - continued

\begin{tabular}{|c|c|c|c|c|c|c|c|c|c|}
\hline $11-01-73$ & $B \mid A$ & - & 130 & 74 & 330 & 6.6 & 350 & 9 & 770 \\
\hline $01-25-74$ & $B \mid A$ & - & 94 & 47 & 170 & 5.1 & 250 & 20 & 370 \\
\hline $04-03-74$ & $B \mid A$ & - & 94 & 50 & 160 & 4.7 & 260 & 15 & 370 \\
\hline $07-08-74$ & $B \mid A$ & - & 96 & 53 & 180 & 1.2 & 230 & 24 & 430 \\
\hline $10-21-74$ & $B \mid A$ & - & 130 & 80 & 320 & 7.8 & 450 & 44 & 700 \\
\hline $03-06-75$ & $B \mid A$ & - & 92 & 44 & 170 & 6.3 & 250 & 23 & 390 \\
\hline $03-28-75$ & $B \mid A$ & - & 94 & 46 & 170 & 5.5 & 270 & 13 & 400 \\
\hline $04-20-76$ & $B \mid A$ & - & 98 & 43 & 200 & 6.3 & 260 & 5 & 410 \\
\hline $09-12-76$ & $B \mid A$ & - & 54 & 55 & 200 & 7.0 & 140 & 13 & 490 \\
\hline $04-06-77$ & $B \mid A$ & - & 98 & 50 & 200 & 7.8 & 260 & 19 & 410 \\
\hline $05-31-78$ & $B \mid A$ & - & 100 & 50 & 210 & 7.4 & $300^{*}$ & $0^{*}$ & 490 \\
\hline $07-20-78$ & $\mathrm{~B} \mid \mathrm{A}$ & 2.3 & 100 & 50 & 200 & 6.7 & $320 *$ & $0^{*}$ & 470 \\
\hline $11-01-78$ & $B \mid A$ & 6.4 & 100 & 49 & 200 & 7.4 & $320^{*}$ & $0^{*}$ & 420 \\
\hline $01-31-79$ & $B \mid A$ & 9.0 & 96 & 44 & 172 & 7.8 & $310^{*}$ & $0^{*}$ & 370 \\
\hline
\end{tabular}




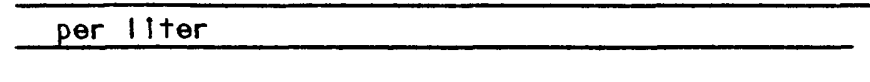

\begin{tabular}{|c|c|c|c|c|}
\hline & & $\begin{array}{l}\text { Calclum } \\
\text { magneslum }\end{array}$ & & \\
\hline $\mathrm{ChlO}$ & & $\begin{array}{l}\text { hardness } \\
\text { (as }\end{array}$ & $\begin{array}{l}\text { Hardness, } \\
\text { noncar- }\end{array}$ & Dissolved \\
\hline ride & sillca & $\left.\mathrm{CaCO}_{3}\right)$ & bonate & solids \\
\hline
\end{tabular}

Spe-

cific

conduct-

ance

(micro-

Temper- mhos per Sodium Irri-

ature

(degrees

celsius) $\mathrm{pH}$ centimeter adsorp-gation

at $25^{\circ}$ tion gation

celsius) ratio class

$\begin{array}{llllllllll}180 & - & 630 & 340 & 1,750 & - & 7.7 & 2,310 & 5.8 & c_{4} s_{2} \\ 110 & - & 430 & 230 & 1,080 & - & 8.5 & 1,510 & 3.6 & c_{3} s_{1} \\ 120 & - & 440 & 230 & 1,080 & - & 8.4 & 1,500 & 3.3 & c_{3} s_{1} \\ 120 & - & 460 & 270 & 1,170 & - & 8.5 & 1,600 & 3.7 & c_{3} s_{1} \\ 190 & - & 660 & 290 & 1,800 & - & 8.3 & 2,470 & 5.4 & c_{4} s_{2} \\ 120 & - & 410 & 210 & 1,040 & 12.0 & 8.4 & 1,470 & 3.6 & c_{3} s_{1} \\ 120 & - & 430 & 200 & 1,090 & - & 8.5 & 1,520 & 3.7 & c_{3} s_{1} \\ 130 & - & 420 & 200 & 1,240 & 14.0 & 8.6 & 1,700^{*} & 3.9 & c_{3} s_{1} \\ 140 & - & 360 & 220 & 1,100 & 14.0 & 8.8 & 1,650^{*} & 4.6 & c_{3} s_{1} \\ 130 & - & 450 & 200 & 1,110 & 13.0 & 8.1 & 1,600^{*} & 4.2 & c_{3} s_{1} \\ 140 & 19 & 470 & 230 & 1,260 & 17.5 & 8.2^{*} & 1,700^{*} & 4.3 & c_{3} s_{1} \\ 130 & - & 470 & 220 & 1,160 & 25.0 & 8.1 * & 1,700^{*} & 4.0 & c_{3} s_{1} \\ 130 & - & 460 & 210 & 1,130 & 13.0 & 8.2^{*} & 1,660^{*} & 4.0 & c_{3} s_{1} \\ 130 & - & 420 & 190 & 1,050 & 0.0 & 7.8 * & 1,530^{*} & 3.7 & c_{3} s_{1}\end{array}$




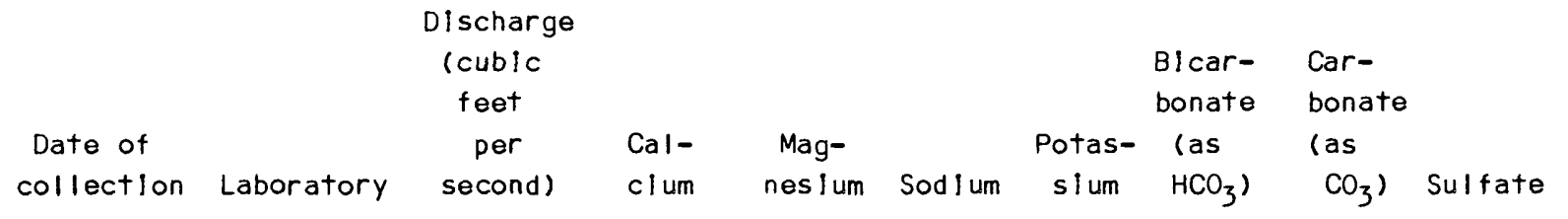

\section{Rlo San Jose at Seama Diversion $(10.7 .34 .242)$}

\begin{tabular}{|c|c|c|c|c|c|c|c|c|c|c|}
\hline $04-$ & -61 & $B \mid A$ & - & 160 & 120 & 530 & 5.9 & 390 & 15 & 930 \\
\hline 05- & -61 & $B \mid A$ & - & 150 & 160 & 870 & 7.8 & 360 & 30 & 1,700 \\
\hline 06- & -61 & $B \mid A$ & - & 37 & 75 & 290 & 6.8 & 320 & 19 & 550 \\
\hline $07-$ & -61 & $B \mid A$ & - & 80 & 130 & 55 & 8.6 & 140 & - & 220 \\
\hline $08-$ & -61 & $B \mid A$ & - & 100 & 44 & 200 & 8.6 & 260 & 8 & 460 \\
\hline $09-$ & -61 & $B \mid A$ & - & 84 & 69 & 240 & 7.0 & 220 & 30 & 600 \\
\hline $10-$ & -61 & $B \mid A$ & - & 98 & 49 & 210 & 7.0 & 250 & 24 & 470 \\
\hline $02-$ & -62 & $B \mid A$ & - & - & - & - & - & - & - & - \\
\hline $11-$ & -62 & $B \mid A$ & - & - & - & - & - & - & - & - \\
\hline $06-2$ & $6-67$ & $B \mid A$ & - & 250 & 85 & 610 & 8.6 & 320 & 16 & 1,500 \\
\hline $07-$ & -68 & $B \mid A$ & - & 89 & 75 & 320 & 7.8 & 320 & $T$ & 700 \\
\hline $10-1$ & $4-68$ & $B \mid A$ & - & 150 & 130 & 540 & 4.8 & 260 & 11 & 1,400 \\
\hline $05-0$ & $6-69$ & $B \mid A$ & - & 170 & 270 & 1,100 & 15 & 280 & 17 & 2,900 \\
\hline $06-$ & -69 & $B \mid A$ & - & 120 & 97 & 440 & 7.8 & 320 & 29 & 970 \\
\hline $07-$ & -69 & $B \mid A$ & - & 150 & 140 & 750 & 6.3 & 370 & 20 & 1,700 \\
\hline \multicolumn{2}{|c|}{$08-08-69$} & $B \mid A$ & - & 82 & 34 & 75 & 13 & 160 & $T$ & 640 \\
\hline
\end{tabular}




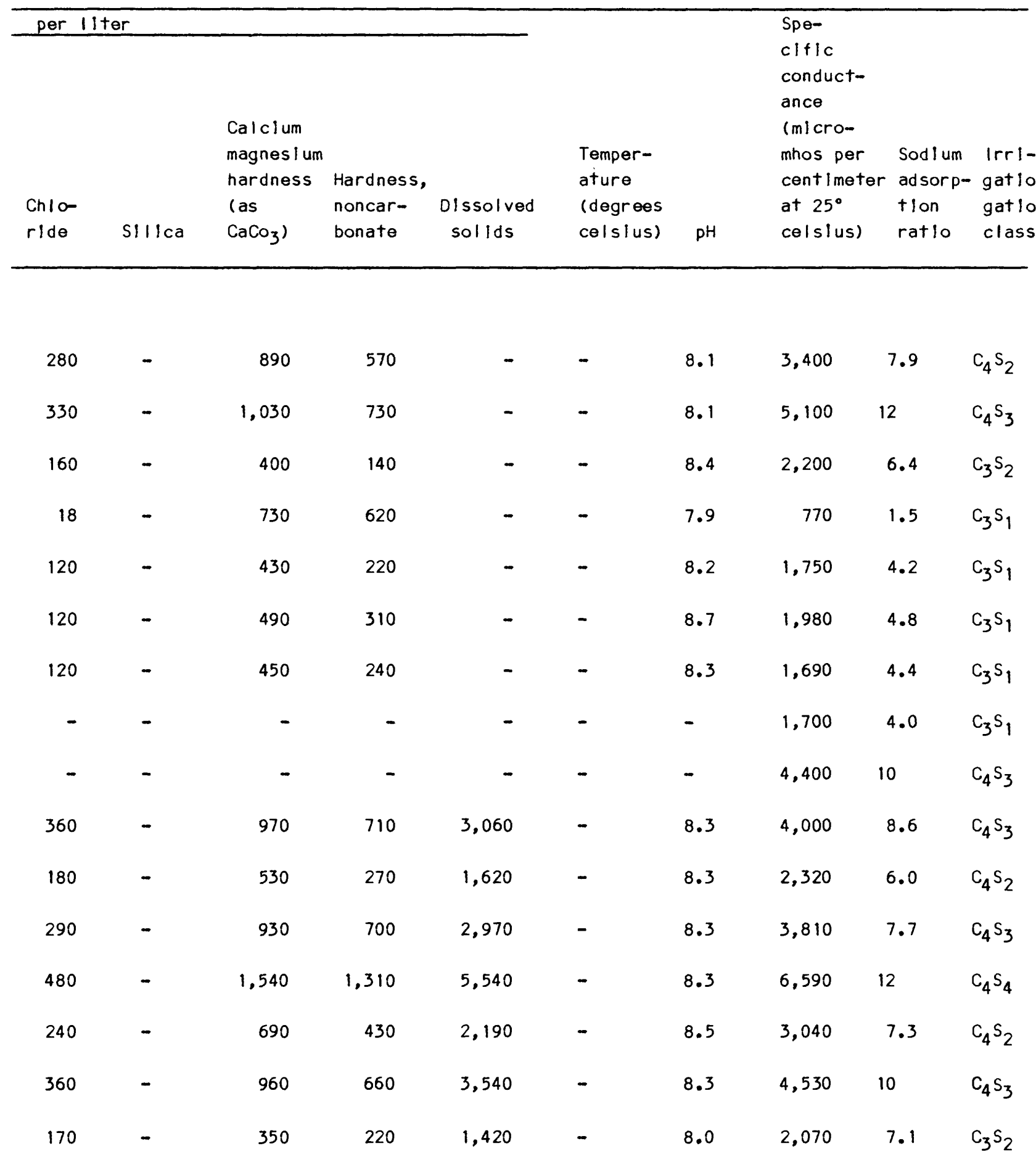




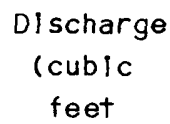

Date of collection Laboratory per second)

\begin{tabular}{|c|c|c|c|c|c|}
\hline & & & & $\begin{array}{c}\text { Blcar- } \\
\text { bonate } \\
\text { (as }\end{array}$ & $\begin{array}{l}\text { Car- } \\
\text { bonate } \\
\text { (as }\end{array}$ \\
\hline $\begin{array}{l}\text { Cal- } \\
\text { clum }\end{array}$ & $\begin{array}{c}\text { Mag- } \\
\text { nes l um }\end{array}$ & Sod I um & $\begin{array}{c}\text { Potas- } \\
\text { sium }\end{array}$ & $\begin{array}{l}(\mathrm{as} \\
\left.\mathrm{HCO}_{3}\right)\end{array}$ & $\begin{array}{l}(\mathrm{as} \\
\left.\mathrm{CO}_{3}\right)\end{array}$ \\
\hline
\end{tabular}

Rlo San Jose at Seama Diversion (10.7.34.242) - continued

\begin{tabular}{|c|c|c|c|c|c|c|c|c|c|c|}
\hline 09- & -69 & $B \mid A$ & - & 110 & 36 & 110 & 5.5 & 210 & 4 & 440 \\
\hline $10-$ & -69 & $B \mid A$ & - & 140 & 97 & 420 & 4.3 & 350 & 21 & 940 \\
\hline $05-07$ & $7-70$ & $B \mid A$ & - & 150 & 200 & 930 & 9.4 & 460 & 36 & 2,100 \\
\hline 06- & -70 & $B \mid A$ & - & 140 & 130 & 360 & 7.4 & 190 & 38 & 1,500 \\
\hline $08-05$ & $5-70$ & $B \mid A$ & - & 80 & 22 & 89 & 6.6 & 130 & $T$ & 300 \\
\hline 09- & -70 & $B \mid A$ & - & 150 & 110 & 480 & 2.4 & 380 & 21 & 1,100 \\
\hline $07-26$ & $6-71$ & $B \mid A$ & - & 140 & 64 & 310 & 11 & 270 & 28 & 700 \\
\hline $08-$ & -71 & BIA & - & 110 & 60 & 240 & 12 & 270 & 25 & 550 \\
\hline $10-27$ & $7-71$ & $B \mid A$ & - & 96 & 56 & 260 & 11 & 250 & 17 & 520 \\
\hline $07-10$ & $0-72$ & $B / A$ & - & 140 & 190 & 1,100 & 1.6 & 360 & 43 & 2,400 \\
\hline $08-3$ & $1-72$ & $B \mid A$ & - & 58 & 18 & 91 & 5.1 & 190 & $T$ & 180 \\
\hline $09-13$ & $3-73$ & $B \mid A$ & - & 112 & 49 & 210 & 13 & 240 & 19 & 530 \\
\hline $01-25$ & $5-74$ & $B \mid A$ & - & 100 & 61 & 240 & 5.1 & 270 & 25 & 500 \\
\hline $04-03$ & $3-74$ & $B \mid A$ & - & 100 & 63 & 230 & 5.5 & 280 & 20 & 480 \\
\hline $07-0$ & $1-74$ & $B \mid A$ & - & 96 & 81 & 290 & 3.1 & 300 & 29 & 650 \\
\hline $10-2$ & $1-74$ & $B \mid A$ & - & 160 & 110 & 510 & 4.7 & 280 & 61 & 1,100 \\
\hline
\end{tabular}




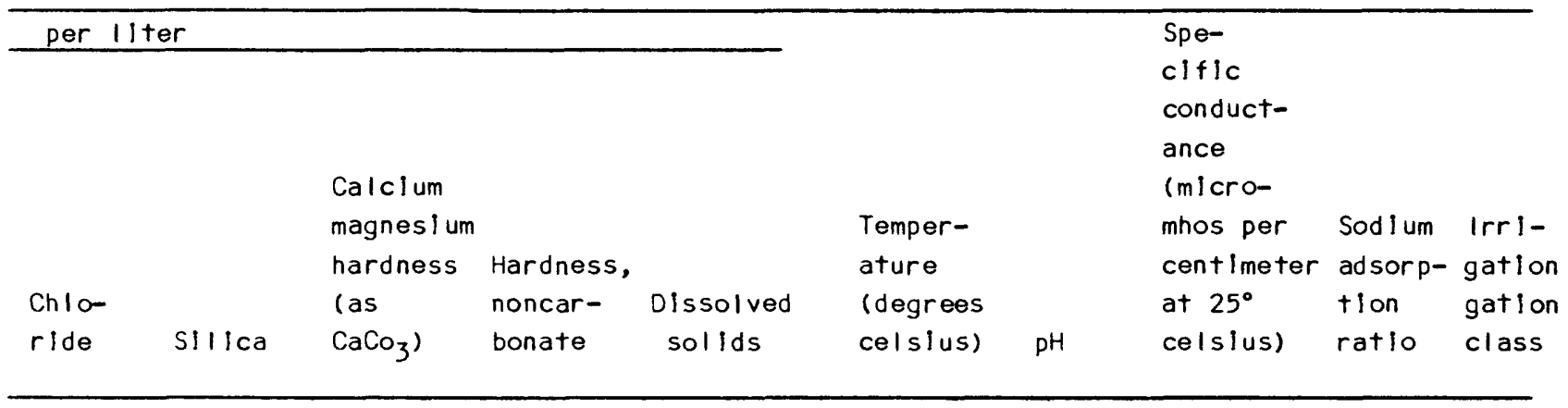

\begin{tabular}{|c|c|c|c|c|c|c|c|c|}
\hline 100 & - & 420 & 250 & 1,110 & - & 8.2 & 1,520 & 3.6 \\
\hline 230 & - & 740 & 450 & 2,260 & - & 8.4 & 2,970 & 6.7 \\
\hline 480 & - & 1,190 & 820 & 4,310 & - & 8.4 & 5,400 & 12 \\
\hline 330 & - & 890 & 730 & 3,050 & - & 8.3 & 4,210 & 9.3 \\
\hline 55 & - & 290 & 180 & 608 & - & 8.3 & 1,100 & 2.3 \\
\hline 260 & - & 830 & 520 & 2,580 & - & 8.4 & 3,380 & 7.2 \\
\hline 200 & - & 620 & 400 & 1,660 & - & 8.2 & 2,360 & 5.4 \\
\hline 150 & - & 530 & 300 & 1,370 & - & 8.5 & 1,940 & 4.5 \\
\hline 150 & - & 470 & 260 & 1,340 & - & 8.3 & 1,930 & 5.1 \\
\hline 510 & - & 1,150 & 850 & 4,850 & - & 8.5 & 5,900 & 14 \\
\hline 48 & - & 220 & 66 & 547 & - & 8.1 & 840 & 2.7 \\
\hline 150 & - & 480 & 280 & 1,250 & 16 & 8.2 & $1,900^{*}$ & 4.1 \\
\hline 140 & - & 510 & 280 & 1,320 & - & 8.5 & 1,910 & 4.6 \\
\hline 140 & - & 520 & 290 & 1,370 & 6 & 8.4 & $1,800 *$ & 4.4 \\
\hline 180 & - & 580 & 330 & 1,680 & 20 & 8.3 & $2,100^{*}$ & 5.3 \\
\hline 280 & - & 870 & 640 & 2,610 & 12 & 8.2 & $3,000^{*}$ & 2.5 \\
\hline
\end{tabular}




\begin{tabular}{|c|c|c|c|c|c|c|c|c|c|}
\hline & & $\begin{array}{c}\text { Discharge } \\
\text { (cublc } \\
\text { feet }\end{array}$ & & & & & $\begin{array}{l}\text { Blcar- } \\
\text { bonate }\end{array}$ & $\begin{array}{l}\text { Car- } \\
\text { bonate }\end{array}$ & \\
\hline $\begin{array}{l}\text { Date of } \\
\text { collection }\end{array}$ & Laboratory & $\begin{array}{c}\text { per } \\
\text { second) }\end{array}$ & $\begin{array}{l}\text { Cal- } \\
\text { clum }\end{array}$ & $\begin{array}{c}\text { Mag- } \\
\text { nesium }\end{array}$ & Sod lum & $\begin{array}{l}\text { Potas- } \\
\text { slum }\end{array}$ & $\begin{array}{l}\text { (as } \\
\mathrm{HCO}_{3} \text { ) }\end{array}$ & $\begin{array}{l}(\mathrm{as} \\
\left.\mathrm{CO}_{3}\right)\end{array}$ & Sulfate \\
\hline
\end{tabular}

\section{Rlo San Jose at Seama Diversion (10.7.34.242) - continued}

\begin{tabular}{|c|c|c|c|c|c|c|c|c|c|}
\hline $03-28-75$ & $B \mid A$ & - & 110 & 57 & 230 & 6.3 & 280 & 28 & 520 \\
\hline $08-08-75$ & $B \mid A$ & - & 220 & 110 & 660 & 12 & 420 & 34 & 1,400 \\
\hline $03-25-76$ & $B \mid A$ & - & 100 & 64 & 240 & 6.7 & 310 & 10 & 500 \\
\hline $01-11-77$ & $B \mid A$ & - & 140 & 88 & 350 & 7.4 & 350 & 16 & 890 \\
\hline $04-04-77$ & $B \mid A$ & - & 100 & 62 & 270 & 6.7 & 280 & 14 & 540 \\
\hline $07-07-77$ & $B \mid A$ & - & 90 & 86 & 390 & 11 & 300 & 10 & 780 \\
\hline $10-03-77$ & $B \mid A$ & - & 110 & 57 & 260 & 8.6 & 280 & 17 & 540 \\
\hline $01-10-78$ & $B \mid A$ & - & 110 & 63 & 280 & 7.8 & 310 & $T$ & 620 \\
\hline $03-01-78$ & $B \mid A$ & - & 100 & 62 & 260 & 7.8 & 300 & 12 & 540 \\
\hline $06-05-78$ & $B \mid A$ & - & 150 & 94 & 530 & 11 & 370 & 10 & 1,100 \\
\hline $09-05-78$ & $B \mid A$ & - & 150 & 84 & 400 & 11 & 360 & 7 & 1,010 \\
\hline $01-08-79$ & $B \mid A$ & - & 100 & 56 & 210 & 9.0 & 270 & 7 & \\
\hline $03-01-79$ & $B \mid A$ & - & 100 & 54 & 230 & 7.4 & 300 & $T$ & 510 \\
\hline $06-06-79$ & $B \mid A$ & - & 130 & 69 & 350 & 11 & 340 & 2.4 & \\
\hline
\end{tabular}




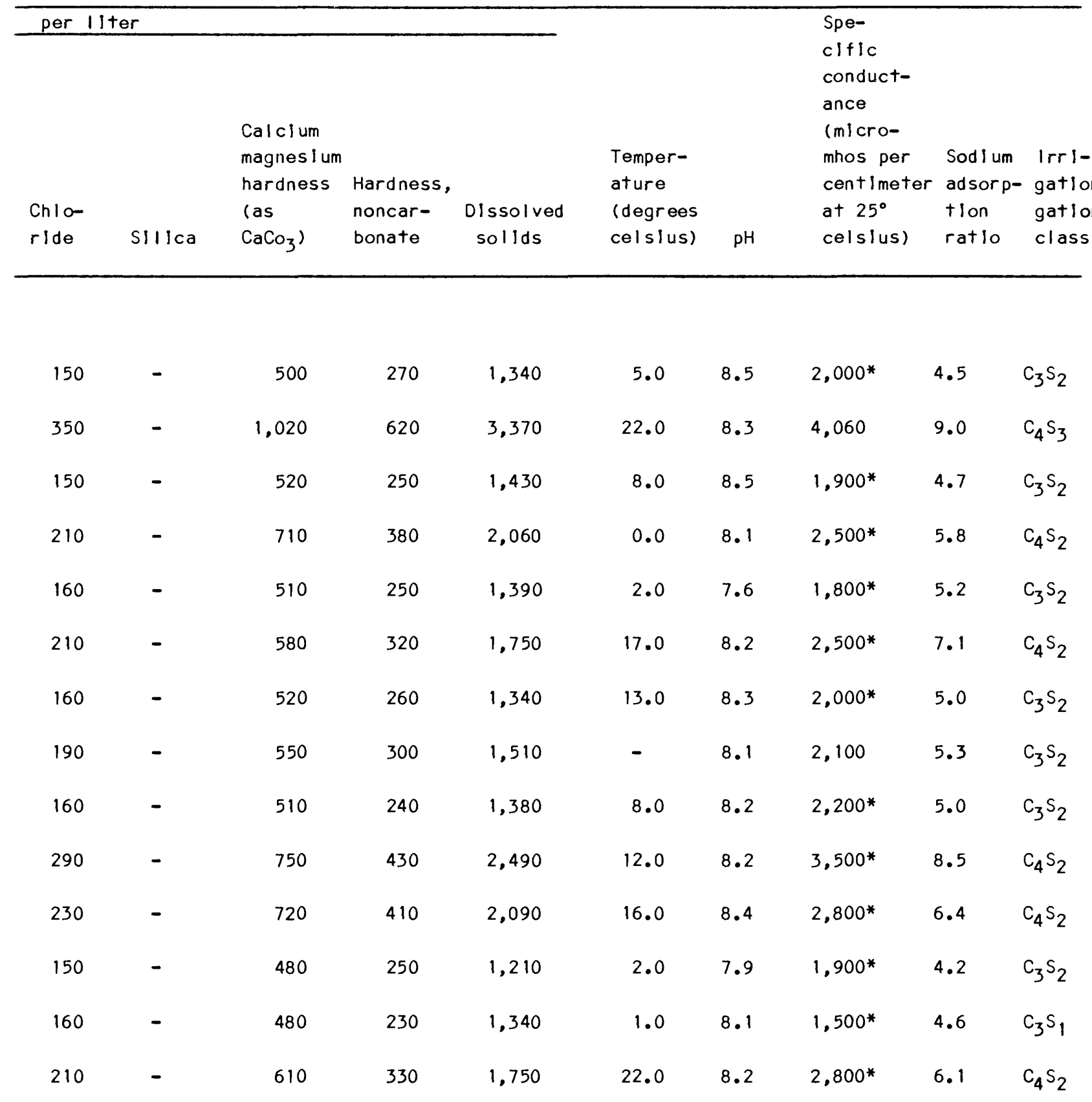




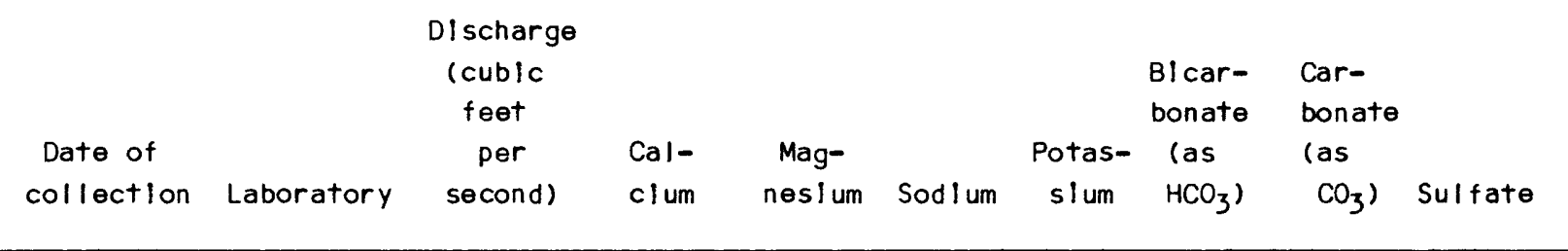

Cubero Creek at Budville (10.7.25.211)

$\begin{array}{llllllllll}11-04-74 & \text { BIA } & .42 & 92 & 18 & 46 & 6.3 & 260 & 20 & 150 \\ 04-20-78 & \text { USGS } & .30 & 87 & 25 & 52 & 6.6 & 290^{*} & 11^{*} & 150 \\ 07-25-78 & \text { BIA } & .25 & 64 & 19 & 51 & 7.8 & 250^{*} & 8^{*} & 130 \\ 10-26-78 & \text { BIA } & .24 & 78 & 23 & 51 & 7.0 & 320^{*} & 4^{*} & 150 \\ 01-29-79 & \text { BIA } & .40 & 78 & 19 & 51 & 8.2 & 280^{*} & 10^{*} & 130\end{array}$

Rlo San Jose at Casa Blanca Diversion (9.6.6.222)

\begin{tabular}{|c|c|c|c|c|c|c|c|c|c|c|}
\hline 04- & -61 & $B \mid A$ & - & 150 & 110 & 500 & 5.9 & 380 & 13 & 920 \\
\hline 05- & -61 & $B \mid A$ & - & 140 & 100 & 360 & 10 & 380 & 17 & 120 \\
\hline 06- & -61 & $B \mid A$ & - & 110 & 110 & 390 & 11 & 300 & 11 & 950 \\
\hline $07-$ & -61 & $B \mid A$ & - & 77 & 18 & 100 & 8.6 & 150 & - & 300 \\
\hline 08- & -61 & $B \mid A$ & - & 88 & 51 & 190 & 7.8 & 240 & 4 & 460 \\
\hline $09-$ & -61 & $B \mid A$ & - & 96 & 46 & 230 & 7.8 & 250 & 21 & 490 \\
\hline $10-$ & -61 & $B \mid A$ & - & 92 & 51 & 220 & 7.8 & 250 & 18 & 500 \\
\hline \multicolumn{2}{|c|}{$06-26-67$} & $B \mid A$ & - & 160 & 15 & 220 & 9.9 & 200 & $T$ & 580 \\
\hline \multicolumn{2}{|c|}{$05-06-69$} & $B \mid A$ & - & 160 & 250 & 1,100 & 18 & 290 & 18 & 2,900 \\
\hline 06- & -69 & $B \mid A$ & - & 120 & 98 & 440 & 5.1 & 280 & 23 & 960 \\
\hline
\end{tabular}




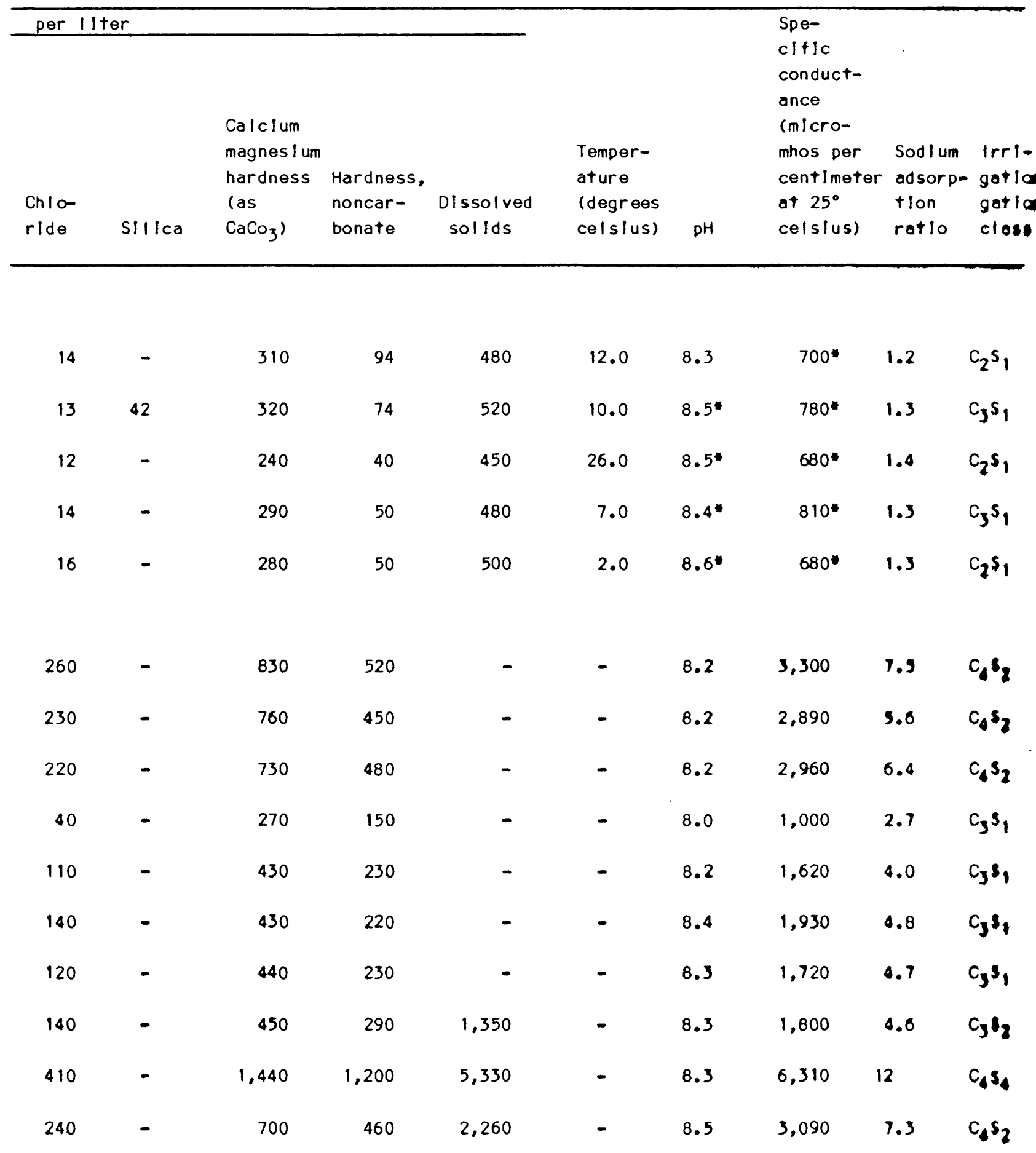


Table 9.-Selected major chemical constituents of surface water-Continued

Constituents in milligrams

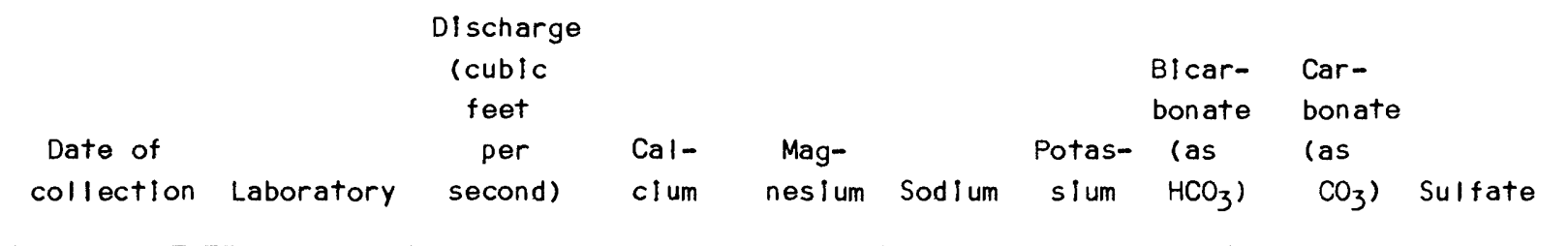

Rlo San Jose at Casa Blanca Diversion (9.6.6.222) - contInued

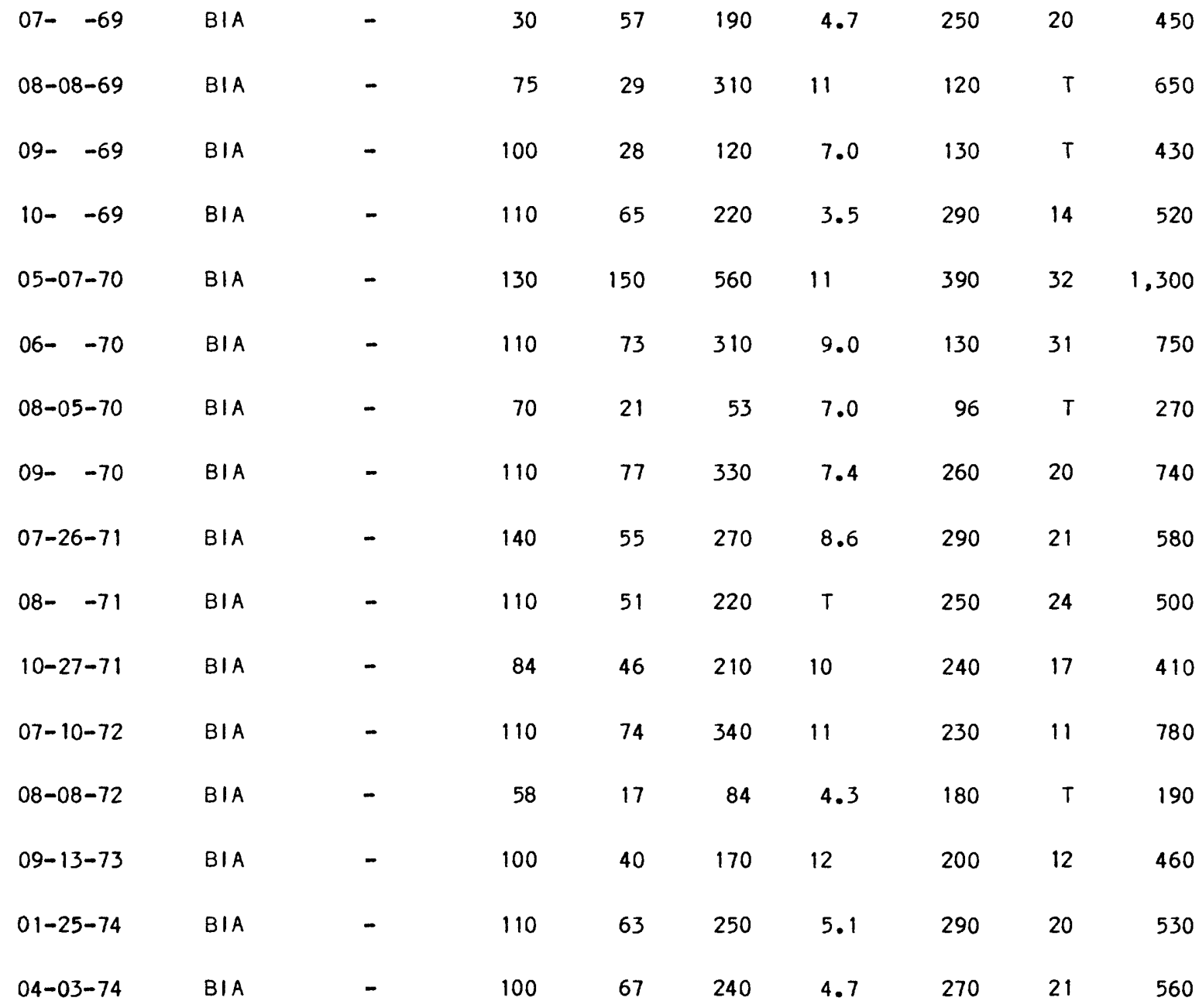




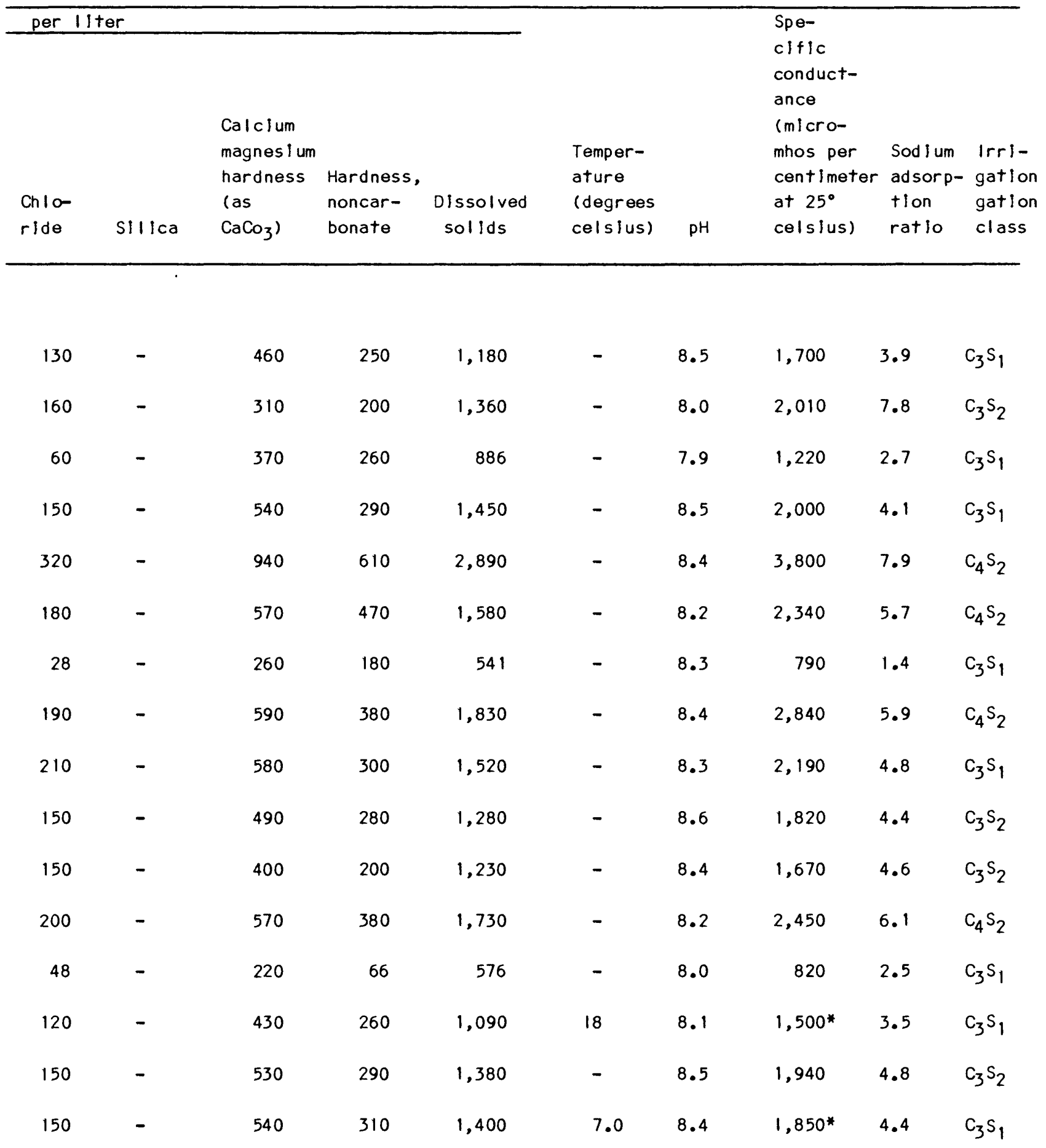




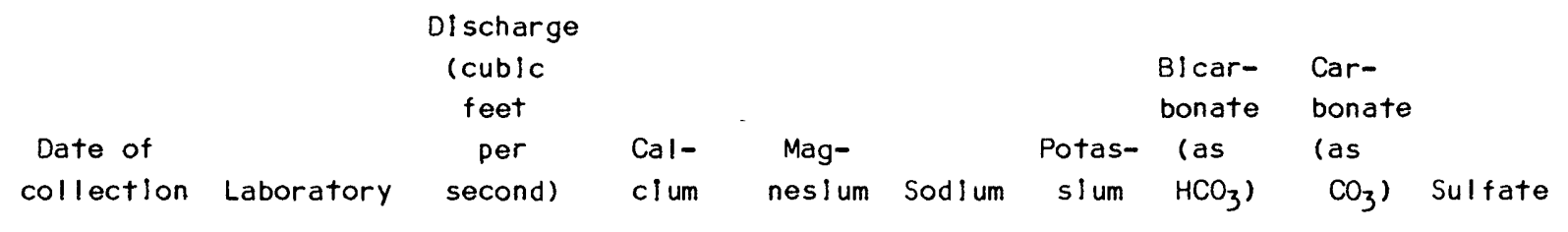

Rlo San Jose at Casa Blanca Dlverslon (9.6.6.222) - continued

\begin{tabular}{|c|c|c|c|c|c|c|c|c|c|}
\hline $07-01-74$ & $B \mid A$ & - & 68 & 57 & 230 & 2.0 & 210 & 13 & 480 \\
\hline $10-21-74$ & $\mathrm{~B} \mid \mathrm{A}$ & - & 170 & 110 & 500 & 4.7 & 300 & 47 & 1,200 \\
\hline $03-28-75$ & $B \mid A$ & - & 100 & 64 & 240 & 5.9 & 280 & 30 & 540 \\
\hline $03-25-76$ & $B \mid A$ & - & 100 & 62 & 240 & 7.0 & 310 & 14 & 540 \\
\hline $01-10-77$ & $B \mid A$ & - & 120 & 100 & 130 & 7.0 & 280 & 12 & 750 \\
\hline $04-04-77$ & $B \mid A$ & - & 120 & 75 & 280 & 8.6 & 320 & 22 & 620 \\
\hline $07-07-77$ & $B \mid A$ & - & 70 & 29 & 170 & 9.8 & 200 & 5 & 360 \\
\hline $10-03-77$ & $B \mid A$ & - & 110 & 60 & 270 & 9.0 & 280 & 19 & 550 \\
\hline $01-10-78$ & $B \mid A$ & - & 110 & 63 & 290 & 9.4 & 290 & 19 & 670 \\
\hline $03-01-78$ & $B \mid A$ & - & 110 & 63 & 280 & 7.8 & 270 & 22 & 590 \\
\hline $06-05-78$ & $B \mid A$ & 0 & 240 & 50 & 330 & 11 & 520 & $T$ & 750 \\
\hline $09-05-78$ & $B \mid A$ & - & 130 & 73 & 310 & 12 & 280 & 10 & 820 \\
\hline $01-08-79$ & $B \mid A$ & - & 98 & 60 & 220 & 9.0 & 270 & 10 & 500 \\
\hline $03-01-79$ & $B \mid A$ & - & 100 & 54 & 230 & 7.4 & 300 & $T$ & 520 \\
\hline $06-07-79$ & $B \mid A$ & - & 150 & 74 & 380 & 6.3 & 360 & 7.2 & 870 \\
\hline
\end{tabular}




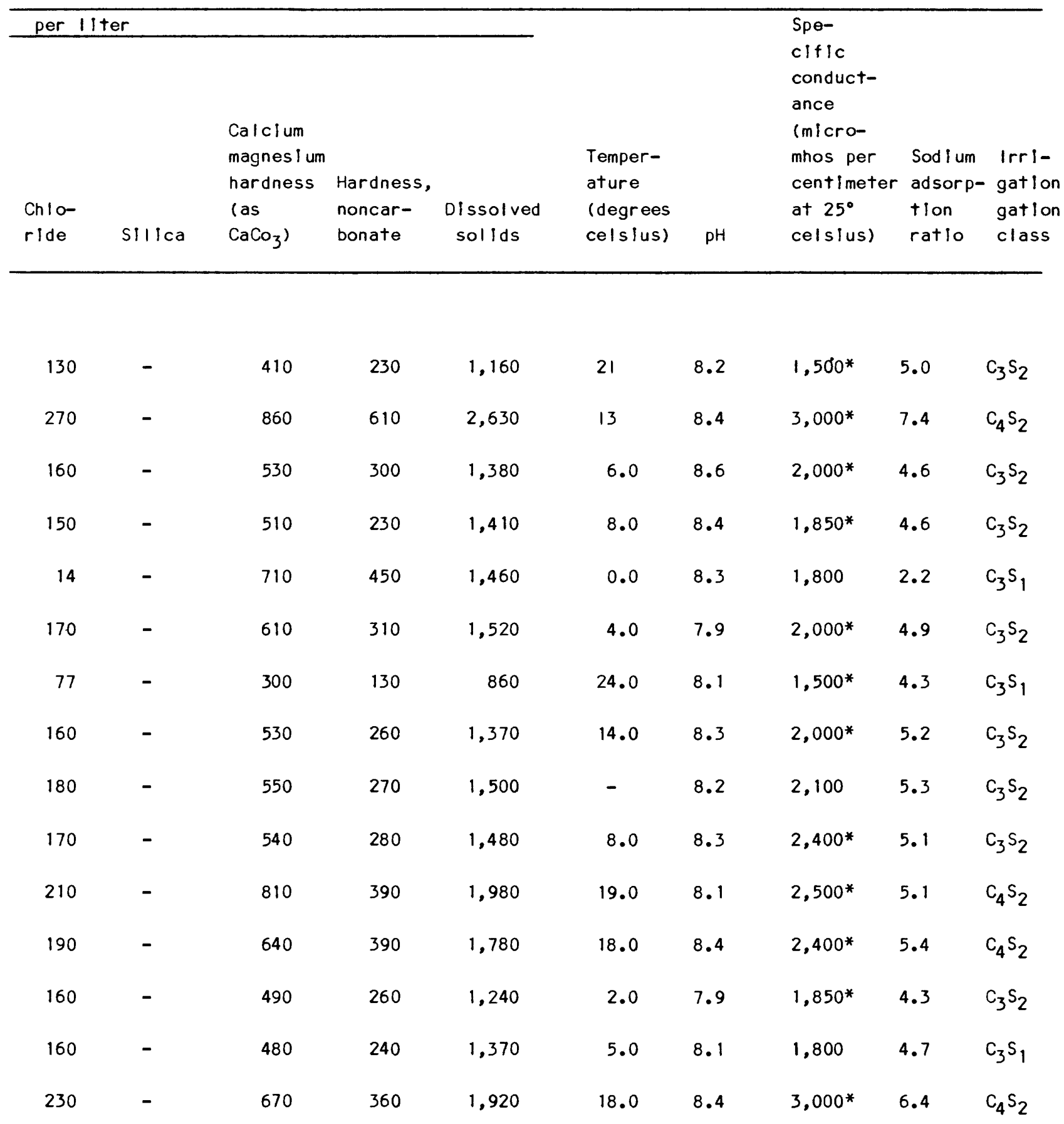




\begin{tabular}{|c|c|c|c|c|c|c|c|c|}
\hline & $\begin{array}{c}\text { Discharge } \\
\text { (cublc } \\
\text { feet }\end{array}$ & & & & & $\begin{array}{l}\text { Blcar- } \\
\text { bonate }\end{array}$ & $\begin{array}{l}\text { Car- } \\
\text { bonate }\end{array}$ & \\
\hline $\begin{array}{l}\text { Date of } \\
\text { collection . Laboratory }\end{array}$ & $\begin{array}{l}\text { per } \\
\text { second) }\end{array}$ & $\begin{array}{l}\text { Cal- } \\
\text { clum }\end{array}$ & $\begin{array}{l}\text { Mag- } \\
\text { neslum }\end{array}$ & Sod lum & $\begin{array}{l}\text { Potas- } \\
\text { slum }\end{array}$ & $\begin{array}{l}\text { (as } \\
\left.\mathrm{HCO}_{3}\right)\end{array}$ & $\begin{array}{l}(\mathrm{as} \\
\left.\mathrm{CO}_{3}\right)\end{array}$ & Sulfate \\
\hline
\end{tabular}

Runoff from Casa Blanca Mosa $(9 \cdot 6 \cdot 24.311)$

$\begin{array}{lllllllllll}10-10-78 & \text { BIA } & - & & 22 & 0.6 & 2.3 & 2.4 & 52 & T & 19\end{array}$

Rlo San Jose at New Laguna Dam (9.6.1.322)

\begin{tabular}{|c|c|c|c|c|c|c|c|c|c|}
\hline $08-07-75$ & $B \mid A$ & - & 92 & 19 & 66 & 11 & 160 & 7 & 250 \\
\hline $01-12-77$ & $B \mid A$ & - & 160 & 100 & 400 & 8.6 & 420 & 22 & 980 \\
\hline $04-06-77$ & $B \mid A$ & - & 110 & 64 & 290 & 7.4 & 290 & 14 & 600 \\
\hline $10-04-77$ & $B \mid A$ & - & 120 & 50 & 230 & 9.4 & 290 & 12 & 460 \\
\hline $01-10-78$ & $B \mid A$ & - & 120 & 60 & 280 & 9.4 & 290 & 24 & 650 \\
\hline $03-07-78$ & $B \mid A$ & - & 110 & 57 & 270 & 9.0 & 270 & 12 & 540 \\
\hline $09-06-78$ & $B \mid A$ & 0 & 330 & 100 & 510 & 19 & 360 & $T$ & 1,670 \\
\hline $01-09-79$ & $B \mid A$ & - & 100 & 57 & 230 & 9.4 & 250 & 22 & 520 \\
\hline $03-02-79$ & $B \mid A$ & - & 110 & 55 & 250 & 9.0 & 330 & $\mathrm{~T}$ & 530 \\
\hline $06-08-79$ & $B \mid A$ & - & 140 & 62 & 290 & 11 & 310 & $T$ & 730 \\
\hline
\end{tabular}

Rio Paguate upstrean from Paguate, New Mexico (II.5.30.234)

$\begin{array}{llcccccccrr}06-26-67 & \text { BIA } & - & 32 & 12 & 13 & 4.3 & 150 & \text { T } \\ 04-21-78 & \text { USGS } & .79 & 37 & 14 & 17 & 4.7 & 180^{*} & 4^{*} & 23 \\ 07-19-78 & \text { BIA } & .20 & 34 & 10 & 16 & 5.5 & 190^{*} & 0^{*} & 25\end{array}$




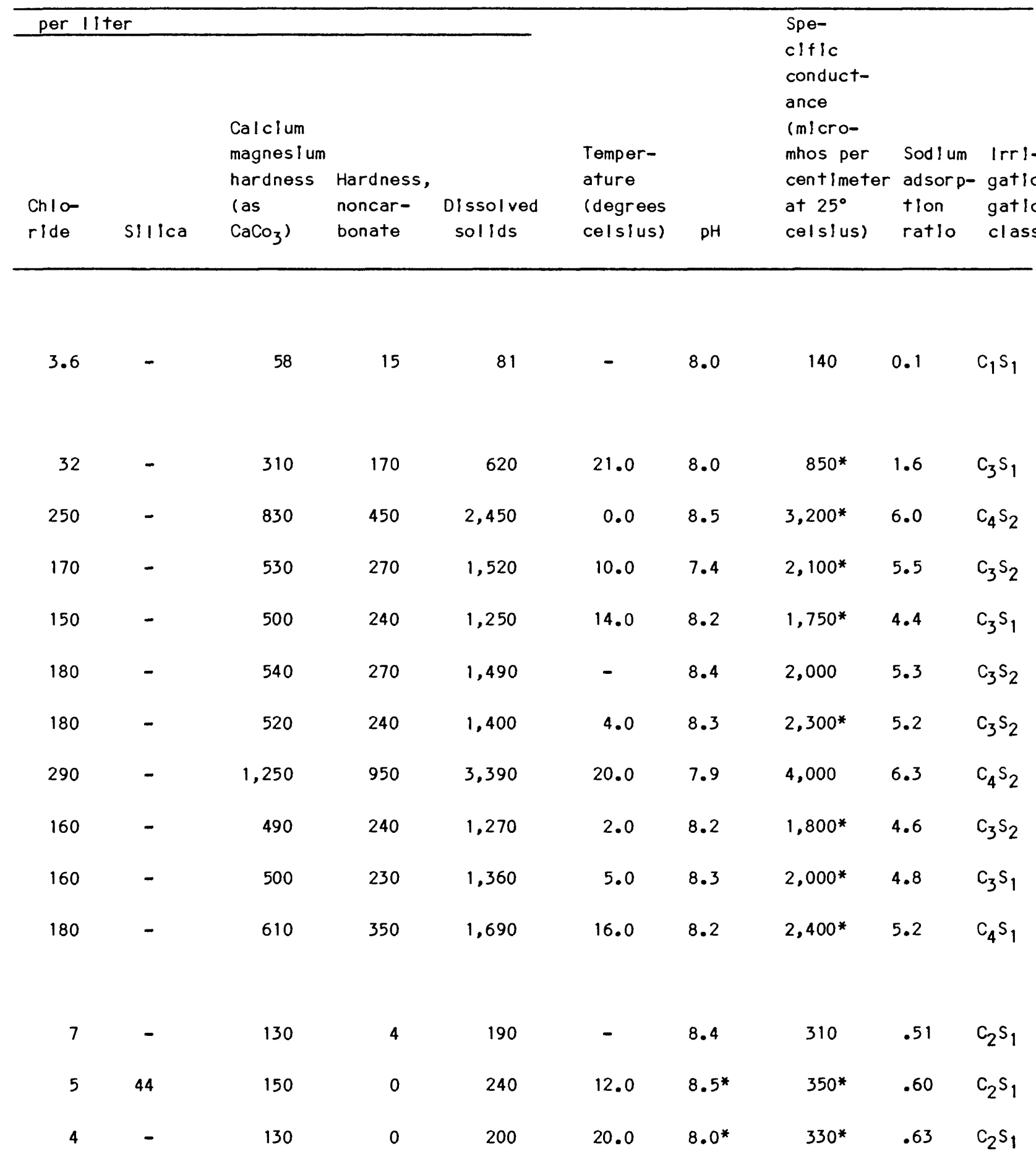




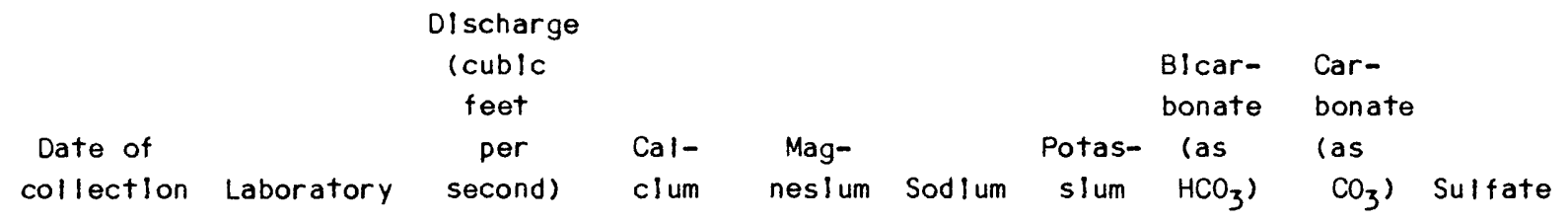

RIo Poguate upstrean trom Poguate, Nowico (11.5.30.234) - continued

$\begin{array}{lrrrrrrrrr}10-30-78 & \text { BIA } & 2.4 & 40 & 11 & 18 & 5.5 & 190^{*} & 0^{*} & 25 \\ 01-30-79 & \text { BIA } & .93 & 48 & 13 & 23 & 7.0 & 210^{*} & 0^{*} & 49\end{array}$

Rio Paguate upstream from Jackpll e-Paguate Mine $(11.5 .32 .424)$

\begin{tabular}{|c|c|c|c|c|c|c|c|c|c|}
\hline $04-01-76$ & $B \mid A$ & - & 84 & 3 & 41 & 5.1 & 300 & 5 & 140 \\
\hline $01-13-77$ & $B \mid A$ & - & 68 & 19 & 23 & 5.5 & 230 & 14 & 94 \\
\hline $01-18-77$ & USGS & - & 53 & 18 & 22 & 4.2 & 230 & 0 & 64 \\
\hline $04-05-77$ & $B \mid A$ & - & 74 & 22 & 34 & 5.1 & 280 & 12 & 92 \\
\hline $01-10-78$ & $B \mid A$ & - & 68 & 22 & 30 & 7.0 & 240 & 10 & 110 \\
\hline $03-07-78$ & $B \mid A$ & - & 64 & 18 & 28 & 8.6 & 230 & 12 & 99 \\
\hline $04-21-78$ & USGS & .33 & 98 & 35 & 35 & 5.3 & $370^{*}$ & $4^{*}$ & 150 \\
\hline $06-06-78$ & $B \mid A$ & - & 84 & 30 & 37 & 6.3 & 300 & 12 & 140 \\
\hline $07-19-78$ & $B \mid A$ & .12 & 82 & 33 & 41 & 6.8 & $330^{*}$ & $0^{*}$ & 190 \\
\hline $09-06-78$ & $B \mid A$ & - & 100 & 24 & 34 & 6.7 & 270 & $\mathrm{~T}$ & 190 \\
\hline $10-26-78$ & $B \mid A$ & .20 & 110 & 35 & 34 & 6.2 & $400^{*}$ & $0^{*}$ & 170 \\
\hline $01-08-79$ & $B \mid A$ & - & 96 & 33 & 34 & 5.5 & 300 & 22 & 140 \\
\hline $01-29-79$ & $B \mid A$ & 1.4 & 60 & 19 & 25 & 6.7 & $250^{*}$ & $0^{*}$ & 63 \\
\hline
\end{tabular}




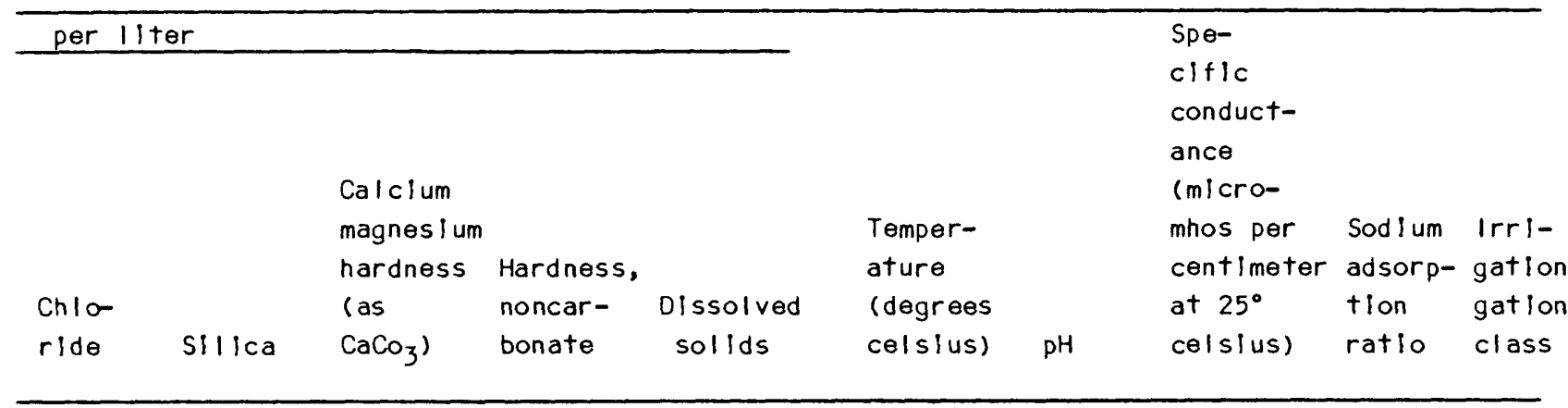

\begin{tabular}{|c|c|c|c|c|c|c|c|c|}
\hline 5 & - & 150 & 0 & 210 & 10.5 & $8.1^{*}$ & $380^{*}$ & .42 \\
\hline 5 & - & 180 & 1 & 290 & 0.0 & $8.3 *$ & $350^{*}$ & .76 \\
\hline 16 & - & 340 & 79 & 500 & - & 8.5 & 770 & .98 \\
\hline 7 & - & 250 & 38 & 380 & 0.0 & 8.2 & 560 & .63 \\
\hline 7 & 37 & 210 & 15 & 320 & 4.0 & $8.0^{*}$ & $490^{*}$ & .70 \\
\hline 9 & - & 280 & 25 & 420 & 6.0 & 7.7 & 610 & .90 \\
\hline 13 & - & 260 & 46 & 400 & - & 8.2 & 590 & .81 \\
\hline 7 & - & 240 & 27 & 420 & 9.0 & 8.3 & 510 & .78 \\
\hline 10 & 32 & 390 & 100 & 540 & 8.0 & $8.4^{*}$ & $800^{*}$ & .80 \\
\hline 12 & - & 340 & 66 & 510 & 17.0 & 8.3 & $800^{*}$ & .87 \\
\hline 12 & - & 340 & 130 & 520 & 28.0 & $7.9 *$ & $820^{*}$ & .98 \\
\hline 12 & - & 350 & 130 & 590 & 15.0 & 8.3 & $850^{*}$ & .80 \\
\hline 12 & - & 410 & 100 & - & 11.0 & $8.0^{*}$ & $890^{*}$ & .74 \\
\hline 18 & - & 380 & 92 & 550 & 0.0 & 8.2 & $950^{*}$ & .77 \\
\hline 9 & - & 230 & 16 & 360 & 1.0 & $8.0^{*}$ & $475^{*}$ & .73 \\
\hline
\end{tabular}




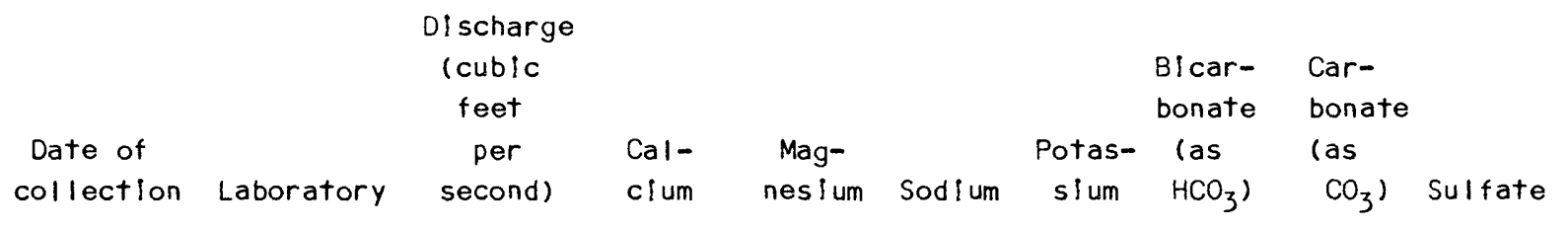

Rio Paguate upstrean from Jackpi le-Paguate Mine $(11.5 .32 .424)$ - continued

$\begin{array}{llllllllll}03-01-79 & B \mid A & - & 100 & 30 & 37 & 5.9 & 350 & 5 & 160 \\ 06-06-79 & B I A & - & 100 & 12 & 35 & 9.0 & 330 & 2.4 & 130\end{array}$

RIo Moqulno upstream from Jackpi le-Paguate Mine (I I.5.22.344)

\begin{tabular}{|c|c|c|c|c|c|c|c|c|c|}
\hline $04-01-76$ & $B \mid A$ & .37 & 170 & 100 & 180 & 11 & 250 & 10 & 900 \\
\hline $01-13-77$ & $B \mid A$ & - & 130 & 100 & 150 & 8.6 & 310 & $T$ & 800 \\
\hline $01-18-77$ & USGS & 3.7 & 130 & 63 & 110 & 6.1 & 310 & 0 & 540 \\
\hline $04-05-77$ & $B \mid A$ & - & 170 & 80 & 170 & 7.8 & 300 & $T$ & 790 \\
\hline $07-06-77$ & $B \mid A$ & - & 190 & 120 & 240 & 14 & 180 & 7 & 1,200 \\
\hline $10-03-77$ & $B \mid A$ & - & 200 & 92 & 200 & 12 & 220 & 24 & 1,030 \\
\hline $01-10-78$ & $B \mid A$ & - & 150 & 83 & 160 & 9.0 & 300 & $\mathrm{~T}$ & 780 \\
\hline $03-07-78$ & $B \mid A$ & - & 180 & 110 & 210 & 10 & 320 & $T$ & 1,010 \\
\hline $04-20-78$ & USGS & .31 & 190 & 140 & 250 & 11 & $270^{*}$ & $4^{*}$ & 1,300 \\
\hline $06-05-78$ & $B \mid A$ & - & 240 & 190 & 370 & 15 & 230 & 2 & 1,760 \\
\hline $09-06-78$ & $B \mid A$ & - & 240 & 120 & 260 & 12 & 240 & $T$ & 1,360 \\
\hline $11-02-78$ & $B \mid A$ & .75 & 180 & 96 & 190 & 8.6 & $300^{*}$ & $0^{*}$ & 990 \\
\hline $01-08-79$ & $B \mid A$ & - & 190 & 100 & 190 & 8.6 & 320 & 14 & 920 \\
\hline
\end{tabular}




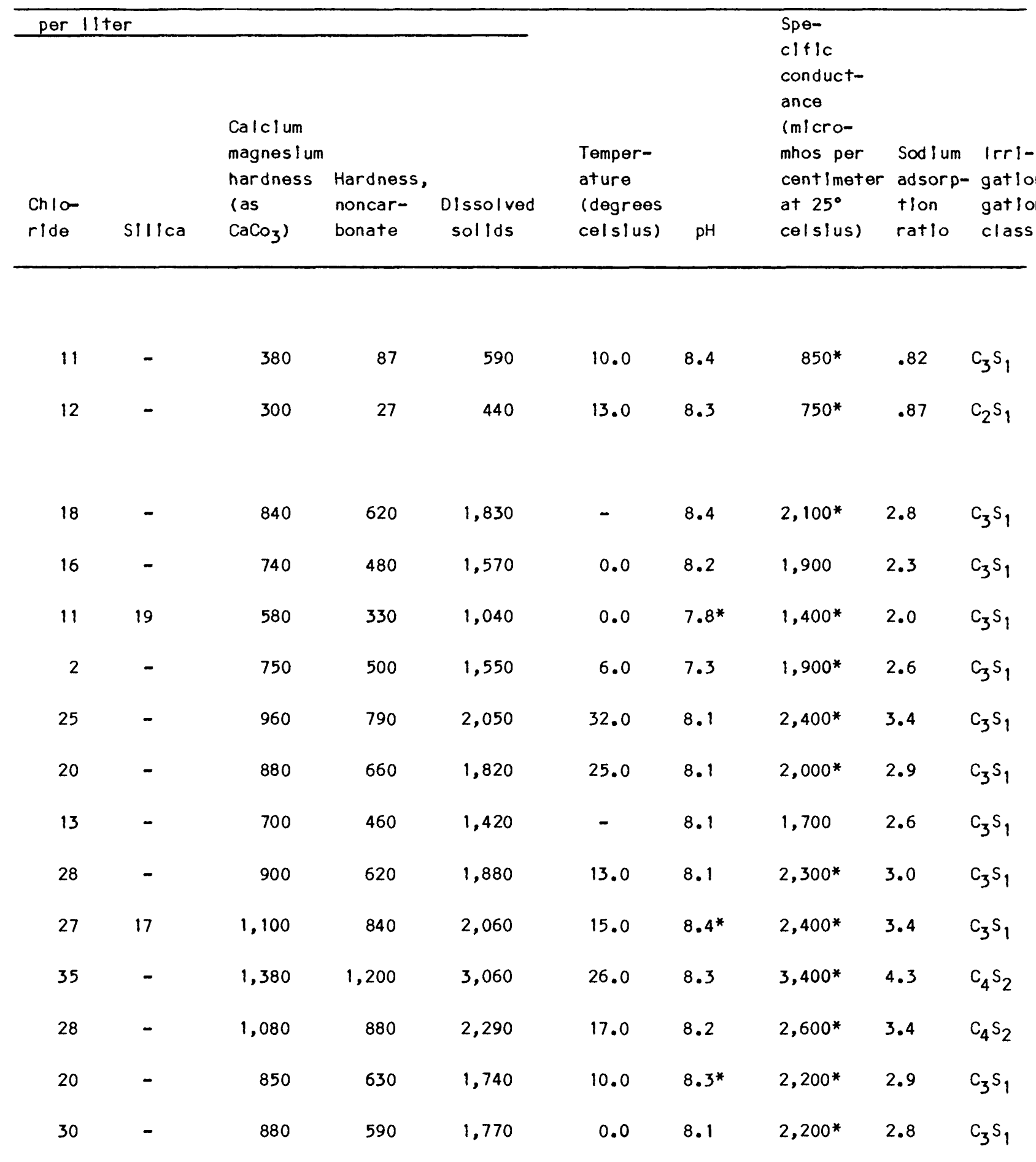


Table 9.--Selected major chemical constituents of surface water-Continued

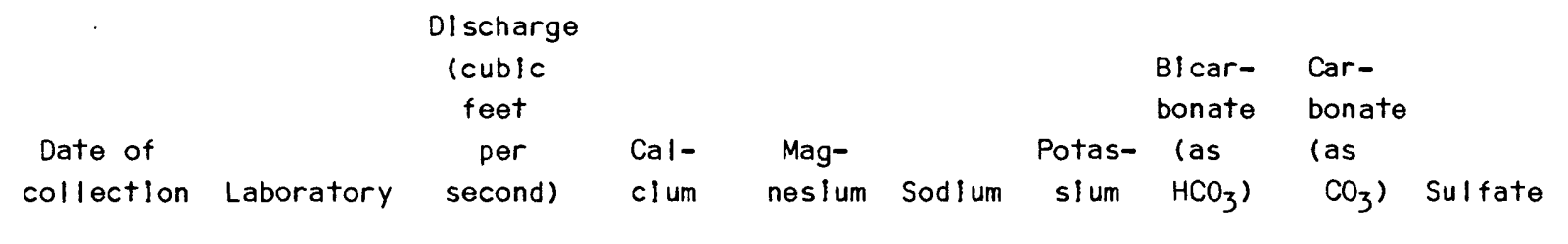

Rio Moquino upstream from Jackpile-Paquate Mine (11.5.22.344) - continued

$\begin{array}{llllllllll}01-30-79 & \text { BIA } & .53 & 180 & 90 & 170 & 11 & 440^{*} & 0^{*} & 830 \\ 03-01-79 & \text { BIA } & - & 130 & 64 & 130 & 7.4 & 280 & 28 & 600 \\ 06-06-79 & \text { BIA } & - & 180 & 73 & 160 & 11 & 260 & \text { T } & 880\end{array}$

Rio Paguate downstream from Jackpi le-Paguate Mine $(10.5 .2 .434)$

\begin{tabular}{|c|c|c|c|c|c|c|c|c|c|}
\hline $04-01-76$ & $B \mid A$ & 1.4 & 120 & 94 & 160 & 8.2 & 250 & 12 & 700 \\
\hline $01-13-77$ & $B \mid A$ & $2.0 \mathrm{~g} /$ & 120 & 79 & 110 & 7.0 & 300 & 17 & 580 \\
\hline $01-18-77$ & USGS & 4.6 & 110 & 65 & 110 & 5.8 & 270 & 0 & 530 \\
\hline $01-24-77$ & USGS & 1.5 & 130 & 81 & 140 & 9.3 & 300 & 0 & 690 \\
\hline $04-04-77$ & $B \mid A$ & $2.1 \mathrm{~g} /$ & 120 & 71 & 130 & 8.2 & 250 & 19 & 570 \\
\hline $07-08-77$ & $B \mid A$ & $.25 \mathrm{~g} /$ & 190 & 150 & 310 & 13 & 250 & 7 & 1,580 \\
\hline $01-10-78$ & $B \mid A$ & $1.3 \mathrm{~g} /$ & 140 & 84 & 160 & 7.8 & 310 & $T$ & 760 \\
\hline $03-07-78$ & $B \mid A$ & $1.7 \mathrm{~g} /$ & 120 & 69 & 140 & 6.3 & 220 & 14 & 670 \\
\hline $04-18-78$ & USGS & 1.1 & 160 & 120 & 200 & 9.4 & $320^{*}$ & $8^{*}$ & 1,000 \\
\hline $06-05-78$ & $B \mid A$ & $.46 \mathrm{~g} /$ & 110 & 88 & 160 & 9.0 & 250 & 5 & 700 \\
\hline $07-25-78$ & $B \mid A$ & .14 & 190 & 140 & 340 & 11 & $340^{*}$ & $0^{*}$ & 1,520 \\
\hline $09-06-78$ & $B \mid A$ & $.10 \mathrm{~g} /$ & 260 & 150 & 300 & 12 & 300 & $T$ & 1,620 \\
\hline
\end{tabular}




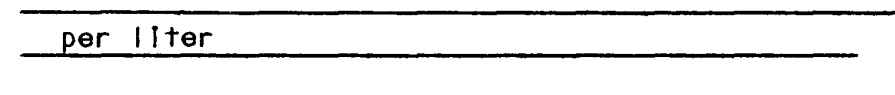

Spe-

c] $f$ ic

conduct-

ance

(micro-

Temper-

ature

(degrees

celsius) $\mathrm{pH}$ mhos per Sodium Irricentlmeter adsorp-gation at $25^{\circ} \quad$ tion gation celslus) ratio class

$\begin{array}{rrrrrrrrrr}25 & - & 810 & 490 & 1,650 & 0.0 & 8.2^{*} & 2,000^{*} & 2.6 & C_{3} S_{1} \\ 18 & - & 580 & 300 & 1,230 & 11.0 & 8.3 & 1,500 & 2.4 & C_{3} S_{1} \\ 14 & - & 750 & 540 & 1,470 & 18.0 & 8.2^{*} & 1,900 & 2.6 & C_{3} S_{1}\end{array}$

$\begin{array}{rrrrrrrrrr}23 & - & 670 & 440 & 1,490 & - & 8.5 & 1,800^{*} & 0.9 & c_{3} s_{1} \\ 5 & - & 620 & 340 & 1,190 & - & 8.4 & 1,500 & 1.9 & c_{3} s_{1} \\ 12 & 22 & 540 & 320 & 990 & 0.0 & 8.0^{*} & 1,370^{*} & 2.1 & c_{3} s_{1} \\ 16 & 22 & 660 & 410 & 1,240 & 9.0 & 8.3^{*} & 1,640 & 2.4 & c_{3} s_{1} \\ 16 & - & 600 & 360 & 1,160 & 15.0 & 8.0 & 1,200^{*} & 2.4 & c_{3} s_{1} \\ 28 & - & 1,100 & 880 & 2,410 & 20.0 & 8.1 & 3,000^{*} & 4.1 & C_{4} s_{2} \\ 21 & - & 690 & 430 & 1,370 & - & 8.1 & 1,700 & 2.6 & c_{3} s_{1} \\ 11 & - & 600 & 390 & 1,210 & 14.0 & 8.3 & 1,500^{*} & 2.4 & c_{3} s_{1} \\ 20 & 20 & 890 & 640 & 1,680 & 14.0 & 8.5 * & 2,200^{*} & 2.9 & c_{3} s_{1} \\ 20 & - & 640 & 430 & 1,350 & 26.0 & 8.3 & 1,700^{*} & 2.7 & c_{3} s_{1} \\ 35 & - & 1,050 & 800 & 2,640 & 23.0 & 8.3 * & 3,000^{*} & 4.6 & c_{4} s_{2} \\ 27 & - & 1,250 & 1,010 & 2,770 & 22.0 & 8.2 & 3,000^{*} & 3.7 & C_{4} s_{2}\end{array}$




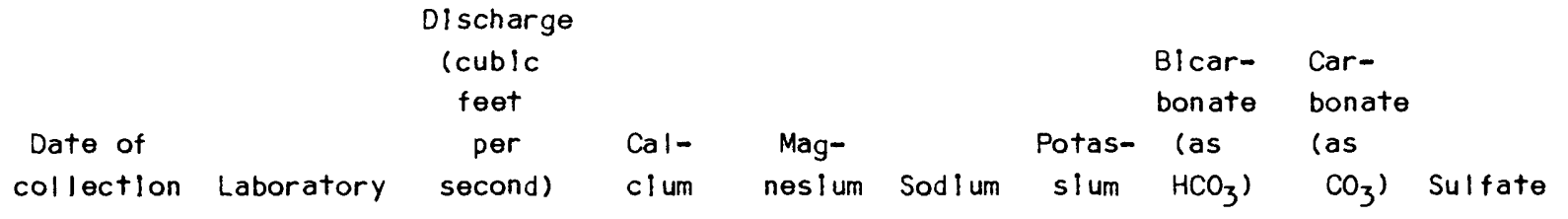

Rio Paguate downstream from Jackpil lo-Paguate Mine (19.5.2.434) - continued

$\begin{array}{llllllllll}10-30-78 & \text { BIA } & .51 & 200 & 160 & 260 & 10 . & 340^{*} & 0^{*} & 1,320 \\ 01-08-79 & \text { BIA } & 2.0 \mathrm{~g} / & 180 & 120 & 210 & 8.6 & 310 & 24 & 1,050 \\ 01-24-79 & \text { B।A } & 1.5 & 260 & 16 & 160 & 9.8 & 420^{*} & T^{*} & 720 \\ 03-02-79 & \text { B।A } & 2.2 \mathrm{~g} / & 140 & 75 & 150 & 7.8 & 280 & T & 730 \\ 06-07-79 & \text { BIA } & .84 \mathrm{~g} / & 170 & 79 & 190 & 14 & 240 & 2.4 & 960\end{array}$

Rio Paguate downstream from Paguate Dam (10.5.25.133)

\begin{tabular}{|c|c|c|c|c|c|c|c|c|c|}
\hline $09-13-73$ & $B \mid A$ & - & 160 & 43 & 78 & 9.8 & 120 & 6 & 640 \\
\hline $01-15-74$ & $B \mid A$ & - & 210 & 120 & 240 & 9.8 & 230 & 20 & 1,200 \\
\hline $04-04-77$ & $B \mid A$ & - & 160 & 100 & 220 & 11 & 230 & 17 & 1,000 \\
\hline $07-05-77$ & $B \mid A$ & - & 170 & 97 & 200 & 10 & 240 & 12 & 970 \\
\hline $01-10-78$ & $B \mid A$ & - & 230 & 100 & 240 & 13 & 320 & $T$ & 1,150 \\
\hline $03-07-78$ & $B \mid A$ & - & 170 & 86 & 200 & 11 & 310 & 10 & 930 \\
\hline $06-06-78$ & $B \mid A$ & 0 & 500 & 320 & 790 & 27 & 120 & $T$ & 3,950 \\
\hline $09-06-78$ & $B \mid A$ & - & 190 & 24 & 76 & 12 & 190 & $T$ & 580 \\
\hline $01-08-79$ & $B \mid A$ & - & 130 & 54 & 130 & 11 & 130 & 14 & 640 \\
\hline $03-02-79$ & $B \mid A$ & - & 140 & 56 & 130 & 9.4 & 240 & $T$ & 620 \\
\hline $06-07-79$ & $B \mid A$ & - & 130 & 97 & 250 & 9.8 & 150 & $\mathrm{~T}$ & 1,100 \\
\hline
\end{tabular}




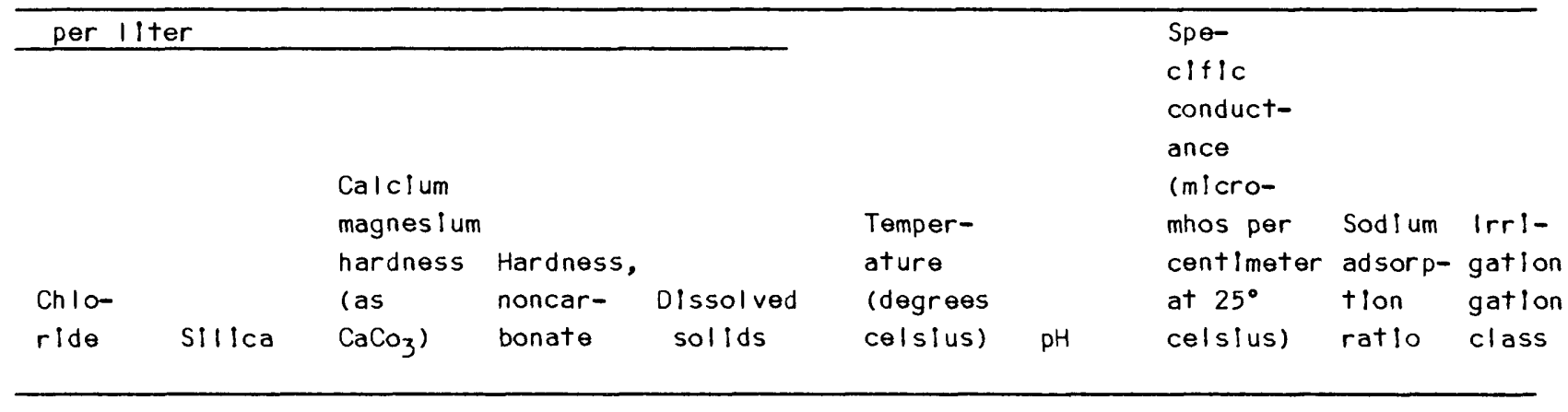

\begin{tabular}{|c|c|c|c|c|c|c|c|c|}
\hline 25 & - & 1,150 & 910 & 2,300 & 12.0 & $8.3^{*}$ & $2,600^{*}$ & 3.4 \\
\hline 37 & - & 940 & 640 & 1,920 & 0.0 & 8.1 & $1,800^{*}$ & 3.0 \\
\hline 16 & - & 720 & 440 & 1,470 & -0.5 & $8.4^{*}$ & $1,700^{*}$ & 2.5 \\
\hline 16 & - & 650 & 420 & 1,400 & 11.0 & 8.3 & $1,500^{*}$ & 2.6 \\
\hline 20 & - & 750 & 550 & 1,650 & 27.0 & 8.3 & $1,900 *$ & 3.0 \\
\hline 13 & - & 590 & 490 & 1,080 & - & 7.9 & 1,370 & 1.4 \\
\hline 31 & - & 1,050 & 860 & 2,240 & - & 8.2 & 2,520 & 3.2 \\
\hline 25 & - & 820 & 600 & 1,800 & 15.0 & 7.8 & $2,000^{*}$ & 3.4 \\
\hline 20 & - & 820 & 600 & 1,720 & - & 8.1 & 1,900 & 3.0 \\
\hline 33 & - & 990 & 720 & 2,090 & - & 8.0 & 2,400 & 3.3 \\
\hline 27 & - & 780 & 510 & 1,610 & 12.0 & 8.2 & $2,000^{*}$ & 3.1 \\
\hline 93 & - & 2,550 & 2,450 & 6,420 & 19.0 & 7.9 & $6,100^{*}$ & 6.8 \\
\hline 12 & - & 580 & 420 & 1,080 & 25.0 & 8.1 & $1,300^{*}$ & 1.4 \\
\hline 21 & - & 540 & 410 & 1,080 & 4.0 & 8.0 & $1,400^{*}$ & 2.4 \\
\hline 18 & - & 580 & 380 & 1,220 & 9.0 & 8.2 & $1,500^{*}$ & 2.4 \\
\hline 25 & - & 730 & 610 & 1,810 & 22.0 & 8.2 & 2,200 & 4.0 \\
\hline
\end{tabular}




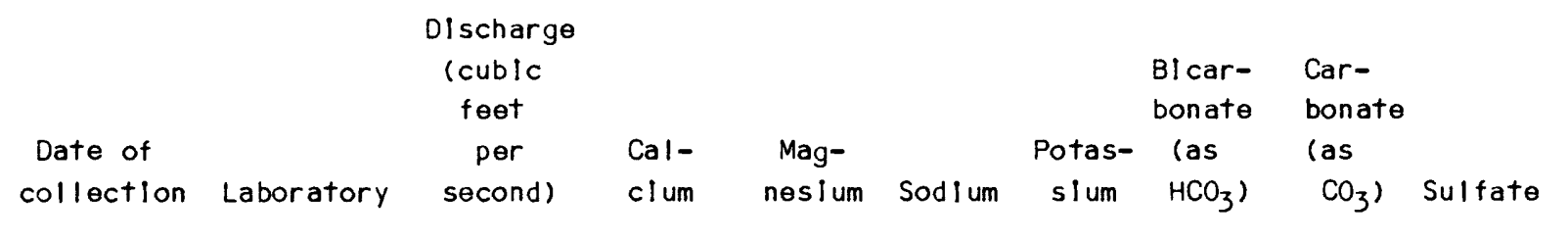

Rlo San Jose at Mesita Diversion $(9.5 .12 .133)$

\begin{tabular}{|c|c|c|c|c|c|c|c|c|c|c|}
\hline 04- & -61 & $B \mid A$ & - & 120 & 77 & 330 & 7.0 & 270 & 8 & 710 \\
\hline 08- & -61 & $B \mid A$ & - & 66 & 9.1 & 78 & 7.8 & 140 & 3 & 170 \\
\hline $10-$ & -61 & $B \mid A$ & - & 94 & 60 & 270 & 3.8 & 240 & 18 & 620 \\
\hline $06-2$ & $6-67$ & $B \mid A$ & - & 180 & 22 & 200 & 9.4 & 170 & $T$ & 650 \\
\hline $05-0$ & $6-69$ & $B \mid A$ & - & 150 & 100 & 500 & 7.4 & 220 & 12 & 1,300 \\
\hline $06-$ & -69 & $B \mid A$ & - & 410 & 81 & 880 & 13 & 250 & 11 & 2,300 \\
\hline $08-0$ & $8-69$ & $B \mid A$ & - & 250 & 71 & 160 & 9.4 & 130 & 6 & 1,100 \\
\hline 09- & -69 & $B \mid A$ & - & 380 & 24 & 40 & 4.3 & 61 & $T$ & 1,000 \\
\hline $10-$ & -69 & $B \mid A$ & - & 120 & 67 & 290 & 5.9 & 220 & 10 & 740 \\
\hline $05-0$ & $8-70$ & $B \mid A$ & - & 170 & 130 & 600 & 9.8 & 240 & 27 & 1,400 \\
\hline $06-$ & -70 & $B \mid A$ & - & 160 & 130 & 670 & 14 & 120 & 25 & 1,700 \\
\hline $08-0$ & $5-70$ & $B \mid A$ & - & 89 & 26 & 120 & 7.8 & 130 & $T$ & 390 \\
\hline 09- & -70 & $B \mid A$ & - & 110 & 38 & 180 & 11 & 140 & $T$ & 560 \\
\hline $07-2$ & $6-71$ & $B \mid A$ & - & 90 & 30 & 150 & 9.3 & 130 & 8 & 440 \\
\hline $08-$ & -71 & $B \mid A$ & - & 110 & 44 & 210 & 3.9 & 190 & 15 & 550 \\
\hline $10-2$ & $7-71$ & $B \mid A$ & - & 78 & 50 & 210 & 11 & 240 & 15 & 400 \\
\hline
\end{tabular}




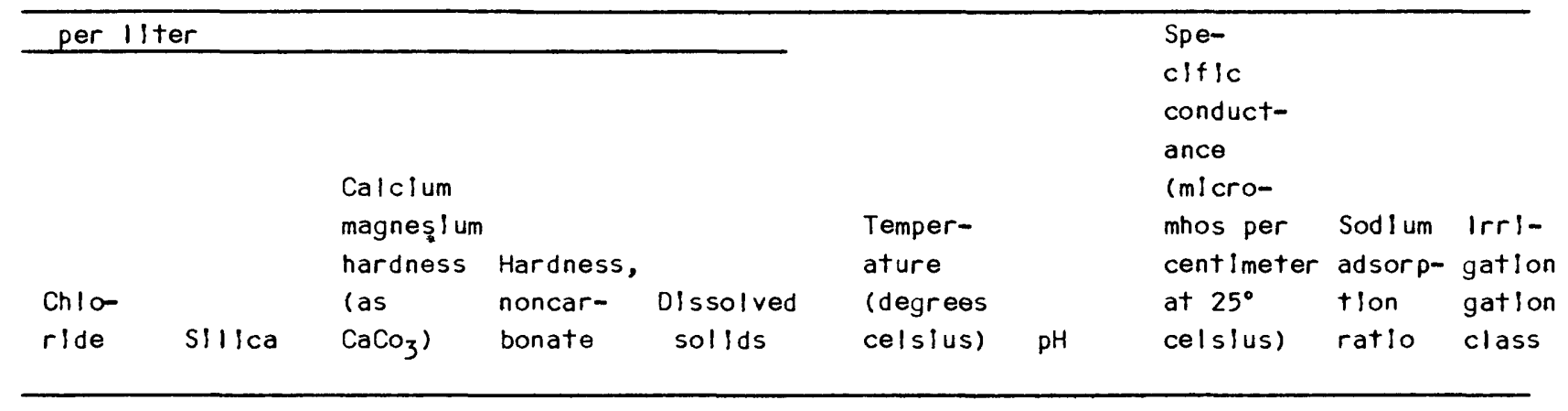

\begin{tabular}{|c|c|c|c|c|c|c|c|c|}
\hline 190 & - & 390 & 170 & - & - & 8.0 & 2,500 & 5.7 \\
\hline 53 & - & 170 & 55 & - & - & 8.0 & 900 & 2.4 \\
\hline 140 & - & 300 & 100 & - & - & 8.2 & 2,000 & 5.4 \\
\hline 120 & - & 530 & 390 & 1.360 & - & 8.4 & 1,780 & 3.7 \\
\hline 270 & - & 810 & 630 & 2,630 & - & 8.4 & 3,430 & 7.7 \\
\hline 480 & - & 1,360 & 1,160 & 4,640 & - & 8.2 & 5,600 & 10 \\
\hline 32 & - & 910 & 810 & 1,890 & - & 8.1 & 2,190 & 2.4 \\
\hline 15 & - & 1,060 & 1,010 & 1,640 & - & 7.6 & 1,860 & .5 \\
\hline 170 & - & 590 & 410 & 1,740 & - & 8.3 & 2,330 & 5.3 \\
\hline 340 & - & 940 & 740 & 3,120 & - & 8.3 & 4,020 & 8.6 \\
\hline 330 & - & 420 & 310 & 3,200 & - & 8.3 & 4,250 & 9.5 \\
\hline 59 & - & 330 & 220 & 841 & - & 8.2 & 1,220 & 2.8 \\
\hline 90 & - & 950 & 850 & 1,200 & - & 8.1 & 1,630 & 3.9 \\
\hline 83 & - & 350 & 220 & 907 & - & 8.1 & 1,360 & 3.6 \\
\hline 130 & - & 450 & 300 & 1,250 & - & 8.5 & 1,800 & 4.4 \\
\hline 150 & - & 400 & 200 & 1,130 & - & 8.4 & 1,670 & 4.5 \\
\hline
\end{tabular}




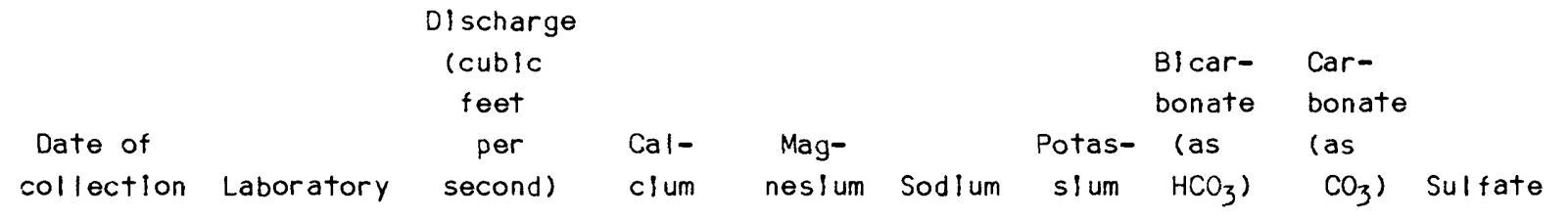

\section{RIo San Jose at Mesita Diversion (9.5.12.133) - continued}

\begin{tabular}{|c|c|c|c|c|c|c|c|c|c|}
\hline $08-31-72$ & $B \mid A$ & - & 74 & 44 & 100 & 6.4 & 140 & 5 & 260 \\
\hline $09-13-73$ & $B \mid A$ & - & 92 & 18 & 64 & 11 & 140 & 6 & 240 \\
\hline $01-25-74$ & $B \mid A$ & - & 130 & 73 & 310 & 7.4 & 290 & 19 & 770 \\
\hline $04-03-74$ & $B \mid A$ & - & 120 & 77 & 300 & 7.0 & 270 & 20 & 690 \\
\hline $10-21-74$ & $B \mid A$ & - & 170 & 67 & 300 & 9.0 & 190 & 42 & 890 \\
\hline $03-28-75$ & $B \mid A$ & - & 120 & 73 & 300 & 7.4 & 300 & 26 & 700 \\
\hline $03-30-76$ & $B \mid A$ & - & 130 & 78 & 300 & 7.0 & 310 & 14 & 710 \\
\hline $01-10-77$ & $B \mid A$ & - & 190 & 120 & 450 & 11 & 390 & 38 & 1,220 \\
\hline $01-24-77$ & USGS & - & 140 & 84 & 340 & 12 & 340 & 0 & 950 \\
\hline $04-06-77$ & $B \mid A$ & - & 130 & 78 & 340 & 8.6 & 280 & 22 & 770 \\
\hline $07-06-77$ & $B \mid A$ & 0 & 370 & 100 & 570 & 13 & 150 & $\mathrm{~T}$ & 1,910 \\
\hline $10-04-77$ & $B \mid A$ & - & 140 & 52 & 290 & 11 & 240 & 10 & 680 \\
\hline $01-10-78$ & $B \mid A$ & - & 140 & 74 & 330 & 9.4 & 320 & 19 & 770 \\
\hline $03-07-78$ & $B \mid A$ & - & 130 & 68 & 330 & 10 & 310 & 19 & 790 \\
\hline $04-19-78$ & USGS & .50 & 190 & 130 & 610 & 10 & $370^{*}$ & $14^{*}$ & 1,500 \\
\hline $06-06-78$ & $B \mid A$ & 0 & 360 & 150 & 780 & 13 & 250 & 5 & 2,330 \\
\hline
\end{tabular}




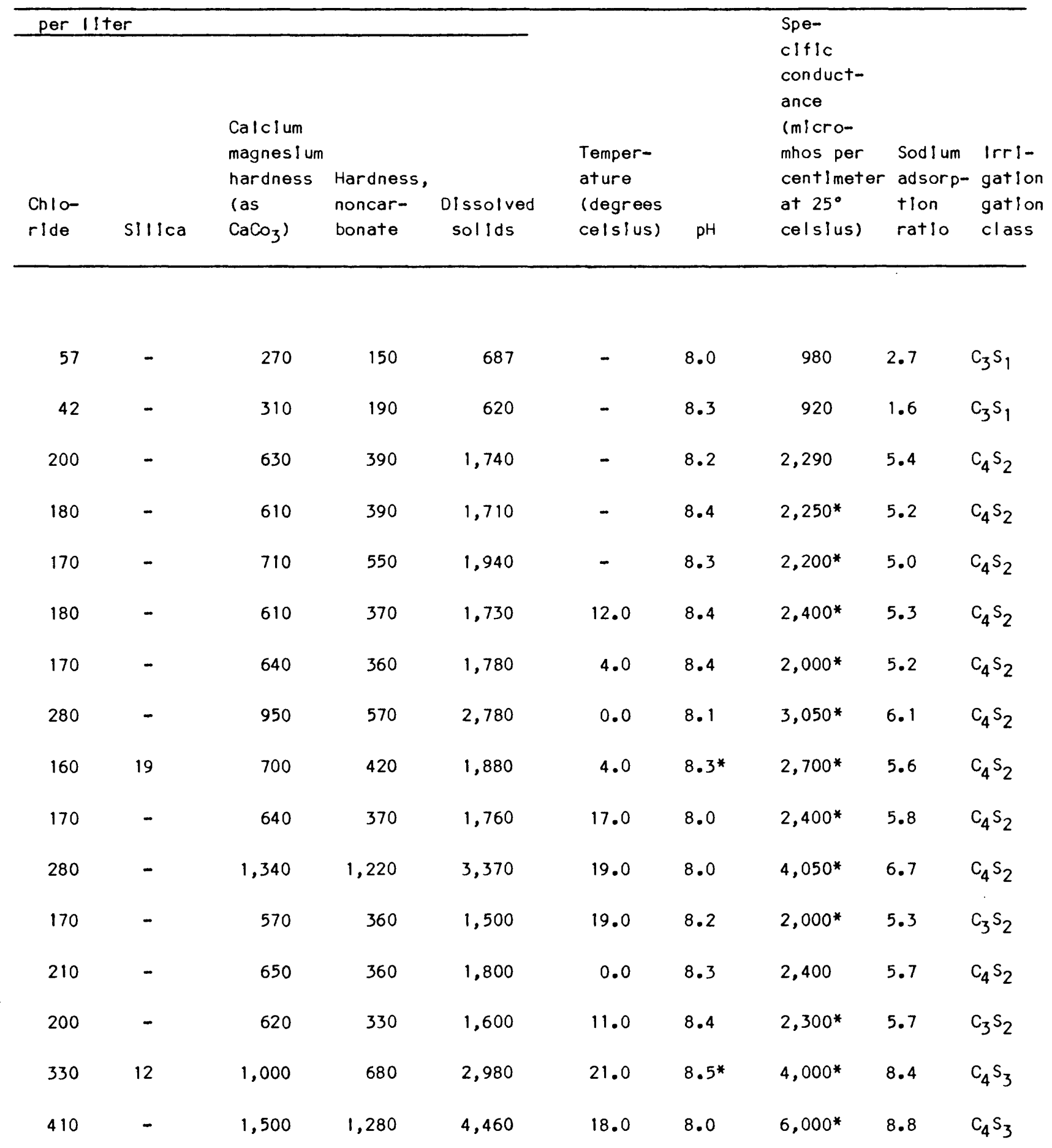




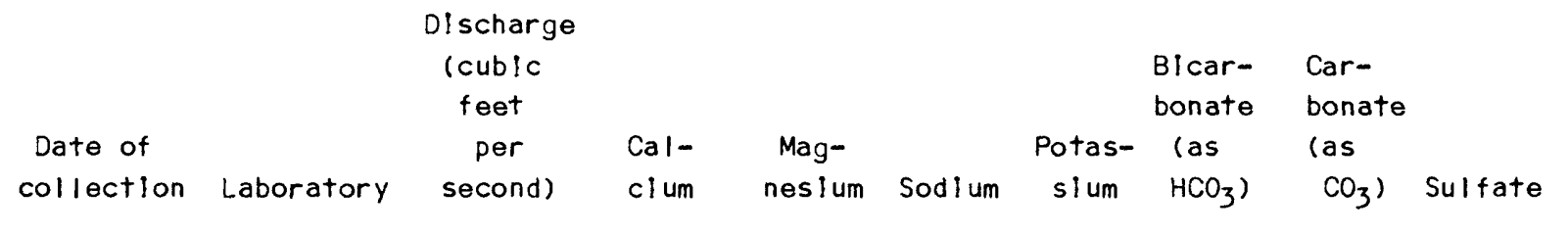

Rlo San Jose at Mesita Diversion (9.5.12.133) - continued

$\begin{array}{llcccccccr}09-07-78 & \text { BIA } & 0 & 350 & 67 & 310 & 12 & 200 & T & 1,450 \\ 01-09-79 & \text { BIA } & - & 110 & 60 & 260 & 9 & 280 & 17 & 620 \\ 01-24-79 & \text { BIA } & 8.1 & 200 & 12 & 280 & 9.8 & 310^{*} & 0^{*} & 630 \\ 03-06-79 & \text { B।A } & - & 120 & 64 & 290 & 7.8 & 270 & T & 650 \\ 06-06-79 & \text { BIA } & - & 150 & 61 & 400 & 11 & 320 & 1.2 & 930\end{array}$

Rlo Puerco at Rt. 66 bridge $(9.1 .4 .412)$

$\begin{array}{llllllllll}08-24-78 & B I A & - & 210 & 35 & 170 & 9.4 & 130 & T & 900\end{array}$




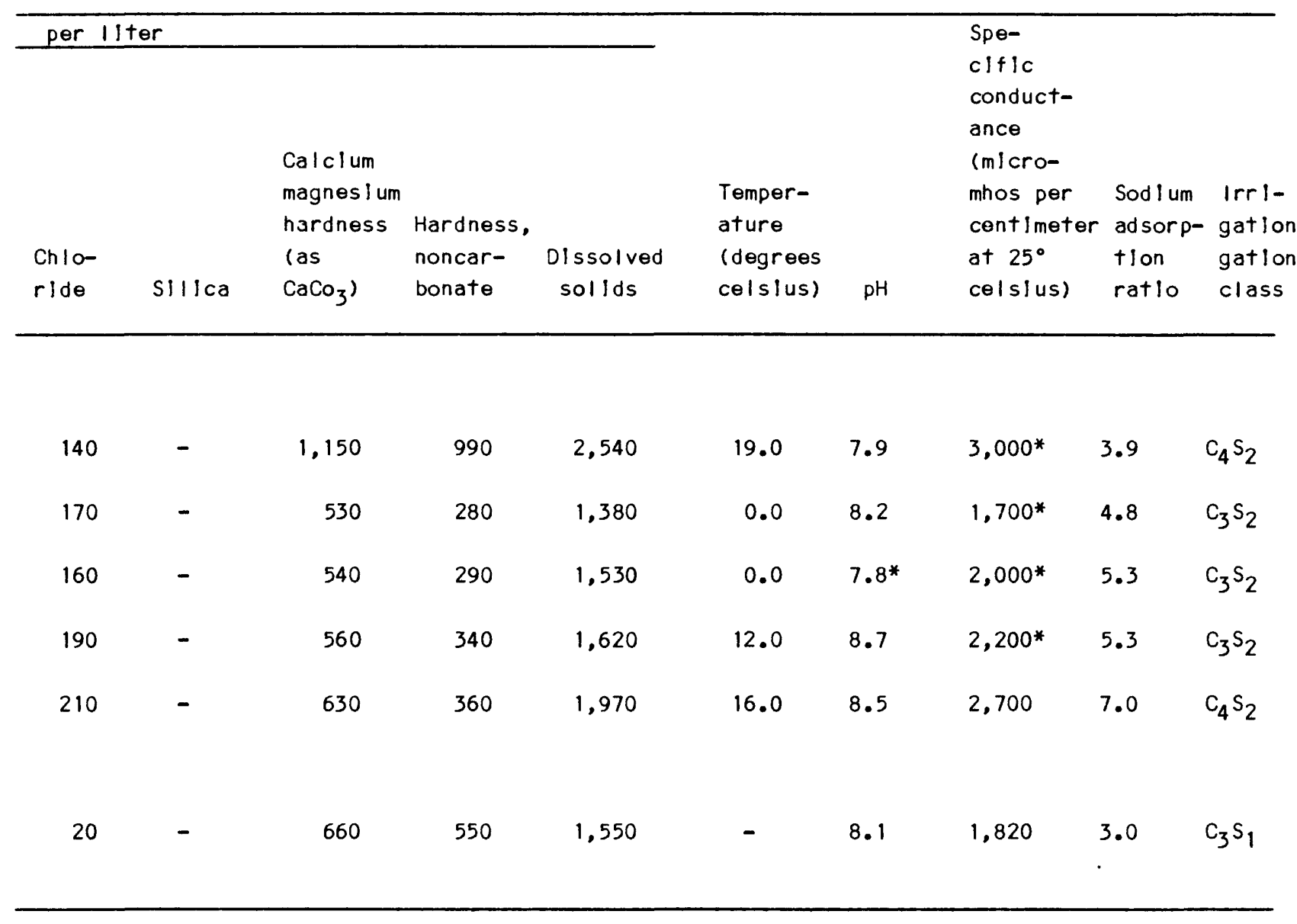


Table 10. Nutrlents, bacterla, and selected minor elements in surface water

Notes: All constituents are reported In milligrams per Ilter unless noted. Analyses of total nitrate (as N), total phosphorus (as P), fluorIde, and boron were performed by U.S. Bureau of Indlan Affairs (BIA) laboratory except where marked with asterlsk w* . Those analyses and all others were performed by U.S. Ceologlcal Survey (USGS) laboratory. Concentratlons less than the detection IImit of a particular analytical technique are Indicated by "Tn by BIA and "<n by USGS Iab. DIssolved oxygen was measured on site.

\begin{tabular}{|c|c|c|c|c|c|c|c|c|c|}
\hline Date of & $\begin{array}{l}\text { Nitrate } \\
\text { (total }\end{array}$ & $\begin{array}{l}\text { Nitrite } \\
\text { plus } \\
\text { nitrate } \\
\text { itotal }\end{array}$ & $\begin{array}{c}\text { NItrite } \\
\text { plus } \\
\text { nltrate } \\
\text { (dissolved }\end{array}$ & $\begin{array}{l}\text { Nitrogen, } \\
\text { ammonla } \\
\text { (total }\end{array}$ & $\begin{array}{l}\text { N!trogen } \\
\text { Itotal } \\
\text { organlc }\end{array}$ & $\begin{array}{c}\text { NItrogen } \\
\text { (total } \\
\text { Kjeldahl }\end{array}$ & $\begin{array}{c}\text { Nitrogen } \\
\text { (total }\end{array}$ & $\begin{array}{l}\text { Fluo- } \\
\text { ride } \\
\text { (dis- }\end{array}$ & $\begin{array}{l}\text { Phos- } \\
\text { phorus } \\
\text { (total }\end{array}$ \\
\hline collection & as $N$ ) & as $N$ ) & as $N$ ) & as $N$ ) & as $N$ ) & $\operatorname{as} N$ ) & as $N$ ) & solved) & as $P$ ) \\
\hline
\end{tabular}

RIo San Jose at Seama Diversion $(10.7 .34 .242)$

\begin{tabular}{|c|c|c|c|c|c|c|c|c|c|}
\hline $06-26-67$ & 0.50 & - & - & - & - & - & - & 1.4 & T \\
\hline $07-\quad-68$ & .50 & - & - & - & - & - & - & 2.4 & 0.04 \\
\hline $10-14-68$ & .37 & - & - & - & - & - & - & 1.8 & .06 \\
\hline $05-06-69$ & .62 & - & - & - & - & - & - & 1.8 & .10 \\
\hline $06-\quad-69$ & .12 & - & - & - & - & - & - & 1.4 & .01 \\
\hline $07-\quad-69$ & .25 & - & - & - & - & - & - & 1.9 & .01 \\
\hline $08-08-69$ & 1.9 & - & - & - & - & - & - & .7 & .12 \\
\hline $09-\quad-69$ & .62 & - & - & - & - & - & - & .8 & .03 \\
\hline $10-\quad-69$ & 1.2 & - & - & - & - & - & - & 1.2 & .16 \\
\hline $05-07-70$ & .12 & - & - & - & - & - & - & 1.4 & .12 \\
\hline $06-\quad-70$ & .12 & - & - & - & - & - & - & 1.1 & .22 \\
\hline $08-05-70$ & .62 & - & - & - & - & - & - & .6 & .03 \\
\hline $09-\quad-70$ & T & - & - & - & - & - & - & .8 & .10 \\
\hline
\end{tabular}




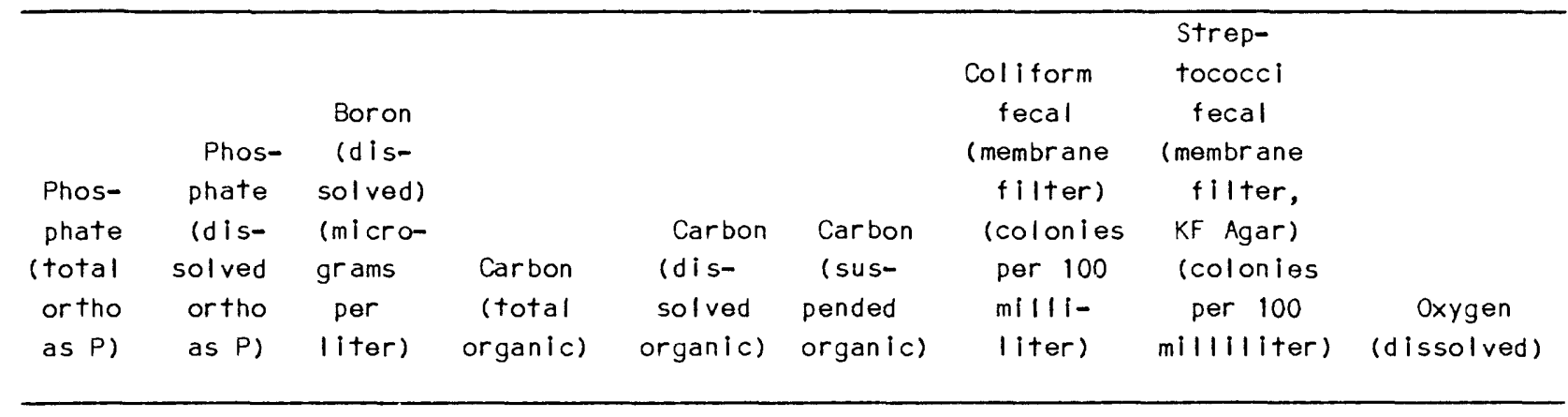

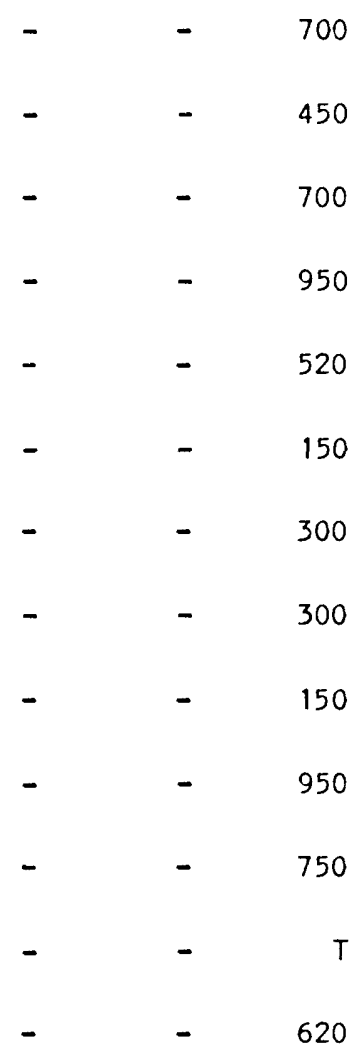




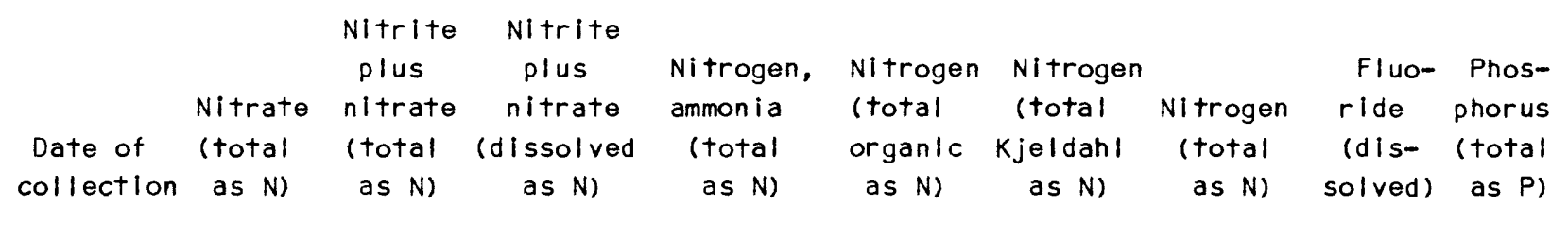

Rio San Jose at Seama Diversion (10.7.34.242)-Continued

\begin{tabular}{|c|c|c|c|c|c|c|c|c|c|}
\hline $07-26-71$ & 2.5 & - & - & - & - & - & - & .8 & .78 \\
\hline $08-\quad-71$ & .12 & - & - & - & - & - & - & 1.0 & .18 \\
\hline $10-27-71$ & 5.0 & - & - & - & - & - & - & .7 & 1.4 \\
\hline $07-10-72$ & .25 & - & - & - & - & - & - & 2.2 & .05 \\
\hline $08-31-72$ & 1.9 & - & - & - & - & - & - & .7 & .27 \\
\hline $09-13-73$ & 5.0 & - & - & - & - & - & - & .6 & .32 \\
\hline $01-25-74$ & 6.8 & - & - & - & - & - & - & 1.0 & .40 \\
\hline $04-03-74$ & 1.9 & - & - & - & - & - & - & 1.1 & .16 \\
\hline $07-01-74$ & 3.7 & - & - & - & - & - & - & 1.4 & .05 \\
\hline $10-21-74$ & 5.6 & - & - & - & - & - & - & 1.4 & .10 \\
\hline $03-28-75$ & 0.98 & - & - & - & - & - & - & 1.0 & 0.06 \\
\hline $08-08-75$ & 0.11 & - & - & - & - & - & - & 1.1 & 0.02 \\
\hline $03-25-76$ & 1.5 & - & - & - & - & - & - & 0.6 & 0.73 \\
\hline $01-11-77$ & 2.4 & - & - & - & - & - & - & 1.2 & 0.63 \\
\hline $04-04-77$ & 0.98 & - & - & - & - & - & - & 1.1 & 0.37 \\
\hline $07-07-77$ & 0.28 & - & - & - & - & - & - & 1.2 & 0.19 \\
\hline
\end{tabular}




\begin{tabular}{|c|c|c|c|c|c|c|c|c|}
\hline Phos- & $\begin{array}{l}\text { Phos- } \\
\text { phate }\end{array}$ & $\begin{array}{l}\text { Boron } \\
\text { (dis- } \\
\text { solved) }\end{array}$ & 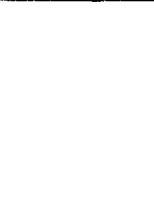 & & & $\begin{array}{c}\text { Colliform } \\
\text { fecal } \\
\text { (membrane } \\
\text { tilter) }\end{array}$ & $\begin{array}{l}\text { Strep- } \\
\text { tococcl } \\
\text { fecal } \\
\text { (membrane } \\
\text { filter, }\end{array}$ & \\
\hline $\begin{array}{l}\text { phate } \\
\text { (total } \\
\text { ortho } \\
\text { as } P \text { ) }\end{array}$ & $\begin{array}{l}\text { (dis- } \\
\text { solved } \\
\text { ortho } \\
\text { as } P \text { ) }\end{array}$ & $\begin{array}{l}\text { (micro- } \\
\text { grams } \\
\text { per } \\
\text { (iter) }\end{array}$ & $\begin{array}{c}\text { Carbon } \\
\text { (total } \\
\text { organic) }\end{array}$ & $\begin{array}{l}\text { Carbon } \\
\text { (dis- } \\
\text { solved } \\
\text { organic) }\end{array}$ & $\begin{array}{l}\text { Carbon } \\
\text { (sus- } \\
\text { pended } \\
\text { organic) }\end{array}$ & $\begin{array}{l}\text { (colonies } \\
\text { per } 100 \\
\text { milli- } \\
\text { (iter) }\end{array}$ & $\begin{array}{l}\text { KF Agar) } \\
\text { (colonies } \\
\text { per } 100 \\
\text { milliliter) }\end{array}$ & $\begin{array}{c}\text { Oxygen } \\
\text { (dissolved) }\end{array}$ \\
\hline
\end{tabular}

\begin{tabular}{|c|c|c|}
\hline - & - & 710 \\
\hline - & - & 400 \\
\hline - & - & 820 \\
\hline - & - & 1,500 \\
\hline- & - & $T$ \\
\hline - & - & 270 \\
\hline - & - & 420 \\
\hline- & - & 500 \\
\hline - & - & 200 \\
\hline - & - & 680 \\
\hline - & - & 26 \\
\hline - & - & 760 \\
\hline - & - & 620 \\
\hline - & - & 920 \\
\hline - & - & 530 \\
\hline - & - & 760 \\
\hline
\end{tabular}


Table 10. Nutrients, bacterla, and selected minor elements in surface water - Continued

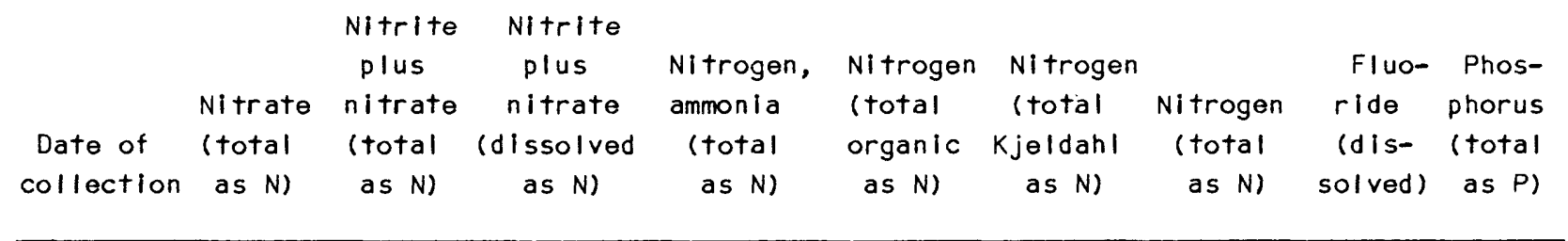

Rio San Jose at Seama Diversion (10.7.34.242) - concluded

\begin{tabular}{|c|c|c|c|c|c|c|c|c|c|}
\hline $10-03-77$ & 0.28 & - & - & - & - & - & - & 0.9 & 0.43 \\
\hline $01-10-78$ & 1.5 & - & - & - & - & - & - & 1.1 & 0.69 \\
\hline $03-01-78$ & 0.98 & - & - & - & - & - & - & 1.0 & 0.88 \\
\hline $06-05-78$ & 0.28 & - & - & - & - & - & - & 1.2 & 0.38 \\
\hline $09-05-78$ & 0.04 & - & - & - & - & - & - & 1.3 & 0.20 \\
\hline $01-08-79$ & 2.5 & - & - & - & - & - & - & 2.3 & 1.3 \\
\hline $03-01-79$ & 1.5 & - & - & - & - & - & - & 0.9 & 1.8 \\
\hline $06-06-79$ & 1.4 & - & - & - & - & - & - & 0.9 & .85 \\
\hline \multicolumn{10}{|c|}{ Cubero Creok at Budville $(10.7 .25 .211)$} \\
\hline $11-04-74$ & 0.84 & - & - & - & - & - & - & 0.8 & - \\
\hline $04-20-78$ & - & 0.04 & 0.00 & 0.01 & 0.25 & 0.26 & 0.30 & $0.8^{*}$ & 0.01 \\
\hline $07-25-78$ & 0.04 & - & 0.01 & - & - & - & - & 0.9 & $T$ \\
\hline $10-26-78$ & 0.01 & 0.05 & - & 0.0 & 0.04 & '0.04 & 0.09 & 0.7 & 0.02 \\
\hline $01-29-79$ & $0.05^{*}$ & 0.07 & - & 0.01 & 0.08 & 0.09 & 0.16 & 1.1 & 0.04 \\
\hline
\end{tabular}




\begin{tabular}{|c|c|c|c|c|c|c|c|c|}
\hline $\begin{array}{l}\text { Phos- } \\
\text { phate } \\
\text { (total } \\
\text { ortho } \\
\text { as P) }\end{array}$ & $\begin{array}{l}\text { Phos- } \\
\text { phate } \\
\text { (dis- } \\
\text { solved } \\
\text { ortho } \\
\text { as P) }\end{array}$ & $\begin{array}{l}\text { Boron } \\
\text { (dis- } \\
\text { solved) } \\
\text { (micro- } \\
\text { grams } \\
\text { per } \\
\text { liter) }\end{array}$ & $\begin{array}{c}\text { Carbon } \\
\text { (total } \\
\text { organic) }\end{array}$ & $\begin{array}{l}\text { Carbon } \\
\text { (dis- } \\
\text { solved } \\
\text { organic) }\end{array}$ & $\begin{array}{l}\text { Carbon } \\
\text { (sus- } \\
\text { pended } \\
\text { organ lc) }\end{array}$ & $\begin{array}{l}\text { Collform } \\
\text { fecal } \\
\text { (membrane } \\
\text { filter) } \\
\text { (colonies } \\
\text { per } 100 \\
\text { milli- } \\
\text { liter) }\end{array}$ & $\begin{array}{l}\text { Strep- } \\
\text { tococcl } \\
\text { fecal } \\
\text { (membrane } \\
\text { fllter, } \\
\text { KF Agar) } \\
\text { (colonies } \\
\text { per } 100 \\
\text { milllliter) }\end{array}$ & $\begin{array}{c}\text { Oxygen } \\
\text { (dissolved) }\end{array}$ \\
\hline- & - & 400 & - & - & - & - & - & - \\
\hline- & - & 1,000 & - & - & - & - & - & - \\
\hline - & - & 680 & - & - & - & - & - & - \\
\hline- & - & 490 & - & - & - & - & - & - \\
\hline- & - & 570 & - & - & - & - & - & - \\
\hline- & - & 380 & - & - & - & - & - & - \\
\hline- & - & 480 & - & - & - & - & - & - \\
\hline - & - & 540 & - & - & - & - & - & - \\
\hline- & - & 120 & - & - & - & - & - & - \\
\hline- & 0.01 & $50^{*}$ & - & 2.1 & 0.5 & - & - & 9.6 \\
\hline- & 0.0 & 70 & - & 1.8 & 0.4 & 147 & 245 & 8.5 \\
\hline 0.01 & - & $T$ & - & 1.6 & 0.3 & - & - & 9.7 \\
\hline 0.04 & - & $T$ & - & 2.3 & 0.6 & 9 & 78 & 11.8 \\
\hline
\end{tabular}


Table 10. Nutrients, bacteria, and selected minor elements in surface water - Continued

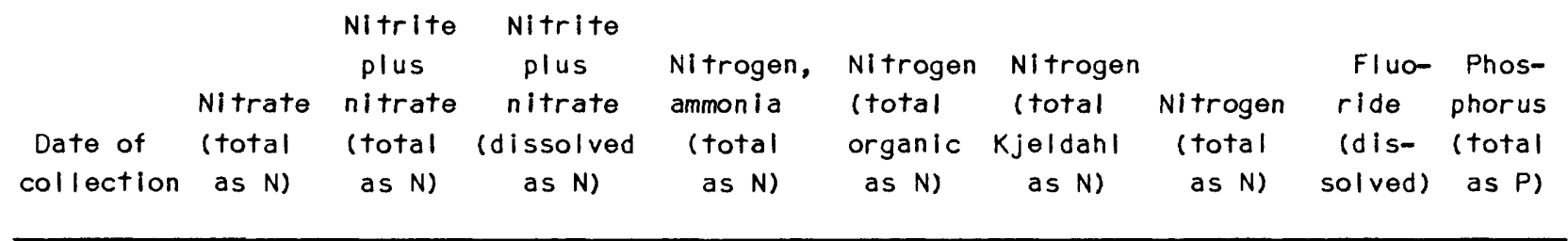

\section{Rio San Jose at Casa Blanca Diversion (9.6.6.222) - continued}

\begin{tabular}{|c|c|c|c|c|c|c|c|c|c|}
\hline $06-26-67$ & 0.74 & - & - & - & - & - & - & 0.9 & $T$ \\
\hline $05-06-69$ & .62 & - & - & - & - & - & - & 1.8 & 0.03 \\
\hline $06-\quad-69$ & .25 & - & - & - & - & - & - & 1.4 & .05 \\
\hline $07-\quad-69$ & .12 & - & - & - & - & - & - & 1.0 & .14 \\
\hline $08-08-69$ & 2.5 & - & - & - & - & - & - & .7 & .06 \\
\hline $09-\quad-69$ & .62 & - & - & - & - & - & - & .7 & .01 \\
\hline $10-\quad-69$ & .62 & - & - & - & - & - & - & 1.0 & .18 \\
\hline $05-07-70$ & .12 & - & - & - & - & - & - & 1.2 & .20 \\
\hline $06-\quad-70$ & 1.2 & - & - & - & - & - & - & .8 & .48 \\
\hline $08-05-70$ & 2.5 & - & - & - & - & - & - & .6 & $T$ \\
\hline $09-\quad-70$ & .12 & - & - & - & - & - & - & .7 & .04 \\
\hline $07-26-71$ & 2.0 & - & - & - & - & - & - & .8 & .70 \\
\hline $08-\quad-71$ & $T$ & - & - & - & - & - & - & 1.0 & .98 \\
\hline $10-27-71$ & 3.1 & - & - & - & - & - & - & .7 & 1.2 \\
\hline $07-10-72$ & .25 & - & - & - & - & - & - & 1.2 & $T$ \\
\hline $08-08-72$ & 2.5 & - & - & - & - & - & - & .8 & .23 \\
\hline
\end{tabular}




\begin{tabular}{cccccc}
\hline & & & & Strep- \\
tococci \\
Boron \\
fos-
\end{tabular}

\begin{tabular}{|c|c|c|}
\hline- & - & 280 \\
\hline - & - & 1,100 \\
\hline - & - & 600 \\
\hline - & - & 250 \\
\hline - & - & 300 \\
\hline - & - & 300 \\
\hline - & - & 250 \\
\hline - & - & 700 \\
\hline - & - & 450 \\
\hline - & - & $\mathrm{T}$ \\
\hline - & - & 490 \\
\hline - & - & 680 \\
\hline - & - & 320 \\
\hline - & - & 820 \\
\hline - & - & 680 \\
\hline- & - & $T$ \\
\hline
\end{tabular}




\begin{tabular}{|c|c|c|c|c|c|c|c|c|c|}
\hline Date of & $\begin{array}{l}\text { Nitrate } \\
\text { (total }\end{array}$ & $\begin{array}{l}\text { Nitrite } \\
\text { plus } \\
\text { nitrate } \\
\text { itotal }\end{array}$ & $\begin{array}{c}\text { Nitrite } \\
\text { plus } \\
\text { nitrate } \\
\text { (dissolved }\end{array}$ & $\begin{array}{l}\text { Nitrogen, } \\
\text { ammonia } \\
\text { (total }\end{array}$ & $\begin{array}{l}\text { Nitrogen } \\
\text { (total } \\
\text { organic }\end{array}$ & $\begin{array}{c}\text { Nitrogen } \\
\text { (total } \\
\text { Kjeldahl }\end{array}$ & $\begin{array}{c}\text { Nitrogen } \\
\text { (total }\end{array}$ & $\begin{array}{l}\text { Fluo- } \\
\text { ride } \\
\text { (dis- }\end{array}$ & $\begin{array}{l}\text { Phos- } \\
\text { phorus } \\
\text { (total }\end{array}$ \\
\hline collection & $\operatorname{as} N$ ) & as $\mathrm{N}$ ) & as $N$ ) & as $N$ ) & as $N$ ) & as $N$ ) & as $N$ ) & solved) & as $P$ ) \\
\hline
\end{tabular}

\section{Rio San Jose at Casa Bianca Diversion (9.6.6.222) - continued}

\begin{tabular}{|c|c|c|c|c|c|c|c|c|c|}
\hline $09-13-73$ & 6.8 & - & - & - & - & - & - & .6 & .13 \\
\hline $01-25-74$ & 8.1 & - & - & - & - & - & - & 1.0 & .50 \\
\hline $04-03-74$ & 1.9 & - & - & - & - & - & - & 1.1 & .16 \\
\hline $07-01-74$ & 3.7 & - & - & - & - & - & - & 1.1 & $T$ \\
\hline $10-21-74$ & 6.8 & - & - & - & - & - & - & 1.3 & .14 \\
\hline $03-28-75$ & 1.3 & - & - & - & - & - & - & 1.1 & 0.51 \\
\hline $03-25-76$ & 0.42 & - & - & - & - & - & - & 0.9 & 0.60 \\
\hline $01-10-77$ & 0.28 & - & - & - & - & - & - & 0.6 & 0.02 \\
\hline $04-04-77$ & 0.56 & - & - & - & - & - & - & 1.1 & 0.10 \\
\hline $07-07-77$ & 0.42 & - & - & - & - & - & - & 1.1 & 0.06 \\
\hline $10-03-77$ & 0.42 & - & - & - & - & - & - & 1.0 & 0.43 \\
\hline $01-10-78$ & 1.5 & - & - & - & - & - & - & 1.0 & 0.55 \\
\hline $03-01-78$ & 0.28 & - & - & - & - & - & - & 0.9 & 0.88 \\
\hline $06-05-78$ & 0.07 & - & - & - & - & - & - & 1.4 & 0.03 \\
\hline $09-05-78$ & T & - & - & - & - & - & - & 1.2 & 0.03 \\
\hline $01-08-79$ & 2.5 & - & - & - & - & - & - & 3.1 & 1.1 \\
\hline
\end{tabular}




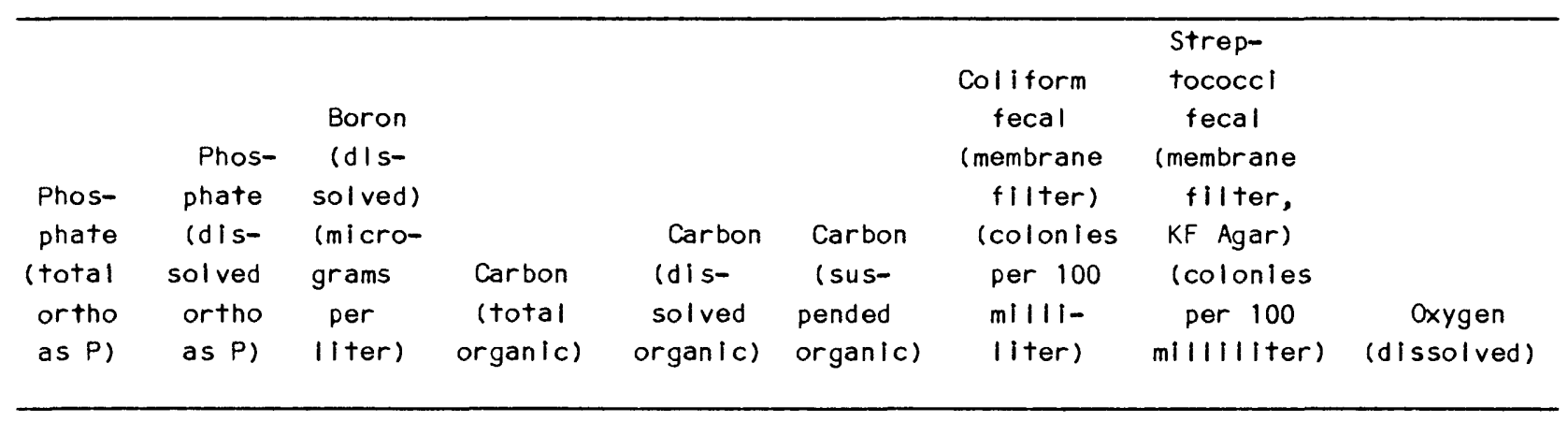

\begin{tabular}{|c|c|}
\hline- & - \\
\hline- & - \\
\hline - & - \\
\hline - & - \\
\hline - & - \\
\hline - & - \\
\hline - & - \\
\hline - & - \\
\hline - & - \\
\hline - & - \\
\hline - & - \\
\hline - & - \\
\hline - & - \\
\hline - & - \\
\hline- & - \\
\hline - & - \\
\hline
\end{tabular}




\begin{tabular}{|c|c|c|c|c|c|c|c|c|c|}
\hline Date of & $\begin{array}{l}\text { Nitrate } \\
\text { (total }\end{array}$ & $\begin{array}{l}\text { Nitrite } \\
\text { plus } \\
\text { nitrate } \\
\text { itotal }\end{array}$ & $\begin{array}{c}\text { Nitrite } \\
\text { plus } \\
\text { nitrate } \\
\text { (dissolved }\end{array}$ & $\begin{array}{l}\text { Nitrogen, } \\
\text { ammonla } \\
\text { (total }\end{array}$ & $\begin{array}{l}\text { Nitrogen } \\
\text { (total } \\
\text { organle }\end{array}$ & $\begin{array}{l}\text { Nitrogen } \\
\text { (total } \\
\text { Kjeldahl }\end{array}$ & $\begin{array}{c}\text { NItrogen } \\
\text { (total }\end{array}$ & $\begin{array}{l}\text { Fluo- } \\
\text { rlde } \\
\text { (dis- }\end{array}$ & $\begin{array}{l}\text { Phos- } \\
\text { phorus } \\
\text { itotal }\end{array}$ \\
\hline collection & as $N$ ) & $\operatorname{as} N$ ) & as $N$ ) & as $N$ ) & as $N$ ) & as $N$ ) & as $N$ ) & sol ved) & as $P$ ) \\
\hline
\end{tabular}

RIo San Jose at Casa Blanca Diversion (9.6.6.222) - concluded

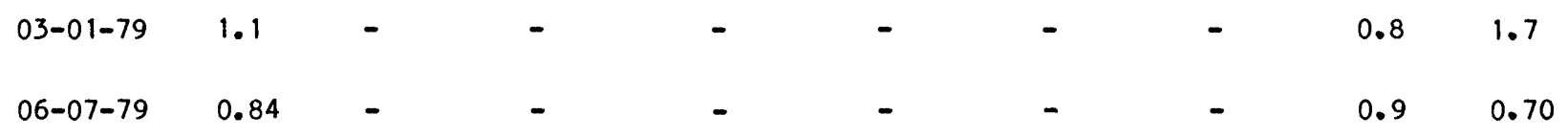

Rlo San Jose at Now Laguna Dam (9.6.1.322)

$\begin{array}{lll}08-07-75 & 0.11 \\ 01-12-77 & 1.8 & - \\ 04-06-77 & 0.70 \\ 10-04-77 & 0.06 \\ 01-10-78 & 0.70 \\ 03-07-78 & 0.03 \\ 09-06-78 & 0.14 \\ 01-09-79 & 0.70 \\ 03-02-79 & 0.42 \\ 06-08-79 & 0.04\end{array}$

Rlo Paguate upstream from Paguate (11.5.30.234)

$\begin{array}{ccccccccccc}04-21-78 & - & 0.01 & 0.01 & 0.0 & 0.25 & 0.25 & 0.26 & 0.2 * & 0.05^{*} \\ 07-19-78 & 0.07 & - & 0.01 & - & - & - & - & 0.3 & 0.01\end{array}$




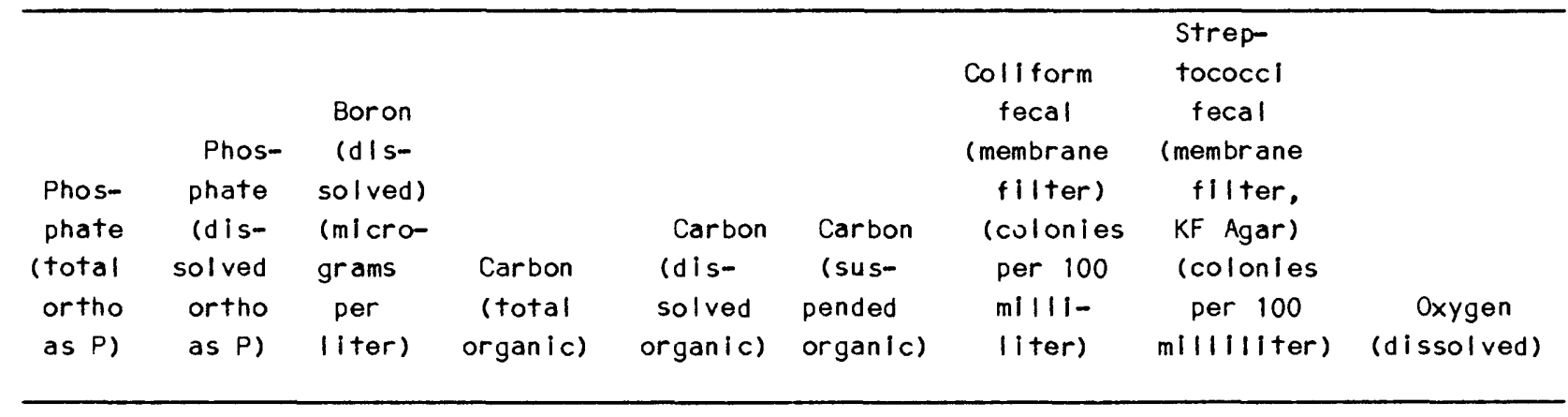

$\begin{array}{lll}- & - & 600 \\ - & - & 540\end{array}$

$\begin{array}{lll}- & - & 320 \\ - & - & 3,730 \\ - & - & 430 \\ - & - & 400 \\ - & - & 780 \\ - & - & 540 \\ - & - & 690 \\ - & - & 250 \\ - & - & 500 \\ - & - & 400\end{array}$

- 0.0320 *

1.20 .7

$2.4 \quad 0.7$
8.6

9.0 
Table 10. Nutrlents, bacterla, and selected minor elements in surface water - Contlnued

\begin{tabular}{|c|c|c|c|c|c|c|c|c|c|}
\hline & & Nitrite & Nitrite & & & & & & \\
\hline & Nitrate & $\begin{array}{l}\text { plus } \\
\text { nitrate }\end{array}$ & $\begin{array}{l}\text { plus } \\
\text { nitrate }\end{array}$ & Nitrogen, & $\begin{array}{l}\text { Nitrogen } \\
\text { (total }\end{array}$ & $\begin{array}{l}\text { Nitrogen } \\
\text { (total }\end{array}$ & Nitrogen & Fluo- & Phos- \\
\hline Date of & (total & (total & (d) ssolved & ctotal & organlc & KjeldahI & (total & (dis- & (total \\
\hline collectlon & $\operatorname{as} N$ ) & as $N$ ) & as $N$ ) & as N) & as N) & as $N$ ) & as N) & solved) & as $P$ ) \\
\hline
\end{tabular}

Rio Paguate upstrean from Paguate, New Mexico (11.5.30.234) - contInued

$\begin{array}{ccccccccccc}10-30-78 & 0.01^{*} & 0.01 & - & 0.01 & 0.02 & 0.03 & 0.04 & 0.2 & 0.04^{*} \\ 01-30-79 & 0.0^{*} & 0.02 & - & 0.01 & 0.05 & 0.06 & 0.08 & 1.2 & 0.11^{*}\end{array}$

Rlo Paguate upstream from Jackplle-Paguate MIne (11.5.32.424)

\begin{tabular}{|c|c|c|c|c|c|c|c|c|c|}
\hline $04-01-76$ & 0.28 & - & - & - & - & - & - & 0.2 & $\mathrm{~T}$ \\
\hline $01-13-77$ & 0.14 & - & - & - & - & - & - & 0.3 & 0.02 \\
\hline $01-18-77$ & - & - & 0.03 & - & - & - & - & $0.3^{*}$ & - \\
\hline $04-05-77$ & 0.01 & - & - & - & - & - & - & 0.4 & 0.01 \\
\hline $01-10-78$ & 0.14 & - & - & - & - & - & - & 0.3 & 0.01 \\
\hline $03-07-78$ & 0.03 & - & - & - & - & - & - & 0.4 & 0.03 \\
\hline $04-21-78$ & - & 0.01 & 0.01 & 0.01 & 0.31 & 0.32 & 0.33 & $0.4^{*}$ & $.03^{*}$ \\
\hline $06-06-78$ & $T$ & - & - & - & - & - & - & 0.4 & $T$ \\
\hline $07-19-78$ & 0.01 & - & 0.04 & - & - & - & - & 0.4 & 0.05 \\
\hline $09-06-78$ & $T$ & - & - & - & - & - & - & 0.4 & 0.01 \\
\hline $10-26-78$ & $0.01 *$ & 0.01 & - & 0.0 & 0.12 & 0.12 & 0.13 & 0.3 & $.03^{*}$ \\
\hline $01-08-79$ & 0.04 & - & - & - & - & - & - & 1.6 & 0.03 \\
\hline $01-29-79$ & $0.00 *$ & 0.02 & - & 0.01 & 0.05 & 0.06 & 0.07 & 0.9 & $0.05^{*}$ \\
\hline
\end{tabular}




\begin{tabular}{|c|c|c|c|c|c|c|c|c|}
\hline $\begin{array}{l}\text { Phos- } \\
\text { phate } \\
\text { (total } \\
\text { ortho } \\
\text { as P) }\end{array}$ & $\begin{array}{l}\text { Phos- } \\
\text { phate } \\
\text { (dis- } \\
\text { solved } \\
\text { ortho } \\
\text { as P) }\end{array}$ & $\begin{array}{l}\text { Boron } \\
\text { (dis- } \\
\text { solved) } \\
\text { (micro- } \\
\text { grams } \\
\text { per } \\
\text { liter) }\end{array}$ & $\begin{array}{c}\text { Carbon } \\
\text { (total } \\
\text { organic) }\end{array}$ & $\begin{array}{l}\text { Carbon } \\
\text { (dis- } \\
\text { solved } \\
\text { organic) }\end{array}$ & $\begin{array}{l}\text { Carbon } \\
\text { (sus- } \\
\text { pended } \\
\text { organic) }\end{array}$ & $\begin{array}{l}\text { Coliform } \\
\text { fecal } \\
\text { (membrane } \\
\text { fllter) } \\
\text { (colonies } \\
\text { per } 100 \\
\text { milli- } \\
\text { liter) }\end{array}$ & $\begin{array}{l}\text { Strep- } \\
\text { tococci } \\
\text { fecal } \\
\text { (membrane } \\
\text { filter, } \\
\text { KF Agar) } \\
\text { (colonies } \\
\text { per } 100 \\
\text { milllliter) }\end{array}$ & $\begin{array}{c}\text { Oxygen } \\
\text { (dissolved) }\end{array}$ \\
\hline 0.02 & - & $T$ & - & 2.1 & 0.2 & - & - & 8.9 \\
\hline 0.03 & - & $T$ & - & 2.5 & 0.5 & - & - & 10.8 \\
\hline - & - & 120 & - & - & - & - & - & - \\
\hline- & - & - & - & - & - & - & - & - \\
\hline- & 0.01 & $20^{*}$ & - & - & - & - & - & - \\
\hline- & - & $T$ & - & - & - & - & - & - \\
\hline- & - & 260 & - & - & - & - & - & - \\
\hline- & - & $T$ & - & - & - & - & - & - \\
\hline- & 0.02 & $30^{*}$ & - & 1.1 & 0.5 & - & - & 8.6 \\
\hline- & - & 40 & - & - & - & - & - & - \\
\hline- & 0.02 & $T$ & - & 2.1 & 0.5 & - & - & 6.6 \\
\hline- & - & 40 & - & - & - & - & - & - \\
\hline 0.02 & - & $T$ & - & 1.7 & 0.4 & 730 & 1,150 & 8.3 \\
\hline- & - & $T$ & - & - & - & - & - & - \\
\hline 0.03 & - & $T$ & - & 2.4 & 0.9 & - & - & 9.8 \\
\hline
\end{tabular}




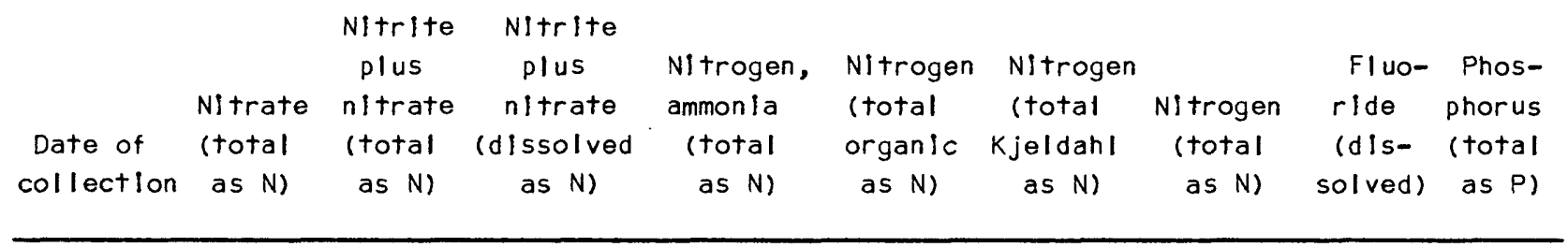

Rlo Paguate upstream from Jackplle-Paguate Mine (11.5.32.424) - continued

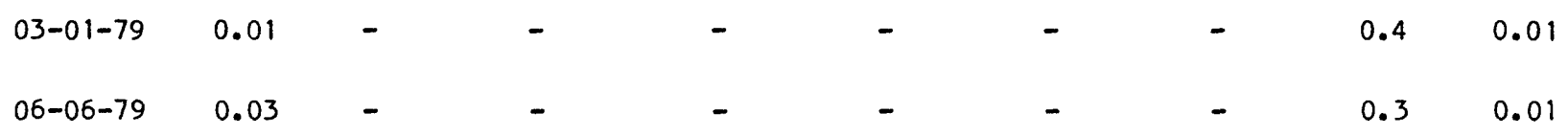

Rlo Moquino upstream from Jackplle-Paguate MIne $(11.5 .22 .344)$

\begin{tabular}{|c|c|c|c|c|c|c|c|c|c|}
\hline $04-01-76$ & 0.01 & - & - & - & - & - & - & 0.4 & 0.02 \\
\hline $01-13-77$ & 0.56 & - & - & - & - & - & - & 0.6 & $T$ \\
\hline $01-18-77$ & - & - & 0.87 & - & - & - & - & $0.4^{*}$ & - \\
\hline $04-05-77$ & 0.14 & - & - & - & - & - & - & 0.6 & $T$ \\
\hline $07-06-77$ & 0.03 & - & - & - & - & - & - & 0.6 & $T$ \\
\hline $10-03-77$ & $T$ & - & - & - & - & - & - & 0.5 & $T$ \\
\hline $01-10-78$ & 0.14 & - & - & - & - & - & - & 0.5 & 0.01 \\
\hline $03-07-78$ & 0.03 & - & - & - & - & - & - & 0.6 & 0.03 \\
\hline $04-20-78$ & - & 0.01 & 0.01 & 0.01 & 0.39 & 0.40 & 0.41 & $0.6^{*}$ & $0.01^{*}$ \\
\hline $06-05-78$ & $T$ & - & - & - & - & - & - & 0.8 & $T$ \\
\hline $09-06-78$ & 0.03 & - & - & - & - & - & - & 0.7 & 0.01 \\
\hline $11-02-78$ & $0.03 *$ & 0.04 & - & 0.01 & 0.99 & 1.0 & 1.0 & 0.5 & $0.00^{*}$ \\
\hline $01-08-79$ & 0.14 & - & - & - & - & - & - & 2.1 & 0.01 \\
\hline
\end{tabular}




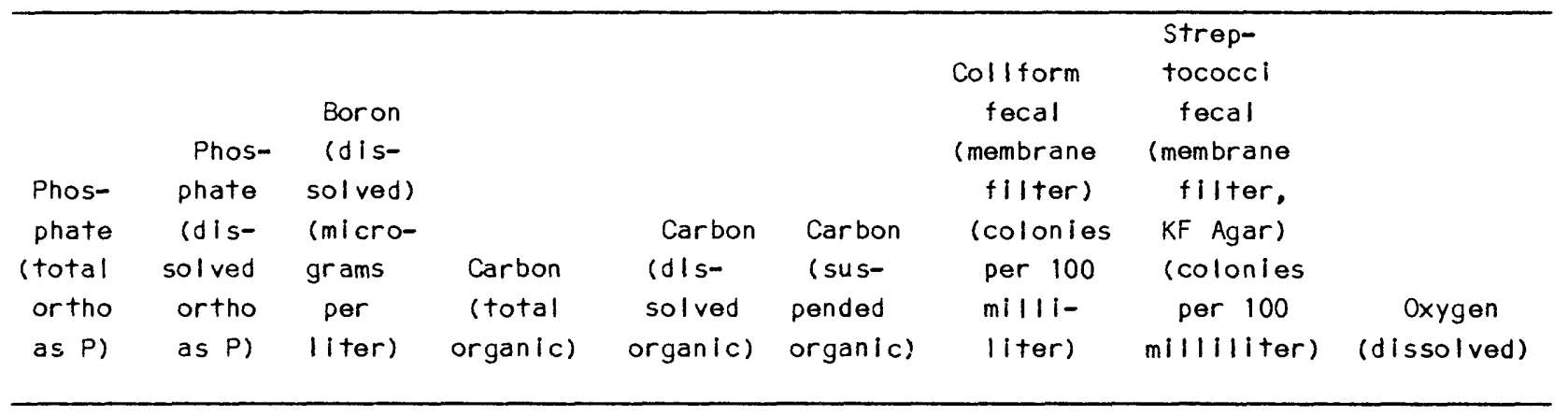

$\begin{array}{cccc}- & - & 20 & - \\ - & - & T & -\end{array}$

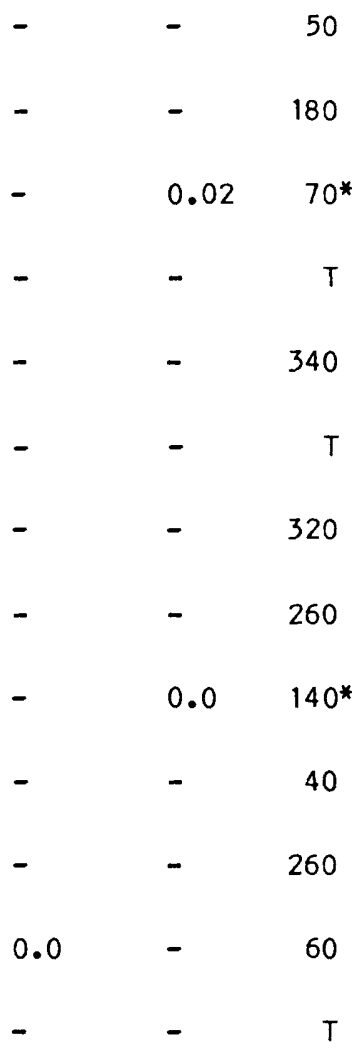

2.6

0.5

8.4

2.3

0.2

9.8 


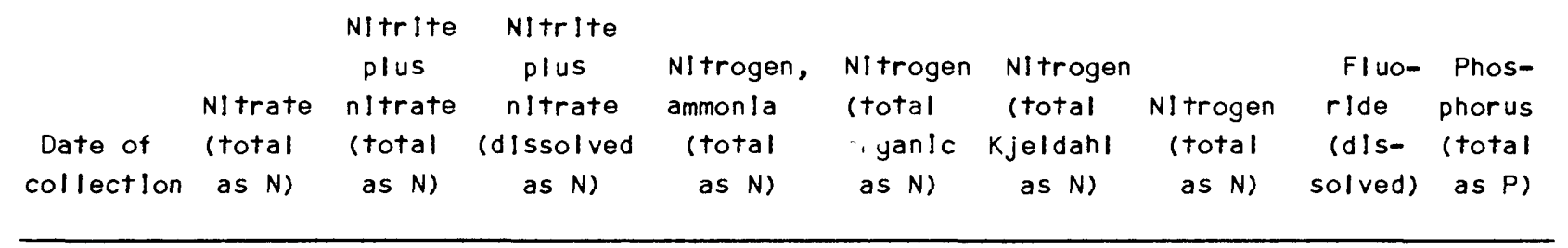

Rlo mopino upstrean from Jackplle-Paguate MIne (11.5.22.344) - continued

$\begin{array}{cccccccccc}01-30-79 & 0.43^{*} & 0.45 & - & 0.05 & 0.41 & 0.46 & 0.91 & 2.1 \\ 03-01-79 & 0.07 & - & - & - & - & - & - & 0.14^{*} \\ 06-06-79 & 0.04 & - & - & - & - & - & - & - & 0.6 \\ 0.4 & 0.01\end{array}$

Rlo Paguate downstrem froe Jackp Ile-Paguate MIne (10.5.2.434)

\begin{tabular}{|c|c|c|c|c|c|c|c|c|c|}
\hline $04-01-76$ & 0.01 & - & - & - & - & - & - & 0.6 & $\mathrm{~T}$ \\
\hline $01-13-77$ & 0.28 & - & - & - & - & - & - & 0.5 & 0.02 \\
\hline $01-18-77$ & - & - & 0.24 & - & - & - & - & $0.6^{*}$ & - \\
\hline $01-24-77$ & - & 0.18 & 0.16 & - & - & 0.41 & - & $0.6^{*}$ & $0.26^{*}$ \\
\hline $04-04-77$ & 0.28 & - & - & - & - & - & - & 0.6 & $T$ \\
\hline $07-08-77$ & 0.03 & - & - & - & - & - & - & 0.8 & 0.02 \\
\hline $01-10-78$ & 0.28 & - & - & - & - & - & - & 0.6 & 0.01 \\
\hline $03-07-78$ & 0.03 & - & - & - & - & - & - & 0.6 & 0.01 \\
\hline $04-18-78$ & - & 0.01 & 0.0 & 0.0 & 0.29 & 0.29 & 0.30 & $0.7^{*}$ & $0.03 *$ \\
\hline $06-05-78$ & 0.04 & - & - & - & - & - & - & 0.7 & $T$ \\
\hline $07-25-78$ & 0.04 & - & 0.01 & - & - & - & - & 1.1 & 0.03 \\
\hline $09-06-78$ & $T$ & - & - & - & - & - & - & 0.8 & 0.01 \\
\hline
\end{tabular}




\begin{tabular}{|c|c|c|c|c|c|c|c|c|}
\hline & & & & & & & Strep- & \\
\hline & & & & & & Collform & tococci & \\
\hline & & Boron & & & & fecal & fecal & \\
\hline & Phos- & (dis- & & & & (membrane & (membrane & \\
\hline Phos- & phate & solved) & & & & fllter) & filter & \\
\hline phate & (dis- & (micro- & & Carbon & Carbon & (colonies & KF Agar) & \\
\hline (total & solved & grams & Carbon & (dis- & (sus- & per 100 & (colonles & \\
\hline ortho & ortho & per & (total & solved & pended & milli- & per 100 & Oxygen \\
\hline as $\mathrm{Pl}$ & as $P$ ) & (iter) & organic) & organic) & organic) & (iter) & milliliter) & (dissolved) \\
\hline
\end{tabular}

\begin{tabular}{|c|c|c|c|c|c|c|c|c|}
\hline 0.02 & - & $T$ & - & 4.3 & 1.0 & - & - & 11.0 \\
\hline - & - & 100 & - & - & - & - & - & - \\
\hline - & - & $\mathrm{T}$ & - & - & - & - & - & - \\
\hline- & - & 50 & - & - & - & - & - & - \\
\hline - & - & 180 & - & - & - & - & - & - \\
\hline- & 0.03 & $70^{*}$ & - & - & - & - & - & - \\
\hline 0.05 & 0.02 & $80^{*}$ & 4.3 & - & - & - & - & - \\
\hline - & - & $T$ & - & - & - & - & - & - \\
\hline - & - & 340 & - & - & - & - & - & - \\
\hline - & - & 50 & - & - & - & - & - & - \\
\hline - & - & 260 & - & - & - & - & - & - \\
\hline - & 0.0 & $120^{*}$ & 2.1 & 1.6 & 0.5 & 120 & 280 & 8.2 \\
\hline - & - & 150 & - & - & - & - & - & - \\
\hline - & 0.0 & 70 & 3.1 & 2.5 & 0.6 & 1,138 & 532 & 8.3 \\
\hline- & - & 210 & - & - & - & - & - & - \\
\hline
\end{tabular}




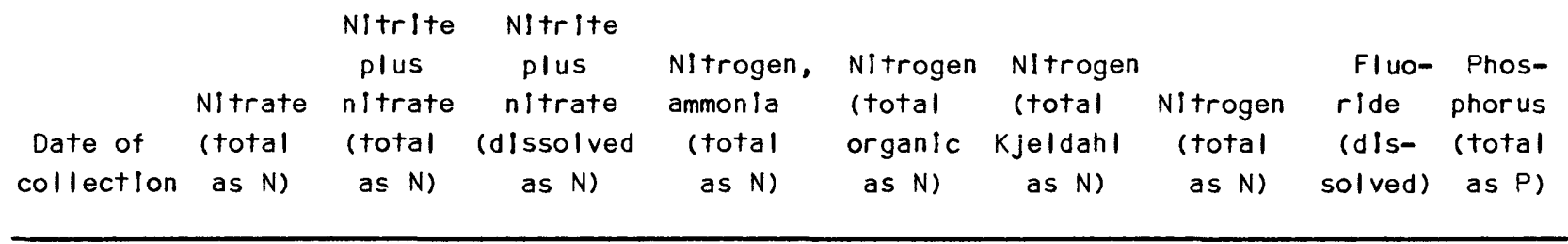

\section{Rio Paguate downstream from Jackpllo-Paguate MIne (10.5.2.434) - continued}

\begin{tabular}{|c|c|c|c|c|c|c|c|c|c|}
\hline $10-30-78$ & $0.01 *$ & 0.02 & - & 0.01 & 2.9 & 3.0 & 3.0 & 0.7 & $0.07 *$ \\
\hline $01-08-79$ & 0.14 & - & - & - & - & - & - & 2.4 & 0.01 \\
\hline $01-24-79$ & $0.18^{*}$ & 0.22 & - & 0.03 & 0.36 & 0.39 & 0.61 & 0.7 & $0.15^{*}$ \\
\hline $03-02-79$ & 0.07 & - & - & - & - & - & - & 0.6 & 0.01 \\
\hline $06-07-79$ & 0.04 & - & - & - & - & - & - & 0.7 & T \\
\hline
\end{tabular}

Rlo Paguate downstrean from Paguate Dai (10.5.25.133)

\begin{tabular}{|c|c|c|c|c|c|c|c|c|c|}
\hline $09-13-73$ & 3.7 & - & - & - & - & - & - & 0.5 & $T$ \\
\hline $01-15-74$ & 3.1 & - & - & - & - & - & - & 0.7 & $T$ \\
\hline $04-04-77$ & 0.28 & - & - & - & - & - & - & 0.6 & $T$ \\
\hline $07-05-77$ & 0.03 & - & - & - & - & - & - & 0.6 & $T$ \\
\hline $01-10-78$ & 0.14 & - & - & - & - & - & - & 0.7 & 0.01 \\
\hline $03-07-78$ & 0.28 & - & - & - & - & - & - & 0.6 & $T$ \\
\hline $06-06-78$ & 0.01 & - & - & - & - & - & - & 1.2 & $T$ \\
\hline $09-06-78$ & 0.03 & - & - & - & - & - & - & 0.7 & 0.01 \\
\hline $01-08-79$ & 0.14 & - & - & - & - & - & - & 1.9 & 0.01 \\
\hline $03-02-79$ & 0.01 & - & - & - & - & - & - & 0.5 & $T$ \\
\hline $06-07-79$ & 0.04 & - & - & - & - & - & - & 0.7 & $T$ \\
\hline
\end{tabular}




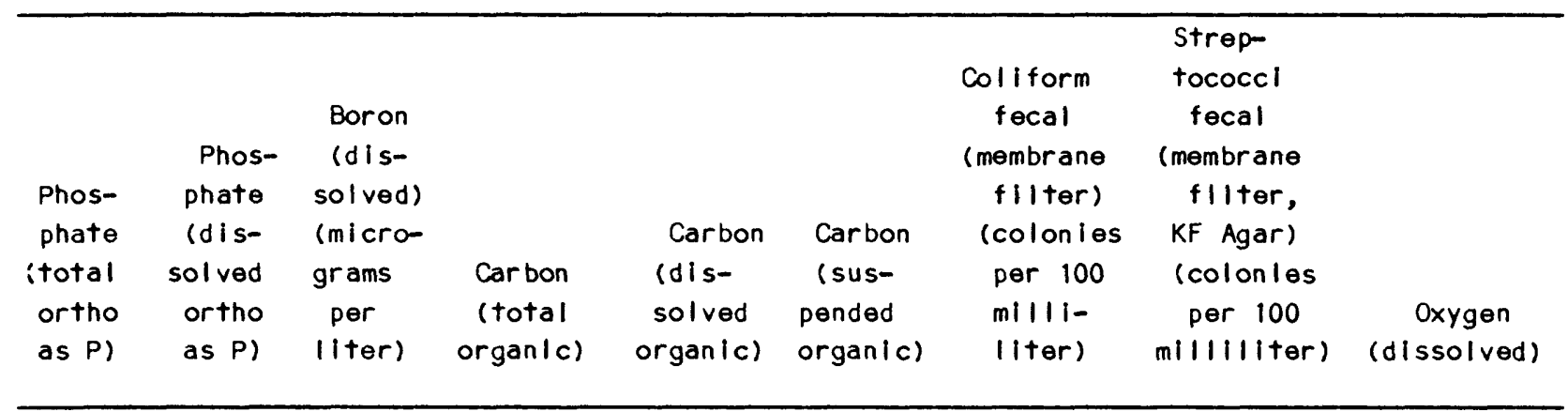

$\begin{array}{rrrrrrrrr}0.04 & - & 60 & 2.9 & 2.2 & 0.7 & - & - & -2 \\ - & - & T & - & - & - & - & - \\ 0.03 & - & T & 5.1 & 3.9 & 1.2 & 10 & 275 & 10.9 \\ - & - & 100 & - & - & - & - & - \\ - & - & T & - & - & - & - & -\end{array}$


Table 10. Nutrients, bacteria, and selected minor elements in surface water - Continued

\begin{tabular}{|c|c|c|c|c|c|c|c|c|c|}
\hline Date of & $\begin{array}{l}\text { Nitrate } \\
\text { (total }\end{array}$ & $\begin{array}{l}\text { Nitrite } \\
\text { plus } \\
\text { nitrate } \\
\text { itotal }\end{array}$ & $\begin{array}{c}\text { Nitrite } \\
\text { plus } \\
\text { nitrate } \\
\text { (dissolved }\end{array}$ & $\begin{array}{l}\text { Nitrogen, } \\
\text { ammonia } \\
\text { (total }\end{array}$ & $\begin{array}{l}\text { Nitrogen } \\
\text { (total } \\
\text { organic }\end{array}$ & $\begin{array}{l}\text { Nitrogen } \\
\text { (total } \\
\text { Kjeldahl }\end{array}$ & $\begin{array}{c}\text { Nitrogen } \\
\text { (total }\end{array}$ & $\begin{array}{l}\text { Fluo- } \\
\text { ride } \\
\text { (dis- }\end{array}$ & $\begin{array}{l}\text { Phos- } \\
\text { phorus } \\
\text { (total }\end{array}$ \\
\hline collection & as $N$ ) & as $N$ ) & $\operatorname{as} N$ ) & as $N$ ) & as $N$ ) & $\operatorname{as} N$ ) & as $N$ ) & solved) & as $P$ ) \\
\hline
\end{tabular}

Rio San Jose at Mesita Diversion $(9.5 .12 .133)$

\begin{tabular}{|c|c|c|c|c|c|c|c|c|c|}
\hline $06-26-67$ & 0.74 & - & - & - & - & - & - & 0.9 & T \\
\hline $05-06-69$ & .12 & - & - & - & - & - & - & 1.2 & $T$ \\
\hline $06-\quad-69$ & .62 & - & - & - & - & - & - & 1.5 & T \\
\hline $08-08-69$ & .12 & - & - & - & - & - & - & 1.2 & $T$ \\
\hline $09-\quad-69$ & 2.5 & - & - & - & - & - & - & .4 & $T$ \\
\hline $10-\quad-69$ & .62 & - & - & - & - & - & - & 1.1 & $T$ \\
\hline $05-08-70$ & 1.2 & - & - & - & - & - & - & 1.1 & $T$ \\
\hline $06-\quad-70$ & .25 & - & - & - & - & - & - & .9 & 0.03 \\
\hline $08-05-70$ & 1.9 & - & - & - & - & - & - & .8 & .04 \\
\hline $09-\quad-70$ & 2.5 & - & - & - & - & - & - & .4 & $T$ \\
\hline $07-26-71$ & .50 & - & - & - & - & - & - & .8 & .06 \\
\hline $08-\quad-71$ & $T$ & - & - & - & - & - & - & 1.0 & .03 \\
\hline $10-27-71$ & .25 & - & - & - & - & - & - & .9 & 1.2 \\
\hline
\end{tabular}




\begin{tabular}{|c|c|c|c|c|c|c|c|c|}
\hline & & & & & & & Strep- & \\
\hline & & & & & & Coliform & tococci & \\
\hline & & Boron & & & & fecal & fecal & \\
\hline & Phos- & (dis- & & & & (membrane & (membrane & \\
\hline Phos- & phate & solved) & & & & filter) & filter, & \\
\hline phate & (d) Is- & (micro- & & Carbon & Carbon & (colonies & KF Agar) & \\
\hline (total & sol ved & grams & Carbon & (dis- & (sus- & per 100 & (colonies & \\
\hline ortho & ortho & per & (total & solved & pended & milli- & per 100 & Oxygen \\
\hline as $P$ ) & as P) & Iter) & $\operatorname{organ}(c)$ & $\operatorname{organ}(c)$ & organic) & (iter) & milliliter) & (dissolved) \\
\hline
\end{tabular}

220

490

, 100

200

150

200

640

740

80

270

380

320

600 


\begin{tabular}{|c|c|c|c|c|c|c|c|c|c|}
\hline Date of & $\begin{array}{l}\text { Nitrate } \\
\text { (total }\end{array}$ & $\begin{array}{l}\text { Nitrite } \\
\text { plus } \\
\text { nitrate } \\
\text { (total }\end{array}$ & $\begin{array}{c}\text { Nitrite } \\
\text { plus } \\
\text { nitrate } \\
\text { (d) ssolved }\end{array}$ & $\begin{array}{l}\text { Nitrogen, } \\
\text { ammonla } \\
\text { (total }\end{array}$ & $\begin{array}{l}\text { Nitrogen } \\
\text { (total } \\
\text { organlc }\end{array}$ & $\begin{array}{c}\text { NItrogen } \\
\text { (total } \\
\text { Kjeldahl }\end{array}$ & $\begin{array}{l}\text { Nitrogen } \\
\text { (total }\end{array}$ & $\begin{array}{l}\text { Fluo- } \\
\text { ride } \\
\text { (d)s- }\end{array}$ & $\begin{array}{l}\text { Phos- } \\
\text { phorus } \\
\text { (total }\end{array}$ \\
\hline collection & $\operatorname{as} N$ ) & as N) & $\operatorname{as} N$ ) & $\operatorname{as} N$ ) & as $N$ ) & as $N$ ) & as $N$ ) & solved) & as $P$ ) \\
\hline
\end{tabular}

Rlo San Jose at Mesita Diversion (9.5.12.133) - continued

\begin{tabular}{|c|c|c|c|c|c|c|c|c|c|}
\hline $08-31-72$ & 1.9 & - & - & - & - & - & - & .8 & .34 \\
\hline $09-13-73$ & 7.4 & - & - & - & - & - & - & .6 & $\mathrm{~T}$ \\
\hline $01-25-74$ & .48 & - & - & - & - & - & - & 1.0 & .42 \\
\hline $04-03-74$ & .19 & - & - & - & - & - & - & 1.2 & .05 \\
\hline $10-21-74$ & 3.7 & - & - & - & - & - & - & .9 & .01 \\
\hline $03-28-75$ & 0.70 & - & - & - & - & - & - & 1.1 & 0.19 \\
\hline $03-30-76$ & 0.28 & - & - & - & - & - & - & 0.6 & 0.27 \\
\hline $01-10-77$ & 1.82 & - & - & - & - & - & - & 1.2 & 0.72 \\
\hline $01-24-77$ & - & 0.88 & 0.88 & - & - & 1.5 & - & $0.9 *$ & $0.42^{*}$ \\
\hline $04-06-77$ & 0.42 & - & - & - & - & - & - & 1.1 & 0.12 \\
\hline $07-06-77$ & 0.14 & - & - & - & - & - & - & 0.8 & 0.02 \\
\hline $10-04-77$ & 0.03 & - & - & - & - & - & - & 0.9 & T \\
\hline $01-10-78$ & 0.56 & - & - & - & - & - & - & 1.0 & 0.34 \\
\hline $03-07-78$ & 0.14 & - & - & - & - & - & - & 0.9 & 0.51 \\
\hline $04-19-78$ & - & 0.02 & 0.02 & 0.01 & 0.48 & 0.49 & 0.51 & $1.2^{*}$ & $0.10^{*}$ \\
\hline $06-06-78$ & 0.01 & - & - & - & - & - & - & 0.9 & $T$ \\
\hline
\end{tabular}




\begin{tabular}{|c|c|c|c|c|c|c|c|c|}
\hline & & & & & & Coliform & $\begin{array}{l}\text { Strep- } \\
\text { tococcl }\end{array}$ & \\
\hline & & Boron & & & & fecal & fecal & \\
\hline & Phos- & (dis- & & & & (membrane & (membrane & \\
\hline Phos- & phate & solved) & & & & filter) & filter, & \\
\hline phate & (d) s- & (micro- & & Carbon & Carbon & (colonies & KF Agar) & \\
\hline (total & solved & grams & Carbon & (dis- & (sus- & per 100 & (colonies & \\
\hline or tho & ortho & per & (total & solved & pended & milli- & per 100 & Oxygen \\
\hline as $P$ ) & as $P$ ) & $(i$ ter) & organic) & organic) & $\operatorname{organ}(c)$ & (iter) & milliliter) & (dissolved) \\
\hline
\end{tabular}

\begin{tabular}{|c|c|c|c|c|c|c|c|c|}
\hline- & - & $T$ & - & - & - & - & - & - \\
\hline - & - & 40 & - & - & - & - & - & - \\
\hline- & - & 350 & - & - & - & - & - & - \\
\hline- & - & 290 & - & - & - & - & - & - \\
\hline- & - & 250 & - & - & - & - & - & - \\
\hline - & - & 12 & - & - & - & - & - & - \\
\hline- & - & 280 & - & - & - & - & - & - \\
\hline- & - & 840 & - & - & - & - & - & - \\
\hline 0.31 & 0.24 & $380^{*}$ & 4.4 & - & - & - & - & - \\
\hline- & - & 550 & - & - & - & - & - & - \\
\hline- & - & 760 & - & - & - & - & - & - \\
\hline- & - & 400 & - & - & - & - & - & - \\
\hline- & - & 320 & - & - & - & - & - & - \\
\hline- & - & 540 & - & - & - & - & - & - \\
\hline- & 0.10 & $780^{*}$ & 5.3 & 4.7 & 0.6 & 1 & 36 & 8. \\
\hline- & - & 900 & - & - & - & - & - & - \\
\hline
\end{tabular}




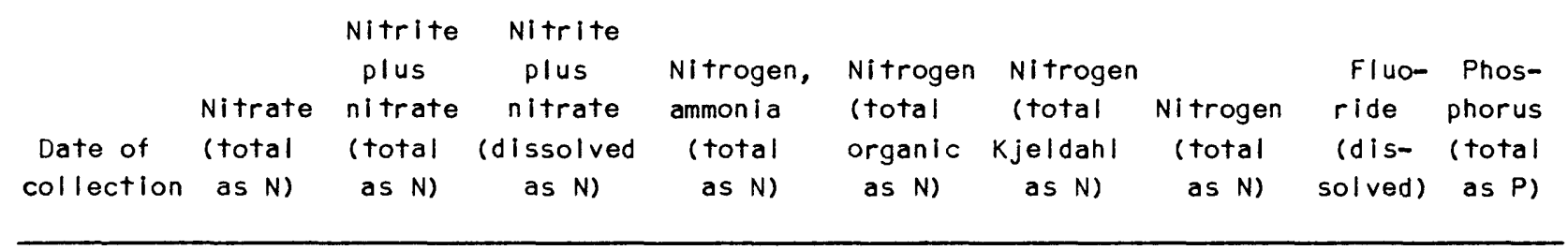

Rio San Jose at Mosita Diversion (9.5.12.133) - concluded

$\begin{array}{llllllllll}09-07-78 & 0.03 & - & - & - & - & - & - & 0.7 & 0.01 \\ 01-09-79 & 0.84 & - & - & - & - & - & - & 3.4 & 0.46 \\ 01-24-79 & 1.0^{*} & 1.1 & - & 0.62 & 0.68 & 1.3 & 2.4 & 1.0 & 0.65^{*} \\ 03-06-79 & 0.28 & - & - & - & - & - & - & 0.9 & 0.84 \\ 06-06-79 & 0.04 & - & - & - & - & - & -1.0 & 0.14\end{array}$




\begin{tabular}{|c|c|c|c|c|c|c|c|c|}
\hline $\begin{array}{l}\text { Phos- } \\
\text { phate } \\
\text { (total } \\
\text { ortho } \\
\text { as P) }\end{array}$ & $\begin{array}{l}\text { Phos- } \\
\text { phate } \\
\text { (dis- } \\
\text { solved } \\
\text { ortho } \\
\text { as P) }\end{array}$ & $\begin{array}{l}\text { Boron } \\
\text { (dis- } \\
\text { solved) } \\
\text { (micro- } \\
\text { grams } \\
\text { per } \\
\text { (iter) }\end{array}$ & $\begin{array}{c}\text { Carbon } \\
\text { (total } \\
\text { organic) }\end{array}$ & $\begin{array}{l}\text { Carbon } \\
\text { (dis- } \\
\text { solved } \\
\text { organic) }\end{array}$ & $\begin{array}{l}\text { Carbon } \\
\text { (sus- } \\
\text { pended } \\
\text { organic) }\end{array}$ & $\begin{array}{l}\text { Collform } \\
\text { fecal } \\
\text { (membrane } \\
\text { filter) } \\
\text { (colonles } \\
\text { per } 100 \\
\text { milli- } \\
\text { liter) }\end{array}$ & $\begin{array}{l}\text { Strep- } \\
\text { tococci } \\
\text { fecal } \\
\text { (membrane } \\
\text { fllter, } \\
\text { KF Agar) } \\
\text { (colonies } \\
\text { per } 100 \\
\text { millilliter) }\end{array}$ & $\begin{array}{c}\text { Oxygen } \\
\text { (dissolved) }\end{array}$ \\
\hline- & - & 500 & - & - & - & - & - & - \\
\hline- & - & 120 & - & - & - & - & - & - \\
\hline 0.51 & - & 300 & 6.6 & 5.6 & 1.0 & 3 & 152 & 12.2 \\
\hline- & - & 480 & - & - & - & - & - & - \\
\hline- & - & 590 & - & - & - & - & - & - \\
\hline
\end{tabular}


Table II.--Selected trace elements in surface water

Notes: All constituents reported In micrograms per IIter. All constituents are reported as "totaln concentrations unless noted otherwise. Analyses were performed by both U.S. Bureau of Indian Affalrs (B|A) laboratory and the U.S. Geologlcal Survey (USGS) laboratory. Concentrations less than the detection limit of a particular analytical technlque are Indlcated by "Tw by BIA lab and "<" by USGS lab.

Date of

Barlum Cadmlum Chromlum Cobalt Copper Iron (dissolved) Lead

Cubero Creak at Budville (10.7.25.211)

$\begin{array}{rrrrrrrrrr}04-20-78 & 4 & - & 50 & - & - & - & - & 30 & - \\ 07-25-78 & 3 & 53 & T & T & - & - & 150 & T & T \\ 10-26-78 & 1 & 200 & <1 & <10 & - & - & 250 & T & T \\ 01-29-79 & 2 & 100 & 3 & T & - & - & 110 & 10 & T\end{array}$

Rlo Paguate upstrean from Paguate, Now Moxico (II.5.30.234)

$\begin{array}{rrrrrrrrrr}04-21-78 & 5 & - & - & - & - & - & - & 20 & - \\ 07-19-78 & T & 42 & T & T & - & - & 100 & 10 & T \\ 10-26-78 & <1 & 220 & <2 & <10 & - & - & 80 & T & T \\ 01-30-79 & 1 & T & 10 & T & - & - & 50 & 10 & 20\end{array}$

Rlo Paguate upstrean from Jackplle-Paguate Mine (I1.5.32.424)

$\begin{array}{cccccccccc}04-21-78 & - & - & - & - & - & - & - & 40 & - \\ 07-19-78 & 1 & 110 & T & T & - & - & 290 & 10 & 38 \\ 10-26-78 & <1 & 220 & <1 & <10 & - & - & 370 & T & T \\ 01-29-79 & 1 & T & 3 & T & - & - & 500 & 50 & T\end{array}$




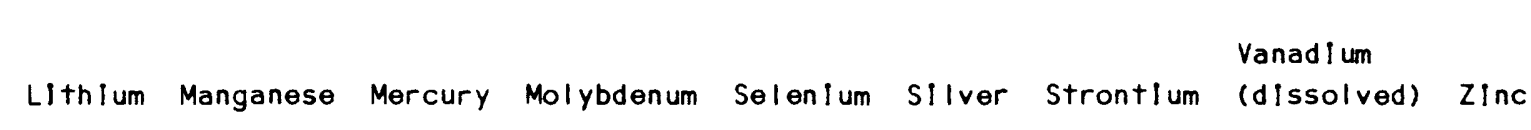

$\begin{array}{llllllllll}- & - & - & 10 & 1 & - & - & 4.0 & - \\ - & - & T & - & 5 & T & - & 3.8 & - \\ - & - & 2 & - & T & <10 & - & 5.4 & - \\ - & 32 & 3 & - & T & T & - & 4.9 & -\end{array}$

\begin{tabular}{|c|c|c|c|c|c|c|c|c|}
\hline - & - & - & 5 & 0 & - & - & 4.0 & - \\
\hline - & - & $\mathrm{T}$ & - & $T$ & $T$ & - & 4.5 & - \\
\hline - & - & $<2$ & - & $T$ & $<10$ & - & 5.8 & - \\
\hline - & $T$ & $<2$ & - & $T$ & $T$ & - & 3.3 & - \\
\hline - & - & - & 6 & 3 & - & - & 0.0 & - \\
\hline - & - & $T$ & - & $T$ & $T$ & - & 0.0 & - \\
\hline - & - & $<2$ & - & $\mathrm{T}$ & $<10$ & - & 0.0 & - \\
\hline - & 78 & $<2$ & - & $\mathbf{T}$ & $T$ & - & 1.6 & - \\
\hline
\end{tabular}


Rlo Paguate downstream from Jackplle-Paguate Mine (10.5.2.434)

$\begin{array}{rrrrrrrrrr}01-24-77 & <5 & 100 & 10 & 1 & <50 & 10 & 7,500 & 70 & <100 \\ 04-18-78 & 4 & - & 2 & 20 & 3 & 4 & 1,600 & 10 & 23 \\ 07-25-78 & T & 42 & T & T & - & - & T & T \\ 10-30-78 & <10 & 240 & 2 & <10 & - & - & 1,990 & T & T \\ 01-24-79 & 3 & 61 & T & 6 & - & - & 2,660 & T & -\end{array}$

Rlo San Jose at Mesita. Diversion (0.5.12.133)

$\begin{array}{cccccccccc}01-24-77 & 4 & 0 & <10 & 0 & <50 & 10 & 3,600 & 40 & <100 \\ 04-19-78 & 5 & - & 2 & 0 & 1 & 8 & 310 & 40 & 90 \\ 01-24-79 & 5 & 41 & T & T & - & - & 930 & T & -\end{array}$

Rlo Puerco at Rt. 66 brldge (9.1.4.412)

$\begin{array}{lllllllllll}08-24-78 & 1 & 700 & T & T & - & - & 70 & 40 & 13\end{array}$




\begin{tabular}{|c|c|c|c|c|c|c|c|c|}
\hline 50 & 180 & 0 & 2 & 8 & $<10$ & 1,500 & 0.3 & - \\
\hline - & 50 & 0 & 7 & 9 & - & - & 0.0 & 20 \\
\hline - & - & $T$ & - & $T$ & $T$ & - & 0.0 & - \\
\hline - & - & $<2$ & - & $T$ & $<10$ & - & 0.0 & - \\
\hline - & 110 & $<2$ & - & $T$ & $T$ & - & 0.5 & - \\
\hline 290 & 110 & 0 & 3 & 4 & $<10$ & 2,100 & 3.4 & - \\
\hline - & 140 & 0 & 8 & 1 & - & - & 5.0 & 20 \\
\hline - & 88 & $<2$ & - & $T$ & $T$ & - & 3.5 & - \\
\hline - & - & $T$ & - & $T$ & - & - & - & - \\
\hline
\end{tabular}


Table 12. MIscellaneous onslte masurements of streanflow and water quality

Note: All measurements were performed onslte.

An Asterlsk Indicates discharge measurement was the mean value for the day recorded at a streamflow-gaging station. All other discharge measurements were of Instantaneous flow.

\begin{tabular}{|c|c|c|c|c|c|c|c|}
\hline & & $\begin{array}{l}\text { Speclfic } \\
\text { conductance } \\
\text { (mlcromhos }\end{array}$ & & & & & \\
\hline $\begin{array}{l}\text { Date of } \\
\text { collection }\end{array}$ & $\begin{array}{l}\text { Discharge } \\
\text { (cublc feet } \\
\text { per second) }\end{array}$ & $\begin{array}{l}\text { per centi- } \\
\text { meter } \\
\text { at } 25^{\circ} \\
\text { celsius) }\end{array}$ & $\begin{array}{c}\mathrm{pH} \\
\text { (units) }\end{array}$ & $\begin{array}{l}\text { Temperature } \\
\text { (degrees } \\
\text { celslus) }\end{array}$ & $\begin{array}{l}\text { Bl carbonate } \\
\text { (milligrams } \\
\text { per } \| \text { ter } \\
\text { as } \mathrm{HCO}_{3} \text { ) }\end{array}$ & $\begin{array}{l}\text { Carbonate } \\
\text { (milllgrams } \\
\text { per llter } \\
\text { as } \mathrm{CO}_{3} \text { ) }\end{array}$ & $\begin{array}{l}\text { Dissolved } \\
\text { oxygen } \\
\text { (milligrams } \\
\text { per liter) }\end{array}$ \\
\hline
\end{tabular}

Rio San Jose at Seama Diversion $(10.7 .34 .242)$

\begin{tabular}{|c|c|c|c|c|}
\hline $10-02-73$ & - & 3,100 & - & 13.0 \\
\hline $11-01-73$ & - & 3,500 & - & 8.0 \\
\hline $12-03-73$ & - & 6,000 & - & 2.0 \\
\hline $02-11-74$ & - & 1,400 & - & 5.0 \\
\hline $03-14-74$ & - & 1,700 & - & 7.0 \\
\hline $05-06-74$ & - & 2,000 & - & - 18.0 \\
\hline $06-13-74$ & - & 3,250 & - & 26.0 \\
\hline $08-09-74$ & - & 3,000 & - & 24.0 \\
\hline $09-20-74$ & - & 3,500 & - & 17.5 \\
\hline $11-04-74$ & - & 2,900 & - & 7.0 \\
\hline $01-14-75$ & - & 1,540 & - & 2.0 \\
\hline $03-05-75$ & - & 1,900 & - & 6.0 \\
\hline $04-07-75$ & - & 1,800 & - & 10.0 \\
\hline $05-06-75$ & - & 2,060 & - & 8.0 \\
\hline $06-09-75$ & - & 3,200 & - & 24.0 \\
\hline $08-04-75$ & - & 3,000 & - & 25.0 \\
\hline
\end{tabular}


Specific

conductance

(micromhos

per centi-

Discharge

meter

Blcarbonate

Carbonate

Dissolved

Date of (cublc feet Temperature (milligrams (mil) igrams collection per second) at $25^{\circ}$ $\mathrm{pH}$ celsius) (degrees

(units) celsius) per IIter as $\mathrm{HCO}_{3}$ ) per IIter as $\mathrm{CO}_{3}$ ) oxygen (m) 1) Igrams per IIter)

\section{Rlo San Jose at Seama Diverslon (10.7.34.242) - Continued}

\begin{tabular}{|c|c|c|c|c|}
\hline $12-05-75$ & - & 6,050 & - & 2.0 \\
\hline $01-02-76$ & - & 4,000 & - & 3.0 \\
\hline $02-15-76$ & - & 1,950 & - & 3.0 \\
\hline $05-05-76$ & - & 3,000 & - & 16.0 \\
\hline $06-02-76$ & - & 3,000 & - & 22.0 \\
\hline $07-06-76$ & - & 5,000 & - & 18.0 \\
\hline $08-03-76$ & - & 1,550 & - & 24.0 \\
\hline $09-02-76$ & - & 2,200 & - & 17.0 \\
\hline $10-15-76$ & - & 4,000 & - & 8.0 \\
\hline $11-02-76$ & - & 2,300 & - & 4.0 \\
\hline $12-06-76$ & - & 2,100 & - & -1.0 \\
\hline $02-02-77$ & - & 1,850 & - & 3.0 \\
\hline $03-01-77$ & - & 1,800 & - & 5.0 \\
\hline $05-02-77$ & - & 2,000 & - & 11.5 \\
\hline $06-01-77$ & - & 3,000 & - & 16.0 \\
\hline $08-01-77$ & - & 3,500 & - & 18.0 \\
\hline
\end{tabular}


Table 12. Miscelfaneous onsite measurements of streamflow and water quallty - Continued

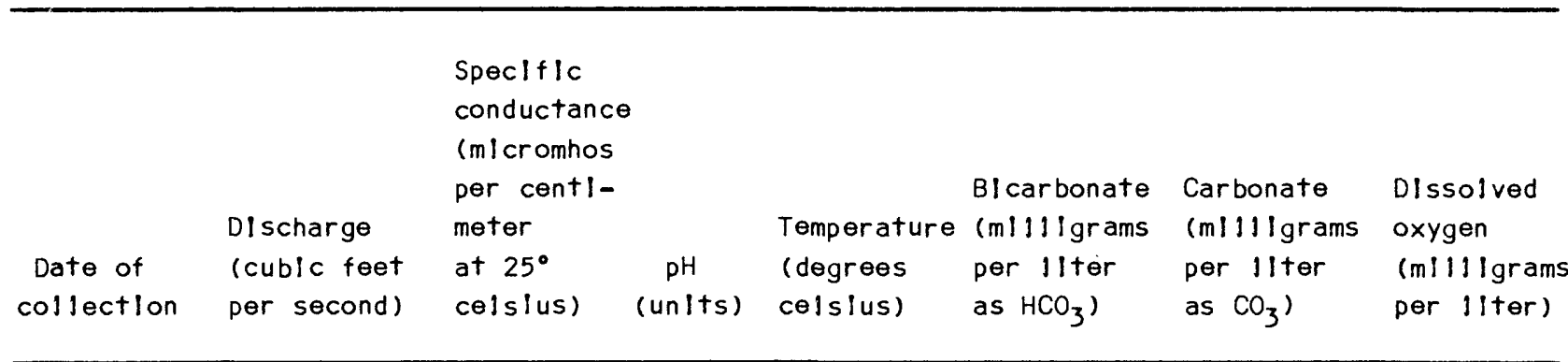

Rlo San Jose at Seama Diversion (10.7.34.242) - Concluded

\begin{tabular}{|c|c|c|c|c|}
\hline $09-07-77$ & - & 1,300 & - & 19.0 \\
\hline $10-31-77$ & - & 1,800 & - & 11.0 \\
\hline $11-02-77$ & - & 1,600 & - & 5.0 \\
\hline $12-05-77$ & - & 2,100 & - & 4.0 \\
\hline $01-02-78$ & - & 2,200 & - & 4.0 \\
\hline $02-07-78$ & - & 2,000 & - & 5.0 \\
\hline $04-03-78$ & - & 2,400 & - & 10.0 \\
\hline $05-01-78$ & - & 5,000 & - & 11.0 \\
\hline $07-05-78$ & - & 3,000 & - & 14.0 \\
\hline $08-01-78$ & - & 2,100 & - & 17.0 \\
\hline $10-02-78$ & - & 3,000 & - & 14.0 \\
\hline $11-01-78$ & - & 2,500 & - & 11.0 \\
\hline $12-01-78$ & - & 2,000 & - & 4.0 \\
\hline $02-05-79$ & - & 1,900 & - & 1.0 \\
\hline $04-05-79$ & - & 1,700 & - & 15.0 \\
\hline $05-01-79$ & - & 2,800 & - & 10.0 \\
\hline $07-02-79$ & - & 1,300 & - & 16.0 \\
\hline $08-06-79$ & - & 6,000 & - & 20.0 \\
\hline
\end{tabular}




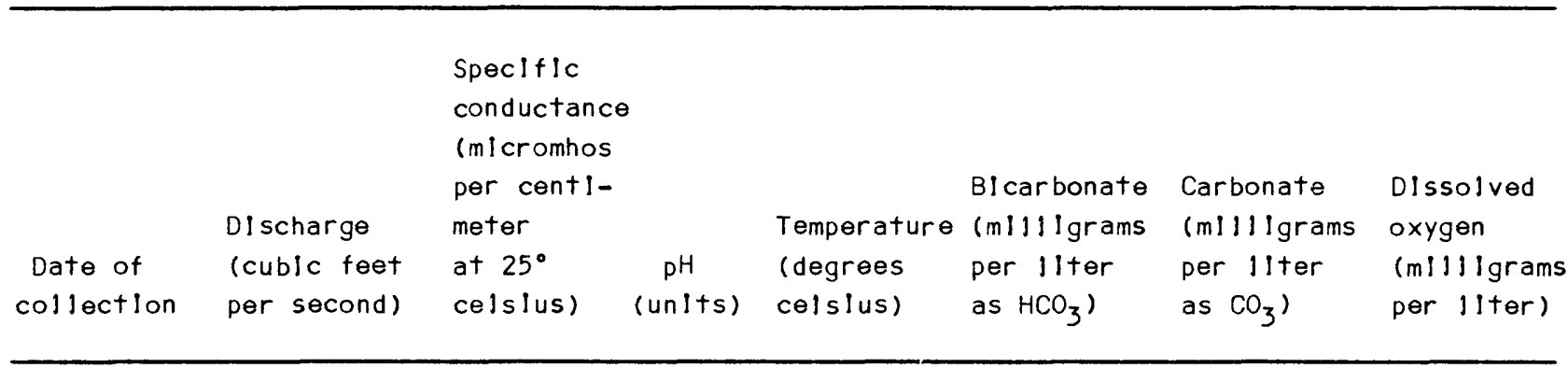

\section{Acomita Ditch at Laguna-Acoma Boundary (10.7.35.411)}

$\begin{array}{lllll}05-27-76 & 0.89 & 2,120 & - & 21.0 \\ 06-16-76 & 0.21 & 1,720 & - & 24.0 \\ 07-20-76 & 0.07 & 1,900 & - & 26.0 \\ 09-02-76 & 0.93 & 1,700 & - & -\end{array}$

New York Ditch at Laguna-Acoma Boundary (10.7.35.213)
$05-24-78$
0.23
1,600
8.6
24.0
$252^{*}$
13

Paraje and Acomita Ditches at Acoma-Laguna Boundary (10.7.35.244)

$\begin{array}{llllllll}05-24-78 & 2.02 & 1,800 & 8.5 & 17.5 & 287 & 16 & - \\ 06-21-78 & 0.45 & 2,030 & 8.4 & 21.0 & 338 & 8 & 9.9 \\ 07-26-78 & 4.0 & 1,700 & 8.3 & 18.0 & 320 & 0 & 8.2 \\ 08-30-78 & 0.91 & 1,900 & 8.2 & 15.0 & 316 & 0 & 9.0 \\ 09-27-78 & 1.7 & 1,870 & 8.4 & 13.0 & 310 & 6 & 8.3\end{array}$

Rlo San Jose at Laguna-Acoma Boundary (10.7.35.231)

$\begin{array}{lllll}04-01-76 & 7.2 & 1,970 & - & - \\ 04-29-76 & 4.7 & 2,200 & - & 8.5 \\ 05-27-76 & 0.10 & 5,040 & - & 21.0 \\ 06-16-76 & 0.43 & 5,890 & - & 21.5\end{array}$




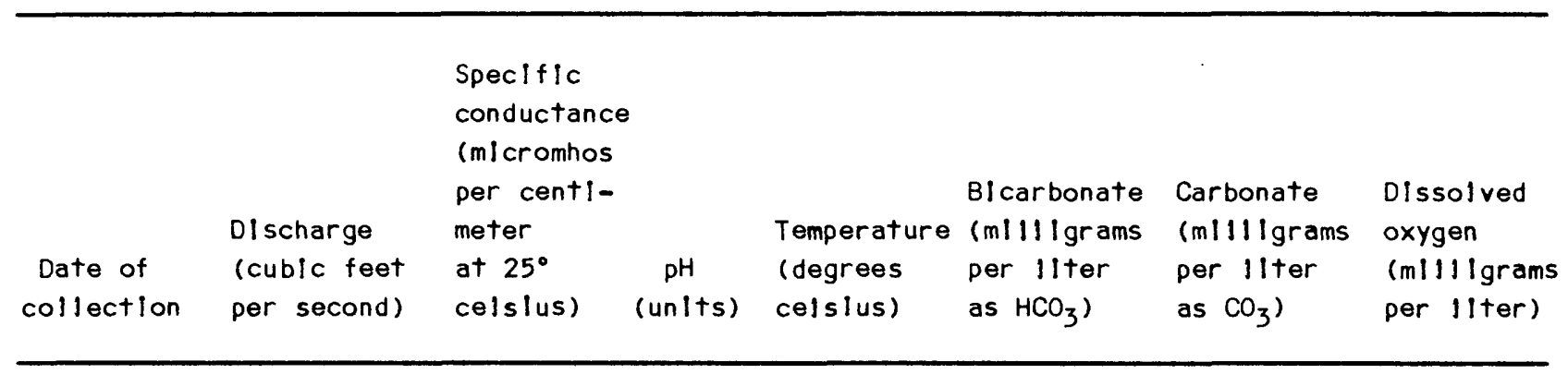

Rlo San Jose at Laguna-fcoma Boundary (10.7.35.231) - Concluded

\begin{tabular}{|c|c|c|c|c|c|c|c|c|}
\hline $07-20-76$ & 0.02 & & 3,000 & - & 26.5 & - & - & - \\
\hline $09-02-76$ & 1.04 & & 2,700 & - & - & - & - & - \\
\hline $10-04-76$ & 3.9 & & 2,310 & 8.3 & 12.5 & - & - & - \\
\hline $01-18-77$ & 4.6 & & 2,000 & - & 0.0 & - & - & - \\
\hline $02-18-77$ & 6.5 & & 2,300 & - & 9.5 & - & - & - \\
\hline $03-17-77$ & 10.2 & . & 2,000 & - & 5.5 & - & - & - \\
\hline $04-13-77$ & 9.4 & . & 2,000 & - & 10.5 & - & - & - \\
\hline $05-12-77$ & 0.67 & & 2,300 & - & 13.0 & - & - & - \\
\hline $05-24-78$ & 0.76 & & 3,500 & 8.3 & 22.0 & 449 & 0 & - \\
\hline $06-21-78$ & 0.02 & & 5,500 & 8.5 & 28.0 & 456 & 12 & 9.9 \\
\hline $07-26-78$ & 0.55 & & 1,900 & 8.2 & 20.0 & 324 & 0 & 7.6 \\
\hline $08-30-78$ & 0.68 & & 2,000 & 8.1 & 16.0 & 320 & 0 & 7.8 \\
\hline $09-27-78$ & 0.63 & & 3,000 & 8.4 & 13.5 & 386 & 8 & 8.0 \\
\hline $11-02-78$ & 4.7 & & 2,080 & 8.5 & 12.0 & 344 & 8 & 9.8 \\
\hline $01-03-79$ & 6.0 & & 2,130 & - & 0.5 & - & - & - \\
\hline $01-30-79$ & 7.9 & & 2,200 & 8.3 & 0.0 & 352 & 0 & 11.0 \\
\hline $02-28-79$ & 7.3 & & 1,830 & 8.5 & 5.5 & 328 & 6 & 11.1 \\
\hline $03-27-79$ & 7.8 & & 2,000 & 8.3 & 11.0 & 328 & 0 & 8.3 \\
\hline
\end{tabular}


Table 12. Miscellaneous onsite masurements of streanflow and water quality - Continued

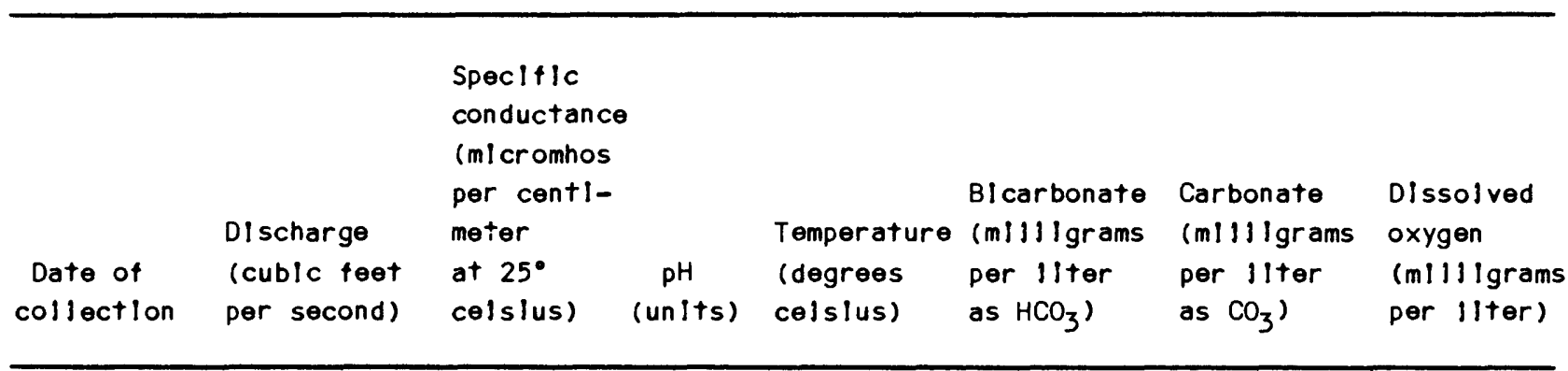

Paraje Ditch at Lagune-Acoma Boundery (10.7.35.233)

$\begin{array}{lllll}05-27-76 & 0.66 & 3,570 & - & 21.0 \\ 06-16-76 & 1.54 & 3,270 & - & 21.5 \\ 07-20-76 & 1.24 & 2,300 & - & 26.0 \\ 09-02-76 & 1.99 & 2,600 & - & - \\ 05-12-77 & 1.17 & 2,100 & - & 13.0\end{array}$

Cubero Creek at Budville (10.7.25.211)

\begin{tabular}{|c|c|c|c|c|c|c|c|}
\hline $12-17-74$ & 0.40 & 750 & - & 9.0 & - & - & - \\
\hline $03-28-75$ & - & 740 & - & 10.0 & - & - & - \\
\hline $05-26-78$ & 0.26 & 700 & 7.9 & 12.0 & 290 & 0 & - \\
\hline $06-27-78$ & 0.34 & 650 & 8.3 & 20.5 & 310 & 0 & 7.8 \\
\hline $08-29-78$ & 0.23 & 740 & 8.2 & 29.5 & 280 & 0 & 6.9 \\
\hline $09-26-78$ & 0.23 & 780 & 8.4 & 26.0 & 300 & 4 & 7.3 \\
\hline $12-29-78$ & 0.38 & 650 & 8.7 & 9.0 & 280 & 10 & 9.2 \\
\hline $02-28-79$ & 0.27 & 700 & 8.8 & 12.0 & 250 & 16 & 10.4 \\
\hline $03-28-79$ & 0.22 & 680 & 8.75 & 10.5 & 270 & 12 & 9.7 \\
\hline $05-14-79$ & 0.25 & 700 & 8.9 & 23.0 & 260 & 8 & 8.9 \\
\hline
\end{tabular}




\begin{tabular}{|c|c|c|c|c|c|c|c|}
\hline & & $\begin{array}{l}\text { Specific } \\
\text { conductance } \\
\text { (mlcromhos }\end{array}$ & 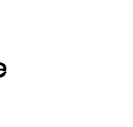 & & & & \\
\hline $\begin{array}{l}\text { Date of } \\
\text { collection }\end{array}$ & $\begin{array}{l}\text { Discharge } \\
\text { (cublc feet } \\
\text { per second) }\end{array}$ & $\begin{array}{l}\text { per centi- } \\
\text { meter } \\
\text { at } 25^{\circ} \\
\text { celsius) }\end{array}$ & $\begin{array}{c}\mathrm{pH} \\
(u n i t s)\end{array}$ & $\begin{array}{l}\text { Temperature } \\
\text { (degrees } \\
\text { celslus) }\end{array}$ & $\begin{array}{l}\text { Bl carbonate } \\
\text { (mlll Igrams } \\
\text { per llter } \\
\text { as } \mathrm{HCO}_{3} \text { ) }\end{array}$ & $\begin{array}{l}\text { Carbonate } \\
\text { (mIlligrams } \\
\text { per llter } \\
\text { as } \mathrm{CO}_{3} \text { ) }\end{array}$ & $\begin{array}{l}\text { Dissolved } \\
\text { oxygen } \\
\text { (mllligrams } \\
\text { per liter) }\end{array}$ \\
\hline
\end{tabular}

\section{Rlo San Jose at Casa Blanca Diversion $(9.6 .6 .222)$}

\begin{tabular}{|c|c|c|c|c|}
\hline $10-02-73$ & - & 3,500 & - & 13.5 \\
\hline $11-01-73$ & - & 3,000 & - & 6.5 \\
\hline $12-03-73$ & - & 5,000 & - & 2.0 \\
\hline $01-14-74$ & - & 2,400 & - & 3.0 \\
\hline $02-11-74$ & - & 1,500 & - & 2.0 \\
\hline $03-14-74$ & - & 1,800 & - & 7.0 \\
\hline $05-06-74$ & - & 2,200 & - & 18.5 \\
\hline $06-13-74$ & - & 2,600 & - & 27.0 \\
\hline $08-09-74$ & - & 2,400 & - & 27.0 \\
\hline $09-20-74$ & - & 3,000 & - & 19.0 \\
\hline $11-04-74$ & - & 2,000 & - & 6.0 \\
\hline $11-22-74$ & - & 1,800 & - & 7.0 \\
\hline $01-14-75$ & - & 1,560 & - & 1.0 \\
\hline $03-05-75$ & - & 1,900 & - & 5.5 \\
\hline $04-07-75$ & - & 1,650 & - & 11.0 \\
\hline $05-06-75$ & - & 3,000 & - & 11.0 \\
\hline $06-09-75$ & - & 3,000 & - & 26.0 \\
\hline
\end{tabular}




\begin{tabular}{|c|c|c|c|c|c|c|c|}
\hline & & $\begin{array}{l}\text { Speclflc } \\
\text { conductance } \\
\text { (micromhos }\end{array}$ & & & & & \\
\hline $\begin{array}{l}\text { Date of } \\
\text { collection }\end{array}$ & $\begin{array}{l}\text { Discharge } \\
\text { (cublc feet } \\
\text { per second) }\end{array}$ & $\begin{array}{l}\text { per centl- } \\
\text { meter } \\
\text { at } 25^{\circ} \\
\text { cels(us) }\end{array}$ & $\begin{array}{c}\mathrm{pH} \\
\text { (unlts) }\end{array}$ & $\begin{array}{l}\text { Temperature } \\
\text { (degrees } \\
\text { celsius) }\end{array}$ & $\begin{array}{l}\text { Bicarbonate } \\
\text { (m/lllgrams } \\
\text { per } 11 \text { ter } \\
\text { as } \mathrm{HCO}_{3} \text { ) }\end{array}$ & $\begin{array}{l}\text { Carbonate } \\
\text { (mllllgrams } \\
\text { per } 11 \text { ter } \\
\text { as } \mathrm{CO}_{3} \text { ) }\end{array}$ & $\begin{array}{l}\text { Dissolved } \\
\text { oxygen } \\
\text { (milligrams } \\
\text { per liter) }\end{array}$ \\
\hline
\end{tabular}

\section{Rlo San Jose at Casa Blanca Diversion (9.6.6.222) - Continued}

\begin{tabular}{|c|c|c|c|c|}
\hline $08-04-75$ & - & 2,000 & - & 25.0 \\
\hline $12-05-75$ & - & 5,050 & - & 3.0 \\
\hline $01-02-76$ & - & 3,000 & - & 4.0 \\
\hline $02-25-76$ & - & 1,850 & - & 5.0 \\
\hline $05-05-76$ & - & 2,800 & - & 15.0 \\
\hline $06-02-76$ & - & 3,100 & - & 20.0 \\
\hline $07-06-76$ & - & 2,200 & - & 22.0 \\
\hline $08-03-76$ & - & 1,600 & - & 22.0 \\
\hline $09-02-76$ & - & 2,300 & - & 18.0 \\
\hline $10-12-76$ & - & 2,600 & - & 10.0 \\
\hline $11-02-76$ & - & 2,300 & - & 4.0 \\
\hline $12-06-76$ & - & 2,100 & - & 0.0 \\
\hline $02-02-77$ & - & 1,800 & - & 2.0 \\
\hline $03-01-77$ & - & 2,100 & - & 5.0 \\
\hline $05-02-77$ & - & 1,700 & - & 12.5 \\
\hline $06-01-77$ & - & 2,200 & - & 16.0 \\
\hline $08-01-77$ & - & 2,450 & - & 19.0 \\
\hline
\end{tabular}




\begin{tabular}{|c|c|c|c|c|c|c|c|}
\hline & & $\begin{array}{l}\text { Speciflc } \\
\text { conductance } \\
\text { (micromhos }\end{array}$ & 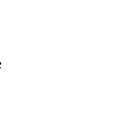 & & & & \\
\hline $\begin{array}{l}\text { Date of } \\
\text { collection }\end{array}$ & $\begin{array}{l}\text { Dlscharge } \\
\text { (cublc feet } \\
\text { per second) }\end{array}$ & $\begin{array}{l}\text { per centl- } \\
\text { meter } \\
\text { at } 25^{\circ} \\
\text { celslus) }\end{array}$ & $\begin{array}{c}\mathrm{pH} \\
\text { (unlts) }\end{array}$ & $\begin{array}{l}\text { Temperature } \\
\text { (degrees } \\
\text { celslus) }\end{array}$ & $\begin{array}{l}\text { Blcarbonate } \\
\text { (mllllgrams } \\
\text { per llter } \\
\text { as } \mathrm{HCO}_{3} \text { ) }\end{array}$ & $\begin{array}{l}\text { Carbonate } \\
\text { ( } \mathrm{m} / 1 \text { lgrams } \\
\text { per } \| \text { ter } \\
\text { as } \mathrm{CO}_{3} \text { ) }\end{array}$ & $\begin{array}{l}\text { Dlssolved } \\
\text { oxygen } \\
\text { (mllligrams } \\
\text { per liter) }\end{array}$ \\
\hline
\end{tabular}

\section{Rlo San Jose at Casa Blanca Diversion $(9.6 .6 .222)$ - Concluded}

\begin{tabular}{|c|c|c|c|c|}
\hline $09-07-77$ & - & 2,000 & - & 20.0 \\
\hline $12-05-77$ & - & 2,100 & - & 4.0 \\
\hline $01-02-78$ & - & 2,400 & - & 4.0 \\
\hline $02-07-78$ & - & 2,200 & - & 5.0 \\
\hline $04-03-78$ & - & 2,800 & - & 10.0 \\
\hline $05-01-78$ & - & 3,500 & - & 13.0 \\
\hline $07-05-78$ & 0 & 2,800 & - & 22.0 \\
\hline $08-01-78$ & - & 2,000 & - & 26.0 \\
\hline $10-02-78$ & - & 2,200 & - & 15.0 \\
\hline $11-01-78$ & - & 2,200 & - & 11.0 \\
\hline $12-01-78$ & - & 2,000 & - & 4.0 \\
\hline $02-05-79$ & - & 1,900 & - & 2.0 \\
\hline $03-01-79$ & - & 1,500 & - & 5.0 \\
\hline $04-05-79$ & - & 2,000 & - & 16.0 \\
\hline $05-01-79$ & - & 1,600 & - & 14.0 \\
\hline $07-02-79$ & - & 2,200 & - & 20.0 \\
\hline $08-06-79$ & - & 2,000 & - & 22.0 \\
\hline
\end{tabular}


Table 12. Miscellaneous onsite masurements of streanflow and water quality - Continued

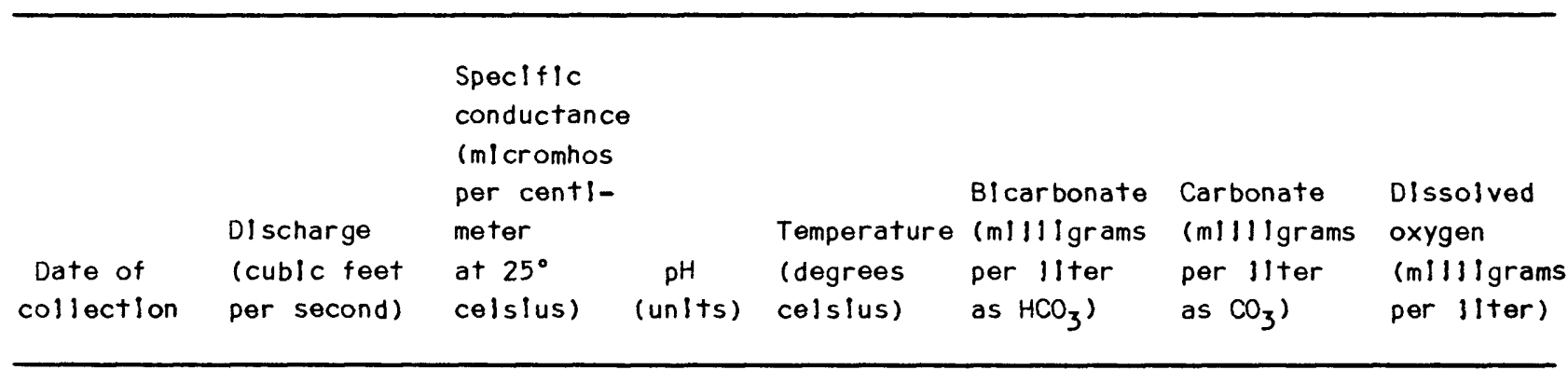

Rlo San Jose at New Laguna Dam (9.6.1.322)

\begin{tabular}{|c|c|c|c|c|c|c|c|}
\hline $12-03-73$ & - & 3,000 & - & 4.0 & - & - & - \\
\hline $01-18-74$ & - & 2,100 & - & 4.0 & - & - & - \\
\hline $02-15-74$ & - & 1,800 & - & 5.0 & - & - & - \\
\hline $03-11-74$ & - & 1,800 & - & 10.0 & - & - & - \\
\hline $04-03-74$ & - & 2,100 & - & 7.0 & - & - & - \\
\hline $05-06-74$ & - & 2,200 & - & 22.0 & - & - & - \\
\hline $08-09-74$ & - & 800 & - & 20.0 & - & - & - \\
\hline $10-21-74$ & - & 1,600 & - & 12.0 & - & - & - \\
\hline $11-04-74$ & - & 1,700 & - & 10.0 & - & - & - \\
\hline $01-14-75$ & - & 2,040 & - & 1.0 & - & - & - \\
\hline $02-12-75$ & - & 1,800 & - & 6.0 & - & - & - \\
\hline $03-05-75$ & - & 1,900 & - & 5.5 & - & - & - \\
\hline $03-28-75$ & - & 2,100 & - & 7.0 & - & - & - \\
\hline $04-15-75$ & - & 2,000 & - & 12.0 & - & - & - \\
\hline $05-06-75$ & - & 3,000 & - & 12.0 & - & - & - \\
\hline $12-05-75$ & - & 2,020 & - & 2.0 & - & - & - \\
\hline
\end{tabular}


Table 12. Miscellaneous onsite measurements of streamflow and water quality - Continued

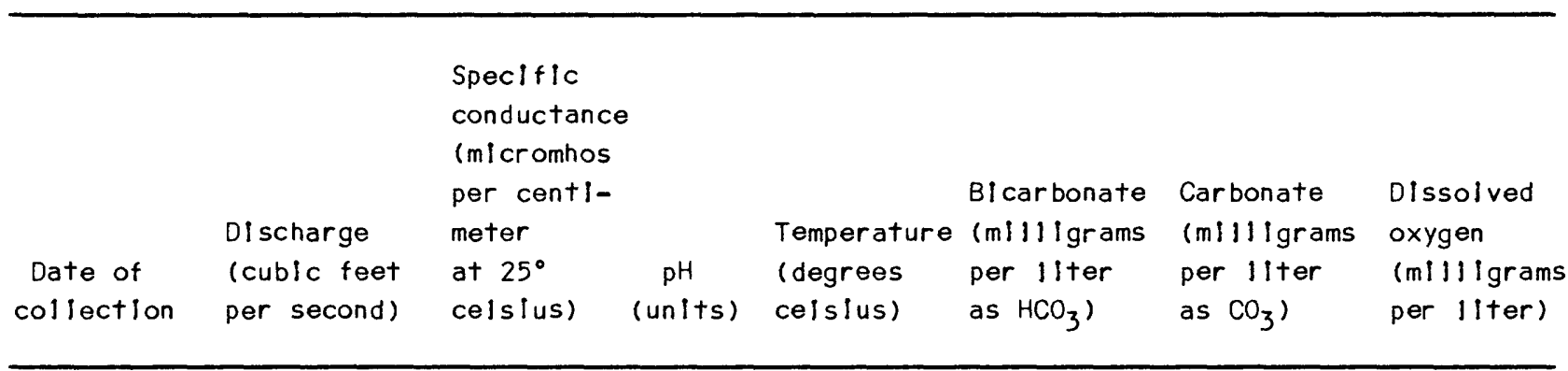

Rio San Jose at Now Laguna Dam (9.6.1.322) - Continued

\begin{tabular}{|c|c|c|c|c|}
\hline $01-04-76$ & - & 2,000 & - & 3.0 \\
\hline $03-25-76$ & - & 2,000 & - & 9.0 \\
\hline $05-05-76$ & - & 3,600 & - & 14.0 \\
\hline $08-03-76$ & - & 1,400 & - & 22.0 \\
\hline $09-02-76$ & - & 1,100 & - & 26.0 \\
\hline $10-04-76$ & - & 2,600 & - & 17.0 \\
\hline $11-01-76$ & - & 2,400 & - & 8.0 \\
\hline $12-07-76$ & - & 2,200 & - & 0.0 \\
\hline $02-02-77$ & - & 1,500 & - & 7.0 \\
\hline $03-01-77$ & - & 1,000 & - & 3.0 \\
\hline $05-03-77$ & - & 2,100 & - & 15.0 \\
\hline $06-02-77$ & - & 5,000 & - & 23.0 \\
\hline $08-01-77$ & - & 1,400 & - & 30.0 \\
\hline $09-08-77$ & - & 1,130 & - & 22.0 \\
\hline $10-31-77$ & - & 2,000 & - & 9.0 \\
\hline $12-07-77$ & - & 2,000 & - & 3.0 \\
\hline $01-03-78$ & - & 2,200 & - & 2.0 \\
\hline $02-08-78$ & - & 1,750 & - & 7.0 \\
\hline
\end{tabular}




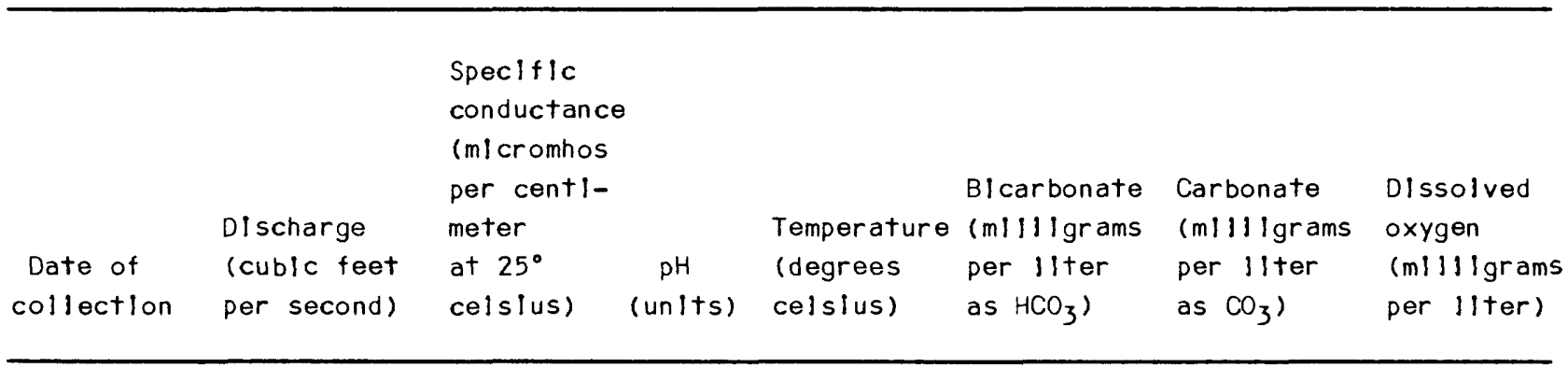

\section{Rlo San Jose at Now Laguna Dam (9.6.1.322) - Concluded}

$\begin{array}{lllll}04-04-78 & - & 2,600 & - & 9.0 \\ 05-01-78 & - & 3,100 & - & 11.0 \\ 10-03-78 & - & 2,400 & - & 14.0 \\ 11-01-78 & - & 2,200 & - & 12.0 \\ 12-05-78 & - & 1,900 & - & 2.0 \\ 02-06-79 & - & 1,800 & - & 0.0 \\ 04-05-79 & - & 2,000 & - & 14.0 \\ 05-03-79 & - & 3,000 & - & 9.0 \\ 07-05-79 & - & 4,000 & - & 22.0\end{array}$

RIo Paguate upstrean from Paguate, New Mexico (11.5.30.234)

\begin{tabular}{|c|c|c|c|c|c|c|c|}
\hline $05-25-78$ & 1.07 & 330 & 8.1 & 17.0 & 190 & 0 & - \\
\hline $06-27-78$ & 0.44 & 320 & 8.1 & 16.0 & 190 & 0 & 8.4 \\
\hline $08-28-78$ & 0.40 & 330 & 8.5 & 19.5 & 160 & 8 & 8.8 \\
\hline $09-28-78$ & 0.70 & 330 & 8.6 & 16.0 & 180 & 6 & 8.1 \\
\hline $01-02-79$ & 2.0 & 460 & 8.3 & 1.0 & 250 & 0 & 10.8 \\
\hline $02-27-79$ & 1.1 & 300 & 8.3 & 4.0 & 200 & 0 & 10.2 \\
\hline $03-28-79$ & 0.97 & 380 & 8.6 & 6.5 & 180 & 4 & 9.2 \\
\hline $05-10-79$ & 1.1 & 370 & 8.6 & 8.0 & 190 & 4 & 9.2 \\
\hline
\end{tabular}




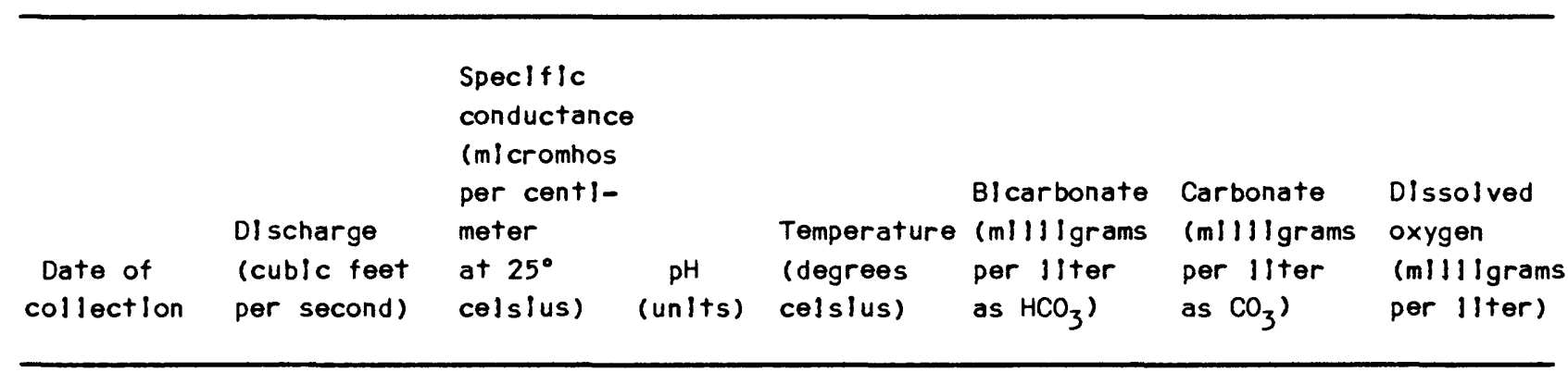

Rlo Paguate upstream from Jackplle-Paguate Mine (11.5.32.424)

\begin{tabular}{|c|c|c|c|c|}
\hline $02-04-74$ & - & 900 & - & - \\
\hline $04-04-74$ & - & 780 & - & 8.5 \\
\hline $11-22-74$ & 0.57 & 700 & - & 8.5 \\
\hline $12-05-74$ & - & 850 & - & 8.0 \\
\hline $12-17-74$ & 0.47 & - & - & 3.0 \\
\hline $02-10-75$ & - & 870 & - & 7.5 \\
\hline $03-18-75$ & - & 850 & - & 10.0 \\
\hline $03-28-75$ & - & 900 & - & 5.0 \\
\hline $04-14-75$ & - & 700 & - & 13.0 \\
\hline $05-07-75$ & - & 540 & - & 13.0 \\
\hline $06-12-75$ & - & 550 & - & 13.0 \\
\hline $08-06-75$ & - & 830 & - & 19.0 \\
\hline $12-03-75$ & - & 780 & - & 4.0 \\
\hline $01-06-76$ & - & 700 & - & 4.0 \\
\hline $01-30-76$ & - & 1,000 & - & 9.0 \\
\hline $04-29-76$ & 0.67 & 890 & - & 10.5 \\
\hline
\end{tabular}


Table 12. Miscelianeous onsite measurements of streanflow and water quality - Continued

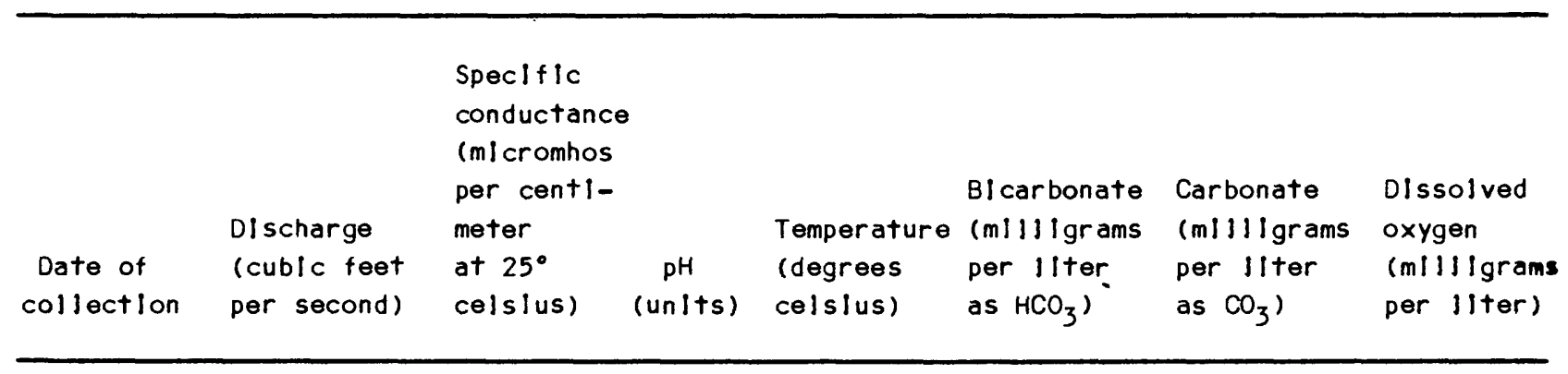

Rlo Paguate upstrean from Jackplle-Paguate MIne (11.5.32.424) - Continued

\begin{tabular}{|c|c|c|c|c|}
\hline $05-05-76$ & - & 830 & - & 14.0 \\
\hline $05-27-76$ & 0.15 & 1,060 & - & 23.0 \\
\hline $06-04-76$ & - & 700 & - & 18.0 \\
\hline $06-16-76$ & 0.32 & 830 & - & 24.5 \\
\hline $07-15-76$ & - & 830 & - & 22.0 \\
\hline $08-03-76$ & - & 930 & - & 20.0 \\
\hline $09-02-76$ & 0.10 & 900 & - & - \\
\hline $09-03-76$ & - & 950 & - & 15.0 \\
\hline $10-04-76$ & - & 970 & - & 13.0 \\
\hline $10-06-76$ & - & 950 & - & 11.0 \\
\hline $11-01-76$ & - & 850 & - & 8.0 \\
\hline $12-08-76$ & - & 680 & - & 2.0 \\
\hline $01-12-77$ & - & 580 & - & 0.0 \\
\hline $02-02-77$ & - & 540 & - & 5.0 \\
\hline $03-01-77$ & - & 800 & - & 3.0 \\
\hline $05-03-77$ & - & 750 & - & 9.0 \\
\hline $06-01-77$ & - & 930 & - & 24.0 \\
\hline
\end{tabular}


Table 12. MIscellaneous onsite measurements of streanflow and water quality - Continued

\begin{tabular}{|c|c|c|c|c|c|c|c|}
\hline & & $\begin{array}{l}\text { Speclflc } \\
\text { conductance } \\
\text { (mlcromhos }\end{array}$ & & & & & \\
\hline $\begin{array}{l}\text { Date of } \\
\text { collection }\end{array}$ & $\begin{array}{l}\text { Discharge } \\
\text { (cublc feet } \\
\text { per second) }\end{array}$ & $\begin{array}{l}\text { per centl- } \\
\text { meter } \\
\text { at } 25^{\circ} \\
\text { celslus) }\end{array}$ & $\begin{array}{c}\mathrm{pH} \\
\text { (units) }\end{array}$ & $\begin{array}{l}\text { Temperature } \\
\text { (degrees } \\
\text { celslus) }\end{array}$ & $\begin{array}{l}\text { Blcarbonate } \\
\text { (milligrams } \\
\text { per } 1 \text { lter } \\
\text { as } \mathrm{HCO}_{3} \text { ) }\end{array}$ & $\begin{array}{l}\text { Carbonate } \\
\text { (milligrams } \\
\text { per IIter } \\
\text { as } \mathrm{CO}_{3} \text { ) }\end{array}$ & $\begin{array}{l}\text { Dissolved } \\
\text { oxygen } \\
\text { (mllligrams } \\
\text { per llter) }\end{array}$ \\
\hline
\end{tabular}

Rlo Paguate upstrean from Jackpl Je-Paguate Mine (11.5.32.424) - Continued

\begin{tabular}{|c|c|c|c|c|c|c|c|}
\hline $07-08-77$ & - & 950 & - & 19.0 & - & - & - \\
\hline $08-02-77$ & - & 930 & - & 15.0 & - & - & - \\
\hline $09-07-77$ & - & 900 & - & 26.0 & - & - & - \\
\hline $10-05-77$ & - & 560 & - & 15.0 & - & - & - \\
\hline $10-31-77$ & - & 900 & - & 9.0 & - & - & - \\
\hline $12-06-77$ & - & 730 & - & 8.0 & - & - & - \\
\hline $01-04-78$ & - & 680 & - & 2.0 & - & - & - \\
\hline $02-09-78$ & - & 800 & - & 2.0 & - & - & - \\
\hline $04-04-78$ & - & 800 & - & 19.0 & - & - & - \\
\hline $05-04-78$ & - & 900 & - & 14.0 & - & - & - \\
\hline $05-25-78$ & 0.21 & 800 & 7.8 & 19.0 & 340 & 0 & - \\
\hline $06-27-78$ & 0.19 & 850 & 8.1 & 18.5 & 380 & 0 & 8.8 \\
\hline $07-07-78$ & - & 850 & - & 13.0 & - & - & - \\
\hline $08-03-78$ & - & 830 & - & 19.0 & - & - & - \\
\hline $08-28-78$ & 0.12 & 820 & 8.0 & 21.5 & 350 & 0 & 6.9 \\
\hline $09-29-78$ & 0.13 & 800 & 8.2 & 20.5 & 350 & 0 & 7.2 \\
\hline
\end{tabular}




\begin{tabular}{|c|c|c|c|c|c|c|c|}
\hline & & $\begin{array}{l}\text { Speclfic } \\
\text { conductance } \\
\text { (micromhos }\end{array}$ & & & & & \\
\hline $\begin{array}{l}\text { Date of } \\
\text { collection }\end{array}$ & $\begin{array}{l}\text { Discharge } \\
\text { (cublc teet } \\
\text { per second) }\end{array}$ & $\begin{array}{l}\text { per centi- } \\
\text { meter } \\
\text { at } 25^{\circ} \\
\text { celsius) }\end{array}$ & $\begin{array}{c}\mathrm{pH} \\
\text { (units) }\end{array}$ & $\begin{array}{l}\text { Temperature } \\
\text { (degrees } \\
\text { celslus) }\end{array}$ & $\begin{array}{l}\text { Bicarbonate } \\
\text { (mllllgrams } \\
\text { per llter } \\
\text { as } \mathrm{HCO}_{3} \text { ) }\end{array}$ & $\begin{array}{l}\text { Carbonate } \\
\text { (m)lllgrams } \\
\text { per } 11 \text { ter } \\
\text { as } \mathrm{CO}_{3} \text { ) }\end{array}$ & $\begin{array}{l}\text { Dissolved } \\
\text { oxygen } \\
\text { (mll ligrams } \\
\text { per } 1 \text { tter) }\end{array}$ \\
\hline
\end{tabular}

Rlo Paguate upstream from Jackpl Je-Paguate MIne (11.5.32.424) - Concluded

$\begin{array}{llllllll}10-02-78 & - & 830 & - & 19.0 & - & - & - \\ 11-01-78 & - & 850 & - & 14.0 & - & - & - \\ 12-04-78 & - & 900 & - & 4.0 & - & - & - \\ 01-03-79 & 0.50 & 630 & 8.35 & 1.0 & 320 & 2 & 11.0 \\ 01-08-79 & - & 950 & - & 0.0 & - & - & - \\ 02-05-79 & - & 750 & - & 0.0 & - & - & 8.8 \\ 02-27-79 & 0.35 & 800 & 8.4 & 10.0 & 390 & 6 & 8.3 \\ 03-26-79 & 0.28 & 780 & 8.3 & 12.0 & 370 & 0 & - \\ 04-05-79 & - & 800 & - & 17.0 & - & - & - \\ 05-02-79 & - & 630 & - & 10.0 & - & - & - \\ 05-11-79 & 0.40 & 730 & 8.4 & 10.0 & 350 & 4 & - \\ 07-03-79 & - & 800 & - & 15.0 & - & - & - \\ 08-02-79 & - & 750 & - & 14.0 & - & -10\end{array}$

Rlo Moquino upstream from Jackplje-Paguate MIne (11.5.22.344)

$\begin{array}{lllll}02-04-74 & - & 1,700 & - & - \\ 04-04-74 & - & 1,900 & - & 4.0 \\ 11-22-74 & 0.57 & 1,550 & - & 11.5\end{array}$


Tabje 12. Misceljaneous onslte measurements of streanflow and water quajity - ContInued

\begin{tabular}{|c|c|c|c|c|c|c|c|}
\hline & & $\begin{array}{l}\text { Speciflc } \\
\text { conductance } \\
\text { (micromhos }\end{array}$ & & & & & \\
\hline $\begin{array}{l}\text { Date of } \\
\text { collection }\end{array}$ & $\begin{array}{l}\text { Discharge } \\
\text { (cublc feet } \\
\text { per second) }\end{array}$ & $\begin{array}{l}\text { per centl- } \\
\text { meter } \\
\text { at } 25^{\circ} \\
\text { celslus) }\end{array}$ & $\begin{array}{c}p H \\
\text { (unlts) }\end{array}$ & $\begin{array}{l}\text { Temperature } \\
\text { (degrees } \\
\text { celslus) }\end{array}$ & $\begin{array}{l}\text { Blcarbonate } \\
\text { (mllligrams } \\
\text { per liter } \\
\text { as } \mathrm{HCO}_{3} \text { ) }\end{array}$ & $\begin{array}{l}\text { Carbonate } \\
\text { (mllligrams } \\
\text { per liter } \\
\text { as } \mathrm{CO}_{3} \text { ) }\end{array}$ & $\begin{array}{l}\text { Dissolved } \\
\text { oxygen } \\
\text { (mllligrams } \\
\text { per liter) }\end{array}$ \\
\hline
\end{tabular}

Rio Moquino upstrean from JackplJe-Paguate Mine (11.5.22.344) - ContInued

\begin{tabular}{|c|c|c|c|c|}
\hline $12-05-74$ & - & 1,850 & - & 7.0 \\
\hline $12-17-74$ & 0.84 & - & - & 0.0 \\
\hline $02-10-75$ & - & 1,300 & - & 7.5 \\
\hline $03-18-75$ & - & 1,600 & - & 14.0 \\
\hline $03-28-75$ & - & 2,300 & - & 1.0 \\
\hline $04-14-75$ & - & 1,400 & - & 18.0 \\
\hline $05-07-75$ & - & 2,000 & - & 12.0 \\
\hline $06-12-75$ & - & 2,030 & - & 13.0 \\
\hline $08-06-75$ & - & 2,020 & - & 24.0 \\
\hline $12-03-75$ & - & 2,000 & - & 2.0 \\
\hline $01-06-76$ & - & 2,050 & - & 3.0 \\
\hline $03-30-76$ & - & 2,000 & - & 7.0 \\
\hline $04-29-76$ & 0.11 & 2,200 & - & 16.0 \\
\hline $05-05-76$ & - & 2,150 & - & 20.0 \\
\hline $05-27-76$ & - & 2,110 & - & 26.0 \\
\hline $06-04-76$ & - & 2,000 & - & 22.0 \\
\hline $06-16-76$ & 0.04 & 2,600 & - & 24.0 \\
\hline $07-15-76$ & - & 1,700 & - & 27.0 \\
\hline
\end{tabular}


Tabje 12. Misceljaneous onsite measurements of streamflow and water quality - Contlinued

\begin{tabular}{|c|c|c|c|c|c|c|c|}
\hline & & $\begin{array}{l}\text { Specific } \\
\text { conductance } \\
\text { (micromhos }\end{array}$ & & & & & \\
\hline $\begin{array}{l}\text { Date of } \\
\text { collection }\end{array}$ & $\begin{array}{l}\text { Discharge } \\
\text { (cublc feet } \\
\text { per second) }\end{array}$ & $\begin{array}{l}\text { per centl- } \\
\text { meter } \\
\text { at } 25^{\circ} \\
\text { celslus) }\end{array}$ & $\begin{array}{c}\mathrm{pH} \\
(u n ! t s)\end{array}$ & $\begin{array}{l}\text { Temperature } \\
\text { (degrees } \\
\text { celslus) }\end{array}$ & $\begin{array}{l}\text { Blcarbonate } \\
\text { (milligrams } \\
\text { per } 1 \text { iter } \\
\text { as } \mathrm{HCO}_{3} \text { ) }\end{array}$ & $\begin{array}{l}\text { Carbonate } \\
\text { (m)lligrams } \\
\text { per } 11 \text { ter } \\
\text { as } \mathrm{CO}_{3} \text { ) }\end{array}$ & $\begin{array}{l}\text { Dissolved } \\
\text { oxygen } \\
\text { (mllligrams } \\
\text { per liter) }\end{array}$ \\
\hline
\end{tabular}

Rlo Moquino upstream from Jackplje-Paguate Mine (11.5.22.344) - Continued

\begin{tabular}{|c|c|c|c|c|c|c|}
\hline $08-03-76$ & - & 2,200 & - & 26.0 & - & - \\
\hline $09-02-76$ & 0.22 & 2,600 & - & - & - & - \\
\hline $09-03-76$ & - & 2,100 & - & 14.0 & - & - \\
\hline $10-04-76$ & - & 2,190 & 7.9 & 15.0 & - & - \\
\hline $10-06-76$ & - & 2,100 & - & 18.0 & - & - \\
\hline $11-01-76$ & - & 1,950 & - & 14.0 & - & - \\
\hline $12-08-76$ & - & 2,100 & - & 0.0 & - & - \\
\hline $02-02-77$ & - & 1,900 & - & 10.0 & - & - \\
\hline $03-01-77$ & - & 2,000 & - & 2.0 & - & - \\
\hline $05-02-77$ & - & 2,400 & - & 25.0 & - & - \\
\hline $09-06-77$ & - & 1,500 & - & 32.0 & - & - \\
\hline $10-31-77$ & - & 2,000 & - & 6.0 & - & - \\
\hline $12-07-77$ & - & 2,400 & - & 10.0 & - & - \\
\hline $01-04-78$ & - & 1,500 & - & 0.0 & - & - \\
\hline $02-09-78$ & - & 1,900 & - & 0.0 & - & - \\
\hline $04-04-78$ & - & 1,700 & - & 17.0 & - & - \\
\hline $05-04-78$ & - & 1,800 & - & 13.0 & - & - \\
\hline $05-26-78$ & 0.52 & 2,000 & 8.0 & 17.0 & 270 & 0 \\
\hline
\end{tabular}




\begin{tabular}{|c|c|c|c|c|c|c|c|}
\hline & & $\begin{array}{l}\text { Speciflc } \\
\text { conductance } \\
\text { (m/cromhos }\end{array}$ & 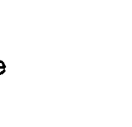 & & & & \\
\hline $\begin{array}{l}\text { Date of } \\
\text { collection }\end{array}$ & $\begin{array}{l}\text { Discharge } \\
\text { (cublc feet } \\
\text { per second) }\end{array}$ & $\begin{array}{l}\text { per centi- } \\
\text { meter } \\
\text { at } 25^{\circ} \\
\text { cels(us) }\end{array}$ & $\begin{array}{c}\mathrm{pH} \\
\text { (unlts) }\end{array}$ & $\begin{array}{l}\text { Temperature } \\
\text { (degrees } \\
\text { celslus) }\end{array}$ & $\begin{array}{l}\text { Blcarbonate } \\
\text { (milligrams } \\
\text { per } 11 \text { ter } \\
\text { as } \mathrm{HCO}_{3} \text { ) }\end{array}$ & $\begin{array}{l}\text { Carbonate } \\
\text { (mIlligrams } \\
\text { per llter } \\
\text { as } \mathrm{CO}_{3} \text { ) }\end{array}$ & $\begin{array}{l}\text { Dissolved } \\
\text { oxygen } \\
\text { (milligrams } \\
\text { per liter) }\end{array}$ \\
\hline
\end{tabular}

Rlo Moquino upstream from Jackplle-Paguate Mine (11.5.22.344) - Concluded

\begin{tabular}{|c|c|c|c|c|c|c|c|}
\hline $08-03-78$ & - & 3,500 & - & 25.0 & - & - & - \\
\hline $08-28-78$ & 0.30 & 3,150 & 8.2 & 28.5 & 284 & 0 & 6.2 \\
\hline $09-29-78$ & 0.22 & 2,550 & 8.4 & 25.0 & 256 & 2 & 7.8 \\
\hline $10-02-78$ & - & 2,400 & - & 23.0 & - & - & - \\
\hline $11-01-78$ & - & 1,450 & - & 17.0 & - & - & - \\
\hline $12-04-78$ & - & 2,200 & - & 1.0 & - & - & - \\
\hline $01-02-79$ & 0.40 & 2,480 & 8.4 & 0.5 & 452 & 4 & 13.1 \\
\hline $02-05-79$ & - & 2,000 & - & 0.0 & - & - & - \\
\hline $02-27-79$ & 1.2 & 1,500 & 8.6 & 8.5 & 326 & 6 & 10.1 \\
\hline $03-26-79$ & 1.0 & 1,580 & 8.6 & 19.0 & 300 & 10 & 7.6 \\
\hline $04-05-79$ & - & 1,700 & - & 22.0 & - & - & - \\
\hline $05-02-79$ & - & 1,500 & - & 10.0 & - & - & - \\
\hline $07-02-79$ & - & 2,100 & - & 31.0 & - & - & - \\
\hline $08-02-79$ & - & 2,800 & - & 18.0 & - & - & - \\
\hline
\end{tabular}

Rlo Paguate downstrean from Jackplle-Paguate MIne (10.5.2.434)

$\begin{array}{lcccc}02-12-74 & 1.7 & 1,700 & - & 9.0 \\ 04-04-74 & - & 2,400 & - & 11.0 \\ 11-22-74 & 1.4 & 2,000 & - & 9.0 \\ 12-05-74 & - & 2,000 & - & 8.0\end{array}$


Table 12. Misceljaneous onsite measurements of streamflow and water quajity - Continued

\begin{tabular}{|c|c|c|c|c|c|c|c|}
\hline & & $\begin{array}{l}\text { Speclfic } \\
\text { conductance } \\
\text { (m) cromhos }\end{array}$ & 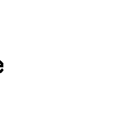 & & & & \\
\hline $\begin{array}{l}\text { Date of } \\
\text { collection }\end{array}$ & $\begin{array}{l}\text { Dlscharge } \\
\text { (cublc feet } \\
\text { per second) }\end{array}$ & $\begin{array}{l}\text { per centl- } \\
\text { meter } \\
\text { at } 25^{\circ} \\
\text { celslus) }\end{array}$ & $\begin{array}{c}\mathrm{pH} \\
\text { (unlts) }\end{array}$ & $\begin{array}{l}\text { Temperature } \\
\text { (degrees } \\
\text { celslus) }\end{array}$ & $\begin{array}{l}\text { Bicarbonate } \\
\text { (mllligrams } \\
\text { per liter } \\
\text { as } \mathrm{HCO}_{3} \text { ) }\end{array}$ & $\begin{array}{l}\text { Carbonate } \\
\text { (m!lllgrams } \\
\text { per } 11 \text { ter } \\
\text { as } \mathrm{CO}_{3} \text { ) }\end{array}$ & $\begin{array}{l}\text { Dlssolved } \\
\text { oxygen } \\
\text { (m)lligrams } \\
\text { per liter) }\end{array}$ \\
\hline
\end{tabular}

Rlo Paguate downstrean from Jackplle-Paguate MIne (10.5.2.434) - Continued

$\begin{array}{lllll}12-17-74 & 1.4 & - & - & 1.0 \\ 02-10-75 & - & 1,600 & - & 7.5 \\ 03-18-75 & - & 2,000 & - & 18.0 \\ 03-28-75 & - & 2,700 & - & 0.5 \\ 04-14-75 & - & 1,400 & - & 18.0 \\ 05-07-75 & - & 2,000 & - & 21.0 \\ 06-12-75 & - & 2,030 & - & 22.0 \\ 08-06-75 & - & 2,020 & - & 22.0 \\ 12-03-75 & - & 1,580 & - & 5.0 \\ 01-06-76 & - & 2,000 & - & 6.0 \\ 03-25-76 & - & 1,950 & - & 19.0 * \\ 04-29-76 & 0.93 & 1,800 & - & 13.5 \\ 05-27-76 & 1.1 & 1,930 & - & 29.5 \\ 06-16-76 & 0.37 & 2,170 & - & 24.0 \\ 07-15-76 & 0.46^{*} & 1,700 & - & 26.0 \\ 08-03-76 & 0.50^{*} & 2,500 & - & 26.0\end{array}$


Tabje 12. Misceljaneous onsite masurements of streanflow and water quajIty - ContInued

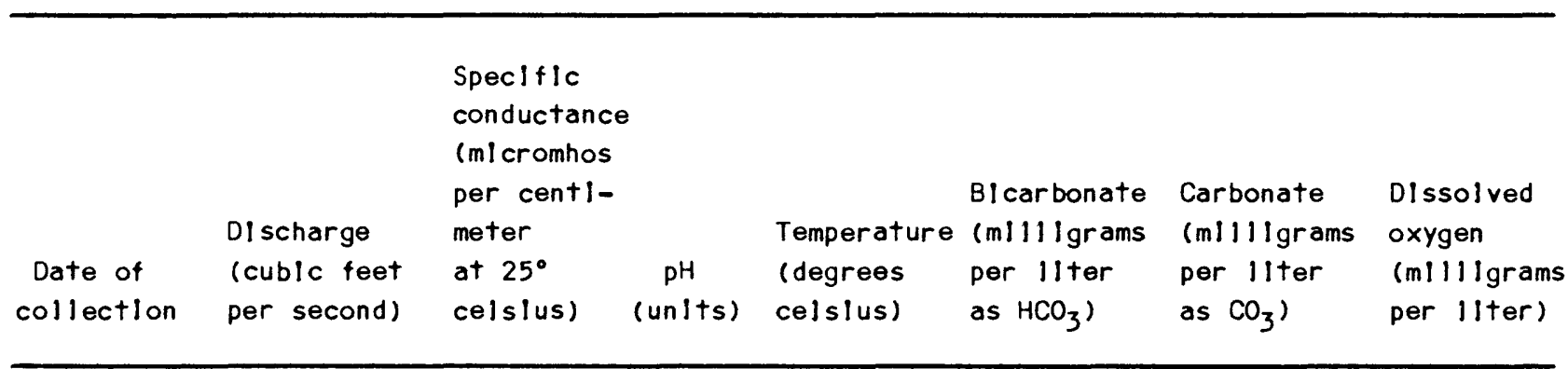

\section{Rlo Paguate downstrea from Jackplle-Paguate Mine (10.5.2.434) - ContInued}

\begin{tabular}{|c|c|c|c|c|}
\hline $09-03-76$ & $0.87^{*}$ & 3,000 & - & 28.0 \\
\hline $10-04-76$ & $0.37^{*}$ & 2,800 & - & 24.0 \\
\hline $11-01-76$ & $1.1^{*}$ & 2,200 & - & 13.0 \\
\hline $12-08-76$ & $1.2^{*}$ & 1,900 & - & 0.0 \\
\hline $01-10-77$ & $2.0^{*}$ & 1,850 & - & 0.0 \\
\hline $02-02-77$ & $2.0^{*}$ & 1,650 & - & 5.0 \\
\hline $03-01-77$ & $1.8^{*}$ & 1,900 & - & 0.0 \\
\hline $05-03-77$ & $2.3^{*}$ & 1,800 & - & 12.0 \\
\hline $06-02-77$ & $1.0^{*}$ & 2,400 & - & 16.0 \\
\hline $08-02-77$ & $0.05^{*}$ & 3,000 & - & 25.0 \\
\hline $09-07-77$ & $2.0^{*}$ & 3,000 & - & 30.0 \\
\hline $10-05-77$ & $0.54 *$ & 1,750 & - & 15.0 \\
\hline $10-31-77$ & $0.48^{*}$ & 2,200 & - & 9.0 \\
\hline $12-06-77$ & $0.52^{*}$ & 2,800 & - & 10.0 \\
\hline $01-04-78$ & $1.8^{*}$ & 1,800 & - & 0.0 \\
\hline $02-09-78$ & $2.3^{*}$ & 2,000 & - & 0.0 \\
\hline $04-04-78$ & $0.61^{*}$ & 2,300 & - & 19.0 \\
\hline $05-05-78$ & $1.1^{*}$ & 1,500 & - & 10.0 \\
\hline
\end{tabular}


Table 12. Miscellaneous onsite measurenents of streanflow and water quality - Continued

\begin{tabular}{|c|c|c|c|c|c|c|c|}
\hline & & $\begin{array}{l}\text { Speclfic } \\
\text { conductance } \\
\text { (mlcromhos }\end{array}$ & & & & & \\
\hline $\begin{array}{l}\text { Date of } \\
\text { collection }\end{array}$ & $\begin{array}{l}\text { Discharge } \\
\text { (cublc feet } \\
\text { per second) }\end{array}$ & $\begin{array}{l}\text { per centi- } \\
\text { meter } \\
\text { at } 25^{\circ} \\
\text { cels(us) }\end{array}$ & $\begin{array}{c}\mathrm{pH} \\
\text { (unlts) }\end{array}$ & $\begin{array}{l}\text { Temperature } \\
\text { (degrees } \\
\text { celslus) }\end{array}$ & $\begin{array}{l}\text { Bl carbonate } \\
\text { (mllligrams } \\
\text { per liter } \\
\text { as } \mathrm{HCO}_{3} \text { ) }\end{array}$ & $\begin{array}{l}\text { Carbonate } \\
\text { (mllligrams } \\
\text { per } 11 \text { ter } \\
\text { as } \mathrm{CO}_{3} \text { ) }\end{array}$ & $\begin{array}{l}\text { Dissolved } \\
\text { oxygen } \\
\text { (mlliligrams } \\
\text { per liter) }\end{array}$ \\
\hline
\end{tabular}

Rlo Paguate downstrean from Jackplje-Paguate Mine (10.5.2.434) - Concluded

\begin{tabular}{|c|c|c|c|c|c|c|c|}
\hline $05-25-78$ & 0.76 & 2,300 & 8.0 & 16.0 & 290 & 0 & - \\
\hline $06-27-78$ & 0.14 & 3,000 & 8.2 & 24.0 & 330 & 0 & 7.4 \\
\hline $07-07-78$ & $0.50^{*}$ & 3,000 & - & 22.0 & - & - & - \\
\hline $08-03-78$ & $0.07 *$ & 3,000 & - & 27.0 & - & - & - \\
\hline $08-28-78$ & 0.22 & 3,150 & 8.0 & 23.0 & 350 & 0 & 6.9 \\
\hline $09-28-78$ & 0.34 & 3,050 & 8.4 & 17.0 & 350 & 4 & 7.9 \\
\hline $10-02-78$ & $0.12^{*}$ & 3,000 & - & 22.0 & - & - & - \\
\hline $11-03-78$ & $6.0^{*}$ & 850 & - & 10.0 & - & - & - \\
\hline $12-04-78$ & $0.99 *$ & 1,900 & - & 2.0 & - & - & - \\
\hline $01-03-79$ & $1.0^{*}$ & 2,800 & 8.3 & 0.0 & 410 & 0 & 10.6 \\
\hline $02-05-79$ & $2.4^{*}$ & 1,400 & - & 0.0 & - & - & - \\
\hline $02-27-79$ & 1.4 & 1,750 & 8.6 & 14.0 & 330 & 12 & 8.0 \\
\hline $03-26-79$ & 1.7 & 1,750 & 8.4 & 14.5 & 320 & 8 & 7.7 \\
\hline $04-05-79$ & $1.3^{*}$ & 2,000 & - & 22.0 & - & - & - \\
\hline $05-02-79$ & $1.7^{*}$ & 1,600 & - & 14.0 & - & - & - \\
\hline $05-11-79$ & 1.0 & 1,950 & 8.5 & 20.0 & 290 & 6 & 6.9 \\
\hline $07-03-79$ & $0.23^{*}$ & 3,000 & - & 20.0 & - & - & - \\
\hline $08-02-79$ & $0.07^{*}$ & 2,600 & - & 25.0 & - & - & - \\
\hline
\end{tabular}


Tabje 12. Miscelianeous onsite measurements of streamflow and water quality - Continued

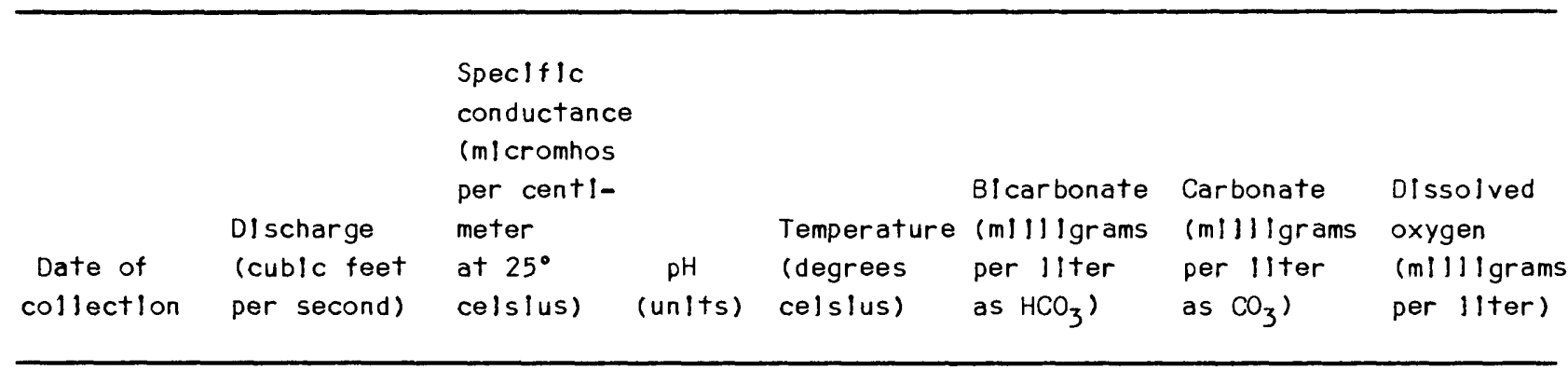

Rlo Paguate downstrean from Paguate Dan (10.5.25.133)

\begin{tabular}{|c|c|c|c|c|}
\hline $09-13-73$ & - & 1,300 & - & 15.0 \\
\hline $01-15-74$ & - & 2,800 & - & 2.0 \\
\hline $02-11-74$ & - & 3,000 & - & 8.0 \\
\hline $03-11-74$ & - & 2,500 & - & 4.0 \\
\hline $04-04-74$ & - & 3,000 & - & 6.5 \\
\hline $08-02-74$ & - & 2,200 & - & 16.0 \\
\hline $10-21-74$ & - & 2,200 & - & 16.0 \\
\hline $01-14-75$ & - & 3,050 & - & 2.0 \\
\hline $02-10-75$ & - & 2,000 & - & 8.0 \\
\hline $03-03-75$ & - & 1,900 & - & 14.0 \\
\hline $03-18-75$ & - & 1,800 & - & 15.0 \\
\hline $04-14-75$ & - & 2,200 & - & 17.0 \\
\hline $05-12-75$ & - & 1,560 & - & 23.0 \\
\hline $12-04-75$ & - & 2,090 & - & 7.0 \\
\hline $01-06-76$ & - & 3,000 & - & 9.0 \\
\hline $03-25-76$ & - & 2,600 & - & 13.0 \\
\hline $05-05-76$ & - & 2,250 & - & 13.0 \\
\hline
\end{tabular}


Tab1e 12. Miscelianeous onsite measurements of streanflow and water quajity - ContInued

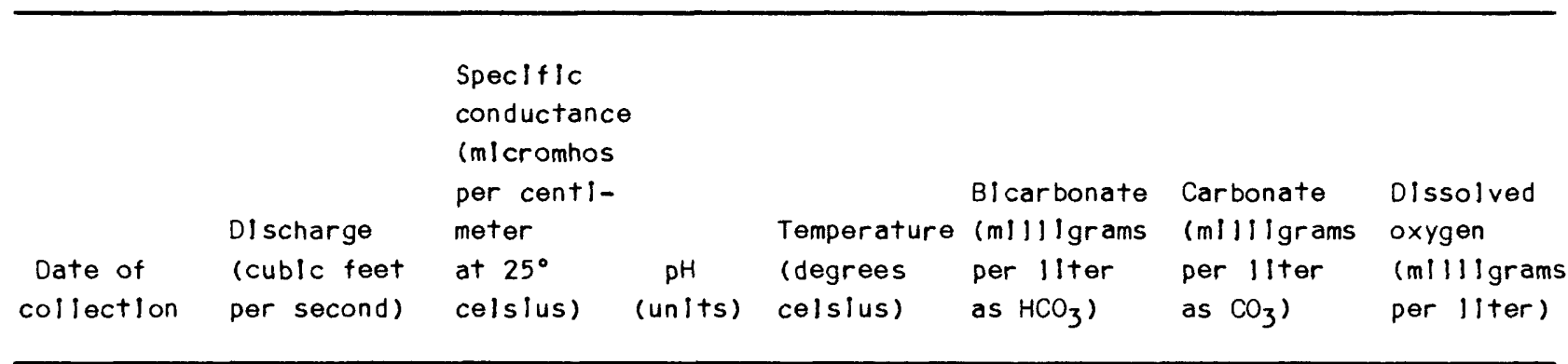

Rlo Paguate downstrean from Paguate Daa (10.5.25.133) - Continued

\begin{tabular}{|c|c|c|c|c|}
\hline $09-02-76$ & - & 3,000 & - & 27.0 \\
\hline $10-04-76$ & - & 3,030 & - & 16.0 \\
\hline $12-07-76$ & - & 3,000 & - & 4.0 \\
\hline $02-03-77$ & - & 1,600 & - & 3.0 \\
\hline $03-01-77$ & - & 1,280 & - & 1.0 \\
\hline $05-03-77$ & - & 2,400 & - & 13.0 \\
\hline $08-02-77$ & - & 2,400 & - & 23.0 \\
\hline $09-07-77$ & - & 2,150 & - & 28.0 \\
\hline $10-04-77$ & - & 2,100 & - & 25.0 \\
\hline $01-04-78$ & - & 1,200 & - & 0.0 \\
\hline $02-09-78$ & - & 2,100 & - & 6.0 \\
\hline $04-05-78$ & - & 1,900 & - & 6.0 \\
\hline $05-05-76$ & - & 2,100 & - & 8.0 \\
\hline $08-03-78$ & 0 & 3,030 & - & 27.0 \\
\hline $10-02-78$ & - & 1,500 & - & 22.0 \\
\hline $11-03-78$ & - & 1,700 & - & 13.0 \\
\hline $12-04-78$ & - & 1,600 & - & 4.0 \\
\hline
\end{tabular}




\begin{tabular}{|c|c|c|c|c|c|c|c|}
\hline & & $\begin{array}{l}\text { Speclf lc } \\
\text { conductanc }\end{array}$ & & & & & \\
\hline & Dl scharge & $\begin{array}{l}\text { per centl- } \\
\text { meter }\end{array}$ & & Temperature & $\begin{array}{l}\text { Bl carbonate } \\
\text { (ml) l) Igrams }\end{array}$ & $\begin{array}{l}\text { Carbonate } \\
\text { (mll)lgrams }\end{array}$ & $\begin{array}{l}\text { Dlssolved } \\
\text { oxygen }\end{array}$ \\
\hline $\begin{array}{l}\text { Date of } \\
\text { collection }\end{array}$ & $\begin{array}{l}\text { (cublc feet } \\
\text { per second) }\end{array}$ & $\begin{array}{l}\text { at } 25^{\circ} \\
\text { cels(us) }\end{array}$ & $\begin{array}{c}\mathrm{pH} \\
\text { (unlts) }\end{array}$ & $\begin{array}{l}\text { (degrees } \\
\text { celslus) }\end{array}$ & $\begin{array}{l}\text { per } 11 \text { ter } \\
\text { as } \mathrm{HCO}_{3} \text { ) }\end{array}$ & $\begin{array}{l}\text { per 1lter } \\
\left.\text { as } \mathrm{CO}_{3}\right)\end{array}$ & $\begin{array}{l}\text { (mlllgrams } \\
\text { per llter) }\end{array}$ \\
\hline
\end{tabular}

Rlo Paguate downstrean from Paguate Das (10.5.25.133) - Concluded

$\begin{array}{lllll}02-05-79 & - & 2,000 & - & 0.0 \\ 04-05-79 & - & 1,650 & - & 11.0 \\ 05-02-79 & - & 1,900 & - & 16.0 \\ 07-02-79 & - & 2,400 & - & 27.0 \\ 08-02-79 & - & 3,030 & - & 26.0\end{array}$

Rlo San Jose at Mesita Diversion $(9.5 .12 .133)$

\begin{tabular}{|c|c|c|c|c|}
\hline $11-01-73$ & - & 5,200 & - & 13.0 \\
\hline $12-03-73$ & - & 4,000 & - & 2.0 \\
\hline $01-14-74$ & - & 3,000 & - & 1.0 \\
\hline $02-14-74$ & - & 1,900 & - & 7.0 \\
\hline $03-08-74$ & - & 2,200 & - & 5.0 \\
\hline $05-06-74$ & - & 3,300 & - & 28.0 \\
\hline $11-05-74$ & - & 2,300 & - & 5.0 \\
\hline $01-14-75$ & - & 2,080 & - & 2.0 \\
\hline $02-14-75$ & - & 2,000 & - & 10.0 \\
\hline $03-05-75$ & - & 2,400 & - & 12.0 \\
\hline $04-15-75$ & - & 2,200 & - & 10.0 \\
\hline
\end{tabular}




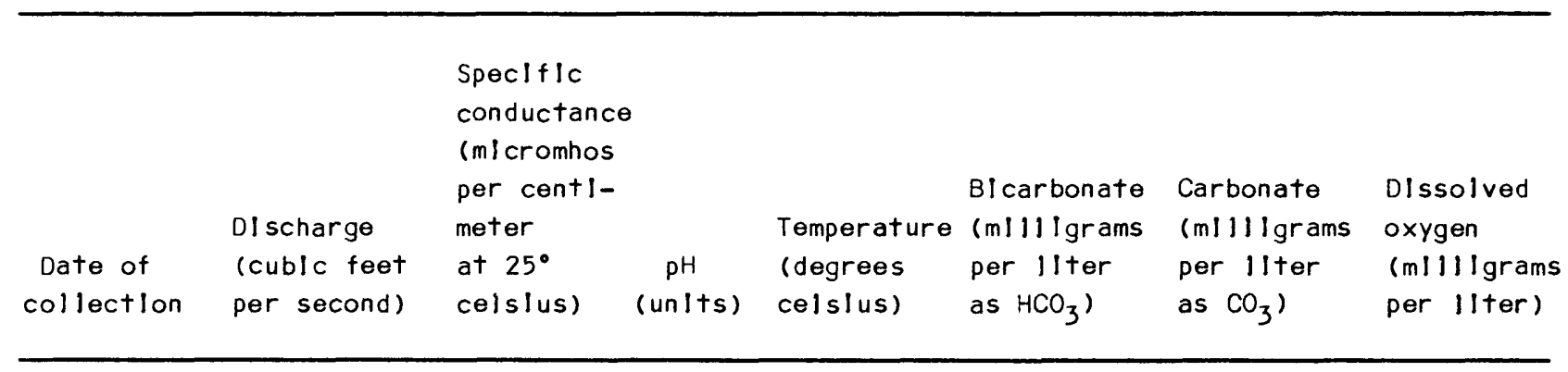

\section{Rio San Jose at Mesita Diversion (9.5.12.133) - Continued}

\begin{tabular}{|c|c|c|c|c|}
\hline $05-15-75$ & - & 3,500 & - & 21.0 \\
\hline $08-05-75$ & - & 1,560 & - & 20.0 \\
\hline $12-03-75$ & - & 2,050 & - & 2.0 \\
\hline $01-04-76$ & - & 2,050 & - & 2.0 \\
\hline $02-20-76$ & - & 2,300 & - & 2.5 \\
\hline $05-05-76$ & - & 2,000 & - & 12.0 \\
\hline $07-12-76$ & 0 & 3,000 & - & 27.0 \\
\hline $08-03-76$ & 0 & 4,050 & - & 23.0 \\
\hline $09-02-76$ & - & 3,200 & - & 28.0 \\
\hline $10-04-76$ & - & 3,050 & - & 14.0 \\
\hline $11-01-76$ & - & 2,800 & - & 6.0 \\
\hline $12-07-76$ & - & 2,500 & - & 0.0 \\
\hline $02-03-77$ & - & 3,000 & - & 0.0 \\
\hline $03-01-77$ & - & 2,000 & - & 0.0 \\
\hline $05-04-77$ & - & 4,000 & - & 10.0 \\
\hline $06-01-77$ & - & 4,500 & - & 21.0 \\
\hline $09-07-77$ & - & 950 & - & 18.0 \\
\hline $11-01-77$ & - & 2,400 & - & 10.0 \\
\hline
\end{tabular}




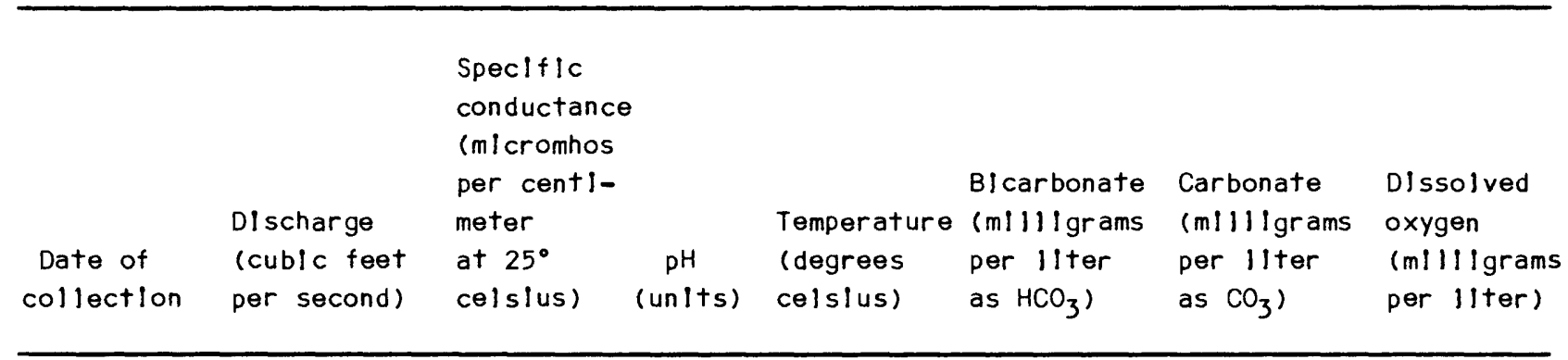

\section{Rlo San Jose at Mesita Diversion (9.5.12.133) - Concluded}

\begin{tabular}{|c|c|c|c|c|c|c|c|}
\hline $12-05-77$ & - & 2,600 & - & 9.0 & - & - & - \\
\hline $01-02-78$ & - & 2,600 & - & 7.0 & - & - & - \\
\hline $02-09-78$ & - & 2,600 & - & 2.0 & - & - & - \\
\hline $04-04-78$ & - & 3,500 & - & 6.0 & - & - & - \\
\hline $05-04-78$ & - & 4,000 & - & 19.0 & - & - & - \\
\hline $05-26-78$ & .30 & 4,750 & 8.0 & 19.0 & 282 & 0 & - \\
\hline $07-07-78$ & 0 & 5,000 & - & 27.0 & - & - & - \\
\hline $08-03-78$ & - & 850 & - & 19.0 & - & - & - \\
\hline $10-03-78$ & 0 & 3,500 & - & 20.0 & - & - & - \\
\hline $11-03-78$ & 0 & 3,000 & - & 11.0 & - & - & - \\
\hline $12-04-78$ & - & 2,050 & - & 0.0 & - & - & - \\
\hline $12-28-78$ & 5.0 & 2,300 & 8.7 & 0.0 & 320 & 10 & 15.4 \\
\hline $02-07-79$ & - & 2,000 & - & 1.0 & - & - & - \\
\hline $02-28-79$ & 7.1 & 2,200 & 8.8 & 2.0 & 300 & 16 & 15.5 \\
\hline $04-05-79$ & - & 2,400 & - & 13.0 & - & - & - \\
\hline $05-03-79$ & - & 4,000 & - & 13.0 & - & - & - \\
\hline $05-14-79$ & 0.41 & 4,200 & - & 12.5 & 390 & 0 & 3.5 \\
\hline $07-05-79$ & - & 2,400 & - & 24.0 & - & - & - \\
\hline $08-06-79$ & 0 & 4,000 & - & 30.0 & - & - & - \\
\hline
\end{tabular}


Table 13. Selected radlocheilcals in surface water

Notes: All analyses are In picocurles per 1 Iter unjess noted otherwise. All analyses were performed by U.S. Geologlcal Survey. Concentratlons less than the detection linit of a partlcular analytlcal method are narked "<n.

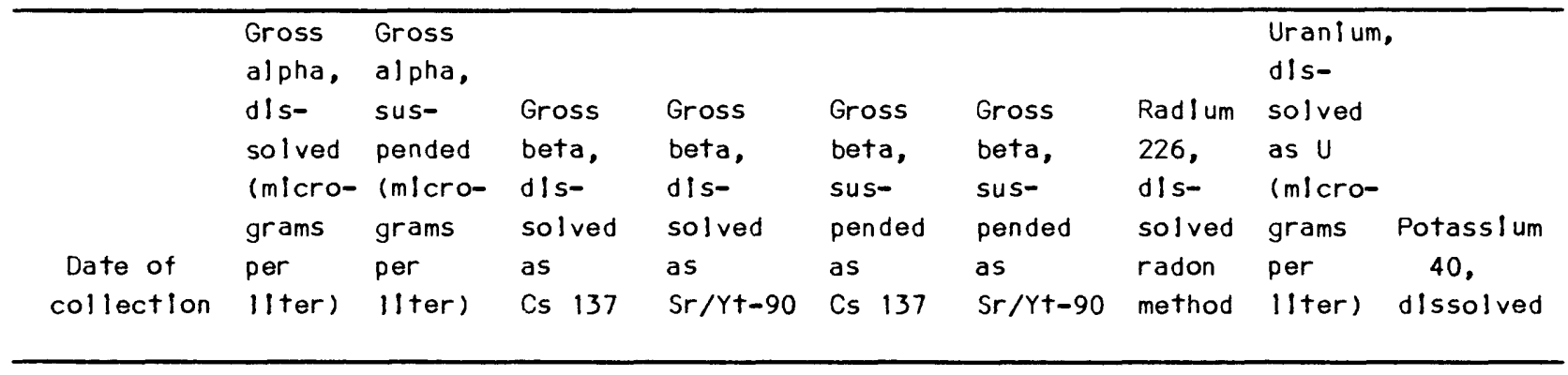

Cubero Creek at Budvi11e (10.7.25.211)

$\begin{array}{rrrrrrrrrr}04-20-78 & - & - & - & - & - & - & .14 & 6.4 & - \\ 07-25-78 & 7.9 & <0.4 & 7.8 & 7.3 & <0.4 & 0.4 & .06 & 5.4 & 6.1 \\ 10-26-78 & 14.0 & <0.4 & 6.6 & 6.1 & 0.5 & 0.5 & .07 & 5.4 & 5.1 \\ 01-29-79 & 12.0 & <0.4 & 8.5 & 7.8 & 0.5 & 0.5 & .10 & 6.7 & 5.2 \\ 05-14-79 & 11.0 & <0.4 & 5.4 & 5.0 & 0.4 & 0.4 & .08 & 5.7 & 5.5\end{array}$

RIo Paguate upstrean from Paguate (11.5.30.234)

$\begin{array}{rrrrrrrrrr}04-21-78 & - & - & - & - & - & - & .06 & .65 & - \\ 07-19-78 & <2.8 & <0.4 & 3.1 & 2.8 & <0.4 & <0.4 & .04 & .60 & 3.6 \\ 10-30-78 & 3.5 & <0.4 & 4.0 & 3.8 & <0.4 & <0.4 & .09 & .80 & 3.6 \\ 01-30-79 & <4.4 & <0.4 & 2.7 & 2.5 & <0.4 & <0.4 & .07 & 1.60 & 3.4 \\ 05-10-79 & 3.5 & 0.4 & 5.2 & 4.8 & <0.4 & <0.4 & .07 & .80 & 3.6\end{array}$

Rlo Paguate upstream from Jackplle-Paguate Mine (11.5.32.424)

$\begin{array}{rrrrrrrrrr}04-21-78 & - & - & - & - & - & - & .08 & 2.1 & - \\ 07-19-78 & <4.7 & <0.4 & 3.8 & 3.6 & <0.4 & <0.4 & .08 & 1.4 & 5.1 \\ 10-26-78 & <5.0 & <0.4 & 8.2 & 7.5 & <0.4 & <0.4 & .07 & 0.7 & 4.6 \\ 01-29-79 & <5.8 & 1.1 & 4.0 & 3.7 & 0.7 & 0.7 & .08 & 2.2 & 3.5 \\ 05-14-79 & 7.3 & <0.4 & 4.6 & 4.2 & 0.4 & 0.4 & .07 & 1.4 & 4.0\end{array}$

Rlo Moquino upstrean from Jackpl1e-Paguate MIne (11.5.22.344)

$\begin{array}{rrrrrrrrrr}04-20-78 & - & - & - & - & - & - & .12 & 8.3 & - \\ 11-02-78 & 21 & <0.4 & 9.5 & 8.7 & <0.4 & <0.4 & .11 & 6.1 & 6.8 \\ 01-30-79 & <35 & 12 & <9.5 & <8.7 & 9.3 & 8.7 & .12 & 7.4 & 7.5 \\ 05-11-79 & <24 & 0.4 & <8.1 & <8.7 & 0.4 & 0.4 & .08 & 4.7 & 6.0\end{array}$


Tabje 13. Selected radlochenlcals in surface vater - Concluded

\begin{tabular}{|c|c|c|c|c|c|c|c|c|c|}
\hline & Gross & Gross & & & & & & Uranlum, & \\
\hline & a]pha, & alpha, & & & & & & dis- & \\
\hline & dis- & sus- & Gross & Gross & Gross & Gross & Radlum & solved & \\
\hline & solved & pended & beta, & beta, & beta, & beta, & 226 & as $U$ & \\
\hline & (micro- & (micro- & dls- & dis- & sus- & sus- & d/s- & (micro- & \\
\hline Date of & $\begin{array}{l}\text { grams } \\
\text { per }\end{array}$ & $\begin{array}{l}\text { grams } \\
\text { per }\end{array}$ & $\begin{array}{l}\text { solved } \\
\text { as }\end{array}$ & $\begin{array}{l}\text { solved } \\
\text { as }\end{array}$ & $\begin{array}{l}\text { pended } \\
\text { as }\end{array}$ & $\begin{array}{l}\text { pended } \\
\text { as }\end{array}$ & $\begin{array}{l}\text { solved } \\
\text { radon }\end{array}$ & $\begin{array}{l}\text { grams } \\
\text { per }\end{array}$ & $\begin{array}{c}\text { Potass I um } \\
40\end{array}$ \\
\hline collection & (1ter) & (1ter) & Cs 137 & $\mathrm{Sr} / \mathrm{Yt}-90$ & Cs 137 & $\mathrm{Sr} / \mathrm{Yt}-90$ & method & (1ter) & dissolved \\
\hline
\end{tabular}

\section{Rlo Paguate downstrean from Jackplle-Paguate MIne (10.5.2.434)}

$\begin{array}{rrrrrrrrrr}06-17-76 & 360 & 3.2 & 44 & 39 & 2.1 & 1.7 & 4.6 & 210 & 3.4 \\ 01-24-77 & 120 & 150 & 20 & 17 & 56 & 47 & 1.7 & 73 & 5.2 \\ 04-18-78 & 77 & 28 & 23 & 22 & 16 & 16 & 2.2 & 78 & - \\ 07-25-78 & 590 & 18 & 70 & 63 & 44 & 43 & 3.6 & 330 & 9.0 \\ 10-30-78 & 410 & 120 & 67 & 61 & 50 & 44 & 8.3 & 220 & 7.5 \\ 01-24-79 & 230 & 62 & 58 & 58 & 39 & 37 & 3.4 & 110 & 6.6 \\ 05-11-79 & 180 & 36 & 20 & 18 & 22 & 20 & 2.3 & 78 & 6.7\end{array}$

Rio San Jose at Mesita Diversion (9.5.12.133)

$\begin{array}{lrrrrrrrrr}01-24-77 & 140 & 6.0 & 21 & 16 & 30 & 24 & .11 & 91 & 6.4 \\ 04-19-78 & <34 & 0.5 & 11 & 9.7 & 1.9 & 1.9 & .26 & 11 & - \\ 01-24-79 & <32 & 3.5 & 10 & 9.4 & 4.0 & 3.8 & .07 & 10 & 1.3 \\ 05-14-79 & <66 & <0.4 & <20 & <18 & 1.4 & 1.5 & .07 & 41 & 8.2\end{array}$




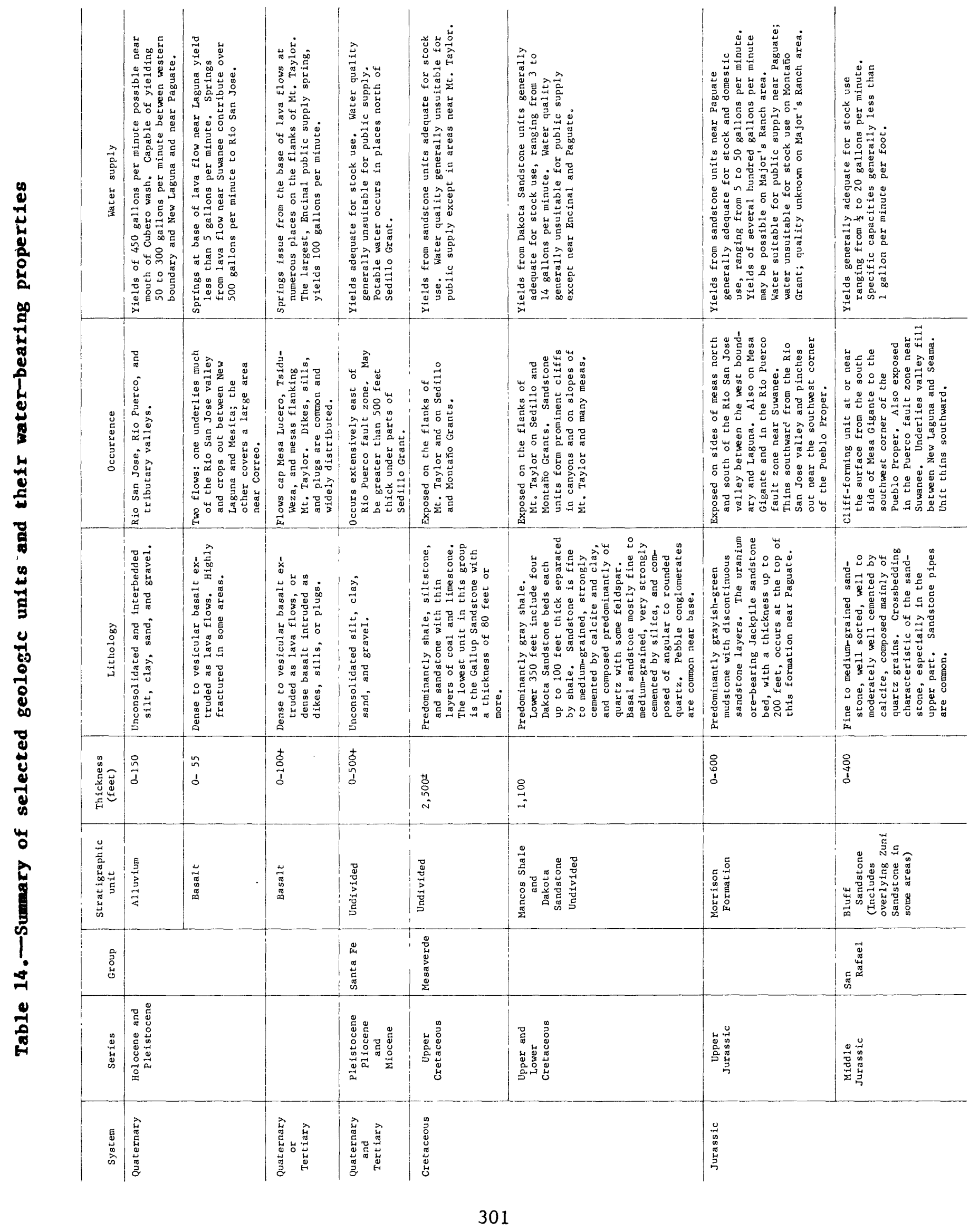




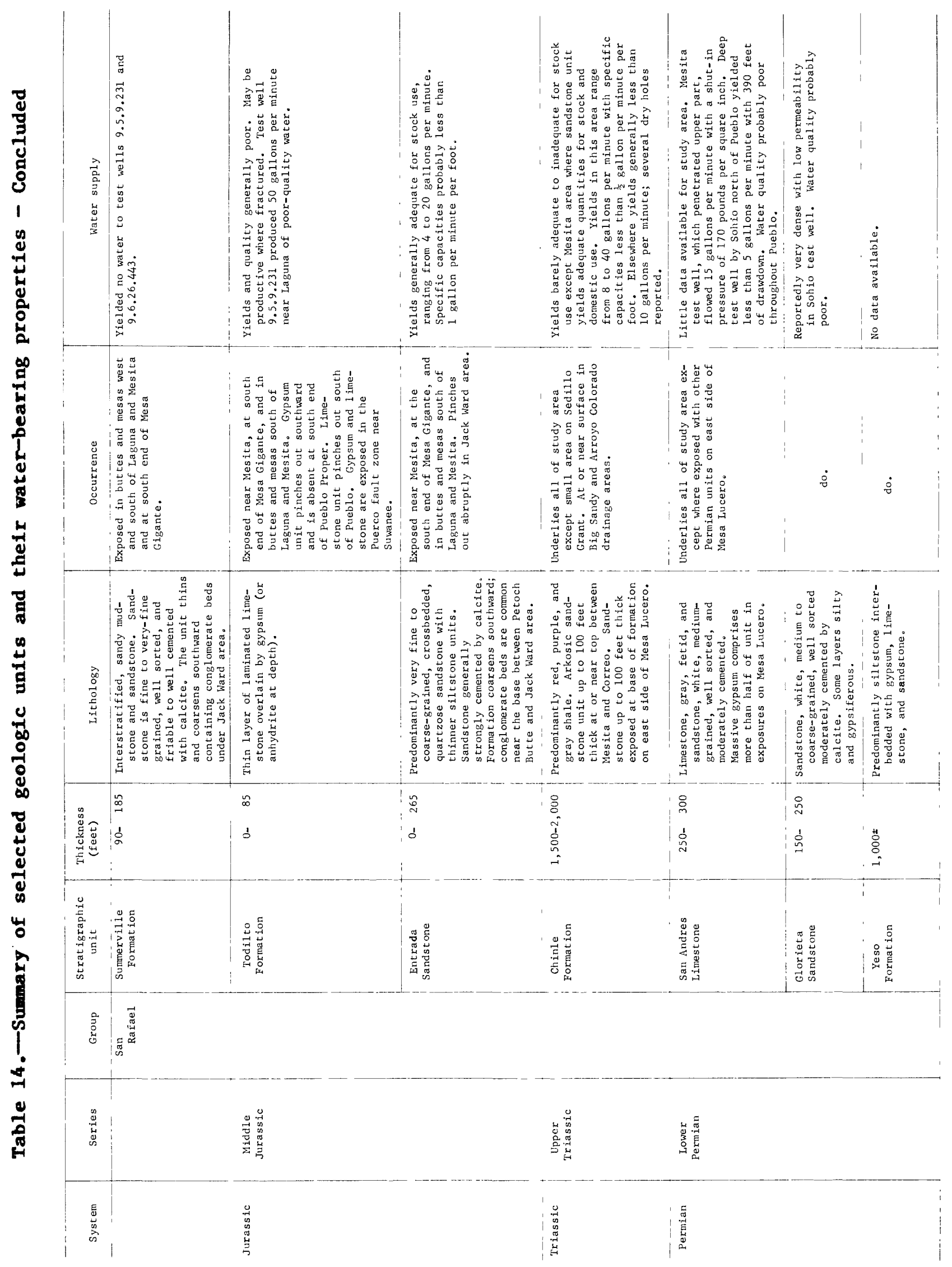


Tabje 15. Estlmated wegnitude and frequency of 1-day flood, peak-fjow discharge, and total annual streanflow for tributarles of Rlo San lose.

Note: Magnitude and frequencles calculated at wouth of strean according to techniques in Borland (1970) and Scott (1971).

\begin{tabular}{|c|c|c|c|c|c|c|c|c|c|c|c|}
\hline 2. & 2-Year & Flood & 5-Year & Flood & 10-Year & Flood & 25-Year & Flood & 50-Year & Flood & \\
\hline $\begin{array}{l}1 \\
f \\
v c \\
(c\end{array}$ & $\begin{array}{l}\text { 1-Day } \\
\text { flood } \\
\text { volume } \\
\text { (acre- } \\
\text { feet) }\end{array}$ & $\begin{array}{c}\text { Peak } \\
\text { flow } \\
\text { (cublc } \\
\text { feet } \\
\text { per } \\
\text { second) }\end{array}$ & $\begin{array}{l}\text { 1-Day } \\
\text { flood } \\
\text { volume } \\
\text { (acre- } \\
\text { feet) }\end{array}$ & $\begin{array}{l}\text { Peak } \\
\text { flow } \\
\text { (cublc } \\
\text { feet } \\
\text { per } \\
\text { second) }\end{array}$ & $\begin{array}{l}\text { 1-Day } \\
\text { flood } \\
\text { vol ume } \\
\text { (acre- } \\
\text { feet) }\end{array}$ & $\begin{array}{l}\text { Peak } \\
\text { flow } \\
\text { (cublc } \\
\text { feet } \\
\text { per } \\
\text { second) }\end{array}$ & $\begin{array}{l}\text { 1-Day } \\
\text { flood } \\
\text { volume } \\
\text { (acre- } \\
\text { feet) }\end{array}$ & $\begin{array}{l}\text { Peak } \\
\text { flow } \\
\text { (cublc } \\
\text { feet } \\
\text { per } \\
\text { second) }\end{array}$ & $\begin{array}{l}\text { 1-Day } \\
\text { flood } \\
\text { volume } \\
\text { (acre- } \\
\text { feet) }\end{array}$ & $\begin{array}{l}\text { Peak } \\
\text { flow } \\
\text { (cublc } \\
\text { feet } \\
\text { per } \\
\text { second) }\end{array}$ & $\begin{array}{c}\text { Total } \\
\text { annual } \\
\text { stream- } \\
\text { flow } \\
\text { (acre- } \\
\text { feet) }\end{array}$ \\
\hline Rlo Paguate & 170 & 1,400 & 380 & 2,800 & 560 & 4,000 & 830 & 6,000 & 1,100 & 7,900 & 4,600 \\
\hline Cañon Seama & 8 & 430 & 22 & 930 & 34 & 1,400 & 58 & 2,200 & 79 & 3,000 & 72 \\
\hline Enclnal Creek & 32 & 640 & 79 & 1,400 & 120 & 2,000 & 180 & 3,100 & 240 & 4,200 & 640 \\
\hline Cañon Largo & 69 & 1,100 & 180 & 2,200 & 260 & 3,100 & 420 & 4,800 & 580 & 6,300 & 940 \\
\hline Arroyo & & & & & & & & & & & \\
\hline Conchas & 130 & 1,500 & 340 & 3,000 & 500 & 4,300 & 810 & 6,500 & 1,100 & 8,600 & 2,800 \\
\hline Cubero Creek & 58 & 770 & 130 & 1,600 & 190 & 2,400 & 300 & 3,600 & 380 & 4,900 & 720 \\
\hline Acoma Creek & 160 & 1,900 & 430 & 3,700 & 670 & 5,200 & 1,100 & 7,700 & 1,600 & 10,000 & 1,100 \\
\hline Arroyo Lucero & 34 & 990 & 99 & 2,000 & 160 & 2,900 & 280 & 4,500 & 400 & 6,000 & 3,000 \\
\hline $\begin{array}{l}\text { Arroyo } \\
\text { Colorado }\end{array}$ & 210 & 2700 & 670 & 5100 & 1100 & 7200 & 2000 & 11 ח & 3000 & 14 ח & 4.000 \\
\hline $\begin{array}{l}\text { Standard } \\
\text { error, In } \\
\text { percent }\end{array}$ & 59 & 92 & 55 & 83 & 55 & 82 & 60 & 87 & 66 & 91 & 53 \\
\hline
\end{tabular}


Tab1e 16. Chemlcaj analyses of bed materlaj in Rlo Paguate and Rlo Moquino

Note: Location number - see.text for explanatlon. All analyses were performed by U.S. Geological Survey. Dlscharge, temperature, pH, speclfic conductance, were measured onsite.

\begin{tabular}{|c|c|c|c|c|c|c|c|c|}
\hline & & & & Water & & & & \\
\hline & & & & speclfic & & & & \\
\hline & & & & conduct- & Sus- & Arsenlc & Cyanlde & Lead \\
\hline & Water & Water & & ance & pended & In bed & In bed & In bed \\
\hline & d) scharge & temper- & & (m) cro- & sollds & materlal & materlal & materlal \\
\hline & (cublc & ature & & mhos & $(m \mid 1) 1-$ & (m) cro- & (m) cro- & (m) cro- \\
\hline & feet & (degrees & & per cent1- & grams & grams & grams & grams \\
\hline Date of & per & centl- & Water & meter at & per & per & per & per \\
\hline collection & second) & grade) & $\mathrm{pH}$ & $25^{\circ}$ Celsius) & (1ter) & gram). & gram) & gram) \\
\hline
\end{tabular}

Rlo Paguate upstrean from Jackplje-Paguate MIne (11.5.32.424)

$\begin{array}{lllllllll}07-06-79 & .25 & 14.0 & 8.2 & 700 & - & 11 & 0 & 15\end{array}$

Rlo Moquino upstream from Jackplle-Paguate Mine (11.5.22.344)

$\begin{array}{rrrrrrrr}07-06-79 & .10 & 21.0 & 8.4 & 2,900 & - & 11 & 0\end{array}$

Rlo Paguate downstrean from Jackpl1e-Paguate Mlne (10.5.2.434)

\begin{tabular}{|c|c|c|c|c|c|c|c|}
\hline $04-18-78$ & 1.1 & 14.0 & 8.5 & 2,200 & 98 & 5 & 0 \\
\hline $04-18-78$ & 1.1 & 14.0 & 8.5 & 2,200 & 98 & 3 & 0 \\
\hline $04-18-78$ & 0 & - & - & - & - & 4 & 0 \\
\hline $07-25-78$ & .14 & 23.0 & 8.3 & 3,000 & 65 & 6 & 0 \\
\hline $07-25-78$ & 0 & - & - & - & - & 4 & 0 \\
\hline $07-25-78$ & 0 & - & - & - & - & 4 & 0 \\
\hline $10-30-78$ & .51 & 12.0 & 8.3 & 2,600 & 174 & 0 & 0 \\
\hline $10-30-78$ & 0 & - & - & - & - & 4 & 0 \\
\hline $10-30-78$ & 0 & - & - & - & - & 0 & 0 \\
\hline $01-24-79$ & - & -0.5 & 8.3 & 1,700 & - & 3 & 0 \\
\hline $01-24-79$ & - & -0.5 & 8.3 & 1,700 & - & 4 & 0 \\
\hline $01-24-79$ & 0 & - & - & - & - & 5 & 0 \\
\hline
\end{tabular}

Rlo Paguate 1.5 miles downstream from Jackplle-Paguate MIne $(10.5 .12 .334)$
$05-11-79=$
25.0
2,100
0
6

Rlo Paguate 3 miles downstream from JackplJe-Paguate MIne (10.5.24.123)
$05-11-79$
25.0
2,130
2
0
4

RIo Peguate 4 miles downstream trom JackplJe-Paguate MIne (10.5.24.413)
$05-11-79$
25.0
2,250
5

0 


\begin{tabular}{|c|c|c|c|c|c|}
\hline $\begin{array}{l}\text { Moly- } \\
\text { bdenum } \\
\text { in bed } \\
\text { materlal } \\
\text { (mlcro- } \\
\text { grams } \\
\text { per } \\
\text { gram) }\end{array}$ & $\begin{array}{l}\text { Selenlum } \\
\text { In bed } \\
\text { materlal } \\
\text { (mlero- } \\
\text { grams } \\
\text { per } \\
\text { gram) }\end{array}$ & $\begin{array}{l}\text { Vanadlum } \\
\text { In bed } \\
\text { materlal } \\
\text { (mlcro- } \\
\text { grams } \\
\text { per } \\
\text { gram) }\end{array}$ & $\begin{array}{l}\text { Uranlum } \\
\text { In bed } \\
\text { materlal } \\
\text { (mlcro- } \\
\text { grams } \\
\text { per } \\
\text { gram) }\end{array}$ & $\begin{array}{l}\text { Radlum } \\
\text { In bed } \\
\text { materla } \\
226 \\
\text { (pCl } \\
\text { per } \\
\text { gram) }\end{array}$ & $\begin{array}{l}\text { Secondary } \\
\text { Remarks on channel sampling chanr }\end{array}$ \\
\hline 0 & 0.2 & - & 8.9 & 1.33 & Composite across channel \\
\hline 0 & 0.2 & - & .31 & .23 & Composite across channel \\
\hline 0 & 0.0 & 8.0 & 16.0 & 8.4 & Primary - flow channe\} \\
\hline 0 & 1.0 & 7.0 & 2.5 & 2.7 & Secondary - flow channel \\
\hline 0 & 0.0 & 5.0 & 5.4 & 1.9 & Center of active channel \\
\hline 4 & 1.0 & - & 17.0 & 2.0 & Primary - flow channel \\
\hline 3 & 1.0 & - & 5.0 & 4.3 & $6 \mathrm{ft}$ from left bank of active channel \\
\hline 5 & 2.0 & - & 17.0 & 4.3 & $50 \mathrm{ft}$ from left bank actlve channel \\
\hline 3 & 1.0 & 5.9 & 4.6 & 3.9 & Primary - flow channel. \\
\hline 5 & 3.0 & 7.1 & 10.0 & 2.4 & Center of active channel \\
\hline 4 & 1.0 & 5.0 & 5.1 & 2.4 & $15 \mathrm{ft}$ from left bank actlve channel \\
\hline 0 & 0.6 & 6.7 & 10.0 & 4.5 & Primary - flow channel \\
\hline 0 & 0.5 & 3.8 & 4.9 & 2.8 & Secondary - flow channel \\
\hline 0 & 0.6 & 4.8 & 8.3 & 3.1 & $50 \mathrm{ft}$ from left bank actlve channel \\
\hline 0 & 1.0 & - & 293 & 124 & Composite across channel \\
\hline 0 & 0.0 & - & 194 & 121 & Composite across channel \\
\hline 0 & 0.0 & - & 308 & 153 & Composite across channel \\
\hline
\end{tabular}


Table 17. Selected water-quality standards and criteria for public water supply, freshwater aquatic 11fe, 11vestock, and irrigation

\section{PUBLIC-WATER SUPPLY}

Selected primary standards from the U.S. Environmental Protection Agency interim drinking water standards (1976a). The maximum allowable limits for these constituents are set according to health criteria.

Constituent
Arsenic
Barium
Cadmium
Chromium
Lead
Mercury
Nitrate (as N)
Selenium
Silver

$\begin{gathered}\text { Maximum concent } \\ \text { (milligrams per }\end{gathered}$
0.05
1.00
0.01
0.05
0.05
0.002
10.0
0.01
0.05

Recommended quality-criteria for secondary constituents in public-supply water (modified from U.S Environmental protection Agency, 1976b). The recommended limits were set mainly to provide esthetic and taste characteristics.

\begin{tabular}{lc} 
Constituent & $\begin{array}{c}\text { Maximum recommended concentration } \\
\text { (milligrams per 1iter) }\end{array}$ \\
\cline { 2 - 2 } Bicarbonate & 700 \\
Calcium & $75-200$ \\
Carbonate & 350 \\
Chloride & 250 \\
Specific conductance & 1,000 micromhos \\
Copper & 3 \\
Hardness & 250 \\
Iron & 0.3 \\
Manganese & 125 \\
pH & 0.5 \\
Potassium & $6.0-8.5$ \\
Sodium & 1,000 \\
Sulfate & 200 \\
Zinc & 5
\end{tabular}


Table 17. Selected water-quality standards and criteria for public water supply, freshwater aquatic life, livestock, and irrigation Continued

\section{FRESHWATER AQUATIC LIFE}

The following are some selected water-quality criteria for freshwater aquatic life recommended by the U.S. Environmental Protection Agency, 1976a. An asterisk next to the concentration value indicates the value was estimated based on 96-hour bioassay data for rainbow trout survival.

\section{Constituent}

Alkalinity

Ammonia

Beryllium

Cadmium

Chromi um

Copper

Cyanide

Dissolved Oxygen

Iron

Lead

Mercury

$\mathrm{pH}$

Zinc
Maximum recommended concentration (milligrams per liter)

Greater than 20
0.02
1.10
$0.0012 *$
0.10
$0.09 *$
0.005
5.0
1.0
$0.05 *$
0.0003
$6.5-9.0$
$0.72 *$

\section{LIVESTOCK}

The following are selected water-quality criteria for livestock recommended by the Federal Water Pollution Control Administration, 1968.

\section{Constituent}

Specific conductance for: poultry

swine

horses

dairy cattle

beef cattle

sheep
Maximum recommended concentration (micromhos per centimeter at $25^{\circ}$ (elsius))

$$
\begin{array}{r}
4,000 \\
6,000 \\
9,000 \\
10,000 \\
14,000 \\
17,000
\end{array}
$$


Table 17. Selected water-quality standards and criteria for public water supp1y, freshwater aquatic life, livestock, and irrigationConcluded

\section{IRRIGATION}

The following are some selected water-quality criteria for irrigation. Values with asterisks were recommended by the U.S. Environmental Protection Agency, 1976a. All other values are from the Federal Water Pollution Control Administration, 1968.

\section{Constituent}

Arsenic

Beryllium:

(Continuous irrigation on all soils)

(Neutral to alkaline soils)
Maximum recommended concentration (milligrams per liter)

Boron:

(Continuous irrigation of sensitive crops)

$$
0.75 *
$$

(Semitolerant crops)

(Tolerant crops)

$$
\begin{aligned}
& 1.0-2.0 \\
& 2.0-4.0
\end{aligned}
$$

Dissolved solids:

(Usually no detrimental effects to crops)

(May have detrimental effects on sensitive crops)

(May have adverse effects on many crops. May require careful management practices)

(May be used for tolerant plants on permeable soils if careful management practices are followed) less than 500

$500-1,000$

$1,000-2,000$

$2,000-5,000$ 